ERDÉLYI TUDOMÁNYOS FÜZETEK

275

\author{
BERKI TÍMEA
}

\title{
MAGYAR-ROMÁN KULTURÁLIS KAPCSOLATOK A 19. SZÁZAD MÁSODIK FELÉBEN
}

Értelmiségtörténeti keret

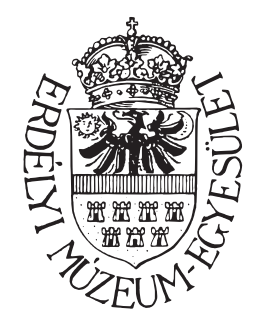

Kolozsvár, 2012 
Cartea a apărut cu sprijinul Administrației Fondului Cultural Național A kötet megjelenését támogatta

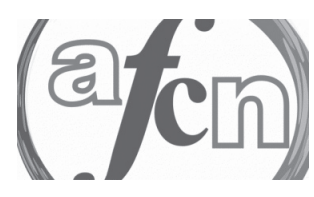

(C) Berki Tímea

(C) Erdélyi Múzeum-Egyesület, 2012

Felelős kiadó

BIRÓ ANNAMÁRIA

Szerkesztette

BIRÓ ANNAMÁRIA

Korrektúra

ANDRÁS ZSELYKE

Müszaki szerkesztés, borítóterv

BODÓ ZALÁN

Nyomdai munkálatok

GLORIA, Kolozsvár

Felelős vezető

NAGY PÉTER

Descrierea CIP a Bibliotecii Naţionale a României

BERKI, TÍMEA

Magyar-román kulturális kapcsolatok a 19. század második

felében. Ertelmiségtörténeti keret / Berki Tímea. - Cluj-Napoca :

Societatea Muzeului Ardelean, 2012

Bibliogr.

Index

ISBN 978-606-8178-60-8

008(498:439) 


\section{TARTALOM}

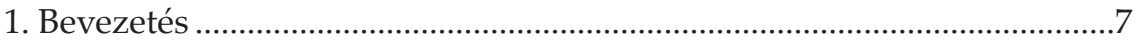

2. Mihai Eminescu a magyarországi (román) irodalomban ..........................11

2.1. A költő első publikációi ..................................................................12

2.1.1. Színház és (politikai) publicisztika ..........................................17

2.2. Az Eminescu-recepció aspektusai........................................................31

2.2.1. A románok nemzeti költőjéről ..................................................31

2.2.2. Magyar nyelvű nekrológok, szócikkek, életrajzi

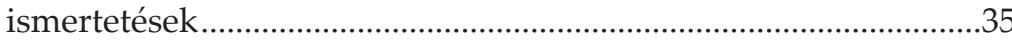

2.2.3. Az első magyar nyelvü értelmezések .....................................39

3. Román költészet magyar nyelven a 19. század végén.

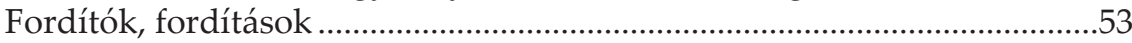

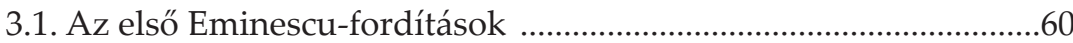

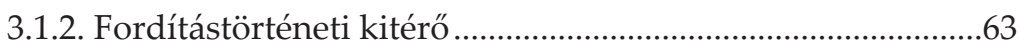

3.2. Sándor József mint fordító .................................................................73

3.2.1. Elsőként fordítani - érték és történetiség................................74

3.2.2. Egy (fordítói) karriertörténet ....................................................78

3.3. Az első fordításkötet. A recepció visszásságai ....................................88

3.3.1. Brán Lőrinc/Laurențiu Bran ...................................................8

3.3.2. Fordítói gyakorlat és kötetszerkesztési poétikák ....................95

3.4. Fordítók, intenciók és kánon. Zárógondolatok.............................100

4. Kultúrák találkozása: románok a kolozsvári egyetemen (1872-1918)..107

4.1. A kolozsvári egyetem és bölcsészkara..........................................109

4.2. Egyetemi hallgatók és adattáraik .....................................................117

4.2.1. A prozopográfiai kutatások margójára .................................117

4.2.2. Egyetemlátogatás, egyéni és közösségi preferenciák..........120

4.2.3. Román bölcsésztudorok. Címek, értekezések, életpályák .......133 
4.3. A román egyetemi hallgatók Iulia-egylete.

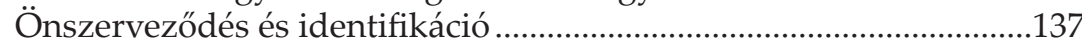

4.4. Összegzés ……..................................................................................148

5. Kolozsvári értelmiségiek. Egyetemi oktatók és identitásaik a 19. század

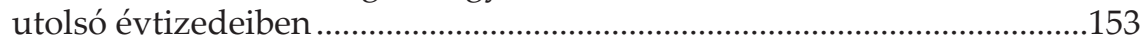

5.1. Többnyelvűség - nemzeti és egyetemes …………………….......154

5.1.1. Meltzl Hugó ........................................................................154

5.1.2. A társszerkesztő Brassai.........................................................162

5.1.3. Felekezeti identitás és nemzeti irodalmak ...........................170

5.2. Grigore Moldovántól Moldován Gergelyig ...................................175

5.2.1. A Moldován-irodalom dilemmái .........................................175

5.2.2. Fordítás - népisme. Moldován, az etnográfus .....................178

5.2.3. Karrier és életmü. A szövegek mögötti én .............................187

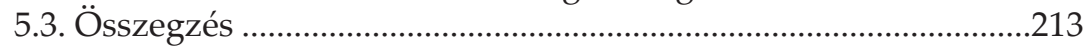

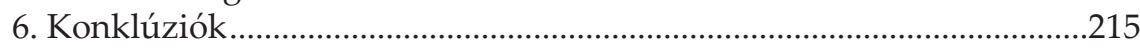

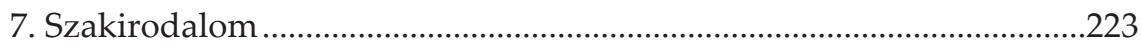

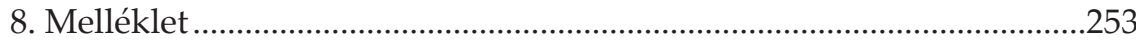

8.1. Kulturális egyezmény ...................................................................253

8.2. A Kolozsvári Magyar Királyi Ferenc József Tudományegyetem

Bölcsészkara román diákjai....................................................................255

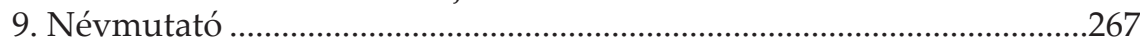

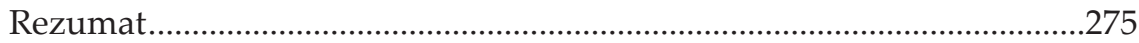

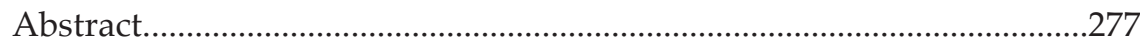




\section{BEVEZETÉS}

Az Osztrák-Magyar Monarchia utolsó évtizedeinek történelmi-kulturális kontextusába vezeti olvasóit e kötet. Nem recepciótörténeti, sem monografikus igénnyel megírt komparatisztikai munka ez, hanem egy kapcsolattörténeti kísérlet, amely témaválasztásában, forrásaiban is gazdagítani látszik a 19. századi magyar-román fordítástörténetet. ${ }^{1}$

A román irodalom korai recepciója az egymásról nem tudó alkalmi fordítók magyar nyelvű szövegeinek folyóiratokban szórt közlését jelenti. A kapcsolattörténeti szakirodalom értékeli ugyan ezeket az úttörő jellegü fordításokat - amelyek minél korábbiak, annál értékesebbek, hiszen a két irodalom közötti kapcsolatok kiindulópontjai -, viszont elmarasztalja a fordítókat szövegeik művészi értékeinek hiánya és dilettantizmusa miatt.

Az első Eminescu-fordításoktól induló kutatás nem az irodalmi értékekre irányult, hanem az egyes szövegek használatát vizsgálta, így nem csak a román költemény magyar nyelvü változata érdekelt, hanem a fordítás és megjelenési közege, a fordítói intenciók, kompetenciák és preferenciák rekonstruálása, hiszen az előfeltevéseknek kiszolgáltatott az, hogy kik, mit, mikor, miért és hogyan fordítanak, és minek következtében válik a fordítás egyik ideológiájává a kultúra-közvetítés. Ezért keretezi a vizsgált kapcsolattörténetet a 19. század utolsó évtizedeinek értelmiségtörténeti megközelítése, hiszen kulturális közvetítésről lévén szó, a közvetítők és/vagy a fordítások létrehozói ekkor még föszereplői a kapcsolatok alakulásának.

\footnotetext{
${ }^{1}$ Lásd erről legutóbb FARKas 2008, illetve FARKAs 2010.
} 
A kötet módszertani előfeltevéseit különböző diszciplínák alakították² Ezek számos ponton összekapcsolódnak. Az antropológiai, társadalomtörténeti alapozottság mellett a történetiség, a mikrostrukturális vizsgálatok, az eseményszerúség, a kontextualizmus és a kutatói reflexivitás visszatérő elemeknek bizonyulnak. Kutatásaimat elsősorban ezek határozták meg, és a források feldolgozását, megértését és értelmezését is ezek az elméletek segítették.

Az első fejezet a román irodalomban debütáló Mihai Eminescu korai publikációival foglalkozik, különösen azért, mert polemikus jellegü publicisztikája kapcsán olyan politikai érdekeltségű forrásokra (országgyűlési, képviselőházi jegyzőkönyvekre) irányíthatja a figyelmet, amelyek egyfelől a nemzetiségi kérdést, másfelől a kulturális intézményrendszer kiépítését tematizálják, és kapcsolattörténeti szempontból is megfontolandóak. E két témakör a 19. század második felétől egyre fontosabbnak látszó nemzetiesedés folyamatával áll kapcsolatban. Ez az a fejezet tulajdonképpen, amely mintegy kiindulópontul szolgál a kötet további kérdésfelvetéséhez.

A fordítások szövegkörnyezetét feltárva átértelmeződhet a magyarországi folyóirat kultúrával kapcsolatos tudásunk, hiszen olyan lokális - eddig csupán sajtótörténeti adatként számottevő - lapok adnak teret a román irodalom magyar fordításainak, amelyek a kapcsolattörténet felől jelentőségeknek minősülnek. A Kolozsvári Közlöny, a Szilágy-Somlyó alkalmi lapszámában vagy tárcarovatában a magyar Eminescu-versek jelenléte részint a lapszerkesztők, részint a potenciális - többnyelvü, több kultúrájú erdélyi - olvasóközönség igényét, részint a fordítást megkövetelő, esetünkben a magyar és román nyelvi jártassággal rendelkező, legfentebb kettős szocializációjú értelmiségiek (a politikus-intézményszervező Sándor József, a teológus Laurențiu Bran) írásgyakorlatait reprezentálja.

Ezek után a kötet második fele értelemszerüen kapcsolódik ahhoz a módszertani kérdésfelvetéshez, amely a szocializációs folyamatok következményeként látja a több kultúrában való jártasságot és annak kamatoztatását, amit a regionális sajátosságok szerencsésen megalapoznak. A kolozsvári magyar királyi, majd Ferenc József Tudományegyetem bölcsészkara román nemzetiségü diákjainak azonosítása párbeszédet folytat mind az egyetemtörténeti, mind a kapcsolattörténeti kutatások eddigi eredményeivel. Nagyon termékenynek tűnt ez a vizsgálat, mert egyértelmúen jelezte, hogy a román nyelv és irodalom tanszék oktatási kínálata a 19. század végén a román nemzetiségü diákok számára bírt vonzóerővel.

\footnotetext{
${ }^{2}$ Antropológiai ihletettségű fordításelmélet, a történeti keresztezés módszertana, a komparatisztika történeti és kurrens elméletei, kontextualizmus. Vö. N. Kovács (szerk.) 2004., WERnER-Zimmermann 2007., TAKáts 2007.
} 
A kötet olyan értelmiségi életpályák felől értelmezi újra a kapcsolattörténetet, amelyek a kultúrák, és az általuk megjelenített nyelvi-nemzeti sajátosságok közötti viszonyokat különbözőképpen látják. A kultúrák közötti kapcsolatok értelmiségtörténeti kontextusa egyik olyan lehetséges keretét jelenti a kutatásnak, amely koherenssé tudja szervezni az esettanulmányokból építkező disszertációt. Ennek kapcsán Takáts Józsefet idézhetjük, aki az irodalomtörténet-írást egy skandináv etnológus megállapításaival legitimálja, amikor az etnológia öt erényét saját tudományága esetében is érvényesnek találja: „,történeti, a mindennapok iránt érdeklődő, esettanulmány-központú, kontextualista s az elméletekhez való viszony terén barkácsoló jellegü". ${ }^{3}$

A multikulturalitás és multietnicitás bonyolult kérdésköre elválaszthatatlan tehát a 19. század vége Magyarországának kapcsolattörténeti vizsgálatától. Következésképp, a többnyelvű, többkultúrájú, és ezért mára kevésbé egyértelműnek tűnő egyéni és közösségi identitások történelmi (társadalmi-, felekezeti-, szakmai stb.) életvilágába vezet el a kötet, amely esettanulmányok soraként az értelmiségtörténet felől szervezhető koherens elbeszélésbe.

A most megjelenő kötet a BBTE Bölcsészettudományi Karán 2011-ben megvédett doktori disszertációm szerkesztett változata. Kutatásaim irányításáért, a szakmai és szellemi támogatásért köszönetet mondok Kozma Dezsőnek, a doktori dolgozatom irányítójának, T. Szabó Leventének - aki mind elméleti, mind gyakorlati téren hasznos tanácsokkal látott el -, a doktori dolgozat véleményezőinek (Egyed Emesének, Tapodi Zsuzsának, Lucian Nastasă-Kovácsnak), a BBTE Bölcsészkara magyar tanszékein dolgozó kollégáknak, volt évfolyamtársaknak, a magyar tanszéki könyvtár munkatársainak, az Unitárius Egyház Nagykönyvtára és Gyüjtőlevéltára vezetőinek, Kovács Sándornak és B. Molnár Lehelnek. Illesse köszönet a budapesti ELTE román tanszékének tanárait, Farkas Jenőt és Miskolczy Ambrust, a 18-19. Századi Magyar Irodalomtörténeti Tanszék munkatársát, Szilágyi Mártont, a Szegedi Tudományegyetem Klasszikus Magyar Irodalom tanszékét, doktori munkacsoportját.

\footnotetext{
3 TAKÁTs 2007.
} 



\section{MIHAI EMINESCU A MAGYARORSZÁGI (ROMÁN) IRODALOMBAN}

Mihai Eminescu Atât de fragedă című költeményét a magyar nyelven olvasó kolozsváriak már 1885 karácsonyán megismerhették Cseresnyefa fehér virága címmel. ${ }^{4}$ Az újrafordításoknak köszönhetően a 20. század harmincas éveiben, majd 1950-ben bizonyára népesebb olvasótábora volt a magyarra átültetett román költeménynek. De miért problematikus ez a történet? Mert a Cseresnyefa fehér virágától jut el az Oly zsenge vagy-ig? Román-magyar irodalmi kapcsolatokkal foglalkozó kutatásaim innen, a magyar Eminescu-recepció kezdetétől indultak.

A román és magyar nyelvü, Eminescuval kortárs értelmező jellegü irodalom számos olyan kérdést körvonalaz, amelyek átlépnek mind az irodalom, mind a fordítás szükebb jelentésén és sokkal rétegzettebbnek, árnyaltabbnak és nehezebben megragadhatónak mutatják a kérdéskört. Amikor ezt a nehézséget említem, eltekintek a kérdés nemzeti jelentőségeitől, attól, hogy Mihai Eminescut a modern román irodalom kulcsfigurájaként tartják számon. A korai recepciót vizsgáló fejezet az irodalomtörténeti szempontok mellett kénytelen intézménytörténeti, kulturális és politikai kérdésekkel foglalkozni, miközben fordításelméleti dilemmákkal is találkozik.

A magyarországi román irodalmat érintőlegesen szóba hozó, Mihai Eminescu életmúvét és annak magyar nyelvű recepcióját taglaló fejezet láttatni enged olyan kérdéseket, amelyek a kapcsolattörténet sajátjai, és amelyek tárgyalása előtanulmányként szolgál az értelmiségtörténeti megközelítéshez, a kultúrák közötti kapcsolatok alaposabb megértéséhez.

\footnotetext{
${ }^{4}$ Ekkor közli Sándor József az általa szerkesztett Kolozsvári Közlönyben Eminescu versfordítását Cseresnyefa fehér virága címen.

${ }^{5}$ Franyó Zoltán az 1960-as években Oly zsenge vagy címen fordítja magyarra ugyanazt a verset. Mindkét szövegváltozathoz lásd Doмокоs 1966.
} 


\subsection{A költő első publikációi}

Mihai Eminescu 16 évesen, 1866-ban Iosif Vulcan Pesten megjelenő Familia c. lapjához ${ }^{6}$ küldi be első költeményeit, így először a magyarországi román nyelvü irodalom körforgásába kerül be. Eminescu abban az időben a csernovici iskola patvarista diákja, Aron Pumnul tanítványa. A Familiában közölt versek jelentik Eminescu költészetének indulását, mindamellett, hogy a csernovici intézménnyel kapcsolatos, ebben az időben megjelent két alkalmi költeményéről is tud a román irodalomtörténet. Milyen kontextust teremt a Familia az Eminescu-versek számára?

Ha megvizsgáljuk az 1865 júniusában induló ismeretterjesztő és szépirodalmi lapot, láthatóvá válik tudatos szerkesztése. ${ }^{7}$ Úgy kíván családi lap lenni a román olvasók számára, hogy a szűkebb, lokális és a tágabb olvasóközönséget is megszólítja.

Iosif Vulcan a nagyváradiak számára ismerős kereskedő-mecénás Nicolae Zsiga portréjával és életrajzával indít, akit címlapon Dimitrie Bolintineanu, a „nemzeti bárd”, majd Timotei Cipariu tudós és az Erdélyi Iskola több tagja követ. A nemzeti költőként tisztelt Bolintineanu mellett Vasile Alecsandri költőt is korán bemutatja a hetilap. Mihai Eminescu Familia-beli publikációi idejében nem kerül címlapra: neve nem ismerős, nem figyelemfelkeltő információ, hiszen a fiatal (költő) ekkor jelentkezik első verseivel a román nyelven olvasó (nem csak) magyarországi közönség előtt. A később román panteonként összeszerkesztett, címlapon szereplő portrékéletrajzok nemzeti kánonként tételeződnek. ${ }^{8}$

A lapban a biográfiákat minden esetben a bemutatott költők művei követik. Más rovat részeiként tekintendők a további vers-, prózaközlések vagy népköltészeti gyüjtések, ennél fogva hangsúlyuk sem akkora, mint a címlapi értelmiségiek esetében. Több verset olvashatunk Dimitrie Bolintineanu ${ }^{9}$, Iosif Vulcan ${ }^{10}$, H. Grandea ${ }^{11}$, G. Tăutu' ${ }^{12}$, Vasile Alecsandri ${ }^{13}$, A.

${ }^{6}$ Familia. Foia enciclopedica si beletristica cu ilustratiuni, proprietariu, redactoru si editoru: Iosif Vulcanu, Pesta, s'a tiparitu prin Alesandru Kocsi (in tipografia lui Érkövy, Galgóczy si Kocsi), Piata de pesci nr. 9.

${ }^{7}$ Lásd erről bővebben: Crișan 1973, Drimba 1974, Petrușan f.a., Ábrahám 2004.

${ }^{8}$ Lásd erről bővebben: BERKI 2008a.

${ }^{9}$ Dimitrie Bolintineanu (1825, Bolintin-Vale-1872, Bukarest) nemzeti költőként elismert a 19. században román nyelvterületen, de 1852-es verskötete angol, majd francia fordításban is olvasható az 1850-es években. Az 1848/49-es forradalom után Párizsba emigrál. Vö. VulCaN 1869.

${ }^{10}$ Iosif Vulcan (1841, Hollód-1907, Nagyvárad) bihari román értelmiségi, jogász, lapszerkesztő, intézményszervező, író, 1891-től a Román Tudományos Akadémia rendes tagja.

${ }^{11}$ H. Grandea (1843-1897) népszerű költő a 19. század közepén, később újságszerkesztő, Ioan Slavici munkatársa, az Orientul lap indítója.

${ }^{12} \mathrm{G}$. Tăutu (1823, Dorohoi-1885), költő.

${ }^{13}$ Vasile Alecsandri (1821, Bacău-1890, Mirceşti) író, folklorista, politikus, a Román Tudományos Akadémia alapító tagja. 
Densusianu ${ }^{14}$ tollából, mielőtt Eminescu versei megjelennének. 1866. január 15/27-én ${ }^{15}$, a 2. számban, Aron Pumnul-nekrológot közöl a lap. Arra a tanárra emlékezik, amely a csernovici iskola jelentős tudós-oktatója, Eminescu személyiségének alakítója ${ }^{16}$. Később, a február 25./március 6-i 6. számban közlik Eminescu beküldött költeményét, De-aş avé... címmel, szerkesztői üzenetben pedig a pályakezdő költőt köszöntik. ${ }^{17}$ Egy, a szerkesztő számára ismeretlen fiatal legelső verseiről van tehát szó.

A megjelenés, majd a folyamatos jelenlét a lapban még nem biztosít akkora ismertséget a fiatal számára, mint amekkorával költőtársai már rendelkeznek. Ha a kortársi közeget nézzük, akkor a Familia kontextusában nehezen látható a Vulcan - Pumnul - Eminescu együttállás. Például az Aron Pumnul-nekrológ közlése csak laza kapcsolatba hozható Eminescu szövegeinek beküldési idejével. Valószínű, hogy Pumnul könyvtárában olvashatta Eminescu a Familia c. lapot, és látott benne publikációs lehetóséget. Másfelől, az 1865-ben alapított lap is gyermekcipőben jár még, akkor kezdi el kialakítani szerzői, munkatársi körét és ez lehet egyik oka annak, hogy a pályakezdőknek nagyobb teret szán.

Két számmal Eminescu első versének megjelenése után, Vulcan szerkesztői üzenetéből tudható, hogy nem egyszeri közlésre számított Emines$\mathrm{cu}$, valamint az is, hogy kulturális különbségek adódtak köztük: Vulcan kéri, hogy az általuk használt latinista helyesírást kövesse.

Három hónappal az első közlés után, májusban olvasható Eminescu második verse, amelyet nem kísér szerkesztői üzenet. A rákövetkező lapszám címoldalán Aron Pumnul-életrajz található, amelyben Vulcan, a szerző, nem teremt összefüggést a csernovici diák és Pumnul, a tanár között. ${ }^{18}$

A lapszerkesztő számára látszólag nincs különösebb jelentősége e beküldött verseknek. Az talán fontos lehet, hogy mikortól kerülnek címlapra Eminescu versei. A harmadik (Din străinătate), negyedik (La Bucovina) publikációja már a második oldalra kerül, az ötödik (Speranța) és hatodik (Misterele nopții) a címlapra ${ }^{19}$. Szeptemberre, az együttműködés kilencedik

\footnotetext{
${ }^{14}$ Aron Densusianu (1837, Densus-1900, Iaşi), irodalomtörténész, folklorista, költő, 1877-től a Román Tudományos Akadémia levelező tagja.

${ }^{15}$ A lap jelzi a kétféle időszámítást, azaz azt, hogy a (görögkeleti) románság nem követi az ún. Gergely-naptárt, amelyet Magyarország már a 16. században elfogadott.

${ }^{16}$ Aron Pumnul görög katolikus tanár, Balázsfalván, Kolozsváron és Bécsben tanult, 1848/49 után menekült Iaşi-ba és Bukovinába, ahol a Hurmuzachi család pártfogolta, majd román tanárként dolgozott. „Ő hozta be Bukovinába a latin betüket a rumén írásnál és igyekezett ezt tisztán fonetikus alapra fektetni”. Vö. SzINNYEI 1891-1914.

${ }^{17} \mathrm{Cu}$ bucuria deschidemu colónele fóiei nóstre acestui june numai de 16 ani, care cu primele sale incercari poetice tramise noue ne-a surprinsu placutu. Red. = Familia 1866/2, 68. [Szeretettel nyitjuk meg lapunk hasábjait a 16 éves fiatal előtt, aki első poétai kísérleteivel kellemes meglepetésben részesített - fordítás általam, B.T.]

${ }^{18}$ Arom Pumnul = Familia 1866/15, 169-171.

${ }^{19}$ Sperantia $=$ Familia $1866 / 29$.
} 
hónapjában történik ez meg. Persze, 19. századi viszonylatban másként értelmeződik ez a kilenc hónap, hiszen más időviszonyokkal, a kommunikáció sajátos lehetőségeivel is számolnunk kell: mennyi idő szükséges egy levélváltáshoz, milyen gyakorisággal születnek a költemények, milyen ritmusban küldi őket Eminescu, Vulcan akkor épp mivel foglalatoskodik, mennyire telített tartalmilag a lap és így tovább. A hatodik versnél megszakad a közreműködés és folytatására csak 1883-ban kerül sor.

1866-ban, amikor a Familiánál jelentkezik Eminescu, Erdélyben tartózkodik, és a görög katolikus szeminárium diákjaként pár hónapot Balázsfalván tölt. Nem egyértelmű beiratkozásának oka. Eltérő véleményeket találunk a szakirodalomban: csernovici tanára, Aron Pumnul mintájára keresi fel az erdélyi iskolát, vagy vizsgázni szeretne, vagy Nagyszeben fele átutazóban látogat el ide. Mindenképp, életének fontos kitéróje a balázsfalvi időszak. Ismeretségeket köt a román diákokkal: Filimon Ileával, St. Cacoveanuval, Mihai Strajanuval, akikkel később Bukarestben is lesz alkalma találkozni, hiszen mindannyian az akkori Romániában keresnek megélhetést. ${ }^{20} \mathrm{E}$ fiatalok generációját meghatározó értelmiségiek (mind például Aron Pumnul, a Tribuna szerkesztője, Ioan Slavici, a Junimea vezetője, Titu Maiorescu valamennyien mind Erdélyből vándoroltak ki. A később nemzeti költőként elképzelt Eminescu identitását kevésbé befolyásolta származása, sokkal inkább (rendszertelen) iskolai tapasztalatai, önálló és vándorszínészi utazásai, külföldi tanulmányai során kialakított kapcsolatai, majd a Junimea értelmiségi közege határozta meg. Mihai Eminescu Magyarországon, majd Bécsben ismerkedhetett meg jobban az ott élő/tanuló erdélyi románok egy részének politikai terveivel is. ${ }^{21} \mathrm{~A}$ monarchiabeli románok nemzetiségi törekvései hatására írja politikai cikkeit is. Gáldi László találóan állapítja meg, hogy „Eminescu a nagy-román problémákat is az erdélyiek szemüvegén át nézte, azok felfogását tette magáévá, s így akarva-akaratlan, valósággal részesévé vált a történeti Magyarország szellemi közösségének". 22

Kérdés, tehát, hogy milyen értelemben volt román Eminescu, és az egységes román nemzet építését óhajtó kortársai. Főként felekezeti oktatásban volt részük, egyházi vagy magánszemélyek alapítványától kaptak ösztöndíjat, amely továbbtanulásukat biztosította. Mintakövetőek voltak olyan értelemben is, hogy elődeikhez hasonlóan ugyanazokban a városrészekben laktak, találkoztak, olvasó- és diáktársaságokba szerveződtek egy-egy szellemi irányító köré. Románia függetlenedése után mind a külföldön, mind a Magyarországon élő román értelmiségiek számára Bukarest migrá-

\footnotetext{
${ }^{20}$ RÉGENi 1958, BuZAȘi 1994.

${ }^{21}$ Vö. GÁLDi 1942, 126.

${ }^{22}$ Gáldi 1942, 128.
} 
ciós és akár komoly szakmai lehetőségekkel kecsegtető centrumként értelmeződött. Emellett, irodalmi szempontból a Junimea és Titu Maiorescu által kidolgozott kánonépítési folyamatok hatalmi diskurzusként települtek rá az addigi kulturális viszonyrendszerekre, illetve vonzóerőt jelentettek főként az útkereső fiatalabb generáció számára. Ez a vonzóerő akár anyagi támogatás formáját is képezhette. Például Eminescu is e támogatás révén végezhetett külföldi tanulmányokat. Hazatérésekor álláskeresésében, betegsége kezelésében, az anyagi háttér megteremtésében is segítségére volt ez a szellemi közeg.

A földrajzi távolság mellett a szellemi eltávolodás járult hozzá ahhoz, hogy megszakadjon a kapcsolata a Familiával. A lapnak a későbbi irodalomtörténészi értékelések tulajdonítanak jelentőséget, akárcsak Iosif Vulcannak vagy Aron Pumnulnak, mert Eminescu kanonizációjában történetileg ők jelentik a kiindulási pontot.

Tüzetesen átvizsgálva a Familia lapszámait, megállapítható, hogy Iosif Vulcan megjelentette a hozzá beküldött szövegeket, és nem viszonyult kritikailag hozzájuk. Lapja enciklopédikus jellege miatt történhetett meg, hogy a különböző írók egymástól eltérő véleményeinek, elkülönülő irodalmi elképzeléseknek és felfogásoknak megjelenési közege lehetett. Fiatal tehetségeket értékelés nélkül népszerüsítő szerkesztői gesztusa tökéletesen illeszkedett lapja profiljához: a román kultúra és annak nemzeti értékei megmutatása felől a román közösség széles rétegeinek civilizálására törekedett a szerkesztő.

Lucian Drimba, a Vulcan-életmű kutatója helyesen állapítja meg, hogy a lapszerkesztő Vulcan nem járult hozzá a fiatalok költői kibontakozásához, irodalmi formálódásához; érdeme annyi, hogy lapjában teret nyitott első próbálkozásaik számára. ${ }^{23}$ Ha egyetértünk ezzel, akkor a dolog másik oldalát is ki kell emelnünk, jelesül: a Familiában debütáló fiatalok ismerték a lap profilját és alkalmazkodtak költeményeikkel ahhoz. ${ }^{24}$ Drimba hívja fel a figyelmet arra is, hogy az a szerkesztői megjegyzés, amely Eminescu első versét kíséri, nem egyedi a lapban, hiszen például Mihai Strajan, 19. századi költőt is ez a mondat mutatja be az olvasóknak: „örömmel nyitjuk meg lapunk hasábjait ez igazi költői tehetség számára"25. Ilyenformán túloz a szakirodalom, amikor Eminescu debütálása kapcsán felnagyítja Vulcan szerepét. Nyilván a modernné olvasás következtében van erre szükség.

\footnotetext{
${ }^{23}$ Vö. Drimba 1974, 72.

${ }^{24}$ Eminescu például a Din străinătate és Speranța című verseivel a magyar-német szentimentalizmushoz. Vö. GÁldi 1935.

${ }^{25} \mathrm{Uo}$.
} 
1883-ban és 1884-ben az Eminescu-versek ${ }^{26}$ közlése a lapban mind Vulcan, mind a költő számára más jelentéssel bírtak. Vulcan ekkor már „otthon", Nagyváradon szerkeszti a lapot, (népköltészeti fordításai és tanulmánya révén) tagja a Kisfaludy Társaságnak, kapcsolatba kerül a Román Tudományos Akadémiával. Eminescu pedig külföldi tanulmányai, csavargásai, a Iaşi-ban töltött idő, számos verse, írása megjelenése után Bukarestben hírlapírással foglalkozik. Ekkor már egymást személyesen ismerik. E későbbi verseiért Vulcan honoráriumot fizet, ami a költô számára az első ilyen anyagi elismerés. ${ }^{27}$

Arra hívja fel a figyelmet ez a gesztus, hogy eltérő módon müködött a román kultúrában a szerkesztő-lapvállalkozás és bedolgozó szerzők közötti viszony. Amíg a hatvanas években, amikor a lap is gyermekcipőben jár, Vulcan nem fizet tiszteletdíjat Eminescunak, addig két évtizeddel később, Nagyváradon, vidékinek számító környezetben, más lehetőségek között szerkesztve a már történetiséggel rendelkező lapot, megteheti azt. Másfelől, román vonatkozásban is érdemes lenne látni a honorárium kérdését, illetve a szellemi alkotómunka és annak pénzben mérhető értékét, mindazt, ami az irodalom piacosodásához, ezáltal pedig hivatásosodásához csatolja a fent említett problémát. ${ }^{28}$

A történetet folytatva, a későbbiekben sem szakad meg Vulcan kapcsolata a költővel, hiszen lapjában közvetett módon figyeli a költő életének alakulását: tájékoztatja olvasóit annak egészségi állapotáról, a számára felajánlott anyagi segítségekről, a költő szerelmének, Veronica Miclenek a haláláról. Eminescu halála után őrzi emlékét, olvasóit is felszólítja erre. A német nyelvű Eminescu-fordításokról, a megzenésített versekről is hírt ad. ${ }^{29}$

Eminescu anyagi helyzeténél elidőzve, élettörténetéből nyilvánvaló, hogy az irodalmi munka (versközlések, lapszerkesztés, hírlapi cikkek), vagy az értelmiségi foglalkozások (könyvtáros, tanár) számára nem biztosítottak megélhetést. Ezt pedig több tényező befolyásolhatta: részben alkata, személyisége, részben a kialakulóban lévő irodalmi nyilvánosság, az (össznépességhez képest) csekély számú értelmiségi és befogadó közönség, és nem utolsósorban a román író fogalma, szereplehetőségei ${ }^{30}$ és

\footnotetext{
${ }^{26}$ 1883-ban: S-a dus amorul, Când amintirea, De-acuma (Adio!), Ce e amorul?, Pe lângă plopii fără soț, 1884-ben: Din noaptea c. verseket közli Vulcan.

${ }^{27}$ Drimba 1994, 22.

${ }^{28}$ A magyar irodalom kapcsán a hivatásosodás kérdését különböző társadalomtörténeti aspektusaiból közelíti meg számos írásában T. Szabó Levente.

${ }^{29}$ Vö. Drimba 1994.

${ }^{30}$ A 19. század második felében, a 20. század elején még nagyrészt egybeesik az írói és politikai szerep az értelmiségiek többségénél. Vö. BoıA 2009.
} 
szerepértelmezései, valamint az irodalom és tudomány pozíciója, használata és jelentései az akkori román társadalomban.

\subsubsection{Színház és (politikai) publicisztika}

Az írás közegén kívül Mihai Eminescu és Vulcan személyesen is találkozott, amikor Vulcan Iustin Popfiuval ${ }^{31} 1868$-ban Aradra utazik, hogy láthassa a vándorszíntársulat jeles tagját, Eminescut. Később Budapesten és Bukarestben is hasonló alkalmakon találkoztak. Egy olyan intézmény közelében kerültek közvetlen kapcsolatba, amely hiányában vált létezővé az 1860-as évek (magyarországi) románsága számára. Mivel mind Vulcan, mind Eminescu kapcsolódik a román színügy kérdéséhez, jelen alfejezetben különböző forrásokon vizsgálom a román intézményépítő törekvéseket, hiszen azok kettejük koncepciója mellett általánosabb kérdéseket is felvetnek.

Amint arra legutóbb Farkas Jenő ismét felhívta a figyelmet, Eminescu életmúve több szállal kötődik a magyar fővároshoz. ${ }^{32}$ Bár Eminescu költőként vonult be a modern kori román irodalomtörténetbe, mára az életművét tárgyaló román és magyar szakirodalom publicisztikájára is figyel. Színházi tárgyú, majd politikai cikkei magyarországi román lapokban láttak napvilágot. Nem Iosif Vulcan lapja az egyetlen magyarországi közeg, amely teret ad a fiatal román költőnek. ${ }^{33}$

„Az ifjú román poéta első színibírálatát az erdélyi románok Albina (1870) című újságjában publikálta, majd első politikai cikkeit Alexandru Roman lapjában (Federațiunea, 1870)".34

Iosif Vulcan mellett egy újabb magyarországi román lapszerkesztővel találkozunk a pesti egyetem román tanszékének tanára, Alexandru Roman személyében. Ố huszonegy évig volt országgyưlési képviselő Magyarországon. Ezzel kapcsolatos tevékenysége Román Sándor név alatt kereshető vissza az országgyülési jegyzőkönyvekben.

Eminescu politikai cikksorozata a magyar országgyűlés 1870. évi februári „,belügyi költségvetési” vitájához kapcsolódik..$^{35}$

\footnotetext{
${ }^{31}$ Görög katolikus esperes, tanár, költő. Irodalmi jelentőségéről lásd: Simuț 2010.

${ }^{32}$ FARKAS 2010, különösen 35-91.

${ }^{33}$ Eminescun kívül Miron Pompiliu, George Coşbuc, Octavian Goga is a Familiában közli első verseit.

${ }^{34}$ FARKAS 2008.

${ }^{35}$ Farkas 2008, Farkas 2010.
} 


\subsubsection{1. „Nemzeti” intézmény és politikum}

Azért tartom fontosnak a „belügyi vita” alaposabb elemzését, mert részint kiváltó oka a politikai cikksorozatnak, részint olyan kérdésekre világít rá, mint a magyarországi etnikumok és azok képviselőinek politikai önértelmezései, szerepkörei, lehetőségei a magyar országgyűlésben. Kutatásaim szempontjából nagyobb jelentőséggel bírt egy az irodalom külterületéhez ${ }^{36}$ tartozó szövegkorpusz vizsgálata és esetleges irodalomtörténeti következményeinek belátása, mint a költőként érdekes Eminescu politikai cikkeinek újraértelmezése. ${ }^{37}$ Farkas Jenő részletesen elemzi és fordításban közli Eminescu politikai publicisztikáját legutóbb megjelent tanulmánykötetében ${ }^{38}$, de e tárgyban Nagy Levente ironikus felütésü szövegére is utalhatunk, amely szintén ezt a kérdést tárgyalja. ${ }^{39}$ Ezért mellőzöm a Varro álnévvel szignált cikkek vizsgálatát.

Az Alexandru Roman által 1868 óta szerkesztett Federațiuneában megjelent cikkek következménye mind a szerkesztő, mind a cikkíró Eminescu számára sajtóper. Alexandru Roman korábban, 1861-től a Concordia c. lapot szerkeszti Pesten, amely két sajtóperbe keveredik, főszerkesztőjét, Sigismund Popot, (akinek a lánya Roman felesége) pénz- és börtönbüntetésre ítélik. ${ }^{40}$ Ezek a sajtóperek azért is érdekesek, mert a perbe fogott szerkesztők országgyưlési képviselők. Emiatt az országgyúlés elé kerül például annak megvitatása, hogy büntethetö-e és miként egy országgyülési képviselö. ${ }^{41}$

A magyar országgyúlésben 1870. február 8-ától szerepel napirendi pontként a belügyminiszteri költségvetés tárgyalása, ami egy hétig tart. A tárgyalás során előkerült nagyobb vitakérdések - a növekvő költségvetés és az adófizetők erejének csökkenése, a nagy kiadást jelentő erdélyi

\footnotetext{
${ }^{36}$ Vö. TAKÁTs 2007. Az irodalom külpolitikája iránt érdeklődő, az irodalomtörténetet művelődéstörténetként értelmező kutató szociológiai, politikai eszmetörténeti, tudományfilozófiai, szociállingvisztikai, kognitív pszichológiai érveket sorakoztat fel amellett, hogy az irodalmi szövegek életvilága (az irodalom külterülete) mennyire fontos, hiszen annak körülményeit hordozzák magukkal, abban múködtek eseményjellegüen.

${ }^{37}$ A vizsgált források megragadhatóbbá teszik a "nemzeti” és „,nemzetiségi” irodalom, színház, kultúra intézményeinek alapítását, működtetését, a hozzájuk való viszonyulást, hiszen kiderül, hogy mindezek politikai döntések eredményei (is). Egy-egy létrehozása előtt kudarcba fulladt intézményalapító kezdeményezés tehát nem csak a kezdeményező közösség anyagi és személyi forrásain múlik.

${ }^{38}$ FARKAS 2010.

${ }^{39}$ NAGY 2001.

${ }^{40}$ Vö. Dinurseni 1897, 12-15., Farkas 2010.

${ }^{41}$ Román Sándor néven visszakereshetők Alexandru Roman interpellációi, hozzászólásai, valamint a sajtópereivel kapcsolatos viták. Például az 1868. május 7-i országgyűlés tárgyalja Roman mentelmi ügyét. Továbbá: Képviselőházi Irományok 1869/182, 184, 200, 201, 203, 238. [http://mpgy.ogyk.hu - utolsó látogatás: 2012. május 7.]
} 
királyi biztos megszüntetése (sőt Erdély és Magyarország uniójának viszszásságai is ${ }^{42}$ ), a főispánok fizetésének aránytalan nagysága (például az egyetemi tanárok fizetéséhez képest) - között többször felbukkan a nemzetiségi kérdés a román képviselők felszólalásaiban. Igaz ugyan, hogy már a vita elején felveti Lazăr Ionescu azt, hogy a nemzetiségi kérdés - például a nemzetiségi nyelvhasználat biztosítása a közigazgatásban - belügyi kérdés, mégsem ez a pillanat képezi vizsgálódásom célpontját.

A vita harmadik napján tárgyalják a nemzeti színházra előirányzott 62000 forintot, ezt Széll Kálmán jegyző jelenti be. Öt követően szólal fel Zsedényi Ede előadó: „1869-re volt 58000 frt, tehát 1870-re több 4000 frt. Miután a miniszter jelentése szerint két új zenatanár felvétele és a házbér felemeltetése 1000 frttal nagyobb segélyt igényel, a bizottság a dalmü- és zeneképezdének támogatására 51000 forintot s a nyugdíj alapjának segélyezésére 8000 forintot, összesen tehát 59000 forintot megszavazandónak, a 3. rovat alatti 3000 forintot pedig törlendőnek véli". ${ }^{43} \mathrm{~A}$ jegyző és az előadó felterjesztése különbözik. Míg az első a színház támogatását említi, addig a második a zenetanárról, dalmü-, és zeneképezdéről beszél. Ez a szövegében elkülönülő napirendi pont teszi lehetővé a román képviselők számára a nemzetiségi kérdés konkrétabb, tematikus felvetését: a román nemzeti színház segélyezésének szükségességét.

Az erdélyi románok kulturális szervezete, az ASTRA tagjaként Iosif Vulcan korábban már felhívja a figyelmet a színházlétesítés kérdésére. 1869-ben a Familia címlapján szólítja fel olvasóit egy nemzeti színház alapítására, azzal érvelve, hogy a kultúrának nemzetivé kell válnia megmaradása érdekében ${ }^{44}$ Idővel a hozzá beküldött, mások által írt, színházzal kapcsolatos szövegeket rendszeresen közli a címlapon. ${ }^{45}$ Amikor később létrejön a román nemzeti színház anyagi megalapozását célzó egyesület (Societatea pentru fond de teatru național), az enciklopédikus, szépirodalmi, illusztrált Familia ${ }^{46}$ e társaság közlönyévé is válik. Mellékesen megjegyzem, hogy a Familia minden, a román kultúrával kapcsolatos aktuális kérdéssel napirenden van, ennek köszönhetően jogosan népszerúsíti a magyarországi románság körében az őket is érintő (nemzetiségi) kulturális

\footnotetext{
${ }^{42}$ Ehhez l. PÁL 2010.

${ }^{43}$ 117. Országos Gyűlés, február 10., = Képviselőházi napló, 1869/ V., 278. [http://mpgy. ogyk.hu, illetve www.arcanum.hu/onap - utolsó látogatás: 2012 júliusa]

${ }^{44}$ VULCAN 1869, 337-338.

${ }^{45}$ Nicolae Butariu, La fondarea unui teatru nationalu = Familia 1869/38, 445-446., George Crăciunescu, Echo din Banatulu Temesianu la fondarea unui teatru national = Familia 1869/469-470. Ion Lapedatu, Publicatiuni literarie si cestiunea teatrala = Familia 1869/42, 493-494., Mihail Strajanu, Cestiunea teatrala la noi si ceva despre originea teatrului in Romania libera = Familia 1869/ 529-530. Mihai Eminescu, Repertoriulu nostru teatralu = Familia 1870/ 3, 25-28.

${ }^{46}$ Familia, fóia enciclopedica si beletristica cu ilustratiuni totu odata organulu publicationiloru "Societatii pentru fondu de teatru nationalu", Pesta, tipariu lui Alexandru Kocsi.
} 
teendőket, kihívásokat. Mind a Familia olvasói körében, mind az ASTRAban támogatókra talál az ügy, ezért sem véletlen, hogy a román képviselők 1870 februárjában az országgyűlésben felvetik a román színház kérdését.

Sigismund Borlea ${ }^{47}$ első hozzászólóként azt kifogásolja, hogy miként segélyezhető csupán a magyar nemzeti színház és a nemzetiségek színházai nem. Indítványában az összeg eltörlését kéri. Felszólalása a nemzetállamot legitimáló nemzetiségi törvény bírálata is egyben. A nemzetiségek képviselői a magyar nemzet nemzetiségek fölöttiségét ellenzik, és minden adandó alkalommal vitát gerjesztenek e kapcsán az országgyűlésben elég ehhez egy-egy nemzetiségi képviselői hozzászólásba beleolvasni. De a kérdés ennél árnyaltabb. A politikai- és kultúrnemzet fogalmak ${ }^{48}$, pontosabban az állam hagyománya felől politikai hatalmat képviseló és az azt kikezdő kulturálisan építkező nacionalizmus egymásmellettiségét mutatják ezek a hozzászólások.

Iosif Hodoş ${ }^{49}$ a román nemzeti színház segélyezésére tesz módosító javaslatot, annak ellenére, hogy még nem létezik ez az intézmény. Megalapozott érvei vannak javaslatát alátámasztandó, és nem véletlenül hivatkozik ő is a jogegyenlőségre. Ráadásul megoldásokat kínál a pénzalap biztosítására, átszervezné például a minisztériumokat. Az erre vonatkozó elképzelései közül egyet idézek: „,[...] maga a kultuszminisztérium is; ez egészen eltörlendő lenne, mert ha van az államban szabad egyház, ha az illetô egyházakra van a nevelés bízva, akkor a kultusz- és közoktatási minisztériumnak nincs értelme, s azon fölügyeleti jog, melyet a kultuszminisztérium gyakorol, tökéletesen átruházható volna a belügy- vagy az igazságügyminisztériumra[!]".$^{50}$ Bár az idézet érvként szolgál a pénzforrást jelentő költségvetési átszervezés mellett, mégis láttatja a román képviselő oktatással kapcsolatos álláspontját. Az oktatást állami felügyelet alá helyező elképzelés és törvény mellett a ",szabad egyházak"-nak nincs szüksége minisztériumra. 1870 februárjában Hodoş úgy érzékeli, hogy sokkal erőteljesebben múködik az egyházi oktatás, mint az állami, ezért tartja fölöslegesnek az állami befolyást az oktatásra. Nem hiszem, hogy álláspontja kialakításában Hodoşt görögkeleti felekezethez tartozása vagy román nemzetisége befolyásolná csupán. Az egyházi és állami oktatás alá-fölérendelői viszonya részletezésével itt nem foglalkozom, csak jelzem, hogy az állam mint hatalmi apparátus kiépülése a 19. század utolsó harmadában számos konfliktust, vitát gerjesztő, folyamatként alakuló jelenség.

\footnotetext{
${ }^{47}$ Román politikus. Világoson született, Pozsonyban és Pesten tanult filozófiát, álnéven közölt humoros írásokat. Vö. Familia 1867/14.

${ }^{48}$ E differenciálás elméleti alapvetéseihez lásd: BRETTER-DEÁK 1995, 52-67.

${ }^{49}$ Román politikus, ügyvéd, történész, a RTA alapító tagja.

${ }^{50} 118$. országos gyűlés, 1870. február 11. = Képviselőházi napló, 1869/V., 290. [http://mpgy. ogyk.hu, illetve www.arcanum.hu/onap - utolsó látogatás: 2012 júliusa]
} 
A vita folyását megakadályozandó Rajner Pál belügyminiszter pontosít: nyomtatási hiba a színház részére való adomány. A segélyezés a „dalmü- és zeneképezdére” vonatkozik, és „a dalmü oly tárgy, mely minden nemzetiséget egyaránt érdekel" ${ }^{51}$, zárja le hozzászólását.

A zene, a szépművészetek vagy az egyetem nemzet, nemzetiség fölöttiségét állítja mind a miniszter, mind a később felszólaló Bobory Károly. (Viszont a nemzetiségi képviselők éppen ezen intézmények univerzális, kozmopolita jellegét kifogásolják.) Ezek az intézmények a hazát szolgálják. A nem nemzetiségi felszólalók úgy érvelnek a nemzeti intézmények kapcsán, hogy elfedve a kérdés politikai élét, azt tágabb kontextusba helyezik, visszautalva a nemzetállam előtti haza fogalmába, a hungarusalapú közösségi identitásba. Ez a bonyolult érvelési technika leplezi le a nemzetiségi törvények és gyakorlatba ültetésük közötti ellentmondást, azt, hogy korántsem müködik egységes nemzetállamként Magyarország.

Kuk Jenő, nem magyar képviselő ${ }^{52}$ - ezt maga jelzi felszólalásában -, precedensekre hivatkozik, és ez a gesztusa az alfejezet szempontjából igen jelentőségggel teli. Egyrészt arra utal Kuk, hogy korábbi években is szerepelt a nemzeti színház támogatása a költségvetési vitában és nincs meggyőződve arról, hogy itt nyomtatási hiba lenne. Másrészt az egy évvel korábbi (1869-es) költségvetési vitára emlékezteti az országgyülést. Ez a hivatkozása azért nagyon fontos, mert a vita szöveganyagát visszakeresve, abból megtudható, hogy akkor a szerb nemzeti színház, azaz a már létező újvidéki színház segélyezését követelték a nemzetiségi képviselők. Látjuk tehát, hogy a román színház segélyezését követelők nem járatlan úton indultak el. De vizsgáljuk meg az előzményeket.

\footnotetext{
${ }^{51}$ Uo.

${ }^{52}$ Kuk Jenő az a román Eugeniu Cucu, aki a színház ügyét aláírásával támogatja képviselőtársaihoz hasonlóan 1870-ben. Vö. Familia 1870/7, 73. A Familia következő száma már halálhírét közli: Familia 1870/8., 95. 1870. március 7-én az országgyűlésben is megemlékeznek haláláról: “Elnök: T. ház! Mielött a napirendre áttérnék, kötelességem a t. ház tudomására hozni, miszerint Közép-Szolnok megyei Tasnád kerületi orsz. képviselő Kuk Jenő képviselőtársunk megszűnt élni. Tegnapelőtt reggel 10 órakor, élete delén, még be nem töltött 33-ik évében ragadta el a kérlelhetlen halál. A boldogultat a természet dús tehetségekkel áldotta meg, melyeket saját szorgalmával úgy képzett ki, hogy méltán jogosított bennünket és az egész hazát a legszebb reményekre. E remények meghiúsultak. Mint tavaszon a fagyverte virágok hullottak le, és az elhunytnak hamvaival együtt porlódnak el. Midőn e veszteség feletti sajnálkozó részvétet fejezem ki, úgy hiszem, találkozom a t. ház közérzelmével; (Úgy van!) ugyanazért bátor vagyok felkérni, engedje meg határozatilag e részvétnek nyilvánítását a jegyzőkönybe felvétetni. A boldogult hủlt tetemei lakásáról Lipót-utca 38. sz. a., ma délután 3 órakor fognak a görög-katholika egyház szertartása szerint beszenteltetni, és örök nyugalomra kisértetni, mire a t. képviselő urak ezennel meghívatnak. Szaplonczay József: T. ház! Hogy elhunyt képviselőtársunk temetésén megjelenhessünk, bátor vagyok fölkérni a t. házat, hogy a mai napon az ülést valamivel korábban bevégezni szíveskedjék." = Képviselőházi napló, 1869/VI., 333. [www.mpgy.ogyk.hu - utolsó látogatás: 2012 júliusa]
} 
A szerbek 1868 júliusában kérik a támogatást, arról novemberben tárgyal az országgyűlés. 5000 forintos támogatást igényeltek. Ha átolvassuk ezt az országgyưlési vitát, meggyőződhetünk, hogy a rákövetkező évi vitával szembetúnő hasonlóságokat mutat. Ahogy felvetik a kérdést, Wenckheim Béla belügyér rögtön pontosít: „Nem a pesti nemzeti színház segélyezése van itten kitéve, hanem az ének s zenészeti szaknak előmozdítása. A pesti nemzeti színház biztosítva van azon összeg s azon tőkék által, melyek szabad ajánlás útjain gyűltek össze, s melynek kamataiból a magyar dráma támogattatik. A zenének s éneknek nemzetisége nincs, s éppen azt akartuk kikerülni, nehogy a kassai, a debreczeni, a pozsonyi s még nem tudom miféle színházak is követeljenek. Én részemől ezen indítványt nem fogadhatom $\mathrm{el}^{\prime \prime}{ }^{53}$

A nemzetiségi egyenjogúság érve alapján kérik a szerbek saját nemzeti intézményük támogatását. Nyáry Pál azzal érvel, hogy Magyarországon csak a magyar és német nemzetiségeknek van kellő „terjedelemben” ilyen intézményük az újvidéki színház pedig nem szerepelhet „nemzeti” színházként.

Deák Ferenc hozzászólása dönti el a vitát. Szerinte jogosak a nemzetiségi követelések, de ha a költségvetés nem fedezi azokat, akkor egyformán kell viszonyulni minden nemzetiséghez. Ő zárja le a napirendi pontot, öszszefoglalva, hogy mi felől is kell dönteni: „Több időt vesztünk, ha most e tárgy felett tovább vitatkozunk. Úgy tetszik, az enyémen kívül még két indítvány van: egyik Dimitrievics képviselőtársunké, ki a szerb nemzetnek kíván subventiót adni; a másik Nyáry Pálé, ki az újvidéki színháznak kíván subventiót adatni. E kérdéseken leghamarabb átesünk szavazás által: ha elesik Dimitrievics képviselő indítványa, következik Nyáry képviselő úré; s ha ez is elesik, úgy az enyém. (Helyeslés.)". Végül nem támogatják a szerb színházat.

Nyilvánvalóak tehát a hasonlóságok az 1869-es és 1870-es költségvetési vitán felmerülő nemzetiségi intézményépítő próbálkozások között. A románok számára a szerbek kezdeményezése mintaként és érvként szolgál. Ilyenformán pedig a nemzetiségi szolidaritások közvetlen formáira ismerhetünk a közös, de megoldatlan kérdéseikben, mint amilyen a színházügy. Az is látszik az előbb vázoltakból, hogy miként hárítják el a kérdést a magyar képviselők vagy az, hogy a nemzet homonimikus fogalomként miként tartalmaz elkülönülő jelentéseket a különböző állásfoglalásokban.

Az 1870-es vitában Tisza Kálmán is felszólal. Amellett, hogy rosszallását fejezi ki a napirendi pontban szereplő hibáért, kijelenti, hogy nem támogatja a nem fővárosi, azaz provinciális intézmények segélyezését,

\footnotetext{
${ }^{53}$ 1868. november 14. = Képviselőházi napló, 1865/ X., 312. [www.mpgy.ogyk.hu - utolsó látogatás: 2012 júliusa]
} 
mert azokat az adott vidékek kell, hogy megsegítsék. Ez a megjegyzése a fővárost kiemeli és intézményeit nemzeti reprezentációs funkcióval látja el a vidékiekkel szemben.

Idézek további gondolatmenetéből: „Oly országban lakunk, mely poliglottnak nevezhető; különböző nemzetiségek lakják e hazát, és egyik sincs azon helyzetben, mint Franciaországban a francia, hogy annyira túlnyomó legyen a többi fölött, hogy kérdés ne támadhasson aziránt: hogy a jövő kit illet e haza határai között; de éppen azért azt tartom, hogy ily hazában okvetlenül szükséges, hogy egyik vagy másik az itt lakó nemzetiségek közül a vezérszerepet vigye, és az egész államra saját jellegét ráüsse, azokban, mik állami teendők, meghagyván e határon belül a többi nemzetiségeknek szabadságukat. (Általános élénk helyeslés.) Ezen szerepet viszi ma a magyar, viszi históriai múltjánál, relatív többségénél fogva, és viszi - $\mathrm{s}$ ezeket tartom legfőbb tényezőknek - anyagi és szellemi fölénye által". ${ }^{54}$

Az idézetből kitűnik, hogy a magyarországi helyzet nehezen feleltethető meg a politikai nemzetállam fogalmát „,tökéletesen” reprezentáló Franciaországnak. Ennek ellenére a magyar nemzet magáénak tudja a vezérszerepet. A nemzetiségi kérdés kapcsán Tisza a következőket állítja: „[E]gy részről az mondatott, hogy mindnyájunknak, és éppen nekünk magyaroknak, kik e hazában lakunk, érdekünk, hogy a többi nemzetiségi lakosok és az egész haza mentül inkább múveltebb legyen. Tökéletesen helyeslem ezt. Más oldalról egy képviselő úr azt mondotta, hogy lehetetlenség azt kívánni, hogy egyik vagy másik nemzetiség műveltségi intézeteihez, és művelődésére a többi nemzetiségek adójából is fordíttassék valami, mert ha nem fordíttatik azok részére is valami, ez igazságtalanság. Ami az elsőt illeti, hogy t. i. a hazában nemzetiségre való tekintet nélkül múvelt legyen mindenki, azt gondolom, senki kétségbe nem vonja. A másikat illetőleg, mi ezzel ellentétben áll, bátor vagyok figyelmeztetni azon t. képviselő urat, ki ezt fölhozta, hogy nehezen szolgálna az ő saját szempontjának és érdekének, ha ezt elvként mondanánk ki: mert a közművelődésnek fóeszköze - bár különben nagy súlyt fektetek rá - nem a színház, hanem az iskola, és pedig a népiskola [...]".

Valószínü, hogy Tisza fenti állításai válthatták ki a románság, és talán Eminescu felháborodását, és szolgáltak politikai írásainak alapul. Tisza Kálmán sértő kijelentései a november 14-i ülés végén, stratégiailag jókor hangzottak el, hiszen aznap már nem volt lehetőség hozzászólni a kérdéshez. (Egyébként a reagáló felszólalásokat, azok gyakoriságát a házszabályok is meghatározták.)

${ }^{54} 118$. országos gyülés, 1870. február 11. = Képviselőházi napló, 1869/V., 290. [http://mpgy. ogyk.hu, illetve www.arcanum.hu/onap - utolsó látogatás: 2012 júliusa] 
A költségvetési vita folytatásában későbben is szóba hozzák a nemzetiségi törvény be nem fejezettségét, hiányosságát, a vidék és főváros intézményeinek lehetőségeit és funkcióit. Irányi Dániel igazat adva a nemzetiségi követelésnek, a népnevelést és a haza érdekeit helyezi azok fölé. Henszlmann Imre is hasonlóképp gondolja.

A román képviselők másnap visszautalnak Tisza beszédére. Alexandru Mocioni például a magyar nemzet szupremáciáját hangsúlyozó részt hozza szóba. Mocioni „históriai erőszaknak” nevezi Tisza álláspontját. Stănescu Imre, Vicențiu Babeş képviselők is reagálnak arra a felvetésre, miszerint a romániai magyarok nem követelőznek. Mindketten hangsúlyozzák, hogy az történelmileg más helyzet, a magyarok főként bevándorlók, hozzájuk képest a magyarországi románok és nem magyar nemzetiségüek történelmi létüknél fogva jogokkal bírnak. Ez a történeti-jogi érv akkor kerül elő a román etnikum képviselői felszólalásaiban, amikor már kevésbé legitim, hiszen éppen a dualizmus idején „amalgámozódik” át a magyarországi társadalom a történeti-jogi rendiségből a viselkedésszociológiai rendiségbe. ${ }^{55} \mathrm{~A}$ történelem által szavatolt jogok követelése szintén problematikusnak tünhet a magyar országgyülésben, hiszen olyan etnikum képviselői részéről hangzik el az, akik egy ún. „csonka (paraszti) társadalomból érkeznek, ahol az etnikum nem rendelkezik „saját uralkodói osztállyal". ${ }^{56}$

Ivánka Imre képviselő arra kérdez rá, hogy hol állítanák fel a románok a színházat. Vicențiu Babeş - „Tessék csak megszavazni, majd azután megmondom" - válaszát bekiabálás előzi meg: Brassóban. Ebből az apróságból arra következtethetünk, hogy részint ironikusan reagál Vicențiu Babeş, hiszen nem véletlenszerüen vetik fel a román képviselők a színház kérdését: terveik vannak. Egyértelművé válik az is, hogy nem személyes ötletről van szó, hanem közösségi kérdésről, érdekről, amennyiben az országgyűlés soraiban ülők ugyanazt kiáltják be. A bekiabált helyszín kapcsán ad hangot csodálkozásának Csernátony Lajos: Brassó a szászok fontos központja, miért nem a szászok kérnek ilyen típusú támogatást. ${ }^{57}$

Az országgyülési vita irataiból annyi áll még rendelkezésünkre ennek kapcsán, hogy Brassó és vidéke képviselője, Wachter Frigyes kijelenti, hogy Brassó szász és királyföldi település, nem román. Szerinte nincs helye ott román színháznak, a német színházat pedig megvalósíthatatlannak

\footnotetext{
${ }^{55}$ Lásd erről bővebben: GYÁNI-KövÉR 1998, különösen 92-104.

${ }^{56}$ I.m. 143.

${ }^{57}$ Nem áll módomban ezt a kérdést részletezni, de azt megjegyzem, hogy valószínűleg a románokétól jelentősen eltér a szászok viszonyulása, nemzetiségi önreprezentációja a Monarchiában.
} 
tartja. ${ }^{58}$ P. Szathmáry Károly az alulról való építkezést javasolja, jelesül: a románok kezdeményezzenek, hozzanak létre saját színház-létesítési alapot, és utána kérjenek támogatást.

A vita végén összegeznek: Sigismund Borlea tett módosító indítványt, majd azt nyilatkozta, hogy kénytelen belátni, hogy semmiképp sem viheti át módosításait. Végül az országgyűlés megszavazza a dalmü- és zeneképezde számára előírt pénzösszeget. Ugyanúgy zárul tehát ez a vita is, mint az egy évvel korábbi.

A nemzetiségi képviselet, bár támogatja egymást (a szerbek a románokat és fordítva), nem tud nyertesen kikerülni az országgyűlési vitákból. Ezt az is gátolhatja, hogy minden adódó alkalommal, még akkor is, amikor általánosító megjegyzések hangzanak el például Erdély kapcsán, felemlegetik sérelmeiket, a be nem tartott nemzetiségi törvényt, az egyenjogúságszupremácia történelmietlen viszonyát.

Kétélűnek tűnik az a viszonyulásmód, amelyet a magyar képviselők gyakorolnak: miközben a haza érdeke alá helyeznek minden nemzetiségi törekvést, mégis hangsúlyozzák Magyarország államiságát, a magyar nemzet legitimitását, nemzetiségek fölötti vezérszerepét és ezt főként kulturális érvekkel támasztják alá, holott politikai diskurzusról van szó. Ez a tudathasadásos állapot jelzi, mennyire bonyolult a 19. század végén többnemzetiségű nemzetállamot létrehozni, konfliktusmentesen müködtetni, ha egyáltalán lehetséges.

A két idézett vitában Deák Ferenc az egyedüli, aki szorgalmazza az egyenjogúságot, de olyan kontextusban, amely a vita mellékszálát képezi, és magától értetődő, hogy nem esnek komolyan latba érvei.

Politikai játszmák tanúi vagyunk, amikor az országgyülési iratok szövegeit tanulmányozzuk. Ezt az egymást követő belügyi vitákban rendre felmerülő nemzetiségi színházi segélyezés is példázza. A precedensteremtés és a rá való hivatkozás ellenére sem sikerül a szerb és román képviselőknek állami támogatást szerezni létező vagy alapítandó intézményeikre, miközben a magyar nemzeti színház állami támogatása a következő években is szerepel a költségvetési vitákon.

\footnotetext{
${ }^{58}$ A román közösség urbanizációját vizsgáló szövegében Ábrahám Barna Brassót és Nagyszebent sorolja olyan városként, amelyekben nagyobb arányú (20-30\%-os) román lakosság élt. Vö. ÁвRAнÁм 2004, 224. Ahhoz, hogy egy települést városként definiáljunk, a jogi és a népességszám (Brassó 8. helyen) szerinti meghatározást ki kell egészíteni egyéb elméletekkel, például a funkcionális szemlélettel vagy az intézményközpontú központi hely-elmélettel. Ez utóbbiak felől körvonalazódó városhierarchiában a századfordulón Brassó már nem szerepel az élmezőnyben, míg Kolozsvár (Budapest, Pozsony és Zágráb után 3.), Temesvár (7.), Arad (9.) és Nagyvárad (10.) igen. Nagyszeben hiányzik az akkori első tíz legfontosabb magyarországi város sorából. Vö. GYáNI-Kövér 1998, 55-57.
} 
A nemzetiségpolitikai felszólalások az országgyűlési vitákban sajátosan szemléltetik azt, hogyan gondolkodtak az egyes nemzetiségi képviselők, és azt is, hogy a közös sérelmek miként szolgáltak kohéziós erőként a különböző nemzetiségek között, miként segítették a szolidaritásuk kialakítását ${ }^{59}$. Azt is kiolvashatjuk mindebből, hogy miként válik nemzetpolitikaiként felvezetett üggyé egy-egy kulturális kezdeményezés, hogyan értelmezik sajátosan ugyanazt a fogalmat: a „nemzeti”-t, amely az állam és politika révén rátelepszik a 19. század vége diskurzusaira. Ebből a szempontból lesznek igazán érdekesek a kötet további fejezetei, hiszen láttatni engedik, hogyan birkóznak az irodalmi, fordítói gyakorlatok azzal a különbséggel, amit a „nemzet” és „nemzeti”, „magyar” és „román” fogalmak egyes jelentés(értelmezés)ei hordoznak. A belügyi vita, mindamellett, hogy komparatív szempontból az ekvivalencia igénye felől nézi a magyarromán kapcsolatokat, vizsgálata az összehasonlíthatatlanságot erősíti. ${ }^{60}$ Az egyenlőtlen kapcsolatok konfliktusossága mutatkozik meg ebben a vitában. Általa számolnunk kell azzal, hogy a komparatisztika nem csupán pozitív történetek tudománya, hanem az ellenségteremtés és negativitás is része, illetve velejárója az irodalmi-, kulturális-, politikai kapcsolatoknak.

\subsubsection{A román színházügy három példája}

Talán P. Szathmáry Károly javaslatára figyelnek a magyarországi románok, amikor már 1870 februárjában gyưlést hívnak össze a pesti városi redut refektóriumába a Kárpátokon inneni nemzeti színház létesítéséért. Ekkor a Familia ismét címlapon szólítja meg Pest-Buda értelmiségét, de közli az indítvány aláíróinak névsorát is, akik többségben országgyülési

\footnotetext{
${ }^{59}$ A csoporttudat és etnikai identitás viszonyához lásd bővebben: BRUBAKER 1996, BRUBAKER 2001.

${ }^{60}$ Lásd: DéTIENNE 2000. Marcel Détienne bővíti ki az összehasonlítás módszertanát az öszszehasonlíthatatlanság kérdésével akkor, amikor a francia kultúra történelemszemléletében a más kultúrák, az azokat vizsgáló etnográfia és antropológia iránti érdeklődés hiányáról, vagy kései megjelenéséről értekezik. Elgondolása egybevág a társadalomtudományi kontextusból kibontakozó histoire croisée / történeti keresztezés módszertanával, miszerint például az általunk magyar-román kapcsolatoknak nevezett kulturális kölcsönhatások a közös történelmi múlt felől is eredményesen vizsgálhatóak, mivel elválaszthatatlan kapcsolatok kötik össze a két kultúrát és éppen ezek történetisége teheti újszerűvé a kutatás kérdésfelvetését. Mindemellett, ez a megközelítés a hagyományos összehasonlító (irodalom/történet) tudományhoz képest a kutatói objektivitást, a megfigyelői pozíciót lazítja föl olyan értelemben, hogy az előfeltevésekre irányítja a figyelmet, jelesül: a kutató kutatási tárgya iránti akaratlan elfogultságára, elkötelezettségére, a vizsgált kérdésben való „benne-lét"-re, a nyelv- és fogalomhasználatra, az előzetes tudásegyüttesre. Ez az elmélet például Európa történetének megírását nem korlátozza a nemzetállamok és politikai kapcsolataik vizsgálatára, hanem a kölcsönhatások, viszonyok, azok újraértelmezései változatosságára kíváncsi, azaz folyamatorientált megközelítést szorgalmaz.
} 
képviselők. ${ }^{61}$ Az intézményszervezés mellett Vulcannak versírásra is jut ideje, ekkor közli a Templulu Thaliei romane címü alkalmi, mozgósító célzatú költeményét. Amint a Familia következő számai is mutatják, égető kérdésként tartják napirenden a színház létrehozását, több felhívás, színházelméleti szöveg lát napvilágot a lapban. ${ }^{62}$

Többek között, mind Vulcan, mind Eminescu értekezést írnak a román színház ügyéről. Vulcan értekezése ${ }^{63}$ el is hangzott a színházalapító társaság első közgyűlésén, Déván, 1870. október 4-én. Ebben az alfejezetben kettejük álláspontját vetem össze, mert részint ugyanazon jelenséghez, a román színügy kérdéséhez kapcsolhatók, egy szövegkorpuszt alkotva, részint pedig különbségeket rajzolnak ki kérdésfelvetéseik.

Vulcan a színházat állami intézménynek, ezáltal hivatalosan is támogatottnak képzeli ${ }^{64}$, kulturáltnak, amely nem a szellemi szórakozás, hanem a „külső igaz és szép temploma” ${ }^{65}$, az emberi élet tükre, az erkölcsiség iskolája. Érvelése szerint a színház a nyelv, a nemzet, a kultúra iskolája, amelynek harcolnia kell a barbársággal, civilizálatlansággal, de a nyelv fejlődésének és csiszolásának lehetősége is. Hangsúlyozza, hogy a nemzeti nyelven előadott darabok erősebben hatnak a közönségre, sőt a színpadon megjeleníthetőek a nemzeti múlt fontos eseményei és alakjai. A színház erkölcsi, didaktikus funkcióját a mintaadásban látja: a színpadon megjelenített események, szereplők mintaként szolgáljanak a románság számára, a hősiesség, szabadságvágy példáiként. ${ }^{66}$ Az eddigiekből is nyilvánvaló,

${ }^{61}$ Anton Mocioni, George Mocioni, Alexandru Mocioni, Eugen Mocioni, Ioan Eugeniu Cucu, Sigismund Popovici, Iosif Pop, Dr. Aurel Maniu, Vicenție Bogdan, Sigismund Borlea, Iosif Hodoş, Ladislau Buteanu, Vasile Jurca, Ionescu, Petru Mihályi, Demetriu Ionescu, E. B. Stănescu, Vicențiu Babeș, Iosif Vulcan. Vö. Catra inteligintia romana = Familia 1870/7, 73. Alexandru Roman például azért hiányzik az aláírók sorából, illetve azért nem szólalhatott fel az országgyűlési vitában, annak ellenére, hogy képviselő, mert börtönbüntetésre ítélték és a váci fogházban ült.

${ }^{62}$ Iosif Vulcan, Se fondamu teatru nationalu = Familia 1870/12, 133-135., Iosif Vulcan-Iosif Hodoş, Apelu catra publiculu romanu = Familia 1870/13, 145-146., Fr. Schiller, Scena ca institutu de moralitate $=$ Familia 1870/15, 169-171. [tradus de Mihai Cirlea], Iosif Vulcan-Iosif Hodos, Proiectu de statute pentru societatea spre scopulu crearii unui fondu de teatru nationalu romanu = Familia 1870/28., Iosif Vulcan, De ce voimu s'avemu unu teatru nationalu = Familia 1870/40, 469-477.

${ }^{63}$ VulCan 1870.

${ }^{64}$ Vulcan itt nem pontosít, hogy melyik államra gondol, feltételezhetően a magyar államtól, a Monarchiától várja el az anyagi és szellemi támogatást, amennyiben az ügyet is a magyar parlamentben terjesztik elő. Ennélfogva, az erdélyi románság valóban politikailag kiszolgáltatott egy másik, fölötte hatalmat gyakorló nemzetnek, esetünkben a magyarnak.

65 ,[...] templu alu frumosului si adevarului externu"-VulCAN 1870, 470.

${ }^{66} \mathrm{~A}$ nőkre is figyel, amennyiben számukra is történelmi példákat sorol: Dimitrie Bolintineanu legendájából jól ismert „muma lui Ştefan cel Mare”, vagy Moldva történetének többször is megidézett alakja: „doamna Rocsanda”.( Vö. Grigore Ureche, Letopisețul țării Moldovei -krónikája, irodalmi adaptációja: Costache Negruzzi, Alexandru Lăpuşneanul-novellája) E példák hasznossága Vulcan értelmezése szerint abban rejlik, hogy a hazafiasságtól meghatott anyák 
hogy bár az igaz és szép kategóriái felől, azaz az esztétikum és erkölcs paradigmájában értekezik a színházról, amennyiben a nemzeti kultúra részeként nevezi meg az intézményt, ideologikussá válik az általa elképzelt román színház léte és szerepe.

Eminescu vándorszínészként Vulcanhoz képest gyakorlati tapasztalatokkal rendelkezik azon a területen, amelyről értekezik. ${ }^{67}$ A művészet-mesterség párost megkérdőjelezve bírálja a színház intézményének konkrét vonatkozásait. A mai román irodalom kanonikus rendszerének ellentmondó értékítéleteket találunk Eminescu írásában. Alecsandri népszerű színjátékait erkölcstelenség dolgában ítéli el, és nyelvi szempontú vádakkal illeti. A Shakespeare tragédiáit utánzó román drámaírók darabjait azért nem tartja megfelelőknek, mivel bár kitűnő költők, mégsem képesek a valódi utánzásra, és ennek egy velős oka szerinte az, hogy az angol tragédiaíró nem utánozható. Tehát az eredetiség és utánzás kérdése felől ítélkezik a román darabok fölött, amikor azok repertóriumával leszámol. Alig talál játszásra alkalmas darabot: kevés az olyan darab, amely ne kárhoztatná még létével sem a nemzeti színjátszást, gyakran korrupt, barbár és múveletlen szinten (lásd I. Caragialy[sic!] eredeti vígjátékait). ${ }^{68}$ A bécsi színházat mintául elképzelő Eminescu megoldásokat is kínál. Előremutató ötletei vannak: a közönséget kell felemelni, például a Pascaly társulata által játszott Sardou- és Scribe- vagy más darabok színvonalára, tragikai/komikai témákat a paraszti világból meríteni, eredeti munkákat írni, s ennélfogva létrehozni a román nemzeti repertóriumot, ösztöndíjakkal támogatni a színészek, színésznők megélhetését - nem írja, hogy képzését, mivel ez a folyamat egy későbbi történet lenne, amivel akkor még nem számol. Írásából kiolvasható megszólalásának pozíciója, ő a fiatal, szegénységben tengődő színésznemzedék nevében értekezik, felrója, hogy nem jutnak hozzá a mintaként szolgálandó drámai művekhez, sőt mi több, a felhasználható színműirodalom sem játszható komoly kritikai megfontolások nélkül. Ezzel kapcsolatos sorai leplezik le írásának poétiká-

gyermekeiket majd Gelu, Claudiu, Menmorotu, Dragosiu és Negru ükunokáiként/nak nevelik. Az eredetmondák szereplőinek felvonultatása akár egy újabb, nemzeti honfoglalást jelképezhet, amennyiben Vulcan elvárásai teljesülnek. A román nemzeti történelem kiemelt alakjai, valamilyen értelemben honfoglalók: Gelu, Menmorut Anonymus krónikájából is ismert figura, Dragoş Moldva eredetmondájának szereplője. Negru vajda leghamarabb Az ardzsesi zárda c., 1864-ben Kriza János Vadrózsáinak fogadtatása kapcsán lefordított román népballada szereplőjeként jut eszünkbe, ilyenként elsősorban vallásos funkciójú területek honfoglalója. Erdély mellé tehát Moldvát és Havasalföldöt is megidézi a történelem szereplőinek emlegetése során, sőt megteremti szimbolikus összetartozásukat.

${ }^{67}$ Eminescu 1871.

${ }^{68}$ Szabad fordítása a következő részletnek: su puține piesele acelea, cari prin esistentia loru nu prostitua teatrulu nationalu - si adese-ori intr' unu modu, pe câtu de coruptu pe atâtu şi de barbaru şi de necultu. (Vedi Comedii originale ale dlui I. Caragialy).= Emınescu 1871, 27. 
ját/politikáját: ha más lehetőség nincs, akkor se utánozzuk az olyan okkult nyelvek szerzőit, mint az oroszok, magyarok, szerbek - annál az egyszerú oknál fogva, hogy igaz ugyan, hogy rendelkeznek eredeti alkotásokkal, amelyek tetszhetnek, viszont etikai elemeik ezeknek fertőzöttek. ${ }^{69} \mathrm{E}$ szöveg itt jut el oda, ahova a Vulcané: az erkölcsiséghez, amely a nemzeti elkülönülés kérdéséhez, a másik nemzet idegenként való érzékeléséhez, és e ponton, az attól való távolmaradás irányába mutat. Az ellenségteremtés gesztusa $^{70}$ munkál Eminescu írásában akkor, amikor azt taglalja, hogy a nemzetek erkölcseikben is eltérőek, az idegen nemzetek eredeti darabjai csupán belterjesen hordozhatnak érvényes referenciákat, kerülni kell tehát átvételüket, adaptációjukat. Fura mód, nem minden nemzetet határol el e fenti idézet, hanem csupán azok eredeti darabjaitól óvja a románságot, amelyekkel annak valamiféle kapcsolata van. A román kultúra érintkezik a magyar, orosz, szerb és szláv kultúrákkal, és ennek következtében csak úgy ớrizheti meg integritását, ha távolságot tart és elhatárolódik.

Összegezve, Vulcan és Eminescu cikke a színház elméleti és gyakorlati problematikussága mellett azt is megmutatja, hogy valóban analogikusan gondolták el a nemzeti kultúrák létét, alakulását, intézményesülését a különböző nemzetek, de az egyazon nemzethez tartozó, más állam keretei között élő románok is. Esetükben ez bonyolultabb volt, mivel nem csupán saját, Magyarországról szabadnak látszó „nemzetük” mintakövetése hatott rájuk, hanem alkalmazkodniuk kellett azon állam politikai, kulturális hatalmához, amelynek keretei között kívánták megalapozni intézményüket. Amint a képviselőházi iratokból is kitetszik, valószínű ezért sem sikerült Vulcannak és a képviselőknek az erdélyi színházat létrehozni.

A kolozsvári Magyar Polgár napilapban folytatásokban olvasható egy másik szerző, Grigore Moldován színházüggyel foglalkozó tárcája. ${ }^{71}$ Moldován ${ }^{72}$ ismerteti a magyarországi románok színház-alapítási folyamatát. Az iskolai színjátszás és a vándortársulatok fontosságát említi, valamint Iosif Vulcan szerepét hangsúlyozza, mivel ő tette tulajdonképpeni létkér-

\footnotetext{
${ }^{69}[\ldots]$ a nu imita autori din limbi oculte, d.e. ruşi, maghiari, serbi - din causa simpla, cumca acestia in adeveru au câte ceva originalu, care place, însă elementulu eticu din ei e infectatu. - i.m. 28 .

${ }^{70}$ Koselleck 1998, Szabó 1998.

${ }^{71}$ A tárca fejezetei a magyarhoni, romániai és moldvai színügyet különböztetik meg, a hiányokra világítanak rá, néhol ironikusan. Moldován e tanulmányának forrásait is megjelöli, ezek között pedig éppen Vulcan, Hodoş, és Strajanu nevei szerepelnek, azoké, akik a színügyet létkérdésként vetették föl. Lásd: Magyar Polgár 1872/31, 36, 37, 38, 39, 42, 43.

${ }^{72}$ Grigore Moldován a kötet későbbi fejezeteinek kulcsfigurája lesz. Elöljáróban csak annyit jegyzek meg, hogy olyan román származású értelmiségi, aki a magyar állam polgáraként lojális a hazához, és aki főként magyar nyelven publikál. A Grigore és Gergely, keresztnevének román és magyar névváltozatai egyaránt előfordulnak vezetékneve mellett. Családnevét magyarosan használom, mint ahogy ő tette.
} 
déssé az ügyet. Viszont hozzáteszi, hogy a románság nem rendelkezik elég anyagi és szellemi potenciállal: „a román nemzetnek jelenleg még népiskola kell. A szórványosan jelentkező kevés számú intelligencia egy nemzeti színház fenntartását nem eszközölheti, s nincs hely, ahová ezen színház felépíttethessék oly módon, hogy fenntartása a románság által lehetővé tétessék". ${ }^{73}$

Moldován tárcájáról az állapítható meg, hogy a magyarországi román színház kapcsán ugyanazokat az ellenérveket sorakoztatja fel, mint amelyeket az országgyűlésben a magyar képviselők megfogalmaztak. Nem saját nemzetisége álláspontját képviseli, hanem azzal ellentétesen nyilatkozik. ${ }^{74}$ Sajátos módon, az intelligencia igényeként határozza meg a színház létét, és ezzel amellett érvel, hogy a románság olyan társadalmi tagoltságot mutat, amely bipolárisan elkülönül értelmiségre és köznépre. Érvelésében inkább társadalmi és nem nemzeti gondként értelmeződik a színházalapítás kérdése. Amit a politikum nemzetiként jelenít meg például a magyar országgyülésben, az Moldován szerint értelmetlen és megvalósíthatatlan, hiszen szerinte hiányzik a megfelelő támogatottság.

A románság ebben az értelmezésben olyan csoportot jelent, amely nem tud egyenrangú társa lenni a magyarságnak elsősorban eltérő szervezettsége miatt. Moldován szociális kérdésként látja azt, amit a román nemzetiségü képviselők politikaiként hoznak szóba az országgyülésben.

A színház-alapítás tehát többrétü probléma a kor román társadalmában. A fentebb elemzett szövegek ezt a többrétúséget világítják meg és segítenek belátni, hogy egy etnikai csoport intézményszervező kezdeményezései miként változnak politikaivá és ezáltal a nemzeti identitás megalapozóivá, erősítőivé.

A színház-alapítási vállalkozás mibenléte feltárásában nagy segítségünkre lehetnek, amint láttuk az országgyűlési naplók, képviselőházi jegyzőkönyvek. Ami e forráscsoport használhatóságát hangsúlyozza egy ilyen recepciótörténeti dolgozatban, az nem pusztán a szakirodalomból nyert megerősítés ${ }^{75}$, hanem annak ténye is, hogy kontrollforrásai lehetnek a történelmi-, irodalomtörténeti ismereteinknek.

Valóban nem rendelkezett a magyarországi román közösség olyan centrummal, mint Budapest, vagy mint a lassan Románia fôvárosává váló Bukarest. ${ }^{76}$ A román színházügy tehát nem önállóan, hanem viszonyítási pontok mozgásában mutatkozik meg az 1870-es években. A magyar nemzeti intézményekhez képest láttatott helyzetük miatt a szerbek vagy románok színházügye egymástól sem függetleníthető.

\footnotetext{
${ }^{73}$ A román színügy = Magyar Polgár 1872/37.

${ }^{74}$ Moldován sajátos viszonyulását a róla szóló fejezetben részletezem.

${ }^{75}$ SZILÁGyi 2003.

${ }^{76}$ Vö. ÁвRAна́м 2004, különösen: 130-172.
} 
Látszólag úgy tűnik, hogy ezek a gondolatok távolítanak az Eminescurecepciótól és a magyar-román kapcsolatoktól. Mégis, mind a színházügyre vonatkozó politikai jellegü források, mind a színház-alapítási kísérletek részeként tekinthető Eminescu-publicisztika kontextusai a magyarországi románok kulturális életének. Annak a kultúráénak, amelynek Eminescu elsősorban költőként válik szereplőjévé.

\subsection{Az Eminescu-recepció aspektusai}

\subsubsection{A románok nemzeti költőjéről}

Egy alfejezet erejéig felvillantok néhány mozzanatot a román nyelvü, Eminescu kanonizálásával foglalkozó irodalomból. Teszem ezt azért, mert ez a szerző nemzeti költőként került mindenek fölötti helyre abban a román irodalomban, amely „nemzeti”, ,"egységes" jellegét a 20. században nyerte el.

A 19. század végén visszásan viszonyulnak Mihai Eminescu életéhez. Múvei egykorú irodalomtörténeti megítélése sem egyértelmű. Példának okáért, a kevésbé ismert, első irodalomtörténeti munkaként tekintett kötet $^{77}$ életrajzi adatokat közöl, majd értékeli Eminescu költészetét, anélkül, hogy elhelyezné azt az akkori román irodalmi kánonban vagy kortársi közegében. Valószínű, leíró szándékkal készült a kötet, és csak esetleges értékeléseket tartalmaz, Eminescu esetében például kijelenti: az ellentéteket túlzottan is kedvelő, könnyen verselö, mélyen ironikus költő az antik művészet ismeretéról tesz tanúbizonyságot verseiben. A tehetséges fiatalnak nevezett költő gyengén képzettségét rója fel a kötet, a Venere şi Madonă c. verset pedig furcsának találja. Olyan értékelő megfogalmazások és kifogások ezek, amelyek keveset árulnak el arról, hogyan gondolkodnak Eminescu verseiről kortársai. Az irodalomtörténeti munka szerzője litterétípusú irodalomfogalmat használ, a román irodalom múvelőit Dácia román területeihez társítja, következésképp havasalföldi, moldvai, erdélyi, magyarországi, bukovinai, besszarábiai írókat mutat be. Ezzel a kötetszervezési elvvel egységesnek láttatja azt a román nyelvű irodalmat, amely akkoriban éppen területileg, regionálisan a legdifferenciáltabb, és amelynek része a modern idők embere, a tehetséges Eminescu. Ha előrefutunk az időben, akkor a 20. századi, nemzeti román irodalom hasonló általánosításaira ismerünk. Ugyanakkor, csak részben ismerhette az irodalomtörténeti munka szerzője Eminescu szövegeit, hiszen elsősorban csak költőként nevezi meg, másodsorban pedig 1875-ben, Gherman Pop művének megjelenésekor az Eminescu-szövegkorpusz még folyóiratokban és kéziratos

${ }^{77}$ Pop 1875. 
formában olvasható, hiszen jóval később, 1883-ban adja ki Titu Maiorescu a költő első verskötetét. A Gh. Pop-mű azért lehet értékesebb, mint például Maiorescu, későbbi, 1889-es tanulmánya, mert még a költő életében tárgyalja annak első verseit, így lesz a kortársi recepció egyik kevésbé vizsgált dokumentuma.

Eminescut a Maiorescu által szerkesztett 1883-as kötetből, annak újabb kiadásaiból ismerhették meg kortárs olvasói. Bizonyára romló egészségi állapotának híre, az arról írt beszámolók, tudósítások is növelték ismertségét. Vannak olyanok, akik színjátszóként, vagy a román vándortársulatok tagjaként személyesen is találkozhattak vele. Az utóbbi kapcsolatok a kultikus viszonyulásmód csíráit jelentik, amelyek majd a visszaemlékezésekben bontakoznak ki. ${ }^{78}$

Miután 1902-ben Titu Maiorescu a Román Akadémiának átadja a birtokában levő Eminescu-kéziratokat, megjelennek az első filológiai jellegü feltárások, a Perpessicius-féle kritikai kiadás kötetei, majd az utolsó „eminescolog", Petru Creția munkája, amely a kiadástörténetet tekinti át, és értelmezi. ${ }^{79} \mathrm{~A}$ filológiai szempontú feltárás mellett oktatástörténeti, kultusztörténeti, sőt mítosztörténeti szempontból is értékelhető a 20. században kibontakozó román Eminescu-recepció.

A recepció szempontjából is jelentős változást jelentett Erdély, majd a Partium Romániához való csatolása. A történelmi változással lassan átrendeződtek a kulturális arányok is. Az első világháborút követő trianoni változástól a második világháborúig, majd annak végétől 1945-ig, onnan a hatvanas-nyolcvanas évekig, a rendszerváltásig, az 1989 utáni időszakig számos politikai, társadalmi, kulturális tényező befolyásolta az egymás mellett élő két kultúrát.

Mérvadó lehet e kérdésben, például az, hogy a költő halálának 50. évfordulóján ${ }^{80}$ a tisztelgő Convorbiri Literare c. lap milyen Eminescu-képet tár elénk. Az akkori román irodalomtörténet jelentős képviselői szerepelnek e lapban köszöntésekkel, tanulmányokkal, esszékkel vagy szépirodalmi szövegekkel. A kiadvány szerzői a következő szerepekben látják Eminescut: a generációs közösséget létrehozó költő (a balázsfalvi, „,fiatalokat megrontó" hatása ellenében), a román nép költője, nemzetünk nevelője, alkotó (vagyis nem imitáló) géniusz, nacionalista, a gazdasági nacionalizmus híve, politikai gondolkodó. ${ }^{81} \mathrm{~A}$ tanulmányok egyikében sem tapintható ki a fenti szerepek társított vagy akár koherens rendezése, mégis jelzik, hogy

\footnotetext{
${ }^{78}$ Ilyen típusú visszatekintésre szorgalmazza a Familia olvasóit a költő halála után, majd a költő kortársai fogalmaznak meg különböző felhívásokat. Több kötet is készült a 20. században. Pl. CRĂCIUn- CRĂCIUn (ed.) 1989.

${ }^{79}$ CREȚia 1998.

${ }^{80}$ Convorbiri literare 1939/6-9., 731-1676.

${ }^{81}$ Uo.
} 
merre tart a román Eminescu-recepció, és széttartásuk ellenére az emlékezést szolgáló kiadványban egységesülnek. A gazdagon dokumentált különszám a külföldnek is üzen, önálló rovatban közli francia, német, olasz, angol, lengyel és magyar nyelven I.E. Torouțiu és Al. Ionescu összefoglaló írását, amelynek címe: Eminescu, valoarea dominantă a secolului nostru [Eminescu századunk uralkodó értéke]. ${ }^{82}$ Ez a kiadvány, a költő halála után ötven évvel előremutatóan foglalja össze mindazt, ami Eminescuval kapcsolatos, és a külföldnek szánt szöveg címe jelmondatként is érvényes marad a 20. századi román irodalomtörténet alakulására.

A 20. században kötelezővé tett, államilag szabályozott román nyelv és irodalomoktatás, a tankönyvekben közölt Eminescu-fejezetek, a tanítandó múvek, értelmezéseik meghatározták a felnövekvő nemzedékek, mind a román, mind az erdélyi magyar fiatalok költőről alkotott képét, tudását. A totalitárius rendszerek, az átpolitizált irodalomértés pedig amellett, hogy ideologikusan sajátította ki a költő életművét, kultuszt épített köré, amelynek nyomait, sajátos jelentéseit például a költő születésének 100. évfordulóján, 1950-ben megrendezett országos Eminescu-ünnepélyek szövegei hordozzák.

Az 1989-es változás oktatás szempontjából megőrizte a korábban már bevett Eminescu-szövegeket, az újabb alternatív tankönyvek nem szöveg-, hanem múfajközpontú felépítése az oktatóra bízza a tanítandó szövegek kiválasztását. Évente megrendezik tavasszal Iaşi-ban az Eminescu-konferenciát. E konferencia felhívása szerint, főleg szövegközpontú műelemzések szerzőit várják, vagy azokat, akik az Eminescu-életmű esszészerü megközelítését választják, tehát sokkal irodalmibbak az elvárások.

A '89 utáni román irodalomtörténet megkerülhetetlen jelensége a Dilema folyóirat Eminescu-ügyként elhíresült cikksorozata. ${ }^{83}$ Miért keltett felháborodást ez a cikksorozat? Egyrészt elég későn - a totalitárius rendszer bukása után majdnem 10 évvel - 1998-ban veti fel a lap az Eminescu-kérdést. Kérdésként fogalmaz meg egy nyilvánvalóvá vált jelenséget, egy mítoszt. Másrészt, a destruálás szándéka mellett a cikksorozatban ${ }^{84}$ Eminescut, a román irodalom létmódját érintő írásokat olvashatunk, amelyek mentén általánosabb konzekvenciák is levonhatóak. A kortárs Eminescu-ismeretek a költő olvasottsága/nem olvasottsága felől mérhetők leginkább, és ezt több cikk is szóvá teszi. Az olvasói befogadás mellé az

\footnotetext{
${ }^{82}$ Convorbiri literare 1939/6-9, 1665-1676.

${ }^{83}$ Dilema 1998/265.

${ }^{84}$ Nicolae Manolescu, E o întrebare; Mircea Cărtărescu, Fapte; Zigu Ornea, Poetul național; Mircea Vasilescu, O comparație; Cezar-Paul Bădescu, Un argument; Răzvan Rădulescu, Eminescu văzut de departe; T.O. Bobe, Poezie, haine grele; Tita Chiper, imaginile succesive. Convorbire си Al. Paleologu [http://www.dilemaveche.ro/old/arhiva_dilema/fw.htm?current=numant1. htm - utolsó látogatás: 2012 júliusa]
} 
újraértelmezés, módszertanilag korrektebb újrakiadás szükségessége társul. A „világirodalmi rangú" „,nemzeti költő” fogalmak újragondolandók, ahogy Răzvan Rădulescu találóan illusztrálja. ${ }^{85}$ Következésképp, újragondolandó minden, ami az ember Eminescu köré mítoszt, személyi kultuszt, vallási projektet épített, ezáltal abszolútumként határozva meg őt. Emiatt a történetileg Eminescut megelőző, de az utána elkövetkező irodalom is lehetetlen helyzetbe kerül. Eminescu, az ember fizikai létére leginkább kortársainak emlékei utalhatnak, amelyekkel a posztmodern, aleatorikus szerkesztésü, de lábjegyzetes tudományossággal legitimált Mircea Cărtărescu-szöveg játszik. De a költőt ábrázoló figurális reprezentációk nevetségességén is ironizál a lap némelyik cikke: megtörténhet, hogy már csak bankjegyként ismerjük Eminescut.

A cikksorozat írói főként a kulturális lap alapítói, akiket a szerkesztő kért fel a kérdés megválaszolására. Nem véletlenül bukkan fel tehát a téma, hanem szerkesztői felkérésre írnak a munkatársak vagy a megkeresett írók, költők, irodalomtörténészek. A tematikusan szerkesztett - az esszé, az irodalmi publicisztika, de a szabad véleménynyilvánítás iránt nyitott - lap az Eminescu-kérdés fórumaként működik. A kortárs irodalomhoz tartozó cikkíró értelmiségiek pedig sajátos nézőpontból közelítenek a kérdéshez. Esetenként felemlegetik személyes, a román irodalom (ezen belül Eminescu) oktatásakor-tanulásakor szerzett tapasztalataikat, amelyek az értetlenségtől, érdektelenségtől, elutasítástól az (ön)iróniáig vezetnek. Nyilvánvaló, hogy az irodalmi kánon és oktatás szoros kapcsolata tudta csak oly mértékben befolyásolni a széles olvasóközönséget, hogy Eminescu neve minden román állampolgár számára ismerős legyen és egyúttal kliséként kiüresedjen.

Az Eminescu-kérdés felvállalása, a lap különszáma vitát keltett. Vannak, akik a kortárs média manipulálását látták az ügyben. Mások pedig a Dilema-beli hozzászólókat a román irodalom(történet)ben való jártasságuk, hozzászólásuk jogossága felől kifogásolták. ${ }^{86} \mathrm{~A}$ kötetbe szerkesztett cikksorozat elindított ugyan egy folyamatot, amely azóta sem zárult le, hanem

\footnotetext{
${ }^{85} \mathrm{Nu}$ cred că Eminescu este poetul nostru național și universal. (În legătură cu acest ultim aspect, mă îndoiesc de universalitatea oricărui poet, atîta timp cît universalitatea este o chestiune de traducere și circulație. Traduceți poeziile lui Eminescu în engleză, italiană sau franceză, și dați-le spre citire unor nativi ai acestor limbi. Foarte frumoase poezii, vor spune ei. Ne-ați dat să citim poeziile unui romantic tîrziu, un poet talentat din secolul trecut. Cam discursiv și cam plicticos. Astea cu natura sînt mai dragute, dar n-au amploarea poemelor despre natura ale lui Lamartine sau Hugo. Asta cu împăratul și proletarul este de-a dreptul pompoasă. În rest să juri ca e un poet romantic de-al nostru. E român?)

${ }^{86}$ Például Farkas Jenő, Mihai Eminescu - mítosz és valóság = FARKAs 2010, 35-91. [különösen 35-42.]
} 
rá tíz évre több alkalommal is előkerült: 2008-ban, 2009-ben, 2010-ben. ${ }^{87}$ A kérdés médiában való felvetéséhez képest előrelépést jelent az említett cikk-kötet, de a Ioana Bot és az általa vezetett kutatóműhely tanulmánykötete is. ${ }^{88}$ Ez utóbbi kötet az 1998-as vita alappilléreit felhasználva, a nemzeti költőgéniusz mítoszának archeológiáját tárja fel tizenkét tanulmányban. A tanulmányok arra mutatnak rá, hogy mennyire megkonstruált a román olvasók történelmileg, politikailag, irodalompolitikailag változó Eminescu-képe.

$\mathrm{Az}$ Eminescu-irodalom fentebb kiemelt mozzanatai betekintést engednek a "nemzeti költôvé" válás folyamatába, annak ideologikusságába. Kérdés, hogy a 19. századi román, de akár a magyar nyelvü magyarországi (olvasó)közönség miképp gondolkodott, ha gondolkodott egyáltalán e költő írásairól, legyenek azok versek, fordítások vagy publicisztikai szövegek. Elsősorban ez érdekli recepciótörténeti szempontú kérdésfelvetésem. Az Eminescu életével, munkásságával kapcsolatos néhány korabeli újságcikk, lexikon-szócikk és értekező szöveg alapján vizsgálom a kötet szempontjából primér forrásként működő ún. másodlagos irodalomban körvonalazódó recepciót. A korai magyar nyelvű Eminescu-fordításokkal külön fejezetben foglalkozom.

\subsubsection{Magyar nyelvü nekrológok, szócikkek, életrajzi ismertetések}

Jelen alfejezet időrendi sorrendben tekinti át és értelmezi az Eminescu-recepció mozzanatait. A román költő magyarországi román és magyar kultúrával való közvetlen kapcsolatától halad az egykorú befogadásán át a magyar nyelven megjelenő recepcióig. Más kérdés, hogy miként értelmezhető recepcióként a vizsgált szövegegyüttes, hiszen a 19. század végének irodalmi kapcsolatai nem tették lehetővé a teljes életmü befogadását, vagy rétegzettségének, sokszínűségének belátását.

A költő halála mind a román, mind a magyar sajtó számára hírértékkel bírt.

A recepció részeiként a kultikus viszonyuláshoz köthetők azok a nekrológok, amelyek magyar nyelvterületen adnak hírt a költő haláláról. Ezeket a szövegeket a kapcsolattörténészek a recepció részeinek tekintik, de csak érintőlegesen hozzák szóba, pedig a költő halála hírértéke mellett többletjelentéssel is bírnak.

\footnotetext{
${ }^{87} \hat{I n}$ dezbatere $=$ Observator cultural 2008/444, Salvați-l pe Eminescu sau lăsați-l să doarme = Adevărul literar şi artistic 2009/956, Eminescu după renumerarea voturilor = Mozaicul 2010/1.

${ }^{88} \mathrm{Az}$ ő munkájuk a következő kötet: Вот (coord.) 2001.
} 
A Kolozsvár c. lapban található ${ }^{89}$ magasztaló szöveg amellett, hogy ",a román világ legkitünőbb lantosainak egyike"-ként nevezi meg és Vasile Alecsandrival együtt emlegeti Eminescut, szociális érzékenységgel figyel a költő őrültségére, szegénységére, és halálát nemzeti gyászként tekinti. A nekrológ Románia gyászaként értelmezi a halálesetet, nagyvilági hírként, elfedve azt, hogy esetleg a magyarországi románok is osztozhatnak a gyászban.

A nekrológból tudjuk meg azt is, hogy államköltségen temették el a költőt, és „,a román törvényhozás annak idejében évi négyezer frankot szavazott számára".$^{90}$ A családi élet eseménye válik itt anyagi és ezáltal állami kérdéssé úgy, hogy szóba sem kerül a nemzeti vonatkozás. A szöveg szerint az állami támogatás felemlegetése szolidárissá teszi a román világot.

A másik nekrológ az aradi Alföld c. lapban látott napvilágot az Irodalom és müvészet rovatban..$^{91} \mathrm{E}$ szövegben hangsúlyosabb az a tény, hogy „élete delén” hunyt el a román költő. „Temetése a román politikai, társadalmi és tudományos világ jeleseinek általános részvétele mellett ment végbe július 1-jén. A temetés költségeit az állam viselte" ${ }^{92} \mathrm{Az}$ Irodalom és müvészet rovat eleve tematikusan helyezi el a hírt, amely az állam szerepének hangsúlyozása mellett kiegészül pár többletinformációval: a Lenauhoz való hasonlítás mellett, a költő kiválósága elismerésének jele az, hogy a gyászolók között megemlíti a politikai, társadalmi, politikai elitet is. A román költő halálának alkalma, temetése tehát reprezentációs lehetőséget nyújt a román elit számára. ${ }^{93}$

Az aradi nekrológ nem lehet véletlen, ugyanis vándorszínészként Eminescu a Bánságot is bejárta, Aradon találkozott Iosif Vulcannal. Továbbá a Lenau-vonatkozás is lokális hangsúllyal gazdagodik. Egyszerú lehetett a bánsági olvasók számára a hír dekódolása: Eminescu mint a román Lenau, azaz a bánsági származású osztrák költő" ${ }^{94}$, akinek hasonló sors jutott.

A magyar nyelvű nekrológok alapján állíthatjuk, hogy egyértelmúen romániai román költőként tartják számon Eminescut, nem hozzák szóba magyarországi publikációit, vagy kapcsolatait, az ország gyásza mellett a román elitet emlegetik, amely számára a temetés az önmegmutatkozás

\footnotetext{
${ }^{89}$ A román világ legkitünóbb...= Kolozsvár, 1889. július.

${ }^{90}$ Uo.

${ }^{91}$ Egy román költő halála $=$ Alföld 1889. július 5.

${ }^{92}$ Uo.

${ }^{93}$ A halálról és a gyászszertartásról mint reprezentációs alkalomról lásd: LAKNER 1993, KALLA (szerk.) 1997 és Szabó 1989.

${ }^{94}$ Lenau, Nikolaus (1802. aug. 8, Csatád-1850. aug. 22., Bécs, költő, Bécsben jogot, orvostudományt, filozófiát és tanult. Vö. Österreich-Lexikon [http://www.aeiou.at/aeiou.encyclop.l/ 1461666.htm - utolsó látogatás: 2012. május 7.], illetve SzINNYEI 1891-1914.
} 
alkalma. Ugyanakkor e szövegek olyan érvként is működnek, amelyek a halott költő kiválóságát hivatottak legitimálni.

A 19. században a század utolsó éveiből pár életrajzi összefoglalót idézhetünk, amelyek szintén informáló jellegűek, mindamellett, hogy el is helyezik Eminescu általuk ismert munkásságát a román irodalomban. Ilyen életrajzi ismertetést tartalmaz A Pallas nagy lexikona és Révai nagy lexikona, mindkettő a költő halála után jelent meg. ${ }^{95} \mathrm{~A}$ biográfiai adatok mellett a Pallas kötetében (1894) szakirodalmi hivatkozást találunk (Petraşcu munkája $)^{96}$, és Eminescu verseinek népies kiadását is említik. A Révaiban a már ismert mondat zárja a cikket: „Ez a legnagyobb román költő.” A lexikonok szócikkei ismerik Eminescu magyarországi első versközléseit, és jelzik, hogy „későbbi költői hírnevét mint bécsi diák alapította meg, amidőn (1870) a Convorbiri Literareban közzétette eme két gyönyörü verset: Venere şi Madonă és Epigonii, melyek közül kivált az utóbbi ért el nagy hatást" ${ }^{97}$ Látjuk, hogy a korábbi alfejezetben idézett román irodalomtörténeti munkához (1875) képest két évtizeddel később értékesnek tartják ugyanazt a verset, igaz, hogy ekkorra már a kötetbeli közlés és a Maiorescu-tanulmány után vagyunk.

A lexikonok költészete pesszimizmusát, illetve a német hatást is hangsúlyozzák. A költő születési dátuma eltérő a két szócikkben: a Pallasban 1849. december 20., Révainál 1850. január 15. szerepel. Nem meglepő a bizonytalanság ${ }^{98}$, hiszen a 19. században, de korábban sem tulajdonítottak olyan jelentőséget a pontos dátumnak, fontosabbnak mutatkozott például a keresztelés időpontjának rögzítése. A kanonizációs folyamat során a Révai-féle időpont vált érvényessé.

Nem kivételszerű a román vagy más, szomszédos (pl. délszláv) nép(ek) irodalmi alakjainak jelenléte a magyarországi lexikonokban. Román vonatkozásban Andrei Mureşanun kívül minden jelentősebb 19. századi román költő szerepel ilyen típusú gyüjteményekben: Vasile Alecsandri (Révai, Tolnai), Dimitrie Bolintineanu (Révai), George Coşbuc (Pallas, Révai, Tolnai, Irodalmi), Octavian Goga (Tolnai, Irodalmi). Külön szócikkek tárgyalják ezeket az irodalmakat is.

\footnotetext{
${ }^{95}$ Mindkét lexikon román vonatkozású szócikkeit Gheorghe Alexi, a pesti egyetem akkori romántanára írta, majd őt ebben a munkában Ioan Costa követte. Erre utal FARKAs 2010, 100.

${ }^{96}$ Nicolae Petrașcu az első olyan kritikus, amely átfogó munkában tárgyalja Mihai Eminescu életmúvét. Lásd: Petrașcu 1892.

${ }^{97}$ Pallas 1893-1897.

${ }^{98}$ Eminescu különböző helyzetekben eltérő dátumokat közöl, de a hivatalosnak számító egyházi nyilvántartás vagy iskolai igazolások is más-más időpontra teszik születését. Lásd erről bővebben: STEFANELLI 1983, 59.
} 
Érdemes utalni a „román irodalom” szócikkére. Szerzője tágabb irodalomfogalmat használ, hiszen egyrészt az első román nyelvủ egyházi használatú, nem kimondottan irodalmi nyomtatványoktól tekinti át a szövegtermést, másrészt nyelvészeti, történeti tekintélyeket, szakmunkákat is sorol. Vessünk egy pillantást a szócikk 19. századdal kapcsolatos részére: „Románia legismertebb költője Alexandri[sic!] Vazul, aki mint lírikus legnagyobb, de az epikai költészetben is maradandó becsű műveket teremtett. Az ódai költészet legméltóbb képviselője Mureşanu András, Bolintineanut történeti balladái teszik halhatatlanná. Negruzzi is írt néhány hangulatos költeményt. Ezeken kívül jól ismert művelói még a pesszimista Eminescu és Nicoleanu, Sion, Macedonski és mások". ${ }^{99}$ Ebből az idézetből arra következtethetünk, hogy Eminescut halála után röviddel már az elismert költők társaságában találjuk. Igaz ugyan, hogy a mai irodalomtörténeti álláspont felől még a kevésbé jelentős (de a 19. század második felében népszerü tekintély) George Sion, az elfeledett Nicolae Nicoleanu és Alexandru Macedonski mellett szerepel; Nicoleanuval pesszimistákként. Vasile Alecsandri jelenti a viszonyítási pontot és az ő lírájához képest látszik differenciálódni - műfajilag- a román irodalom. A klasszikus műfajnak számító, de Mureşanunál hazafias jelleget öltő óda mellett a történeti ballada képviselőit nevezi meg az idézet. Nicoleanu meg Eminescu nem múfajilag, hanem költeményeik bölcseleti iránya miatt lesznek érdekesek a 19. század legvégén.

Heinrich Gusztáv 1903-tól négy kötetbe szerkeszti a munkatársakkal közös vállalkozást, az egyetemes irodalomtörténetet. Ebben közli a fentebb említett lexikonok szócikkírójának, Gheorghe Alexinek románokról írott dolgozatát, ami önálló kiadványként is megjelent ugyanazon évben. Alexi az Eminescura vonatkozó életrajzi felvezetés és az életmú általános ismertetése mellett maga is lefordít két verset, és megjegyzi, hogy Révai Károly sikerülten ültette át magyarra az $O$ mamă/Anyám címú verset. Alexi szövegének két pontját hangsúlyoznám. Elsősorban, Eminescu Kant-fordításáról írja: „mondják, hogy Kant Kritik der reinem Vernuft munkáját le is fordította” ${ }^{100}$ - jelzem, hogy a "mondják” használata azt is jelentheti, hogy szóbeli információkat is forrásértékünek tartott Alexi, amikor dolgozatát készítette, hiszen egy frissen lezáródó, kánoni helyét kereső életmű kapcsán fogalmaz így. Másodsorban, Alexi Eminescu munkásságát feldolgozó két tanulmányt is említ: Ilie Cristea és Szőcs Géza írásait. Továbbá megjegyzi, hogy a fiatalok olvassák Eminescu verseit, és mind Magyarországon, mind Erdélyben a De ce nu-mi vii / Oh, mért nem jössz c. versét éneklik,

\footnotetext{
${ }^{99}$ Pallas 1893-1897.

${ }^{100}$ Alexics György [Gheorghe Alexi], Az oláhok. Európaivá formálódó oláh kultúra és irodalom $=$ HEINRICH 1905, 853.
} 
sőt inkább megzenésített változatában ismerik. ${ }^{101} \mathrm{Ez}$ az adat hasonlóan Eminescu Kant-fordításának lehetőségéhez, szóbeliségen alapuló információ. Megzenésített változatában a vers a recepció egy másik szintjét jelenti, azt, amely a magas irodalomból a populáris regiszterekbe vezet, hiszen a közösségi éneklés szövegévé alakuló szépirodalmi alkotás a folklorizáció útjára lépett, énekelve, megzenésítve hagyományozódik. A 20. században megszaporodó Eminescu-megemlékezések gyarapítják az adott alkalmakra megzenésített költemények sorát, így azok visszatérő, rituális elemeivé válnak a kultikus jelentésekkel telített ünnepségeken. ${ }^{102}$

Alexi írásai tájékozottságát, román irodalomban és szakirodalomban való jártasságát példázzák. Arra is például szolgálnak, hogy az írott és nyomtatott források mellett a 19. század végén még a szóbeliségen alapuló, irodalomhasználattal kapcsolatos információ is dokumentumértékű lehet.

Mind a nekrológok, mind az első lexikonszócikkek jelentős költőként tüntetik fel Mihai Eminescut. Az életrajzi adatok e szövegek műfajisága miatt is nagyobb súllyal bírnak, mégis a költő munkásságát értékelő részeket is találunk bennük. Azért sem elvetendők ezek a szövegek, mert amellett, hogy a recepció bizonyos modalitását képezik, önmagukról is árulkodnak: a cikkíró tájékozódásáról, forráshasználatáról, előfeltevéseiről, a román irodalom általa belátott helyzetéről. A német hatás és a pesszimizmus viszszatérő motívumként van jelen ezekben az értékelő szövegekben.

\subsubsection{Az első magyar nyelvü értelmezések}

Az alkalmi jellegű, hírértékű és a lexikonok ismeretterjesztő szövegei után elsőként egy tankönyvvel foglalkozom. Grigore Moldován 1888-ban tankönyvi használatra szánt, román nyelvet tárgyaló kézikönyvében az újabb román költőnemzedék kapcsán így fogalmaz: „kiválik Eminescu Mihály (1849-)[!], akit Alexandri [!] Vazul után szokás emlegetni. Újabb időben, súlyos betegsége miatt elhallgatott. Nyelve búbájos, érzései igazak. Költeményei egyes lapokban jelentek meg". ${ }^{103}$

Moldován, akit korábban a román színházzal kapcsolatos állásfoglalása miatt idéztem, fontos figurája a kapcsolattörténetnek. A 19. század végén a kolozsvári egyetem román tanszékének tanára, ilyen minőségében professzionális nyelv- és irodalomtudósnak tekinthető. Tájékozott saját nemzete irodalmában, amennyiben az élő költőt megemlíti tankönyvében. Eminescu szerepeltetése jelzi, hogy könyve nem pusztán történeti munka, hanem a kortárs jelenségekig követi a román nyelv alakulását. Persze, elna-

\footnotetext{
${ }^{101}$ Erre utal, és nem egészíti ki egyéb információval Elena Stan könyvében: STAN 1969.

${ }^{102}$ Lásd erről bővebben STAN 1969.

${ }^{103}$ Moldován 1888.
} 
gyoltnak találhatjuk ezt a pár sort a román költőről, viszont tankönyvbeli előfordulása a kanonizálása felé mutat, ugyanakkor a könyv használata által e pár mondat kielégíti az ismeretátadás funkcióit. Nem irodalmi vagy kritikai értelmezés ez a tankönyvi hivatkozás, de utólag azért vált fontossá, mert kortársi szöveg, a költő életében (hosszúra nyúló haldoklásának idején) jelentették meg.

Moldován tankönyvet ír, hiszen oktatási segédanyagra van szüksége a hivatalosan magyar nyelvü egyetemen. Más irányba tereli viszont a történetet e könyv nyelve. Moldován 1887. október 2-án magyar nyelvü levélben fordul a Magyar Tudományos Akadémia könyvkiadójához, megbízatást remélve: „A magyar irodalomban nincs mü, mely a román nyelv és irodalom történetét tárgyalná. Egy ily mű fontosságát kétségbe vonni nem lehet, akkor nem volna a román nyelv és irodalom a magyar közönség előtt merőben ismeretlen föld. Egyetemünkön a román nyelv és irodalom történetének előadását befejezem, csekély fáradsággal kéziratomat át alakíthatnám akként, hogy a magyar akadémia könyvkiadó vállalatának múvei között helyet foglalhasson". ${ }^{104}$ Moldován koncepciója szerint az átdolgozott egyetemi előadások megfelelőképpen informálhatnák a román irodalom iránt érdeklődő magyar közönséget. Ily módon bár apró részleteként is annak, de e tankönyv rendeltetését tekintve, az Eminescu-utalás irodalmon kívüli célt szolgál: általa megismertetni egy idegen nyelvet és irodalmat a magyar olvasókkal. Az, hogy mit ért Moldován "magyar közönségen”, illetve saját egyetemi hallgatóit beleérti-e, kérdéses lehet. ${ }^{105}$

Érvelése felől a szakmai ismeretek nem különülnek el a tájékoztató, népszerüsítő, „népismertető” munkáktól, és ehhez igen közel áll a szélesebb olvasóközönséghez eljuttatandó, ugyanakkor a szűkebb rétegü egyetemi hallgatóságnak előadandó tudományos igényű szöveg. E koncepció mögött, amint az imént említettem, meglehet, hogy nem annyira a modern értelemben vett szakmaiság munkál, mint inkább az egymás mellett élő népcsoportok megismerhetőségének ideológiája, amelynek szolgálatába kívánja állítani tankönyvét Moldován. Következésképp, a kolozsvári egyetem román tanára szemlélete eltér/elmarad például a pesti egyetemen gyakorolt, professzionalizálódó magyar irodalomtörténet-felfogástól. ${ }^{106}$

Álljon itt egy másik egyetemközeli példa.

\footnotetext{
${ }^{104}$ Moldován Gergely megbízatást kér a román nyelv és irodalomtörténeti munkája megírása tárgyában. Kézirat lelőhelye: MтAк Kt., jelzete: Ral 1007/1887.

${ }^{105}$ A kötet egy későbbi fejezete részletesen foglalkozik a kolozsvári egyetem bölcsészkarának oktatóival, hallgatóival, azzal a közösséggel, amelyben Moldován dolgozott, és amely tankönyve olvasótáborát képezhette.

${ }^{106}$ Az utóbbiról bővebben: T. SzABó 2006.
} 
Miron Cristea 1891 és 1895 között a budapesti egyetem bölcsészkarának diákja, és 1895. május 15-én szerez doktori címet. ${ }^{107}$ Disszertációja címe: Eminescu élete és müvei. ${ }^{108}$ Mind a magyar, mind a román szakirodalom számon tartja ezt a munkát és korai megjelenése miatt értékeli. A korai megjelenés mellett értékét az növeli, hogy a szerző egyetemi évei végeztével doktori dolgozatként publikálja. Viszont nem egyedi eset a Cristeáé. Dulfu Péter 1881-ben jelenteti meg Vasile Alecsandri működését feltáró doktori dolgozatát. ${ }^{109}$ Dulfu témaválasztásának érdekessége, hogy lezáratlan életművet vizsgál, ami nem gátolja őt abban, például, hogy rendszerezze, korszakolja Alecsandri addig megjelent müveit. ${ }^{110}$

Miron Cristea disszertációjával részletesebben foglalkozom, hiszen az első magyar nyelven írt tanulmány Eminescu költészetéről. Más kérdés, hogy mennyiben a magyar recepció része ez a szöveg, hiszen a pesti egyetem román tanárának, Alexandru Romannak a román származású diákja írta. Roman és Cristea között szoros kapcsolat lehetett, aminek egyik bizonyítéka az, hogy 1893-ban, Alexandru Roman harmincéves egyetemi tanári jubileumát Cristea szervezi. ${ }^{111}$

A disszertáció szövege nyelvválasztásával játssza ki a modern értelemben vett nemzeti irodalomfogalmat, és világít rá arra, hogy a nyelvismeret, nyelvhasználat és nemzeti identitás nem minden esetben egybeeső kategóriák. Nem pusztán a többnyelvű kultúrában való szocializáció tette lehetővé Cristea számára a magyar nyelven történő értekezést, hanem azt az egyetemi bürokrácia is szabályozta. ${ }^{112}$

${ }^{107}$ Cristea Illés, ortodox, Toplița, Mureș-Turda, Gimn. Sup. Năsăud, bursă de stat (ort.), S. Transilvania, 1891/92, 1892/93, 1893/94, 1894/95, Doctorat litere şi filosofie 15 mai 1895. Vö. SigmiREAN 2000, 433.

${ }^{108}$ CRISTEA 1895.

${ }^{109}$ Dulf 1881.

${ }^{110}$ A lezáratlan életművek, élő alkotók egyetemi oktatás, élő személyiségek portréinak, életrajzainak publikálása természetesnek tünik a 19. századi román kultúrában. Ez ellentmond annak a szerző- és szövegfogalomnak, amely ekkor meghatározza a magyar irodalmi gondolkodást. Lásd erről bővebben: T. Szaвó 2001, 43-68.

${ }^{111}$ Dinurseni 1897, 18. (Mellesleg, az Ilie Dinurseni egy álnév, amely Miron Cristeát fedi. Vö. Straje 1973. Cristea Alexandru Romanról írt életrajzi ismertetést, amelyet az egyetemi tanár halála évében már meg is jelentetett.)

112 1892-ben gróf Csáky Albin válaszol arra az április 4-i egyetemi tanács által kiállított jegyzőkönyvre, amely a Magyar Királyi Ferenc József Tudományegyetem Bölcsészet-, Nyelv- és Történettudományi karán román nyelven szerkesztett doktori értekezést fogadott el. Csáky az 1868/44. törvény 19.\$-ára hivatkozva jelzi, hogy a doktori értekezések nyelve a magyar vagy a latin lehet. A vallás-és közoktatásügyi m.k. minisztérium által a kolozsvári FJTE tanácsához intézett elvi jelentőségü rendeleteinek gyüjteménye az 1872/3-1898/99 tanévekről, Kolozsvárt, 1900, 417. 
Fontos megjegyezni ennek kapcsán, hogy a „nemzeti irodalom” modern fogalmával ellentétesen vagy másként müködhetnek az olyan szövegek, mint a Cristeáé, hiszen egyszerre részei Mihai Eminescu „román” és „magyar” recepciójának. Látható, hogy Cristea nyelvválasztása nem személyes döntése, hanem a szabályzat kényszerének következménye: a nyelv teszi a magyar Eminescu-recepció részévé. Nem csupán az eddigiek, hanem általánosan, az irodalom- és kapcsolattörténet szempontjából releváns kérdést fogalmazhatunk meg: mennyiben jogos a nyelv alapján kategorizálni egy alkotó műveinek recepcióját?

A modern értelemben vett, nyelvalapú irodalomfogalmak egyik viszszásságát leplezi le az előbbi kérdés. Ugyanitt az is megállapítható, hogy a nyelvhasználat a 19. század végén még nem esett egybe egyértelműen az etnicitással, illetve még nem volt kizárólagos jegye ennek. Szükséges ennek belátása, illetve annak a környezetnek a rekonstruálása - egy későbbi fejezetben Miron Cristeát egyetemi hallgatóként vizsgálva -, amely konvencionálisan megszabta azt, hogy Cristea magyar nyelven írja dolgozatát; így lesz perspektívafüggő nyelvhasználata, és ezt az a cselekvési szituáció magyarázhatja leginkább, amelyben szövege létrejött.

Visszatérve Cristea doktori értekezésére, a címben megjelölt kettős szerkesztésű kötet (élete és múvei) mottóval indul, amely Al. Vlahuță, Răspuns la o cronică rimată c. verséből származik. ${ }^{113}$ Vlahuță személyes ismeröse volt Eminescunak, több versben tiszteleg a halott költő előtt, sőt ihletettséget is verseiből nyer. E tisztelettel és kegyelettel telt dicsőító paratextus a végtelen időbe tágítja a mester nagyságát és felülír bármiféle kritikai beállítódást. A halál felől ok-okozati láncként beállított életrajz eseményeit e telikus szemlélet mellett a költő alkotásaiból vett idézetek magyarázzák.

Cristea az életrajz valóságát azonosíthatónak tartja a költészetben megmutatkozó lírai én versbeli életeseményeivel, életérzéseivel, ezért mossa egybe az egyén és a lírai én valóságait, például: „nem tudjuk biztosan, de egyik költeményéből következtetjük, hogy e kóborlás előtt vagy után mint magántanuló, tartózkodott még Csernowitzban"114, és hivatkozásként Cristea idéz Eminescu La mormîntul lui Aron Pumnul [Aron Pumnul sírjánál] c. verséből.

Az idézetek román nyelven kerülnek a főszövegbe, lábjegyzetben pedig magyar nyelvú prózai fordításaik, a verscímek megjelölése nélkül. Miron Cristea nem vállalkozik versfordításra, az ismertetés szándékával,

${ }^{113}$ Măreț pluti-va printre veacuri / Maiestrul dulce Eminescu, / Er' jos cu-a lor bagaj de flécuri, ...[Büszkén evez a századokon át az édes mester, Eminescu, és lent a semmiségekkel tele terhekkel...] - ez a kiválasztott mottó, amely hiányos olyan értelemben, hogy hasonlításra épül a vers, innen pedig lemarad az, akihez képest Eminescu a szárnyaló zseni, a halhatatlan: „Toncescu fi-va tot Toncescu!...", azaz Toncescu, ö Toncescu marad...

${ }^{114}$ CRISTEa 1895, 6. 
és nem a vers teljes, művészi értékű tolmácsolásának igényével fordul e költészethez. Valószínű a nyelvi korlátok miatt sem teszi azt. Ilyenképpen munkája sajátos párbeszédet hoz létre a román versszövegek és azok magyar parafrázisai között, és úgy ír a román költőről, hogy értekezése magyar nyelve nem fedi el teljességében a vizsgált román nyelvű Eminescuszövegeket, amelyek itt ismét irodalomtól távolodó funkciót töltenek be: Cristea az ismertetés kedvéért idézi be őket. A verseket nem kezeli megtörhetetlen egységekként, hiszen csak az őt éppen érdeklő verssort, szakaszt vagy hosszabb részletet közöl. Az ismertetés szándéka mellett illusztratív funkcióval látja el az idézeteket, hiszen az Eminescu-versek felől talál magyarázatot a költő életrajzára.

Az értekezés szoros olvasásakor felszínre bukkan az azt szervező retorika is. Ez nem más, mint a determinált lét narratívája, ahonnan jobban belátható a költő halála. Már a családot is úgy írja le Cristea, hogy generációs, vérségi meghatározottságot feltételez: anyai ágon továbböröklődő betegségek hordozója lesz a költő. Eminescu életképtelenségét Cristea a pesszimizmus mellett a hiányzó pályaválasztással, oklevéllel igazolható képzettséggel is magyarázza - amikor ezt teszi, akkor kora értelmiségideálját kéri számon a költőn. Mivel Eminescu nem illik ebbe a képbe, kézenfekvőnek tűnő analógiákat sorakoztat fel: „lángeszű férfiakat”, Lenaut, Petőfit, Arany Jánost, Schillert, Körnert, hozzátéve, hogy „, a költők többnyire nem alkalmasak semmiféle hivatalra és pályára"115. A német romantika zseniképzetére ismerünk ebből a párhuzamból. Arany János kilóg Cristea érveléséből, hiszen Arany tanárként, majd az MTA titkáraként működik.

A magyar irodalom felől pedig érdekes Arany szerepeltetése Petőfi mellett, az előbbivel való párhuzam az irodalomtörténeti értékelések során elkopik, és marad a nemzeti költők, azaz Petőfi Sándor és Mihai Eminescu analógiája. Ezek a párhuzamok Cristea irodalmi jártasságáról árulkodnak, arról, hogy milyen nyelvü irodalmak mely képviselőihez próbálja hozzárendelni analogikusan az Eminescu-versek sajátosságait. Úgy gondolom, hogy nem véletlen a német, majd a magyar példák felemlegetése, hiszen részint Eminescu külföldi tanulmányútjai, bölcseleti jellegű költeményei, pesszimizmusa magukért beszélnek, másfelől pedig Cristea magyarországi képzettsége (Beszterce, Naszód, Nagyszeben, Budapest) a magyar meg a német irodalomban való jártasságát feltételezi.

A disszertáció az első fejezetet a költőt ábrázoló művészi reprezentációk említésével zárja: a román ifjúság Botoşani-ban bronz mellszobrot, sírjánál márványemléket állított. Egyértelműnek tűnik tehát számára, hogy

${ }^{115}$ Cristea $1895,16$. 
az ifjúságnak kell kegyelettel viszonyulnia a költőhöz, hiszen kortársa volt. ${ }^{116}$

Cristea kilencvenhat Eminescu-költeményről tud, amelyeket tematikusan mutat be. A költő pesszimizmusa képezi fő érdeklődési körét, tájékozódik ebben a kérdésben, Vlahuțát, Maiorescut, Ghereát, Emilian Corneliát idézi, akik különböző okait fogalmazták meg Eminescu búskomorságának. Cristea két dolgot emel ki e kérdésből: egyrészt azt, hogy a fatalistává lett Eminescu istentagadó, holott a keresztény hit támasz - ez persze Cristea saját személyes perspektívája, egyházi képzésben részesült; másrészt a barátok, s főként egy feleség hiánya (azaz kora társadalma elvárásainak be nem tartása) volt végzetes a költő számára. Az értekező tehát saját létfelfogását kéri számon az általa vizsgált költőn: ő az optimista létet közösségben, Isten iránti alázattal, családban képzeli el, szociális és vallásos biztonságban.

A hazaszeretet és nemzeti érzelem kérdését részletesebben tárgyalja, mivel cáfolni szeretné azokat a bírálókat, akik Eminescut emiatt elítélték. Eminescu verseit hozza példaként, amelyek a költő román nép iránti szeretetét közvetítik, és megjegyzi, hogy „midőn hazájáról van szó, kedélyének legjellemzőbb vonása - pesszimizmusa - teljesen eltünik"117. Eminescu tehát optimista is tud lenni, de kizárólag hazafias, nemzeti költészetében, írásaiban. Ilyen versekként sorolja a Din străinătate, La Bucovina, Epigonii, Ce-ți doresc eu ție, dulce Românie..., Doina címüeket. Ezek nagy részét a magyarországi román lapban, a Familiában közölték.

Annak ellenére, hogy az értekezés második fejezete elején azt állítja ezekről a korai versekről, hogy kísérletek és gyászos ódai emelkedettség jellemzi őket, mégis a haza- és nemzetszeretet kapcsán optimistáknak találja. Miért fontos ez Cristea számára? Magyarországi románként saját büszkesége lehet Eminescu költői indulása. Ezen továbblépve, másként értelmeződik számára a nemzet-, és hazaszeretet fogalma, hiszen idegennek láthatja a magyarországi viszonyokat a többnyelvú kulturális szocializálódás ellenére is.

A pesti román közösség intézményeit létrehozó és fenntartó értelmiségiek, az egyetemi tanár, a lapszerkesztők, az egyetemi diákság olvasótársaságai ${ }^{118}$ mind a román kultúra megmaradását szorgalmazzák, és ezt

\footnotetext{
${ }^{116}$ A román ifjúság szívesen kapcsolódik be jótékonykodási akciókba a 19. század végén. Pénzt gyűjtenek a költő orvosi kezeléséhez. Vö. CăLInEscu 1989. De más alkalmakkor is, például a pesti egyetemi ifjúság több ízben szervez jótékonykodással egybekötött bált az AsTRA, a színügy előmozdítására. Ezt teszi a kolozsvári román egyetemisták Iulia-egylete is. Lásd a Kolozsvári Közlöny évfolyamaiban 1872-től a Mi újság rovatot.

${ }^{117}$ CRistea 1895, 60.

${ }^{118}$ A Petru Maior Irodalmi Társaság lapja, a Rosa cu ghimpi mottója: „Cultura va salva Romanimea"[A kultúra menti meg a Románságot].
} 
a románokkal való szolidaritásként, majd hazafias cselekedetként értelmezik. Nem mellékes az sem, hogy Cristea Eminescu politikai cikkeit is megemlíti, sőt arra hivatkozik, hogy sokan érdeklődnek ez iránt.

Mindemellett beszédes hiányként van jelen Cristea disszertációjában az a topikus elem, amely a 20. századi Eminescu-recepció meghatározó fogalma: Eminescu mint nemzeti költő. Amint látszik, a különböző irodalomtörténeti szempontú munkák kanonizálni próbálják, hierarchikusan vagy Vasile Alecsandri után vagy vele egyenrangúként sorolják; vagy a mára, a román irodalmi kánon másodvonalába tartozó szerzők között említik. Megtörténhet, hogy az, ami mára hierarchiának látszik, az a primus inter pares elv alapján múködött, és ezek az Eminescu-értelmezések ezt a működési elvet illusztrálják. Hiszen a nemzeti mint kategória nem fordul elő egyetlen szövegben sem. A román nép vagy a románság költője megfogalmazás arra a közösségre utal, amelyhez a költő nyelvileg, származását tekintve tartozik, és amely közösség számára halála gyászt jelent. A román nép költője itt még nem a modern értelemben vett „nemzeti költő"-jelentésben használt kifejezés. ${ }^{119}$

Kontrollforrásként vizsgáljuk meg a másik, 1895-ben publikált Eminescu-monográfiát ${ }^{120}$, amelynek szerzője Szőcs Géza nagyszebeni tanár, a kolozsvári egyetem végzettje ${ }^{121}$. A lábjegyzetben idézett életrajzi adatokat kiegészítendő jegyzem meg, hogy Szőcs Géza 1896. május 30-án bölcsészdoktori címet szerez a kolozsvári egyetemen. ${ }^{122}$ Valószínűsíthető, hogy doktori értekezését is Eminescuról írta.

Szőcs meg kívánja ismertetni az olvasókkal a román irodalom „legérdekesebb, legmodernebb, legjelesebb lírikusát, [...] a magyar-román testvériség, jóbarátság erősítése, nevelése céljából. [...] Román ajkú honfitársainknak pedig be akarom mutatni egy magyar embernek - s elmerem mondani: jó magyar embernek felfogását az ő jeles költőjükről" ${ }^{123} \mathrm{~A}$ politizálás vádját elhárítandó hangsúlyozza a két nép közti barátságot, a munkája iránti román érdeklődést. Innen nézve, megtörténhet, hogy a magyar érdeklődést a román irodalom, kultúra iránt eleve politikai gesztus-

\footnotetext{
${ }^{119}$ A „"nemzet”, „nemzeti” mint nyelvenként különböző jelentéstartalmú, a definíciónak ellenálló fogalmak értelmezéséhez lásd: SzILÁGYI N. 2003.

${ }^{120}$ Szốcs 1895.

${ }^{121}$ Szinnyeinél a következőket olvassuk róla: „bölcseleti doktor, állami főgymnasiumi tanár, szül. 1870. Vizaknán (Alsó-Fehérm.); 1890. tett tanári vizsgát a magyarból és latinból, 1895. magyarból és ruménból. Jelenleg tanár a nagyszebeni áll. főgymnasiumban." [http:// mek.niif.hu/03600/03630/html/index.htm - utolsó látogatás: 2012 júliusa]

${ }^{122}$ Geysa Szöcs, 26, ev.ref., Vízakna, in doctorem Philosophiae promotus die 30 mensis Maii anni 1896. Vö. A kolozsvári m.k. Ferenc József Tudományegyetem Tanácsa és doktorai névkönyve, I.kötet, 1872/1873-1899/1900. [Kézirat lelőhelye: Román Âllami Levéltár, Kolozsvár. Jelzete: Fond 315, reg. 111.]

${ }^{123}$ Sző́cs 1895, 5.
} 
nak vélte mind a magyar, mind a román olvasóközönség. Ezért van talán előszava ennek a kiadványnak, olyan előszava, amely a szerzői intenciókat láttatja, és erkölcsi alapon érvel mellettük. Szőcs már felvezetőjében is egyértelműen kijelenti szerzői szándékait, amelyek sokkal hangsúlyosabban állítják a kultúrák közötti megismerés, és ennél tovább lépve: a testvériség, barátság szolgálatába a munkát.

Visszatérve Eminescu politikai és hazafias költészetére, Szőcsnél a következőket találjuk. Ő is a Ce-ți doresc eu ție, dulce Românie c. verssel illusztrálja a költő hazafiúi érzéseit, amelyért a politikai agitációkkal teli kor nem tudott kellőképpen lelkesedni. „A hazafias líra terén nem alkotott Eminescu annyit, amennyit nemzete kívánt és kíván költőitől, s ez volt legfőbb oka annak, hogy - mint Xenopol megjegyzi - költői »boltja« nem jövedelmezett sem anyagilag, sem szellemileg annyit, amennyit a tulajdonos jeles [szórend!] megérdemelt volna".${ }^{124} \mathrm{~A}$ bolt-metafora akaratlanul is jelzi annak a folyamatnak a létét a román irodalomban, ami a magyar irodalom hivatásosodásának is fontos része. Ennek lesz áldozata Eminescu, vélik kortárs kritikusai, mert nem ismeri fel azt a gazdasági lehetőséget, amelyet a nemzeti költészettel megszerzett írói népszerüség hordozhat.

Egy rövid kitérő erejéig utalok azokra a közösségi alkalmakra, amelyek a hazafias érzületet, a nemzet iránti tiszteletet hivatottak reprezentálni és megerősíteni, azért, mert éppen az így felhasználható szövegek hiányát kifogásolja Szőcs Eminescunál. Főként magyarországi példákkal találkoztam kutatásaim során.

A pesti Petru Maior Olvasótársaság - amelynek mind Roman, mind Vulcan elnöke volt - nyilvános alakuló ülésén, 1873. június 9-én a nyitó- és záróbeszéd között Andrei Mureşanu Un răsunet; Vasile Alecsandri Sentinela română és George Sion Limba română címü versét énekli a kórus, valamint Iosif Vulcan Cătră română címü költeményét deklamálja I. Panea. ${ }^{125}$ A kolozsvári román egyetemi hallgatók Iulia-egylete is évente négy deklamáló koncertet szervez, amelyen „nemzeti öltözet"-ben járják a „călusart”"126. Ezeken az alkalmakon a felsorolt költeményeket - Alecsandri, Cântecul gintei latine (kórusmüként) és Odă ostaşilor români, I. Bădescu, Sigiliul negru, G. Sion, Steaua României (kórusmúként), I. Popfiu, La moartea lui Andrei Mureşanu (kórusmüként) adják elő vagy deklamálják ${ }^{127}$. A bállal vagy majálissal egybekötött kolozsvári „koncertek” nyitottak a nyilvánosság számára. $\mathrm{Az}$ (ön)ünneplés alkalmai, ahol az ünnep magasztosságát népviselettel, de

\footnotetext{
${ }^{124}$ Sző́cs 1895, 1011.

${ }^{125}$ Almanahul Societății de lectură Petru Maior din Budapesta, ed. Propria, Gherla, Tipografia Andrei Todoran „Aurora”, 1901.

${ }^{126}$ Román néptánc. Pünkösd hetén járták a falusi férfiak.

${ }^{127}$ Más hazafias dalokat is énekelnek: Sub Ştefan Vodă vagy Nainte, nainte frați. Vö. Micu (red.) 1880.
} 
alkalmi ünnepi beszéddel, kórusművel, szónoklattal, deklamációval, előadással, zongora-, hegedűjátékkal, körtánccal biztosítják.

A közösségi identitást erősítendő hangzanak el ezek a hazafias-történelmi tárgyú költemények, kórusművek. Ilyen típusú művekre volt szüksége a két egyetemi központ ünneplő ifjúságának és érdeklődő közönségének. Igaz ugyan, hogy ezek az alkalmak egyben a szórakozás vagy éppen a jótékonykodás alkalmai is, viszont mindig ",nemzeti” színt kapnak, mindamellett, hogy a magyarországi románok saját hazafias tettként tartják számon őket.

Tehát Szőcs érvelése értelmében, ettől a szöveghasználati lehetőségtől esik el Eminescu, amikor nem válik hazafias versek szerzőjévé.

A két Eminescu-tanulmányt összevetve az alábbiakat állapíthatjuk meg: Cristea Illés-értekezése szakmunkának tekinthető ${ }^{128}$, tájékozottsága, korpuszismerete a lehetőségekhez képest értékelendő. Párhuzamokat keres és talál az Eminescu-életmü elhelyezéséhez, és a zseni toposzát találja megfelelőnek. A tudományos igénnyel megírt értekezés adatokat, forrásokat közöl, a költői életmüvet szintén (irodalomtörténeti) forrásként használja. Ismeri azokat a szaktekintélyeket, akik korábban értékelték Eminescut, hivatkozik rájuk, és állást is foglal velük szemben. Állásfoglalásai amellett, hogy kijelölik tudományos pozícióját és ismereteinek leképezései, megmutatják módszertanilag, hogy hogyan építi fel szövegét, hogyan gondolkodik ő maga a költészetről, Eminescuról, az utánzásról. Pozitivistának nevezhető módon viszonyul kutatási kérdéseihez. Amikor Eminescu egyéb foglalatosságait, azok eredményét „ephemernek”, múlónak, elillanónak nevezi, implicit módon a költészet örökkévalósága mellett foglal állást. A költészetet határozottként, teljesként, egészként képzeli el, melynek ,"a lélekre fölemelö, kielégítő s megnyugtató hatást kell gyakorolnia. Ennél fogva a költészet célja nem lehet az, hogy minden reményt, minden illúziót tönkre tegyen, s hogy minden idealizmust elpusztítva lelkünket a kétségbeesés karjaiba vesse" ${ }^{129} \mathrm{~A}$ zárógondolatok amellett, hogy mü egésze Eminescut jelentős költőként állítja be, mintha burkoltan bírálnák gyászos pesszimizmusa miatt, talán azért is, mivel követői ezt utánozzák, holott Cristea véleménye az, hogy a jó tulajdonságokat kellene utánozniuk.

\footnotetext{
${ }^{128} \mathrm{Az}$ általam olvasott példány a RTAK Kolozsvári Könyvtárában található és Gyulai Pál hagyatékából származik. Ha a tulajdonosok névbejegyzéseit, pecsétjeit forrásokként tekintjük, akkor megkockáztathatjuk, hogy Gyulai Pál tulajdonosként el is olvasta a múvet, talán tudhatott a doktori értekezésről.

${ }^{129}$ CRISTEA $1895,77$.
} 
Szőcs Géza monográfiáját Szamosi Jánosnak ${ }^{130}$ ajánlja. Ajánlásában Szamosi Jánost az Irodalmi Társaság alelnökeként szólítja meg. Az Erdélyi Irodalmi Társaság a népek közeledésének, megismertetésének kitartó munkásait, a fordítókat nagyra tartja, tagjai sorába választja, ezért sem véletlen ez az ajánlás. Miron Cristea pedig valószínűleg nagyszebeni kapcsolathálója ${ }^{131}$ révén értesül Szőcs tervéről, hiszen munkája végén található, Eminescu magyar recepciójáról írt pár sorában jegyzi meg, hogy a román költőt a Pallasban ismertetik és Szőcs Géza is értekezést jelentet meg róla. Szintén Cristea írja le, hogy „tudtunkkal egyetlen egy költeménye sincs magyarra fordítva [Eminescunak]"132.

A magyar, román és latin nyelvek tanárának, Szőcsnek a monográfiája sok mindenben hasonlít a Cristeáéra: ugyanazt a korpuszt vizsgálja (96 költemény), ugyanúgy prózában fordítja magyarra a román nyelvű versidézeteket. A költő pesszimizmusát is érvként hozza fel meg nem értettségére. Petőfivel állítja párhuzamba „lángelméje” kapcsán. Szőcs Géza viszont másképp gondolkodik Mihai Eminescuról. Életművét 1883-mal bezárólag tárgyalja, azaz lehatárolja. Ebben az évben Titu Maiorescu kötetbe válogatta és előszóval ellátva megjelentette Eminescu költeményeit. Szőcs szerint az 1883-ban megjelent versek sokasága, a kötetbeli új versek, de a kötet maga is Eminescu pályájának tetőpontját, költészete teljes elismerését jelentik. ${ }^{133}$

A magyarítás mellett Szőcs többnyire újrafogalmazza a versszövegeket, időrendben ismertetve azokat. A két monográfia azonban szembetünő különbségeket is mutat.

A Petőfi-párhuzam hívó szóként működik a 19. század végén Eminescu magyar irodalomba való beléptetésekor. Ez képezi az összehasonlító vizsgálatok kiindulópontját. Évekkel később Gáldi László viszont azt kifogásolja, hogy még Kristóf György is ezt a párhuzamot boncolgatja 1935-ben, holott Vörösmarty, Kölcsey, Vajda, Reviczky, Madách költészete

\footnotetext{
${ }^{130}$ A kolozsvári egyetem klasszika-filológia tanszékének tanára, a tanárvizsgáló bizottság tagja, az EME bölcseleti osztályának vezetője.

${ }^{131}$ Amint egyetemre való beiratkozási adatai mutatják, kétféle ösztöndíjjal támogatják Cristeát: állami ortodox ösztöndíjjal és a Transilvania Egyesület ösztöndíjával. Ortodox ösztöndíjjal a nagyszebeni érsekség támogatta Cristeát, hiszen korábban az ottani Teológiai Intézetben tanult, majd oda tért vissza a pesti tanulmányai végeztével. Téves lehet az állami megnevezés Sigmireannál. Ennek kapcsán mégis őt idézhetem, hiszen ő vizsgálta az ösztöndíj-támogatások szerepét az erdélyi és bánsági román értelmiség képzésében, és vonatkozó múvében Cristea nevét a nagyszebeni ortodox érsekség által felügyelt alapítványi ösztöndíjazottak között említi. Vö. Sigmirean -Pavel 2002, 16.

${ }^{132}$ CRISTEA $1895,77$.

${ }^{133}$ Szócs 1895, 11.
} 
megfelelőbb összehasonlítási pont lehetne. ${ }^{134}$ A két Eminescu-tanulmány ebben a kontextusban a következőképpen mutat: részint szerzőik irodalmi tájékozottsága, jártassága korlátozza őket a Gáldi által felvetett összehasonlításban, részint pedig a felsorolt szerzők ismertsége, magyar irodalmi kanonizációjának az alakulása sem hirtelen, hanem folyamatszerűen működött. Mást láthatott be és érthetett meg Cristea és Szőcs 1895-ben Magyarországon a fent sorolt szerzők költészetéből, mint Gáldi 1940-ben. Ez a szemléletbeli eltérés még inkább megerősít abban, hogy a prezentizmus nem járható út történeti jellegű vizsgálatokban.

Cristea egyetlen esetben utal a Petőfi-párhuzamra, amikor Eminescut a lángelmék sorában említi, és nem ez az egyetlen párhuzama. Szőcs Géza munkája viszont már első mondatával önkéntelenül erre a hasonlító, azonosító tevékenységre ösztönzi olvasóit, amikor így fogalmaz: „Eminescu Mihály született abban az esztendőben, amelyben a mi nemzetünk örökre elveszítette Petőfit." ${ }^{135}$ Nyilvánvaló, hogy Szőcs saját, magyar irodalmi nézőpontján keresztül viszonyul hozzá, és teszi felismerhetővé a nyelvileg is magyarrá tett román költészetet. Így a magyar nyelven olvasók saját tudásuk felől olvassák magyarrá az idegen, esetünkben a román irodalmat. Értekezése szempontjai a következők: írásmodor (Petőfi szárnyal, Eminescu nyugodtabb, a nirvánát keresi), a szabadság kérdése (a boldogság eszköze, áldozathozatal - mások a viszonyok, nincs lehetőség áldozatra, természetbeli különbözőség), temperamentum (tǔz, fa, villám, harcmező - víz, tenger, habok). Az utóbbi ellentétpár egyértelműen a költők egy-egy versére rímel: Petőfi, Egy gondolat bánt engemet, és Eminescu, Mai am un singur dor. Másképp lángész Petőfi, aki ilyenként egyedülálló a világirodalomban. Eminescut inkább alkotásai, tehetsége, fokozatos fejlődése alapján tekinti olyannak, aki „az óriási Petőfi mellett” feltünést kelthet. ${ }^{136} \mathrm{Az}$ életrajzi egybeesések is az összehasonlítás melletti érvek. A költészet perspektívájából olvasott életműhöz való viszonyulás etikai kérdésként értelmeződik: „olvashatjuk, magyarázhatjuk müveit, ezzel nem tesszük azt jóvá, hogy életében igen sokszor éhezett és fázott, ha ugyan lelkének lángja nem melegítette, és pipáját nem szorongatta dermedező ujjai között, mint Petőfi

\footnotetext{
134 „Eminescut [...], sajnos magyar részről igen későn fedezték föl, s bár ez nem volt különösen nehéz feladat, bajosan találták meg azokat a magyar irodalmi alakokat, kikkel Eminescu életműve, ha nem is hatásszerü összefüggésben, de mély lelki rokonságban áll". Vö. GáLDI 1940.

${ }^{135}$ Sző́cs 1895, 7.

${ }^{136}$ „Többször említettük már, hogy Eminescu világpolgárias elvei, s komor hangulata miatt nem nagy kedveltségnek örvendett; s többen visszatetszéssel fogadták Maiorescunak azt a véleményét, hogy Eminescu egyike Románia legelső költőinek, akit bátran lehet a közkedveltségű és nagyszerencséjü Alecsandri mellé állítani". = Szőcs 1895, 16.
} 
Debrecenben" ${ }^{137}$ Szőcs szövege tehát az utókor felelősségét hangsúlyozza a román költővel szembeni igazságtételben.

A Petőfi-párhuzam a későbbi recepció számára magyarázó és kanonizációs elvvé válik, hiszen míg Petőfi a magyar irodalomban, addig Eminescu a román irodalomban lesz nemzeti költővé, és ezáltal átpolitizálódik recepciója, kliséként működik.

Szőcs esetében sem merül fel a nemzeti mint kategorizációs szempont. Még Petőfi kapcsán sem, egyszerúen az életrajzaik egybeeső mozzanatai és a zseni-toposz alkalmazhatóságának következménye lehet a párhuzamba állítás oka.

Cristeához hasonlóan Szőcs is megpróbál tájékozódni az Eminescu-életmüben, a vonatkozó szakirodalomban, viszont kevésbé egyediek megállapításai. Cristea munkája doktori értekezés lévén, átfogóbb elemzéseket, tudományos igénnyel megírt szöveget jelent. Ha Szőcs valódi szándékát komolyan vesszük, és nem Cristea doktori értekezése felől állapítjuk meg érdemeit, akkor kijelenthetjük, hogy számos verset közöl mind román nyelven, mind magyar parafrázisban vagy gyengébb fordításban, amelyek által a magyar nyelven olvasók szélesebb körben is megismerhetik a költő Eminescut.

Cristeától eltérően, Szőcs magyar nyelvű mutatványokat (négy verset: Departe sunt de tine, La steaua, Adio, Ce e amorul?) közöl - mellékletként Eminescu költeményeiből, megjelöli az eredeti román nyelvű verscímeket is. ${ }^{138}$ Reflektáltan teszi mindezt: miközben jelzi fordítói kompetenciájának hiányosságait, tudja, hogy a gyengébb tolmácsolások is jelzésértékűek, a román irodalom iránti érdeklődéséről tanúskodnak, és ahogy ő állítja, talán a gyakorlottabb fordítók könyve olvastán kedvet kapnak az Eminescufordításhoz.

Ezen a ponton e sokcélú munka újabb távlata nyílik meg, nemcsak a recepcióba íródik bele az irodalom-népszerüsítés, hanem iránytűként jelöli ki az értékes, lefordításra érdemes alkotásokat más nyelvű irodalomból. Ez fordítva is működhet, bár nincsen rá példám, hogy a magyarra fordított versek alapján születnének magyar nyelvű értékelések.

Egy pillanatig időzzünk még el Szőcs könyvénél. Egy róla szóló recenzióból idézek: „Nálunk e nevet [Eminescu] aligha ismeri valaki, míg délkeleti szomszédunk, Románia egyik legjelesebb költőjét siratta el benne ezelőtt 8 évvel [!]. Elborult elmével az őrültek házában halt meg az emberszeretet és önzetlenség ezen ábrándos kedélyü apostola, hazája, nemzete

137 Szócs 1895, 33.

138 „Gyenge és hézagos fordításban, de mégis teljes szövege szerint kívánom közölni Eminescunak legalább egy-két költeményét, s igen sajnálom, hogy a legszebbeket fordítói gyakorlatlanságom miatt nem közölhetem. Remélem azonban, hogy jeles fordítóink rávetik szemüket Eminescura is." = Szốcs 1895, 34. 
nem méltányolta őt életében, mert ahelyett, hogy a szokásos ultrahazafias áradozásnak adott volna bombasztikus frázisokban kifejezést, a szegény, nyomorgó elnyomott köznépet vette védelmébe. [...] Az egész tanulmány tanulságos, élvezetes olvasmányt képez mindenki számára, aki az irodalom és költészet iránt érdeklődik". ${ }^{139}$ A népszerüsítő, ismertető szándékkal megírt recenzió amellett, hogy az olvasók figyelmébe ajánlja Szőcs könyvét, utal arra, hogy magyar viszonylatban még mindig ismeretlen Eminescu annak ellenére, hogy ma már tudjuk, ekkorra Sándor József és Laurențiu Bran fordításai megjelentek, de a nekrológokat is olvashatták az azokat megjelentető lokális lapok olvasói. Ezek a tények arra világítanak rá, hogy az, amit recepcióként definiálunk, hosszas folyamat eredménye.

A halálhír, a lexikonszócikk, tankönyvrészlet ellenében az önálló kiadványként megjelenő értekezés mint másodlagos irodalom nagyobb hatással bírhat. A 19. század utolsó éveiben kevésbé ismert tehát Eminescu a magyar nyelvű olvasók számára. Kérdés, hogy ez az ismertségi szint kiterjeszthető-e a román nyelvű irodalom egészére, legyen az magyarországi vagy romániai. Vonatkozó olvasásszociológiai kutatások hiányában nem vállalkozhatunk e kérdés megválaszolására. Az viszont látszik, mennyire időigényes az a folyamat, amely a kultúrák közötti kapcsolatot legitimálja. A román irodalom magyar fogadtatását ebben az időszakban még mindig a nyelvi kommunikáció nehézsége, a diszperzív fordítási gesztusok, a mögöttük meghúzódó előfeltevések (a megismertetés a fontos, a művészi tolmácsolás másodrendű) jellemzik.

Az elemzett szövegek felől egyértelműnek tünik, hogy egy idegen kultúrát a róla szóló másodlagos irodalom alapján is meg lehet ismerni és az idegenség felfedése, érthetővé tétele feltételezi a kultúrák és a mögöttük álló népcsoportok/etnikumok/nemzetiségek/nemzetek közötti testvériség és barátság lehetőségét. A barátság és testvériség itt nem alárendeltségi kapcsolatot feltételez, és ezt próbálják fellazítani a bemutatott szövegek mind referenciáikban (lásd a Petőfi-párhuzam), mind ideologikusságukban.

A korai Eminescu-recepciót vizsgáló fejezet folyamatában láttatja mind a 19. század második fele román nyelvű irodalmának, kultúrájának alakulását, mind azokat a nyomokat, viszonyulásmódokat, amelyek a magyar nyelvű kultúrában ennek kapcsán létrejöttek. A fejezetnek nem célja e román nyelvű kultúrát elhelyezni a magyar recepcióban, ezért is hiányzik egy, a magyar-román kapcsolatokat történetileg vázoló fejezet a kötet-

${ }^{139}$ (-nd.), Eminescu = Erdélyi Híradó 1895/248, 7. 
ből ${ }^{140}$, hanem inkább olyan kérdések megfogalmazása, amelyek árnyaltabb kifejtésére és alaposabb vizsgálatára a további fejezetek nyújtanak teret.

A fejezetben tárgyalt kérdések, amelyek az egyéni identitások nemzeti összetevőit, a nemzetiségi képviselők és a nemzeti viszonyát, a románként számon tartott értelmiségiek bonyolult önazonosságát érintik ${ }^{141}$, akkor válnak igazán izgalmassá, ha megkíséreljük visszaállítani azt a környezetet, amelyben megfogalmazódtak. A román irodalom nemzeti költőjének nevezett Eminescu pályája kezdetén egy olyan magyarországi irodalomhoz tartozott, amely egy etnikai csoport, a románság bizonyos rétegének volt sajátja, és korántsem müködött ekkor még (össz)nemzeti értékként. Ugyanakkor e fejezetből derül ki az is, mennyire alkalmatlan nemzetiként definiálni a 19. század végének román vagy magyar kultúráját, hiszen a magyarul megszólaló román etnikumú országgyűlési képviselők, a magyar nyelven publikáló egyetemi tanárok vagy doktori értekezést író egyetemi hallgatók szövegeit a többnyelvűség természetessége (vagy kényszere) a 20. században, a térség ún. nemzetállamainak létrejötte után is fölülírja a modern értelemben vett román vagy magyar (egyéni és közösségi) identitást.

\footnotetext{
${ }^{140}$ A román-magyar irodalmi kapcsolatokat vizsgáló kutatók általában ilyen történeti felvezetőkkel indítják munkáikat, amelyek nagyjából ugyanazokat az adatokat sorolják fel újra meg újra, ezért redundánsnak tartom egy ilyen bevezető fejezet beékelését a kötetbe, viszont hivatkozásként mindenképp itt a helyük. Például: Dомокоs 1985, FARKAs 2008.

${ }^{141}$ A bonyolultság az egy nyelv, egy nemzet elv alapján létrejövő modern értelemben vett nemzetértelmezés következménye lehet, és megmutathatja, mennyire inhomogén ez a fogalom a 19. század utolsó évtizedeiben.
} 


\section{ROMÁN KÖLTÉSZET MAGYAR NYELVEN A 19. SZÁZAD VÉGÉN. FORDÍTÓK, FORDÍTÁSOK}

Magyar-román kapcsolattörténeti szempontból Domokos Sámuel bibliográfiája ${ }^{142}$ képezi az alapforrást. Ez a jelentős filológiai munka feltárja a román irodalom magyar recepcióját a 19. századtól a 20. század derekáig. Ebből a munkából tudható meg mindaz, amivel a recepciótörténészek is foglalkoznak, és ami továbbhagyományozódik: már a 19. század előtt léteztek kapcsolatok a két nyelv, a két kultúra képviselői között, és a kapcsolat főként a többnyelvú régiókban, például Erdélyben volt hangsúlyosabb. Viszont, amit Domokos figyelmen kívül hagy, és amivel számolnunk kell, az arra vonatkozik, hogy ezek a kapcsolatok korántsem a nemzeti kategóriája felől szerveződtek, hanem inkább a mecenatúra ${ }^{143}$, a közös származáson alapuló szolidaritás, szociális érdekek járultak hozzá kibontakozásukhoz, és csak egy későbbi nézőpontból határozhatóak meg nemzeti irodalmak közötti kapcsolatokként.

Domokos bevezető tanulmánya szerint az egymás mellett élő népek megismerése képezte a kultúrák egymásra figyelésének hajtóerejét. Ezért érdeklődtek korábban a népköltészet iránt. Innen vezetett az út román vonatkozásban a népköltészeti gyüjtő Vasile Alecsandri ${ }^{144}$, Iosif Vulcan és

\footnotetext{
${ }^{142}$ Dомокоs 1966.

${ }^{143}$ Például Kovachich Márton Györgynek Gheorghe Șincai alkalmazottja és támogatottja is egyben, Virág Benedek Samuil Micu Klein szótárának munkatársa. Ezekben a kapcsolatokban a közös latin nyelvú kultúra vagy a közös szakmai érdeklődés munkált. Az „erdélyi iskola" képviselői és a budai egyetemi nyomda közötti kapcsolatok a regionális identitás erősségét és közösségteremtő hatását is példázzák.

${ }^{144}$ Jókai Mór iskolatársának, Ács Károlynak népköltészeti fordításkötete irodalom-, és politikatörténeti értékkel is bír Domokos szerint, hiszen a két nép közti barátságot szolgálja. Dомокоs 1966, 17.
} 
Moldován Grigore ${ }^{145}$ felé. Iosif Vulcant 1871-ben a Kisfaludy Társaság tagjául választja a román népköltészetet ismertető tevékenységéért. Megjegyzendő, hogy nem Vulcan az egyetlen, aki egy nemzetiség képviselőjeként, saját kultúrájának ismertetéséért értékelt értelmiségi a magyar irodalom és kultúra rendszerében. Jaroslav Vrchlick cseh költőt és múfordítót anynyira értékeli a magyar irodalom - mert annak rendszerét egy más, jelen esetben a cseh kultúra termékeinek magyarra fordításával gazdagította -, hogy tagjává választja mind a Petőfi, mind a Kisfaludy Társaság. ${ }^{146}$ E két társaság az irodalmi Deák-párt fóruma, a nemzeti kánon kitermelője, ezért azok az alkotók, akik felvételt nyernek ezekbe a társaságokba az akkori magyar irodalom rendszere szempontjából is hasznosíthatót, értékeset, kiemelendőt alkotnak.

A népköltészeti gyưjtemények magyar nyelvü tolmácsolását időben a lírai alkotások fordítása követi. Domokos bevezetője egyrészt munkája műfajából eredően nem problematizálóan veti fel a fordítással kapcsolatos kérdéseket, másrészt követi a román irodalom aktuális nemzeti kánonát, hiszen előbb foglalkozik Eminescu korai recepciójával, mint Vasile Alecsandri vagy Dimitrie Bolintineanu, a 19. század második felében ismertebb költők magyar fordításaival. Óket George Coşbuc követi, hiszen ő a leggyakrabban tolmácsolt költő a századfordulón. A 20. század elejéről Ady Endre és Octavian Goga neveit említi Domokos.

Tudjuk, hogy a magyar irodalmi mező kialakulása a XIX. század közepén kezdődő folyamat. Ekkor zajlanak azok a (tudomány-, kritika-, fordítás-, nőíró-) viták, amelyek sorsdöntőek az irodalom alakulásában, szaklapok jelennek meg, létrejönnek az irodalom intézményei (az akadémia mellett a Kisfaludy, majd a Petőfi Társaság, specializálódik az egyetemi oktatás, beindul a tanárképzés, megképződik a magyar/nemzeti irodalmi kánon, megjelennek az első irodalomtörténetek stb. ${ }^{147}$. Korábban a szélesebb körú irodalomfogalom volt használatos.

\footnotetext{
${ }^{145}$ Domokos bibliográfiájából hiányzik Grigore Moldován külön tételként, pusztán a népköltészeti tolmácsolások vagy egy-egy szerzői bibliográfiájába tartozó szakirodalmi munkássága kap teret a kötetben. Ennek az nem lehet az oka, hogy Moldovánnak nincs szűk értelemben vett irodalmi tevékenysége, hiszen Nicolae Bălcescu, Timotei Cipariu, Gheorghe Şincai, Andrei Şaguna munkássága szerepel a kötetben. Moldován olyan román értelmiségi, aki románsága hangsúlyozásával egyidőben magyar állampolgárnak vallja magát. Identitása semmiképp sem egyértelmú a modern nacionalizmusfogalom alapján.

${ }^{146}$ Erre csak utal, viszont a cseh-magyar kulturális kapcsolatokat részletesen tárgyalja: Richard Pražák, Cseh-magyar történelmi kapcsolatok. Korona könyvek, Budapest, 2001, különösen 11-33.

${ }^{147}$ Lásd erről bővebben DávidHázi 2004, SzajBÉly 2005, T. SzABó 2008, különösen: 197-339.
} 
Román vonatkozásban Marius Lazăr a kérdés kutatója, az 1890-es évekre teszi a román irodalom intézményesülésének kezdetét ${ }^{148}$, miután 1877-ben megalakult a független Román Királyság, és létrejöhetett az irodalom önálló intézményrendszere. Érdekes adattal is szolgál Lazăr (olyan adattal, amelyet magyar vonatkozásban még nem összesítettek), amikor megjegyzi, hogy az 1870-es év az írói lét maximuma, mivel ekkor 472-en élnek és alkotnak. Ugyanekkor kerül Bukarest központi helyzetbe, és ennek következtében Moldva kulturális szempontból hanyatlásnak indul, sőt csökkenni látszik az erdélyi értelmiségiek ${ }^{149}$ hatása az egykori román fejedelemségek kulturális életére. Ami a magyar irodalom román nyelvü fordítását illeti, 1861 és 1900 között Jókai-művet ötször, Petőfit tizenhatszor fordítanak, míg legtöbb alkalommal Victor Hugót (hatvanszor), és legkevesebbet Heine és Musset műveiből (huszonhétszer). A fordítási szándékot vagy ízlést Lazăr a fordítók társadalmi helyzetéhez rendeli, valamiféle különbséget tételezve fel az eltérő társadalmi státusú fordítók és olvasási szokásaik, irodalmi, műfaji érdeklődéseik között. Ez a társadalomtörténeti szempont a maga statisztikaszerü alkalmazásával Lazăr könyvében kissé túlzottnak tưnik, mivel egyrészt korszakolja az időszakot (1821-1840, 1841-1860, 1860-1881, 1881-1890), másrészt egyaránt többes számban jeleníti meg a különböző foglalkozásúakat, bár tudjuk, hogy ezek a társadalmi rétegek nem homogének és nem azonosak méreteiket tekintve, emellett aránytalanul oszlik meg a román értelmiség a különböző területeken. Abban az időben még nem létezett az egységes értelemben vett román irodalom. Összességükben tekintve, az adatok mégis segíthetnek az irányok kijelölésében. A román fordítók a francia irodalom iránt érdeklődnek leginkább, a realista regénytől a könnyedebb müfajú ponyvaregényekig vagy népszerű színművekig. Hiányzik a felsorolt fordítások közül a népköltészeti alkotások román nyelvű tolmácsolása. Ez talán azért maradt ki Lazăr vizsgálataiból, mivel nem tartozik szorosan az irodalom tárgyköréhez. Az 1980-ban kiadott, a román és más népek irodalmi kapcsolatainak adatait tartalmazó bibliográfia ${ }^{150}$ közöl ilyen típusú adatokat is. George Coşbuc az indiai eposzokból, a Mahâbhâratából, Ramayanából és a Rig-Védából fordít,

\footnotetext{
${ }^{148}$ Instituționalizarea literaturii survine abia după ce societatea română a început să instituie un raport instituționalizat cu propriul ei patrimoniu cultural, - aşadar la destulă vreme după ce fuseseră aşezate bazele statului modern, cucerită independența, proclamat, ca semn al suveranității depline, Regatul României, - ca urmare a unui îndelungat proces de construcție a tuturor componentelor ce-i asigură funcționarea ca un câmp de practici culturale distincte de celelalte. = LAZĂR 2002, 25.

149 „Este binecunoscutul grup de ardeleni care vor ajuta la instituționalizarea învățământului din Principate, diplomele lor superioare dovedindu-se în acelaşi timp un bun şi o resursă de plasament social superior." = LAZĂR 2002, 35.

${ }^{150}$ LUPU-ȘTEFĂNESCU 1980.
} 
Ştefan Octavian Iosif pedig magyar népköltészeti alkotások román nyelvű tolmácsolásával foglalkozik.

Lazăr könyve tehát olyan értelemben is hasznosítható e kötet szempontjából, hogy részletesen taglalja a román nyelvű irodalom intézményesülésének, önállósodásának történetét. Ebből derül ki, hogy míg a magyar irodalomban már a hetvenes évek körül lezárulóban van ez a folyamat, addig román vonatkozásban fáziseltolódás észlelhető. Időben eltérnek az irodalom-képzetek, a környezetek, korántsem szimmetrikus a két irodalom hivatásosodása. A fordítások tehát nem azonos paradigmák találkozásából jönnek létre. Amíg a magyar irodalom túl van a népiesség/kelmeiség-vitán, amíg itt a saját népköltészet iránti érdeklődésről áttevődik a hangsúly a más népek ilyen típusú költészetére, addig a román irodalom berkeiben nem lelhető fel hasonló érdeklődés a magyar folklór iránt, s ha létezik is, az erdélyi indíttatású.

Domokos Sámuel bibliográfiai adatai alapján készítettem egy táblázatot, amely a költők 19. századi (1918-ig) magyar tolmácsolását és az adott költőt bemutató magyar nyelvú életrajzot, ismertetést, monográfiát tartalmazza. Azért csak a költőkét, mert a 19. században a román prózai vagy drámai szövegek nagyon ritkán és csak részletekként jelentek meg magyar nyelven.

A táblázatban nem jeleztem a versek fordításváltozatait, a zárójelezett számok azt jelzik, hány versét fordították le egy költőnek. Két nagy szempont köré sorakoztattam fel a fordítókat, értelmezőket: a szerző életében és halála után 1918-ig publikálókat. Természetesen a recepció nem áll meg 1918-ban, viszont határt kell szabnom kutatásaimnak. 


\begin{tabular}{|c|c|c|c|c|c|}
\hline 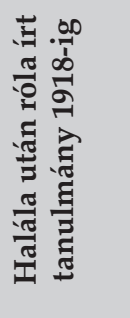 & 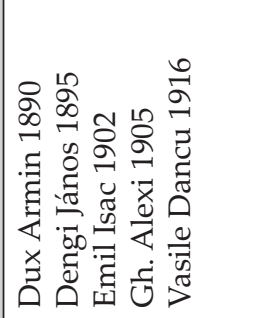 & 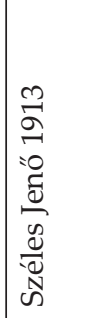 & 1 & 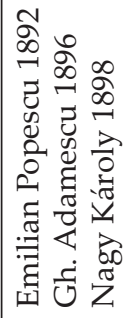 & 1 \\
\hline 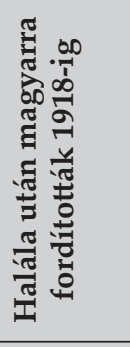 & 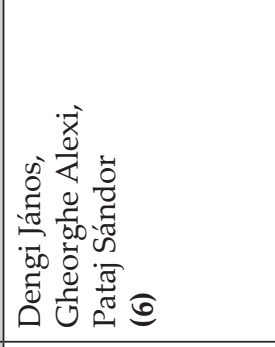 & 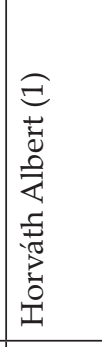 & 1 & 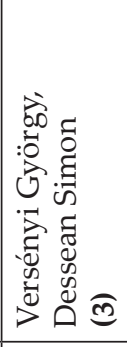 & 1 \\
\hline 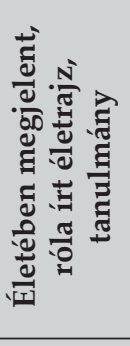 & 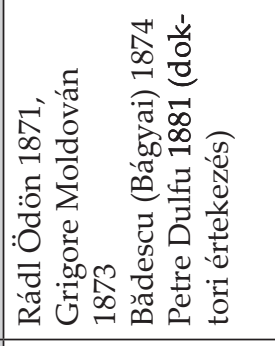 & 1 & 1 & 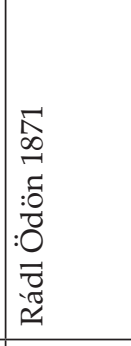 & 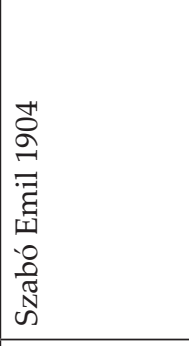 \\
\hline 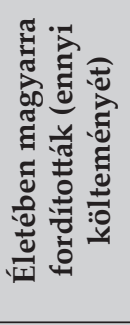 & 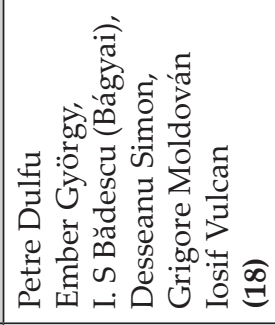 & 1 & 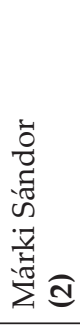 & 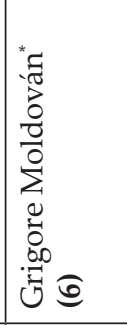 & 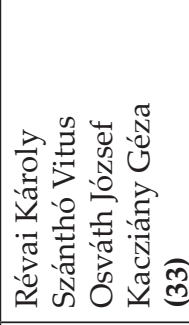 \\
\hline $\begin{array}{l}\text { : } \\
\text { N } \\
\text { N }\end{array}$ & 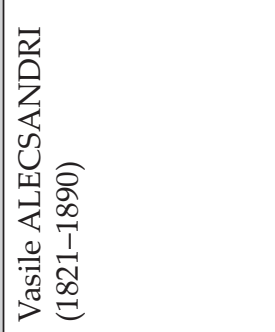 & 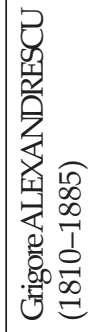 & 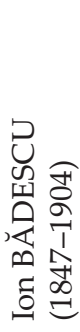 & 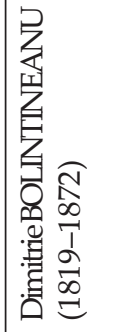 & 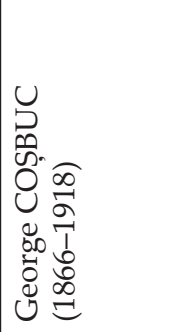 \\
\hline
\end{tabular}




\begin{tabular}{|c|c|c|c|c|c|c|}
\hline 1 & 1 & 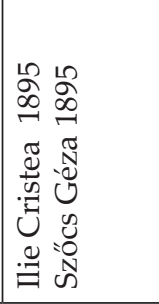 & 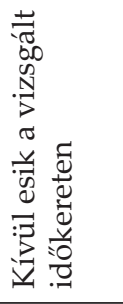 & 1 & 1 & 1 \\
\hline 1 & 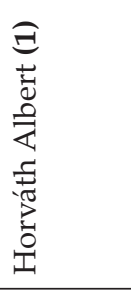 & 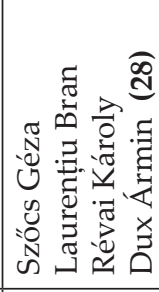 & 1 & 1 & 1 & 1 \\
\hline 1 & 1 & 1 & 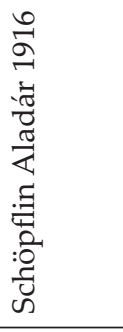 & 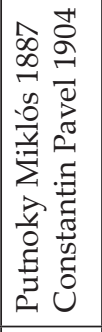 & 1 & 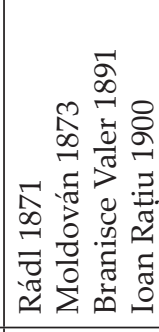 \\
\hline 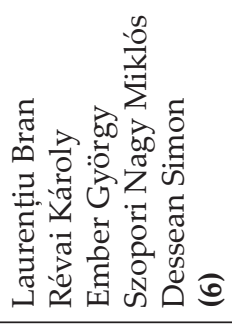 & 1 & 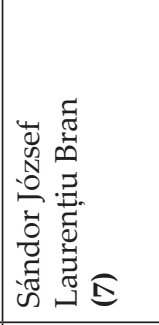 & 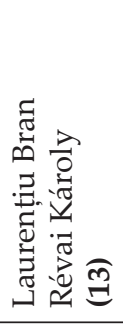 & 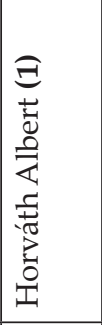 & 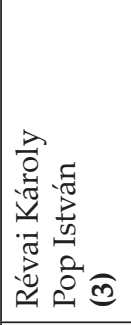 & 1 \\
\hline 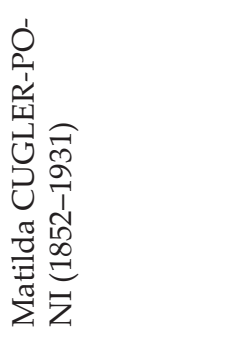 & 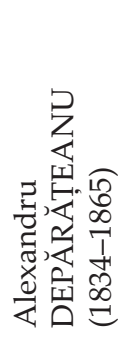 & 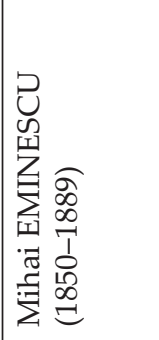 & 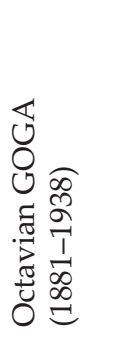 & 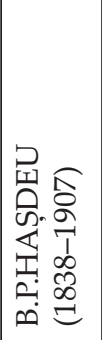 & 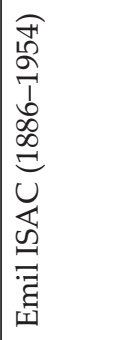 & 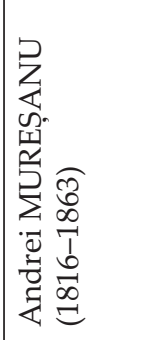 \\
\hline
\end{tabular}



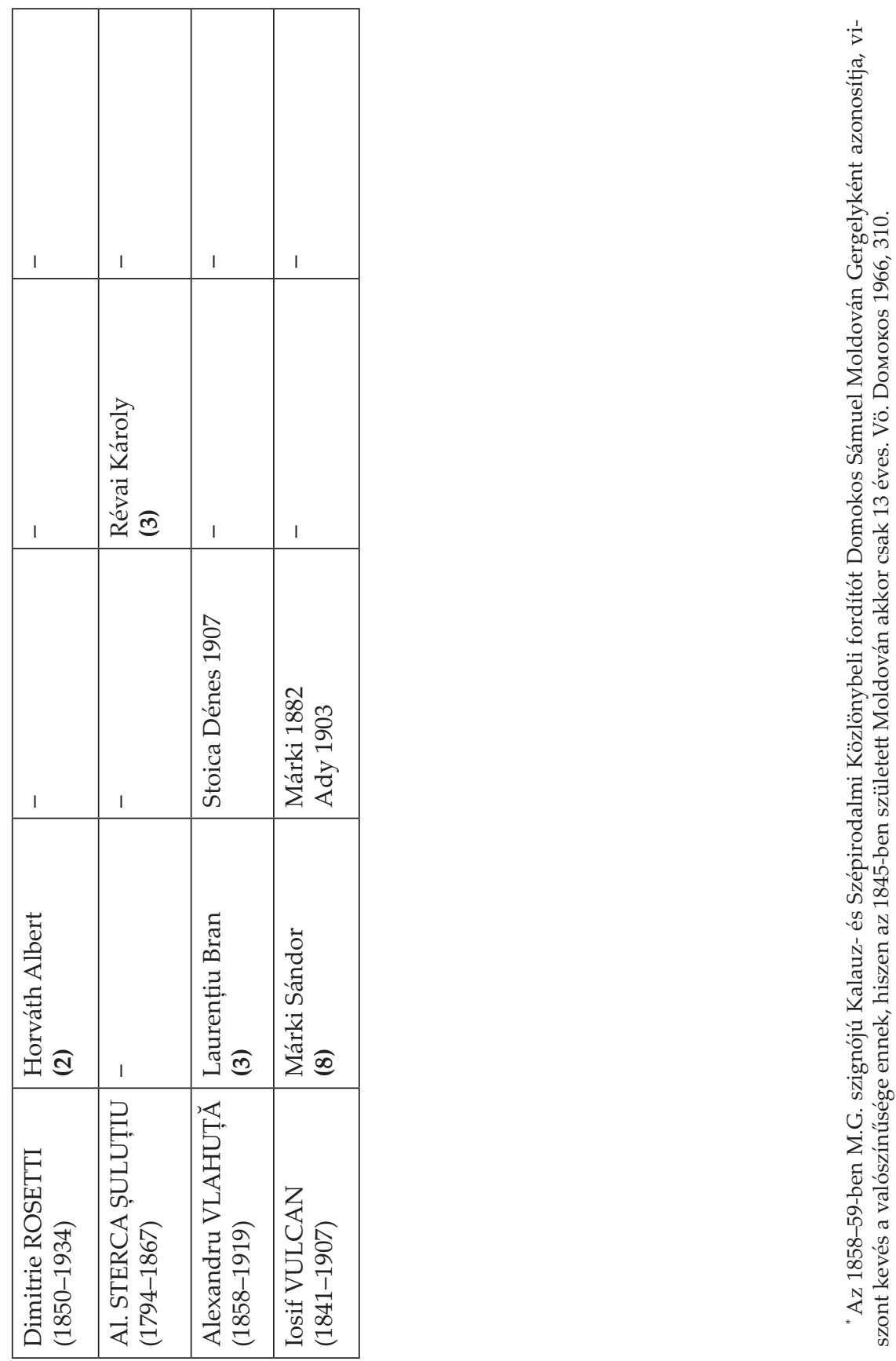
Itt vannak a román irodalomban jártas olvasó számára ismerős, kanonikus nevek: Alecsandri, Eminescu, Coşbuc, Goga, azaz a klasszikus román irodalom jelentős alkotói. Mellettük kevésbé ismerős neveket is találunk. Matilda Cugler Poni nőíró hat költeményét öten fordítják le, de fordítanak D. R. Rosetti verset is. Az egyházi, illetve nyelvtörténeti irodalomból ismerős Al. St. Șuluțiu, illetve B. P. Haşdeu versei iránt is érdeklődtek a 19. század második felében. Aki Iosif Vulcant csupán a Familia szerkesztőjeként vagy intézményszervezőként ismerné, megtudhatja e táblázatból, hogy költő is volt, akinek verseit életében lefordították magyarra. Szintén a bibliográfiából tudhatjuk, hogy például a költőként tolmácsolt Emil Isac magyar nyelvű prózát és publicisztikát is írt.

A fordítók sorában találunk magyar és román nevűeket is. Mivel Domokos a neveket 19. századi használatukban, magyarosítva (például Laurențiu Brant Brán Lőrincként) közli, nem kis fáradságába kerül a kutatónak beazonosítani a fordító identitását. Főként, mivel a fordítók sorából első látásra talán csak Alexics György neve tűnhet ismerősnek. Értelmiségtörténeti nyomozásként kereshető vissza töredékesen a fordítók identitása(i). Ezt azért tartom fontosnak, mert a táblázatban szereplő fordítók közül senki nem tartozik a magyar irodalom egykorú alkotói élvonalába. A táblázatban szereplő, az életrajzok vagy az első szakmai igénnyel megírt ismertető vagy értelmező szövegek szerzői is - Grigore Moldován tanszékvezetőn és Ady Endrén meg Schöpflin Aladáron kívül - idővel nem váltak a magyar vagy a román irodalmi rendszer emlegetett szereplőivé. Csupán a két irodalom között kialakult fordítás-, kapcsolattörténeti szövegek emlékeznek meg róluk. Ők román anyanyelvüek vagy a román irodalom iránt érdeklődők, többen a magyarországi egyetemek bölcsészhallgatói, akik kétnyelvüségüket, nyelvtudásukat például fordítások készítésében is próbára teszik. Ertekezéseikben olyan forrásokhoz is hozzáférnek, amelyek román nyelvǔek és a magyar irodalom számára ismeretlenek. Értekezéseik magyar nyelve mindamellett, hogy az Eminescu-recepció része, eltávolítja őket a román nyelvű irodalomtól.

\subsection{Az első Eminescu-fordítások}

A 19. század utolsó évtizedeiben elszórtan megjelenő, magyarra fordított Eminescu-versek a román költő iránti érdeklődés első jelei. Esetükben, mivel számolnom kell azzal a történeti távolsággal, amely elválaszt ezektől, nem tartom járható útnak azt az esztétikai vagy formai szempontú kérdésfelvetést, amely eltekint a fordítások történetiségétől. ${ }^{151}$ Ezért sem

\footnotetext{
${ }^{151}$ Léteznek is a magyar Eminescu-recepcióban ilyen szempontú kérdésfelvetések. Például Dомокоs 1985, 44-54.
} 
foglalkozom ebben az alfejezetben a fordítások összehasonlító elemzésével. Kutatásom során érdekesebbnek tünt a versek szelekciójára, a fordító identitására, a fordítás megjelenési idejére, közegére figyelni, amelyek jelentéses aspektusai egy-egy fordításnak, illetve látni engedik a fordítói gyakorlatok mögött meghúzódó különböző előfeltevéseket. Szükségesnek tartom egykorú kontextusok hozzárendelését a fordításokhoz, hiszen látnunk kell mind az előtörténetek hagyományait, mind az egyedi (szórtnak mutatkozó) fordítási gyakorlatok poétikáját és politikáját. Mindehhez viszont irodalmon kívüli, tágabb értelemben vett fogódzók kellenek, mint például a fordítók kilétének, érdeklődésének felderítése, nyelvi kompetenciájuk felbecsülése, egyáltalán: kapcsolatuk egy anyanyelvükön kívüli nyelvvel és irodalommal. A fordítások poétikája és politikája vizsgálata az eddigi szakirodalomhoz képest új lehetőségek felé nyitja meg az utat: részint bővíti a kapcsolattörténeti szövegkorpuszt, új módszertani szempontokat próbál ki, amelyek az irodalom, fordítás kérdését a „nemzeti”-n kívüli vagy annak korlátait belátó kontextusba helyezik. Ugyanakkor, ebből a vizsgálatból juthatunk el ahhoz a kérdéshez, hogy miért éppen ezek az értelmiségiek, szabad foglalkozásúak fordítanak, e kérdés alapos feltárása pedig értelmiségtörténeti téttel is bír.

Az Atât de fragedă vers első fordítója, a politikus, intézményszervező Sándor József. Az általa vezetett, kolozsvári szabadelvű párthoz közeli lapban jelenteti meg fordítását alkalmi mellékletben, 1885 karácsonyán.

Hasonlítasz címmel Révai Károly 1910-ben magyarítja a költeményt és a Laurențiu Brannal közösen összeállított kötetben jelenteti meg ${ }^{152}$. Révai foglalkozását tekintve bányatiszt, de kacérkodik az irodalmi tevékenységgel is. ${ }^{153}$ Kibédi Sándor 1934-es fordításváltozata az Oly zsenge vagy címet viseli és Eminescu-fordításkötetben jelent meg, akárcsak Finta Gerő 1939-es Gyöngéd vagy változata. ${ }^{154}$ Mind Kibédi, mind Finta költőként és műfordítóként szerepel a Romániai magyar irodalmi lexikonban. Berde Mária 1939-ben, a Pásztortüz c. irodalmi és múvészeti lapban közli a vers fordítását, Nyíló fehér címmel. Berde tanár és költő volt.

A harmincas években készült fordítások mozdítják elő Mihai Eminescu ismertségét, főként az erdélyi magyar nyelven olvasók között. Ezek a fordítások időben nagyon távol esnek a Sándor Józsefétől. Persze ez idő alatt számos más Eminescu-verset lefordítottak a 19. század végén, a 20.

\footnotetext{
${ }^{152}$ BRAN-RÉVAI 1910, 116-117.

${ }^{153}$ A kolozsvári egyetem bölcsészkarának hallgatója 1875 és 1877 között. Vö. [http://regi.pim. $\mathrm{hu} /$ Online/adattar/diplomasok.php? $\mathrm{mit}=\mathrm{N} \% \mathrm{e} 9 \mathrm{v} \&$ ertek=oblatek\&valt=kereses\&alsoi $=1 \& \mathrm{kul}$ $=5 \& k i a z=1-$ utolsó látogatás: 2012 júliusa], valamint SzINNYEI 1891-1914. Elsőként nyeri el az Erdélyi Irodalmi Társaság ballada-pályázatának fődiját, erre utal SzÁDECzKy 1905/168-173. Román költőket fordít magyarra.

${ }^{154}$ KibÉdi 1934 és Finta 1939.
} 
század elején, mindamellett, hogy többszörösen is megváltoztak a történelmi körülmények, s közvetve a társadalmiak és a kulturálisak is. Franyó Zoltán müfordító Oly zsenge vagy címmel magyarítja e verset és közli egy kétnyelvű fordításkötetben 1965-ben.

Ha címeik alapján nézzük a fordításokat, akkor a Kibédi Sándoré és a Franyó Zoltáné szó szerint is felismerhetővé teszi az eredeti verset, a Sándor Józsefé távolodik el leginkább a román paratextustól.

Domokos Sámuel az első Eminescu-fordítók esetében arra figyelmeztet, hogy a nemes szándék, mármint Eminescu magyar nyelven történő népszerüsítése, nem párosul a nagy feladathoz szükséges költői tehetséggel, nem vérbeli költők munkái, ,[Mégis], fordításai[k] megütik a korai román tolmácsolások átlagos mértékét mind a szöveghűség, mind pedig az eredeti költői forma betartásában". 155

Dávid Gyula a magyar olvasó Eminescu-képét vizsgálva állapítja meg, hogy 1918 és 1944 után válik ismertté a román költő a magyar közönség előtt, és fordítói nemcsak szerény érdemű verselők, hanem a romániai magyar líra és múfordítás élvonalába tartoznak. ${ }^{156}$

Avram P. Todor kapcsolattörténeti tanulmánykötetében összegzi a román irodalom korai magyar recepcióját több területen (népköltészet, költészet, próza, doktori dolgozatok/tanulmányok). Itt jegyzi meg, hogy az első fordítók dilettánsak, nem rendelkeznek kellő tehetséggel ${ }^{157}$, kevésbé hűséges tolmácsolók, fordításaik, tanulmányaik visszhang nélkül maradtak.

Mindhárom hivatkozás említést tesz a korai fordítókról, a laudanda est voluntas-elv alapján, szerény érdemű verselőknek nevezi őket. Domokos és Todor a hűség szempontját is felveti. Megjegyzendő, hogy a hivatkozott szerzők a 20. századi magyar és román irodalomtörténet ismeretében fogalmazzák meg állításaikat, történetileg is ismerik az Eminescu-recepció alakulását, fejlődéstörténetbe rendszerezhetik a fordításokat. Koncepciójuk nem egyedülálló, hanem a számukra kortárs irodalom- és fordításfogalomba illeszkedik. Értékítéletük nem számol kellőképpen azzal a környezettel, amelyben létrejöttek ezek a fordítások, a fordítók szándékaival, a befogadók elvárásaival és olyan más tényezőkkel, amelyekre az utóbbi időkben figyelt fel a 19. századdal foglalkozó irodalomtörténet. Takáts

${ }^{155}$ Doмокоs 1985, 44-54. [Ez a szöveg változtatás nélküli újraközlése Domokos egy korábbi tanulmányának. Vö. Filológiai Közlöny, 1962/1-2., 147-151.]

${ }^{156}$ DÁvid 1976, 129.

157 „Mulți dintre aceşti traducători sunt diletanți, traducerile lor fără ninc o scînteiere de talent, ecoul lor a rămas mediocru.", továbbá: „Acestor primi traducători diletanți, cu excepția lui Géza Szőcs, Laurențiu Bran şi Carol Révai, le putem acorda doar un recunoscător »laudanda est voluntas « căci în afară de bunăvoință şi dragoste față de poeziile lui Eminescu, nu au prea avut însuşiri care să-i impună pe ei şi traducerile lor publicului". Vö. ToDor 1983, 62, 131, 135. 
József Nyolc érv az elsődleges kontextus mellett ${ }^{158}$ címü tanulmánya felől, a magyar-román fordítás 19. századi kérdése visszanyeri történetiségét és a művészi fordítás számon kérhető mércéjéhez képest másféle jelentésekkel gazdagodhat.

Az Eminescu-fordítások elsődleges értelmezési kontextusát a 19. század utolsó évtizedei jelentik. Az erre az időszakra vonatkozó fordítástörténet monografikus áttekintése egyrészt hiányos vagy hiányzó része az irodalomtörténetnek, másrészt pedig létmódjában problematikus.

A továbbiakban a 19. század második felében publikált, tehát Eminescuval kortárs magyar fordításelméleti és -történeti irodalommal foglalkozom. Ez az irodalom jelenti az Eminescu-fordítók fordítói gyakorlatának egyik lehetséges szövegkörnyezetét, amely ugyanakkor megmutathatja, milyen elvek szervezték a fordítók tevékenységét, milyen indíttatásból fordítottak, milyen nyelvekből és hogyan gondolkodtak a lefordított szöveg és a magyar (nyelvû) irodalom viszonyáról.

\subsubsection{Fordítástörténeti kitérő}

Kiindulópontul a Pallas szócikkét idézem, mert ez az első egykorú nagylexikon: „[A] müfordítás szépirodalmi müvek áttétele egy nyelvből a másikba. Az ily fordítás már céljánál fogva sem törekedhetik másra, minthogy a fordított mú ugyanazt a hatást tegye, azt a gyönyörérzetet keltse, amit az eredeti. Ebből következik, hogy költőt csak költő, lírai költőt csak lírai költő, gazdag képzeletű költőt szintén gazdag fantáziájú költő fordíthat méltóképp, s általában a kongenialitás a költő és a fordító közt szükséges előfeltétel. Azt az elvet, hogy a fordított mű eredetijének hatását tegye, a hüség követelményének mondjuk. [... A müfordítás] közvetíti a népek szellemi termékeit, s nagy jelentősége van az irodalmak történetében és fejlődésében". ${ }^{159}$

A szócikk lényegi összefoglalása mindannak, ami a 19. század utolsó évtizedeiben fordításelméleti kérdésként felvetődött. Ekkorra került hangsúlyosabban is elötérbe az ekvivalencia kérdése, amit a szócikk kongenialitásnak nevez és aprólékosan szétszálaz. A fordítás gyakorlata viszont előfeltételek által meghatározott: közvetítő funkciót tölt be, kapcsolatokat hoz létre nyelvek, irodalmak, kultúrák között, ennélfogva ideologikus. Másfelől pedig a befogadó irodalomra pozitív hatással lehet, befolyásolhatja alakulását, annak dinamikáját.

\footnotetext{
${ }^{158}$ TAKÁTs 2007, 78-92.

${ }^{159}$ Pallas 1893-1897.
} 
Ugyanakkor a bizonytalanságokat is megragadja ez az összefoglaló. Léteznek ugyan ezek a bizonytalanságok, de a fordítás legitimálásakor túl kell lépni rajtuk, mert ellenben érvényét veszítené a meghatározandó irodalmi cselekvés. A fordítás tehát a nyelvek közti kongruenciára alapoz, és mindamellett, hogy belátja e kongruencia/ekvivalencia lehetetlenségét azt, hogy a fordítás hatása sohasem mérhető az eredetihez, hogy nehezen kiküszöbölhető technikai akadályok vannak-, mégis a hü fordítás léte és szükségessége mellett érvel.

A lexikon szócikkének írója hivatkozásként Radó Antal műfordítástörténetére utal. Bár Radó Antal munkája korábbi időszak fordítástörténeti elveit szemlézi, kitűnik belőle az is, hogy előzményei vannak a fordításelméleti gondolkodásnak. ${ }^{160}$ Radó a műfordítás fogalmával indítja bevezetőjét és jelzi, hogy ez a fogalom koronként, nemzetenként, de a hüség követelménye felől is eltérő. Batsányi János és Rájnis József szövegeitől számítja a magyar fordítástörténeti szakirodalmat a szerző, miközben saját elveit is megfogalmazza. A fordítás hasznáról a következőket írja: „A mi íróink, például a német és nagyobbrészt francia irodalmat az eredetiben olvassák, de már például az olasz költőkkel, az angolokkal, a spanyolokkal, az oroszokkal csak fordítás útján ismerkednek meg. [...] A remekmúvek nem egyes nemzetek birtokai, hanem az egész világéi, a müfordítás teszi őket az emberiség köztulajdonává". ${ }^{161}$

Ebből az idézetből az is látszik, hogy nem egyenrangúak a különböző nyelvek és irodalmak a magyar nyelv felől. Vannak ismertebb és kevésbé ismert vagy ismeretlen nyelvek. Ezek megértésében a fordítás csak úgy segíthet, ha többszörös nyelvvesztésre ítéli az eredetinek tekintett változatot. A német és francia nyelvtudás mellett a 19. századi olvasók nyelvismerete szempontjából az angol is kiváltságosabb helyzetben van, mint a latin nyelvcsaládba tartozó olasz és spanyol, vagy éppen a távolabbi orosz. Az sem mellékes, hogy milyen irodalmakat implikálnak ezek a nyelvek. Az idézet érvelése felől remekműveket érdemes fordítani. Ebben az esetben a fordítás nem pusztán idegen irodalmak megismertetésének és érthetővé, befogadhatóvá tételének a lehetősége, hanem szelekciós tevékenység is, intencionált. Nyilvánvaló, hogy a nyelvi korlátokat hivatott felszabadítani, itt viszont még két dolgot érdemes megjegyezni, amit Radó is elődeitől továbbít: a fordításnak nem csak az olvasóközönségre, hanem az írókra is hatással kell lennie; másodsorban pedig a remekmúvek egyetemes értéküknél fogva képesek nemzetek fölöttiként müködni. Erre hivatott a fordítás: eltörölni a nemzeti különbségeket, hogy köztulajdonná válhassanak a múvek. Radó érvei arra is rámutatnak, hogy mit, mikor és hogyan

\footnotetext{
${ }^{160}$ RAdó 1883.

${ }^{161}$ RADÓ 1883, 12.
} 
fordítanak, azt elsősorban a fordításra kiválasztott irodalmakra vonatkozó előfeltevések határozzák meg.

A Radó által vizsgált korszakban még nem beszélhetünk nemzetekről, nemzeti irodalmakról. Akik fordításra vállalkoztak akkoriban, több nyelvet ismertek, vagy éppen közvetítő nyelven keresztül fordítottak magyarra, például angolból. Vitkovics Mihály szerb-magyar költő magyar népköltészeti fordításait említi, amelyekkel Vitkovics felhívta a figyelmet a magyar népdalra. Vitkovics múfordítói tevékenysége eszerint a 19. század elején a szerb szövegeket az idegen, esetünkben magyar nyelven tolmácsolva, ráirányította a figyelmet egy olyan szövegtípusra, amely a befogadó kultúrában is létezett, csak addig jelentéktelennek tünt vagy a hivatalos kánon peremén érvényesült. ${ }^{162}$ Innen nézve úgy tünik, hogy a fordítás az irodalom rendszerében jelentős változtatásokat tehet; a lefordított, idegen nyelvü irodalom termékenyítő hatással bírhat. Az is jelentéses a fenti gondolatmenetből, hogy a fordító Vitkovics éppen kettős nyelvi szocializációját kihasználva vállalkozik fordítói tevékenységre, hasonlóan a román irodalmat fordítókhoz. A saját, nemzetiséginek tekintett irodalom irányából közeledik és sikeresen teremti meg a határátlépést magyar nyelvü fordításaiban.

A Domokos Sámuel bibliográfiája alapján összeállított táblázat szerint hasonló történik román vonatkozásban: a román-magyar fordító magyar nyelven tolmácsolja anyanyelve (nép)költészetét és ez számára könnyebben megvalósítható, mint a 19. századvégi magyar anyanyelvű fordítónak román szövegeket átültetni magyarra. Ez a nemzetiségi kezdeményezés alapozza meg tehát fordítástörténetileg a magyar és más magyarországi irodalmak közötti kapcsolatok kialakulását. Ebben a vonatkozásában is hangsúlyozandó a kötet újszerű kérdésfelvetése.

Másfelől a román irodalom magyar fordításában kevés példát találunk a közvetítő nyelvből történő fordításra, hiszen a fordítók listáját végigtekintve, vagy román anyanyelvűek, vagy szocializációjuk révén közelebbi kapcsolatba kerültek ezzel a kultúrával. A szöveghüséghez való ragaszkodás példáiként több mindent sorolhatunk.

Az Eminescuval foglalkozó doktori értekezés prózában magyarítja a költő verseit, hiszen számára egyszerűbb lehetőségét jelenti a tolmácsolásnak, az olvasói számára pedig hozzáférhetővé teszi az idegen nyelvű szövegeket.

Márki Sándor közvetítő nyelv helyett (többnyelvü) közvetítő segítségét kéri monográfiája primér forrásainak megértéséhez és tolmácsolásához. ${ }^{163}$

\footnotetext{
${ }^{162}$ A fordítás hasonló, de intencionált hasznáról értekezik Török Zsuzsa következő tanulmányában: TöRöк 2005, 27-41.

${ }^{163}$ Márki 1881.
} 
Ezek a román és a magyar nyelv használatával kapcsolatos példák a fordításhoz szükséges gyakorlottság és eszközkészlet hiányáról árulkodnak, illetve a fordítások minőségét és mennyiségét magyarázzák. Következésképp: nyelvi korlátok hátráltatták a kultúrák közötti közvetítés rétegzettebb kiépülését.

Amennyiben a 19. század közepe utáni fordításelméleti gondolkodásra is figyelünk, akkor a gyakorló fordítók elméleti írásait (fordítói önértelmezéseit) sem árt megvizsgálni.

Szász Károly ${ }^{164}$ műfordításainak köszönheti akadémiai tagságát. Akadémiai székfoglalóként elhangzott értekezése is e témát taglalja, „különös tekintettel Shakespeare és a Biblia fordítására". ${ }^{165}$ Értekezése több ponton problematizálja a fordítás gyakorlatát. Beszámol arról, hogy fordítási előtanulmányokat végez (angol és francia irodalomból), mielőtt Shakespeare, a „költők királya”-fordításába kezdene. Elvileg tehát Szász hierarchikusan gondolkodik a lefordítandó irodalomról, a fordítást pedig (impliciten) gyakorlottságot igénylő tevékenységként határozza meg. Látjuk, hogy Szász is saját előfeltevései alapján válogat a különböző irodalmak és müvek között.

Értekezésében eloszlatja annak az illúzióját, hogy minden lefordítható, és a fordítás ama eszméjét is, miszerint a fordítás útján nyert szöveg azonos lehetne az eredetivel. A magyar Shakespeare-fordítások számos olyan kérdést felvetnek, amelyre maguknak a vállalkozóknak kell megoldást találniuk. Szász számára az angol költő nyelvhasználata jelent gondot, emellett az is például, hogy a szójátékok ",nem jönnek át” fordításban, és fóként az, hogy Shakespeare gyakran illemtelen. Ezek a "gondok" egyszerre jelzik a fordító/fordítás korlátait és a befogadó nyelv hatalmát. Ugyanis nem csak befogadja a magyar nyelv az angol nyelvü alkotást, hanem kulturálisan is szabályozza azt, etikai kérdéssé teszi az idegen tartalmak befogadásának kérdését. Szász a Shakespeare-fordítás helyét keresi a magyar irodalomban akkor, amikor a potenciális befogadói közeg hozzárendelésén gondolkodik. Szerinte a "felsőbb körök", azaz a müvelt olvasóréteg eredetiben elolvashatja, nem nekik készül a fordítás, noha éppen ezek a több nyelven olvasók lennének képesek összehasonlítani, esetleg megítélni a fordítói gyakorlat sikerességét, a fordítói hűség kérdését. (Zárójelben jegyzem meg, hogy innen nézve, a hűség mint a fordításelmélet alapfogalma tematizálása nem tartozik akárkire, aki több nyelven olvas, hanem a fordítói gyakorlattal és elméleti felkészültséggel rendelkező szaktudós vagy múfordító

\footnotetext{
${ }^{164}$ Bölcseleti doktor, református püspök, a MTA másodelnöke, tiszteleti s az igazgató tanács tagja, a Kisfaludy-Társaság rendes tagja és alelnöke. Vö. SzInNYei 1891-1914. [http://mek.niif. hu/03600/03630/html/index.htm - utolsó látogatás: 2012. július 19.] Szász Károly fordítói tevékenységének értelmezéséhez lásd például: BENő 2003.

165 SzÁsz 1859.
} 
feladata. Ha ez így van, akkor Szász koncepciójában a fordítás önálló tudományként kezd működni.) Az eredetit olvasók kizárása azt is jelentheti, hogy a nyelvi tudás, az idegen nyelvek birtoklása bizonyos szempontból privilegizált helyzetet teremt számukra, ezért esetükben érvényét veszíti a fordítás. Hasonlóképpen gondolkodik erről Arany János is, amikor az Akadémián bemutatja a Shakespeare-kiadással kapcsolatos jelentését. ${ }^{166}$ Amint látjuk, kérdésként fogalmazódik meg mindkettejük számára az irodalmat befogadók rétegzettsége, amit például a specializálódó folyóirat-kultúra messzemenően kiaknázott. Szász azt állítja, hogy a lányoknak (vagyis éppen a század derekán kibontakozó nőíróvitákkal korelláló alkotó- és befogadóközösség számára) nem való, hiszen számukra a színpadi változat törlésekkel lesz teli. ${ }^{167} \mathrm{E}$ két utóbbi, etikai szempontú álláspont távolítja el például magát a fordítást (a recepció feltételét) a szélesebb olvasó-, színházlátogató közönségtől. Szász csupán irodalmi célból látja érdemesnek Shakespeare magyarra fordítását, „hogy saját irodalmunknak újjászülő örök erejű kovásza legyen". ${ }^{168} \mathrm{~A}$ fordítás irodalmi rendeltetését elöíró értekezésében müvészet és erkölcs, esztétika és etika kettéválasztása mellett érvel, amikor a következőket állítja: „művészi szempontból semmi sem illetlen, ami igaz és természetes" ${ }^{169}$ Tehát mind Szász, mind azok a fordítók, akik „idegen remekeket minél hűvebben” tolmácsolnak, a szép terjesztését szolgálják, kizárólag olyan esztétikai, szépirodalmi célt, amely fölülírja a hatás-befogadás etikai mércéjét. A fordítás itt az íróvá, az irodalom művelőjévé válás egyik termékeny lehetőségét jelenti. ${ }^{170}$

A fordításelmélet sajátos szövege Brassai Sámuel kommentárja, azaz folytatásokban közölt cikksorozata, amelyben a magyar fordításirodalommal számol le, miközben a magyar nyelv mibenlétéről, működéséről értekezik. ${ }^{171}$ Most eltekintek Brassai cikksorozatának nyelvészeti érdeme-

\footnotetext{
166 „Óhajtja a bizottság, hogy az áttétel ne annyira azt az olvasót igyekezzék kielégíteni, ki az eredeti Shakespeare-rel kezében szót szóval összehasonlít, s inkább nehézkes fordítással is beéri, csakhogy egy jota se vesszen el az eredetiből; mint inkább azt, ki az angolhoz nem férhetvén, szépségeit a nagy költőnek, magyarban kívánja élvezni; s a színpadot, mely nagy hiányt szenved jó fordításokban". Lásd: Arany 1966, 341.

${ }^{167}$ SzÁsz 1859/222, 903.

${ }^{168}$ Uo.

${ }^{169}$ Uo.

${ }^{170}$ A fordításon gyakorlott (férfi) író ideálja rajzolódik ki a koncepcióból és talán ennek mintájára gondolják el a nőiróság kérdését. Hiszen Szendrey Júlia írói tevékenységét éppen a jól megválasztott téma (Andersen meséi, ergo gyermekirodalom) és a fordítói munka révén értékeli Gyulai Pál. A fordítás itt az eredeti alkotáshoz képest másodrangú foglalatosságnak minősül, és tematikailag szabályozódik. Vö. Gyulai 1905, 272-307.

${ }^{171}$ BRASSAI 1861.
} 
itől172; a fordítás és irodalom általa elképzelt kapcsolatára utalok az alábbi idézettel: „Igaz, hogy az ízlést fejtő remekek nincsenek elzárva senki elől, de mennyivel könnyebben hozzájárulhatókká teszik a fordítások! Reánk nézve pedig éppen kétszeres fontosságúak. Mert amellett, hogy - amint nem örömest ismétlem - saját kamaránkból nem telik minden drága csemege, még azt is meg kell fontolnunk, hogy territoriális viszonyainknál fogva már a közélet is oly poliglottusságra kényszerít, amely midőn egyfelől éltünk, tehetségeink egy részit[!] igénybe veszi, más felől a magasabb irodalmak élvezhetésivel mégse fizet" ${ }^{173}$ Brassai felfogásában is ízlésformáló erővel bírnak a fordítások és a saját irodalom hiányait pótolhatják. A fordítások hűségének kérdését a magyar irodalmi befogadás felől ugyanúgy értelmezi, mint Szász: az eredeti irodalomban való jártasság mellett a fordítónak el kell tüntetnie nemcsak a lefordított mű szellemének, hanem hatásának idegenségét is.

Szász az eredeti és fordítása hatása mellett a nemzetit mint fordítói elvet találja problematikusnak, amikor kijelenti a következőket: „világos, hogy nem a külsőben, nem a nyelvnek netalán lefordíthatatlan sajátságaiban van az ok, hanem abban, hogy a mü lényege: a szellem, az eszme, a tárgy bír oly valamivel, hogy egészen élveztessék, megkívánja, hogy az olvasónak véréböl való vér, s lelkével egybeforrott legyen". ${ }^{174}$

Brassai a kritika és a fordítás hatása kapcsán így fogalmaz:

„Összeolvashatod a világ széptanát, Platóm Phaidroszától, Longinustól fogva a Vischer hat vastag kötetes Aesthetik-jáig - amelyről én is azt mondom, amit egy jeles akadémiai tudósunk a kelta nyelvtanról, hogy 'vesződjék más vele' - ha nem élnek lelkedben, nem állanak képzelődésed előtt a müvészi és irodalmi remekek, csak zsargont tanulsz belőlük, nem ítéletet, még kevésbé ízlést. [...] Hogy a lehető legrövidebben fejezzem ki a viszonyt köztük: az ítélet fogalmakba, szókba öltöztetett ízlés, eme pedig a kedélybe, érzelembe átment, úgyszólva vérré vált itélet. ${ }^{175}$ [...] Amiért - de mit részletezzek, amidőn elvben kimondhatom - azért, hogy a népnek igazibb, hathatósabb jótevóje az, aki őt az ő elidegenithetlen, elévülhetlen jogai élvezetében, ha kell élvezetére, segiti és abban biztositja, mint aki nem tudom miféle újdonsült jogokat akar számára octroyáltatni -szemfényvesztésre. És most már kérdem, van-e szebb, érdekesebb joga az emberiségnek, mint az, hogy ki-ki körülményei és tehetsége szerint elérhető legmagasabb fokára juthasson el a müveltségnek, és nem erkölcsi kötelessége-e minden adományozott elmének erre segítő kezet nyújtani? A müveltségnek

${ }^{172}$ Brassai cikksorozatára több alkalommal hivatkozik a nyelvészeti alapú fordításelmélet, ma is korszerű megállapításait értékelik, mégpedig azt, hogy a fordítói figyelmet a mondatra, mint értelmi struktúrára irányította. Lásd ezzel kapcsolatosan: KLAUdy 1991, 387-394., KLAUDY 1995, 15-31.

${ }^{173}$ BRASSAI 1861, 307.

${ }^{174}$ SzÁsz i.m., 894.

${ }^{175}$ Mind Szász, mind Brassai szövegében a kiemelések tőlem származnak. 
pedig nincs oly egészen ártatlan, oly minden kifogáson kívüli része, mint a jó, a nemes ízlés kifejlése" ${ }^{176}$

A Takáts József által írt kitünő tanulmány vázolja Arany János szokásjogi gondolkodását Arany eposzkeletkezési nézetei kapcsán ${ }^{177}$. A Savigny-féle jogkeletkezési elmélet és szokásjogi gondolkodás módszertanilag egybeesik Szász és Brassai elgondolásával. Takáts szerint a szokásjogi gondolkodás Arany, Gyulai és értelmezői köre sajátos társas gondolkodási mintázata. Ebbe a társas gondolkodási mintázatba illeszkedik mind Szász, mind Brassai, amikor a fordítások hatását metaforikusan a befogadók vérévé válásához kötik. De ugyanerre az elvre utal a Pallas szócikke is. E gondolkodási mintázat pedig a nemzeti irodalom hagyományközösségi fogalmához köthető. ${ }^{178}$ Brassai koncepciója szerint mind a kritika, mind a fordítás keletkezési és múködési mechanizmusa azonos tehát a Savignyféle jogkeletkezéssel. Az ízlést kidolgozó és megítélő másodlagos nyelvnek, azaz a kritikának, valamint a lefordított szöveg nyelvének, azaz a fordításnak ugyanazon elvek alapján kell működnie, mint az anyanyelvnek, vagyis az olvasók vérévé, nem „octroyálható”, sőt szóbeliségben létező nyelvérzékké kell válnia ahhoz, hogy befogadható legyen.

Brassai cikke rátapint arra a meghasonlott állapotra, ami a hazai többnyelvüség adta lehetőségek és a külföldi idegen irodalmak között kialakult. A közélet többnyelvüsége természetes életteret képezett a Magyarországon élök számára a történelem folyamán is. ${ }^{179} \mathrm{Ez}$ a többnyelvüség, mibenléténél fogva nem biztosíthatja az ún. „magasabb irodalmak” ismeretét. Az egymás mellett élő népek egyenrangúak lehetnek a magyar irodalommal, ergo nem rendelkeznek világirodalmi rangú remekmüvekkel, ezért minősülnek kevésbé értékesnek, ennek következtében pedig kiesnek a magyar fordítói gondolkodás homlokteréből. A nyelv alapú nemzeti irodalmak önmeghatározásának kirekesztő gesztusaira ismerhetünk ebben a viszonyulásmódban, ez a hatalomgyakorlás pedig találkozik azzal az elméleti állásponttal, amit a kutatás által hasznosított szakirodalom is hangsúlyoz, amikor a fordítás kérdését kulturális stratégiának tekinti. ${ }^{180}$

Az angol „költőkirály” vagy a világirodalmi remekművek fordítása más regiszterét jelentette a fordítói gyakorlatnak, mint például a román vagy szerb irodalom tolmácsolása. Amikor recepciótörténetről beszélünk, látnunk kell ezeket a finom választóvonalakat, amelyek a különböző nem-

\footnotetext{
176 BRAsSAi 1861, 305-307.

177 TAKÁTS 2007, 202-234.

${ }^{178}$ Lásd erről bővebben S. VARGA 2005.

${ }^{179}$ Vö. Fried 2002, 151-168.

${ }^{180}$ Lásd erről bővebben a következő kötet tanulmányait: N. Kovács (szerk.) 2004, különösen: $133-175$.
} 
zeti irodalmak (magyar) megítélésében érzékelhetők, és amelyek felől nem ártatlan döntések eredményei a fordítások.

Ács Károly Jókait megszólító szövege (ön)legitimáló célzatú, egyaránt tartalmazza Ács fordítói szándékait, valamint a szerkesztő, Jókai megjegyzését is, miszerint bátorítandó Ács terve. Ács Károly a fordítás mellett érvelve mutat rá a kétoldalúságra: amíg a magyar irodalom az angol, francia, német, azaz gazdag irodalmú népek műkincseit fordítja, ezek az irodalmak nem igen akarnak tudni a magyarról. Ács közvetlenül leplezi le az irodalmak hierarchikus rendszerének hatalmi viszonyait és a fordítói érdeklődést azokra az irodalmakra tereli, amelyek müvelői „velünk egy éghajlat alatt egy rámába foglalva sorsunkat osztják" ${ }^{181}$ A történelmi különbözőségek, a nemzetiségi konfliktusok fölé való emelkedés jó szándéka és a közös érdek érve vezérli Ácsot, amikor a román, török, szerb, illír, tót és lengyel irodalom időnkénti ismertetésére vállalkozik. ${ }^{182}$ Kérdésfelvetése és későbbi publikációi a lapban egyértelműen az együtt élő nemzetiségek irodalmai, pontosabban népköltészeti remekei felé távolodnak el attól a fordítói elképzeléstől, amelyet Szász vagy Brassai megfogalmazott. Ilyen módon, amíg Szász fordítói gyakorlottságot és a különböző nyelvű irodalmakhoz hierarchikusan kialakítandó viszonyt feltételez, addig Ács Károly egyenrangú irodalmak kapcsolatait keresi a közös földrajzi-történelmi régióban.

Ács is osztja Brassai véleményét, miszerint analogikus viszonynak kell lenni fordító és lefordítandó mü között ${ }^{183}$, azaz a remekműveket csak remekművek alkotói fordíthatják megfelelőképpen, mégis lábjegyzetben szabadkozik, hogy csak diákéveiben verselgetett. Körvonalazódni látszik egy olyan tendencia, amely az ún. hivatalos, akadémiai fordításgyakorlattal párhuzamosan bontakozik ki, és Magyarország sajátosan többnyelvủ társadalompolitikai helyzetét aknázza ki. Ez a gyakorlat nem annyira a szépérzék, az ízlés finomításában, vagy a fordítás elméleti kérdéseinek megválaszolásában érdekelt, hanem sokkal köznapibb előfeltevések határozzák meg fordítói törekvéseit: az egymás mellett élő népek megismerése. Ez a humanitárius, tolerancián alapuló elképzelés létesít (irodalmi) kapcsolatokat az egyenrangúként elképzelt román, szerb, török, lengyel kultúra között. Tehát a 19. század közepétől kezd el működni az a fordí-

\footnotetext{
${ }^{181}$ Ács 1857, 745-746.

${ }^{182}$ Lásd: Ács Károly, A román népköltészet = Magyar Sajtó 1857/213, 857-858., Ács Károly, A szerb népköltészet = Magyar Sajtó 1857/238, 957-959., Ács Károly, Értekezés általában az irodalom s különösen a román irodalom fölött (Román-oláh nyelvböl) = Magyar Sajtó 1857/287, 289, 291, 1153-1154, 1162, 1169-1170.

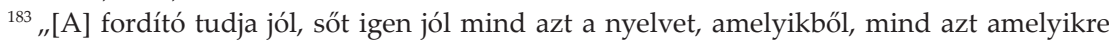
fordít, hogy a tárggyal szorosan és terjedelmesen ismeretes legyen, hogy költői míveket csak költő, szónokiakat csak szónok - e lehet valaki tollal is szintúgy, mint szájjal - fordítson, vita alá nem jövő, nem jöhető igazságok, mondhatni trivialitások". = BRAssAI 1861, 418.
} 
tói praxis, amely a kulturális közvetítés ideologikusságát hangsúlyozza. Ez pedig, amint látjuk, meghatározza azt, hogy milyen irodalmakból mit fordítanak (Ács például népköltészeti alkotásokat). Azért is múködhet ez a típusú fordítói elképzelés, mert a régió többnyelvűségének köszönhetóen esély van a kölcsönösség megvalósítására, a hierarchikus viszonyok is átminősülnek az egyenrangúnak feltételezett irodalmi rendszerek között, és nem marad olyan egyoldalú a viszony, mint az angol, német, francia irodalom magyarra fordítása esetén. Ezért történhet meg az, hogy a külföldi, ún. magasabb irodalmak remekmúvei fordítása mellett új igények, a magyarországi nemzetiségek irodalmát tolmácsoló szövegek jelentek meg. Ez az igény pedig lassan beszivárgott a magas irodalomba is (lásd például a Kisfaludy Társaság és Iosif Vulcan, vagy a Petőfi Társaság és Octavian Goga esetét). A 20. századi történelmi változások után pedig többszörösen is ideologikusan telítődött: a nemzetállami kontextusba került erdélyi/romániai, szlovákiai, jugoszláviai stb. magyar irodalomnak feladatává vált a többségi nemzet iránti érdeklődés, és ezt az érdeklődést leginkább a fordítások példázhatták.

Az idézett fordításelméleti munkák az akadémiai, hivatalos irodalmi rendszer részei. A magyar nyelvet és irodalmat a világirodalom olyan részének tekintik, amely alacsonyabb fejlődési fokon áll, mint a remekművekkel rendelkező angol, német vagy francia irodalmak. A fordítások magyar irodalmat megtermékenyítő, esztétikai ízlést formáló hatását elismerték ugyan, de ez a hatás olyan kérdéseket vetett fel, mint esztétika és etika kapcsolata; a fordítói hűség problematikája; a fordító képzettsége és a lefordítandó szöveg közötti viszony; tágabb értelemben pedig az idegenség és nemzetiesség, a nyelvrontás kérdése. A másik irányú fordítói elképzelés a befele tekintést hangsúlyozza, és a magyarországi élettérnek köszönhetően a nemzetiségi irodalmak fele tájékozódik.

Amint a fentiek is mutatják, nehezen körvonalazható egy egységes fordításelméleti gondolkodás a 19. század második felében. Sokkal rétegzettebb és szórtabb a fordítással kapcsolatos irodalom, ennélfogva monografikus megjeleníthetősége is kétséges. Az idézett szövegek oly módon reprezentálják a 19. század második felének fordításelméletét, hogy egyben megmutatják a fordítói gyakorlat dilemmáit, az elmélet és praxis közötti különbségeket. Azok a megoldatlan kérdések, amelyeken túllépnek a korabeli szövegek, miközben a fordítást definiálják vagy legitimálják, alappillérei a 21. századi antropológiai fordításelméletnek. „[A] fordítással kapcsolatos gondolkodás hagyományosan a nyelvek közti ekvivalencia feltételezéséből indult ki. [...] Az ekvivalencia nyelvészeti problémájának az irodalomtudomány kontextusában - némileg leegyszerűsítve - a hưség és a hűtlenség kérdése felel meg. A fordítás sokáig uralkodó felfogása 
ugyanis a fordítás folyamatának kiinduló és végpontjait az egymástól jól elkülönülő és ugyanakkor homogén nemzeti irodalmakban és az ezeket »körbevevo"«, ugyanígy tisztán elhatárolódó kultúrákban látta." ${ }^{184}$ - olvashatjuk a fordítást kulturális praxisként értelmező fordításkötet előszavában, amelyet N. Kovács Tímea 2004-ben szerkesztett Pécsett.

H. R. Jauss $A$ recepció elmélete címü írásában ${ }^{185}$ amellett, hogy a recepciót történeti fogalomként magyarázza, e történetiség láncolatában megállapítja, hogy - a szellemi javak, és ezek rendjén - a költészet egy, például a vallásnál későbbi időszakban recipiált terület, többfázisú elsajátítással rendelkezik. Jauss a fordítást a recepció önállótlan, a klasszikus alkotást önálló, míg a modernizmusba illeszkedő műalkotást a recepció emancipált fázisaként képzeli el. A hagyományos irodalomtörténet-írást marxista és formalista elméletekre elkülönítve, majd fogyatékosságaikra rámutatva jelöli ki a múértés újabb horizontjait $A z$ irodalomtörténet mint az irodalomtudomány provokációja c. írásában. Bár irodalomtörténet-elméleti a kérdésfeltevés, mégis módszertani fogódzókat tartogathat a hatásvizsgálat számára is. Ilyen fogódzó éppen a Jauss-féle irodalomszociológia-kritika egy mozzanata, mégpedig: az eredeti műalkotáshoz képest, annak lefordított változata esetében inkongruencia van a mű és a befogadó társadalmi csoport között, mivel a mú fordítás útján idegen nyelvi közegbe kerül. Azért is fontos ez a gondolat e dolgozat számára, mivel az elsődleges nyelvi inkongruencia, amint látszik, további inkongruenciákhoz vezet.

Továbbá, a fordítások történetiségének felismerése is a posztkolonialista fordításelméletnek köszönhető. Eszerint „,[a] fordítások nem csupán maguk mögött hagyták az eredeti kontextust, hanem már nincsenek is abban a helyzetben, hogy hatással lennének annak nyelvi és textuális szabályaira és normáira, forrástörténetére, vagy a forrásszövegre, mint olyanra". ${ }^{186}$ Ugyanezt a módszertani elvet erósíti az is, hogy az egyes versfordítások korában a forrásszöveg (román) és fordítás (magyar) irodalmának szinkronitása, ekvivalenciája is kétséges. A létrehozott fordítás, mivel kiemeli az eredetit a saját otthonos kontextusából, nyelvéből és a nyelv által megjelenített gondolkodásmódbó $1^{187}$, soha nem lesz azonos az eredetivel. ${ }^{188}$

A fordítás és eredeti viszonya emellett annak a kérdését is felveti, hogy mennyiben tekinthető öncélúnak a fordítás gyakorlata. Ez az alfejezet arra világít rá, hogy tagadó választ adhatunk a kérdésre, hiszen a vizsgált időszakban különböző célok szolgálatában látjuk a fordításokat: a befogadó irodalomban megtermékenyító hatásúak, a szép terjesztői, ízlésformálóak,

\footnotetext{
${ }^{184}$ N. Kovács 2004, 5-6.

${ }^{185}$ H.R. Jauss 1999, 9-36.

${ }^{186}$ N. Kovács 2004, 145.

${ }^{187}$ Vö. SZILÁGyI N. 1978, N. Kovács 2004, 97-133.

${ }^{188}$ Vö. N. Kovács 2004, 165.
} 
az íróvá válás lehetőségét rejtik magukban, befogadói rétegenként eltérő intencionalitással bírnak. Mindemellett erőteljesen ideologikusak. Ez a ideologikusság nem csupán a fordításkoncepciókból kihámozható sajátos vonása a 19. század vége kapcsolattörténetének, hanem a kulturális közvetítés, a kultúrák közötti kapcsolatok létmódja is egyben. A megismerés, megértés, elfogadás, barátság, majd megbékélés és testvériség eszmeisége mind olyan hatalmi erőviszonyokról árulkodnak, amelyek a kötet majdnem minden fejezetében felbukkannak és vizsgálati szempontként kohéziós erővel bírnak.

\subsection{Sándor József mint fordító}

A fordítástörténeti kitérő előtt Eminescu első magyarra fordított versének fordításváltozatait soroltam fel, kiemelve a következő szempontokat: ki a fordító, mi a foglalkozása, hol és mikor publikálta fordítását. A forrásszövegen, a román nyelvtudáson, a másik kultúra iránti érdeklődésen, illetve a kapcsolattörténeti kutatáson kívül laza kapcsolatok füzhetik össze a lefordított szövegeket és fordítóikat.

Az idézett szakirodalmi hivatkozások (Avram P. Todor, Domokos Sámuel, Dávid Gyula) egyöntetüen elhatárolják az első fordításokat a későbbiektől - ezt a differenciáló gesztust mindenképp megvizsgálandónak tartom. Bár az összehasonlító értelmezéseknek a különbségekre is kell figyelniük, mégsem tartom gyümölcsözőnek jelen dolgozatom szempontjából például a különböző korokban született Eminescu-fordítások filológiai, szövegközeli összehasonlító vizsgálatát. Úgy gondolom, hogy a fordításra kiválasztott vers eredeti irodalomban betöltött szerepétől, értelmezésétől, a másik kultúrában való jártasság fokától, a fordítók szocializációjától, életpályájától a fordítói preferencián és kompetencián át a fordítás hogyanjáig, magyar nyelvű megjelenéséig minden apró mozzanat része annak a folyamatnak, amelyet egyszerúen fordításnak nevezünk, de amelyet sajátos előfeltevések irányítanak.

Amint arra a román költészet magyar nyelvű befogadásával foglalkozó alfejezet is rámutatott, a 19. század második felétől, annak nyolcvanas éveitől szilárdul meg a modern értelemben vett román irodalom fogalma, rendszere föként Titu Maiorescu és köre munkásságának köszönhetően. Ha viszont félretesszük a modernitás fogalmi szemüvegét, láthatóvá válik több minden. Például az, hogy a magyar irodalom, de az erdélyi és romániai román irodalmak is regionálisan differenciáltak. Történetileg egyre kevésbé lehet egységes nemzeti irodalmakként látni azt, amit román és magyar nyelven megjelenő irodalomnak nevezünk. A kánonértékủ, a nem- 
zeti irodalmakhoz képest alternatív irodalomfogalmakkal is számolnunk kell a 19. század második felében. Ilyen irodalomfogalmak: a magyarországi román irodalom, a monarchiabeli magyar irodalom, a monarchiabeli román irodalom ${ }^{189}$, a romániai magyar ${ }^{190}$ és román irodalom, amelyekkel az egykorú szövegek is operálnak. Mindemellett olyan regionális irodalomfogalmakkal is találkozunk a magyarországi románság esetében, mint a Balázsfalván és környékén kialakuló, sajátosan görög katolikus, vagyis felekezetileg is szerveződő román irodalom, vagy az Arad, Temesvár, Lugos környéki, azaz bánsági irodalom, vagy a bihari románok irodalma, kultúrája, amelynek szövegi kidolgozója Márki Sándor, a majdani kolozsvári történész, egyetemi tanár. ${ }^{191}$ Magyar vonatkozásban is sorolhatunk regionális irodalomfogalmakat. ${ }^{192}$ A nemzeti irodalmak rendszere tehát a 19. század végén még korántsem egyértelmű és egységes rendszer. ${ }^{193}$ Továbbá, a nemzetiségi irodalmak fordítói, jelesül a román irodalmat fordítók a szórványos publikáláson kívül nemigen vállalkoznak fordításelméleti szövegek írására, ezért koncepciójukat csupán fordításgyakorlatukból ismerhetjük meg.

Az előbbieket összefoglalva, hasznosabbnak tartom egy-egy fordítás köré építhető kontextus megtalálását, hozzárendelését. Igy töredékessé válhat ugyan a (fordítás-, kapcsolat)történet, de amennyiben történeti szempontú és visszahelyezi a fordítást a fordítói gyakorlatba és elsődleges megjelenési közegébe, kisléptékű vizsgálatként alaposabb megértési lehetőséget kínál az adatokat felsorakoztató és folyton önismétlő fordítástörténeti áttekintés helyett.

\subsubsection{Elsőként fordítani - érték és történetiség}

Az első Eminescu-fordító, Sándor József fordítói szerepe történetileg nyer(t) értéket. Sándor József fordítása a recepció feltételeként működhet, akár más korai fordítók publikációi, mivel értékét éppen egy más nyelvű irodalom iránti korai érdeklődés növeli. Viszont a fentebb említett műfordítás-elméleti koncepciók felől, és egy későbbi nézőpontból, pl. Berde vagy

\footnotetext{
${ }^{189}$ Kettős központtal, viszont Budapest és Bécs nem egyenrangú központja a magyar és román nyelvü monarchiabeli irodalomnak, kultúrának.

${ }^{190}$ Például a bukaresti magyar anyanyelvű református közösség kultúrája, és ennek irányításában Koós Ferenc szerepvállalásai.

191 Vö. MárKi 1881.

192 Erről például T. Szaвó 2007, 21-32., T. Szaвó 2008, 13-100.

${ }^{193}$ A kérdést a nemzetfejlődés és az imaginárius nemzetegység kontextusában részletesen tárgyalja a következő kötet néhány tanulmánya: ÁbraHám - Gereben - Stekovics 2003, 150-181, 535-541.
} 
Franyó kontextusából kevésbé lesz ekvivalens, már csak azért is, mert Sándor József nem költőként tolmácsolja a román költőt.

A fordítások történetisége vizsgálati szempontként deríthet fényt mindarra, amit a müfordítás-elmélet kifogásol: jelesül, ha kevésbé sikerültek/hitelesek/értékesek művészi szempontból az első fordítások, akkor mit kezdhetünk azzal a szövegkorpusszal, amely a két irodalom között kialakuló kapcsolat első jelét és a recepció feltételét jelenti.

Sándor József valószínű nem tudta, hogy ő az első fordítója Eminescunak. Állításom megerősíthetem Engel Károlyra hivatkozva, aki szerint az első (Eminescu) fordítók egymástól elszigetelten, egymás munkájáról mit sem tudva dolgoztak, így munkásságuknak csak szúk körben lehetett visszhangja. ${ }^{194}$ Ehhez a gondolathoz kapcsolódva, vizsgáljuk meg Sándor József fordításának megjelenési helyét.

A Kolozsvári Közlöny karácsonyi mellékletét összehasonlítva a Kolozsvár címü, Petelei István által szerkesztett lap karácsonyi mellékletével ${ }^{195}$, kitűnik, hogy amíg a Közlöny tudomány-népszerűsítő, szórakoztató, könynyedebb olvasmányokat közöl karácsony napján ${ }^{196}$, addig a Kolozsvár jeles helyi kutatók, egyetemi tanárok szakszövegét hozza olyan Erdéllyel kapcsolatos kérdésekről, mint múlt, történelem, politikai súly, tanügy, egyházak, birtokrendezésünk, székelyek, művelődési viszonyok, iparviszonyok, románság, cigányság, hadászat, erdők, fürdők. Ezzel a megjegyzéssel nem a lapok szembeállítása, egyik-másik fölértékelése a célom, csupán kontrollforrásként vetem össze a két kolozsvári lap mellékletét. Az Eminescuvers beleillik a Kolozsvári Közlöny mellékletébe, hiszen az más fordítást is tartalmaz, a szintén református Szász Béláét ${ }^{197}$.

A lefordítandó vers kiválasztása egy költői életmü többi darabjai közül elsősorban fordítói döntés, amelynek jelentése lehet. Itt egy olyan versről van szó, amely nem a Maiorescu által elkülönített, Familia-beli korai „zsengék" közé tartozik, hanem Eminescu a Convorbiri Literareban közölte. Sándor vagy e román lapból, vagy a Maiorescu által szerkesztett verskötetből ${ }^{198}$ olvashatta. Az utóbbi évtizedek Eminescu-kutatói rámutattak a Maiorescu-féle Eminescu-kötet konstruált, kanonikusnak szánt jellegzetessé-

\footnotetext{
${ }^{194}$ ENGEL 1964, 724.

${ }^{195}$ Vö. Kolozsvár 1889. dec. 24./298.

${ }^{196}$ A Kolozsvári Közlöny Karácsonyfájának „díszei”: Szász Béla angol Longfellow-tolmácsolásai, Lövei Klára lengyel fordítása, Petelei rajza, ez utóbbiak karácsonnyal kapcsolatos történetet dolgoznak fel. Azután olvashatunk még székely népmesét, csevegést a zsidókról, történelmi írást Cuza fejedelemről, berlini levelet, és Zilahi Béla cikkét az irodalomról.

${ }^{197}$ Szász Béla nem egyszeri fordító, Longfellow-fordításait 1897-ben kötetben is publikálta. Vö. Longfellow költeményeiból. Makkabeus Judás, Pandora és kisebb költemények. Bpest, 1897. (Ism. M. Kritika 6., Vasárnapi Újság 13. sz.) = SzINNYEr 1891-1914.

${ }^{198}$ Maiorescu 1883.
} 
geire. ${ }^{199}$ E megkonstruáltságot akár a korban is tapasztalhatták a román irodalommal foglalkozók. De mivel Sándor József esetében hiányzik bármiféle interpretatív gesztus a fordítást vagy a fordítói koncepciót illetően, nem oldhatjuk meg egyértelműen a versválasztás kérdését. A jeles Eminescu-filológus, Petru Creția e verset az értékes alkotások közé sorolja, a versváltozatokat (Perpessicius szerint e versnek 18 változata ismeretes) nem tartja problematikusnak, vagy filológiai szempontból jelentékenynek. ${ }^{200}$

Tudjuk, hogy az a magyar nyelvű olvasó, aki 1885 karácsonyán kezébe vette a Kolozsvári Közlönyt és végigolvasta a mellékletet is, megismerkedhetett a román költő versével, illetve annak magyarított, nagyrészt szó szerinti fordításával. De ha azt feltételezzük, hogy nem került kezébe a román nyelvü eredeti, akkor számára egy magyar nyelvü verset, mondhatjuk, a magyar irodalom részét jelentheti a szöveg. Ezért a fordítói hűség kérdése számára talán nem is kérdés. Egyébként, ha a lapnak magyarul tudó román anyanyelvü olvasója is akadt volna, akkor számára teljesen mást jelent ez a versfordítás, főként, ha már ismeri Eminescut korábbról, a magyarországi vagy a romániai (irodalmi) lapokból. E versfordítás utóletét csak az 1964-es recepciótörténeti felfedezés jelenti. A fordító és a fordítás ténye adatként rögzült, amelyet történetileg számon tartanak. Azonkívül, hogy ez az első magyar nyelvű Eminescu-vers, korábban nem vizsgálták meg sem megjelenési környezetét, sem a fordítás kortársi befogadását.

Míg a Korunk 1964. évi májusi számában Engel Károly a Szamosújvári álnéven író, román Laurențiu Brant említi első fordítóként, és két Eminescu-nekrológot idéz a magyar Eminescu-kultusz első jeleiként, addig októberben Teofil Bugnariu az elsőként 1881-ben németre fordított román költő következő idegen nyelvű megjelenését, Sándor József magyar nyelvű fordítását említi az 1887-es olasz nyelvű előtt. ${ }^{201}$ Bugnariu röviden ismerteti Sándor József életpályáját, majd felsorolja az Atât de fragedă c. vers fordításváltozatait.

Mire irányítja figyelmünket ez az első fordítás?

Egyrészt rég elfeledett napilap alkalmi számában közölték, ami a véletlen folytán lelhető fel 80 év, de 130 év után is. A könyvtárakban felgyüjtött lappangó forráscsoport kerül így a figyelem középpontjába, mint például a 19. századi regionális (napi) sajtó. (A kolozsvári Egyetemi Könyvtár őrzi azt a példányát a Kolozsvári Közlönynek, amelyben még megtalálható a melléklet, a lap legtöbb alkalmi melléklete e könyvtár példányaiból is hiányzik, és csak utalásokból rekonstruálható, hogy volt pl. húsvéti melléklete is, vagy korábbi években karácsonyi.)

\footnotetext{
${ }^{199}$ Lásd erről bővebben pl.: Pericle Martinescu, Odiseea editării "Poeziilor" lui Eminescu. $\hat{I}$ prima sută de ani. 1884-1984, editura Ex Ponto, 2000.

${ }^{200}$ Vö. CRetia 1998.

${ }^{201}$ Vö. Engel 1964, Bugnariu 1964/10.
} 
Laurențiu Bran, Eminescu következő magyarra fordítója a SzilágySomlyó címü társadalmi hetilapban publikál Szamosújvári álnéven. ${ }^{202}$

Másrészt, amint Bugnariunál is látszik, sorrendbe illeszthető a magyar Eminescu: a német fordítás után a magyar következik, tehát a román kultúra érintkezési pontjait is leképezheti e sorrend. Lehet, hogy túlzás jelentőséget tulajdonítani ennek, főként hogy nem kortársi információ, hanem későbbi kutatás eredménye. Viszont jelzi, hogy milyen nyelvi közeg érdeklődik a román irodalom iránt. Mite Kremnitz, a német fordító, Eminescu személyes ismerőse, ez magyarázza fordítói preferenciáját. Az olasz érdeklődést a román nyelvvel való rokonság, a nyelvi hasonlóság magyarázhatja. Rögtön e két fordítás kapcsán megjegyezhetö, hogy a lefordítandó nyelv, szöveg, általánosabb értelemben kultúra nem esetleges, hanem fordítói szándékok állnak mögötte: esetünkben személyes kapcsolat vagy a románság iránti érdeklődés (A. M. Canini és Sándor József).

Ezért nem tartom járható útnak azt sem, hogy a fordításokat ne csak egymás között, hanem rendre összevessem az eredeti költeménnyel. Csupán az egyes fordítások saját kontextusát lehet felgöngyölíteni, és ezek az apró történetek állhatnak össze időbeli sorrendben valamiféle fordítás- és kapcsolattörténetté. Azért választom ezt a lehetőséget, mert egyrészt az első román nyelvről átültetett irodalomfordítások egymástól elszigetelten, rendszertelenül jelentek meg, másrészt, az általam használt módszertan is arról győz meg, hogy célszerübb kontextualizálni a fordításokatto3, már csak azért is, mert ez az eljárás az esztétikai értelemben vett irodalom a szöveghűséget mércének tekintő hagyományos fordításfogalmat érvényesítő értelmezés alternatíváját jelenti.

A német, magyar és olasz nyelvű fordítás más-más kultúrában teremti újjá Eminescu költeményét, ezáltal pedig három különböző szöveget termel, amelyek egymáshoz, de az Eminescu-szöveghez képest is eltérő képet mutatnak, ezáltal összehasonlíthatatlanságukra hívják fel a figyelmet. Eminescu neve tartja össze őket csupán. Fordítástörténetileg e három szöveg azért lesz értékesebb a későbbi fordításoknál, mert kortársak Eminescuval.

A román nyelvű Eminescu-versre figyelnek a fordítók, tudják, hogy kortársuk a költő, ez pedig irodalomhasználati szokásaikat is példázza. Fordításaik ebben az esetben arra mutatnak rá, hogyan érdeklődnek a másik kultúra, nyelv és irodalom iránt. Azt példázzák, hogy nem egyszerü

\footnotetext{
202 Szilágy-Somlyó 1889-1991.

203 "[Fordítás esetén] nem két mondatsorozat absztrakt összeillesztésével van dolgunk, hanem egy életmódba ágyazott társas tevékenységgel.” = AsAD 2004, 112. Továbbá: „,a kulturális fordítások konstruált természetének felismerése megmutatja, hogy a fordítás mindig létrehoz, ahelyett, hogy visszatükrözné, vagy utánozná az »eredetit«". = Niranjana 2004, 165. [kiemelés az eredetiben - B.T.]
} 
haszonélvezői (értsd: olvasói) a másik irodalomnak, hanem saját képességeiket próbára téve használják azt: fordításra. A fordítás gesztusán túl pedig egyébre: ismertetésre, személyes kapcsolatépítésre, tisztelet kifejezésére.

Mivel retrospektív értelemben kap jelentőséget a fordítás, önreflexíven kell viszonyulnunk hozzá, hiszen amint azt az újabb, antropológiai ihletettségü fordításelméletben láttuk ${ }^{204}$, tarthatatlan az a gondolkodásmód, miszerint az egyes nyelvek nemzeti irodalmakat reprezentálnak, olyanokat, amelyek egymástól jól elkülöníthetőek. Az egyes irodalmak egymáshoz képest aszimmetrikusak, és vizsgálatukból kiderül konstruált jellegük. De az is, hogy épp az általam kutatott időszakban, a 19. század második felétől alakulnak modern értelemben vett irodalmakká, változásban vannak, és folyamatosan viszonyulnak egymáshoz. Ez a viszonyulás és differenciálódás pedig állandó ismérvük lesz, folyamatosan versengenek egymással - például az elsőségért.

Fontosnak tartom a korábbi fordítástörténeti eredményeket és egyúttal láttatni szeretném, hogy nem jelentés nélküliek. Eminescu verseinek magyar fordítóit főként a 20. században kezdték kutatni, és megtalálni, abban az időben, amikor az egységesülő román társadalomnak és irodalomnak legitimációs nehézségei akadtak, amikor a hatalomnak kanonikus figurákra, mitikus hősökre, legnagyobb román nemzeti költőre volt szüksége. Lucian Boia ${ }^{205}$ könyve után talán érthetőbb e folyamat konstruált jellege.

Visszatérve a felfedezett első fordításra, az forrástörténeti értéke mellett kultikus tartalommal is bír, amit így utólag jobban beláthatunk. Az élő költó és az általa megnyilatkozó román nyelv, irodalom és kultúra iránti tiszteletként is értelmezhető a romántól idegen anyanyelvű fordítók gesztusa.

\subsubsection{Egy (fordítói) karriertörténet}

Sándor József fordításának publikálása önmagában csak egy gesztus. Jelentéseit a fordítástörténet, a román-magyar kapcsolattörténet, de a kiválasztott Eminescu-vers későbbi fordításváltozatai, a román Eminescuszakirodalom is alakítják. Az is problematikus, hogy milyen fordító Sándor József. Egyszeri Eminescu-fordítása két szempontból lehet igazán érdekes. Egyfelől megjelenési közege jelezheti használatát, lehetséges értelmezéseit, a befogadás hogyanját, amelyek a kontextualista módszertan felől válnak érdekesekké, másfelől a fordító személye, életpályájának e verssel kapcsolatos mozzanatai megvilágíthatják a román kultúra iránti érdeklődését. Azért is fontos e két megközelítési lehetőség, mert Sándor Józsefet nem

\footnotetext{
${ }^{204}$ N. Kovács 2004.

${ }^{205}$ BoIA 1999.
} 
tartja számon sem a magyar, sem a román irodalomtörténet, mivel foglalkozását tekintve nem irodalmár, hanem politikus, intézményszervező. Egyébként hiányát tekinthetjük úgy is, hogy az irodalomhoz kívülálló fordítóként közelítő Sándor és fordítástörténeti értékű munkája nem tartozik szorosan az irodalomtörténethez, hanem vagy a világirodalomhoz vagy a (recepció-,) kapcsolattörténethez, vagy peremhelyzetben létező segédtudományként biztosít átjárást az irodalomtudomány alrendszerei között

Mivel a kutatás szempontjából alapvető fontossággal bír Sándor József életrajza, részletesebben foglalkozom vele. Szülei, a háromszéki Sándor Dénes és a jász-kun Keresztes Erzsébet Magyarország egymástól távol eső régiókból származnak, és 1848/49 után egy román városban, Bukarestben találnak otthonra. A Bukarestben élő magyarság kiépített intézményrendszerrel bír, amellyel minden bizonnyal Sándor is érintkezik. ${ }^{206}$ Mégis, az elemi iskola elvégzése után fiuk magyarországi oktatási intézményekben tanul tovább ${ }^{207}$, eltávolodik szülőhelyétől, de közelebb kerül az etnikai identitását egyértelmüsítő régióhoz, kultúrához. Az 1866/67-es tanévben iratkozik be a nagyenyedi református kollégium első középosztályába az 1853-ban, Bukarestben született Sándor József. ${ }^{208}$ Az apa/gyám oszlopban az a Salamon János, bukaresti kovács szerepel, aki például 1860-ban az MTA-székház felépítését támogató adakozók között is szerepel. ${ }^{209}$

Sándor József 1 cipó és 20 forint támogatásban („évi kegylet”) részesül középiskolai tanulmányai alatt. A kollégium magaviseleti tabelláiból pár érdekességre hívom fel a figyelmet: a középiskolai évek alatt Sándor Józsefnek magántanítói voltak, például ötödik osztályban a hatodikosok

\footnotetext{
${ }^{206}$ Bukarest Cuza fejedelem trónra lépésekor válik román fővárossá, de csak I. Károly uralkodásától, a század utolsó évtizedeiben kezdődik el rohamos fejlődése. Az erre tartó magyar migrációt a Rákóczi-féle szabadságharctól számítják. 1849 után ismét tömbben vándorolnak ide magyar értelmiségiek és nemcsak, akik közül páran a kiegyezés után is maradnak, mint Szathmáry Pap Károly, Fialla Lajos, a Veress család, stb. Magyar részről olyan intézmények vannak jelen a román városban, mint az egyházak (római katolikus, református, evangélikus), kaszinó, múvelődési egylet, református iskola, Bukaresti Magyar Közlöny. Vö. BEKe 1971., illetve KovÁch 1996.

${ }^{207}$ A Bukarestet elhagyó és Magyarországon tanuló Sándor József kapcsán hangsúlyoznunk kell a magyarországi református egyház szórványmissziós tevékenységét és annak jelentőségét a 19. század második felében. Valószínü, ennek köszönhetően került Sándor József is Nagyenyedre, hiszen a bukaresti református lelkész és a gyámként szereplő Salamon János támogatták tanulmányaiban.

${ }^{208}$ A magyar ev.ref. collegium magaviseleti tabellái az 1866/67 tanévről. . [A kézirat lelőhelye: Erdélyi Református Egyházkerület Gyüjtőlevéltára, Kolozsvár]

${ }^{209}$ Koós Ferenc református lelkipásztor csatlakozik gróf Dessewffy Emil felhívásához és hívei között szervezi meg a gyüjtést. Erről értesíti a grófot, valamint felhívását és az adakozók névsorát is mellékeli a hozzá írt levélben. A lelkészhez hasonlóan, 6 ezüst huszast adományoz a kovács Salamon János is. Vö. Demény 2000.
} 
osztályvezetője: Bartók György. ${ }^{210}$ Ő pedig két tanévben is több negyedikes diák magántanítójaként szerepel. Az 1870/71-es tanév kimutatásában csupán az ő nevénél található megjegyzés: „priv. Studio”-ként tanulja az antik irodalom költői darabjait és Cicero beszédét. Kollégiumi bölcsészhallgatóként irodalmi érdeklődésének és szorgalmának bizonyítéka a fenti megjegyzés, és a dicséretes minősítéssel szerzett érettségi 1874-ben. ${ }^{211}$ Mind Bartók György értelmiségi profilja, mind Sándor kollégiumi éveiből származó adataink a bölcseleti diszciplínák iránti érdeklődését erősítik.

Mind a Petőfi Irodalmi Múzeum honlapjáról elérhető Diplomások Adattára ${ }^{212}$, mind a kolozsvári egyetem medikus hallgatóinak prozopográfiai adatai ${ }^{213}$ között megtaláljuk a Sándor Józseféit. Bár mindkét adattár összeállításán ugyanazok a kutatók (Karády Viktor és Lucian Nastasă) dolgoztak, mégsem azonosak Sándor József adatai: az adattár szerint 1854-ben, a medikusok adatai szerint 1853-ban született. Az adattár a kolozsvári egyetem bölcsészettudományi karának hallgatójaként jeleníti meg: az 1883/4-es tanévre iratkozik be, ahol mindössze két félévnyi időszakot tölt. ${ }^{214}$ Ugyanitt szerepel az is, hogy 1880-tól a pesti egyetem orvostanhallgatója. A medikusok adatai alapján Sándor József 1881-ben iratkozik be a kolozsvári egyetem orvosi karára, ahol 1881-1885-ig 6 félévet tanul, miközben az 1883/4-es tanévet Budapesten tölti. Az 1883/4-es tanév az az időszak, amelyben nem egyértelmü, hol is tanul Sándor, az adattárak meg összecserélhették a kolozsvári és budapesti időszakot.

Mindenképpen, életpályájának alakulása az egyetemi végzettséghez képest eltérő szakmai orientációt mutat. Szinnyei József életrajzgyüjteményében is jelzi Sándor József szakmai bizonytalanságát: „[J]ellemző, hogy a kolozsvári egyetem bölcseleti kara Descartes Discours de la methode... munkájának ismertetését tűzvén ki pályakérdésül, a díjat ő, az orvosnövendék nyerte el. Hírlapírói pályája Kolozsvárt kezdődött, hol mint

\footnotetext{
${ }^{210}$ A nagyenyedi ev.ref. Collegium tanuló ifjúsága magaviseleti tabellái az 1870/71.ik tanévról. [A kézirat lelőhelye a Erdélyi Református Egyházkerület Gyűjtőlevéltára, Kolozsvár]

${ }^{211} \mathrm{Az}$ 1874-ben 18 érettségiző diák közül összesen négy (köztük Sándor József) szerez dicséretes és három kielégítő minősítést. A többi 11 diák vagy javíthat, vagy visszavettetett. Vö. A nagyenyedi ev.ref. teljes gymnasiumban az 1873/4. tanév végével tartott érettségi vizsgálatról Kimutatás. [A kézirat lelőhelye a Erdélyi Református Egyházkerület Gyűjtőlevéltára, Kolozsvár]

${ }^{212}$ A Petőfi Irodalmi Múzeum által összeállított Diplomások adattára Karády Viktor, Lucian Nastasă és Nagy Péter Tibor által készített, az „,egyetemet végzett értelmiségi elit rekrutációja, képzése és európai kapcsolathálója a 20. században, különös tekintettel a foglalkozási, nemi, regionális, felekezeti és nemzetiségi egyenlőtlenségekre" című NKFP-kutatás eredményeit, valamint a magyar egyetemeken 1994-2003 között PhD-fokozatot elértek adatait tartalmazza. [Az adattár online elérhetősége: http://regi.pim.hu/Online/adattar/diplomasok.php?mit=N\% e9v\&ertek=s\%e1ndor+j\%f3zsef\&valt=kereses\&alsoi=1\&kul=5\&kiaz=1 - utolsó látogatás: 2012 júliusa]

${ }^{213}$ KARÁDY-NASTASĂ 2004, 316.

${ }^{214}$ Köszönöm Lucian Nastasănak, hogy megerősítette ezeket az adatokat.
} 
egyetemi hallgató segédszerkesztője lett a Kolozsvári Közlönynek. E minőségben kezdte meg a magyar sajtóban legelőször az oláh kérdés taglalását. Szerkesztője volt a kolozsvári Protestáns Közlönynek 1884. szept. 28-tól dec. 28-ig. Mint hírlapíró működött azután is, kiválólag a nemzeti kérdésekkel foglalkozott, e nemben úgy a fővárosi, mint az erdélyi lapokba sok cikket írt". 215

Szinnyei adatait ki kell egészítenem, egyfelől azért, mert többkötetes munkája megjelentetésekor még lezáratlan Sándor József életrajza, másrészt pedig kontrollforrások alapján helyenként pontosításra szorulnak.

Egy, a Sándor József munkásságát részben összesítő könyvészeti kimutatás ${ }^{216}$ szerint 1884 szeptemberétől 1885. december 31-ig, egy évnél jóval több ideig szerkeszti a Protestáns Közlönyt, ahova valószínüleg felekezeti kapcsolathálója révén került. ${ }^{217}$ Nagy Péter református püspök halálával a szerkesztői tisztséget betöltő Szász Domokos lesz a püspökhelyettes, ezért kérik fel Sándort a lap szerkesztésére. Mihelyt megválasztják az EMKE titkárának, nem vállalja a megbízatást. 218

Mielőtt szerkesztő lenne, már 1884 augusztusától publikál a Közlönyben: iránycikket ír, amelyben a jezsuiták és szabadkőmúvesek összehasonlításával foglalkozik, és az utóbbiakat arra szólítja fel, hogy „lépjenek a világosság elé" ${ }^{219}$ és közeledjenek a protestáns anyaszentegyházakhoz. Több aktuál- és egyházpolitikai cikket, egy tanulmányt $A z$ akaratról, és Salvator címmel háromszakaszos költeményt olvashatunk tőle ugyanitt. ${ }^{220}$ Mindezzel párhuzamosan, 1883. augusztus 1-től 1886. december 31-ig segédszerkesztője a Kolozsvári Közlönynek, továbbá, szerkesztői tevékenységét ez év karácsonyától már a Kolozsvár c. lapnál folytatja 1891. szeptember 30-ig. ${ }^{221}$ Látszik tehát, hogy Kolozsvárra kerülvén a rövid ideig tartó egyetemi tanulmányok mellett szerkesztői, újságírói munkát vállal, bizonyára megélhetése biztosításául. Ez a döntése mind medikusi, mind bölcsészeti érdeklődését felülírja és egy harmadik szakmai identitás felé közelíti a fiatal Sándort.

\footnotetext{
215 SZINNYEI 1891-1914.

${ }^{216}$ A magyarságért. Könyvészeti kimutatás Sándor József udvari tanácsos, az EMKE t. alelnök főtitkárának a nemzetegység érdekében írt és nyilvánosan megjelent dolgozatairól és önállóbb hírlapi közleményeiről. SIPOS 1915.

${ }^{217}$ A lap korábbi szerkesztője, Nagy Péter református püspök 1884. szeptember 16-án halt meg. Mivel a helyettes püspököt, Szász Domokost időközben püspökké választották, a lapszerkesztést Sándor Józsefre bízták, amíg Szász Gerö át nem vette tőle ezt a feladatot. Vö. Erdélyi Protestáns Közlöny. Egyházi és iskolai hetilap, Kolozsvár, 1884, 1885, 1886.

${ }^{218}$ Vö. Erdélyi Protestáns Közlöny 1884. szept.28. és 1885. dec.6.

${ }^{219}$ Sándor József, Jezsuiták és a szabadkőmüvesek = Erdélyi Protestáns Közlöny 1884/35., 284.

${ }^{220}$ Erdélyi Protestáns Közlöny 1884. okt. 5., 328, 336.

${ }^{221}$ Sipos 1915.
} 
A felekezeti, illetve a politikai lap szerkesztése után 1896-tól 1906-ig szabadelvű országgyűlési képviselő. A közoktatásügyi bizottság tagja. Felszólalásairól is tudunk ${ }^{222}$, de főként (pisztoly)párbajai kapcsán tárgyalja mentelmi ügyeit az országgyűlés. Bartha Miklóssal, az erdélyi független párt politikai lapja szerkesztőjével (többször), és dr. Várady Auréllal párbajozik.

Az Országgyúlési almanachok közlik életrajzi adatait. ${ }^{223}$ Ezekben két, részben eltérő életrajzot találunk, emiatt is fontosnak tartom összehasonlításukat. A korábbi életrajzból kimarad az, ami számunkra érdekes adat, és a későbbiből tudjuk: Sándor József budapesti egyetemi hallgatóként pályadíjat nyert a „Deák Ferenc haláláról” címü ódájával. Tudjuk azonban, hogy a kolozsvári egyetemen is pályadíjat nyer, a Descartes-mú ismertetésével, amit mindkét életrajz elhallgat. A budapesti pályázat tematikusan is politikusi tevékenységét bizonyíthatja, és országgyưlési képviselőként benyújtott életrajzában a Deákkal kapcsolatos munkásság értékesebbnek minősül, mint a Descartes-recenzió. Korábban utaltam arra, hogy az egyetemtörténeti kutatások, a prozopográfiai adattárak egymásnak ellentmondó adatokat közölnek Sándor egyetemi tanulmányainak színhelyeiről. A későbbi életrajzban ő maga rendezi sorba tanulmányai helyszíneit: előbb Budapest, majd Kolozsvár. Az értekező tanulmányhoz képest a politikus Deák halálra írt alkalmi költeményét emeli ki Sándor József, saját korai politikai érdeklődését erősítendő.

Származását tekintve is jelentéses a két életrajz: míg a korábbi a dátum mellett Bukarestet jelöli szülőhelyéül, addig a későbbiben az szerepel, hogy ősrégi primor családból származik, szülőhely nélkül. Eszerint Sándor József számára (vagy országgyűlési képviselői minőségét tekintve) az 1890-es évek végén nem vállalható a bukaresti születési hely, annál inkább fontosabb az, hogy a Háromszék megyei, kovásznai kerület képviselője székely eredetét igazolja. A nyolcvanas években Sándor József Ifjú Erdély címmel lapot indított. A korábbi életrajz nem minősíti a lap szerepét, csak profilját: „kereskedelmi és ipari szaklap”. ${ }^{224} \mathrm{~A}$ későbbi hozzáteszi: „közgazdasági lapot, mely különösen a Romániával folytatott vámháború alatt tett nagy szolgálatot". ${ }^{225}$ Csak az első életrajz tartalmazza azt az információt, hogy „tanulmányutat tett az orosz-török háború alatt a Balkánon, a

\footnotetext{
${ }^{222}$ Erdély ev. ref. egyházkerület közgyűlésének kérvénye az erdélyi római kath. püspök hivatalos czímzése tárgyában kiadott vallás- és közoktatásügyi miniszteri rendelet ellen 1901-ben. (1896), Sándor József és a kunfélegyházai választókerület tanítóinak Holló Lajos képviselő által beadott kérvényét a tanítói fizetés rendezése tárgyában. Vö. www.mpgy.ogyk. hu

${ }^{223}$ StUrm 1897, StUrm 1901.

${ }_{224}$ STURM 1897, 334.

${ }^{225}$ StURM 1901, 353.
} 
nemzetiségi viszonyok megismerése végett ismételten beutazta Romániát és Bukovinát" ${ }^{226}$ Ezek a jelentéktelennek tűnő átfogalmazások Sándor József Romániához füződő viszonyának átértékelésére utalnak. Valamiért ezekben az önéletrajzaiban elhallgatja korábbi tapasztalatait, a nemzetiségi viszonyok iránti érdeklődését, utazásait, miközben továbbra is érdekli a téma. Kolozsvári közéleti és a református egyházban betöltött szerepeit mindkét életrajzban felvállalja.

A magyar-román viszonyok politikai kérdésének országgyűlési jelenléte mindenképp megfontolandó Sándor József hezitálása szempontjából. E két életrajzban tehát Sándor József eltérő módon jeleníti meg önmagát. Ez az eltérés több mindent megértet: egyrészt azt, hogy Sándor József életének adott időszakában mit vél kiemelendőnek, említésre méltónak, önmeghatározó tényezőnek, másrészt azt, hogy közvetve ugyan, de milyen etnikai csoportokkal vállal sorsközösséget, illetve ezzel egyidőben milyen kapcsolatait, információit hallgatja el. Ezek a szövegei nagyon jól példázzák azt, amit a nacionalizmuskutatás újabban előtérbe helyez, vagyis azt, hogy az egyéni döntések és preferenciák felől kellene megközelíteni például az etnikai csoportok múködését ${ }^{227}$, akár a nemzeti identitás különböző értelmezéseit is. Érdemes utalni arra az érvelésre is, amely a kultúravizsgálattól, a hagyomány és civilizáció viszonyának kutatásától jut el a közösség és identitás fogalmainak értelmezéséhez és ezáltal az etnicitás elméleteihez.

Sándor József, de amint a későbbiekben látni fogjuk, Grigore Moldován életművében is számos olyan szöveget találunk, amelyek csoportkötődéseiket, identifikációs gyakorlatukat nagyon érzékletesen szemléltetik, és e szövegek komparatív vizsgálata azt is megmutathatja, hogy mennyiben helyzetfüggő például az, hogy mikor hogyan nyilatkoznak önmagukról, többes kulturáltságukat, többnyelvűségüket hogyan kamatoztatják.

Sándor József politikai tevékenysége 1921-től a romániai Erdélyi Magyar Pártban folytatódik. 1922-től a román kamara, majd a szenátus tagja. Ide a sepsiszentgyörgyi választókerület juttatja. A korábbi kovásznai, a mostani sepsiszentgyörgyi kerületi képviselőség, a Pákei előnév használata az időközben felértékelődő székely identitáshoz való ragaszkodásának bizonyítékai. Kitűnő román nyelvtudásának köszönhetően a legtevékenyebb magyar képviselő volt a román szenátusban. ${ }^{228}$

1885-ben az EMKE egyik alapító tagja, tiszteletbeli alelnöke, az EKE alapító dísztagja, alelnöke. Az 1884-es országgyủlési választásokon kerül többségi helyzetbe a szabadelvű párt, ennek következményeként láttatja

\footnotetext{
${ }^{226}$ StURm 1897, 335.

${ }^{227}$ A csoportok nélküli identitás fogalmához lásd: BRUBAKER 1996, BRUBAKER 2001.

${ }^{228}$ Vö. GYÖRGY 2006.
} 
Sándor József a nemzetegységi érdekként szerveződő EMKE-t, általánosabban, az Erdély-ügy tematizálását. Talán ezekben a szervezetekben vállalt szerepei juttatják el oda, hogy elhatárolódjon a nemzetiségi kérdésektől, illetve azokat a magyar állam és nemzet érdekei felől ítélje meg vagy el.

Lapszerkesztőként és hírlapíróként, később országgyűlési képviselőként tölti be az EMKE alelnöki tisztségét, ennélfogva, ő ad elő leggyakrabban a szervezet köz- és választmányi gyűlésein. ${ }^{229}$ Mindemellett, az EMKE működésének első negyedszázadában adja ki Sándor József mintegy 21 munkáját, amelyek főként az egylet szervezésével, működtetésével kapcsolatosak. Az általa írt történeti munka, amely az EMKE első negyedszázadát tekinti át, jól mutatja azt, ahogyan létrejön az egylet: már müködő személyes kapcsolathálón, intézményeken - itt ki kell emelnünk a (református) egyház rendszerére való ráépülést - keresztül indítanak el újabb fiókegyleteket Erdélyben. ${ }^{230}$

Sándor József életpályáját az is befolyásolhatta, hogy 1887. április 23-tól, a kolozsvári elithez hasonlóan, tagja a kolozsvári Unió szabadkőmúves páholynak. ${ }^{231} \mathrm{Az}$ EMKE Irodalmi szakosztályaként nyilván tartott Erdélyi Irodalmi Társaság a szabadkőműves páholy társasága is egyben.

Sándor József nős, felesége Sólyom Fekete Margit. Értelmiségi családból származó művelt hölgy, aki Kuun Géza életrajzát és munkásságát vizsgálja, cikket is ír róla, valamint Kuun Goethéról írt munkáját németből magyarra fordítja. Aktívan bekapcsolódik például az EMKE 25 éves évfordulójára szervezett ünnepségbe. Ekkor az EMKE-hez tartozó Erdélyrészi Kárpát-Egyesület kirándulást szervez, ahol angolul informálja a részt vevő nőket, és Gálfi Lőrinc unitárius teológiai tanár tolmácsolja őt. ${ }^{232}$ Nem véletlen Sólyom Fekete Margit közéleti érdeklődése, hiszen apja, a nagyváradi Sólyom Fekete Ferenc (1839-1906) Kuun Gézával alapítja meg a Hunyad megyei Történelmi és Régészeti Társulatot 1880-ban. Sólyom Fekete Ferenc a jogtudomány doktora, királyi törvényszéki elnök, történész, jelentős kéziratgyüjtemény tulajdonosa volt. „Sólyom-Fekete tudományszeretete, agitátori tevékenysége s a gróf Kuun Géza nagy tudományos tekintélye és elnöki tisztének odaadó, lelkiismeretes gondossága a Hunyad megyei Történelmi és Régészeti Társulatot úgy is, mint múzeumot fenntartó intézetet, úgy is, mint tudományművelő egyesületet országos hírűvé, sőt Eu-

\footnotetext{
${ }^{229}$ SÁNDOR 1910, 93114.

${ }^{230}$ Sándor József személyesen látogat el Orbai székre, amelynek alkalmával létrehozzák a Mikes- és Körösi-emlékek bizottságait. A bizottságok megszervezésével megalakultnak tekintik az Orbai széki EMKE-t. Vö. SÁndor 1910, 166.

${ }^{231} 1887$. május 27 -től 2. fokozat, 1887. május 10-től 3. fokozat; ugyanekkor az Irodalmi Bizottság tagja és előkészítő mester is. Vö. BERÉNYI 2005. A kolozsvári Unio-páholyról is lásd: SĂLĂGEAN-EPPEL 2007, különösen: 77-83, 187-193, illetve legutóbb VARGA 2010.

232 SÁNDOR 1912.
} 
rópa-szerte ismertté fejlesztette". ${ }^{233}$ Sólyom Fekete Ferenc felesége a Hunyad vármegyei EMKE nőválasztmányának alelnöke ${ }^{234}$, - aktív társadalmi életük lányuk számára követendő példaként hathatott. A vej Sándor József pályája pedig számos hasonlóságot mutat apósáéval: mindketten egyetemi éveik során kerülnek kapcsolatba az irodalommal, politikai tudósításokat írnak, lapot szerkesztenek, az EMKE-ben tisztséget vállalnak (gróf Kuun Géza volt az 1884-ben alapított EMKE alelnöke), miközben intézményépítő munkásságuk a legjelentősebb. Sándor József 1945-ben halt meg, családi sírja a kolozsvári Házsongárdi temetőben található.

Szocializációja járult hozzá ahhoz, hogy naprakész információi legyenek a románsággal kapcsolatban. Ez megmutatkozik mind az általa szerkesztett és írt napilapban, mind egyéb munkáiban. A korabeli román lapok román-magyar politikai kérdéseket tárgyaló, szélsőséges megfogalmazásaira állandóan válaszol a Kolozsvári Közlönyben, a Kolozsvárban, de az egyházi lapban is.

1915-ben dr. L. Sipos Kamilló A nemzetiségi kérdés történetéhez c. kötetéből különlenyomatként jelenik meg $A$ magyarságért címmel Sándor József publikációs listája. ${ }^{235}$ Ebből a különlenyomatból tudható, hogy 1884-ben is fordítóként van jelen a Kolozsvári Közlöny karácsonyi számában. Akkor Al. Vazul allegóriáját fordította Maros és Olt címmel. Sándor József többször fordít román nyelvből különböző irodalmi regiszterekhez tartozó szövegeket. 1884-es választása az akkor a román irodalomban ünnepelt költőre, Vasile Alecsandrira esik. Az imént szándékosan írtam Alecsandri Vazult, ugyanis a 19. századi magyar nyelvű szövegek magyarítják az idegen neveket, eltörlendő a kulturális különbségeket. Fordítás és gyarmatosítás, valamint fordítás és hatalom kérdése rejlik a névmagyarításban ${ }^{236}$, valamint abban is, hogy a magyar irodalom, de főként az erdélyi, később romániai magyar irodalom számára utólag jelent presztízskérdést az, hogy a majdani román nemzeti költőóriás munkássága iránt legkorábban érdeklődött.

Ha Sándor Józsefet szabadelvű politikusként látjuk, aki református vallású és egyházában aktív szerepet vállal ${ }^{237}$, országgyűlési tevékenységén kívül alapítója és szervezője a magyarság egységesítő törekvéseit szolgáló Erdélyrészi MKE-nek, akkor nem lepődünk meg azon, hogy az

\footnotetext{
${ }^{233}$ KRISTÓF 1942.

${ }^{234}$ SÁNDOR 1910,169.

235 Sipos 1915.
}

236 „A fordításelméletnek a fordítás humanista természetével kapcsolatos rögeszméje hályogként ül a szerzők szemén, s megakadályozza, hogy saját belátásaikban felismerjék a fordítás és a gyarmatosító elképzelés összetett viszonyrendszerét”. N. Kovács 2004, 133., 146.

${ }^{237}$ A reformátusok felekezetspecifikus lapjának szerkesztője, egyházkerületi képviselő, lásd állásfoglalását Bartha Miklóssal és gróf Bethlen Bálinttal - nyomtatvány, válasz Zeyk Domokos főgondnok úr cikkére a reformátusoknak az osztrák-magyar bankkal folyó kölcsönügye kapcsán: Az egymilliós ügy, Kolozsvár, 1890. október 24. 
1915-ben összeállított Sándor-bibliográfia azokat a munkáit listázza, amelyek a nemzetegység érdekében születtek. Bár az Alecsandri-fordítás benne van, az egy évvel későbbi, az 1885-ös hiányzik. Az Eminescu-fordítást, amennyiben tudtak róla, talán nem tartották politikai munkának, illetve olyannak, amely a magyarság érdekeit szolgálja. Szintén az EMKE-ben vállalt szerepe magyarázza a református egyházi lap szerkesztőségének elhagyását. 1885-öt tehát fordulópontnak tekinthetjük Sándor politikai viselkedésmódja szempontjából. Amint egyre erőteljesebben a politika tölti ki mindennapjait, úgy távolodik el korábbi munkásságától, és annak bizonyos aspektusait kiemelve fed el másokat, gondoljunk a képviselőként megírt életrajz-változataira. Annak ellenére, hogy nem sikerült kontrollforrást találni, igazat adhatunk Teofil Bugnariunak abban, hogy Eminescu versét 1885-nél korábban fordította le Sándor.

A tájékozott fordító Sándor szövegeit politikailag elkötelezett lapban teszi közzé, de mindig karácsonyi mellékletben, és nem a címoldal tárcarovatában. Az alkalmi mellékletben a vers (szép)irodalmi értéket nyer, és éppen ezért nem értelmezhető politikai szempontból, szándékosan elkülönül attól. Mégis, politikai döntésként érzékelhető az, hogy kimarad Sándor József műveinek jegyzékéből, már csak azért is, mert ha az Alecsandrifordításról tudott a bibliográfia összeállítója, kevésbé hihető, hogy az Eminescu-tolmácsolásról ne tudott volna. Ezek ugyanabban a lapban jelentek meg, ugyanabban a rovatban.

Sándor József fordítói érdeklődését hírlapírói munkássága keretezi. Úgy foglalkozik irodalommal, hogy szűkebb és tágabb fogalomhasználatban politizál. Figyeli a román és magyar nyelvü napi sajtót, irodalmat és amennyiben érdekli valami, viszonyul is hozzá. Szövegeit a kelet-nyugat paradigmában írja: „,minden keleti állam többet tud nyugati szomszédjáról, mint ez ő róla, Oláhország többet Magyarországról, hazánk Németországról, mint Germánia rólunk és így tovább" - írja a román királynéről szóló cikkében. ${ }^{238}$ Eszerint az ismertetés, a nemzetiségek közötti kölcsönös megértés politikáját játssza akkor, amikor román irodalmi alkotásokkal foglalkozik, vagy azokból fordít, illeszkedik ahhoz a koncepcióhoz, amely ideologikusnak képzeli a fordítások funkcionalitását. Ezzel egyidőben, más játszmaként, harcosan vitatkozik a román lapok magyarellenes cikkeivel, és amint a fentiekből is jól körvonalazható, ez utóbbi játszma válik uralkodóvá írásgyakorlatában.

A szakmai pályát váltó Sándor József hírlapírói, szerkesztői tevékenységét politikai érdeklődése határozza meg, 1885 előtt azért találkozunk nevével a Kolozsvári Közlöny tárca-rovatában. Például 1884-ben színházi előadásokról referál, Madách Az ember tragédiájának bemutatójáról, Feren-

\footnotetext{
${ }^{238}$ Kolozsvári Közlöny 1884/79.
} 
czi Zoltán Aranykakas c. eredeti népdrámájáról, Carmen Sylva Erzsébet román királynéről című szövegéről és más irodalmi műveiről értekezik több számban. Az Ahasvérus mítoszának Carmen Sylva-i értelmezését Madách említett művével hasonlítja össze. Amellett, hogy nagyra értékeli Madách művét, referenciaként használja tehát más nyelvű irodalom olvasásakor. A román és magyar nyelvű irodalommal kapcsolatos szövegei társaságában, az 1884-es évfolyam augusztusi számaiban két eredeti versét olvashatjuk: augusztus 9-én Hirám ${ }^{239}$ szignóval közli a Jób éneke vallásos témájú költeményét, majd 27-én S-f. szignálja a ...Palmyra... című költeményt. ${ }^{240}$ Tervezője és főszerkesztője volt Erdély első bedekker-szerü leírásának, az EMKE útikalauznak. ${ }^{241}$

Az előbbiekből egyértelműen kitűnik, hogy Sándor József már orvostanhallgatóként kipróbálja írói tehetségét, és próbálkozásait szakmailag értékelik, pályadíjjal jutalmazzák mindkét magyarországi egyetemen. A Deák Ferenc halálára írt óda egyszerre jelzi az irodalom és politika iránti érdeklődését. A református lapban közölt tanulmánya és verse egyrészt illeszkedik az általa szerkesztett lap profiljához, másrészt megtörténhet, hogy szerkesztőként tölti ki a lapot és ilyenként alkalmi versírónak bizonyul. A Kolozsvári Közlöny tárcarovatában megjelent írásai egy-egy irodalommal kapcsolatos eseményhez, színházi bemutatókhoz, új könyv megjelenéséhez kötődnek. Irodalmi munkássága inkább fiatalkori érdeklődésének köszönhető, talán a választott bölcsészkari tanulmányoknak, hasonlóan néhány szépirodalmi fordításához, amelyek nem illeszkednek komoly fordítói programba.

Látható tehát, hogy Sándor József román irodalom iránti érdeklődését, fordítói motivációját egyszerre több minden befolyásolja: szépírói, értekező prózai próbálkozásai, úti-kalauzai, a kolozsvári kulturális élet (például színházi bemutatók) referádái, lapszerkesztői munkássága mellett orvostudományi és bölcsészeti tanulmányai, románokkal való (személyes, szocializációs és közvetett) tapasztalatai, kapcsolatai. Szabadelvüsége, politikai feladatköre, intézményszervezői teendői viszont elválasztják ettől az érdeklődéstől. Életpályájára a rapszodikusság, a folyamatos bizonytalanság jellemző addig a pontig, amíg el nem kötelezi magát politikusként.

Sándor József rekonstruált karriertörténete több szempontból is tanulságos. Egyrészt megmutatja, hogy nyelvi kompetenciákra, kapcsolatokra, esetleg adekvát szocializációra támaszkodik az, aki a 19. század

\footnotetext{
${ }^{239}$ Szinnyei József a Hirám és (S.) szignókat Sándor József álneveiként oldja föl. A Hirám használata Sándor szabadkőművességgel való kapcsolatának jele. A református lapban publikált összehasonlító írása a jezsuiták és szabadkőművesek kapcsán, a szabadkőművesek melletti elkötelezettségének explicit példája - pár évvel a páholyba lépése előtt.

${ }^{240}$ Vö. Kolozsvári Közlöny 1884/184 és 1884/197.

${ }^{241}$ Sturm 1901, 353.
} 
utolsó évtizedeiben magyar anyanyelvűként román irodalmat (költészetet, hírlapirodalmat) fordít. Másrészt, innen továbblépve, példája azt is megmutatja, hogy az értelmiségi életpályák jelentéshordozók a fordítások kontextuális vizsgálatában, hiszen fordítói intenciókat leplezhetnek le. Harmadsorban Sándornál épp az derül ki, hogy nem egyértelműsíthető érdeklődése, hiszen egyszerre több mindennel foglalkozik, több diszciplínában jártas, szakmailag viszonylag későn dönt. A szakmainak nevezhető döntés, a politikai elköteleződés viszont megszünteti a számára ismerős román kultúrával kialakított, nem politikai tettnek minősíthető (esetében irodalmi, fordítói) kapcsolatot.

Visszautalok Domokos Sámuel bibliográfiájára és a román költészet 19. századi tolmácsolóira. Nem lenne veszteséges felgöngyölíteni élet- és karriertörténetüket, látni a közös kapcsolódási pontokat és azt, ahogyan különböző foglalkozású, nem profi múfordító magyar és román írástudók nyelvi kompetenciáikat kamatoztatva a román irodalmat magyarítják. Emellett láthatóvá válnának azok az érdekek, amelyek fordítói foglalatosságaikat motiválják. Egy ilyen jellegü kutatás más szempontból, alulnézetből kínálna magyarázatot a recepciótörténet olyan problematikus kérdéseire, mint például a kultúrák közötti közvetítés lehetősége, az első fordítások múvészi értéke, a korai tájékozódás egy idegen nyelvü irodalomban.

\subsection{Az első fordításkötet. A recepció visszásságai}

\subsubsection{Brán Lőrinc/Laurențiu Bran}

Mást jelent mind a magyar, mind a román recepciótörténet szempontjából a sorban második Eminescu-fordító, Laurențiu Bran. Tovább bonyolítja a történetet az a tény, hogy a román anyanyelvű Bran álnéven közli Eminescu-fordításait. A Szamosújvári (lokális identitást hordozó, magyar nyelvü) álnév mögött megbújó szerző nevét amúgy is magyarosított formájában találjuk meg a 19. századi szövegekben, megtörténhet, hogy a magyar olvasóknak eszükbe sem jutott volna, hogy az álnév mögött román nyelvű fordító rejtőzik. Mindennek kiderítésére viszont nélkülözhetetlen kézbe venni azokat a 19. századi forrásokat, amelyek Bran fordításait vagy életrajzát tartalmazzák. Ez a kutatás pedig az egykorú szövegkörnyezet vizsgálatára irányítja a figyelmet, hiszen például a 20. század második felében Domokos Sámuel következetesen Brán Lőrinc alakban használja a fordító nevét abban a tanulmányában, amelyben Eminescu első magyar 
fordítóiról és méltatóiról közöl új adatokat. ${ }^{242} \mathrm{~A}$ tanulmány címének általánosító megfogalmazása problematikus viszonyba kerül e fordító identitásával. Bran csak annyiban lesz itt magyar fordító, hogy magyar nyelvre fordít. E címben tehát a magyar szó a nyelvre utalhat, de a fordító (mai szempontból román nyelvi-nemzeti) identitására nem. Ha erre az apróságra is figyelünk, akkor történetileg átrendezhetjük a magyar Eminescu-recepció hangsúlyait és fenntartásokkal kezelhetjük Domokos Sámuel feltételezését, miszerint: „igazi nevének elrejtéséhez bizonyára az vezette Bránt, hogy ne derüljön ki, miszerint Eminescu első magyar fordítója román volt" ${ }^{243}$ Meglehet, hogy nem annyira Bran számára probléma a származásra utaló, tehát jelentéses álnév, és ez által (nemzeti, nyelvi) identitása elrejtése, mint inkább Domokos számára, aki román fordítóban azonosítja Eminescu első magyar fordítóját. Megfogalmazása nem egyértelmű, ezért sem vizsgálom tovább, hogy hogyan érthette azt, amit feltételezésként kijelentett.

Az álnévválasztás egyértelmü: az 1866-ban született Bran szamosújvári teológiai hallgatóként ${ }^{24}$ küldi be fordításait. Az álnév funkcionalitása viszont kérdéses. A Szilágy-Somlyó címü lapban ${ }^{245}$ a lefordított Eminescuvers magyar címváltozatával szerepel, zárójelben szerepel az, hogy „Románból", jelezve a versek eredeti nyelvét és fordításvoltukat. A versfordítás után feltüntetik a költő nevét (Eminescu, keresztnév nélkül), majd alatta (az álnevet): Szamosujvári [!]. A versfordítások a társadalmi hetilap Tárcza vagy Csarnok rovatában jelennek meg, mintegy elhatárolva a lap egyéb rovataitól. Korábban és (a Bran-szövegközlések közben) ebben a rovatban Mikszáth, Jókai, Kabos Ede, Irányi Ödön, tehát a magyar irodalom ismert szerzőinek írásai olvashatók.

${ }^{242}$ DOMOKOS 1985, 44-55. Először a Filológiai Közlönyben, majd tanulmánykötetben jelenteti meg a fent említett szöveget. Az 1985-ös változatban is még Brán Lőrincet tartja első fordítónak. Viszont 1962-tól 1985-ig, számos új adattal gazdagodott a magyar Eminescu-irodalom, például Teofil Bugnariu tanulmányával, amely Sándor József 1885-ös fordításáról tudósít. Az a visszás ebben a történetben, hogy Domokos 1985-ös tanulmánykötetében mégis hivatkozik Bugnariura, de nem az Eminescuval foglalkozó, hanem a Bevezetót követő első tanulmányban (A román irodalom magyar nyelven), ahol ő is Sándor József érdemének tartja Eminescu első magyar nyelvü tolmácsolását. Bránt ebben a tanulmányban azért tartja többre Sándor Józsefnél, mert nem csak egy verset fordít, hanem többet, sőt kötetbe is szerkeszti fordításait.

${ }^{243}$ Domokos 1985, 47.

${ }^{244}$ Gulyas 1941, 1198.

${ }^{245}$ Szilágy-Somlyó. Társadalmi hetilap, a Szilágy-Somlyó gazdasági egylet közlönye. Felelős szerkesztő és kiadó Nagy László, társszerkesztők Csák Alajos, Hulimka Sándor. Szerkesztőség, kiadóhivatal: ev.ref. papi háznál. [Az általam átnézett lapszámokban, 1888-1890-ig, 1891-től Bölöni Sándor lesz a lap kiadója és szerkesztője.] 
Bran esetében előnyösebb helyzetben van a kutató, hiszen a fordítások és paratextusaik mellett a Szilágy-Somlyó lapban a szerkesztői üzenetek is forrásértékűek. Azért fontos megvizsgálni ezeket, mert az eddigi szakirodalmi munkák figyelmét elkerülték annak ellenére, hogy szerves részét képezik a fordító lapbeli közreműködésének. A fordító és lapszerkesztő munkatársi kommunikációjának forrásai ezek az üzenetek, és e kapcsolat működésének hogyanját teszik érzékelhetőbbé, miközben fogódzókat kínálnak a fordítói gyakorlat behatóbb vizsgálatához, láttatják azt a szövegkörnyezetet, amely életre hívta és a szerkesztői koncepció felól szabályozta Bran versfordításait. Olyan adatokat tartalmaznak, amelyek segítenek beazonosítani az álnevet használó fordítót, még ha nem is magyarázhatják meg az álnévhasználatot.

Rögtön az első versfordítás (Miért nem jösz) közlésekor ez áll a szerkesztői üzenetek-rovatban: „B.L. A fordításoknak szívesen helyt adunk s a lapot megnyitottuk. Csak arra kérjük, hogy a nevesebb román költőket mutassa be fordításban. Így most is az elsőt gyöngének találtuk, míg a másik szép költeménynek szívesen nyitottunk tért". ${ }^{246} \mathrm{~A}$ fordító nevét dekódolva, nyilvánvaló, hogy csakis Laurențiu Branhoz (Brán Lőrinchez) íródtak ezek a sorok. Mivel korábban, 1888-ban vagy az 1890-es évfolyam korábbi számaiban nem közöl Bran, valószínü, hogy a De ce nu-mi vii c. költemény az első, amit a szerkesztők is közlésre méltónak tartanak. A szerkesztői elvárások szabályozzák itt a fordítót. Nem zárkóznak el a fordítások elől, viszont mércét szabnak a fordítói szabadságnak (nevesebb román költőket fordítson) és kompetenciának (kérdés, hogy a "gyönge" kire utal: a fordításra vagy az eredetire, illetve, hogy a szerkesztőség tagjai mennyiben jártasak a román költészetben, mi alapján ítélkeznek?). A második Eminescu-verssel, a Melancholia címúvel egy lapszámban ${ }^{247}$ ez áll: „Szamosujvárinak. For ever! Nagyon örvend a mester! Emil hol van? Tudassa velem. Cs.". ${ }^{248}$

A személyes kapcsolatháló felgöngyölítésével még inkább látható a válaszoló szerkesztővel való szorosabb kapcsolata, amely túllép a lapbeli közreműködés keretein. A Távol áll tóled ${ }^{249}$ és Elválás ${ }^{250}$ után ismét Szamosújvárinak üzennek: A költeményeket adjuk. A költemény, melyet ama fö-

\footnotetext{
${ }^{246}$ Szerkesztôi üzenetek = Szilágy-Somlyó 1889/3.

${ }^{247}$ Szilágy-Somlyó 1889/4.

${ }^{248}$ Szerkesztôi üzenetek = Szilágy-Somlyó 1889/4. Itt a Cs. Valószínűleg Csák Alajos szerkesztő. Bran Emilre utalhat a szerkesztői üzenet, aki Laurențiu testvére, görög katolikus lelkész, pár évig szamosújvári teológiai tanár, 1891-ben éppen a Szilágy-Somlyó hasábjain (33., 34. szám) vitázik Ardeleanuval a románok kapcsán (1897-ben Bősházán, vö. Petri 1901-1904; majd a 20. század elején Dragomérfalván esperes.)

${ }^{249}$ Szilágy-Somlyó 1889/8.

${ }^{250}$ Szilágy-Somlyó 1889/10.
} 
városi lap közlésre elfogadott nálunk csak alkalom híján nem jelenhetett. Különben - felvettük. Üdvözlet" ${ }^{251}$ Mivel szűkszavú az üzenet, és szabadkozni látszik, nem tudhatni, melyik fővárosi laphoz küldte be Bran fordítását, pedig újabb adalékkal gazdagítaná munkásságát.

Bran fordításait heti-kétheti gyakorisággal jelentetik meg a SzilágySomlyóban, mégis a március 7-én publikált Elválás c. fordítás után egy hónappal szólítják meg őt, hogy majd a rákövetkező lapszámban ismét közöljék fordításait. Az említett március 7-i, 10. lapszám után legközelebb a 23. számban ( $A$ büvös vadász), majd a 41-ben (Jó éjszakát) találunk Eminescu-fordítást. Időközben Matilda Poni ${ }^{252}$ és Anton Naum ${ }^{253}$ egy-egy versét tolmácsolja. Mindhárom tolmácsolt költő (Eminescu, Poni, Naum) a Convorbiri Literare címü lapban jelentette meg verseit. Feltételezhetően, Bran a szamosújvári görög katolikus teológiai intézetben jutott hozzá a román laphoz. Bár válogathatott volna Iosif Vulcan Familia címü lapjából is lefordítandó verseket, Bran Iaşi és Bukarest felé tájékozódik, és szövegválasztásával implicit módon azokat a városokat (intézményeket, lapokat) tekinti a román kultúra legitim centrumainak, amelyek romániaiak. Nem véletlen az sem, hogy éppen június első hetében szakad meg a fordítások közlésének a sora. E hónapban következik be Eminescu halála, ami a költő fiatalsága, egészségi állapota, őrültsége mellett magára vonta az érdeklődést. De Bran „elhallgatását” azzal is magyarázhatjuk, hogy elérkezett a teológiai hallgató vakációjának időszaka, amikor nem foglalkozik irodalommal, vagy nem jut hozzá forrásaihoz.

1889 októberében egyszerre két versfordítást is közöl: Eminescutól Jó éjszakát és Alexandru Vlahuțătól $A$ múltból címmel, majd november végén egy újabb Vlahuțăt: Kegyelem!.... Elmaradnak a szerkesztői üzenetek, a fordítások nem. 1890-ben ismét a kora tavaszi számokban jelentkezik Bran Eminescu-fordításaival: Mikor eszembe jutsz ${ }^{254}$, Idő hullámiból255. Júniustól folytatásokban közli Carmen Sylva Les pensées d'une Reine címü kötetének aforizmáit. 1891-ben a 4. szám szerkesztői üzeneteiben olvashatjuk: „Szamosújvári (Böősháza) kérjük olyan költeményeket kiválogatni, melyeknek tartalma megérdemelje a fordítást és kérjük gondosabban ügyelni a kidolgozásra. A beküldött fordítások helyett jobbakat várunk". ${ }^{256}$ A fordításra

\footnotetext{
${ }^{251}$ Szilágy-Somlyó 1889/15.

${ }^{252}$ Matilda Cugler-Poni, Carol von Cugler építész lánya, értelmiségi családból származott. Azon kevés nők közé tartozik, akik a Convorbiri literare révén sikeres irodalmi karriert építhettek, és közölhették lírai költeményeiket. Vö. NAstasă 2010.

${ }^{253}$ Anton Naum a Junimea legidősebb tagja, költő, egyetemi tanár Iașiban. Vö. NAstASĂ 2010, 214, 312.

${ }^{254}$ Szilágy-Somlyó 1890/9.

${ }^{255}$ Szilágy-Somlyó 1890/11.

${ }^{256}$ Szerkesztói üzenetek = Szilágy-Somlyó 1891/4.
} 
kiválasztott alkotásokat másodízben kifogásolják a szerkesztői üzenetben. A korábbi lelkes sorok helyett ez esetben szigorúbb felszólítással találkozunk, amely szóvá teszi a tartalmi szelekciót mint a fordítást elsődlegesen irányító szempontot, és szűkszavúan a minőséget is bírálja. Eszerint nem az volt fontos a szerkesztőknek, hogy Bran milyen nyelvből, hanem, hogy tartalmilag számukra elfogadhatót fordítson. Ennélfogva, meglehet, hogy nem a magyar/román, hanem a fordításra érdemes/érdemtelen irodalom paradigmájában gondolkodtak lapjuk összeállításakor. Ez a feltételezésem akkor Bran munkásságát mint etnikai/nemzeti értelemben vett közvetítést másodlagosnak tekintené és magára a (fordítás által magyarrá tett) szövegre irányítaná a figyelmet.

1894-ig csupán egyetlen alkalommal találni Eminescu-fordítást a lapban: Nem értesz meg ${ }^{257}$. Ha ezt a verset tematikailag összehasonlítjuk a már megjelent Bran-fordításokkal, akkor valamiféleképp körvonalazhatjuk a szerkesztők elvárásait: a szerelmes témájú, érzelemmel telített verseket részesítik előnyben. Úgy tűnik, nem a versszerző költő felett ítélkeznek. Talán az aforizmák múfajában találtak kivetnivalót, mert annak közlése is félbeszakadt.

Nem elhanyagolható tény az sem, hogy 1890 végétôl Bölöni Sándor ügyvéd veszi át Nagy Lászlótól a lapszerkesztést. Ez a váltás is befolyásolhatta a szerkesztői üzenet hangnemét, elvárásait. Ebben az utolsó üzenetben Bran neve mellett Bősháza szerepel ${ }^{258}$, egy szilágysági település. Tudjuk, hogy Bran is 1890-ben fejezi be teológiai tanulmányait, és mivel ez az ő életében, elfoglaltságaiban is változásokat jelent, meglehet, hogy ez magyarázza közreműködése gyakoriságának csökkenését, majd megszakítását.

Az előbbieket összegezve, megállapítható, hogy Laurențiu Bran teológiai hallgatóként intenzíven érdeklődik a román nyelvű irodalom iránt. Érdeklődése és fordítói munkássága iskolázottsága profilja által is meghatározott, gondoljunk a diákönképzőkörökre, amelyek a diákságot irodalmi szárnypróbálgatásra ösztönzik. ${ }^{259}$ Egy irodalmi szempontból irányadó lapból, a Convorbiri Literareból válogat fordításra érdemes szerzőket és műveket. Eminescu verskötetét is ismeri, hiszen a legutolsó Szilágy-Somlyó-beli fordításai eredeti változatai a Maiorescu-féle kötetben jelentek meg először. Sándor Józsefhez hasonlóan ő is a román költő életében tolmácsolja annak pár versét. Nem egyszeri alkalommal, hanem folyamatosan, éveken keresztül. Ezt a munkásságát, amint azt a szerkesztői üzenetek bizonyítják,

\footnotetext{
${ }^{257}$ Szilágy-Somlyó 1891/17.

${ }^{258}$ Emil nevü testvére éppen Bősházán szolgál görög katolikus lelkészként, talán innen küldhette Bran legutóbbi fordítását. Vö. Petri 1901-1904.

${ }^{259}$ A szamosújvári görög katolikus teológusok 1869-tól kéziratos újságot szerkesztenek, a Steaua mariit, ebben már közreműködik Bran. Vö. GYörfi-DeÁk 2001.
} 
nagyban befolyásolta publikálási közege, a szerkesztők fordítással kapcsolatos elképzelései, Bran fordításait értékelő megjegyzései. A megjelenési közeg Sándor József közléseihez képest Bran esetében nagyobb téttel bír és fokozottabban rányomja bélyegét a fordítói gyakorlatra, ezért is hasznos a kontextualista ${ }^{260}$ megközelítés ebben az esetben.

A magyar névhasználat ellenére, Bran vallása, szocializációja, pályaválasztása megjelöli nemzeti identitását: román nemzetiségű egyházi értelmiségi, aki saját kultúráját tolmácsolja a másik, a megtanult magyar nyelven. Merész lenne azt állítani, hogy egyaránt szocializálódik mindkét kultúrába, vagyis a román anyanyelvi, nemzetiségi kultúrába, illetve a magyar nyelvűbe. Jogosabb azt állítani, hogy diákéveiben magyar nyelvtudását a román költészet tolmácsolásában kamatoztatja.

Magyar vonatkozásban őt is a recepciótörténet fedezte fel. Amíg Sándor József fordításának kortárs magyar vagy román recepciójáról nincsenek forrásaink, Bran esetében az egykorú román sajtó értesül a tolmácsolásokról. 1890-ben a Tribuna tárcarovatában Irodalmi jegyzet ${ }^{261}$ címen mutatványt közölnek Bran fordításaiból. A román lap a Sonet címü Eminescu-verset a Szilágy-Somlyó lapból veszi át. Megkockáztathatjuk azt a kijelentést is, hogy maga Bran informálhatta a nagyszebeni Tribunát, például testvére segítségével. A rovatban a versfordítás mellett a rovat szerkesztőjének véleménye olvasható. ${ }^{262} \mathrm{~A}$ cikk szerint a fordítók feladata a két nép egymáshoz közelítése oly módon, hogy a magyaroknak a román sajátosságként tekintett Alecsandri, Eminescu, Bolintineanu, Slavici, Negruzzi, Gane múveit tolmácsolják. Eszerint az elkülönülő sajátosságok tehetik egyedivé a román nyelvű kultúrát, vagy általánosabban fogalmazva, az idegenség megmutatása a fő feladata a fordítónak. Mindemellett a fordítás épp a nyelvi idegenség felszámolását célozza, hiszen e cikk szerint is azok a románok teljesíthetnek fordítói feladatokat, akik a magyar nyelven írás-

\footnotetext{
${ }^{260}$ Vö. ТАKÁTs 2007.

${ }^{261}$ W+a, Foița Tribunei. Notiță literară = Tribuna 1890/143, 569-570. A román álnévlexikon nem dekódolja ezt a szignót. A Familia 1891/15. száma 173. oldalán viszont ugyanígy szignálja valaki az Impresiuni sociale romane din Selagiu című szöveget. Ha helyszíni tudósításként értékeljük ezt az írást, és ehhez tartalmilag fogódzókat is kapunk, akkor szilágysági szerzőt rejt az álnév, Bran pedig onnan származik, és a környéken dolgozik lelkészként, akárcsak testvére. Egy szilágysági hírességeket tömörítő kötetben, valamint a román etnológusok lexikonában azt olvashatjuk, hogy Emil Bran, a fordítónk testvére a nagyszebeni Tribuna munkatársa. Feltételezhetjük, hogy a Bran-fivérek valamelyikét rejti a szignó. Vö. BaLAs-Bóbis 2004, Datcu 2006, 136.

${ }^{262}$ Bran és a Tribuna lehetséges kapcsolata mellett szól az is, hogy a lap szoros viszonyt épített ki a görög katolikus egyházzal. George Coşbuc felelt a fent említett rovatért, viszont a lap 1889-ben anyagi kilátástalanságban tengődött, minek következtében Coşbuc például Romániába ment Slavici közbenjárásával. Septimiu Albini 1886-tól került a laphoz, és amikor Slavici egy évre börtönbe került 1888-ban, ő helyettesíti. Erről bővebben: Pop 2007.
} 
ban is gyakorlottak ${ }^{263}$. Kérdés mennyire őrizhetik meg sajátosságukat ezek a román művek magyar nyelvre átültetve. Erre próbál némiképp választ adni a cikkíró: azért közöl egy Mihai Eminescu és egy Matilda Poni verset a Szilágy-Somlyó c. lapból, hogy a magyar nyelven olvasó románok érzékelhessék: magyarul is szépek maradnak a versek. Ez az eljárás viszont azt feltételezi, ami jellemző volt a kor erdélyi olvasóközönségére, hogy mind a román, mind a magyar nyelvet ismeri.

A cikk szerzője esztétikai kategóriával írja le azt a folyamatot, amely tulajdonképpen a saját nemzeti narratíva része, amely kulturális cserét hoz létre, és amely túlmutatva a szépérzéken, esztétikumon, irodalmon kívüli szerepet kap, a „népek közötti közeledés” eszközévé válik. Továbbá elismeri a román Bran érdemeit, és kifogásolja, hogy magyar részről elmarad a román kultúra iránti érdeklődés. Valószínúleg, Branhoz hasonlóan ez a lap nem értesült Sándor József fordításáról, vagy Márki Sándor átültetéseiről.

Ha végigtekintünk a Domokos Sámuel bibliográfiája alapján összeállított táblázaton, igazat adhatunk a cikkírónak: a felsorolt, lefordítandó román írók közül Bran fordítja a legtöbbjüket. Vasile Alecsandrit például, Ember György kivételével, román anyanyelvűek tolmácsolják magyar nyelven. Márki Sándor az, aki magyarként próbálkozik a bihari román írók fordításával. ${ }^{264} \mathrm{~A}$ szórványosan, helyi érdekeltségü lapokban megjelenő fordítások nem kerülhetnek szélesebb olvasóközönség elé. A Tribuna a Képes Családi Lapokat ajánlja olyan közegként, amely teret adhat a fordításoknak és emellett eléggé népszerü is.

Hogy Bran miként viszonyul a vele kapcsolatos cikkhez, nem tudni. A Tribunára Erdélyből és Romániából egyaránt előfizetnek. Többen elolvashatták, mint a Kolozsvári Közlönyt vagy a Szilágy-Somlyót. E fordító munkássága kapcsán azt állíthatjuk, hogy magyar Eminescuja, Ponija visszakerülve abba a kontextusba, amely sajátja, ott pozitív megerősítést kap. A román nyelv oldaláról sikertörténetként mutatkozik meg. A két irodalom kapcsolata felől pedig 1910-es, Révai Károllyal ${ }^{265}$ közösen szerkesztett kötete válik értékessé. Értékét az is növeli, hogy a korábban megjelent magyar nyelvű román népköltészeti gyűjtemények után ez az első versfordításkötet.

\footnotetext{
263 "Acei Români cu carte pot satisface care și în ungurește mânuiesc cu înlesnire condeiul." = Tribuna 1890/143., 570 .

${ }^{264}$ MÁrKi 1881.

${ }^{265}$ Révai Károly a 20. század első éveiben jelenteti meg Eminescu-fordításait, 1902-ben a Vasárnapi Újságban az Oh, mamă-t, majd a Delelő c. kötetében többet, 1907-ben. Utána időrendben az 1910-es társszerzős kötet következik. Nem tartozik a tulajdonképpeni korai recepcióhoz, ezért nem térek ki részletesebben fordítói tevékenysége ismertetésére.
} 


\subsubsection{Fordítói gyakorlat és kötetszerkesztési poétikák}

Jelen alfejezet a román költészet magyar fordításait önálló kiadványként felölelő első kötetet vizsgálja. A fentiekben ismertett Bran mellett Révai Károly neve szerepel a kötet címlapján.

Révai Károly erdélyi költő, akit 1905-ös kötete után választ tagja közé, fordítói érdemeit méltánylandó, az Erdélyi Irodalmi Társaság, 1910-ben a Petőfi Társaság, 1912-ben a nagybányai Teleki Társaság..266 (Megjegyzem, hogy a 19. század végén egyre gyakoribb ez a típusú értékelés, miszerint az irodalmi társaságok úgy bővítik tagjaik körét, hogy fordítói érdemeik alapján, fordításköteteik megjelenése alkalmával választják meg őket. Ez a tendenciaként mutatkozó fordítókra figyelés a fordításokat irodalmi teljesítményként, de a különböző nemzetiségek - kulturális - megértésének, megismerésének kulcsaként értékeli. ${ }^{267}$ )

A társszerzős kötet tartalmát fordítások képezik, amelyeket előszó vezet be. ${ }^{268}$

Dr. Grigore Moldován egyetemi tanár 1909. augusztus 9-ével keltezi az Előszót. A magyarok románok iránti érdeklődését elmúltként szemléli Moldován, olyan múltként, amely a román kultúra termékeny alapját jelenti. ${ }^{269}$ Bár versfordítások elé írja bevezető gondolatait Moldován, történeti ívet kerekít, a boldog időket jelentő múlt után a francia szabadságharc eszmeiségének hazai törvényét idézi, amely rossz félreértésekhez vezetett. A félreértésektől terhelt jelen ellenére bizalmát fejezi ki: „eljön még az idő, amelyben hazánk nemzetiségei ismét megértik egymást s egy közös gondolatban egyesülve lelkesen fognak együttmüködni egy közös cél felé: boldogítani a szép Magyarországot". 270 A nemzetiségi törvények működésképtelenségének kérdése egybevág azokkal a felszólalásokkal, amelyeket (román) nemzetiségi képviselők mondanak el a magyarországi országygyülésben például a korábban elemzett színházügy kapcsán. De amint ott is láttuk, Modován a magyar képviselők álláspontjára támaszkodik, amikor a színházalapítás ellen érvel. A jövendőre vonatkozó elképzeléseik teljesen különböznek. Amíg a románok által az országgyưlésben vagy

\footnotetext{
${ }^{266}$ Vö. KIss 1924.

${ }^{267}$ Ez az elv pedig továbbhagyományozódik, elég csak arra a Cultura c., 1924-es kolozsvári négynyelvű lapkezdeményezésre utalni, amelyben Révai Károlyról és Ács Károlyról, a román irodalom magyar tolmácsolóiról értekeznek, és amely lapot nyelvi sokszínűsége révén is az Erdélyben együtt élő népek közeledéséért hoznak létre.

${ }^{268}$ Román költókboól. Fordították Brán Lőrincz szamosszéplaki görög katolikus plébános és Révai Károly, az Erdélyi Irodalmi Társaság tagja és a Teleki Társaság elnöke, Nagybánya, Simon Aurél és T. Misztótfalu, é.n. (A kötet hátlapján: Simon Aurél motorerőre berendezett könyvnyomdája, Misztótfalu, 1910) [BRAN-RÉvaI 1910.]

${ }^{269}$ Elöszó = BRAN-RÉVAI 1910, 3.

${ }^{270}$ I.m. 4.
} 
pl. a nagyszebeni Tribunában is hangsúlyozott föderáció vagy autonómia eszméje a hivatalos álláspont, addig Moldován a szép Magyarországról álmodik. Egy magát román nemzetiségü magyar hazafinak valló egyetemi tanár elképzeléséről van szó. A nemzetiségeket egyenrangúakként látja, kiknek közös célja a boldog haza megteremtése. A Hungarus-tudaton alapuló identitásra vezethető vissza Moldován jövőképe; ezért is tűnhet nosztalgikusnak a felemlegetett múlt.. ${ }^{271}$

A politikában megfáradtnak a (kagylóból gyöngyként felszakadón ${ }^{272}$ ) költészet jelenthet pihenést, ezért fontos a nyelvi közvetítés, amely az emberi tudást közkinccsé teszi - foglalhatjuk össze Moldován gondolatmenetének következő részét. Moldován kevesli a fordítások mennyiségét. Megemlít néhány példát: Goga Madách-fordítását ${ }^{273}$, az Ungaria c. lapot ${ }^{274}$, amely Petőfi, Arany, Vörösmarty és a magyar beszélyirodalom müveiből fordít románra. Magyar fordítóként csupán Révai Károlyt nevezi meg. Moldován vagy nem tud a korábbi magyar fordítókról (Ember György, Márki Sándor, Sándor József, Horváth Albert), vagy eltúlozza a kötet fordítóinak érdemeit. Bran szerepét olyannyira felnagyítja, hogy kizárólag az ő kötetének tekinti e fordításgyüjteményt. Mivel Bran fordít a legtöbbet Eminescuból, Moldován megragadja az alkalmat és e kötetet Mihai Eminescu halálának húszéves évfordulója előtti tisztelgésként értelmezi. Moldován érvelése szerint a fordítás a nemzetiségek egymáshoz közeledésének, közelítésének eszköze. Érdekes, hogy úgy látja, hogy a román művek magyarra fordítása a magyar irodalmat gazdagítja, és nem részletezi, hogy a román irodalom számára jelent-e valamit a fordítás. Csak a kölcsönös megismerés közös célját, óhaját szorgalmazza. Ennélfogva a fordítás itt is túlmutat önmagán: a nyelvi különbségek megszüntetése mint a megismerés lehetősége impliciten a nemzetiségi különbségek kiküszöbölését jelenthetné. Ennek pedig közös ügynek kell lennie - a kölcsönösség jegyében. E kölcsönösség illuzórikus marad, hiszen erősen egyoldalú kapcsolat körvonalazódik Moldován előszavában: a román irodalom magyar recepciója nem oda-vissza működő folyamatként, hanem a román nyelvűség fordítás általi elfedésével a magyar nyelv és kultúra gazdagításaként nyer értelmet. Koncepciója tehát ahhoz a már felvetett szemponthoz kapcsolható, misze-

\footnotetext{
${ }^{271}$ Ennek ad hangot egy másik írásában is, amelyben Eminescu védelmére kel: Moldován 1924.

${ }^{272}$ Moldován metaforikusan fogalmaz a költészet kapcsán. De olyan metaforát használ, amelyet Cs. Gyímesi Éva transzszilvanizmuskritikájában is megtalálunk, és amely a „gyöngy" és „homok” , illetve a "kagyló” metaforájaként az 1990-es évektől vált a kisebbségi helyzetértelmezés toposzává. Vö. Cs. Grímesi 1992.

${ }^{273}$ Egyetemi hallgatóként Octavian Goga 1903-tól folyamatosan közli Madách Az ember tragédiája c. művének fordítását. Kötetben 1934-ben jelenteti meg. Vö. GÁLdi 1943.

${ }^{274} \mathrm{Az}$ Ungaria szerkesztője nem más, mint Grigore Moldován. Tehát, itt önkanonizációs gesztusról is szó lehet.
} 
rint a kulturák közötti kapcsolatok kevésbé homogének, alá-fölérendeltségi viszonyban múködnek, ennélfogva, a kultúrák közötti közvetítések nem öncélúak, hanem ideologikusak, politikával telítettek ${ }^{275}$.

Az Előszó szerint Révai kiváló költő és fordító, és Bran költői lélek, aki megszerzi az elismerés koszorúját. Költők fordítják le a verseket, ezért itt már nem kerül elő a fordítói hűség kérdése, mert magától értetődik. Viszont, amint jeleztem, a fordításnak egyik nyelvi közösségből egy másikba kerülve a megismerést kell szolgálnia. A fordító munkája így nem egyszerü irodalmi feladat, hanem hazafias tett. Az 1910-es összeállítás, a paratextusként szolgáló előszótól eltekintve, irodalmi szempontból is érdekes. Nehezen hozzáférhető munkáról van szó, amelyet legtöbb esetben csak adatként vagy az összehasonlító stilisztikai elemzésekhez szükséges idézetekért használnak a kapcsolattörténeti szakirodalomban. Nem egyetlen költő életművének fordításait tartalmazza, hanem antológiaszerú. A szerkesztők nem jelzik expliciten a szerkesztési elveket, csak következtetni lehet azokra, ha voltak egyáltalán.

Két részből áll a kiadvány: majdnem száz oldalon Bran (30 db), ötvenhárom oldalon pedig Révai $(27 \mathrm{db})$ versfordítását tartalmazza. Kakukktojásként szerepel a kötetben, Bran fordításai közé ékelve két költemény: Mihai Eminescu, Éjjel - Aurel Simon ${ }^{276}$ fordításában, és Folyamba megy (románból A.S. után). A kötetet kiadó nyomdászról van szó, aki költő-fordítóként van jelen az általa nyomtatott kötetben.

Laurențiu Bran Mihai Eminescutól 20 verset közöl, de itt találjuk a Szilágy-Somlyóban megjelent Anton Naum és Matilda Cugler-Poni-versek fordításait is. Ezeket két népdal- és három Octavian Goga-versfordítással egészíti ki. ${ }^{277}$

Branhoz hasonlóan Révai Károly is a korábban lefordított és 1905-ben kötetben megjelentetett George Coşbuc-verseket adja itt ki újra.

${ }^{275}$ Ugyanezt a gondolatot hangsúlyozza az antropológiai fordításelmélet is, amely a fordításokat kulturális stratégiák részeként láttatja. Lásd erről bővebben: N. KOVÁCS 2004.

${ }^{276}$ Simon Aurélt Farkas Jenő románként említi. Vö. FARKAS 2008/8. Simonról annyit tudni, hogy nyomdát működtetett Misztótfalun, ilyen minőségében szerepel például a következő nyilvántartásokban: Hazai nyomdák 1899-ben = Magyar Könyvszemle 1899/1.; Horváth Ignácz, A hazai nyomdák 1901-ben = Magyar Könyvszemle 1902/1-2.; Hazai nyomdák 1907-ben = Magyar Könyvszemle 1908/4.

${ }^{277}$ Nazdravin, Pintye vitéz, illetve A szántóvetookról, Nálunk, A mi házunk. A két népköltészeti fordításhoz Bran jegyzeteket ír, amelyekben forrásaira utal (Cziple Sándor, illetve Bud Tit máramarosi népköltészeti gyűjteményei, valamint Palmer Kálmán, Nagybánya és környéke). A román néprajzi-történeti kutatások Dumitru Pop alapján Emil Brannak tulajdonítják Țiple és Bud gyưjteményeinek magyar fordításait. Nem sikerült elérni Pop vonatkozó tanulmányát, viszont a Révaival közösen szerkesztett kötet egyértelműen adatolja Laurențiu Brant mint e gyűjteményekből fordítót. Természetesen, amint éppen az 1910-es kötet mutatja, nem kizárt annak lehetősége sem, hogy Emil és Laurențiu Bran is lefordítja a gyüjtemény ugyanazon darabjait. 
A fordítók korábbi munkásságát ismerve állíthatjuk, hogy hasonló módon gondolkodtak, amikor e kötet szerkesztésén dolgoztak: a korábbi, szétszórtan publikált fordításaikat gyüjtötték egy könyvbe. Ez a kötetszervező elv esetükben párhuzamosságokhoz vezetett: Eminescu egy-egy versének, Matilda Cugler-Poni dalainak, román népballadának két, általuk külön-külön elkészített fordításváltozatát is felveszik. Ezekkel együtt sem unalmas a kötet: Révai fordításai sikerültebbek, Bran az értelmi tartalmak visszaadására törekszik. Az egybeesésekre az lehet a magyarázat, hogy saját műveikként találják értékesnek azok tolmácsolását, és eltekintenek attól, hogy a költő egy adott versének fordítása már egyszer benne van a kötetben. A fordító a kötetben lappangó elgondolás szerint újrafordíthatja a más által lefordított művet. Így válnak egyediekké a fordításváltozatok, és azután már a fordítók saját szövegeiként működnek. E logika felől nem is annyira a lefordítandó mü fontos, hanem az, hogy ki az adott fordítás szerzője, és milyen a fordítása. Tehát az eredeti alkotásról a fordításra tolódik a hangsúly, és egy másik szinten a befogadó irodalomra, mivel annak (főleg nyelvi) szabályrendszeréhez kell igazodnia.

A Brannal közös román szerzők mellett Révai Károly Alexandru Sterca Şuluțiu (1794-1867) görög katolikus püspök három versét, illetve Petre Dulfu, Legenda privighetorii c. müvét is lefordítja.

Amint látjuk, az akkori román irodalom széles skáláján mozognak a fordítók, a népköltészettől a műköltészetig, különböző műfajú szövegekkel birkóznak meg. Mihai Eminescu versei mindamellett, hogy kétféle változatban is olvashatóak magyarul, kortárs román költők műveinek társaságában jelennek meg tömbben. Mondhatni, saját eredeti kontextusuk, viszonyrendszerük is megváltozik a kötetbeli fordításokkal. Ez egyszerre előny és hátrány. Előny, mert úttörő szerepben látjuk a fordítókat, szinkron metszetét nyújtiák az akkori román nyelvú irodalomnak. Hátrány lehet az, hogy a magyar olvasók számára alig ismert költők szövegeit tartalmazza a kötet. Ugyanakkor megtörténhet, hogy a román költőkről való tudás hiánya nem jelentett gondot az olvasóknak, hiszen különösebb tájékozódás nélkül is megértették a magyar nyelvre fordított szöveget, amely így tartalmilag, műfajilag sokkal többet mondott nekik, mint a feltüntetett szerzői név. Ez a megállapítás Bran fordításainak első megjelenési helyéhez vezet vissza, a Szilágy-Somlyó c. laphoz, ahol a szerkesztők a versek tartalmi szelekcióját követelték Brantól. Talán ez az aspektus fontosabb a befogadási folyamatban, mint az eredeti szövegre visszautaló szerzői név. Ezzel a kijelentéssel pedig ismét elbizonytalanítom azt, amire a modern értelemben vett nemzeti, azaz a román és magyar irodalmak kapcsolatának vizsgálata hagyományosan kíváncsi. Bran esetében tehát már másodszor állapítha- 
tom meg azt, hogy nem a nemzeti az elsődleges kategorizációs szempont fordításai befogadásakor.

Bran és Révai kötete a fordítások másodszori megjelentetésével az olvasói befogadás, valamint az irodalmi, irodalomtörténeti emlékezet szintjén nagyobb eséllyel indul. Révai Károly neve ismerős lehet a magyar olvasóközönségnek, hiszen hetente közöl szépirodalmi írásokat a vidéki és fővárosi lapokban, talán ő jelenthette a húzóerőt e kötet kiadásakor. Bran a román közösségben ismertebb.

Visszatérek a nagyszebeni Tribuna címü laphoz. Megerősíthetem azt a feltételezésemet, miszerint Bran kapcsolatban állt a lappal. A román irodalom idegen irodalmakkal való kapcsolatát feltáró egyik bibliográfiában ${ }^{278}$ Laurențiu Bran neve is szerepel. A Tribunában az angol irodalomtörténész, Taine két tanulmányát, illetve Maupassant egy rajzát fordítja le román nyelvre. ${ }^{279}$ Az 1903-ban megszünt nagyszebeni Tribuna szerkesztői Aradon indítják a Tribuna poporului c. lapot 1896-tól és mentik át a szebeni lap szellemiségét. ${ }^{280} \mathrm{Ez}$ a lap jelenti be, hogy megérkezett szerkesztőségébe a Román költókból c. kötet. ${ }^{281}$

Jelentősebb Révai-recepcióról csak az első világháború után beszélhetünk ${ }^{282}$, bár korábbi fordításkötetéhez Gh. Alexi ír előszót. Emlékeztetek arra, hogy mindkét előszó írója egyetemi tanár. Amennyiben a kötetek nem jutottak el szélesebb közönséghez, ezek az egyetemi tanárok biztosan felhívták hallgatóik figyelmét a kötetekre, és így számolhatunk egy szükebb olvasótáborral.

A fordításkötet másik nagyon fontos sajátossága, hogy látszólag magyar-román „koprodukció": Révai magyar, Bran és Simon román nemzetiségü. Nem ezt szeretném taglalni, hanem úgy gondolom, hogy e kettős nemzetiségű szerzőség egyszerre két irányba mutat: mind a magyar, mind a román nyelvű kultúra irányába, annak ellenére, hogy magyar nyelvüek a kötet szövegei. Nem a magyar irodalomtörténet figyelt fel elsőként a kötetre, hanem a fordítás- és kapcsolattörténeti irodalom: hiszen mind Bran, mind Révai neve kapcsolattörténeti bibliográfiákban, a vonatkozó szakirodalomban kerül elő. Révairól például, abban a négynyelvü Cultura címü, kérészéletü lapban értekezik Kiss Ernő, amelyet 1922-től 1924-ig szerkesztenek Kolozsváron. Merészen azt állíthatjuk, hogy a lefordított

\footnotetext{
${ }^{278}$ LUPU-ȘTEFĂNESCU 1980.

${ }^{279}$ Figurile femeiesci in opurile lui Shakespeare = Tribuna 1890/226., 1063., Hamlet de Shakespeare = Tribuna 1893/96, 381-382., Maupassant, Guy de, In cimitir = Tribuna 1894/242., 966., 1896/244., 1091-1092. Vö. Lupu-ȘTEFĂNesCu 1980.

${ }^{280}$ Bora 2008. (Az aradi Tribunát politikai tartalmú lapként tartják nyilván Magyarországon. Lásd: A hazai időszakos sajtó 1910-ben = Magyar Könyvszemle 1911/4.)

${ }^{281}$ Tribuna poporului, Arad, 1910/27., 8.

${ }^{282}$ KIss 1924.
} 
román költők nem is annyira a más nyelvű irodalomtörténetek számára bírnak jelentéssel, hanem annak a tudományterületként kibontakozó kapcsolattörténetnek a forrásai, amely a hosszú 19. század (1918) után a nemzetiségi/nemzeti irodalmak fogalmi kidolgozásával egy időben jön létre.

\subsection{Fordítók, intenciók és kánon. Zárógondolatok}

Az Eminescu-recepció eddig tárgyalt mozzanatait azzal egészíteném ki, hogy nem lezárt a korai recepciót vizsgáló kérdésfeltevés. Ami 19. századi vonatkozásban még érdekes lehet, az a versfordítások gyakorisága, illetve egy-egy vers fordításváltozata. Bran és Révai fordításai mellett, mások is újrafordítanak az életműből, így Horváth Albert és Szőcs Géza.

Hármas tolmácsolásban olvasható két vers: a Departe sunt de tine és a Somnoroase păsărele. Egyetlen verset fordítanak le háromnál többször - öt alkalommal - a 19. században, s az a De ce nu-mi vii. A Domokos Sámuel bibliográfiája alapján készített táblázat fordítói közül csak Sándor József és Dux Ármin nem teszi ezt. A többszöri fordítás e vers népszerüségét jelzi, de azt is, akár a másik két kedvencnek mondható vers esetében, hogy érzelmi telítettségük, könnyed stílusuk, ritmikájuk is befolyásolhatta a fordítói preferenciákat.

Ezek a fordítói szándékok mutathatják meg azt is, hogy miért azok az első fordítók, akik. Miért éppen Sándor József fordítja Eminescut? Miért nem foglalkozik ezzel programszerüen például a Magyar Tudományos Akadémia, esetleg önállóan Szász Károly, Arany János, Brassai Sámuel, vagy azok a mára kanonizált figurák, akiket fordítókként is számon tart az irodalom. ${ }^{283}$ A 19. századi, ún. hivatalos magyar fordításelméleti gondolkodás, amint korábban láttuk, a világirodalminak nevezett remekmüvek iránt érdeklődik, fordításukat tematizálja, és kevésbé figyel a többnyelvű magyarországi közeg lehetőségeire. Érdemes lenne megvizsgálni a magyar irodalmat román nyelvre fordítók (hasonló) stratégiáit annak ellenére, hogy a 19. század végéről alig találunk román nyelvű fordításelméleti szöveget. Úgy tünik, hogy a magyar irodalomban érzékeltetett, a fordítás mibenlétével kapcsolatos teoretikus kérdésfelvetés nem kap akkora hangsúlyt az egykorú román irodalomban.

A többnyelvűséget mint identitásbeli sokszínűséget fedezik fel és kamatoztatják a nemzetiségi irodalmak fordítói oly módon, hogy a népismertetés szolgálatába állítják fordításaikat. Törekvésük nem illeszkedik abba a fordítói programnak tekinthető gyakorlatba, amely a magyar és világirodalom kapcsolatában megmutatkozik. Fordításaikat a román irodalom megismertetése szolgálatába állítják ők maguk, vagy előszóíróik,

${ }^{283}$ Köszönöm Horváth Andornak, hogy a kérdés ezen aspektusára felhívta a figyelmem. 
vagy a későbbi recepciótörténet. Úttörő vállalkozásaik, mivel irodalmon kívüli célra (is) figyelnek, esetenként nem számolnak fordítói elvekkel, vagy a hüség/hütlenség kérdésével. A recepciótörténet pedig retrospektív értelemben, már a müfordítás bizonyos fokú professzionalizálódása után kéri ezt számon az első fordításokon. Felvetődik az a kérdés, hogy mi van abban az esetben, ha ezek a fordítók nem az akadémiai (Szász, Brassai és mások által elképzelt, az ún. műfordítás/művészi) fordításelmélethez tartják magukat, hanem egy más, ideologikusabb paradigmában mozognak.

A magyar nemzeti irodalom rendszere felől érdekes a fordítás fent említett gyakorlata, hiszen a 19. század második felében az irodalmi rendszeren kívül álló magyar anyanyelvű értelmiségiek fordítanak románból, ők két kultúrában mozognak, de nyelvileg legalábbis (ami a modern nemzeti irodalom definíciós aspektusa) saját kultúrájuk részévé teszik a másik, az idegen kultúrát. Jelen fejezet arra is rávilágított, hogy nem magyar anyanyelvű fordítók is magyarul tolmácsolják a román irodalmat. Ez a jelenség ellentétes azokkal az általánosító megfogalmazásokkal, hogy „Mihai Eminescu első magyar nyelvű fordítói/méltatói" stb. Bár román anyanyelvüeknek neveztem, például Laurențiu Brant vagy Grigore Moldovánt, nemzeti identitásuk pontos meghatározása nem írható le egyetlen fogalommal, írásaik, életművük nem sorolható kizárólag a román vagy a magyar nyelvü irodalomba. Identitásuk egyértelmúsítése a nemzeti kategorizálásnál sokkal bonyolultabb (és talán eldönthetetlen) kérdéseket vet fel. ${ }^{284}$

„A magyar olvasók csak az első világháború után ismerték meg közelebbről Eminescut. A román testvér-irodalommal való találkozásunkban ő volt az első mély irodalmi élményünk. Csak szórványos és nem mindig teljes értékű fordítások után ekkor kezdődött meg a román költő-óriásnak hozzá méltó művészettel véghezvitt tolmácsolása". ${ }^{285}$ Eminescu 20. századi magyar recepciójához még annyit füznék hozzá, hogy 1939-ben, Eminescu halála után 50 évvel, a magyar-román kapcsolatokról értekező Avram P. Todor azt állítja, hogy a költő élete és halála tragikumával, azaz nem szorosan irodalmi eseményekkel hatott leginkább, múvei közül pedig a románcaival. ${ }^{286}$

\footnotetext{
${ }^{284}$ Önálló kutatás tárgyát képezhetné a 19. század második felének, utolsó harmadának értelmiségi rétege, kanonizált irodalmárai nyelvismeretének, fordítói preferenciájának öszszehasonlító vizsgálata. Ehhez kapcsolódóan pedig az idegen nyelvek oktatásban betöltött szerepéről is értekezhetünk. Az angol, francia, német (és a népszerüségét vesztett latin és görög) nyelv mellett csak a kevert népességű régiókban, Magyarország peremterületein, a nem magyar nemzetiségek oktatásában kerül elő a nemzetiségi nyelvek használata, ami 1868 után, az Eötvös- féle törvények után az országgyűlésben számtalan (meddő) vita tárgyát képezi.

${ }^{285}$ KAKAsSY 1962, 78.

${ }^{286}$ Todor 1939, 1153-1233.
} 
A tragikus élet, a románc és a versfordítások képezik tehát a magyar Eminescu-recepció korai szakaszát. A korábbi, költészet iránti érdeklődést kiegészítik a román nyelvű prózai és drámaszövegek fordításai. Fordításelméleti szempontból, amint az első magyarra fordított Eminescu-vers kapcsán jeleztem, változást jelent az is, hogy mondhatni fordításra szakosodott költők, müfordítók tiszte lesz az irodalmi szövegek átültetése. Eltűnik az a fordítói réteg, amely a 19. század végét jellemezte. Gyorsan hozzáteszem: megtörténhet, hogy ha nem következik be az erdélyi, partiumi, bánsági magyar irodalom (most nem térek ki e régiók más nyelvű irodalmaira, bár azok is fontos összetevői voltak a nagy-magyarországi kulturális palettának) kisebbségi, romániai irodalommá válása, akkor a későbbi Eminescu-fordítók szintén peremhelyzetbe kerültek volna, vagy ott is vannak, amennyiben Magyarországról tekintjük őket. A „romániai magyar irodalom" kánonába tartozik például Berde Máriaa ${ }^{287}$, Dsida Jenő, Áprily Lajos, Jékely Zoltán, Szemlér Ferenc, Székely János, Bajor Andor. A kapcsolattörténet iránt érdeklődő fordítók sorában Gáldi Lászlót említhetjük, aki mind gyakorlatban, mind elméleti írásaiban legtöbbet foglalkozott a két irodalom közötti kapcsolattal.

A recepció sajátos korpuszát képezik a különböző Eminescu-évfordulókra kiadott (magyar vagy kétnyelvű) fordításkötetek, emlékező (ideologikus) írások.

Amennyiben a korai fordítások vizsgálatánál elsődleges fontosságúnak tekintettem megjelenési közegüket, úgy itt is megjegyezném, hogy Jékely Zoltán fordításait a Magyar-Román Társaság adta ki a Budapesten megrendezett Román Kultúra Hete alkalmából. ${ }^{288}$ Természetesen nem tekinthetünk el attól, hogy e fordításkötet vagy a kulturális rendezvény miként része az országok között kötött első „,kulturális egyezménynek”, a politikailag létrehozott és ekként intézményesített kapcsolattartásnak. ${ }^{289}$ A művésziként értékelt fordítások hátterében irodalminak nem nevezhető érdekek állnak, amelyek egyben kisajátítják azokat. Mint ahogy Eminescu születésének 100. évfordulóján alkalom adódott az első kétnyelvü kiadás megjelentetésére, amelyhez az a Mihai Beniuc írt előszót, aki a Román Író-

\footnotetext{
${ }^{287}$ Finta Gerő is kötetbe gyưjtve adja ki Eminescu-fordításait. Ezt recenzálja Gáldi László. Gáldi formahű, érzelmileg átélt fordításokat vár, és miután Kibédi Sándor 1934-es fordításkötetét laposnak és nehézkesnek nevezi, alaposan megvizsgálja Finta fordításait. Ezeket azért értékeli, mert a politikán felülemelkedve, a szellemi közeledés megnyilatkozásai. Gáldi úgy fogalmazza meg észrevételeit és kifogásait, hogy recenziója elején kijelenti: Berde Mária „magyar Eminescujára” várnak. Vö. Gáldi 1939. Összefoglalva a megjegyzés kontextusát, megállapítható, hogy az egymáshoz időben viszonylag közel megjelenő fordításköteteket összemérik, vagy egy bizonyos mérce felől minősítik.

${ }^{288}$ JéKely 1947. Lásd Dомокоs 1966, 438.

${ }^{289}$ Lásd a mellékletben: 8.1. Kulturális egyezmény
} 
szövetség elnöke, az RTA tagja volt, és az Ének Gheorghiu-Dej elvtársról című verskötet mellett a Nicolae Ceauşescut dicsőítő költészet jelentős szerzője.

A kapcsolat, a recepció tehát e kötet kulcsfogalma. A végigkövetett fordítások igazolják is ezt. Szórványosan jelentkeztek a magyar vagy román fordítók. Az első, kötetben publikált fordításgyüjteményt is elfedte az idő homálya. A 20. század második felének programszerü, némiképp kényszerített kapcsolattörténete biztosítja Eminescu széles körben való megismertetését a romániai magyar közösséggel. Fontos aspektusa ennek a megismerésnek az anyanyelvü kultúra mellett a többségi román kultúra elsajátítása.

Brassai Sámuel idézett fordításelméleti szövegében kijelenti: „ [a] fordítás olyan legyen, mintha a szerző az egész egyéniségével, képzelődésivel és eszével tiszta magyar és magyarul beszélő családban nevekedve, magyarul írta volna az illető munkát, úgy magyarul, hogy azon semmi idegen íz se érezzék." Ezután, írásmodorához híven, kitérőként, képzelt dialógusban teszi érzékletesebbé mondanivalóját ${ }^{290}$ :

„Ő. Ön ellentmond magának. - Én: mennyiben? - Ő. Egész egyéniségét kívánja egyfelől a szerzőnek, más szavával kivetkezteti nemzetiségiből. Avagy nem lényeges alkotó része-e a nemzetiségnek? [...] Midőn oly tiszta és minden idegen íztől ment magyarsággal akarja beszéltetni a szerzőt, nemcsak őt fosztja meg egyénisége egyik érdekes vonásától, de [Azaz: hanem. Ez a szó a mai irodalmi stílusból, úgy látszik, ki van küszöbölve. Természetesen és nemzetiesen beszélő magyar a de és hanem használatában soha se vét. -Brassai jegyzete] nemzete olvasóját is attól a jogától, hogy az eredeti írót egész mivoltában megismerhesse. - Én: jogot jogért, édes barátom. [...] Ön egészen helyesli a Kisfaludy Társaság hajdankori decisióját, amely szerint Anakreon dalai, vagy nem tudom, melyik más klasszikus író fordítását hibáztatta az okon, hogy a görög íz nem érzik rajta? - Ő. Már azt tökélyesen helyeslem és azt mondom, hogy én a fordításban, ha nincs meg benne a görögös íz, nem ismerek Homéroszra, Euripidészre, vagy Tukidideszre, nem Ciceróra vagy Szalluszciuszra, ha nem látszik át a tőlük fordított darabokon a latinság és így tovább. -Én: Ön persze tud nemcsak latinul hanem görögül is, és ama múveket olvasta több mással együtt eredetiben? - Ő. Tudok és olvasom azokat. - Én: így már értem.

[Korcs-magyarsággal úgy kellett volna mondanom: Akkor már értem. (Dann versteh' ich es) - Brassai jegyzete] De - hogy kedve szerint szóljak önnek, mint aki németül is tud - az én mérvadó véleményem szerint, akik nem tudnak görögül és latinul, azok az olvasók aligha fognák érezni az ön részéről annyira sajnált hiányt. Már pedig ismét mérvadólag, úgy vélem, nem azok számára fordítunk, akik az eredetieket bírják olvasni, vagy hogy? - Ó. Azért, hogy valaki elött nem ismeretes valami jó élvezete nem tartóztatandó el tőle. - En: jogot, jogért, most már erősebb nyomatékkal ismétlem. És bizony kétség-

${ }^{290}$ Mivel hosszasan problematizálja Brassai a kérdést, az illusztratív részekből kivágtam. A cikk bibliográfiai adatait lásd: BRASSAI 1861, 433-438. 
telenebb és erősebb jog az anyai nyelv szeplőtlen és fordítatlan állapotában való élvezése, mint az idegen nyelveknek ily helytelen úton és módon való kóstolgatása."

Visszacsatolva Arany János, Gyulai Pál és értelmezői köre szokásjogi gondolkodására, a Brassaitól idézett rész amellett, hogy e társasgondolkodási mintázathoz csatolja szerzőjét, a fordítás miértjére is válaszol. Brassai szerint elsősorban azért fordítanak, hogy az idegen nyelvet nem ismerők anyanyelvükön férjenek hozzá más nyelvü irodalmi munkákhoz. Radó és kortársai nem gondolják tovább ezt a kérdést, a fordítást egyirányú gyakorlatként láttatva. Maga a fordító, illetve az eredeti munka és a fordítás nyelvének ismerője ítélkezhet a fordítás fölött a fentebb vázolt fordításelméleti szempontok alapján. Csak számára kétirányú a folyamat. Annak a befogadónak, aki nyelvi korlátoltsága miatt képtelen az eredeti nyelvhez hozzáférni, összehasonlítani eredetit és fordítást, semmi szüksége elméleti fogódzókra. A fordításnak pedig el kell fednie az idegenséget, az otthonosság érzetét kell keltenie azon a nyelven, amelybe átkerül az eredeti. (Zárójelben jegyzem meg, hogy Brassai elvárásként fogalmazza meg azt, amit a posztkolonialista fordításelmélet negatívumként mutat meg: az ekvivalencia hiányát, a nyelv hatalmát egy másik, azaz idegen nyelv fölött, a fordítás gyarmatosító politikáját.)

Ha a román irodalom fordítóit ebből a perspektívából nézzük, akkor a román anyanyelvűek fordításaitól is ugyanazt kellene elvárnunk, ami ismét a recepció visszásságait jelzi. A magyarra lefordított verseknek a magyar irodalom részeivé kell válniuk, hiszen magyar nyelven kínálják magukat a magyarul tudó olvasóknak. Ezek az olvasók pedig nyelvi korlátoltságuknál fogva nem kérdeznek majd rá a fordítói hűségre/hűtlenségre, mert nem lesz fogódzójuk az összehasonlításra. Brassai felfogását vizsgálatunk tárgyára lefordítva: a román nyelvü Eminescu-versek úgy lesznek a magyar irodalom részei, hogy a paratextuson kívül semmi nem utal vissza eredetükre. A románul nem tudó 19. századi (kevés) olvasónak, amint láttuk, Mihai Eminescu neve sem mond sokat, annál többet a versek műfaja vagy tematikája.

Marad a nyelvét és kontextusát vesztett szöveg, amelyet egy másik nyelv próbál birtokba venni. Mihai Eminescu kortárs befogadásának nem a legelső, a Sándor József-féle fordítás a legjobb példája. 
A korban legtöbbet fordított vers a De ce nu-mi vii. Mi a titka e vers recepciója sikerének? A vers 1887-es megzenésítése ${ }^{291}$ által a nyelvtől független „nyelven”, a dallam és ritmus segítségével válhatott népszerüvé. Olyan közegben jutott el a magyar és román közösséghez, amely korábban a költészet elválaszthatatlan sajátja volt. A zene nyelve eltörölte a szöveg nyelvének idegenségét és ehhez irodalmi értelemben vett fordításra sem volt szükség. Az Eminescu-vers megzenésített változatának népszerűsége azt a holisztikus szemléletet idézi, amely a 19. század második felében az ismeretelméleti paradigmaváltás ellenére még működött. ${ }^{292}$ De ezt a népszerűséget a zenei nyelv egyetemességének tényeként is értelmezhetjük. A zene és tágabb értelemben a művészetek nemzetfölöttiségének érve több mindent jelez e kötet szempontjából. Részint azt, hogy másképp müködik a zenei művek percepciója, recepciója, amely ezáltal fölül is írja, egyes müfajaiban pedig nélkülözi a szóbeli/írásbeli nyelvi kultúrát. Részint visszakapcsolja szövegem az országgyúlési vitához. A fejezet elején ismertetett - a nemzeti (értsd pesti magyar) színház támogatása kapcsán kibontakozó belügyi - vitában, amikor a nemzetiségi képviselők saját színházaik támogatását követelik, az országgyülés szerint félreértelmezik a napirendi pontot. A belügyminiszteri pontosítás szerint nem a nemzeti színház, hanem a nemzeti dalmúintézet/operaház segélyezésének kérdése a megvitatandó. Ekkor hangzik el több ízben a zene nemzetek/nemzetiségek fölöttiségének érve. Természetesen nem tekinthetünk el attól, hogy egy politikai élú vitában hangzik el ez az érv.

Az Eminescu-recepció felől nézve arra is rákérdezhetünk, hogy mi biztosította a népszerüséget: maga a költemény, vagy a zenei kíséret. Állíthatjuk, hogy a zene, hiszen ezt példázza a többi, ismertebb Eminescu-vers is, amelyek románcként folklorizálódtak az évtizedek során. Kétszeres akkulturációt szenved a román nyelvű költôi mü ${ }^{293}$ : elsősorban nyelvét veszítve kerül át egy másik kultúrába, ahol önazonosnak kellene lennie, másrészt a költészet zeneiségét hangsúlyozandó, dallammal gazdagodik. Ez ismét szétfeszíti az irodalminak nevezett kapcsolatkutatás szokványos kereteit.

Igennel válaszolnék tehát Farkas Jenő a Korunk 2008. augusztusi számában megfogalmazott kérdéseire azzal kapcsolatosan, hogy mit kell tartalmaznia a fordítástörténetnek: kizárólag szépirodalmi műveket, a különféle korokban keletkezett fordítások elemzését, fordítói életművek bemutatását? Vagy a szépirodalmi müvek mellett román nyelvkönyveket,

\footnotetext{
${ }^{291}$ Carol Decker zenésíti meg elsőként a románcot. 1889-től a Somnoroase păsărele, majd a Dorința, Peste vârfuri, La mijloc..., Și dacă címü verseket dolgozzák fel. Vö. Drimba 1994.

${ }^{292}$ A költészet és zene kapcsolatáról a 19. század közepén lásd: SzILÁGyI 2001, TAKáTs 2007, különösen a holisztikus világszemléletről: 203.

${ }^{293}$ A magyar nyelv találóan fejezheti ki a szenved szóval a fordításelmélet szerint erőszakosnak tekintett fordítási, befogadási folyamatot.
} 
szótárakat, tankönyveket, politikai-gazdasági jellegű köteteket, kapcsolattörténeti könyveket és egyéb fordításokat is meg kell említeni? Kutatásaim azt igazolják, hogy a fordítás mint kultúrák közötti közvetítés összetettebb, mint tünik, és valóban, ahhoz, hogy kontextuálisan érteni tudjuk a 19. század utolsó évtizedeit, bővítenünk kell mind elméleti alapfeltevéseinket, mind forrásainkat. 


\section{KULTÚRÁK TALÁLKOZÁSA: ROMÁNOK A KOLOZSVÁRI EGYETEMEN (1872-1918)}

Az első Eminescu-fordítások vizsgálata vetette fel azt a kérdést, hogy miért nem a magyar irodalom kanonikus figurái vállalkoznak a 19. század utolsó harmadában a Magyarországon élő nemzetiségek irodalmának ismertetésére vagy fordítására. Ez a felismerés a magyar kultúrától a román felé tolja el a kutatást olyan értelemben, hogy a kapcsolat másik oldalára is felhívja a figyelmet.

A kulturális kapcsolatok kétoldalúságát szóba hozó, az időbeli keresztmetszetek összjátékára kíváncsi módszertan, az „histoire croisée” felől lehet érvelni e fejezet jogossága mellett. A magyar-román kulturális kapcsolatok 19. század végi sajátosságait nem tárgyalhatjuk csak a magyar recepció alapján. A nyelvhasználat és etnicitás vagy nemzetiség nem egybeeső tényezők ebben az időszakban, ezért is érdemes rugalmasan kezelni mind a magyarként, mind a románként megnevezett irodalmat vagy kultúrát. Éppen a nyelvalapú nemzeti kultúradefiníció kérdésességére irányítja figyelmünket e történeti korszak vizsgálata. A magyarországi román kultúra egyfelől ellenpólusa lehet a magyarországi magyarnak, másfelől, amint az alábbi vizsgálat azt láttatni engedi majd, korántsem egynemú és egyenrangú félként. Ezért is fontos tekintettel lenni a románság kulturális helyzetére, a magyar kultúrához, államhoz, magyarországi létéhez való viszonyára. Ebből a perspektívából valószínúleg több dolog felszínre kerül, mint ha csak egyoldalúan, a magyar befogadástörténet felől látnánk a magyar-román irodalmi, kulturális és nemzeti kapcsolatokat. ${ }^{294} \mathrm{Az}$ alapkérdés maga követeli meg a kapcsolatok kétoldalúságának vizsgálatát, hiszen román fordítók tolmácsolják saját irodalmukat magyar nyelven, és a recepció e szakaszát elsősorban nem a magyar érdeklődés határozza meg.

\footnotetext{
${ }^{294}$ A módszertan elméleti kidolgozásához lásd: WeRnER-ZIMMERMANN 2006.
} 
A magyar kultúrában jártasságra szert tevő román anyanyelvű tolmácsolók kapcsán érdemes látni, hogy az ország többnyelvű régióiból származnak, ez a nyelvi és kulturális közeg jelenti a kulturális kapcsolatot létrehozó érdeklődésük termékeny talaját. Szocializációjuk és életpályájuk vizsgálata magyarázatot adhat nyelvi, nemzetiségi kötődéseikre, kapcsolatteremtő munkásságukra, arra, hogy milyen esetekben mutatkozik előnyként vagy hátrányként a többnyelvưség, többes kulturáltság, milyen érdekek szervezik az egyik vagy a másik kultúra használata melletti döntéseiket.

A családi és mikroközösségi szocializáció, az iskoláztatás és a majdani szakmai/értelmiségi szerep, társadalmi-kulturális identitás kialakulása, működtetése elválaszthatatlan tényezők. A Domokos Sámuel bibliográfiája segítségével összeállított táblázatban a 19. század utolsó harmadának fordítóit, értelmezőit soroltam fel. Az ő szocializációjuk a század közepe tájára tehető és jórészt ismert, visszakereshető. Viszont ha a román kultúra magyar recepcióját távlatilag nézzük, akkor azokkal az értelmiségiekkel kell foglalkoznunk, akiknek szakmai karrierje a 20. században bontakozik ki, ellenben lehetőségük volt, vagy a történelmi helyzet úgy kínálta, hogy az osztrák-magyar birodalom akkor hivatásosodó intézményi struktúrájában szerezzenek diplomát. Ebből a szempontból a románság számára is megfontolandó változást jelentett egy második magyarországi egyetem megindítása. A bécsi egyetemek, főiskolák, a pesti egyetem román tanszéke mellett regionálisan is közelebb került a kolozsvári egyetem a tömbben élő magyarországi román nemzetiségü fiatalokhoz.

Ebben a fejezetben azért foglalkozom a kolozsvári egyetem román hallgatóival és későbbi életpályájuk alakulásával, mert ez a vizsgálat egyetemtörténeti jelentősége mellett választ adhat néhány kérdésre. Ezek a következők: milyen lehetőségek adódtak a kor fiataljainak a továbbtanulásra, milyen intézményes keretek álltak rendelkezésükre, hogyan éltek az oktatási kínálattal, milyen egyetemlátogatási stratégiájuk volt, fontos volt-e számukra a külföldi peregrináció, volt-e annak hozadéka szakmai karrierjük alakulása számára, illetve mindezt hogyan befolyásolta két irányból Magyarország vagy a Monarchia és a modernizálódó Románia intézményrendszere.

A Petőfi Irodalmi Múzeum elektronikus adatbázisai között elérhető a Diplomások Adattára, amely 55792 hallgatóról tartalmaz életrajzi adatokat. ${ }^{295}$ A fejezet kontrollforrásai közé tartozik a medikusok adattára ${ }^{296}$,

\footnotetext{
${ }^{295} \mathrm{http}$ ://regi.pim.hu/Online/adattar/diplomasok.php - utolsó látogatás: 2012 júliusa

${ }^{296}$ KARÁDY - NASTASĂ 2004.
} 
illetve Cornel Sigmirean román elitet vizsgáló kötetének prozopográfiai adatai. ${ }^{297}$

Választásom a bölcsészkar román hallgatóságára esett, több okból is. E kar hallgatói sorából kerültek ki azok, akik a nyelv-és irodalomtudományt szakmájuknak választották. Hivatásuknál fogva is érdekeltek lehettek a régióban, hazájukban fellelhető nemzetiségi kultúrák iránt. Másrészt ezen a karon olyan tanárok - Grigore Silaşi, Grigore Moldován, Meltzl Hugó, Brassai Sámuel - is tanítottak, akiknek szakmai identitása olyan kérdéseket vet föl, amelyek az értelmiségtörténeti kutatást a kapcsolattörténettel, tágabb kontextusban pedig a nyelvi-nemzeti identitással kötik össze. Harmadrészt ez a románként azonosított egyetemi populáció a legkisebb számbelileg, ezért viszonylag egyszerübb kilétüknek a felderítése, életpályájuk alakulásának nyomon követése, majd olyan általánosabb tendenciák kimutatása, mint például értelmiségi-szakmai identitásuk alakulása, a román vagy a magyar nyelvü kultúrában vállalt szerepeik, ezek esetleges változása (például 1918 után, hiszen a 19-20. század fordulóján egyetemet végzett fiatalok szakmai karrierje a 20. században bontakozik ki).

\subsection{A kolozsvári egyetem és bölcsészkara}

Az 1872-től múködő kolozsvári Magyar Királyi Tudományegyetemet, amely később felveszi Ferenc József osztrák császár, magyar király nevét, a Pesti Egyetem mintájára hozták létre. A két egyetem közötti viszony emiatt sajátosan értelmeződik a korban: a hierarchizálás, a versengés, a pesti egyetem elsőbbrendűsége mind befolyásolják a frissen indított kolozsvári intézmény (ön)értékelését. ${ }^{298} \mathrm{Az}$ előbbi kérdésre és a régióra jellemző, sajátos nemzetiségi viszonyokra a kolozsvári román egyetemi diákság szempontjából is kitérek.

\footnotetext{
${ }^{297}$ SigmiREAN 2000.

${ }^{298}$ Már az első rektor, Berde Áron beköszöntő beszédében „,nemes verseny”-ként látja a pesti és kolozsvári egyetem viszonyát. Lásd ACTA 1872. Finály Henrik két év múlva, 1874-ben már kifogásolja a kolozsvári egyetem alsóbbrangúságát, illetve azt, hogy a kolozsvári egyetemi tanárok Pestre kerülésüket előreléptetésként értelmezi Budapest. Az erdélyi értelmiség sértegetéseként értelmezi azt a vádat, hogy Kolozsvár nem megfelelő egyetemi központ, amely egyebek mellett a pesti egyetem rektorának számadó beszédéből származik. Lásd ACTA 1874. Jóval később, 1944-ben Imre Sándor, aki a kolozsvári egyetemen a kezdetektől 1886-ig, nyugdíjazásáig a magyar nyelv és irodalom tanára volt, felidézi a budapesti rektor negatív minősítéseit (a kolozsvári egyetem egy „távol keleten” vígan működő diplomagyár), és kisvárosi egyetemként látja intézményét, mindamellett, hogy jelzi, sokaknak szándékában sem állott beilleszkedni az egyetlen kulturális centrum, Budapest körforgásába. Vö. Imre 1944.
} 
Mátrai Ernő Apáczai-idézetes mottóval látja el „Erdély legalaposabb ismerőjének", Brassai Sámuelnek ajánlott, A kolozsvári egyetem mint culturai szükséglet címü röpiratát. ${ }^{299} \mathrm{Az}$ egyetemalapítás melletti érvek felsorakoztatását, a törvénycikkekkel legitimált szöveget egy megoldandó gyakorlati kérdéssel tarkítja, jelesül: a magyar tannyelv mellett mekkora hatáskör biztosítandó a németnek és románnak. ${ }^{300}$ Az Eötvös-féle 1868-as tanügyi törvény cikkelyeit idézi akkor, amikor a két nemzetiség számára tanszéket képzel el, vagy amikor az egyetem előadási nyelveként a magyarra utal. Ugyanakkor, nem sokkal e kérdése után a következőket írja Mátrai: „[a] felsőbb tanulmányt, kultúrát áhító erdélyi német és román ifjú ma Németország vagy Románia egyetemét kénytelen felkeresni, s tudománya mellett egy nagy adag megvetéssel és gyülölettel a magyar iránt tér meg a hazába". ${ }^{301}$ Amikor azt hangsúlyozza, hogy az új egyetemről nem zárhatók ki a német és román diákok, éppen nemzetiségi identitásaikat társítja nemzetiként látott államokhoz, és ezzel érzékelteti azt, ami számára problematikus. A peregrinusokat a magyarral és a hazával ellenségesekként láttatja. Érvelése felől a kolozsvári egyetem hivatott az ellenséges viszonyulás megszüntetésére, hiszen a lakhelyhez közelebb eső továbbtanulási lehetőség kizárná mind a peregrinációt, mind a más (értsd: nem magyar), a sajátnak tekintett nyelvek, nemzetek befolyását.

A magyar nyelvú egyetemi oktatás alól még a bölcsészkar nyelv és irodalom tanszékei sem képeztek kivételt. Hogy mit tanulhattak, az ismét kérdésesként mutatkozik. Finály Henrik a millenniumi ünnepségre készített felsőoktatás-történetbe írt cikkében a következőképpen fogalmaz: [...] maga a német nyelvészet egy csaknem kimeríthetetlen kútforrása a legkülönbözőbb és legváltozatosabb nyelvészeti tanulmányoknak, amelyek szakirodalma, ha csak könyvészeti ismeretét tekintjük is, csaknem megbírhatatlan nagyságban áll előttünk. De ennek a két [román és német] nyelvnek a mívelése a reájok vonatkozó tudományos kutatás nem lehet feladata egy magyar egyetemnek, annál kevésbé, mivel saját nemzeti akadémiái és egyetemei sokkal illetékesebbek a tér mívelésére. Nálunk csak az eredmények ismertetése lehet a feladat, német és román nyelvbúvárok képzése nem tartozik a mi egyetemeink céljaihoz. ${ }^{302}$ Finály szövegében reálisan vet számot a tizennégy éve múködő egyetem bölcsészkarának helyzetével. Az egyetemszervezés takarékosságát kárhoztatja akkor, amikor az induló kar három doktori címmel rendelkező tanárát megnevezi ${ }^{303}$. Ugyanennek a problémának a következménye a tanárok túlterheltsége a gazdag tan-

\footnotetext{
${ }^{299}$ Mátrai 1871.

${ }^{300}$ I.m. 32.

${ }^{301}$ I.m. 34.

${ }^{302}$ BREZnAY et alii 1896, 362.

${ }^{303}$ Hóman Ottó, Meltzl Hugó, Grigore Silași.
} 
tárgykínálat ellenére. A magyar egyetemen a más nyelvek és irodalmak oktatására szánt lehetőségek kérdését is felveti Finály, és kiemelten azokra a nyelvekre utal, amelyek beszélői a régióból származó magyarországiak (és nem angol, francia, szanszkrit vagy más anyanyelvűek). Sajátos regionális problémaként is megfogalmazódik az állami (magyar) egyetemen a nemzetiségi jelenlét és a nemzetiségi kultúra oktatásának hogyanja. Ez azt a dilemmát is jelzi, hogy a magát magyar állami intézményként megjelenítő kolozsvári egyetem hivatott-e (nem hazai államalkotó nemzetek nyelvét beszélő) nemzetiségi ifjakat saját nemzeti-nyelvi ismereteik tudósi képzésére. A nyelvbúvár, azaz a hivatásos szaktudós vagy a tudományos eredményekről ismereteket szerző, passzívabb szakmai beállítódás közötti feszültség munkál Finály szövegében. Visszafordítva, úgy is értelmezhetjük dilemmáját, hogy legitim-e a magyar egyetem részéről például a romániai vagy németországi oktatási intézmény képzésével szemben egyenrangúként mutatkozni, vagy egyenértékü tanári oklevelet kibocsátani. Erre is választ adhat majd az egyetemi hallgatók életpályájának vizsgálata. Mellesleg a nemzeti egyetem és nemzetiségi oktatás kapcsolata gyakorlatban megoldatlannak tűnik, hiába érvényesek az 1868-as nemzetiségi és népoktatási törvények.

A kolozsvári egyetem indulásakor már rendelkezik román tanszékkel, ebben is különbözik a pesti egyetemtől. Ez utóbbin 1862-től létezik román tanszék, vezetője, Alexandru Roman ${ }^{304}$ több ponton is felbukkan a kötetben. Nyilvánvaló, hogy a román tanszék beindítása több tényező együttállásának következménye. Ilyenek: a felekezeti identitás háttérbe szorulása, az egy hazában élő nemzetiségek nemzeti identitásának öntudatra ébredése, ezáltal például a hungarus-tudat gyengülése, a nyelv közösségreprezentációs funkciójának hangsúlyozása és ennek következményei, tudománytörténeti szempontból pedig a felsőoktatási modellek változása, a diszciplinarizálódás, professzionalizáció.

Ebben a korban az egy tanár, egy tanszék elve működött, ebből a szempontból nem szakosodott a román vagy általában az idegen nyelvek és irodalmak oktatása, például az ekkor differenciálódó magyar nyelv és irodalomhoz vagy a pesti új tanszékekhez (esztétika, klasszika-filológia, összehasonlító altáji nyelvtudomány, indogermán, sémi filológia) képest. A kolozsvári egyetem bölcsészettudományi karán a filozófia és történelem (és magyar történelem meg a történelem segédtudományai) tanszékek mellett a magyar, német, a román nyelv és irodalomtudományi, valamint a klasszika-filológiai tanszékek múködnek. A kar összetétele máris jelzi,

\footnotetext{
${ }^{304}$ Alexandru Roman a román nyelv és irodalom mellett a szláv nyelv és irodalom tanára az 1879/80-as tanévtől, e két nyelv és irodalom oktatása pedig a német, francia, angol és olasz mellett a budapesti egyetem Modern Nyelvek és Irodalmak Tanszékéhez tartozik. Vö. BrezNAY et alii, 1896.
} 
hogy indítása kezdetén a magyarországi/erdélyi kolozsvári egyetem nyelvi szempontból leképezi a régió nyelvi összetételét - természetesen nem ez magyarázza a tanszékek felállítását.

A román tanszék tanára a doktorátussal rendelkező, teológiai végzettségü nyelvész, Grigore Silaşi. ${ }^{305}$ Fontosnak tartom a tanszéket vezető tanárok ismertetését, mert mint a nyelvi és irodalmi tudás birtokosai és továbbadói, intézményszerüen működnek ${ }^{306}$, befolyásolva tágabb értelemben az irodalom alakulását, diákjaik tudáskészletét, nyelv- és irodalomszemléletét.

Grigore Silaşi nyelvész és folklorista, 1877 óta a Román Tudományos Akadémia tagja. ${ }^{307}$ Egyetemi tanári kinevezése hírére Naszódról, ahova maga Silaşi is kötődik bethleniként, ötven aláírásos üdvözlet érkezik, tudósít a kolozsvári sajtó ${ }^{308}$, amint arról is, hogy az egyetemnyitó ünnepi lakomán a polgármester és a kormány képviselője után Silaşi arra emelte poharát, hogy a románok és magyarok a tudomány területén egyesüljenek. Megjegyzendő, hogy a nyelv és irodalom tanszékeket betöltő tanárok anyanyelve egybeesik a tanítandó nyelvvel és irodalommal: a román Silaşi a román, a szász Meltzl Hugó pedig a német nyelv és irodalom tanára, de ezzel egyidőben hangsúlyozandó, hogy az egyetemi oktatás hivatalos nyelve a magyar volt, ami ismét további kérdésekhez vezet.

A Kolozsvári Közlöny november 21-én közli a bölcsészeti kar tanrendjét; ebben már szerepelnek Silaşi órái: román nyelvtan hétfőn, kedden, szerdán, román irodalomtörténet a 18. századig csütörtökön, valamint a román nyelv eredete, története pénteken 8-tól 9-ig. A kollegái órarendje sem zsúfoltabb. Látjuk, hogy egyórás előadásokat tartanak, főként délelőtti órákban. A tanárjelöltekkel pedig délutánonként vagy szombaton külön időpontban foglalkoznak. ${ }^{309}$ Az egyetemi beszámolókban, Actákban nyomon követhető Grigore Silaşi gazdag irodalmi munkássága, évenkénti publikációs listája. Kezdettől tagja a tanárvizsgáló bizottságnak. 1883/4-ben a kar dékánja. Az Aurora bank igazgatója, az ASTRA kolozsvári fiókjának elnöke. Az Erdélyi Múzeum-Egylet bölcselet-, nyelv- és történettudományi osztályának tagja és folyóiratának előfizetője az 1890-es években.

\footnotetext{
305 „,Szül. 1836. jan. 27. Bethlenben (Szolnok-Dobokam.); a gymnasiumot Désen és Kolozsvárt, az egyetemet Bécsben végezte, hol 1865. esperesi ranggal seminariumi igazgató lett." = SZINNYEI 1891-1914.

${ }^{306}$ Lásd errôl bővebben: THImÁr 2001.

${ }^{307}$ 1889-ben Alexandru Roman, a pesti tanszék vezetője levélben kéri Silași adatait, hogy az Akadémia rendes tagjának jelölhesse. Korábban Iosif Vulcant is ő jelölte. Alexandru Roman akadémiai tevékenységéről bővebben: NеAмțu 1979.

${ }^{308}$ Magyar Polgár 1872/270., Kolozsvári Közlöny 1872. nov. 21.

${ }^{309}$ Vö. Kolozsvári Közlöny 1872. nov. 21.
} 
Silaşi nyugdíjazásáig, 1886-ig tanára az egyetemnek. Tudjuk, hogy az egyetemi tanárságnak akkoriban általában a halál vetett véget, nem a nyugdíjazás. ${ }^{310}$ Silaşi nyugdíjazását az egyetemtörténetek különbözőképpen tematizálják: egyszerüen, magyarázatok nélkül közlik, hogy nyugalomba vonult ${ }^{311}$, vagy a magyar diákok és a románok Iulia-egylete közötti konfliktus miatti nyugdíjaztatását említik. ${ }^{312}$ Silaşi ötven év körüli férfi. A vele egy esztendőben nyugdíjazott Brassai Sámuel ekkor a nyolcvanas éveiben jár. A két esetet összehasonlítva, szembeötlő a nagy korkülönbség, tehát egyéb oka lehetett Silaşi nyugdíjba vonulásának. ${ }^{313}$

Mind a dékán, Finály Henrik, mind pedig Gaal György elhallgatják Silaşi nyugdíjazása körülményeit, amelyek, mint kiderül, etnikai konfliktusból erednek. A millenniumi reprezentatív kötetbe írt Finály-szöveg talán a kötet politikája miatt hallgatja el ezt a tényt, Gaal pedig nem tartja fontosnak azért, mert viszonylag kényes politikai kérdést is jelent ez a konfliktus. Márki Sándor már a Szegedre menekült egyetem tanáraként, az első világháború után, Makkai László pedig a második bécsi döntés után ír az egyetemről, mindketten a 20. századi Magyarországon publikálják írásaikat. Ez a helyzet is megengedheti számukra a kérdés politikai élü fölvetését, illetve annak érzékeltetését, hogy az egyetemi ifjúság etnikailag elkülönült, és a fiatalok közötti viszony sem volt felhőtlen.

Silaşi számára komoly dilemmát jelent mind nyugdíjaztatása, mind további szakmai karrierje, amint erről George Barițiuhoz írt levele is tanúskodik. Nem talál magyarázatot nygudíjaztatására: nem érzi vétkesnek magát, úgy jelölték ki számára az 1058 Ft-os nyugdíjat, hogy hivatalos papírjait nem kérték és bécsi tanárságát mellőzték annak kiszámításakor. Az igazságtalanságok miatt a miniszternél keres jogorvoslatot. ${ }^{314}$ Az ASTRA

\footnotetext{
${ }^{310}$ „,úgy a rendes, mint a rendkívüli és segédtanárok élethosszig neveztetnek ki és erkölcsi vétség, hivatali hanyagság vagy közbűntény eseteit kivéve el sem mozdíthatók sem más állomásra vagy kisebb fokú fizetésre nem helyezhetők, sem saját beleegyezésük nélkül (a tanári működésre véglegesen tehetetlenné tevő betegség eseteit vagy öregséget kivéve) nyugalomba nem helyezhető"k". Idézi Mátrai 1871, 68.

${ }^{311}$ BreZnAy et ALII 1896, 368.; GAAL 2001.

${ }^{312}$ MaKKai 1997, 11., Márki 1922, 47.

${ }^{313}$ Silaşi esete nem egyedi. Brassai Sámuel nyugdíjaztatása sem volt zökkenőmentes. A tudós polihisztorsága révén került a matematika és természettudományok tanszékre, és a tanárvizsgáló bizottságban ő az egyetlen, akinek neve mellett nem szerepel oktatott tárgya, specializációja, és akire számíthatnak más karok bizottságai is, mint ahogy erre sok esetben sor került. Például 1892-ben Klein Félix francia irodalomból írt házidolgozatához kell feladatokat kitűznie Brassainak, amint ezt Szamosi János hivatalos levele bizonyítja. Vö. Kézirat a Brassai-hagyatékban, Erdélyi Unitárius Egyház Gyüjtőlevéltára, Kolozsvár. Mégis a nyolcvanas éveit taposó tanár önkényesnek tartotta nyugdíjaztatását.

${ }^{314}$ Într-adevăr eu sum preast. domn acuma pensiunat cu 1058 fl. Pensiunat fără vreo culpădocumentată, fără sentență disciplinară, fără să-mi fi cerut măcar documentele de pensionare, fără să-mi fi computat din cei doi ani de concediu în sensul legei măcar unul, fără să-mi fie
} 
Nagyszebenben indítandó leányiskolájához hívják tanárnak, de ellehetetlenített helyzetben érzi magát, tanácstalan: vállalja-e el a nagyszebeni tanárság kockázatát, újabb kellemetlenségekre adva okot, vagy Kolozsváron folytassa irodalmi munkásságát, ahol a kevés számú értelmiség megérti és értékeli tevékenységét. Nyugdíja szegényes megélhetést biztosítana számára. ${ }^{315}$

A nyugdíjazásának egyik oka tehát az etnikai konfliktus, amelyre később részletesebben kitérek, de amelynek következtében eltérő narratívák születtek Silaşi könyvtára és kéziratai tekintetében. Egy, a Román Tudományos Akadémia naszódi tagjait vizsgáló, román nyelvű tanulmány tartalmazza életrajzi adatait, és a könyvtárában felhalmozott irodalom ellenére keveset publikáló poliglott tudósként mutatja be. Silaşi gyűjteménye és könyvtára kapcsán azt olvashatjuk e tanulmányban, hogy 1889. május 14-én magyar xenofób huligánok törtek be lakására, és életét veszélyeztetve égették össze iratait, azzal az indokkal, hogy a kolozsvári egyetemen nem lehet román nyelvü előadásokat tartani. ${ }^{316}$ A Naszódi Alapítványi Főgimnázium gyưijteményei és könyvtárai leírását is tartalmazó Magyar Minerva címú kiadványban az áll, hogy Dr. Szilasi Gergely, volt egyetemi tanár, egész könyvtárát az intézetnek ajándékozta. Adományával e könyvtárat még Papp László kir. táblai bíró gyarapította. ${ }^{317}$ Ez a forrásunk ellentmond az imént idézett tanulmánynak. A kéziratban maradt Silaşihagyaték, mint szellemi örökség és szimbolikus tőke megsemmisítésének

ştiut şi recunoscut măcar unul din cei vreo 11 ani petrecuți ca prefect de studii şi vicerector în „Kais. Kön. Gr. Kath Central-Seminar” de la S. Barbara cu superiori numiți de-a dreptul de ministerul cultelor din Viena, cu un custor superior în frunte şi în persoana unui consiliar ministerial şi preste tot şi în toate stătător direct sub respectivul minister ca şi oricare alt oficiu şi institut de stat. Contra acestei nedreptăți am remustrat la ministerul Trefort şi în cas de negativ am de cuget să mă duc şi la Majestatea sa deşi nu-mi fac ilusiuni în privința resultatului. Közli Dumitru Suciu, Grigore Silași (1836-1897) = Anuarul Institutului de Istorie «G. Bariț», ClujNapoca, 2006., 292-294. [Eredeti lelőhelye: B.A.R., Mss. rom., nr. 1002, f. 226-229.]

${ }^{315}$ Szintén a Barițnak írt leveléből tudjuk, hogy lánytestvére öt gyermeke neveltetését is támogatta. [La toată întâmplarea însă din pensiunea mea deşi nu prea mare tot pot trăi ca un călugăr şi cam pe subțâre mai vârtos că vreo cinci nepoți de soră pre cari ca pre orfani i-am crescut şi purtat la şcoală sunt acum parte de tot parte aproape sburătăciți]. I.m. 293. Nyugdíjaztatása ellenére sem hagy fel támogatói szerepével, hiszen a kolozsvári egyetem egy medikus hallgatója, Abui Valer adatainál Silași neve szerepel a szülő/gyá -kategóriában. Abui 1886-1891-ig hallgatója az egyetemnek, majd 1893-ban védi meg doktori disszertációját. Abui Valernek végig naszódi ösztöndíja van, 200, majd 300 forint. Ebben mind származása, mind Silași gyámsága befolyásoló tényező lehet. Az utóbbi talán hangsúlyosabb, hiszen Abui nem a Naszódi Alapítványi Főgimnáziumban, hanem a kolozsvári piaristáknál érettségizett 1886-ban! Vö. KarádY-Nastasă 2004, 153.

${ }^{316} \mathrm{VÖ.} \mathrm{SENi-SENI} 2006$.

${ }^{317}$ Magyar Minerva. A magyarországi múzeumok és könyvtárak czímkönyve. Közrebocsátják a Múzeumok és Könyvtárak Országos Tanácsa és Országos Főfelügyelősége. 1903-1904., Athenaeum Irodalmi és Nyomdai Rt., Budapest, 1904. 
gesztusa később is felbukkan majd a kötetben. A Naszód-vidéki (hely)történészek hagyományozzák tovább ezt a narratívát, amire azért van szükségük, mert írásaik a lokalitást, a regionalitást hangsúlyosan legitimáló szövegek. Ilyen típusú törekvéseik a dualizmus idejének Naszód-vidéki értelmiségét mindenképp a kulturális értékek hordozóiként láttatják, és erre szolgál jó ellenpéldaként a kolozsvári botrány, valamint a román egyetemi tanár eltávolítása. ${ }^{318}$ Viszont éppen naszódi vonatkozású ellenpéldával gyengíthető narratívájuk. Amikor - a korábban naszódi ösztöndíjas, pesti egyetemi bölcsészhallgató, 1917/18-ban kolozsvári egyetemi docenst - Nicolae Drăganut 1939-ben a Román Tudományos Akadémia rendes tagnak választja és ez alkalomból a naszódi gimnáziumban ünnepséggel köszöntik őt, levélben fordul egykori iskolájához, üdvözletét és háláját kifejezendő. ${ }^{319}$ Ebben a levelében olvashatjuk azt a szempontunkból releváns adatot, miszerint Drăganu külföldi specializációját gátló anyagi helyzete következményeként azért választotta tudományos kutatásai tárgyául a román filológiát, mert ebben a gimnáziumban rendelkezésére állott mind az intézmény, mind Silaşi gazdag könyvtára. Drăganu a 20. század első évtizedében végzi egyetemi tanulmányait, és ezután bontakozik ki mind egyetemi oktatói, mind szakirodalmi munkássága. Ez a tény is amellett szól, hogy nem semmisülhetett meg teljes egészében a Silaşi-könyvtár vagy kézirathagyaték, de arról is szól, miként használható fel ez a hagyaték léte/ nem léte különböző történetek legitimálására.

Silaşi után az első világháború végéig, a kolozsvári egyetem Budapestre, majd Szegedre meneküléséig Grigore Moldován lesz a román tanszék tanára. Mindamellett, hogy Grigore Moldován egyetemi tanár és diákjai közötti viszony kevésbé dokumentálható, meg kell jegyeznünk, hogy Moldován mind képzettségében, mind nemzeti identitásában eltérő paradigmába íródik.

Egyetlen mozzanat erejéig utalok előre és vissza Silaşi ügyére. 1884 novemberében a Kolozsvári Közlöny a nagyszebeni Tribuna c. lap azon cikkét veszi át, amelyben a Silaşi-ügyet nemzetiként tünteti föl, és eltávolításának okát abban látja, hogy Silaşi román, ilyenként akar élni és meghalni, az egyetemnek pedig magyar kell vagy olyan, mint Moldován Gergely. A román lap hozzáteszi, hogy nem a románok, hanem csak a renegátok fogják elfoglalni a meghirdetett állást. ${ }^{320} \mathrm{~A}$ Tribunaból átvett cikk más értelmezését adja Silaşi fölmentésének, nemzeti szempontú magyarázatát kínálja mind az elbocsátásnak, mind az új egyetemi tanár kiválasztásának. A tanszéket

\footnotetext{
${ }^{318}$ Az eltávolítás alatt több mindent értek: fegyelmi kivizsgálást, miniszteri rendelettel történő nyugdíjaztatást, a Iulia-egylet körüli botrányt, majd a szellemi hagyatéka állítólagos elégetését, ergo: Silași totális szakmai megsemmisítését.

${ }^{319}$ O scrisoare... Közli Scurtu 1940.

${ }^{320}$ Még egyszer dr. Szilassi[!] ügye = Kolozsvári Közlöny 1884/275.
} 
betöltő személy ebből a perspektívából csak renegát lehet, mint ahogy Moldován nemzeti identitásához is ez a jelző tapadt az idők során, és vált problematikus figurájává mind a magyar, mind a román nyelvü kolozsvári egyetemtörténeteknek.

Érdemes összehasonlítani a kolozsvári helyzetet a budapestivel, hiszen ott működött Magyarország első román nyelv és irodalom tanszéke, amelyet Alexandru Roman vezetett 1862-tól haláláig, 1897-ig. Ő ajánlja a Román Tudományos Akadémia tagjává Iosif Vulcant 1879-ben, és rendes taggá Grigore Silaşit, tíz évvel később. ${ }^{321}$ A pesti egyetem román ifjúsága a Petru Maior Olvasótársaság megszervezésével és múködtetésével foglalkozik, hasonló kulturális és nemzeti identitást erősítő célzatossággal, mint a kolozsvári Iulia-egylet. Alexandru Roman is meghatározó személyisége a fiatalok önképzőköri szervezkedésének. A halálával megüresedő tanszékre többen pályáznak ${ }^{322}$, köztük a már Kolozsvárt tanító Grigore Moldován. Végül az elkövetkező tíz évben Ioan Ciocan naszódi gimnáziumi tanár, szabadelvű párti országgyưlési képviselő áll a tanszék élén. Politikai hovatartozása is befolyásolhatta megválasztását. Ami Moldovánt illeti, feltételezhető, hogy budapesti tanárrá választása esetén ismét kényes helyzetbe került volna a kolozsvári egyetem és annak román tanszéke, bár ezzel kapcsolatban hiányoznak a bizonyítékok.

Ladányi Andor egyetemtörténeti írása szerint a századforduló után a tanári kinevezéseket már a személyes kapcsolathálók is befolyásolják, és példaként éppen a román tanszék ügyét említi. 1909-ben is többen pályáznak a tanszékre, van olyan is köztük, aki másodszor próbálkozik. ${ }^{323} \mathrm{~A}$ nyertes pályázó Siegescu József is az utóbbiak közé tartozik, akit Ladányi egyetemi tanárként alkalmatlannak ítél, viszont hozzáteszi, hogy a magyar állameszme híve, a legjobb hazafi, ezek az érdemei juttatják ebbe a pozícióba. Moldován Gergely esetében is hasonló érvek dönthettek. Ez pedig annak bizonyítéka, hogy a politikum miként befolyásolja vagy határozza meg az állam felügyelete alatt álló intézmények, esetünkben a szakmai elitet képező egyetemek tanári rekrutációját. Az állami hatalomgyakorlás ilyen példái segítenek belátni a mögöttes jelentéseit annak, ami első látásra szakmai kérdésnek vagy döntésnek tünik.

\footnotetext{
${ }^{321}$ NeAmȚU 1979, 271-293.

${ }^{322} \mathrm{Az} 1898$ februárjában meghirdetett pályázat résztvevői: Moldován Gergely, Alexics György, egyetemi docens, Iosif Siegescu, budapesti hitoktató, Alexiu Viciu és Silvestru Nistor, balázsfalvi gimnáziumi tanárok, Nicolae Bodiu, zombori gimnáziumi tanár, Vincentiu Nicoara, fiumei gimnáziumi tanár, Ioan Ciocan országgyưlési képviselő, korábban naszódi gimnáziumi tanár, Simion Desseanu, kisinyói jegyző. A Gazeta de Transilvania 1898/31. száma alapján Kese Katalin közli a névsort. KESE 1999.

${ }^{323}$ Asbóth Oszkár, Alexics György (másodszor), Popoviciu József, Siegescu József (másodsZor). Vö. LADÁNYI 1969, 191.
} 


\subsection{Egyetemi hallgatók és adattáraik}

\subsubsection{A prozopográfiai kutatások margójára}

1884-ben a Iulia-egylettel kapcsolatos történések és Silaşi fölmentése évében a kolozsvári egyetem bölcsészkarán 61 diák tanult, amelyből három görög katolikus és egy görögkeleti vallású. Megjegyzendő, hogy sem a felekezet-nemzetiség ekvivalencia, sem annak feltételezése, hogy e négy diák román nyelv és irodalom szakra iratkozott be, nem teljesen helytálló. Az egyetem beiratkozási anyakönyvei csak az 1899/1900-as tanévtől tartalmaznak a szakosodásra utaló bejegyzéseket. Ezeknek a bejegyzéseknek az alapján megállapítható, hogy a román diákok magyar-latin, magyar-német, latin-görög, román-latin-történelem, történelem-földrajz és a felsorolt szakok változatos párosítását választják. ${ }^{324}$ Ráadásul, más karok román diákjai is beiratkoznak a román tanszék előadásaira, amint az a végbizonyítványokból kiderül. A beiratkozási anyakönyvek, a végés távozási bizonyítványok azok a levéltári források, amelyek részlegesen ugyan, de fennmaradtak és dokumentálják az egyetemi diákság adatait, képzésének hogyanját. Ezek a források elsődleges fontosságúak jelen alfejezet számára.

A Petőfi Irodalmi Múzeum honlapjáról elérhető elektronikus adatbázis szerint Kolozsváron 1872 és 1918 között 5752 diák tanul, ebből 2831 a bölcsészkaron. A következő adataikra találunk: név, születési dátum, születési hely, kar, egyetem. A levéltári forrás ezeknél bővebb információkat tartogat, hiszen ott a hallgató származását, szüleit vagy gyámját, azok foglalkozását, a hallgató érettségi bizonyítványának keltét, esetenként ösztöndiját is feljegyezték a felekezetiség, évfolyam és hallgatói státus (rendes, rendkívüli) mellett. A levéltárban őrzött (hiányosan fennmaradt) egyetemi beiratkozási anyakönyvek a hallgatók kiléte szempontjából elsősorban a származásra, mikroszociális környezetre és a felekezeti identitásra kíváncsiak az oktatási folyamatban való részvétel számonkérése mellett. Ezek az anyakönyvek képezik az elektronikus adatbázis forrásait. A román diákság azonosításakor mind a levéltári, mind az elektronikus forrásokat felhasználtam, összevetve, ellenőrizve az adatokat.

Az egyetemtörténeti kutatások paradigmaváltását elemző tanulmányokkal is megalapozó Karády Viktor a kolozsvári medikus hallgatók több szempontú vizsgálatakor a következőképpen összegez: „Elemzéseink egyértelmű s fontos tanulsága csak megerősíteni tudja azt a belátást, hogy a honi értelmiség történelmi kialakulásának legfontosabb meghatározói kö-

${ }^{324}$ Vö. A kolozsvári m.k. Ferenc József Tudományegyetem Bölcsészeti Karának hallgatói. [A kézirat lelőhelye: Román Állami Levéltár, Kolozsvár, Fond 315., reg. 141 és 152.] 
zött nem lehet elhanyagolni - mint ahogy ezt történetírásunk a legutóbbi időkig messzemenően gyakorolta - a vallási és az etnikai eredet vagy háttér tényezőit. Az persze jogos (de másutt tárgyalandó) módszertani aggályokat vethet fel, hogy ezek a tényezők mennyire objektiválhatóak az itt használt empirikus jelzésekkel (a családnév nemzeti jellege mint a nemzetiségi háttér mutatója, vagy az anyakönyvi felekezet - a vallásosságra vonatkozó adatok és az esetleges vallásváltások ismerete nélkül). Az is kérdéses lehet, hogy mennyire 'függetlenek' ezek a statisztikai változók, azaz mennyire határolhatók el a regionális eredet (pl. a 'törzsökösség', a helyi társadalmi beágyazottság és kapcsolatháló), a család gazdasági-társadalmi helyzete (apa foglalkozása, vagyon, nemesi státus), valamint a szintén családilag felhalmozott (vagy hiányolt) müveltségi tőke hatástényezőitől. Mindezekre a kérdésekre további kutatásokban kell keresni a választ". ${ }^{325}$

A több szempontú, statisztikai vizsgálatokat és elemzéseket felölelő, nagy ívű egyetemtörténeti kutatás a nehezebben megragadható felekezeti és etnikai jellemzők fontosságát hangsúlyozza. Jelen vizsgálatomnak nem célja az egyetemi diákság rekrutációjának vagy prozopográfiai adatainak objektiválható, empirikus feldolgozása, annál inkább érdekelnek azok a mikrotörténetek, amelyek a románként azonosított bölcsészkari diákság életpályájával kapcsolatosak, és amelyek rekonstruálása segíthet megérteni e diákság egyetemlátogatási stratégiáit, illetve egyetem utáni értelmiségi szerepvállalásait. Mindezt természetesen annak figyelembevételével teszem, hogy az egyetemre kerülő diákok zöme felekezeti főgimnáziumokban érettségizik, ez pedig mind egyéni, mind közösségi identitásuk meghatározó komponense, és fontosabbnak tűnik, mint a nemzeti hovatartozásuk.

Ha a román egyetemi hallgatóságot próbáljuk feltérképezni, akkor mindenekelőtt azzal kell számolnunk, hogy nincsen egyértelmű forráscsoportunk. Mind a levéltári, mind az annak alapján készült prozopográfiai adatbázisokból hiányzik az etnikai aspektus, ahistorikus is lenne számon kérni ezt a hiányt a forrásokon. Fontos megjegyezni, hogy a 19. század utolsó évtizedéig, az egyetemre való beiratkozáskor ez nem volt szempont, nem szerepelt külön kitöltendő rovatként az anyakönyvekben. Az ELTE Levéltára kiadásában megjelent peregrinációs adattárak ${ }^{326}$ sem tartalmazzák a diákok etnikai hovatartozását, viszont megjegyzik az adattárat bevezető szövegben, hogy a felekezeti hovatartozás a görög katolikus és görögkeleti diákok esetében több mint bizonyosan egybeesik az etnikai hovatartozással, és ezek a hallgatók románokként tarthatók számon.

\footnotetext{
${ }^{325}$ KARÁdy 2008, 95.

${ }^{326}$ Lásd az ELTE Levéltára egyetemjárással, felsőoktatás-történettel foglalkozó sorozatának egyes köteteit. [például itt: http://leveltar.elte.hu/index.php?option=com_content\&task=view \&id=22\&Itemid=54 - utolsó látogatás: 2012 júliusa].
} 
A kolozsvári egyetem bölcsészhallgatóinak 1895-ös névjegyzéke már tartalmazza a honosságra, illetve az etnikumra, nemzetiségre vonatkozó adatokat. Elsődleges fontosságúnak bizonyul a különböző adattárak konfrontálása, hiszen ez a levéltári forrás például olyan görög katolikus hallgatókat is tartalmaz, akik nem románnak, hanem magyarnak jegyzik be magukat, jelesül: az ungvári gimnáziumban érettségizett Sztripszky Hiador, a nagybányai állami főgimnáziumból érkezett Rácz Miklós, a tanárként dolgozó Répay Dániel, a Nagykárolyban érettségiző Orosz György, a csíkszeredai Mihutz György. Hat görögkeleti és hat görög katolikus felekezetü hallgatót találtam, akik minden bizonnyal nem románok. Ezt származásuk, születési helyük bizonyítja: vajdasági, illetve kárpátaljai szerbek, valamint ruszinok. Ez újabb érv amellett, hogy az egyetemi diákságot felekezet alapján nem lehet egyértelmúen azonosítani etnikailag. Az etnikai identitás szempontjából jelentésessé válnak a beiratkozási anyakönyvekben található honossága és nemzetisége rovatok.

Az identitás és felekezetiség különállására újabb példa a tíz német etnikumú római katolikus diák 1895 és 1902 között, vagy az a pár római katolikus diák, aki csehként, illetve horvátként, tótként iratkozik be. Valaki oláhként jegyzi be magát, gesztusa jelzi, hogy a román népcsoport képviselői többféleképpen nevezik meg önmagukat: rumén, román, oláh - öndefiniálásuk tehát változó.

Az 1899/1900-as tanévtől az ösztöndíj és a szak/szakpárosítás rovatokat is rendszeresen kitöltik a beiratkozó hallgatók. Nem elhanyagolandó a Megjegyzések rovat, ahol korábbi tanulmányokat, szakváltást vagy épp egyetemről való kilépéssel kapcsolatos információkat rögzítenek.

Látjuk, hogy a rendelkezésünkre álló források akaratlanul is tagolják a kolozsvári egyetem 1872 és 1918 közötti történetét. A változó beiratkozási szempontok szintén cezúraként szolgálnak ebben a történetben. Továbbá, az egymást váltó román tanszékvezetôk is sajátos szakaszokra osztják az egyetemi oktatást. Nem beszélve azokról a politikatörténeti változásokról, amelyek mindezt árnyalják.

A diákok összeírására, létszámára figyelő mai kutató gyakran csapdába eshet, mert a beiratkozók többsége magyar változatban, magyarosítva, magyar helyesírással írja a nevét még akkor is, ha más nemzetiségü. Tehát a név kevésbé tekinthető jelzésértékünek akkor, amikor a román etnikumhoz tartozó diákokat azonosítjuk. Sigmirean Cornelnél (de az elektronikus adattárban is) többször szerepel egy-egy hallgató - nevének különböző változataival, anélkül, hogy az adattárak összeállítói érzékelnék, hogy például két név mögött egyetlen személy áll: például Dumbrava Vasile/ Dumbráva László vagy Presia János/Prézsa János, Bogdan Nicolaus/Bogdanu Miklós. Esetükben a többi adat egybevág. Viszont változó névhasz- 
nálatuk, az egyetemre való többszöri beiratkozásuk magyarázza a kutatók azon tévedését, hogy névváltozataikat külön adatként kezelik. Ezek az esetek az adatok több, mint $2 \%$-át jelentik. Ha ehhez hozzátesszük azt is, hogy egyéb forrással összevetve nem pontos a hallgatók karok szerinti besorolása, akkor újabb százalékokban számolhatók a hibák, és számbelileg csökken az adattárak által nyilvántartott hallgatók száma. Ez arra a következtetésre juttathat, hogy egyenként kellene ellenőrizni a beiratkozott diákokat egy karon, de az egyetem más karain belül is. Mellesleg, ez azért lenne eredményes, mert, amint a későbbiekben kiderül, több diák több szakon tanul, és a szakváltások szakmai preferenciák, értelmiségi pályák alakulását jelentik. A karok diákságának pontos feltárása az egyetemi képzés, a szakmai identitások, szakmai váltások és egyetem utáni életpálya szempontjából válik jelentőssé.

Az általam összegyüjtött diáknévsort felekezetileg elkülönítettem, miután a levéltári forrással, majd a PIM-féle elektronikus és a Sigmireanféle adatbázissal összevetettem. ${ }^{327}$ Több forrás egybevetése után, az adatokat a következő, a hasonló kutatásokban is fellelhető szempontok szerint csoportosítottam: 1. szülőhely, 2. születési dátum, 3. szülő/gyám, 4. szülő foglalkozása, 5. érettségi helye, 6. ösztöndij, 7. egyetemi évek, 8. abszolutórium, 9. szak, 10. egyéb tanulmányok, 11. rendes/rendívüli hallgató, 12. doktori cím.

\subsubsection{Egyetemlátogatás, egyéni és közösségi preferenciák}

A román egyetemi hallgatók egyetemlátogatással kapcsolatos adataira vizsgálom. Kérdéseim arra vonatkoznak, hogy a kolozsvári egyetemre való beiratkozásukkor vannak-e korábbi egyetemi tapasztalataik, később lesznek-e; a külföldi egyetemjárásnak milyen szerepe van tanulmányaikban; milyen egyetemek, szakok iránt érdeklődnek; milyen támogatásban részesülnek, az ösztöndíjak biztosítják-e a külföldön való tanulást vagy jelent-e megkötést az egyetemi tanulmányok után; miként értelmezhetóek szakváltásaik.

Adattáram 42 görögkeleti és 102 görög katolikus román hallgató adatait tartalmazza. Ez a kolozsvári egyetemen tanuló 5752, ebből a bölcsészkaron tanuló 2831 diák öt százalékát képezi, ezzel illeszkedve a nagy ívü egyetemtörténeti kutatás vonatkozó eredményeihez. Karády Viktor szerint a keleti vallásúak a megkésett polgárosodás, városiasodás és moderni-

\footnotetext{
${ }^{327}$ Lásd a mellékletben: A Kolozsvári Magyar Királyi Ferenc József Tudományegyetem Bölcsészkara román nemzetiségü diákjai.
} 
záció, az iskolai asszimiláció ellenzése miatt lesznek alulreprezentáltak a kolozsvári egyetemen. ${ }^{328}$

A tüzetesebb vizsgálat azt is megmutatja, hogyan módosulhat ez az öt százalék, hiszen számos diák csak rövid ideig, 1-2 félévig tanul a karon (görögkeletiek 34,14\%-a, görög katolikusok 48,54\%-a). Néhány esetben a külföldi tanulmányok miatt szűkül le a Kolozsvárt töltött tanulmányi időszak. A görögkeletiek Bécs, Budapest, Leipzig/Lipcse (romanisztika tanszéke), a görög katolikusok Budapest, Graz, Berlin egyetemeit látogatják. Egy diák Szegeden fejezi be a tanulmányait, viszont absolutoriuma ideje, 1922, azt mutatja, hogy egyazon egyetemről, az első világháború után Budapestre, majd Szegedre menekült kolozsvári intézményről van szó, tehát ő nem sorolható a külföldi egyetemi tanulmányokat végzők közé. Páran tanári képesítés elnyerése érdekében lesznek a BTK diákjai. A román diákok valamivel több, mint tíz százaléka vált szakot/kart vagy egyetemet. Legtöbbjük a budapesti egyetemen folytatja vagy fejezi be tanulmányait a természettudományi vagy a bölcsészkaron. Mindkét felekezet szempontjából találunk egy-egy példát arra, hogy valaki a természettudományi kart elhagyva, bölcsészhallgatóként fejezi be tanulmányait. A görögkeletiek 57,5, a görög katolikusok 37,86\%-a vesz részt teljes egyetemi képzésben a bölcsészkaron.

Ezek után állíthatom, hogy az egyetemre való beiratkozás nem jelent egyetemvégzést, hanem tanulmányok abbahagyását, részképzést, esetleg előző egyetemi végzettség mellé tanári oklevél megszerzését. A szak/ karváltások azt jelzik, hogy a természettudományi kar oktatási kínálata vonzóbb számukra, nagyobb presztízzsel rendelkezik. ${ }^{329}$ Jeleznem kell egy alapvető különbséget a pesti és kolozsvári egyetem között, jelesül azt, hogy az erdélyi egyetemen a matematika és természettudományi kar önálló egysége az egyetemnek, nem tartozik a bölcsészkarhoz. ${ }^{330}$ A porosz egyetemi modellt (Humboldt, Shleiermacher elképzelései) követő kolozsvári intézményre is jellemző az állami, minisztériumi felügyelet, a nemzeti oktatáspolitika, a konnektivitást és kutatási perspektívákat kínáló tansza-

\footnotetext{
${ }^{328}$ Elfogadhatjuk Karády Viktor fenti megállapítását, de látnunk kell a keleti vallásúakhoz képest a másik póluson álló zsidó diákok túlreprezentáltságának kérdését, és az ebből a premisszából következő kutatások, értelmezések buktatóit is, amint arra Gyáni Gábor Karádyval folytatott vitái és írásai felhívták a figyelmet. KARÁDY é.n. és GYáNi 2001.

${ }^{329}$ A természettudományi kar presztízsének növekedését általános tendenciaként említi Karády Viktor is, aki a kolozsvári egyetemi oktatás modernizációs jelzéseként értékeli ezt a budapesti egyetemi helyzethez képest. Erről bővebben: KARÁdy (bölcsészkarok). Ugyanakkor a két kar felekezeti szempontú összehasonlítására lásd: NAGY 2006.

${ }^{330} \mathrm{Ez}$ a strukturális eltérés történeti jellegü. Annak ellenére, hogy a pesti bölcsészkar már 1861-ben szorgalmazza a tudományágak kiterjedtsége miatt a bölcsészeti, fizikai-matematikai, valamint a vegytani-természetrajzi tudományok szétválasztását, sem akkor, sem 1867-ben, sem pedig 1871-ben nem sikerül ezt véghez vinni. Vö. Szentpétery 1935.
} 
badság elve, a tudományos diszciplínák specializációja (kommunikáció új formái, tudományos tevékenységgel/dokumentumokkal igazolt tanári reputáció). Az első világháború előtt a matematika és természettudományok oktatása önálló karokként Németországban csak Tübingenben, Strassburgban, Heidelbergben és Frankfurt am Mainban működött. ${ }^{331}$ A természettudományi és bölcsésztanulmányok eltérő lehetőséget kínáltak a pesti, valamint a kolozsvári egyetemi hallgatóknak. E különbség a már jelzett nehézségekhez vezet: természettudományi karon tanuló kolozsvári román hallgatók Budapesten vagy más külföldi egyetemeken bölcsészhallgatókként szerepelnek.

A természettudományi tanulmányok presztízsének növekedésével egyidőben a bölcsészkar jelentősége csökkenni látszik a román diákok körében, annak ellenére, hogy (az orvosi karon hallgatókat kivéve) a jogi és természettudományi kar hallgatói is felveszik a román nyelv és irodalom tantárgyait. ${ }^{332}$

A levéltári forrásokkal bizonyított érdeklődés a maga rendjén szintén forrásértékű, hiszen egyértelmüsítheti azon hallgatók szakválasztását, akiket a kutatott adatbázisok különbözőképpen sorolnak be. Továbbá, a prozopográfiai kutatások nagy ívüségét törik meg ezek a mikrotörténeti jellegü felismerések, amelyek az általános tendenciák mögötti egyéni opciókra is rávilágítanak. Az egyéni döntések láttatása abból a szempontból fontos, hogy kis léptékű megközelítésben ragadhatjuk meg e diákok kapcsolathálózatát, illetve azokat a jelentéstulajdonításokat, gondolkodási mintázatokat, amelyek e közösséget etnikailag koherenssé szervezik. Ilyen egyéni döntés például az, hogy a román nemzetiségű tanárok (Silaşi, Moldován, illetve Pesten Alexandru Roman) román nyelvet és irodalmat tárgyazó előadásain fakultatívan részt vevő diákok szakmai identitásuktól függetlenül, azon túllépve, az ehhez a nyelvhez, kultúrához, nemzethez való tartozásukat fejezik ki, mint ahogy azt a Iulia-egyletben is teszik. Például Tanco Miklós (görögkeleti, Besztercemonor, Naszódi Főgimnázium) 1890 és 1894 között a természettudományi kar román diákjaként többek közt Szinnyei József $A$ magyar nyelv eredete, fejlödése és szerkezete fóbb vonásai címü előadásait heti két órában és Grigore Moldovánnak a román irodalom újkora történetét tárgyaló előadásait heti három órában hallgatta a bölcsészkaron. Vătăşan Miklós, (görögkeleti, zoltáni, 28 éves, Brassói Ortodox Gimnázium), szintén természettudományi kari hallgató, 1894-ben budapesti „peregrinációja” idején, a bölcsészkaron az állattannal, szövettannal, leíró földrajzzal foglalkozó előadások mellett Bodnár Zsigmond, Beöthy Zsolt

\footnotetext{
${ }^{331}$ RüEGG (ed.) 2004.

332 Végbizonyítványok. [A kézirat lelőhelye: Román Állami Levéltár, Kolozsvár, Fond 315, reg. 46., 59., 80., 90., 100., 105.]
} 
magyar irodalomtörténeti előadásain, valamint Alexandru Roman, Conservatorium a román nyomdákról címü (gyakorlati: conservatorium itt társalgás értelemben) elöadásain vett részt. ${ }^{333}$

A Meltzl Hugó által vezetett német nyelv és irodalom tanszéken nem találjuk ezt az analógiát a diákok nemzetisége és a német szak között, annak ellenére, hogy Meltzl nemzetisége egybeesik az általa oktatott tárgygyal. Természetesen, e nyelv, irodalom és kultúra presztízse a 19. század utolsó harmadában eltér a románétól mind világirodalmi, mind magyar irodalmi szempontból, vagy a magyar és a német kultúra közötti kapcsolat hagyománytörténete, valamint a magyar és román kultúra közös történelmi kontextusa ellenére is kitapintható különbségei felől.

Az egyetemi oktatás hivatalos nyelve a magyar vagy a latin volt, amint erre már utaltam a magyar nyelven írott doktori disszertációkhoz kapcsolódó egyik lábjegyzetben. Forrásaim közül csak a távozási bizonyítványok latin nyelvűek. Ez érthető, hiszen a külföldi egyetemek és az oda beiratkozók számára még a 19. század végén is a latin nyelv jelentette a közös kommunikációs közeget. Az egyetemi oktatás hivatalos magyar nyelve ellenére kohéziós erőt jelenthet a román diákság számára a román nyelv és irodalom tárgyak hallgatása. Nyilván, más hangsúllyal rendelkezne ez a tárgy, ha saját nyelvén mutatkozhatna meg. Nagy Péter Tibor azt állítja, hogy a tananyag egy konkrét elemének, tudniillik a magyar nyelvnek az elsajátítása érdekében [az állam] konfliktusokat vállalt a nemzetiségi egyházakkal, felekezeti csoportokkal. Ez a nem magyar anyanyelvű egyének szempontjából egyfelől súlyos jogsérelem, másfelől viszont az ő egyéni továbbtanulásuk, illetve társadalmi, területi mobilitásuk esélyének növelése. ${ }^{334}$

A kolozsvári bölcsész és természettudományi karok hallgatóinak felekezeti rekrutációját vizsgáló tanulmányában Nagy Péter Tibor egy helyen arra kíváncsi, hogy a magyarországi lexikonelitbe kerülés szempontjából mi a helyzet a különböző felekezetekkel: „A görögkeletiek és görög katolikusok állnak a legrosszabbul: az Erdélyből jöttek gyakorlatilag nincsenek jelen az elitben, Magyarországról is kevesen. Ez részben az elitképző tényezők románokkal szembeni közömbösségével, részben a mobilitás objektív törvényeivel magyarázható - az elitbe kerülést tekinthetjük egy következő mobilitási lépcsőnek, melytől az alacsonyabb iskolázottsági szintről induló görögkeleti illetve görög katolikus románok eleve távolabb álltak". ${ }^{335}$ Azok a lexikonok, amelyek segítségével Nagy meghatározza a „lexikonelit" fogalmát túlnyomó részt a 20. században készültek. A tanulmány több ponton

\footnotetext{
${ }^{333}$ Végbizonyítványok. 1893/4-1898/9 [A kézirat lelőhelye: Román Állami Levéltár, Kolozsvár. Jelzete: Fond 315, reg. 46., 120-122, 384-386.]

${ }^{334}$ NAGY 2005, 3.

${ }^{335}$ NAGY 2006, 25.
} 
is tematizálja, de kevésbé tudatosítja azt a kérdést, hogy a 19. század végén és a 20. században nem tekinthetjük homogénnek Magyarország fogalmát. Érvei végsősoron nem meggyőzőek például a románok esetében. És itt nem csupán az elitképző közömbösségéről, esetleg diszkriminatív voltáról van szó, és még kevésbé arról, hogy a mobilitás és alacsonyabb iskolázottsági szintről való indulás összefügg. Máshol keresendők a görög rítusú románok. A kolozsvári egyetem bölcsészkara végzettjei esetében (mármint a rekonstruálható karriertörténetek felől) állíthatom, hogy a román diákok nem feltétlenül Magyarországon, a magyar állam keretein belül, hanem például a nagy vonzerejü, modernizálódó román királyságban keresnek és találnak megélhetést. Érzékelhető társadalmi és területi mobilitásuk: a magyar képzettségű román fiatalok nem a végzett oktatási rendszer outputjának megfelelóen helyezkednek el, hanem annak ellenében. Amit területi mobilitásként vagy migrációként érzékelhetünk a 19. század végén ${ }^{336}$, az a 20. század elején beiratkozó román bölcsészhallgatók esetében már nem az, hanem a történelmi események következményeként kialakuló, készen kapott kontextus, egy más politikai keret: Románia. Ezért sincsenek jelen az Erdélyből jött románok a magyarországi lexikonelitben.

Szintén ezzel a kérdéssel függ össze az, amiről Nagy Péter Tibor a következőképpen fogalmaz: „[v]an azonban még egy tényező: az iskolázott nemzetiségi tisztviselők egy része a felső társadalmi osztályba kerülve feltehetően »nemzetiséget váltott«. Azaz, erre irányuló presszió nélkül is magyarnak mondta magát. Természetesen - a helytörténeti mélyfúrás lehetőségét leszámítva - lehetetlen annak megítélése, hogy egy személy élete különböző szakaszaiban minek mondta magát". ${ }^{337}$ Bár a népszámlálási deklaráció és az egyetemre való beiratkozás mint identifikációs gesztus különböző módon határozhatja meg a személyek önértelmezéseit, valóban mikrotörténeti léptékü kutatásra van szükség ahhoz, hogy biztos fogódzóink legyenek e kérdésben.

A kolozsvári román bölcsészek rekonstruálható karriertörténetei nem példái a nemzetiségváltásnak, annál inkább a tudatos román etnikai betagozódásnak. Kevesen kerülnek tisztségviselői pozícióba közülük, hiszen a legtöbb végzett tanárként helyezkedik el. Érdemes lenne összevetni a kolozsvári egyetem más karain tanuló román nemzetiségű hallgatók karrierjének alakulástörténetét és az alapján árnyalni az idézett megállapítást.

\footnotetext{
${ }^{336}$ Kevésbé kutatott, de jelentős kivándorlási irányként nevezik meg a társdalomtörténeti munka szerzői azt a migrációt, amely a 19. század utolsó évtizedeiben Erdélyből a Regátba, a két volt román fejedelemség területére vezetett. Az örökös tartományok és az Egyesült Államok képeztek hasonló migrációs célpontot. Lásd erről bővebben: GYÁNI-KövÉr 1998, 60-61.

${ }^{337}$ NAGY 2005, 54.
} 
A szociológiából ismerős társadalmi mobilitás fogalmát tárgyalva, Kövér György a csoportos mellett az egyéni mobilitásra is felhívja a figyelmet. Ennek vizsgálata azt követi, ahogyan az egyén életpályája születésétől fogva belerendeződik a körülötte levő változatlan vagy változó társadalomszerkezetbe. ${ }^{338}$ A szocializációs folyamatok adekvát módszere az életútelemzés. Amikor a továbbiakban életpálya alakulásáról vagy karriertörténetekről beszélek, akkor ehhez a módszertanhoz igazodom. A szocializációban az iskoláztatásnak van kulcsfontosságú szerepe. Az egyetemi beiratkozási adatok a családi háttérből csupán az apa nevére és foglalkozására kérdeznek rá.

A románként azonosítható diákok szociális származását tekintve ${ }^{339}$, (hozzávetőlegesen) megállapítható, hogy 45,15\%-uk értelmiségi-hivatalnok, 30,55\%-uk őstermelö ( $25 \%$ földművelő, 5,5\% birtokos), 4,15\%-uk ipari és kereskedelmi foglalkozású szülő(k) gyermeke. 19,5\% esetében hiányosak az adatok, vagy a vonatkozó rovatban a „halott” szó szerepel, foglalkozás megjelölése nélkül. A hivatalnok-értelmiségi családból származó diákfölény a mintakövetéssel és a társadalmi réteg önrekrutációs kísérleteivel hozható összefüggésbe. Az őstermelők, főként a földmúvesek gyermekei a felfelé építkező pályamobilitás-lehetősége szempontjából érdekesek.

A vallási különbség alapján vizsgálva az adatokat az látszik, hogy kb. 15\%-kal több értelmiségi-hivatalnok származású görögkeleti diák van, mint görög katolikus. Az utóbbiak az őstermelő és az ipar-kereskedelem kategóriában felülreprezentáltak 2-3\%-kal. A görögkeletiek esetében a társadalmi réteg önrekrutációja, a görög katolikusoknál pedig a pályamobilitás az erősebb tendencia. Az általam adataiban rekonstruált részleges és teljes karriertörténetek arra is rávilágítanak, hogyan teremthető összefüggés az egyetem előtti iskolázottság, felsőoktatási képzés és későbbi karrier között.

A kolozsvári egyetem bölcsészkarára beiratkozott román diákok érettségi bizonyítványát kiállító intézmények szintén figyelmet érdemelnek. A hiányos adatok ellenére körvonalazódni látszik az, hogy mind a görögkeleti, mind a görög katolikus egyetemi hallgatók többsége felekezetspecifikus középiskolai oktatásban részesül.

Az alábbi táblázatban azokat az intézményeket foglaltam össze, amelyekben legkevesebb három beiratkozó diák érettségizett. Az intézményeket területileg, Kolozsvártól számított távolságuk alapján soroltam, külön jelezve tulajdonosukat.

\footnotetext{
${ }^{338}$ GYÁNI-KövÉR 1998, 154.

${ }^{339}$ A szülők foglalkozása szerinti kategorizációs szempontokat innen kölcsönöztem: GrÁNI-KövÉr 1998, 159-161.
} 


\begin{tabular}{|l|l|c|c|}
\hline \multicolumn{1}{|c|}{ Település } & \multicolumn{1}{|c|}{ Tulajdonos } & $\begin{array}{c}\text { Görög- } \\
\text { keletiek }\end{array}$ & $\begin{array}{c}\text { Görög } \\
\text { katolikusok }\end{array}$ \\
\hline Kolozsvár & Római katolikus egyház & 2 & 7 \\
\hline Szamosújvár & Állami (1894) & 1 & 5 \\
\hline Balázsfalva & Görög katolikus egyház & 4 & 16 \\
\hline Belényes & Görög katolikus egyház & 1 & 6 \\
\hline Naszódi & Alapítványi & 1 & 26 \\
\hline Gyulafehérvár & Római katolikus egyház & 4 & 1 \\
\hline Nagyszeben & Állami & 3 & 3 \\
\hline Szatmár & Római katolikus egyház & - & - \\
\hline Brassó & $\begin{array}{l}\text { Görögkeleti egyház } \\
\text { (1869) }\end{array}$ & 8 & \\
\hline
\end{tabular}

Egy Veritas álnévvel jegyzett monografikus igényű munka a nagy-magyarországi románok intézményhálózatát mutatja be. ${ }^{340} \mathrm{Ez}$ a kötet megjelenési éve, az állami befolyás expanziójának ellenére is felekezeti differenciáltságot jelez az egyes román tanintézetek között. A román diákok prozopográfiai adatai alapján összeállított táblázat azt jelzi, hogy a nagy román felekezeti gimnáziumokból kikerülő diákok az iskolát fenntartó egyházhoz tartoznak. Mindkét felekezetből kerültek diákok mind a kolozsvári, mind a gyulafehérvári római katolikus iskolához, a görögkeletiek ez utóbbi, a katolikusok a kolozsvári felé tájékozódtak inkább ${ }^{341}$, vagy más települések római katolikus iskolái felé, például Szatmárra. Természetesen az iskolaválasztás vizsgálatakor nem lehet pusztán a felekezeti aspektusra szorítkozni. ${ }^{342}$ Számos más tényező befolyásolhatta a diákok döntését. Az egyik ezek közül, például az ösztöndíj lehetősége, amely biztosította a diákok (lakhelytől távolabb eső) taníttatását. Itt kell megemlítenünk a Naszódi Alapítványi Főgimnáziumot, amely, amint látszik, a görög katolikusok oktatási központja lévén, folyamatosan ítélte oda a naszódi vagyonközösség ösztöndíját román fiataloknak. Itt hangsúlyozandó, hogy minden egyes Naszódon végzett román diák részesül a vagyonközösségi ösztöndíjban! Ez a szilárd anyagi háttér a vizsgált korszakban mindvégig tetten érhető. Folytonossága a román fiatalok felsőoktatási képzettségét biztosítja, mi több, impliciten meghatározza egy szélesebb értelmiségi ré-

\footnotetext{
${ }^{340}$ [VERITAS $] 1908$.

${ }^{341}$ A kolozsvári piarista, római katolikus oktatás és a románság közötti kapcsolathoz lásd: VARGA 2000, GYörgY (szerk.) 1926.

${ }^{342}$ Viszont a század második felében például a porosz oktatási rendszerhez képest Magyarországon az állam expanziója ellenére még mindig uralkodó szerepet játszanak az egyházak az oktatásban. Ehhez a kérdéshez és a magyarországi középiskolai tanárok professzionalizációjához lásd például: KELLER 2007.
} 
teg kialakítását. Ha a beiratkozási sorrendre figyelünk az anyakönyvek olvasásakor, szembeötlik, hogy egymás után sorjáznak a naszódi intézmény végzettjei, hiszen csoportosan érkeznek a kolozsvári egyetemre; többen is a bölcsészkar egy-egy évfolyamára iratkoznak be. Nicolae Drăgan és Virgil Şotropa a naszódi gimnázium jubileumára szerkesztett kötetetében ${ }^{343}$ az intézménytörténet áttekintése mellett diák- és tanárnévsorokat közöl, továbbá nyomon követi ezek szakmai karrierjének alakulását. A társszerzők a naszódi gimnázium volt diákjai, budapesti és kolozsvári bölcsészhallgatók, majdani tanárok. Tipikusan reprezentálják a rendelkezésemre álló adatokból kiolvasható tendenciát: egyetem után számos naszódi végzett felsőfokú tanulmányai után visszatér a gimnáziumba vagy annak vidékére tanárként, hivatalnokként, lelkészként. Mellesleg nem elhanyagolandó azoknak a diákoknak a száma sem, akik fiatalon hunynak el, például 1913-ban, a jubileumi ünnepség idején már nem élnek.

A kibocsátó közeg szívóereje, amint az eddigiekből kiderült, nagyon erős. A szomszédos szülőhelyek, a régió, a több tanulási ciklusban közös iskolázottság, a személyes ismerősség kovácsolta eggyé a generációs kapcsolatokat. Nem tekinthetünk el attól sem, hogy Grigore Silaşi, az egyetem első román tanára is a régióból származik és a diákság erősnek mutatkozó lokális identitása szempontjából ez kitüntetett jelentőséggel bír, ami még inkább fokozza a szolidaritás érzését. Emellett a Silaşihoz köthető, az egyetemen kirobbant botrány elősegíti kultusza kibontakozását és lokális felfuttatását. ${ }^{344}$ Azok a diákok, akik nem lakhelyük felé tájékozódnak, hanem Romániában találnak megélhetésre, azok is tanárként dolgoznak, csupán George Coşbuc és Petre Dulfu folytat irodalmi tevékenységet ${ }^{345}$, illetve páran (nyelv)tankönyvet írnak. Ritka az arra vonatkozó információ, hogy magyar nyelvtudásukat, szocializációjukat saját szakmai pályájukon kamatoztatták volna. Többen közülük képviselők az 1918. december 1-jei román nemzeti gyưlésen, amelynek nemzeti jellegét és egyben az unió kérdését Lucian Boia vizsgálja fölül legújabb kötetében. ${ }^{346}$

A balázsfalvi és brassói gimnázium helyzete szintén hasonlít a naszódiéhoz: alapítványi, majd állami ösztöndíjakat biztosítanak a továbbtanuláshoz. Esetenként ezeknek az intézményeknek sikerül visszavonzaniuk

\footnotetext{
${ }^{343}$ ȘOtropa-DrăGANU 1913.

${ }^{344}$ Lásd: Șotropa-Drăganu 1913 és Studii și Cercetări Etnoculturale, Bistrița.

${ }^{345}$ Petre Dulfu a Kolozsvárt és Szamosújváron szerkesztett Amicu Familiei c. lap legelső számában (1878-tól) már versekkel jelentkezik és folyamatosan közöl a lapban: Euripidész-, Shakeaspeare-fordítását, irodalmi tanulmányát (Argiru și Elena 1879). Vulcan Familiájának költészetrovatában is hűségesen publikál. A Iulia-egylet első jelentését is ő írja, szerkeszti annak lapját, a Diorilet, valamint az egylet irodalmi pályázatát is elnyeri Dimitrie Țichindeal életét és munkásságát tárgyaló tanulmányával. Vö. Micu (red.) 1880. Mindezt már egyetemi hallgatóként.

${ }^{346}$ Bora 2009.
} 
diákjaikat, akik egyetemi tanulmányaik végeztével tanárokként dolgoznak egykori iskolájukban. Érdemes azt is látni, hogy a görögkeleti tulajdonú iskola kikerül a görög katolikus diákok érdeklődési köréből, viszont a görögkeletiek továbbra is látogatják más felekezetek gimnáziumait. A görögkeletiek, mondhatni, felekezetre való tekintet nélkül választanak iskolát, minek következtében megkockáztathatom, hogy sokkal rugalmasabbak görög katolikus társaiknál, akiknek persze szélesebb volt a középiskolai oktatási intézményhálójuk Magyarországon. A görögkeletiek esetében a Gozsdu-ösztöndíjról sem szabad megfeledkeznünk, mint ahogy az ASTRA által adományozott pénzösszegekről sem, amelyek középiskolai és egyetemi tanulmányok végzésében támogatták a román fiatalokat. ${ }^{347}$

Látjuk, hogy az ösztöndíjak nem csupán a diákok egyetemvégzését befolyásolták, hanem majdani életpályájukat is, hiszen a támogató intézmény vagy (román) kultúra felé tájékozódnak. Néhányuk számára a magyar nyelvü doktori értekezésük jelenti az irodalmi tevékenységet, illetve a kötődést a magyar kultúrához.

Természetesen, a kolozsvári egyetem első román diákjai és a 20. században beiratkozók között eltéréseket észlelhetünk. A 20. század végzettjei az első világháború sodrásában másként látják önmagukat, nemzeti közösségüket. Az első beiratkozók az 1840-es, 50-es években születtek, sokkal inhomogénebb közösséget jelentenek, életútjuk nehezebben visszakereshető, mint azoké, akik tömegesen érkeznek, kortársaikkal járnak az egyetemre. Az általam felkutatott diákok közül kilenc görögkeleti és közel harminc görög katolikus bölcsészhallgatót taníthatott Silaşi 14 év alatt, 1872 és 1886 között. Átlagban tehát 2-3 hallgató volt évfolyamonként, többségben a görög katolikusokkal. A román egyetemi hallgatók nagyobb része Grigore Moldovántól tanult. A passzív román intelligencia szemében renegátnak tűnő Moldován diákokra tett hatása nem mérhető ebből a szempontból a Silaşiéval. Ugyanakkor tény, hogy az egyetemi ifjúság szoros kapcsolatban állt mind a kolozsvári, mind a magyarországi román értelmiségi körökkel, amelyek egyetemi tanáraik mellett befolyásolták politikai nézetét, ennek egyik példájaként a Iulia-egyletet említhetjük.

A Naszód-vidéki diákokhoz visszatérve, érdemes összevetni a kolozsvári és budapesti bölcsészhallgatók egyetemvégzési stratégiáit, már amennyire a hiányos adatok lehetővé teszik annak rekonstrukcióját. Ez azért is fontos, mert a budapesti egyetem sajátosságaitól eltekintve, mégis egykorú kontextusa lehet a kolozsvárinak.

\footnotetext{
${ }^{347}$ A Gozsdu-alapítvány történetéről lásd bővebben: Sigmirean-Pavel 2002. Az ASTRA kapcsán lásd lapját, a Transilvaniát, különösen az egyesület 50. jubileumát ünneplő 1911/5. számát.
} 
A 384 budapesti, Sigmirean Cornel által románként azonosított bölcsészhallgató közül több mint tíz Naszód-vidékit találtam. Azért nem írok pontos számot, mert azt, hogy ki Naszód-vidéki, nem minden esetben tartalmazzák Sigmirean adatai. Mégis, tudjuk, hogy többen naszódiak, mint akiknél szerepel ez az adat, mert beazonosításukat az teszi lehetővé, hogy a kolozsvári egyetem bölcsészkarára is beiratkoztak. Itt látom annak eredményességét, hogy az életpályák rekonstruálása mozgásba hozhatja az egymástól elkülönültnek mutatkozó egyetemtörténeti, de ezáltal értelmiségtörténeti primér forrásokat is. Ugyanakkor olyan más naszódiak is szerepelhetnek Sigmireannál, akik adatai hiányosak, nem állnak kapcsolatban a kolozsvári egyetem bölcsészkarával (más karával állhatnak, de azt én nem vizsgáltam), nem találtam rájuk az általam vizsgált Naszód-vidéki elitet feltérképező lexikonokban, ezért nem véletlen, ha kimaradhatnak ebből az összevetésből. A budapesti egyetemen tanuló Naszód-vidékiek csupán felének rekonstruálható többé-kevésbé az életpályája.

Nyolc diákból öten tagjai az Eötvös-kollégiumnak, amely elitképző szerepet tölt be a 20. századtól az egyetemen. Ennek, az intézményen belül is hierarchiába szervezett elitképzésnek egyik hozadéka a románság számára az, hogy 1919 után a Kolozsváron megszervezett román egyetemen Nicolae Drăgan rektor, Valer Seni egyetemi leltáros, tanfelügyelő lesz más vidékről származó, Kolozsvárt vagy Budapesten tanuló román kollegáikkal (Victor Onişor a jogi tanszéken, Vasile Bichigean egyetemi könyvtárosként) együtt. Dumitru Țiganetea nevét matematikai verseny és dési gimnázium viseli napjainkban. Ioan Șerban a magyar földművelésügyi minisztériumban miniszteri tanácsos, Ioan Ciocan naszódi kerületi szabadelvű képviselő lesz a magyar országgyưlésben, majd a budapesti egyetem tanára. Ciocan korábban Virgil Şotropához, Grigore Pletosuhoz, Nicolae Drăganhoz, Valer Senihez hasonlóan egyetemi tanulmányai végeztével naszódi gimnáziumi tanárként múködik. Látjuk tehát, hogy a körvonalazódó életpályák a kibocsátó régióhoz és intézményhez való visszatérést mutatják. A majdani helytörténész és folklorista Al. George Florian is szülőhelyén talál megélhetésre. Mindezek alapján állíthatjuk, hogy a naszódi vagyonközösség ösztöndíjrendszere nagyban hozzájárult a 20. századi román értelmiség képzéséhez, főként a saját intézménye tanári karának utánpótlását biztosította ezzel. Az egyetemet végzett fiatalok értelmiségi pályákra léptek, a hagyományosabb tanári és lelkészi pályán kívül a hivatalnoki réteg tagjai közé is bekerültek néhányan közülük. ${ }^{348} \mathrm{~A}$

\footnotetext{
${ }^{348}$ Bár nem kimondottan a fent vizsgáltakat elemzi, de néhány vonatkozásában a naszódi vagyonközösséget, a román értelmiségi réteget tematizálja főként gazdaságtörténeti szempontból a következő munka: Bíró 2002, különösen: 27-74.
} 
lelkészek kapcsán fontos megjegyezni, hogy sajnálatos módon a kommunizmus áldozataiként többen börtönbüntetésre ítéltettek.

A naszódi példa a görög katolikus diákok stratégiáit érzékelteti, de érdemes megnézni a görögkeletiekét is. A kolozsvári egyetemi hallgatók közül nyolcan érkeztek a Brassói Ortodox Főgimnáziumból. Egyikük kivételével, mindannyian görögkeleti lelkészek gyermekei. A Gozsdu-alapítvány vagy állami ösztöndíjak biztosítják egyetemi tanulmányaikat. Egyetemi éveik után valamennyien Erdélyben, Magyarországon maradnak, öten tanárokként dolgoznak Brassóban és az 1869-ben indított görögkeleti gimnáziumban, Brádon. Ioan Scurtu és Silvestru Moldován a román kultúra ismertebb figurái lesznek, mindketten hírlapíróként munkatársai vagy szerkesztői a nagyszebeni Tribuna címü lapnak. Ioan Scurtut az Eminescuirodalom is számon tartja, hiszen a 20. század első éveiben román és német nyelven írt tanulmányt a költőről. Nem mellékes, hogy Scurtu tanulmányai egy részét Budapesten végzi, például 1896-ban a Petru Maior egylet jegyzőjeként millenniumellenes szöveget ír és terjeszt. ${ }^{349}$ Szempontunkból érdemes arra is figyelni, hogy Scurtu akkoriban diák Budapesten, amikor ott Alexandru Roman a tanszékvezető, és amikor Miron Cristea megvédi Mihai Eminescut tárgyaló doktori értekezését. Ezért nem tekinthetjük véletlenszerűnek a román költő iránti nagyfokú érdeklődését. Ezen kívül Miron Cristeával a román ifjúsági mozgalom köti össze Scurtut. Eugenia Glodariu a román ifjak egyleti működése áttekintésekor a monarchiabeli mozgalmakra is kitér. Könyvének ez a fejezete tartalmazza azt az információt, miszerint az egyetemi hallgatók kongresszusain Miron Cristea és Ioan Scurtu, valamint Dan Pompilius ${ }^{350}$ képviselik a magyarországi román diákokat. A politikai jellegű rendezvényeken felszólaló magyarországi román diákok szabadságérzetüknek adnak hangot, miközben megerősítik romániai kapcsolataikat. Az egyetemi hallgatók nemzetközi szövetségének párizsi kongresszusán 1900-ban Scurtu az egyetlen monarchiabeli képviselő, míg Romániából hatan vesznek részt. A románokat külön alosztályba tömörítő, 1890-es évektől müködő szövetség 1905-ig aktív. Scurtu lipcsei doktoranduszként utazik ki Párizsba. A történet folytatásaként azt is meg kell említeni, hogy a Wekerle-kormány kultuszminisztere, Apponyi Albert 1908-tól megtiltja a magyarországi román fiatalok részvételét a diákkongresszusokon.

Látjuk, hogy Scurtu, de más román hallgatók is folytatják a Kolozsvárt megszokott egyleti tagsági életet, bekapcsolódnak egyetemi tanulmányaik aktuális helyszínének román közösségeibe. Ennek az aktivitásnak egyik

\footnotetext{
${ }^{349}$ Lásd: GLODARIu 1998, 282.

${ }^{350}$ Kolozsvári egyetemi hallgató, a Liga Culturală tagja, majd tanár és tanfelügyelő a 20. század húszas éveiben.
} 
meghatározó tényezője a közösségi érzést is erősítő egyetem előtti tapasztalat: a középiskolai, gimnáziumi román önképzőköri tagság. A fiatalok egyetemekre kerülve természetszerűen keresik tehát az ifjúsági önszervezkedés formáit, ők lesznek ezek mozgatórugói. Megemlítendő, hogy a nyolc Brassóban végzett kolozsvári román diákból páran tagjai a betiltott Iulia-egylet örököseként tekintett Agenturának, az ASTRA kolozsvári ifjúsági szervezetének. ${ }^{351}$ 1913/14-ben közremüködnek a Noi c. diáklap szerkesztésében. Valószínű, hogy ez a szervezeti élet ösztönzi őket egyetemet végzettekként például az ASTRA-ban vállalt szerepeikre. Megállapítható, hogy a középiskolai egyleti tevékenységek, a megélhetést, továbbtanulást biztosító magyarországi ösztöndíjak közösséggé kovácsolják mind a görögkeleti, mind a görög katolikus diákokat. ${ }^{352}$ A magyarországi képzés és a külföldi román szervezetekkel való érintkezés ellenére sem hagyják el Magyarországot, hanem az ott terjeszkedő és megerősödő román (előbb felekezetspecifikus, majd állami tulajdonú) középiskolai oktatásban helyezkednek el főként (lelkész)tanárokként.

\subsubsection{Női hallgatók a bölcsészkaron - nemi identitás és „rendkívüli"-ség}

Az egyetemet végzett román nők szakmai pályájának alakulása is figyelmet érdemel, bár csak négy görögkeleti és három görög katolikus lány ${ }^{353}$ iratkozik be a kolozsvári egyetemre 1905-től kezdődően. A gyulafehérvári és kolozsvári római katolikus és református, illetve a besztercei evangélikus gimnáziumban végzik középiskolai tanulmányaikat. Ketten ösztöndíjasok közülük.

Keller Irén történelem-földrajz szakos rendes hallgató, vajdahunyadi szállodatulajdonos lánya, és a budapesti lánygimnáziumban érettségizett. A bácskeresztúri Polivka Margitot Sigmirean Cornel ${ }^{354}$ románként tartja számon görög katolikus felekezete alapján, mindamellett, hogy mind nála, mind a görögkeleti Keller Irénnél zárójelben odateszi, hogy „(lb. maghi-

\footnotetext{
${ }^{351}$ Vö. GLODARIU 1998.

${ }^{352}$ A kötet eddig nem hozta szóba a román fejedelemségekből érkező anyagi támogatást. Példának okért az 1867-ben alakult, bukaresti székhelyű Societatea Transilvania pentru Ajutoriulu Studentiloru Romani din Transilvania si partile ei egyesület felsőfokú tanulmányok végzését támogatja, az ösztöndíjasoktól pedig egyetemvégzés után a románság érdekeinek szolgálatát várja el cserébe. Az egyesület továbbá azt is elöírhatja, hogy a leendő ösztöndíjasok milyen egyetem mely szakjain tanulhatnak, illetve majd igazolniuk is kell tanulmányaikat. A pályázásban az erdélyi irodalmi egyesületek közvetítenek. Lásd erről bővebben: Actele Societatii Transilvania pentru Ajutoriulu Studentiloru Romani din Transilvania si partile ei, Bucuresci, Imprimeria Statului, 1867.

${ }^{353}$ Eleonora Bran Leményi, Görög Elvira Rozália, Keller Irén, Leontina Nemes, valamint Silvia Stețiu, Polivka Margit, Cornelia Rebreanu.

${ }^{354}$ Vö. Sigmirean 2000, 588.
} 
ară)". Viszont mind a báró Rudits József-féle ösztöndíja, mind származása, mind a beiratkozási anyakönybe írt magyar nemzetisége ${ }^{355}$ arra utalnak, hogy Polivka görög katolikus magyar. Akárcsak Keller Irén. Ismét azzal a visszás helyzettel találkoztunk, ahol az alaposabb, egyénekre lebontott életrajzkutatások átírják a prozopográfiai adatbázisokat a felekezeti és nemzetiségi identitások inhomogenitásának szempontjából. A három rendes egyetemi hallgatóból kettő éppen a fent említett ösztöndíjas Keller és Polivka. Leontina Nemes, a harmadik rendes hallgató négyéves tanulmányi ideje alatt pedagógiai képzést támogató ösztöndíjban részesül ${ }^{356}$, bár magyar-latin-francia szakokra iratkozik ${ }^{357}$. A többi lány rendkívüli hallgatóként végzi az egyetemet.

Eleonora Bran-Leményi az egyetlen közülük, akinek rekonstruálható életpályája. A genfi és kolozsvári egyetemen végzi tanulmányait. ${ }^{358}$ 1908-ban már az Astra évkönyve közli német nyelvü írását Goethe Faustjáról. 1909-ben irodalomtörténeti tanulmányt ír Maria Cunțan költőnő Schiller-drámakiadása elé. ${ }^{359}$ Doktori címmel rendelkezik, és ő lesz az ASTRA nagyszebeni lányiskolájának tanára. ${ }^{360} 1918$. december 1-jén a nagy román nemzetgyűlés egyedüli nőtagja, ekkor már férjezett: Eleonora LeményiRozvan. ${ }^{361}$ A 20. századi román források csupán erre a szerepvállalására utalnak. Megjegyzendő, hogy a beiratkozó nők közül többnek halott az apja beiratkozáskor, vagy szerény jövedelemmel rendelkezik, pl. kisbirtokos. Hozzájuk képest Eleonora Leményi-Bran apja ügyvéd, alapítványtevő (szegény lányok taníttatását segélyezi), lánya támogatója. Férje is ügyvéd, de eddig nem sikerült pontosan beazonosítanom. A nők felsőfokú oktatásának lehetősége a 19. század végén bár rendkívüli hallgatókként, de román lányok képzését is jelenti. A rendkívüli hallgatói státusz a női nemi identitásra vonatkozik ezekben az esetekben.

${ }^{355}$ Törzskönyv. 1902-1919. [A kézirat lelőhelye: Román Állami Levéltár, Kolozsvár. Jelzete: Fond 315, reg. 152.]

${ }^{356}$ SigmiReAn 2000, 588.

${ }^{357}$ Törzskönyv. 1902-1919. [A kézirat lelőhelye: Román Állami Levéltár, Kolozsvár. Jelzete: Fond 315, reg. 152.]

${ }^{358}$ Szögi László a francia kultúra iránti szimpátiával magyarázza a svájci egyetemeken észrevehető erőteljes román képviseletet. Másik érdekesség ebben a vonatkozásban, hogy a hallgatók majdnem fele nő. A PIM elektronikusan elérhető adattára szerint Leményi Brán Elenonóra az I. félévben tanul Genfben, 1904-től, ellenben Szögi László kutatásai alapján (Magyarországi diákok svájci és hollandiai egyetemeken 1789-1919., Budapest, 2000, 82.) a bölcsészés természettudományi tanulmányokat folytató Lemény 2 évvel később iratkozik be a genfi egyetemre. Lásd: Lemeny Eleonore de, Hongrois (Magyarország), t: 1906/7, s: Ph Nw.

${ }^{359}$ Maria Cunțanról lásd bővebben: Gabriela Dubenschi, Maria Cunțan, Biblioteca Județeană Astra, Sibiu, Seria Personalia nr. 13, 2007.

${ }^{360}$ Vö. Transilvania 1911/5.

${ }^{361} \mathrm{http}: / /$ ro.wikipedia.org/wiki/Marele_Sfat_Na\%C5\%A3ional_Rom\%C3\%A2n - utolsó látogatás: 2012. május 24. 
A kevés létszámú női egyetemi hallgatóságból ${ }^{362}$, amint láttuk, egyetlen esetben találtunk adatokat az egyetem utáni szakmai élet nyomaira. A tanári munkán kívül irodalomtörténeti és fordítói tevékenységet gyakorló Eleonora Lemenyi-Bran az egyetlen, aki ebben a vonatkozásban követhető. Mind nyomtatásban megjelent irodalmi munkássága, mind politikai szerepvállalásai megelőlegezik számára azt, hogy egy 21. századi kutató nyomába eredhessen. Megfelelő források hiányában lokális jellegű kutatásokra lenne szükség - akár a némiképp rekonstruált Leményi-életrajz esetében is - ahhoz, hogy az oktatási rendszer újabb szereplőinek, a nőknek helyzetét, egyetemi lehetőségeit, egyetem utáni karrierjük, egyáltalán a női értelmiségi szereplehetőségeket biztosabban meg lehessen ragadni. Mert nyilván nem csupán a kirobbanó első világháború miatt változik meg a nemi identitások aránya az egyetemre beiratkozók között. A női hallgatók száma a 20. századtól lesz számottevő a kolozsvári bölcsészkaron, magyar-francia vagy francia-német szakon. Amíg 1914 és 1916 között egyetlen nő iratkozik be, addig az 1918/19-es tanévben a 385 diákból majdnem 220 hölgy. ${ }^{363} \mathrm{Az}$ adatok mögött sokkal bonyolultabb társadalomtörténeti szempontok állnak, de mindenképp jelzésértékűek. Mint ahogy az is, miszerint e női hallgatók közül többen férjezettek. A házassággal járó névváltoztatás szintén nehezíti visszakereshetőségüket.

\subsubsection{Román bölcsésztudorok. Címek, értekezések, életpályák}

Az egyetemen az 1899/1900-as tanévig 1803-an szereznek doktori címet, köztük természetesen a román hallgatók is. A doktori címek, amenynyiben az egyetemi szakképzés csúcsát jelentik, beszédesek lehetnek a román hallgatók egyetemlátogatása felől, ugyanakkor az egyetemi képzés egy másik szintjére is rávilágítanak. Meg kell jegyeznem, hogy az 1803 doktori oklevél azokra az egyetemi tanárokra is vonatkozik, akik az intézmény munkatársai, de még nem rendelkeznek doktori címmel, vagy ha igen, akkor az egyetem tiszteletbeli doktoraivá válnak. Brassai Sámuelt és Berde Áront, az egyetem első vezetőit például 1874-ben választják tiszteletbeli doktorokká. ${ }^{364}$ A teológiai doktorátussal rendelkező Grigore Silaşi neve saját tanítványai társaságában szerepel, amikor 1881 tavaszán Emil

\footnotetext{
${ }^{362}$ A női egyetemi hallgatók alulreprezentáltságáról és diszkriminációjáról lásd bővebben: KARÁDY 1997b, 57-75.

${ }^{363}$ Törzskönyv. 1902-1919. [A kézirat lelőhelye: Román Állami Levéltár, Kolozsvár. Jelzete: Fond 315, reg. 152.]

${ }^{364}$ Berde Âron a jogtudományok, Brassai a bölcsészettudományok doktorává válik 1874 januárjában. Vö. A kolozsvári m.k. Ferenc József Tudományegyetem Tanácsa és doktorai névkönyve, I.kötet, 1872/1873-1899/1900. [Kézirat lelőhelye: Román Âllami Levéltár, Kolozsvár. Jelzete: Fond 315, reg. 111.]
} 
Vajdával és Petre Dulfuval bölcsészettudori címet kapnak. A doktori névkönyv ugyanazt a mára kevésbé egyértelműnek látszó viszonyt tükrözi, ami a prozopográfiai adattárak kapcsán is kiderült, jelesül: egy bizonyos karra beiratkozó diák esetenként nem a feltételezéseink alapján elvárt azonos karon szerez doktori címet. Így a görög katolikus Gerevich Emil vagy a görögkeleti Ioan Radu a természettudományi kar hallgatói matematika és fizika szakot végeznek, de bölcsészettudományi doktorként szerepelnek a névkönyvben. A bölcsészettudományi kar tanárképzést biztosító státusának köszönhetően kerül ebbe a helyzetbe. Valószínű, tanárjelöltként iratkoznak be e karra, miután matematika és fizika szakon bizonyítványt nyernek, majd a bölcsészdoktori címet is megszerzik, annak ellenére, hogy értekezéseik tudományterületük speciális - pl. a lefelé menő lánctörtek - kérdéseit vizsgálják. ${ }^{365}$ Ezek az adatok tehát oly módon árnyalják az adattárak tartalmát, hogy a modern értelemben vett szaktudományágak, a szakképzés kialakulását illusztrálják, esetünkben a matematika- és természettudomány önálló karként való megerősödését, a tanárképzés vagy a szaktudósság és bölcsészettudományi kar hierarchikusan szerveződő viszonyát.

A szakképzés és modern értelemben vett egyetemi szakoktatás sajátos példái között Constantin Poput is említhetjük. A matematika és természettudományi kar görög katolikus (Naszód-vidéki) hallgatója a bölcsészkarra is beiratkozva román nyelv és irodalom, illetve matematika és kísérleti fizika szakon szerez egyetemi oklevelet, majd bölcsészdoktori címet 1892-ben. ${ }^{366} \mathrm{Az}$ a tény, hogy Popu egyetemi hallgatóként két különböző szakot is elvégez, azt jelenti, hogy középiskolai tanulmányai után számára még elérhető közelségben léteztek a humán- és reáltudományi diszciplínák -, esete tehát a modern értelemben vett hivatásosodás folyamatára világít rá.

Amint a fentiekből körvonalazódni látszik, a bölcsészdoktori oklevél nem minden esetben jelenti a modern értelemben vett bölcsészképzést. ${ }^{367}$ A kimondottan nyelv és irodalmi tárgyú doktori értekezést író román hallgatók témaválasztása fontos mutatója lehet mind a tanárok, mind pedig e diákok érdeklődésének, intencionalitásának. Petre Dulfu (Vasile Alecsandri, 1881), Gavril Onişor (Gheorghe Asachi 1882), Ioan Rațiu (And-

${ }^{365}$ Lásd: Gerevich Emil, A lefelé menő láncztörtekröl. Analytikai tanulmány. Máramarossziget, 1885, és A lefelé menő láncztörtek analizise. Beszterczebánya, 1889.

${ }^{366} \mathrm{http}$ ://regi.pim.hu/Online/adattar/diplomasok.php?mit=N\%e9v\&ertek=pop\&valt=keres es\&alsoi=1\&kul=5\&kiaz=3 - utolsó látogatás: 2012. június 2.

${ }^{367}$ Ezért lesznek eltérőek adataim a Nagy Péter Tibor által közöltektől, hiszen a bölcsészettudományi karra beiratkozó diákok számos esetben a tanárképzés miatt lesznek e kar diákjai, és kevesebben választanak kimondottan a nyelv és irodalom tárgykörébe tartozó kérdést doktori értekezéseik tárgyául. Vö. NAGY 2006. 
rei Mureşanu, 1900), Emil Szabó (George Coşbuc, 1904) témaválasztása viszszakereshető, ezeket, de a Budapesten megvédett doktori értekezéseket is bibliográfiai tételként tartalmazza az adott szerzők életművénél Domokos Sámuel kapcsolattörténeti bibliográfiája. ${ }^{368} \mathrm{~A}$ kortárs román irodalom alakjainak életét és múvét tárgyaló értekezések a biográfia felől veszik sorba az esetenként lezáratlan életműveket. Az értekezések magyar nyelve pedig a magyar kultúrába vagy a kapcsolattörténeti kutatások forrásai közé zárja azokat. Hiszen mind Cristea Eminescu-tanulmánya, mind ezek a nyomtatásban is megjelent értekezések, bár a román irodalommal foglalkoznak, mégsem válnak annak részévé, hiszen nem jelennek meg román nyelven. A magyar és a magyarul is olvasni tudó szűkebb olvasóközönség ismerheti meg munkájukat, köztük valószínűleg az egyetemek bölcsészkari oktatói, az értekezőkkel kapcsolatban álló román értelmiségiek, akik a kanonizálódó román irodalomhoz képest eleve peremhelyzetben léteznek, vagy kirekednek a romániai történésekből. Az említett doktori értekezések szerzői közül Dulfu és Onişor a szomszédos államba, a román királyságba távozik. Onişor bârladi tanárként dolgozik és oktatásszervezői feladatokat is ellát, míg Dulfu Bukarestben szerencsésen kapcsolódik be a román irodalom vérkeringésébe, hasonlóan a korábban tárgyalt, irodalomkritikusként, -történészként elismert Ioan Scurtuhoz.

A doktori tanulmányok a szimbolikus érték mellett a magyar nyelvú értekezések publikációját jelentik, de a román hallgatók életpályájának alakulása felől ritkán biztosítják a szaktudósi, kutatói munka továbbfolytatását, nyilván ez a szempont kevésbé lehet releváns az éppen szakosodó, specializálódó oktatás időszakában. A doktori címmel rendelkező tanárok részt vállalnak a román nyelvű oktatás szervezésében, tanfelügyelők lesznek, többen tankönyvírással is foglalkoznak, illetve szerzői az ASTRA által 1898 és 1904 között kiadott első román nyelvű enciklopédiának. A doktori címmel nem rendelkező tanárokhoz képest életpályájuk azt mutatja, hogy bővül ugyan a tudósi, írói szerepeik lehetősége, viszont nem feltétlenül azért, mert doktori cím birtokosai. A felekezeti különbségek nem relevánsak a doktori szempontjából, hiszen a beiratkozó diákok közül mind a görögkeletiek, mind a görög katolikusok kb. 13-14\%-a szerez doktori címet. A Petőfi Irodalmi Múzeum elektronikus adattára alapján 5752 hallgató iratkozik be 1872-től 1918-ig a kolozsvári egyetemre és az 1900-ig doktori címet szerzők száma 1803. A beiratkozás és egyetemvégzés közötti viszonyt, a szakváltásokat, résztanulmányokat figyelembe véve, illetve számolva annak a lehetőségével, hogy más egyetemek végzettjei is doktorálhatnak Kolozsvárt, általánosító megjegyzésem a fenti adatok alapján a következő: az egyetem első huszonöt éve alatt a hallgatók 31\%-a szerepel a doktori

\footnotetext{
${ }^{368}$ Lásd Doмокоs 1966.
} 
névkönyvekben. Ehhez az általános adathoz képest arányaiban alulreprezentált a román bölcsészhallgatók közössége. Természetesen, alaposabb, több szempontú kutatásra van szükség, amennyiben egy egyetem által kibocsátott doktori oklevelek mennyiségét és minőségét vizsgáljuk, illetve a 19. század végén a doktori cím súlyát és jelentéseit értelmezni próbáljuk. Ez azért is fontos lehet, mert több vonatkozó egyetemtörténeti munka ${ }^{369}$ közhelyként említi azt, hogy idővel a kolozsvári egyetem keleten müködő diplomagyárrá vált. Összehasonlító alapvizsgálatokra lenne szükség e kijelentés megerősítésére vagy cáfolására.

A román egyetemi hallgatók közössége felől nézve a bölcsészkari doktori címeket, állíthatom, hogy nagyon szük az a réteg, amely befejezi és továbbfolytatja felsőfokú tanulmányait. Irodalmi témájú doktori értekezéseik a román kultúra jelentős figuráinak kanonizációs kísérleteihez sorolhatóak. Ebben a típusú érdeklődésben nem érzékelhető különbség a disszertációkban, impliciten pedig a román tanszékek élén álló tanárok preferenciáiban. A romániai egyeteme(ke)n megvédett doktori értekezések vizsgálata is figyelmet érdemelne ebben a kérdésben, hiszen a román nyelvű irodalom és kultúra hivatalos centruma a fôvárossá váló romániai Bukarest.

Összegezve, a kolozsvári bölcsészkarra beiratkozó román diákok kapcsán több minden láthatóvá válik. A román tanszéket betöltő tanárok személyisége, iskolázottsága, szakmai és nemzeti identitása mind befolyásoló tényezőként hatnak az évente kis létszámban beiratkozó románokra. Az egyetemre való beiratkozás nem minden esetben jelent teljes egyetemi tanulmányt. A magyarországi és romániai lehetőségek egyaránt szempontként működtek a végzős diákok munkavállalása felől. Bár példáim azt mutatják, hogy a tanári állást leszámítva, csak azok a diákok fordultak Románia és fővárosa felé, akiket ebben kapcsolathálójuk befolyásolt: a Naszód-vidéki George Coşbuc és Petre Dulfu. ${ }^{370}$ Mindketten írói tevékenységükkel váltak elismertekké, kanonikus figurákká. Magyarországi munkát vállaló román diákokról csupán pár évtizedig beszélhetünk, mivel 1918 után megváltozik a történelmi kontextus és okafogyottá válik ez a típusú kérdésfelvetés. Ezért tűnik érdekesebbnek azoknak az életpályája, akik a kolozsvári egyetem első évfolyamain végeznek, és szakmát, helyet választanak a társadalmakban. Állíthatom, hogy elsősorban közösségivé váló és erősödő nemzetiségi identitásuk határozza meg döntéseiket. A megerősö-

\footnotetext{
${ }^{369}$ Többek között IMRE 1944.

${ }^{370}$ Egy lábjegyzet erejéig megfontolandó az a közhellyé váló kijelentés, miszerint az erdélyi románok kultúrfölénnyel rendelkeztek a moldvai vagy havasalföldiekhez képest, illetve nem 19. század végi, hanem hagyománnyal rendelkező sajátossága az erdélyi román értelmiségnek a többségi román vidékek felé való tájékozódás. A kolozsvári piarista gimnázium, majd az egyetem jelentőségét ebben a vonatkozásban részletesen tárgyalja GÁLDI 1987.
} 
dő nemzetiségi/nemzeti identitást példázza a következő alfejezet, amely azért is fontos, mert éppen a román egyetemi hallgatók első évfolyamainak egyetemi és egyetemen kívüli tevékenységét, szerepvállalását szemlélteti.

\subsection{A román egyetemi hallgatók Iulia-egylete. Önszerveződés és identifikáció}

A kolozsvári egyetemen tanuló román diákság önszerveződésének bizonyítéka a Iulia-egylet, működésének feltárása pedig több problémát is megmagyarázhat. Egyfelől az egyetemi tanár, Silaşi nyugdíjaztatásának körülményeire deríthet fényt, másfelől, tagsági listája kontrollforrás lehet a román nemzetiségű egyetemi hallgatók azonosításánál. Mi több, a magyar és román egyetemi hallgatók közötti viszonyt is megvilágíthatja, illetve az egyetem és a nemzetiségek kapcsolatát illusztrálhatja, egy olyan kapcsolatot, amely esetenként konfliktusos lehet.

A kolozsvári egyetem első tanévének indulásával párhuzamosan elkezdődik a ez egyetemi diákság önszerveződése: első évben idegen nyelvű társalgási körök, Bessenyei-ünnepség, egyetemi és jogász bál. ${ }^{371}$

1873 januárjában említik először a magyar egyetem román ifjúságát, amely a Biasini Szállodában dal- és táncestélyt rendez egy Kolozsváron kialakítandó román iskola javára. ${ }^{372} \mathrm{Az}$ ifjak saját ünnepüket ülik ekkor, hiszen rendezvényük az ógörög naptár szerinti óévbúcsúztatáshoz kapcsolódik. A naptári rendszer, az idő mérésének eltérő, hagyományosabb módja sajátosan szervezi a románság életét, miközben erősíti különbözőségüket. Rendezvényük is más lesz, mint a magyar egyetemistáké: nem egyszerüen a szórakozást szolgálja, hanem jótékonysági, az egylet múködésén túlmutató célja van. Március 1-jén már egy román leányiskola javára rendeznek koncertet és zártkörü táncestélyt, amelyen a kolozsvári érdeklődőkön kívül vidékiek és más nemzetiségúek is részt vesznek. ${ }^{373}$ Amennyiben egy nemzetiségi intézmény alapítására törekednek az ifjak, a jótékonykodás közösségivé, közös érdekké válik. A közösségi/nemzetiségi érdeket nem csak a rendezvény zártkörü meghirdetése, a szervező román fiatalok szolidáris közösségként való megmutatkozása képviseli, hanem például maga a program is: a román dalkör előadása, egy Alecsandri-vers, román áriák zongorakísérettel. Emiatt nyilvánvaló, hogy az egyetemi ifjak román közösséggel való szolidaritásának, közös társadalmi-kulturális érdekek nyilvánosságra hozatalának, nem utolsósorban pedig nemzeti identitásának

\footnotetext{
${ }^{371}$ Kolozsvári Közlöny 1872. december 11. [Példáim e lapból származnak, hiszen ennek évfolyamait néztem át tüzetesebben az első Eminescu-fordítás vizsgálatakor.]

${ }^{372}$ Kolozsvári Közlöny 1873. január 3., január 12.

${ }^{373}$ Kolozsvári Közlöny 1873. március 5.
} 
reprezentációs lehetőségei ezek az alkalmak, hasonlóan a külön majálishoz június 12-én, melynek célja a román akadémia alaptámogatása.

Az első tanévben a román egyetemi hallgatók intézményen kívüli rendezvényeiről azt állíthatjuk, hogy nemzetiségi szempontból elhatárolódnak, jótékonysági céljaikat főként anyagi érdekek mozgatják a hiányzó vagy támogatásra szoruló kulturális, szellemi javak biztosításáért. Ezek az alkalmak (nemzeti) összetartozásukat erősítik és csírái az egyetem indulásához képest öt évvel később engedélyezett Iulia-egyletnek. A hovatartozás érzése ebben az esetben már nem csupán relacionálisan kerül kifejezésre (értsd: mi románok elhatárolódunk tőletek, magyaroktól), hanem a hasonlóságokat hangsúlyozva, közös mentális reprezentációkban mutatkozik meg, amikor a fenyegetett relációs identitást attribúciós fogalmakban próbálják meg helyreállítani. ${ }^{374}$

A pesti polgári egyesületek társadalomtörténetét feltáró Tóth Árpád nem tér ki az ifjúsági szervezetekre, egyletekre, de külön tárgyalja a szegénykérdés és az egyesületi jótékonyság viszonyát, a betegsegélyző egyleteket. A téma feldolgozatlanságát említve Tóth kötete ${ }^{375}$ mégis számos dologra felhívja a figyelmet. Arra, hogy a reformkorban a keresztény jótékonyság, a pietizmus vezérelte az első ilyen típusú egyletek létrehozóit, amelyekben az evangélikusok túlreprezentáltak, következésképpen az egyletek a német etnikumhoz köthetők. A protestánsok közül nagyon kevesen, görög katolikusok pedig egyáltalán nem tagjai a reformkori jótékonysági egyleteknek. Pajkossy Gábor a szerbek, szlovákok és románok irodalmi és múvelődési egyleteit a céhes alapon szerveződő kaszinók utódaiként, kultúrájukat erősítőkként, és a nemzetiségi törekvések szolgálóiként láttatja. ${ }^{376}$ Ez utóbbi koncepcióba illeszkedik a Iulia-egylet.

A Kolozsvári BBTE Egyetemi Könyvtárában található az egylet működését bemutató jelentés az 1877/8-as és 1878/9-es tanévről. A román nyelvű jelentés ${ }^{377}$ tartalmazza az egylet tagjainak névsorát is, akik az egyetem orvostudományi-, jogász- és bölcsészhallgatói. E két utóbbi diákcsoport az egyletben számbeli fölénnyel rendelkezik. A rendes tagokon kívül a tiszteletbeli és alapító tagok is szerepelnek a jelentésben. Az egyetem román tanszékvezetője alapító- és tiszteletbeli tagja az egyletnek. Más tiszteletbeli tagok: Aurel Isac és Iuliu Coroian ügyvédek. A névsor évente bővül, 1879-ben például Ioan Vancea görög katolikus és Miron Romanul görögkeleti mitropolita, Timotei Cipariu, az ASTRA elnöke, Iacob Mureşanu, George Barițiu szerkesztő, Gavril Pop esperes lesz tiszteletbeli tag. E névsor jelzi, milyen irányba nyit az egyetemi ifjúság: Kolozsváron, az egyetem

\footnotetext{
${ }^{374}$ INGOLD 2004, 69.

375 То́тн 2005, különösen: 53-141.

376 PAjkossy 1993.

${ }^{377}$ Micu (red.) 1880.
} 
intézményén kívüli egyházi elöljárókat és újságszerkesztőket tiszteli meg ezzel a címmel, akik a román kultúra terjesztését szolgálják, és szellemi példaképeik lehetnek. ${ }^{378}$

Az egylet havi rendszerességgel tartja üléseit; a tagok kari bizottságokat szerveznek, a pénztáráról, könyvtáráról jelentéseket készítenek, pályázatot írnak ki. ${ }^{379}$ Havi egy irodalmi felolvasóülést, évente két rendkívüli ülést, valamint négy deklamáló-zenei koncertet tartanak. Kitűnik a tevékenységi beszámolóból az is, hogy a kezdeti, jótékonykodással egybekötött ünnepi alkalmak kibővülnek nemzetinek tekintett zenei koncerttel, tánccal, politikai témájú versekkel, irodalommal kapcsolatos eseményekkel. Könyvtáruk szegényes, az 1876/7-es tanévben 54 tételt tartalmaz. A könyvekhez főleg adományok útján jutnak, illetve a hallgatók ajánlják fel saját köteteiket. A hírlapokat ${ }^{380}$ ingyen vagy adományként kapják. Vásárolnak is egy-egy Vasile Alecsandri, Dimitrie Bolintineanu, Titu Maiorescu, B. P. Haşdeu-kötetet. A könyvtár hírlapjai és könyvei zöme irodalmi vagy történelmi vonatkozású, ilyenként nehezen egyeztethető az egylet tagságának például jogi vagy medikus szakmai képzésével, ami annak bizonyítéka, hogy az egylet múködése többet jelent a szakmai önszerveződésnél. Az egylet pénztárának bevételét leginkább a koncertek növelik, valószínűleg nyilvánosságukból fakadó népszerűségük miatt. Jelentősebb adományozóik: Erzsébet osztrák császárné, Magyarország királynője, aki az egyik koncertmeghívóra 50 forinttal válaszol (ezt az összeget a pénzügyi részszel összehasonlítva, állíthatom, hogy fedezi az egylet az évi nyomtatási és könyvvásárlási költségeit!) vagy az erdélyi katonai csapatok marsallja, Ringelsheim báró (10 forint). I. Károly román király 100 frankot adományoz az olvasóteremnek. A kolozsvári görög katolikus lelkész a román kaszinó termét bocsátja az egylet használatába ülés- és olvasóteremként. A vármegyei vezetés elengedi a táncos koncertekért fizetendő pénzösszegeket. A Socec\&comp. könyvesbolt 25\%-os árkedvezménnyel kínálja köteteit

\footnotetext{
${ }^{378}$ Megjegyzendő, hogy valamennyien teológiai végzettségűek, esetleg bölcseletet is tanultak külföldi egyetemeken. A szakmai identitások egybeesése (például teológiai végzettség, majd utána újságszerkesztés vagy intézményvezetés) nem szorul különösebb értelmezésre, hiszen kutatások bizonyítják, hogy a román fiatalok a 19. század közepén főként a teológiai és jogi képzés iránt érdeklődtek, illetve közösségi szereplőkként nem csak kultúraszervezéssel foglalkoztak, hanem sok esetben politikai pályára is léptek. Szász Zoltán a románok egyesületeit vizsgálva jut hasonló megállapításra: az egyesületek igazgatói politikusok, de például a román bankok igazgatói is. Vö. Szász 1993.

${ }^{379}$ Ilyen pályázat a Dimitrie Țichindeal (bánsági lelkész, állatmeseíró, fordító, tanár) életét és fabuláinak értékét feltáró kírás, amelyet Petre Dulfu (10forint) és Gavrila Onișor (Silași által felajánlott $5 \mathrm{ft}$ ) nyer meg.

${ }^{380}$ A jelentés a következő román nyelvü lapokat említi: Gazeta Transilvaniei, Observator, Economul, Foaia scholastică, Convorbiri literare, Igiena și școala, Gura satului, Femeia romana, Gazeta medico-chirurgicală, Perdaful, Reforma. Francia nyelvü a Le journal de Bucharest, német a bécsi Musiker Courrier.
} 
az egylet számára. ${ }^{381} \mathrm{Az}$ adományozók felsorolása jelzésértékű: egyházi és világi vezetőik mellett a legmagasabb rangú elöljárók figyelnek a román egyetemi hallgatókra. A helyi vezetők engedményeket tesznek, amelyek arról tanúskodnak, hogy nem az egyetem keretein belül, hanem külső helyszíneken tartják összejöveteleiket, rendezvényeiket, ezáltal pedig szélesebb nyilvánosságot nyer mind az egylet, mind az általa képviselt román kultúra. ${ }^{882}$

A kolozsvári Tudományegyetemi Körnek a fentebb vizsgált jelentéssel egykorú évkönyve a tagok között román nemzetiségű hallgatókat is nyilvántart, de neveiket legtöbbször a tagsági díj-hátralékosok között találjuk. A kör könyvtára tartalmaz német nyelvű kiadványokat, de román nyelvűeket nem. ${ }^{383}$ Úgy tünik, hogy kevésbé érdekli a román diákokat az egyetemi kör, nem vesznek részt benne olyan intenzitással és akkora számban, mint sajátnak tekintett Iulia-egyletükben. ${ }^{384}$

Egyetemtörténeti forrásaink a Iulia-egyletet az egyetemen felbukkanó nemzetiségi konfliktusok felidézésekor említik. Márki Sándor szerint Abt Antal rektorsága idején tapasztalható az első ilyen jellegü összetűzés.

1884. május 14-én az egyetemi ifjúság azt követeli, hogy Silaşi, aki ebben a tanévben a bölcsészkar dékáni tisztjét is betölti, csak magyar nyelvủ előadásokat tartson. Másnap zajosan tüntet a 15-i, balázsfalvi gyűlésre emlékező románok ellen.

„1884. május 17-én román lapokat égettek s előadás közben tüntettek Silaşi tanár ellen, ki másnap valótlannak nyilvánította, hogy valaha és valahol hazafiatlanul nyilatkozott volna. 19-én a bukaresti, 23-án a iași-i egyetem ifjai is tiltakoztak a kolozsvári egyetem magyar ifjai ellen, s 20-án megalapították a Romania irredentát, mely már 22-én kiadta Erdély lefoglalására lázító első röpiratát" ${ }^{385}$

Makkai László történész is említi az országos nyilvánosságra szert tett Iulia-ellenes tüntetéseket. A magyar diákok azt kifogásolják, hogy az egylet nem egyetemi polgárokat is felvesz a tagjai közé. ${ }^{386}$ Már e két egyetemtörténeti jelentőségú írás is jelzi azt a bizonytalanságot, amely a konfliktus

\footnotetext{
${ }^{381}$ Micu (red.) 1880, 22.

${ }^{382}$ Hasonképpen működik a Pesti Egyetem román hallgatóinak Petru Maior Olvasóköre. Könyvtáruk van, felolvasásokat, bálokat tartanak, ahol nemzeti táncot járnak, rendezvényeiken ugyanazokat a politikai témájú költeményeket szavalják. Támogatóik a magánszemélyeken kívül, a század vége felé már a román bankok. Kéziratos kiadványuk a Rosa cu ghimpi. Lásd erről bővebben: Almanachul Societății de lectură Petru Maior din Budapesta, Gherla, Tipografia Aurora (ediție proprie), 1901.

${ }^{383}$ Vö. A Kolozsvári Tudományegyetemi Kör Évkönyve, 1878-1879, Stein, Kolozsvár, 1880.

${ }^{384}$ A román és szász diákok érdeklődnek ugyan az egyetemi képzés iránt, viszont a magyar egyetemi hallgatóktól elszigetelten élik egyetemi éveiket. Vö. IMre 1997, 19.

${ }^{385}$ MárKi 1922, 47.

${ }^{386}$ МАKKAI 1997, 11.
} 
kiváltó okának egyértelmű megfogalmazását ellehetleníti. Az okok rétegzettek: a román nyelvű Silaşi-előadások, a Iulia-egylet emlékünnepsége, az egylet zárt jellege stb.

Jóval beszédesebb a primér forrásnak tekintendő, 25 654. szám alatt közölt egyetemi tanácsi jegyzőkönyv. ${ }^{387} \mathrm{~A}$ jegyzőkönyv megrovásban részesíti azokat a diákokat, akik 1884. május 15-én és 16-án részt vettek Silaşi előadásain és megzavarták annak menetét, annak ellenére, hogy nem voltak e tanár diákjai. A botrány elindítóinak nevét is közli: Zöld Gábor, Páska Zoltán, Nyéki Takács Nándor, Sebesi Jób jogászhallgatók, ifj. Szász Károly és Bónis Sámuel vezérek. ${ }^{388} \mathrm{~A}$ bölcsészeti karon bizottságot hoznak létre a botrány, illetve Silaşi politikai tanári magatartása kivizsgálására, amelynek következtében Trefort miniszter fölmenti Grigore Silaşit egyetemi hivatalos működéséből. ${ }^{389} \mathrm{~A}$ jegyzőkönyv csupán az egyetemi belpolitikát érintő kérdésekkel foglalkozik: a rendbontással, a kifogásolt tanári magatartással.

A román tanszék előadásainak nem magyar nyelve, a román diákok egyleti működése, emlékezéskultúrája eltávolodásukról szól, hiszen mind az előadások nyelvében, mind önszerveződésében elkülönül a román diákság. Ráadásul 1884 májusában az 1848-as balázsfalvi nemzeti nagygyưlésre emlékeznek, amely nemzetiségi törekvéseik sikertörténete ${ }^{390}$ Balázsfalva a 19. században válik román nemzetpolitikai színtérré. A májusi nagygyülésen (a nemzet újjászületésének élményén) kívül 1848 szeptemberében is ide szervezik a második nagygyülést, majd 1861-ben, szintén május 15-én, itt jelentik ki, hogy Erdély Magyarországgal való unióját ellenzik. ${ }^{391}$

A forrásokat összefoglalva az látszik, hogy 1884 májusában a folyamatosan provokáló román diákság ellen lép fel a magyar hallgatóság. Bár sértően, egyetemi polgárokhoz nem illően viselkedtek Silaşi előadásain, ráadásul az egyetemi tanács viselkedésüket kihágásként értelmezi, mégis

\footnotetext{
${ }^{387}$ A vallás- és közoktatásügyi m.k. minisztérium által a kolozsvári FJTE tanácsához intézett elvi jelentőségü rendeleteinek gyüjteménye az 1872/3-1898/99 tanévekról, Kolozsvárt, 1900. [1883/4-es tanév iratai]

${ }^{388}$ I.m. 233. Mellesleg: csupán Sebesi Jób és ifj. Szász Károly adatait sikerült felderíteni, bár nem szerepelnek a PIM adattárában. Szinnyeinél mindketten megtalálhatók, jogászi képzettségüket is említi. Sőt Szász Károlynál azt olvassuk: „Két évig a kolozsvári, kettőig a budapesti egyetemen hallgatója volt. Ekkor élénk részt vett az ifjúság mozgalmaiban; nevezetesen 1883-ban a kolozsvári egyetemen az oláh egyetemi hallgatók magyarellenes »Julia " egylete ellen küzdött eredménynyel." Vö. SzINNYEı 1891-1914.

${ }^{389}$ I.m. 234.

${ }^{390}$ A Iulia-egyletben hagyománya van a majálissal egybekötött ünnepségnek. Lásd például a Kolozsvári Közlöny 1882. május 14-i, 52. számát, amelyben a Stadler-kerti táncmulatsággal egybekötött majálisra hívja fel az olvasók figyelmét, közölve a rendező bizottság névsorát, amelyben az egyetemi ifjúság mellett kolozsvári románok nevei is megtalálhatóak.

${ }^{391}$ KöPECZI (főszerk.) 1986.
} 
ők kerülnek ki nyertesen a botrányból: Silaşit nyugalomba helyezik ${ }^{392}$, az alispán a Iulia-egylet 1884-es majálisát, majd magát az egyletet is betiltja.

A fentebb említett három szöveghez képest az egyetemi Almanach meg sem említi a botrányt, az 1884/5-ös tanévben Silaşit tanárként szerepelteti, de a Iulia-egylet hiányzik az egyetemi hallgatók egyletei sorából. ${ }^{393}$ Nyilván, amikor ezt hiányként érzékelem, nem tekinthetek el attól, hogy milyen indíttatású ez a kiadvány, ki a célközönsége, az egyetem presztízse szempontjából milyen következményekkel járna a botrány említése. Ugyanez vonatkozik Abt Antal leköszönő rektor beszédére, aki csak Silaşi fölmentésére hivatkozik. Az Acta pedig a korábbi évektől eltérően, már nem közli a Iulia-egylet adatait, a román nyelv tanárának nevét vagy például Silaşi előző tanévbeli publikációs listáját. ${ }^{394}$

A botrány nem értelmezhető csupán egyetemtörténeti eseményként. Jóval több annál: a 19. század utolsó évtizedeinek nemzetiségi törekvései, az etnikai-nemzeti identitás megerősödése a (politikai) elit számára megoldatlan kérdést jelent. Kolozsváron, az egyetemen kerül sor a provokációra.

A Iulia-egylet sajátos politikája is kiválthatja a magyar diákok ellenszenvét: egyetemi hallgatók köreként definiálja magát, kizárja a nem román diákok részvételét a tagságban, sőt az egyetemen kívüli, szélesebb román nyilvánosság felé nyit. A román diákság a külföldi peregrinusokhoz vagy a pesti egyetemi hallgatók olvasótársaságához hasonlóan nem az egyetemen, hanem valamelyik mecénás lakhelyén, egyházaik termeiben, esetleg a városi kaszinóban tartja zárt összejöveteleit. A Iulia-egylet tagjai az egyetemhez annyiban kapcsolódnak, hogy vezetőjük a román tanszék tanára, illetve ők az egyetem diákjai. A szakmai témájú irodalmi rendezvényeiken kívül legtöbb tevékenységükben eltávolodnak az egyetemtől. Nem jelentéktelen az a kérdés, hogy egyleti tagságuk milyen előnyöket biztosít számukra. Elsősorban nemzetiségi identitásuk közösségi élményét, a román kultúra ismertetését, szolgálatát jelenti, természetesen emellett a szórakozás, szabadidőtöltés alkalmai például a majálisok vagy a koncertek, amelyek mégis funkcionális többlettel bírnak. Az egyleti tagság generációs kapcsolatokat is kiépíthet, ezért érdemes megnézni, hogy milyen kapcsolatok alakulnak ki a tagok között, illetve továbbélnek-e ezek az egyetemi évek után. A magyar és román hallgatók közötti konfliktus arra mutat rá, hogy egymással párhuzamos, de eltérő nemzetépítés zajlik

\footnotetext{
${ }^{392}$ A források a nyugalomba helyezést eltérő módon keltezik. Az viszont egyértelmű, hogy Grigore Moldován, a megüresedett román tanszéket betöltő tanár az 1886-es tanévtől dolgozik az egyetemen.

${ }^{393}$ Vö. A Kolozsvári Magyar Királyi Ferenc József Tudományegyetem Almanachja - 1884/5, Magyar Polgár könyvnyomdája, Kolozsvár, 1885.

${ }^{394}$ Vö. Acta Reg, Scient. Univ. Claudiopolitanae, Kolozsvár, 1885. [Fasc. I-II.]
} 
a század utolsó évtizedeiben. ${ }^{395}$ Ezt az ellentmondásokkal terhelt párhuzamosságot a korabeli hírlapok tudósításai is tükrözik. A hírlapi tudósítások érvei érdekesek lehetnek kapcsolattörténeti okokból vagy éppen a nemzeti mint ideológia archeológiája kapcsán.

Egyre inkább provokációnak tűnik a májusi esemény, mégpedig a magyar egyetemi hallgatók részéről történő provokációnak. Természetesen a románok Iulia-egylete müködésének korábban jelzett sajátosságai sem elhanyagolandóak a botrányban. A provokáció mindkét fél tevékenységében ott munkált, csak különböző módon. Ennek felderítésében óriási jelentőségűnek tartom a korabeli magyar és román nyelvű sajtó vizsgálatát. A részletes tudósításokból összeállítható egy történetváltozat, amely a botrány és következményeinek román és magyar nyelvű értelmezéseit ragadja meg. Bár májusban kerül sor a konfliktusra, az előzményekkel rendelkedik. Ilyen például annak ténye, hogy a román egyetemi hallgatók az 1884 áprilisától napilappá váló Gazeta de Transilvania laphoz az elsők között küldik el üdvözlő soraikat. ${ }^{396}$ Ekkor érdekeiket, elvárásaikat is megfogalmazzák: harcolni a román nép jogaiért, az ellopott jogokat visszaszerezni, az ősrégi hazában békében élni. Nem a Iulia-egylet nevében írnak, hanem kolozsvári román fiatalokként. A „kolozsvári román ifjúság” általánosító megfogalmazás jelezhette azt, hogy egyetemi ifjakról van szó, mint ahogy az leellenőrizhető a beiratkozási anyakönyvek alapján. A román olvasóközönség és a szerkesztőség számára is egyértelmű lehetett az, ami a kívülállóknak nem, hogy az általánosító megfogalmazás, majd az aláírók névsora a Iulia-egylethez köthető. ${ }^{397}$ Fontos megjegyezni, hogy pár számmal később egy névtelen cikk figyelmezteti a kolozsvári román ifjakat arra, hogy a nemzet szempontjából óvatosságot, körültekintést igényel az ellopott jogokra való hivatkozás. E cikk azt is tematizálja, hogy a kolozsvári egyetem magyarként határozza meg önmagát, annak ellenére, hogy román és más etnikumú ifjak is látogatják. De fölmerül az a kérdés is, hogy mire neveli e fiatalokat a román tanszék, és hogy az egyetem végeztével a közéletbe történő betagolódás felszabadító erővel bír számukra. ${ }^{398}$ A fiatalok üdvözlete és e cikk után jelenik meg Silaşi szerkesztőt köszöntő távirata, amelyben

\footnotetext{
395 „A nemzeti rítusok és diskurzusok a társadalom nacionalizálásának eszközei, elképzelt közösségeket hoznak létre vagy reprodukálnak, itt románokra és magyarokra osztva egy multietnikus társadalom tagjait. Az egymással rivalizáló historizáló beszédmódok, valamint az egymásra feleselő nemzeti rítusok két tágabban értelmezett nemzetépítési, nacionalizálási folyamatnak a részei". Lásd: Feischmidt 2002, 124. Egy későbbi korszakon vizsgálva a kérdést hasonló következtetésre jut: BÁrdi 2000, 137.

${ }^{396}$ Felicitări la adresa noastră. Clusiu la 28 Marte (9 Aprile) $=$ Gazeta de Transilvania 1884/39.

${ }^{397}$ Vö. Micu (red.) 1880.

398 "Drepturile răpite" = Gazeta de Transilvania 1884/52.
} 
hosszú életet kíván a szerkesztőnek, a lapnak, és az általuk képviselt elvek győzelemre jutattását. 399

Tudni kell, hogy a brassói Gazeta de Transilvania a román passzivisták lapja, akik az 1863/4-es nagyszebeni gyűlés törvényei szerint gondolkodnak - alkotmányellenesen. Bár nagyon tapintatosan fogalmaz Silaşi és nem a lapot, hanem annak szerkesztőjét szólítja meg üdvözletében, a magyarok felfogásában együvé tartozik a diákság és Silaşi sürgönye. A kolozsvári magyarok számára politikai tettként minősülnek ezek a nemzeti szolidaritást jelző gesztusok, és ilyenekként bírálandók. A továbbiakban a Kolozsvári Közlöny és a Gazeta de Transilvania vonatkozó cikkeit vetem össze, illetve állítom párhuzamba azzal a megjegyzéssel, hogy más lapok (Ellenzék, Magyar Polgár - Tribuna, Gazeta de Transilvania, Luminatorul) között is elvégezhető ugyanez az összehasonlítás.

Május 15-én a Kolozsvári Közlöny, ${ }^{400}$ a második oldalon az Egyetemünk ifjúsága a román ultrák ellen címmel beszámol az előző nap történetekről. Azokat a mozzanatokat emelem ki, amelyek kulcsfontosságúak a fejezet szempontjából. Egyértelmü, hogy a magyar egyetemi hallgatók a konfliktus tettleges kirobbantói: gyưlést hívnak össze, követeléseiknek adnak hangot. Mivel illetéktelenek a román lapok ellen bármit is tenni, azok ellen fordulnak, akik szolidaritást vállaltak velük: a román ifjúsághoz és vezetőihez. Követelőzéseik provokatívak: asszimilálni a románságot, betiltani a Iuliát az eperjesi joghallgatók pánszláv egyletéhez hasonlóan, magyar fiatalok is iratkozhassanak be Silaşi óráira, aki tartson magyar nyelvü előadásokat, soha többé ne tekintsék kollégának, barátnak azt a románt, aki aláírta a sürgönyt, vagy aki kivonja magát az egyetemi körből.

A pánszlávizmus mellett a dáko-román eszmék is felerősödnek a 19. század utolsó évtizedeiben, amit a magyarországi román közösségben a román ultrák, a passzivisták képviselnek. A Iulia-egylet, Silaşi, az erdélyi román lapok és a dáko-román eszmék összetartozásának példázására Sándor Józsefet idézhetem, illetve ezen eszme koncepciózus használatára azt a Bukarestben megjelent román irodalomtörténeti munkát, amelyet Eminescu kapcsán már említettem. ${ }^{401}$

\footnotetext{
${ }^{399}$ Gazeta de Transilvania 1884/55.

${ }^{400}$ A Kolozsvári Közlöny kormánypárti, szubvencionált napilap, 1886-ban a Magyar Polgár című balközép lappal egyesülve Kolozsvár néven működik tovább. Ez utóbbi kapcsán lásd: Töвӧк 2002.

401, „[...] az 1876-ban elővigyázatlanul miniszterileg engedélyezett egyetemi ifjúsági egyesület, ellentétben az egyetem szabályaival és elzárva magát a magyar ifjúságtól, felnőtt dákoromán izgatók vezetése alatt áll s román középiskolai tanulókat és iparosokat is bevonva sorai közé, a »válaszfalak ledöntése « végett bécsi, bukaresti, jasii, csernovici, balázsfalvi és más diákokkal is összeköttetésben áll. Magyarajkú ifjút jelentkezésre nem fogadnak be s az egyetem ingyen felajánlott helyiségét is a kis Dákorománia érdekében visszautasítják" . = SÁNDOR 1910, 39., illetve a Dácia[!] területének irodalomtörténetét 1875-ben áttekintő munka: Pop 1875.
} 
A Iulia vezetőinek ablakai alatt tartott macskazenét a rendőrség nem akadályozza meg, sem az azt követő Biasini szállói mozzanatot. A Kolozsvári Közlöny sem helyesli a gyưlés végkimenetelét: a macskazenét, a románok lakomájának bojkottálását (magyar nemzeti dalok éneklése, zajongás, majd a Rákóczi-induló felcsendülésével, magyar sorfalon áthaladó, hazatérő románok). ${ }^{402}$

A Kolozsvári Közlöny nem tekinthető pártatlan lapnak ez ügyben, több szempontból sem. Már a beszámoló címe is jelentést hordozó. A magyar nyelvü, kolozsvári politikai (kormánypárti) napilap, illetve a név nélkül közölt cikk „,egyetemünk"-nek nevezi az intézményt, ezzel pedig a kolozsvári jellegén kívül annak, illetve az ifjúságnak a magyarságát hangsúlyozza. Nem minősíti e magyarságot, a románokat ellenben ultráknak nevezi. Az ellenségteremtés gesztusa munkál e címadásban, és ez a provokálók fölmentése is egyben. Ennek másik jele például a Biasini-beli lakoma megzavarásának értékelése: a magyar diákoknak azért volt joguk a részvételre (betolakodásra) a cikkíró szerint, mert nyilvános térben zajlott.

Másfelől a Gazeta de Transilvania brassói lapot táviratban értesítik a kolozsvári eseményekről. Az alábbiakban e lap nézőpontjából értékelem azokat. ${ }^{403}$ Eszerint a május 15-i emlékezés apropóján veti fel a kérdést a $\mathrm{Ga}$ zeta, de amint láttuk fennebb, a botrány 14-én robbant ki. A magyar laphoz képest a román a görög katolikus templom kapujának betörését is tudni véli, illetve azt, hogy a Biasini Szállóban tettlegességre is sor került, miáltal a kolozsvári románság közbiztonságát veszélyeztetettként látja. A szent helyként értelmezett templom megkárosítása csak súlyosbítja a magyarok kulturálatlan viselkedését, provokáló magatartását, amellyel a Iulia-egylet beszüntetésére keresik az okot. A csendháborítók e lap szerint is a magyar egyetemi hallgatók, akiket viszont a kolozsvári magyar lapok románellenes cikkei buzdítanak. Kölcsönös tehát a lapok vádaskodása, ebben mindkét fél egyenlően kiveszi a részét, mint ahogy az egyetemi ifjúság befolyásolásában is. Az a konfliktus, ami a publicisztikában az egymásra figyelés következtében kialakul, és igazságtalan ellenségeskedésként, ferdítésként értelmeződik a másik fél számára, túlmutat önmagán. Az egyetemi ifjúság erőszakos módot választ e mindkét fél által provokált konfliktus megoldására.

A román újság lapzártakor kézhez kapott cikket közöl, amely a kolozsvári magyar lapok vonatkozó írásait foglalja össze. E román nyelvű cikk is hangsúlyozza a Kolozsvári Közlönynek a történtekkel kapcsolatos nemtetszését, és hozza a lap tudósítását a május 15-e előestéjének botrányáról,

\footnotetext{
${ }^{402}$ Egyetemünk ifjusága a román ultrák ellen = Kolozsvári Közlöny 1884/113. [laptulajdonos szerkesztő Békésy Károly, Kolozsvár]

${ }^{403}$ A sorrend, miszerint a magyar lap után szemlézem a románt nem megkülönböztető vagy értékelő jellegü, hanem az eseményre való figyelés sorrendjéhez illeszkedik.
} 
amelyet az egész román nemzet inzultálásaként értelmez, ${ }^{404}$ mint ahogy a Stadler-kerti majálison a magyarok jelenlétét. ${ }^{405}$ Ugyanez a cikk utal Silaşi nyilatkozatára, amelynek létét megkérdőjelezi a Gazeta szerkesztője; de arra is, hogy a magyarok elégetik a Gazeta azon számát, amelyben a kolozsváriak közbiztonságáról írnak. Amint látjuk, május 18-án a Gazeta a magyar lapok perspektívájából is értesül a történtekről és kiegészítő információkhoz jut hozzá. Ilyen például a templomgyalázás vagy egy Justus álnevű tudósító adatai: a román diákok 15-én nem tudnak egyetemre menni, miközben hatvan magyar diák megzavarja Silaşi előadásait (lábtörlőket dobálnak be a terembe, elkergetik a románokat, Silaşi után kiabálnak).406 Justus tudósításai és a kolozsvári táviratok szolgáltatják az anyagot a $G a-$ zetának, ezekből válogatja a különböző információkat.

Május 17-én a Kolozsvári Közlöny így tudósít: „egyetemünk ifjúsága a rend fenntartása [kiemelés tőlem - B.T.], s a netalán mutatkozó kihágások megakadályozása céljából majdnem teljes számban jelent meg a Stadlerkertben azon elhatározással, hogy a mulatság végéig ott marad, s minden a bál ellen irányuló tüntetést megakadályoz" ${ }^{407}$ Május 18-án napi hírként olvassuk, hogy az egyetemi ifjúság román lapokat égetett előző nap. Gesztusuk demonstratív magatartásukról árulkodik, amit az is erősít, hogy délben dobszóra vonulnak ki a Főtérre, majd a város falain kívülre, hogy a román lapokhoz „méltó” helyen Kossuth-nóta és Rákóczi-induló kíséretében semmisítsék meg szimbolikusan az izgató román sajtót. ${ }^{408}$

A Gazeta vezércikkben értekezik erről az eseményről május 20-án, bár 18-án már hírt adott róla. A brassói lap, amint látjuk, késlekedve tudósít a történtekről. E késlekedést több minden magyarázza: elsősorban a fizikai távolság, ami elválasztja az események helyszínétől, csak másodkézből értesülhet róla, tudósítói hírei, a táviratok az események után érkeznek, ezek egyben értelmezései is az eseménynek, amelyeket a Gazeta átvesz, vagy továbbgondol. Kitünik stratégiája: folyamatosan figyel a magyar lapokra a szerkesztőség vagy a tudósítók révén. Érdekesnek tünik érvelése az események kapcsán: a botrány a magyar diákokat, a kolozsvári magyarokat minősíti, ez pedig visszájára fordítja azt az érvet is, miszerint a magyarok a kultúra hordozói Magyarországon, a Keleten.

Dr. Szilasi[!] szerkesztőhöz írott nyilatkozatát, amelyben azt cáfolja, hogy hazafiatlan lenne, hogy üdvözölte volna a Gazetát, azzal egészíti ki a szerkesztőség, hogy nem kutattak Silaşi után, ennélfogva értelmetlen ez a

\footnotetext{
${ }^{404}$ 3/15 maiu in Clusiu = Gazeta de Transilvania 1884/63. [red. Iacob Mureșanu, Brașov, tipografia Ioan Gött]

${ }^{405}$ Scrieri telegrafice. Clusiu 17 maiu = Gazeta de Transilvania 1884/65.

${ }^{406}$ Tulburarile din Clusiu = Gazeta de Transilvania 1884/65.

${ }^{407}$ A május 15-ki román bál = Kolozsvári Közlöny 1884/114.

${ }^{408}$ Vö. Napi hírek. Román lapok megégetése = Kolozsvári Közlöny 1884/115.
} 
nyilatkozat, hozzátéve, hogy: „,csupán azt tapasztaljuk, hogy az egyetemi román ifjúság egy része, amely előadásait is hallgatja, hazafiatlan irányba indult s ez volt, amit megróttunk, s amit ezután is meg fogunk róni". ${ }^{409}$ Bár egy táviratban a Gazetát is értesítik a nyilatkozatról, a szerkesztő furcsállja, és kérdésként ékeli be a tudósításba, hogy hol nyilatkozta ezt Silaşi. A Iulia-egylet sértett félnek tekinti a Gazetát és nehezményezi az ellene indított vizsgálatot.

Látjuk, tehát, hogy az egymásra figyelő magyar és román lapok ugyanazt a stratégiát követik: a másik lap vonatkozó cikkeiből tallóznak, vagy egészében közlik, a másik fél lapjait nemzetiségi izgatással vádolják, miközben gesztusaik kölcsönösek. Oda-vissza működik mindez, ördögkerékként.

Ha összegezni próbáljuk ezt az alfejezetet, akkor a román nemzetiségi önszerveződés zárt, provokatív magatartását látjuk szembekerülni a kolozsvári magyar egyetemi hallgatókkal. Első látásra nem egyenlő felek vesznek részt a konfliktusban. Az áttekintett sajtóanyag viszont azt is bizonyítja, hogy a Iulia-egylet mögött nemcsak az egyetemi tanár és néhány kolozsvári román értelmiség áll, hanem a Gazeta de Transilvania lap is. A botrány kirobbanása után pedig sikeresen sorakoztatja fel e lap például a szebeni, bukaresti román fiataloknak a meggyalázott kolozsváriakkal együttérző nyilatkozatait. Nemzetiségi, sőt nemzeti üggyé minősül mind Silaşi fölmentése, mind a Iulia-egylet feloszlatása, azaz ami eredetileg helyi konfliktus volt. A veszteségek ellenére pozitív nyeresége van a (kolozsvári) románságnak, ez pedig nem más, mint az összetartozás érzésének, a nemzeti öntudatnak a megerősödése. Mindeközben erőteljesen hangsúlyozódik körükben, hogy az ellenük fellépő magyarok tettei visszájára fordíthatóak, önminősítőek is egyben: érvként szolgálnak a barbár, kulturálatlan viselkedés, a nemzetiségi jogok be nem tartása felemlegetésekor. ${ }^{410}$

A magyar egyetemi hallgatók nem számíthatnak olyan típusú értelmiségi támogatókra, mint a románok. Csupán az egyetemi kör mint intézmény szolgáltathat fedezetet számukra. Ők az egyetemhez tartozókként lépnek az egyetemen kívül szerveződő románok ellen. Ez azt is jelenti, mint ahogy a botrány következményei is mutatják, hogy az egyetem nem az egyetemi diákszervezetet oszlatja fel, holott az az érdemi kirobbantója a konfliktusnak, hanem a román egyletet. A rendőrség a magyar fiatalok mellett áll, hiszen nem lép közbe sem 14-én, a "macskazenekor”, sem a Biasiniben, sem a lapégetéskor. A magyar sajtó is mellettük foglal állást, amennyiben ultráknak, agitátoroknak, provokálóknak nevezi a román la-

\footnotetext{
${ }^{409}$ Dr. Szilasi nyilatkozata = Kolozsvári Közlöny 1884/116.

${ }^{410}$ Vö. KoselLeck 1997.
} 
pokat, a Iulia-egyletet. A Magyar Polgár c. lapból például a Gazeta azt emeli ki, hogy a lap a magyar diákok szép tüntetésének nevezi az eseményt. ${ }^{411}$

A konfliktus kimenetele a hatalom müködésének bizonyítéka: az államnak, a vallás- és közoktatásügyi miniszternek, az egyetemnek, illetve a magyar egyetemi hallgatóknak jogában áll a - (fizikai) erőszakos - kontroll és „igazságtétel”, amikor Magyarország egységének illúzióját veszélyeztetve látják.

E feszültségteljes kapcsolat további eseményekben bővelkedik: 1892 és 1894 között a román hallgatók ellen indít fegyelmi eljárást az egyetemi tanács nemzetiségi izgatás vádjával, ugyanis a diákok bekapcsolódtak az ún. Memorandum- és Replica-pörökbe. Az értelmiségi vezetők és egyetemi diákság szoros kapcsolatát példázzák ezek a politikai jelenségek: a diákok azonosulva a röpiratok felhívásaival, politikai üzenetével, részt vállalnak azok terjesztésében, és amikor az egyetemen ezért kihallgatják őket, tetteiket nemzeti szerepvállalásként értelmezik, bátran állnak elébe a fegyelmi kivizsgálásnak. ${ }^{412}$

A kolozsvári állami magyar egyetemre beszivárgó nemzetiségi kérdés problematikusságát, illetve a magyar és román, értelmiséginek készülő fiatalok kapcsolatának konfliktusosságát mutatja ez az alfejezet. Az egyetemi hallgatói státus és a vele járó kötelezettségek mellett az egyetem és az azon kívül szerveződő társadalmi létformák (egyletek, egyesületek), de a kolozsvári, többnyelvü, többkultúrájú társadalom mind befolyásoló tényezői a beiratkozó diákságnak.

\section{4. Összegzés}

A románként azonosított bölcsészhallgatók prozopográfiai leltározása, életpályájuk egyetem utáni alakulása új szempontokkal gazdagították a kötetet. A vizsgált értelmiségi pályák alakulása felől a diákság adatai egyetemtörténeti jelentőségük mellett sajátos forrásai mind a kapcsolattörténetnek, mind a nemzetiségtörténetnek.

A román diákok egyetemlátogatási stratégiái kapcsán fontos megjegyezni azt, hogy a diákszámban alulreprezentált bölcsészkar egyik előnyét az jelentette, hogy az ott tanító tanárok kiscsoportos előadásokat vagy gyakorlati jellegü órákat vezethettek, és ez az oktatás minőségét is befolyásolhatta, nem beszélve az interperszonális kapcsolatok kialakulásának lehetőségéről. ${ }^{413}$ A kapcsolattörténet e példája a konfliktusokkal terhelt viszonyokat mutatja meg, illetve olyan kulturális találkozásra világít rá,

${ }^{411}$ Gazeta Transilvaniei 1884/67.

${ }^{412}$ A kérdésről bővebben lásd: KEMÉNy 1956, 1-13., 18-27., 249-250., 265-266.

${ }^{413}$ KARÁdy (bölcsészkarok). 
amely sajátja a kor új vallásának: a nacionalizmusnak. Amint láttuk, a 19. század utolsó, a 20. század kezdeti éveinek román egyetemi hallgatói minden adódó alkalommal részesei voltak a román nemzetiséget foglalkoztató politikai eseményeknek. A nemzetiségi kérdéseket tárgyazó egykorú iratok bizonyítják szerepvállalásaikat, de azt is, hogyan politizálódtak át olyan események is, mint például a felekezeti püspök- és érsekválasztások, amelyek kiváltották a nemzetiségek tiltakozását, és esetünkben a román egyetemi ifjúság állásfoglalásait. ${ }^{414} \mathrm{~A}$ század végétől hangsúlyosabban erősődő politikai szerepvállalás az egyetemen kívülre mutat. E kifelé tartó erőt az állami magyar intézmény, de a magyarországi törvényhozás és joggyakorlat közötti diszkrepancia, az államnemzet és nemzetiségek közötti viszonyok megoldatlansága táplálja. A szakmai preferenciák számos esetben ide kapcsolódnak, gondolok itt azokra a szakmákra, szabad foglalkozásokra, amelyek népszerüek voltak a román diákság körében: ügyvéd, tanár, tanító, lelkész, hiszen e foglalkozások művelői, elképzeléseik szerint gyakorlatban eredményesebbek voltak a nemzeti közösség építésében, formálásában.

A hatalmi fölényt reprezentáló magyar nyelv mint az egyetem hivatalos nyelve, illetve a hiányzó magyarországi román egyetem, a nemzetiségi nyelvek mint tanítási nyelvek hiánya a felsőfokú intézményben több következménnyel jártak. Kettőt említenék ezekből. Egyfelől a doktori tézisek a román irodalom fontos alakjainak életműveit vizsgálják. Ha az egyetemi beiratkozáskor fontos lett volna már kezdettől a diákok szakválasztása, akkor pontosabban lehetne látni azt, hogy például a hivatkozott értekezések szerzői milyen szakos diákok voltak. Hiszen nem lehet közömbös szempontunkból az, hogy egy magyar-német, egy történelem-földrajz vagy egy román nyelv és irodalom szakos diák ír-e például George Coşbucról. Ennek hiányában mégis állítható, hogy nemzetiségi identifikációs gesztusként is értékelhető témaválasztásuk. A visszakereshető doktori értekezések témaválasztása elhatárolódik például speciális grammatikai kérdések tárgyalásától annak ellenére, hogy mind az oktatási kínálat, mind az egyes nyelv és irodalom tanszékek mellett működő, differenciálódó nyelvészeti tudományágak lehetővé tehették volna azt.

Másfelől a magyar nyelvü oktatás, amint a Iulia-egylet múködése is példázza, problematikusként mutatkozott a román nemzetiségű hallgatók és első tanáruk számára, de homogenizáló erővel bírt. Miközben a román szerzőjű doktori hallgatókat és munkáikat távol tartotta a recepciójuk szempontjából alapvetően fontos román nyelvtől, egy későbbi kapcsolattörténészi nézőpontból a román irodalom magyar recepciójának humanisztikus előfutáraivá léptette őket. Ez az egyszerü tény: az egyetemi

${ }^{414}$ KeMÉNY 1956, 96-100., 830-832. 
oktatás hivatalos nyelve a nemzetiségi hallgató számára tehát a másik és a saját kultúra felől másként értelmeződik. Egy másik, nem nemzetiségi nyelv használata később a saját nemzeti kultúrából szorítja ki az értekezőt, és ebben nemcsak a nyelvhasználat a ludas, hanem a nemzetivé váló saját kultúra hatalomgyakorlása is, aminek következtében az kevésbé értékesnek tünteti föl az (állam)nemzeten kívül élő, monarchiabeli tudományos munkásságot.

Ha a kapcsolattörténet egy másik aspektusához csatoljuk a magyar nyelvű oktatás kérdését, akkor például a fordítók, a közvetítők kilétét is másként értékelhetjük. Az 1895 és 1919 közötti időszakban egyetlen diákot találtam a kolozsvári egyetem bölcsészettudományi karán, aki a román nyelv és irodalom szakra úgy iratkozik be, hogy nem román nemzetiségü. Farkas Vajna/Vajna Farkas izraelita vallású kereskedő fia, Magyarbrettyén született, két félév erejéig magyar-francia szakos rendkívüli hallgató. Valószínűleg Hunyad-vidéki származása tette lehetővé jártasságát a román nyelvben, hiszen az egyetemen már akkor sem fordítottak figyelmet a nyelvtanításra, hanem az adott nyelv nyelvtani és irodalmi problémáival ismerkedhettek meg a hallgatók. Ehhez képest más nyelv és irodalom szakon nem gyakori a szakválasztás és anyanyelv megfeleltetése. Természetesen az anyanyelv és más, ma idegen nyelvként megnevezett nyelv ismerete nem különíthető el nagyon élesen, hiszen az egyetemi hallgatóság ekkor még többnyelvü, többkultúrájú társadalomban szocializálódott. Mégis arra a következtetésre jutunk, hogy a nyelvismeret döntő erejű a diákok szakválasztásakor, és hogy egyediként, rendkívülinek tűnik a nem román nyelvű hallgató román szakválasztása. Ez az adat és kontextusa azt bizonyítja, amit a kapcsolattörténeti kutatásokból tudhatunk, de hangsúlyoznunk kell, jelesül, hogy a 19. század vége román irodalmának első fordítói: Ion S. Bădescu, Iosif Vulcan, Petre Dulfu, Grigore Moldován, Simon Desseanu (Vasile Alecsandri), Laurențiu Bran (Mihai Eminescu, Matilda Cugler Poni, Octavian Goga, Alexandru Vlahuță) román anyanyelvűek. A már említett történész Márki Sándor a bihari román írók bemutatásakor ${ }^{415}$ azok munkáiból magyar nyelvű mutatványokat közöl, de lábjegyzetben hozzá is teszi, hogy tanítványa, Iuliu Drăgan segítségével sikerült megértenie a szövegeket. A közvetítéssel végzett fordítás eszerint nagyon más elvi megfontolásokat követ, mint például a kortárs fordítástörténeti, -elméleti munkák. Ritka az a fordító, közvetítő, mint például Sándor József, aki neveltetési helyének és politikusi érdeklődésének köszönhetően ismeri és gyakorolja a román nyelvet. A fordítás esetében a két nyelv közötti átjárás kezdeményezői a románok, akik egy olyan nyelv birtokosai, amely a

${ }^{415}$ MÁRKI 1881. 
magyarok számára a 19. század végén, a 20. század elején a közös történelem ellenére is ismeretlen maradt. ${ }^{416}$

A román irodalommal foglalkozó, román hallgatók által írt doktori értekezésekben a román kultúra szintén nem saját nyelvén mutatkozik meg. A román irodalom magyar recepciója tehát csak nyelvében válik magyarrá, hiszen román tolmácsolók és értekezők közlik magyar nyelven a román kultúra nagyon szűk szeletét, főként a költészet egyes darabjait, költők életművét. A nyelvi különbségek, a nyelvismeret hiánya tartja távolabb a fordítással foglalkozó magyar anyanyelvű írókat a román kultúrától, illetve ez a hiány építheti ki a másik kultúra befogadásának olyan alrendszereit, ahol irodalmon kívüli célok (bemutatni, megismerni-ismertetni, elfogadni) politikája szervezi a közvetítést.

${ }^{416}$ A népszámlálások vonatkozó kérdésének (anyanyelv és második beszélt nyelv) vizsgálatakor 1888 és 1900 között a magyar „anyanyelvűek” 3\%-a nyilatkozta azt, hogy „elsősorban románul is beszélő". Vö. GYÁNI-KövéR 1998, 141. 



\section{KOLOZSVÁRI ÉRTELMISÉGIEK. EGYETEMI OKTATÓK ÉS IDENTITÁSAIK A 19. SZÁZAD UTOLSÓ ÉVTIZEDEIBEN}

Az egyetemi oktatás közelében maradva, jelen fejezet néhány kolozsvári értelmiségi (egyetemi tanár) viselkedésmódját tárja fel oly módon, hogy életrajzi adataikat, karriertörténeteiket, illetve primér, szekundér, nyomtatott és kéziratos-levéltári források felhasználásával értelmiségi identitásukat (re)konstruálja. Az előző fejezet kérdésfelvetésénel a bölcsészkar vizsgálatát legitimáló egyik érv amellett szólt, hogy a szakmai és etnikai identitás különböző értelmiségi koncepciói összefüggésbe hozhatók mind a kapcsolattörténettel, mind a nyelvi-nemzeti identitás kérdésével. Azért foglalkozom Meltzl Hugó, Brassai Sámuel és Grigore Moldován alakjával, mert mindhárman sajátosan gondolkodtak nyelvről, kultúrákról, az ezek között kialakítható kapcsolatokról és közvetetten vagy közvetlenül saját nemzeti identitásukról. Olyan sajátos vállalkozásokban vettek részt, amelyek e gondolkodás reprezentációs közegei voltak. A (nemzetiségi) egyetemi tanárok interperszonális kapcsolatainak vizsgálatára is kitérhetünk. Közösnek látszik helyzetük, hasonlóak oktatói lehetőségeik. Vállalkozásaik, elméleti gondolkodásuk és tudományos munkásságuk identifikációs szempontból is érdekesek.

A korábbi alfejezetek megerősítik annak tényét, hogy a román nyelv és irodalom oktatása nem vonzotta az egyetemi hallgatókat. A román bölcsészhallgatókat viszont megtaláljuk Meltzl előadásain, német nyelvet gyakorló „practicumain”. Azért tulajdonítok ennek jelentőséget, mert, a fentiek alapján többletjelentőséggel bírhatnak a közös jegyek: nemzetiségi diákok és oktatók kapcsolatai, magyar nyelven oktatott idegen nyelvű irodalmak szerepe és presztízse a nemzetiségiek körében, esetleg az oktatási helyzeten túlmutató közös identifikációs problémák. 


\subsection{Többnyelvüség - nemzeti és egyetemes}

\subsubsection{Meltzl Hugó}

A kolozsvári egyetem által kiállított végbizonyítványok az 1900-as évek elejéig a hallgató adatai mellett tartalmazzák az oktatott tantárgyakat, azok előadóit is. ${ }^{417}$ A végbizonyítványok csak a karra vonatkozó adatokat tartalmazzák, a diákok szakosodását nem jelenítik meg. Ennek ellenére a hiányos adatok beszédesek. Például az 1898-ig kiállított végbizonyítványokon néhány román hallgatónál felbukkan Meltzl Hugó neve és az általa előadott - filozófiai esztétika és kritikai münyelv vagy a filozófia története - tárgy. Egy diák esetében szerepel több tárggyal Meltzl, és ez alapján arra következtethetünk, hogy német szakos volt a román Sztója Miklós (1895-1900-ig diák), hiszen speciálisabb kérdésekre utalnak az előadások címei. ${ }^{418}$ Ezek az adatok és a későbbiekben vizsgálandó szövegek árnyalhatják Meltzl Hugó alakját, és mindazt, amit az összehasonlító irodalomtudomány megalapítása és a kolozsvári Acta Comparationis Litterarum címü lap kapcsán az eddigi szakirodalom ${ }^{419}$ tartalmaz. A hivatkozott írások föként Meltzl nevéhez kötik a lapot, annak ellenére, hogy a társszerkesztő Brassai Sámuel munkássága és különcként értelmezett alakja ugyanolyan jelentős ebben a kérdésben.

A világon egyedülálló kezdeményezésként Meltzl Hugó és Brassai Sámuel folyóiratot szerkeszt Összehasonlító Irodalomtörténelmi Lapok/Acta Comparationis Litterarum címmel 1876/77/-től 1887-ig. Ez a poliglott lap a goethei világirodalom-fogalom mentén ${ }^{420}$ gondolkodik az egyes nemzeti

${ }^{417}$ Végbizonyítványok. 1893/4-1898/9, 1899/1900-1903/4, 1907/8-1910/11, 1911/12-1914/15. [A kézirat lelőhelye: Román Állami Levéltár, Kolozsvár. Jelzete: Fond 315, reg. 46., 59., 80., 90.]

${ }^{418}$ Meltzl 1895 és 1900 között tartott előadásai Sztója Miklós végbizonyítványa alapján: Wulfika és gót nyelvgyakorlatok (heti 1 óra), Sheffel József Győző és kortársai 1826-1876. (heti 2), Modern újfelnémet stil és nyelvgyakorlat (heti 1), Goethe-Schiller-féle Xenia-év 1796, Irodalomtörténeti dolgozatokkal (heti 2), A német nyelv és irodalom története synchronistikai s kritikai átnézete Heljandtól Faust II-ig (heti 3), Irodalmi illemtan alapvonalai (heti 1), A német müvelődés és irodalom kritikai történelme (heti 4), Ôskelta-teuton mitológia (heti 2), Az actualis vagyis legmodernebb német irodalom analyticai átnézete (heti 2), Bevezetés a kritikai irodalomtörténetbe (heti 3), A Tacitus-féle Germánia (heti 2), Faust II és Paralipomena olvasása (heti 1).

${ }^{419}$ Kozma 1969, Engel 1972, GaAl (szerk.) 1975, Dávid 1976, VAjda 2000, 48-69., illetve legutóbb: Fassel (hrsg.) 2002, Damrosch 2007, Fried 2007, Illyés 2008, Kozma 2009.

${ }^{420}$ Eckermann tolmácsolása szerint Goethe így vélekedik: „Így hát én szeretek körülnézni idegen nemzetek háza táján, és mindenkinek azt tanácsolom, hogy cselekedjék ugyanígy. A nemzeti irodalom manapság nem sokat számít, a világirodalom korszaka van most soron, és mindenkire az a feladat vár, hogy siettesse ezt a korszakot. De bármennyire is becsüljük is azt, ami külföldi, nem szabad valami különöshöz odatapadnunk, és azt mindenáron mintaképnek tekintenünk. Nem szabad azt gondolnunk, hogy ami kínai, az lenne az a bizonyos, 
irodalmak viszonyáról oly módon, hogy nem rangsorolja a nemzeti irodalmakat (már az első lapszám 14. oldalán megjegyzi, hogy egyik nyelv ne tartassék különbnek a másiknál ${ }^{421}$ ), hanem a kis népek irodalmait is értékeik felől közelíti meg a kölcsönös megismerés, elismerés és értékcsere szellemében. E kezdeményezés, annak ellenére, hogy számos külföldi munkatárs közreműködésének örvendhet és újszerü elképzeléssel viszonyul a nemzeti irodalmakhoz, a fordítás kérdéséhez, szűk körű olvasóréteggel rendelkezik éppen nyelvi jellege miatt, aminek tényével a szerkesztők is számolnak a lap indításakor. ${ }^{422} \mathrm{Az}$ Egyetemes Philologiai Közlöny és a német Max Koch 1887-es összehasonlító irodalomtörténeti vállalkozása ellenére a Meltzl-Brassai-féle lap nem merült feledésbe, sőt napjainkban egyre több figyelem övezi. ${ }^{423}$

Egyetértek Komáromi Sándorral ${ }^{424}$ abban, hogy a sajátos lapvállalkozása mellett Meltzl további munkásságát is be kell vonni életmüve vizsgálatakor. A végbizonyítványok adatai, egyéb kéziratos források egészíthetik ki a nyomtatásban megjelent Meltzl-szövegekből megragadható koncepciót, olyanok, amelyek Komáromi tanulmányából is hiányoznak. Ezek a poliglott lap szinkron kontextusaiként müködnek. Ezért a lapot csak érintőlegesen hozom szóba, és inkább az eddig figyelmen kívül hagyott források segítségével kísérlem meg munkássága értelmezését.

vagy ami szerb, vagy Calderón vagy a Niebelungok; hanem mintaképre szorulva, térjünk mindig vissza a régi görögökhöz, akik müveikben szüntelenül a szép embert ábrázolták. [...] [a költő] jól teszi, ha fokozatosan megismerkedik minden bel- és külföldivel, hogy megtudja honnan meríthető olyan magasabb rendű világi müveltség, amilyenre a költőnek szüksége van". = Riтоóк 1975, 105., 157. [fordította Györffy Miklós] Illetve a kérdés értelmezéséhez lásd: DAmRosch 2007.

${ }^{421}$ Acta Comparationis Litterarom Vniversarvm. Összehasonlitó Irodalomtörténelmi[!] Lapok, editores et ordinatores dr. Samuel Brassai et dr. Hugo Meltzl, J. Stein, Claudiopoli, 1879, vol. I., 14. [A továbbiakban ACLU]

${ }^{422}$ „Lapunk, mely eredetileg csak két évre volt tervezve, folytatni fogja - bene vixit qui bene latuit - utját jövőre is, csak hogy latin és magyar föcímmel. Mindazon által testestől lelkestől magyar lap marad, um. eddig, ezentúl is, mindörökké, s kérjük azt a kis, de disztingvált és állandó olvasókört, melyet hazánkban volt szerencsés magának szerezni, hogy méltóztassék becses figyelmére méltatni, az idevágó német idézetünket." [A lap mottója Schiller, Epistola ad Körner-ból származik, latinul szerepel a címlapon] ACLU 1879/1, 3.

${ }^{423}$ Nyilván legitimázló szándékokra is ismerhetünk mind a romániai (kolozsvári) magyar, mind a román értelmezések és a Horst Fassel kiadása mögött. A lap egyetemtörténeti jelentősége válik hangsúlyossá, ennek következtében pedig a kolozsvári egyetem európai vagy nemzetközi presztízse is elötérbe kerül. A lap iránti fokozottabb érdeklődés annak is köszönhető, hogy a posztkolonialista kritika és az új kultúratudományok módszertana felől ismét beláthatóvá és egyre értékesebbé válik.

${ }^{424}$ Koмáromi 2005. 
Az Országos Széchényi Könyvtár őrzi Meltzl Hugó egyetemi tanárságával kapcsolatos iratait. Meltzl 1877 júliusában készített jelentést tanári munkája első öt évéről. Holtzmann Adolf, heidelbergi tanára ${ }^{425}$ előadásainak kéziratai alapján tanítja az Edda-dalokat (ezek kapcsán nyelvtörténetet is), az eposzt, Lessing Laokoónját, Schopenhauert, Karthauzit, Petőfit. Előadásai tárgyait rendszerezve, azokat „fő - ó és modern, mellék - szigorú szakmabeli - ó és modern" 426 tárgyakra osztja. Amint látjuk, melléktárgyként ugyanazt a tananyagot adja elő, mint fótárgyként, de valószínúleg speciális, sajátos szakmai ismeretek előadásának alkalmai ezek, zártabb, mühely-jellegü tevékenységek. A végbizonyítványok kapcsán felsorolt tárgyak kissé különböznek ezektől, és azt jelzik, hogy Meltzl aktuális szakmai tájékozódásához, érdeklődéséhez igazította az oktatott tananyagot. Az sem mellékes, hogy szaktanárként határozza meg magát. Eötvös József pesszimizmusával, Petőfi Sándor és a modern német irodalom kapcsolatával, a müfordítás tanával mint „határtudománybeliekkel” foglalkozik. E határtudománybeli érdeklődés a sajátosan német irodalom felé tájékozódik és keres találkozási pontokat. Ezzel meg amellett érvel impliciten Meltzl, hogy a nyelvi közvetítés „határtudománybeliként” a kommunkációt szolgálja, és általa jönnek létre a különböző nyelvű irodalmak és kultúrák közötti kapcsolatok. Ekkor még kevésbé jelentős kari működése ${ }^{427}$ mellett irodalmi müködéséről is jelent. Úgy gondolja, hogy minden tudományban modern elvvel, összehasonlítással kell dolgozni, a tudományos poliglottizmus híve - „ezt a legutolsó mozzanatot nem szabad félreérteni, a szaktanár nem szól itten az úgynevezett nemzeti irodalomról (költészet), mint a mellyben a szigorú monoglottizmus nem csak jogosult, hanem melyre nézve talán valósággal életkérdéses, de szól a tisztán tudományos

${ }^{425}$ Holtzmann Adolf (1810-1870) 1852-től a heidelbergi egyetem német és szanszkrit nyelv és irodalom tanára. Vö. Allgemeine Deutsche Biographie [http://mdz.bib-bvb.de/digbib/lexika/ adb/images/adb013/@Generic_BookView;cs=default;ts=default;lang=hu - utolsó látogatás: 2012 júliusa]

${ }^{426}$ Meltzl Hugó egyetemi tanári müködésére vonatkozó iratok [A kézirat lelőhelye: OSzK Analekta lit. 4083]

${ }^{427}$ A kézirat szerint ő javasolja, hogy Gyulai Pál esztétikusnak az egyetem ítélje oda a dr. honoris causa címet, amit a kar el is fogad, valamint 1875-ben Finály Henrik prorektorral részt vesz a csernovici cs.k. egyetem megnyitóján. 1888/89-ben a bölcsészkar dékánja: „Philosophie Doctore linguae ac litterature Germanicae Professore publ. Ord., Colegii ad tentandos numeris docendi in schol. Med. Candidatos publice missi socio. Nec non Professore Instituti ad aducandos erudiendorque mun. Doc. Candidato constituti, editore et redactore Actorum Comp. Litter. Univers., nec non Fontium Compar., socio virorum redigentium "Cronica de los Cervantitas", societatis litteriae "Freie Deutsche Hochstift" Francofurti ed Moenum magistro et socio h. C., Academiae Reg. Tanormitanae sodali ad hon., societatis archeologicae et numismaticae Philadelphicae socio per litt. Juncto, societatis Philosophorum Trans. Atlanticae sodali, sodalitatis Lipsiensis academico - philosophicae socio hon Causa". Vö. A kolozsvári m.k. FJTE Tanácsa és doktorai névkönyve I. kötet, 1872/1873 - 1899/1900. [A kézirat lelőhelye: Román Állami Levéltár, Kolozsvár, Fond 315., reg. 111.], majd 1894/95-ben az egyetem rektora! 
irodalomról, melyen épen az ellenkező elv életkérdés". ${ }^{428}$ Azaz az összehasonlításon alapuló tudományos irodalmat mindenképpen nemzetek fölöttinek tartja, ennélfogva egyetemesnek, ezért a többnyelvűség mellett foglal állást, és elkülöníti ettől a természetében sajátos, nyelvalapú nemzeti irodalomfogalmat. Érveléséből kiderül, hogy a poliglottizmus bírálói éppen ezt az elkülönülést nem értik. A többnyelvűség és a tudományosság modern elvének, az összehasonlításnak a kapcsán nem felejti el megemlíteni tanárkollégája nevét, akivel közösen szerkesztik a poliglott Összehasonlitó Irodalomtörténelmi Lapokat.

Meltzl szerint a diglottizmus az aktuális politikai konjunktúra, az Osztrák-Magyar Monarchia következménye: a dualizmusnak megfelelő magyar-német, amely a pesti és bécsi németséghez tartozik, viszont amely a tősgyökeres németség számára torzkép. A bécsi, osztrák németség alól kell emancipálnia magát Magyarország kultúrája ${ }^{429}$ A többnyelvüség így a kultúraközi viszonyokat is átértelmezi felfogásukban és a jelentésben impliciten ugyan, de a Monarchia nemzetiségi sokszínüsége válik a lap egy tágabb kontextusává. Látjuk, hogy Meltzl nemzeti, nemzetek fölötti kategóriákban gondolkodik nyelvekről, többnyelvűségről. A legutóbbi idézet arra is rámutat, hogy a német nyelvű kultúra rétegzett, differenciáltan minősíthető centrumokkal rendelkezik, melyek fölé mégis a nemzetiként definiálható „,tősgyökeres” német kerül. Ezzel a kijelentésével Meltzl saját identitását is felülírja: szász-német származása a tősgyökeres németekhez képest kevésbé legitimálhatja őt német nyelvű íróként. De ne feledjük, hogy miközben a pesti és bécsi németek emancipációját szorgalmazza, nem említi az erdélyi német ajkú közösséget, amelynek maga tősgyökeres tagja.

Meltzl egyetemi jelentését időben megelőzi egy sikertelen pályázata 1875-ben. Az MTA Kézirattára őrzi Budenz József véleményeit tanári kinevezések ügyében. Budenz 1872-től a pesti egyetem összehasonlító nyelvészeti tanszékének rendes tanára, pályázata benyújtásakor Meltzl Hugó már a kolozsvári egyetem nyilvános rendes tanára. ${ }^{430}$ Budenz véleménye Metzlnek a német nyelv- és irodalomtudománnyal kapcsolatos elképzeléseire vonatkozik, ugyanis Meltzl pályázatában egyetemi munkásságá-

\footnotetext{
${ }^{428}$ Meltzl Hugó egyetemi tanári müködésére vonatkozó iratok [A kézirat lelőhelye: OSzK Analekta lit. 4083]

${ }^{429}$ Uo.

${ }^{430}$ Valószínúleg a Riedl Szende halála után 1873-ban megüresedett német nyelv és irodalom tanszékre pályázik, ahol Heinrich Gusztáv helyettesként tanít, és 1875-től, tehát a szóban forgó pályázat kihirdetése évétől rendes tanár lesz. Vö. A felsőoktatásügy Magyarországon. Az 1896-i ezredéves országos kiállítás alkalmára a Vallás- és Közoktatásügyi m. Kir. Ministerium megbízásából, Bp., Hornyánszky Viktor könyvnyomdája, 1896. Riedlről és Heinrichről bővebben lásd: SzINNYEI [http://mek.oszk.hu/03600/03630/html/ - utolsó látogatás: 2008. február 25.]
} 
val érvel. A kritikai irodalomtörténet fogalmáról írott dolgozatát nagyon ironikusan bírálja Budenz, az intézményileg felhatalmazott, németországi születésű bíráló, akinek módjában áll ítélkezni. Meltzlben a kezdő tanárt látja. Sőt, nem ért egyet irodalomtörténet-fogalmával, hiszen a pályázó ebben a munkájában „egyszerre nekiront a német irodalomtörténet nagy nevü képviselöinek (Gervinus, Koberstein, Winkernagel, Scherz, etc.), hogy azok »szellemtelen böngészek, kik az irodalmat minden föelv mellözésével adják eló, jobban tennék, ha valami kézi mesterséggel foglalkoznának", mert nem sejtik amit csak ő talált föl, hogy az irodalmat a kritika álláspontjáról az igazság elve szerint kell tárgyalni. Ezen, úgymint kritikai elve szerint az irodalomnak tkp. csak a lángész íróknak világra szóló munkái lehetnek irodalomtörténet méltó tárgyai, mert »költő ki kizárólagosan saját nemzetének élt és írt az irodalom kritikai történetében nagyon alárendelt szerepet játszhat«. S így különösen kárhoztatja az irodalomtörténet azon fölfogását, mely az irodalomban a nemzet szellemi életének fơtükrét látván az irodalomtörténetét is a nemzeti történet kiegészítő részének veszi: »a nemzeti irodalom modern barbár fogalma «" ${ }^{431}$ Eltérő irodalomértési stratégiákra ismerünk Budenz véleményéből: Meltzl szerinte csupán a világirodalmi teljesítményű magyar munkákat értékeli, és ezt etikai mércével teszi, míg Budenz számára az irodalomtörténetnek nemzetreprezentációs funkciói vannak. Meltzl, mint látjuk, a „nemzeti irodalom” elvéhez képest holisztikusabb nézőpontból, a világirodalmi szintű értékek kritikai elve felől szervezné újjá az irodalom történetét. A modern, nyelvalapú irodalomfogalmat értelmezi eltérő módon: „[a] nyelv azon tér, hol a legnagyobb írónak is nemzetinek lenni nem csak szabad, sőt szükségképpen lennie kell"432, viszont a nemzeti nyelv szükségszerü használata önmagában nem elégséges a minőségi, azaz világirodalmi szinten is értékes irodalomhoz. A nyelv - Meltzl érvrendszerében - olyan eszköz tehát, amely azonos értékü az egyes népek és nemzetek esetében. Eszerint nyelvileg nem hierarchizálhatóak a kultúrák. A nyelv kérdése mozgatja mind Meltzl teoretikus elképzeléseit, mind a nemzeti és nemzetek közötti irodalmi viszonyokat. Innen származik a többnyelvűség mint lapszervező elv. Az európai nyelvekhez tartozó szövegeken kívül tanulmányok vagy fordítások által a korban egzotikusnak látszó kultúrák is bekerülnek a lapba, főként a népköltészeti közleményeket tartalmazó Symmikta-rovatba, ezzel antropológiai jelentőséggel ruházva fel a kiadványt. Az antropológiát a lapszerkesztők etnológia értelemben használják már lapuk missziójának közlésekor, ahol ez a fajta érdeklődés az irodalmi, költészeti, filozófiai, metafizikai, esztétikai, és kritikai szempontok

\footnotetext{
${ }^{431}$ Budenz véleményei tanári kinevezések ügyében [A kézirat lelőhelye: MTAK Kt. Nyelvt. 4 o. 154/1.] - Budenz Meltzl pályázatából idéz és emel ki.

${ }^{432} \mathrm{Uo}$.
} 
mellé kerül. ${ }^{433}$ Ezeket a szempontokat összetve a végbizonyítványokban előforduló Meltzl-előadásokkal vagy a fentebb hivatkozott kéziratos forrásokkal, látjuk, hogy olyan „határtudományok” felé nyit a lap, amelyek a többnyelvűség kérdését interdiszciplináris közegbe vonják. Erre épül rá a nyelvileg reprezentált kultúrák és egymás mellé helyezésükből fakadó kommunikációjuk.

Nyilván, a lap rövid élete, a (szerkesztők által is feltételezett és elvárt, no meg a poliglottizmusból fakadó befogadási nehézségek miatt) szűk olvasóközönség sem járulhatott hozzá az erőteljesen modernként feltüntetett módszertan és sajátosan holisztikus és egyetemessé váló tudományszemlélet kellő intézményesüléséhez. Olyan kezdeményezést jelent ez a lap, amellyel Meltzl teoretikusan már egyetemi tanulmányai alatt és után is foglalkozik ${ }^{434}$, és amely túlmutat a vállalkozáson. Mivel mind egyetemi tanárként előadásaiban, mind egyetemi munkásságára reflektáló másodlagos szövegeiben visszatér tudományszemlélete.

Megfontolandó ebben a tekintetben az az indítványa, amelyet francia szakcsoport felállítása érdekében nyújt be 1890-ben, miután a francia és olasz nyelvészet jogosított tanára lesz Kolozsvárt. Ebből idézek: „A jövő szemesztertől fogva ugyanis szándékom lévén az egyetemen eddig (18 év óta) tartott valamennyi ógermán irodalom történelmi és nyelvészeti ágakról szóló előadásaimat - egyedül a tanárvizsgálati szabályzat követelte gót gyakorlatok kivételével - elejteni, illetőleg ezentúl csak annyiban előadni, amennyiben a komparatív modern tudományos elv posztulátuma hozá tényleg magával, már t.i. amennyiben azok az óromán, in specie az ófrancia irodalommal összefüggenek (p.o. a Chanson de Roland, vagy az óolasz Rinardo e Lesengrino, a Pfaff Konrad Rolandjával, illet. a Reine Vossal stb.) valamint később a modernebb, sőt jelenkori francia ${ }^{435}$ és olasz irodalmakat (p.o. Boileau l'art poétique-jét, Danté Infernoját, Voltaire prózáját, Brunel stb.) legalább két órai egyet. előadásban kitüzni, igen természetes, hogy ily nehéz és messzemenő feladat keresztülvitele, sőt már csak a puszta cél kitüzése is, nevezetesen a mi lokális viszonyaink között-meglehetősen platonikusnak tünnék fel" ${ }^{436}$ Indítványa, mint ahogy egyetemi munkásságát tartalmazó jelentése is szorgalmazza az egyetemi könyvtár állományának bővítését, amely oktatói lehetőségeit tágítaná.

\footnotetext{
${ }^{433}$ ACLU 1877/1, 6.

${ }^{434}$ Lásd külföldi tanárait: Holtzmannt, Bartscht vagy egyetemi tanári munkásságát, publikációit.

${ }^{435} \mathrm{~A}$ tanárképezdében indítana egyórás gyakorlati csoportot, ahol például Hugo, Flaubert, Salambo múveivel, újságirodalommal (Journal des Débats, Figaro, Revue des Deux Mondes) is foglalkozna. Lásd 386. lábjegyzet.

${ }^{436} \mathrm{Meltzl}$ Hugó indítványa francia szakcsoport felállitásáról [A kézirat lelőhelye: OSzK Kt. Analekta 4085]
} 
Látjuk, hogy az ACLU megszűnte nem jelenti tudományszemlélete, módszertana, koncepciója elvetését, sőt inkább annak továbbgondolását, szélesebb körű alkalmazását. Annyiban érdekes itt számára korábban előadott tudományterülete, amennyiben az egy újabb nyelv és irodalom perspektívájából hasznosítható, vagy azzal összefüggésbe hozható. Itt jegyzem meg, hogy a Meltzl által platonikusnak értékelt lokális viszonyok is relatívan értendők, hiszen ekkor már mind a francia, mind az olasz nyelvet tanulhatják a diákok, sőt éppen a századfordulón gyarapodik a francia szakos hallgatók száma.

Az ACLU értelmezői valamennyien kitérnek a lap címoldalán szerepeltetett szerkesztőségi tagokra, külföldi munkatársakra, amelyek Meltzl külföldi tanulmányai, illetve Brassai kapcsolathálója révén kerülnek a lap közelébe. Köztük ott találjuk Grigore Silaşit, az egyetem román tanárát, Meltzl kollegáját. Kutatásaim során egy alkalommal találkoztam a kettejük kapcsolatát dokumentáló forrással. Az egyetem bölcsészkarán oktató tanárok minden bizonnyal napi kapcsolatban álltak, az intézmény struktúrájában közös hivatali teendőik voltak: pl. kari gyưlések, tanárvizsgáló bizottsági tagság, periodikusan dékáni tisztség stb. Silaşi kapcsán utaltam már arra a tényre, hogy kettejükben az is közös, hogy doktori fokozattal rendelkeztek, amikor 1872-ben egyetemi tanárokká váltak, külföldi peregrinusok voltak (Bécs, Heidelberg) német nyelvterületen, mindketten nemzetiséginek számítanak a magyar, állami oktatási intézményben. Ez utóbbihoz kapcsolható az a hivatkozás, amelyre pár sorral fennebb utaltam. Traian Pavelea ${ }^{437}$ Silaşi-tanulmányában ${ }^{438}$ az 1884. évi májusi események kapcsán azt állítja, hogy Meltzl Hugó volt az, aki figyelmeztette a román tanárt arra, hogy a diákok botrányt tervelnek ellene. Ezért sikerült Silaşinak elmenekülnie otthonról, a magyar diákok pedig a Fellegváron égették el könyvtárát. ${ }^{439}$ Hogy ez utóbbi mennyire bizonytalan állítás, azt nemcsak egy korábbi fejezetben vizsgáltam ${ }^{440}$, hanem Pavelea tanulmánya két része is arról győz meg. Részint megemlíti, hogy a huligánok megégették Silaşi néprajzi, nyelvészeti, irodalomtörténeti és esztétikai munkásságát őrző kéziratait, nem tudni hol vesztek el, másrészt pedig egy Silaşi-tanítványt, Virgil Şotropát idézi, aki szemtanúként volt jelen; ám Şotropa a Silaşi la-

\footnotetext{
${ }^{437}$ Nyugalmazott tanár, Naszód-vidéki helytörténész, író, kutató.

${ }^{438}$ PAVELEA 1996.

${ }^{439}$ I.m. 155.

${ }^{440} 281$. lábjegyzet és környéke. Az ott hivatkozott tanulmány szintén naszódi szerzők munkája, ezért akár gondolat-hagyományozódásról is beszélhetünk.
} 
kásánál üvöltözők félelemkeltő gesztusaira emlékezik, a lakás feldúlását vagy a könyvtár elégetését nem hozza szóba. ${ }^{441}$

Meltzl gesztusát többféleképpen magyarázhatjuk. Amikor munka- és szerkesztőtársát figyelmezteti, olyan információ birtokosa, ami valószínűleg nem hírértékű Silaşi számára, hiszen azokban a napokban előadásokat tartott, vállalva a következményeket, illetve korábbi tevékenysége révén számíthatott minderre. A kollegialitás és a személyes kapcsolat jelét is felismerhetjük benne. Pavelea információja, miszerint Meltzl, a nem magyar nemzetiségű kolléga figyelmezteti Silaşit, a kettejük közötti szolidaritásra utalhat. A Naszód-vidéki Virgil Şotropa (tanár, történeti munkák szerzője, a naszódi múzeum megalapítója) a kolozsvári egyetemen szerez magyarnémet szakos képesítést. Sajnos nem találtam meg a végbizonyítványát, amelyből egyértelmüen kiderülne, hogy Silaşi tanítványa volt, viszont látva a Naszód-vidéki diákok közösségének erősségét, illetve a Silaşival kiépített kapcsolataikat, feltételezhető, hogy Şotropa is a román tanár köréhez tartozott, amit szemtanúi beszámolója bizonyít. Ellenben Meltzl Hugónak diákja volt. Nos, egy, a Şotropa munkásságát vizsgáló tanulmányban azt olvashatjuk, hogy szerinte "Meltzl de Lomnitz" az egyedüli a kolozsvári egyetem tanárai közül, aki igazságérzettel rendelkezik. ${ }^{442}$ Şotropának magyar-német szakos diákként alkalma volt az egyetem bölcsészkarának különböző oktatóival találkozni, azokat megismerni. A tanárok nemzetiségi identitása különböző volt, a magyar, zsidó tanárok mellett a román és német tanszékek betöltői voltak ún. nemzetiségiek. Meltzl emlegetett igazságérzete szolidaritásából fakadhatott, de joggal feltételezhetjük, hogy sajátos nemzetkoncepciója is segítette megérteni Silaşi és a román nemzetiségü diákok helyzetét. Az etikára, igazságra való hivatkozás kritikai irodalomtörténetének is egyik vezérelve. Mind egyetemi előadásaiban, oktatói munkájában, mind a poliglott lapban egyenrangúaknak, egymásmellettiségükben értékeseknek látja a kultúrákat, ezért sem viszonyulhat másképp a nemzetiségekhez, kis népekhez, illetve azok irodalmához.

Eddig csak érintőlegesen viszonyult a fejezet Meltzl identitásához, holott éppen ez jelenti értelmiségi attitűdjének alapvető összetevőjét. Komáromi Sándor találóan jegyzi meg, hogy a köztes identitású, több nyelvet beszélő Meltzl Hugó besorolásakor irreleváns bármely nemzeti előjel. ${ }^{443} \mathrm{~A}$ kötet már több ponton tematizálta a modern értelemben vett nemzet, nem-

\footnotetext{
${ }_{441}$,[B]ună parte din uriașul tezaur folcloric, lingvistic, dialectologic, de istorie și estetica literaturii a fost mistuit de flăcările rugului aprins de huliganii, bestialii [...], ori Dumnezeu știe numai unde s-au rătăcit.” Majd a Șotropa- idézet: „Parcă aud freamătul surd, aud răcnetele și urletele sălbaticilor care înainte cu 12 ani au asaltat în Cluj modesta locuință a decedatului Silași, voind să-1 prăpădească". Lásd: PAvelea 1996, 150., 156.

${ }^{442}$ URECHE 1996.

${ }^{443}$ Коми́romi 2005, 176.
} 
zeti irodalom fogalmak tarthatatlanságát a 19. század második felének jelenségei vizsgálatakor. Most Meltzl Hugó koncepciója láttatja ezt. A nyelveket egyenrangúan kezelő irodalomtudós, az erdélyi német származású, magyar nyelven oktató és publikáló Meltzl számára kevésbé problematikus identitása, annál inkább a későbbi értelmezőknek, akik a német kultúrfölény egyik példájának tartják e lapot, vagy Meltzl német identitása mellett érvelnek, vagy teljesen neki tulajdonítják a lapot (holott két szerkesztője van a vállalkozásnak). Komáromi köztesnek nevezi ezt az identitást.

Egy többnyelvű, multikulturális régióban alakuló erdélyi identitás ez, amely nem egyedi a korban. Meltzl nemzetiségiként való megnevezése egyébként pont ebből a perspektívából bírálható fölül. Mindemellett a problematikus, köztesnek számító identitásokat elfedik azok a fogalmi kategóriák, amelyek pontosan a 19. század második felében alakulnak és rögzülnek a közgondolkodásban. Az etnicitás és kulturáltság bonyolult összefüggései teszik érdekesebbé és izgalmassá a politikum által hatalomgyakorlással (is) létrehozott kategóriákat.

Meltzl Hugó lapvállalkozása kapcsán Brassai Sámuelt több tekintetben sem hagynám ki e fejezetből. Társszerkesztőként dolgozik együtt Meltzllel, egyetemi tanárokként kollegiális, majd a lap kapcsán üzlettársi, de személyes kapcsolat is kialakul köztük. Miért éppen Brassai társa Meltzlnek vagy Meltzl Brassainak?

\subsubsection{A társszerkesztő Brassai}

A hetvenes éveiben járó, a korábban említett kolozsvári tanároknál jóval idősebb Brassai Sámuel az elemi mennyiségtantanáraként hirdeti egyetemi előadásait hetenként öt órában, szombat kivételével naponként 12 és13 óra között; szombatonként ugyanebben az időpontban a tanárjelölteknek tart előadást. ${ }^{444}$ Első látásra nem sok köze van Brassainak a bölcsészkarhoz, hiszen ő a matematika és természettudományi kar tanára, sőt az induló egyetem prorektora ${ }^{445}$, mégis csatlakozik Meltzl Hugóhoz az ACLU megjelentetésekor, és szerkesztőtársként együtt dolgozik vele. Prorektorként a neve mellett álló rövid ismertető egybevág az egyetemen betöltött szakmai érdeklődéssel, viszont 1874 januárjában már doktori cí-

${ }^{444}$ Vö. Kolozsvári Közlöny 1872. november 23. Brassai egyetemi tanárságáról: GAAL 2001, 179-198.

${ }^{445}$ 17872/1873 - Prorectore magnifico Spectabili ac Clarissimo Domino Samuele Brassai Matheseos elementaris Professore publico ordinario, academiae Scientiarum Hungaricae Socio ordinario, Viro ad tentandos numeris docendi in gymnasiis candidato publice misso. Vö. A kolozsvári m.k. FJTE Tanácsa és doktorai névkönyve I. kötet, 1872/1873 - 1899/1900. [A kézirat lelőhelye: Román Állami Levéltár, Kolozsvár, Fond 315., reg. 111., 2.] Később Brassai a kar dékánja (1875/76), az egyetem rektora (1879/80), majd ismét prorektora (1880/81). 
met szerez a rektor Berde Áronnal együtt. Míg Berde gazdaságtudományi professzorként a jogi-politikai karon egyetemes jogból szerez doktori címet, addig a matematika- és természettudományok karon dolgozó Brassai a filozófia doktora lesz. ${ }^{46} \mathrm{~A}$ különböző tudományok határainak átlépését természetesnek találó idős Brassai számára mindez megtörténhet, hiszen nem a szakmailag elkülönülő oktatási rendszerben szocializálódott tudós, hanem olyan autodidakta, aki korábbi generációk tudósi viselkedésideálját hordozza.

Szocializációját a nagyfokú szabadelvűség jellemzi mind családja, mind felekezete, s annak oktatási intézményei részéről. Családi keretek közt sajátítja el első ismereteit, majd kevés ideig a kolozsvári unitárius kollégium diákja. Históriából például nem nyer absolutoriumot, mégis 1837-ben e tárgyat tanítja a kollégiumban. Időközben főúri családoknál magánnevelő. Neveltetése, pályaválasztása nagyon hasonlít több kortársáéhoz, akik megélhetési gondjaik miatt választják a nevelősködést. Ami Brassai hátrányára válik az átszerveződő oktatási viszonyok miatt, az a peregrináció hiánya, a felsőfokú szakmai továbbtanulásé, illetve a specializálódásé ${ }^{477}$ Fiatalabb értelmiségi társai nem hiába nevezik ahistorikusan a tudományok Nestorának vagy polihisztornak, hiszen az oktatási rendszer differenciálódása új oktatási, szakmai, tanár- és diák-ideált hordoz, amely nagyon eltávolodik attól, amit Brassai képvisel. Ezért van az, hogy részint nem értik Brassai tudományosság-elképzeléseit, következésképp állandóan vitahelyzetbe kényszerül a tudós ${ }^{448}$, másfelől pedig tudása sokrétüsége miatt, de 70-90 évesen is józan gondolkodása, roppant emlékezőtehetsége, teherbírása miatt csodálattal veszik körül ismerősei, tanítványai, a kevésbé szakmai közeg. És itt még nem ejtettünk szót szociális hálójáról, mindazokról, akikkel Erdélyben, Magyarországon, Európában, sőt az Egyesült Államokban is napi levelezésben áll, illetve ezen ismerősi kör előnyeiről, amelyet Brassai nagyon is tudatosan fel- és kihasznál. Ha igazat adunk Vajda György Mihálynak, akkor „rendkívül élénk szelleme, széles érdeklődési köre és nagy nyelvtudása Meltzlt Kolozsvárt hamarosan a korszak nagy polyhistorának, Brassai Sámuelnek körébe vonta; így történhetett, hogy a nála negyvenhat évvel idősebb Brassai megértette és támogatta

\footnotetext{
${ }^{446}$ A természettudományi kar és bölcsészkar viszonyát az előző fejezet részletesen teamtizálja a doktori ügyében is. Brassai kapcsán lásd idézett művek: „1875/76 - Samuele Brassai Philosophiae Doctore matheseos elementaris professore p.o. comissionis professoribus scholarum mediarum examinandis membro, Scientiarum Academiae Hungaricae, societatis reg. Hungaricae rerum naturae studiorum, societatis c.r. zoologicae et botanicae Vindobonensis, naturae studiosorum Cibiniensis membro ordinario, Instituti caes. Reg. Geologici Vindobonensis membro correspondente, universitatis prorectore emerito et facultatis mathematicae et scientiarum naturalium hoc tempore Decano et Praeside."

${ }^{447}$ Lásd erről bővebben: BERKI 2007a, illetve BERKI é.n.

${ }^{448}$ Irodalmi, kritikusi elképzeléseiről bővebben: BERKI 2007b.
} 
Meltzl szándékait, és nevét adta támogatásul az új folyóirathoz. [...] Brassai is a lap szolgálatába állította nemzetközi összeköttetéseit" ${ }^{449}$

Talán nem véletlen, hogy Brassai is, mint ahogy később Meltzl, (pesti) egyetemi, bölcsészettudományi tanszékre pályázik, azaz a hierarchizálódó oktatási rendszer legmagasabb szintjén kíván munkát vállalni.

A továbbiakban az imént megfogalmazott szempont mellett a nagyon szórt Brassai-szakirodalomban nem, vagy csak érintőlegesen vizsgált kéziratos szövegek felől értelmezem tudósi szerepeit.

Brassai 1870-ben a pesti egyetem szanszkrit tanszékének indítása kapcsán panaszkodik Toldy Ferencnek, „a magyar irodalom egyetlen egy historicusának". ${ }^{450}$ Annak ellenére, hogy érvekkel indokolja elvárásait, kénytelen sérelmezni, hogy a tanszék betöltésekor nem merül fel az ő neve. Levelében felhozott érvei nyelvszemléletét legitimálják. A szanszkrit nyelvet autodidakta módon sajátítja el összehasonlító nyelvkutatásai segédeszközeként - a nyelvtudás tehát nem önmagáért fontos számára („előttem a nyelvnek, mint csupán nyelvnek korlátolt becse van”451): a megértésnek, majd az élvezetes olvasásnak, az adott nyelv (kanonikus) irodalma megismerésének eszköze. A fordítói munka és a fordítandó szövegen végzett, a nyelvek közötti konkrét összehasonlítási gyakorlat mindezek fölötti teljesítmény, amit megkoronáz az, hogy tanítani, továbbadni is képes a szerzett nyelvtudást. Az önszántából, pénzen vásárolt könyvekből, saját anyagi befektetéssel végzett nyelvtanulás értékessé minősül, olyannyira, hogy egyetemi szinten gondolja kamatoztathatónak. Mindezt megerősíti azzal az érvvel, hogy nyelvtanító hírében sem áll rosszul, azaz a felhalmozott tudás birtokosaként képes azt sikeresen megosztani tanítványaival. A baráti, tegező hangnemben írt levél fóruma lehet a szakmainak gondolt

${ }^{449}$ VAJDA 1964.

450, ,[... Én Pesten az ötvenes években és éveimben nyelvhasonlítás kedviért megtanultam annyira amennyire a szanszkrit nyelvet. Minthogy pedig előttem a nyelvnek, mint csupán nyelvnek korlátolt becse van, mihelyt annyira juthattam, hogy a megértés nehézsége az élvezetet nem gátolta, igyekeztem megismerkedni a nevezett nyelv irodalmával is. E végre a segédeszközöket legnagyobbára pénzemmel kellett megszerezni, mert Pesten biz' akkor nagyon kevés volt, s még most is a Pulszky ajándéka után van nekem egyedül annyi, amennyi Pesten, de nem mint doublett, hanem kiegészítőleg. Így ellátva, elolvastam én négy jókora Chrestomatiát a Mahabharata külön kiadott episodjait, melyek közül kettő: Nalus és Bhagavadgita) jókora könyvek. A másik nagy eposznak, a Rámájánának három első könyvét, a drámák közül a legjelesebb ötöt, a Hitopadésát, és a számvetést tanító Lilavatit. Azt hiszem ezekből meríthettem legalább oly és annyi ismeretét a nyelvnek, amilyennel ma a magyar ember dicsekedhetik. Eredményeül közlöttem Pesten egy forditmányt (Kandu) valamelyik hírlapban s - jelesen az igeidők elemzésében - összehasonlításokat tettem, melyek a tárgyat sokképp világosították. Még hozzá kell vetnem, hogy számos élő emberről vehetnék bizonyságot, kiket egy s más idegen nyelv értésére tuto, cito et jucunde, segítettem. S' általában mint tanító nem éppen vagyok rossz hírben.[...]" = Brassai Sámuel Toldy Ferenchez [A kézirat lelőhelye: MTAK Kt. Irod. Lev. 4r. 105.]

${ }^{451}$ Uo. 
kompetenciák leírásának, az ilyesfajta személyes sérelmek elpanaszolásának, de a minisztériumi döntések bírálatának, sőt a tanszéket betöltő tanár iránti ellenszenv, az egyéni preferenciák és antipátiák megfogalmazásának is. ${ }^{452} \mathrm{~A}$ levelet olvasó Toldy véleménye érdekes lehetne, mint ahogy Budenz véleményezése is forrásértékünek bizonyult a dolgozat szempontjából, de nem találtam rá. Mindenképp megjegyzendő ezen a ponton, hogy Brassai Sámuel nem tartozik azon értelmiségiek közé, akik gondosan őrzik a hozzájuk intézett leveleket, mivel minden üres papírfecnit - így a kapott levelek hátoldalait - kihasznál, azokra jegyzetel.

Brassait már életében a tudományok Nestorának, poliglott és polihisztor tudósnak tartották kortársai. Tudósi attitűdje, a polihisztori beállítódás furcsa viszonyban állt a 19. század közepe utáni szakmai hivatásosodással, mintha Brassai figyelmen kívül hagyta volna, vagy szándékosan továbbra is benne állt egy régi típusú, túlhaladott tudományosságmodellben.

Békés Vera a 18-19. század fordulóján a göttingai egyetem holisztikus tudományszemléletében véli felfedezni azt a tudományos paradigmát, miszerint: „,a professzoroknak egy személyben oktatói és tudományos kutatói tevékenységet is kellett folytatniuk. [...] [követelmény, hogy] se a tanárok, se a diákok ne essenek a túlzott szakosodás hibájába, amely akadályozná a teljesség kibontakozásának megvalósulását". ${ }^{453}$ A göttingai egyetem programja szerint a tudományok határai dialógusban állanak, a „közös affinitásszféra", a kontextuális megközelítés válik fontossá. A 19. század első harmadában áll be a paradigmaváltás, létrejönnek a modern szaktudósok munkamegosztáson alapuló, hierarchikus felépítésű team-jei, és lassan kihal a kollektivitásban alkotó polihisztorok zseniális típusa. ${ }^{454}$

Brassai nem folytatott külföldi tanulmányokat, első látásra nem illeszthető ebbe a tudományelméleti koncepcióba. Mégis dokumentálható az európai egyetemekkel való közvetlen viszonya. 1844-ben kolozsvári barátjának, Nagy Péter református lelkésznek írt levelében ${ }^{455}$ beszámol a Berlin-Halle-Lipcse-Braunschweig-Göttinga-Frankfurt-Párizs vonalon tett utazásáról. ${ }^{456} \mathrm{~A}$ beszámolóban a göttingai egyetemet pozitívan értékeli

452 “[...] ]oly obscurus nevet hallottam emlegetni, hogy az mellőzésemet még érzékenyebbé tette. Mégis, ha például Mátyás Florianról lett volna szó, mint akinek köszönhetem a legelső segédeszközt tanulmányaimhoz, - nem bámulnék!"- Uo.

${ }^{453}$ BÉKÉs1997, 54., 59.

${ }^{454}$ VÖ. BÉKÉs 1997, 70-74.

${ }^{455}$ Brassai Sámuel Nagy Péterhez (A kézirat lelőhelye: MTAK Kt, Ms 4745/107-108.) Az 1841-ben beiratkozó Nagy Péter a göttingai egyetemen természettudományi tanulmányokat folytatott. Vö. Szabó-Szögi 1998, 340.

${ }^{456}$ A július 4-i, Frankfurtból címzett levél részletesen közli a meglátogatott tanárok, intézmények neveit. Halléban August Herman Francke pedagógiai intézetét és Sprengel Herbariumát keresi fel és utal arra, hogy olyamit tanult, amiről majd hazatértekor beszélgetniük kell. Kunkét, a lipcsei egyetem tanárát többre értékeli a berlini egyetem tanárainál. Ez utóbbi 
és a hazai ifjúság figyelmébe ajánlja, hiszen a berlini egyetemet a rengeteg tanár ellenére sem találja annyira értékesnek, amennyire a göttingai körülményeket és intézeteket meghatározóaknak tartja. Leírásai alapján a botanikus Brassaira ismerünk, akit természettudományi érdeklődése kapcsol Nagy Péterhez. A leírás Brassai tájékozódását bizonyítja: a látottakat egymás között, de a hazai helyzethez is viszonyítja. Ez az utazása a többivel (például zenei és általánosabb kulturális érdeklődése révén többször utazik Bécsbe, Párizsba) együtt még nem tekinthető külföldi peregrinációnak, viszont beszámolója, későbbi életpályája, tudománykoncepciója, írásai (és ezek közül például Criticai Lapja) mind a göttingai modellhez való tartozását erősítik. Ebben a paradigmában akkor is bennemarad tudósunk, amikor azt már elfedte egy újabb.

Szintén Békés Vera állapítja meg, hogy a pozícióját vesztett korábbi tudományos paradigma és az új paradigma között nincs értelme egyetlen fejlődésvonalat húzni tudománytörténeti értelemben ${ }^{457}$, már csak azért sem, mert „,az új paradigmák nem pusztán a régiből, hanem sokkal inkább egy, a régi által megszüntetett, feledésre ítélt, lappangó paradigma zárványaiból születnek" ${ }^{458}$ Brassai mondatelméleti munkássága ilyen lappangó paradigmaként nem korabeli sikere felől, hanem a mai értékek alapján válik napjaink egyik nyelvészeti irányzatának előfutárává. ${ }^{45}$

A porosz oktatási modellben ",a szellemi tevékenység - mégpedig a tudományok egységének, az oktatás és a kutatás egységének, valamint az egyetemi oktató és az egyetemi hallgató egymásrautaltságának elve alapján - szabadon bontakozhatott ki" ${ }^{460} \mathrm{Ez}$ a szabadság a magyarországi egyetemek tanszabadságelvével azonosítható, azzal az elvvel, ami a kolozsvári egyetem arculatának is meghatározó jegye, és amit Brassai rektori

helyen hosszasabban időzött, és a város ridegségét a francia vaudeville kárpótolta. A LipcseBraunschweig útvonalat gyalogosan teszi meg, mert „botanizál”, ezután érkezik meg Göttingába, amelyet, akárcsak Drezdát, kellemes egyetemi központként láttat. Itt Apel és Bartling (botanikus) fogadja, látja a matematikus Gausst és Listinget. Párizs után érkezik Frankfurtba, ahol hasonlóképp intézeteket látogat és múzeumot (Senkenbergisches, Bethmann).

${ }^{457}$ BÉKÉS 2004, 9.

${ }^{458}$ BÉKÉs 1997, 85.

${ }^{459}$ BÉKÉs 2004, 9. Lásd erről bővebben É. Kiss Katalin Brassai nyelvészeti munkáit vizsgáló kutatásait.

${ }^{460}$ Tóth Tamás, A napóleoni egyetemtól a humboldti egyetemig = http://nyitottegyetem.phil-inst. hu/Tarsfil/kut/tanulm/toth2.htm - utolsó látogatás: 2008. március 17. Továbbá: „to view everything from the perspective of scholarship, and to see every individual thing not in isolation, but in its closest scholarly connections, relating it constantly to the unity and entirety of knowledge, so that in all their thought they learn to become aware of the principles of scholarship, and thus themselves aquire the ability to carry out research, to make discoveries, and to present these, gradually working things out in themselves. This is the business of a university". - A humboldti elveket befolyásoló Schleiermacher-passzust idézi RüEGg 1991, 4-33. 
beszédében megfogalmaz. ${ }^{461} \mathrm{E}$ beszédben veszi sorra az egyetem fakultásait, és értékeli azok tudományszemléletét, de ezzel egy időben elvárásainak is hangot ad. Olyan kérdéseket vet fel, mint: a teológia tudomány-e, lehet-e helye az egyetemi oktatásban; a földrajz sem politikai, sem matematikai tudomány, hanem kimondottan fizikai, a természettudomány része, ilyenként nem a bölcsészkaron tanítandó; a statisztika segédtudomány csupán; az antropológia és etnográfia miért hiányzik az egyetemről. Ugyanott a német, francia és angol egyetemi modellek közül nem véletlenül választja a németet, hiszen érvelése szerint ott a tudomány önkéntesen, szabadon, demokratikus módon hozzáférhető. ${ }^{462}$

Brassai Sámuel nyelvtanulásról írott tanulmánya egyike első önálló, elméleti jellegű publikációinak a kolozsvári Nemzeti Társalkodóban. A nyelveket, sőt a tudományterületeket (a nyelv által kisajátítottnak, uraltnak ${ }^{463}$ ) is nemzetkarakterológiai szempontból különbözőeknek, az univerzális nyelvet pedig unalmasnak, a nyelvtanulás gátjának tartja. Ezzel a megfeleltetéssel eleve nemzeti sajátosságként tünteti fel az egyes tudományágak irodalmi remekeit, és a közös találkozási pontokat csak olyan észtehetség, mint a nyelvtanulás, az ízlés művelése által képzeli el, „mivel szépliteratúrai tárgyakban a fordítás sokkal tökélytelenebb surrogatum a rozs vagy makk kávénál" ${ }^{464} \mathrm{~A}$ fordítás kérdése elítélendőként kerül elő ebben a szövegben, hiszen az eleve adott különbözőség érzékeltetésére képtelen, és nem valódi kulcs a kultúra kincseihez. A nemzeti karakterek sokszínűsége olyan érték e gondolatmenet szerint, amely ösztönzi a nyelvtanulást és megfüszerezi a szellemi életet. A tanulmányban a tudásvágy összekapcsolódik az „utazás gyönyörével", ami metaforikus értelemben és elsődleges jelentésében egyaránt működtethető Brassai életpéldáján. A gyönyör visszatéró fogalom érvelésében ${ }^{465}$, a tehetség-vágy-gyönyör a nyelvtanulás fokozatainak hármasa. Nem csak fokozatosan, hanem módszertanilag is jól kidolgozottan gondolkodik Brassai a nyelvtanulásról: az anyanyelv tanulása, szabályai képezik az idegen nyelv elsajátításának keretét, de a grammatikán túl a matematika, kézimunka, rajz, ének, história, „földírás" mind befolyásolja ezen észtehetség kifejlését. A tudományágak különbözősége és egybeeső használata tűnik a legadekvátabbnak a nyelvek elsajátításakor. Azt is leír-

\footnotetext{
${ }^{461}$ Brassai Sámuel programm-beszéde = Acta Reg. Scient. Univ. Caludiopolitanae 1879/80, 49-87. ${ }^{462}$ Uo.

${ }^{463}$ A szemlélődő filozófia német, a mathésis francia, a törvénytudás latin, a história görög, latin, angol nyelvü, ergo azé a nemzeté, amelynek nyelvén legtökéletesebben kifejezésre jut. Vö. Brassai Sámuel, Nyelvtanulás = Nemzeti Társalkodó 1837/6-8.

${ }^{464}$ Brassai 1837, 116.

${ }^{465}$ 1832-ben a gyönyörüségről értekezik egy olyan írásában, mely alapvető esztétikai elveit tartalmazza. Vö. Brassai Sámuel, A gyönyörüuégről, melyet a szép mívek szemlélése vagy hallása okoz bennünk = Nemzeti Társalkodó 1832/11-12.[I. félév], 4-5.[II. félév]. Ugyanezt a szövegét újraközli 1859-ben a Szépirodalmi Közlönyben.
} 
ja Brassai, hogy milyen funkcióját látja a nyelvtanulásnak: „nem annyira beszédi mint litteraturai s olvasási tekintetben kívánom ezen nyelvtudás némi vonzóbb oldalait észrevéltetni". ${ }^{466}$ Innen nézve érthető, hogy miért javasolja a görög, latin, sőt még a szanszkrit nyelv elsajátítását is, hiszen eltünt vagy nem hozzáférhetô már az a közeg, ahol a szóbeli kommunikáció eszközei lehetnének ezek a nyelvek. Mégis értelmet nyer e nyelvek ismerete, hiszen a megértés, az írásbeli kultúrához, az idegen nemzeti múveltséghez való hozzáférés lehetősége. Brassai ugyan a 19. század harmincas éveiben közli ezeket a szövegeit, elméleti koncepcióját az idők során nem változtatja, sőt a gyönyörüségről írott tanulmányát később az ACLU-ban német fordításban közli, és aktuálisnak érzi fél évszázad után is.

A nemzetkarakterológiához csatolt Brassai-féle nyelvkoncepció és tudományszemlélet a többnyelvűség és pluridiszciplinaritás mellett foglal állást. Innen nézve, a nyelvtanulás értékesebbnek minősül, mint a fordítás. A nemzeti sajátosságok reprezentálásának nyelvcentrikussága hangsúlyozódik. Ennek ellenére, amint fordításról írt elméleti értekezése bizonyítja, foglalkoztatta Brassait a fordítás - nyelvi reprezentáció - nemzeti sajátosságok viszonyának a kérdése. Elméleti írásai, nyelvtanári praxisa mellett gyakorló fordítói tevékenységét sem mellőzhetjük. ${ }^{467}$

A személyéhez és munkásságához füződő kultikus viszony jele az a Vasárnapi Újságban, címlapon megjelent levél, amely Brassai kilencvenedik születésnapja alkalmából egy nála tett látogatás és a róla készítendő fénykép apropóján íródott.

A Sz-g.-szignójú levélíró szerkesztői megbízatásnak tesz eleget, amikor meglátogatja a tudóst. 1890-ben e levél szerint Brassai számára az a fájó pont, hogy sok mindent írtak róla, de „azt nem írta meg senki, hogy mit csináltam. Hát írtam egy francia nyelvtant és egy német nyelvtant. És két egyforma talentumú ifjúnak adják kezébe az én könyvemet és akárkiét másét. Fogadok rá, hogy az enyémből tanulja meg hamarább a nyelvet" ${ }^{468}$ Nyelvtanulással kapcsolatos munkái fontosságáról, illetve azok hatékonyságáról való meggyőződésének ad hangot e beszélgetésben és egyértelmüen emeli ki összetett, rengeteg tudományághoz köthető életmúvéből.

A levélíró énelbeszélésének másik fontos részlete Brassai nyelvtudására kérdez rá: „Alkalmam lévén rá, megkérdeztem, hogy sok nyelvet tanult-e?

${ }^{466}$ BRASSAI 1837, 121.

${ }^{467}$ 1860-ban angol és orosz nyelvü szépirodalmat fordít magyarra a Szépirodalmi Figyelóben. De számon tartják francia és szanszkrit tolmácsolásait is. Francia, német, latin nyelvtanítási kézikönyvet ad ki. Vö. GAzDA é.n.

${ }^{468}$ Sz-g. [Szúnyog = Petelei István], Brassai Sámuel. Levél a szerkesztőhöz = Vasárnapi Újság $1890 / 18,2$. 
- Mindegyiket, - felelte, - aminek a literatúrája érdemes volt reá. Dehát nekem könnyü volt, - mondta elgondolkozva, - mert egyéb dolgom se volt. Ha se felesége, se gyermeke nincsen az embernek..." ${ }^{469}$ A család hiányát (egyszerre negatívan és) lehetőségként szemlélve tesz kijelentéseket tudósi státusára: minden figyelme a nyelvtanulásra irányult, és funkcionálisan tette ezt. Brassai válasza felől nem is annyira a nyelvek, mint az értékesnek talált irodalmak kerülnek fókuszpontba. Ezek megismerésének kulcsát pedig a nyelvtanulás, az eredetiben való olvasás jelenti és nem a fordítás. Ezért is kaphatott nagyobb hangsúlyt a többnyelvűség kérdése és az összehasonlítás mint módszer ${ }^{470}$ a Meltzl-lel közös lapvállalkozásban.

A nyelvismeret és nyelvhasználat kérdését a levelezés példájához társítanám. Brassai több nyelven levelezik személyes ismerőseivel, barátaival, Meltzl szintén. Viszont amíg Meltzl Arany Jánosnak és Toldy Ferencnek német nyelven ír levelet, azaz anyanyelvén (ez Toldyval például közös nyelv, de már Arany Jánossal nem, viszont identifikációs gesztus), addig Brassainak magyarul, vagy Henri-Frédéric Amielnek francia nyelven. A levélírás efféle nyelvhasználata kontextusfüggő, és rávilágít gesztusokra, de leginkább arra, hogy nemcsak a levelezésben múködik elvként a többnyelvűség kamatoztatása a címzettel adekvát kommunikációban, hanem az ACLU szerkesztésekor is. Amiellel 1877-től, az ACLU indulásától vált levelet havonta Meltzl, főként a Petőfi-fordításokról. Amiel egy 1878-as válasza figyelemre méltó ebben a vonatkozásban: elméletileg az idegen nyelv ismerete előtt az anyanyelv legjobb birtoklását tartja a legfontosabbnak azoknál, akik fordításra vállalkoznak, és ennél tovább megy Amiel, amikor azt állítja, hogy gyakorlatban lehetetlen az anyanyelvről más, idegen nyelvre való fordítás. Egyetlen esetben lát kivételt: ha két anyanyelvünk van, mint némely magyar(országi) professzoroknak. ${ }^{471}$ Ezzel a megfogalmazásával Amiel nyilván Meltzlre céloz, és innen nézve ugyanannál a kérdésnél vagyunk, amit Komáromi Sándor Meltzl nemzeti identitásának definiálásakor felvetett: mi történik abban az esetben, ha a nemzeti (itt nyelvi) kategória felől nem egy, hanem egyszerre több helyre sorolható be valaki. Az, hogy valakinek két anyanyelve van, paradoxonnak tünik, viszont Meltzl vagy más 19. századi magyarországi, erdélyi értelmiségi szocializációja felól kevésbé az, hiszen rengeteg hibrid identitással rendelkező értelmiségit találunk Erdélyben.

\footnotetext{
${ }^{469}$ Uo.

${ }^{470}$ A Brassai által is művelt összehasonlító történeti filológiából kölcsönözték, amely tudományágban már a 19. század közepén a nacionalizmus és kozmopolitizmus közötti feszültség munkált. A kozmopolitizmus és az összehasonlítás módszertanához lásd: ILLYÉs 2008, VASS 2010.

${ }^{471}$ H. F. Amiel Meltzl Hugónak [A kézirat lelőhelye: MTA Kt. Ms 4744/55-80.]
} 
Megfontolandó Amiel ACLU-val kapcsolatos javaslata: a külföldi munkatársakat anyanyelvi közlésre kell buzdítani. ${ }^{42}$ Ez pedig eleve egybeesik a lap koncepciójával, és annak bizonyítéka, hogy Brassai meg Meltzl nem maradtak magukra abban a koncepcióban, amely az anyanyelvűséget, saját nemzeti nyelvhasználatot részesítette előnyben a fordításokhoz képest.

\subsubsection{Felekezeti identitás és nemzeti irodalmak}

Mivel Meltzl Hugó a Brassai Sámuelről szóló fejezetben a poliglottizmus, a különféle nyelvek, irodalmak és kultúrák iránti érdeklődésük révén az alfejezet szereplőjévé is vált, felhívnám a figyelmet egy alkalmi írására. Brassait méltatva, a tudós felekezeti hovatartozására is érvényesnek találja a poliglottizmus elvét, hangsúlyozva e vallás egyetemességét. Az erdélyi vallásszabadság unitarizmusát a „legcosmopolitábbnak”, „kulturfactornak" nevezi, amely fordítások, külföldi kapcsolatok kiépítése által szabadította ki a magyar nyelvet izoláltságából, és megjegyzi, hogy a British Museum „több rendbeli hivatalnoka részben érti, részben tanulja a magyar nyelvet" a külföldi unitárius akadémiták segítségével. ${ }^{473}$

Meltzl az unitárius vallás angliai kapcsolataiban épp azt az ideális viszonyt véli felfedezni, amely a két idegen nemzetiségü, de a másik nyelvét kölcsönösen elsajátító unitárius között létrejön. Az unitáriusok kapcsán fogalmazza meg a következőket: „Barátokat kell szerezni a magyar irodalomnak, importálni kell minél nagyobb mérvben az idegen irodalom termékeit, hogy ők is kényszerítve legyenek, már csak udvariasságból is, viszonozni ezt a szolgálatot, de természetesen csak a régi, kipróbált jó remek múveket szabad importálni, holott mai nap éppen ellenkezőleg járnak el, még az akadémiában is Budapesten". ${ }^{474}$ A nyelvtanulás, majd fordítások kölcsönösségének gondolatát látjuk ebben az idézetben is. Ugyan megingani látszik a korábbi elmélet, mert amíg Meltzl kérdésfelvetése szerint a magyar irodalom külföldi irodalmak iránti érdeklődését a haszonelvüséggel lehetne definiálni, addig a külföldiek részéről már nem ez az elv, hanem az udvariasság gesztusa, az etikai mérce az elvárt. Viszont a kölcsönösség egyenrangúsága illuzórikusnak tünik éppen a mögötte álló és a Meltzl által impliciten megfogalmazott érdekek miatt. A közvetítés tárgyát képező múvek esetében a goethei világirodalom kapcsán kialakított elveit látjuk: a régi, kipróbált, remekmúvek közvetítése nyer csupán értelmet.

${ }_{472}$ „Mais je n'en tirer qu'une seule conséquence; c'est qu'a l'avenir le Directeur de la Revue Polyglott ferait bien d'inviter les collaborateurs a s'exprimer tout simplement dans leur langue maternelle (au moins par/pour les langues romanes et germaniques)."= H. F. Amiel Meltzl Hugónak [A kézirat lelőhelye: MTA Kt. Ms 4744/65.]

${ }^{473}$ MeLtzl 1878.

${ }^{474}$ Uo. 
Stein János, kolozsvári nyomdász Kovács János teológiai tanár - aki a londoni Manchester New College-ben akadémita volt - kérésére Brassai összes munkáját elküldi az Amerikai Egyesült Államokba, a Harvard Egyetemre. ${ }^{475}$ Ebben a gesztusban nem csupán Meltzlnek a kultúrák közötti közvetítéssel kapcsolatos koncepciója látszik megvalósulni (de felmerül a kérdés, hogy Brassai milyen értelemben „remekmüvek” szerzője), hanem elsősorban az unitárius egyháznak az 1820-as évektől az angliai és amerikai unitáriusokkal kialakított kapcsolata múködik. ${ }^{476} \mathrm{~A}$ kulturális közvetítés imént idézett példájában a hangsúly Brassai felekezetiségére és nem munkássága megítélésére esik, bár nyilván, az sem mellékes szempont, amit kiegészít Meltzl vagy az unitáriusok tudósuk iránti elfogultsága. Brassai Sámuelt unitárius tudósként látni mást is jelent, mint felismerni felekezeti kötődéseit, az egyházi intézményekkel kialakított kapcsolatát, és szerepeit. Jelenti a liberális, szabadelvű gondolkodást, a toleranciát, az egyetemességre való törekvést, Erdélyen kívül az angliai és amerikai hittestvérekkel való kapcsolatot, ${ }^{477}$ és nem árt ezzel is számolni akkor, amikor a 19. századot végigélő tudós outsidernek látszik a vitahelyzetekben, tudománykoncepciójában.

${ }^{475}$ Vö. Stein János levele Brassaihoz [A kézirat lelőhelye: Erdélyi Unitárius Egyház Gyűjtőlevéltára]. A Harvard Egyetem könyvtára elektronikus katalógusában visszakereshetőek, napjainkban is elérhetőek a 19. századi Brassai-munkák, és a róla szóló, későbbi másodlagos szövegek, például Kozma Ferenc és Boros György munkái. Egyébként a Google digitalizálta a küldemény nagyobb részét. Az elektronikus hozzáférésnek köszönhetően kontrollforrásként müködik a HunL 635.1-jelzetű A Collection of Miscellaneous Pamphlets c. munka első kötete, amelyben az egyetem címere és MAY 1897 szerepel, alatta kézírással: from Dr. Sámuel Brassai of Klausenburg, Transylvania, 21.sept.1896. E kötet következő lapján bejegyzés olvasható 1896 augusztusából, amit Frank D. Chester szignál, és Mr. Kirman a megszólítottja. Chester arról számol be Kirmannak, hogy maga és Kovács felszólítására küldeti el a mélyen tisztelt erdélyi Nestor, a legolvasottabb tudós, Brassai összes múveit a Harvard Egyetemnek. A bejegyzésből tudjuk, hogy nem Brassai vagy Stein, hanem az amerikai egyetem könyvtára fizette ki a postaköltségeket.

${ }^{476} \mathrm{Az}$ angolok által kezdeményezett kapcsolat a 19. század első évtizedeiben, az 1820-as években bontakozik ki, elsőként egyház-diplomáciai jellegü, majd intézményesülése után sokrétűvé váló, napjainkig müködő egyházi és kulturális viszonyról van szó. Az angol irodalmárok magyar nyelv iránti érdeklődésének, illetve az angolok magyar nyelvismeretre való törekvésének első jele: John Bowring, Hungarian Literature = Monthly Repository, August 1827, 556-557. Az angol nyelv fakultatív oktatását az 1859-es Főtanácsi Határozat alapján 1861-től kezdik el a kolozsvári unitárius kollégiumban. A kapcsolattörténet aspektusait főként felekezeti szempontból, de múvelődés- és irodalomtörténeti vonatkozásaiban részletesen elemzi az idézett munka: Kovács 2011. [Köszönöm a szerzőnek, hogy rendelkezésemre bocsátotta doktori értekezése kéziratát, amely időközben kiadásra került.]

${ }^{477} \mathrm{Ez}$ azért is fontos, mert másféle kapcsolatot jelent a magyar és amerikai unitáriusok 19. századi kapcsolattörténete, mint pl. a magyar és francia katolikusoké vagy a magyar és németországi reformátusoké. 
Az unitárius egyház angol kapcsolataiban Meltzl felismeri a felekezetiségen túlmutató eredményességüket, hiszen éppen ennek révén kerül ő maga kapcsolatba a Petőfi-fordítóval, John Bowringgal. ${ }^{478} \mathrm{Az}$ angol-magyar kapcsolatok felekzetisége révén kerül az ACLU érdeklődési körébe mind John Bowring, mind a például Vörösmartyt is fordító E. D. Butler, és erre csodákozik rá Meltzl Hugó.

Meltzl írásából nagyon finoman rajzolódik ki ugyanaz a problematika, amely a disszertáció egyik alapkérdése: milyen viszony alakítható ki a különböző nyelvek, nemzeti irodalmak, kultúrák között. Ha megfordítjuk Meltzl koncepcióját, akkor az is látszik, hogy egy olyan felekezetről, az unitarizmusról értekezik, amelyhez a tolerancia, az erdélyi vallászszabadság törvénye füződik, liberális és nem utolsó sorban protestáns. A magyarországi protestantizmus, a felekezeti jogok védelme történetileg a magyar nemzeti eszméhez, annak szimbolikájához köthető ${ }^{479}$ Ilyenformán, az unitárius vallás reprezentálhatná a magyar nemzetideált, amely konfliktusmentes lehetne az identitáskonstrukciók szempontjából, hiszen, amint jeleztem, homogén közösségről van szó. Az értekezés perspektívájából ez az elképzelés fel sem merül, viszont látványosabbnak tartom e szöveg felől utalni a nacionalizmus-kozmopolitizmus feszültségre, ami eddig egy hivatkozás erejéig jelentkezett a kötetben. Mind Brassai, mind Meltzl munkássága, valamint közös lapvállalkozásuk, az ACLU arra bizonyíték, hogyan építhető be a nemzeti szempont abba a modernséghez társított új tudományágba, amelyet „összehasonlító irodalomtörténelem" nek neveznek. A nyelvi esszenciaként megragadható nemzeti fölé helyezödik az egyetemesség igénye. Meglátásaim szerint Meltzl - éppen Brassai és annak felekezeti kötődései és sikertörténetei szemszögéből nézve - úgy oldja föl a nacionalizmus problematikusságát, hogy a felekezeti kapcsolatok apropóján egy, a 19. század közepétől, a nyelv alapú nemzetfogalom következtében egynyelvüsödő politikai-kulturális folyamatnak a roncsoló alternatíváját: a poliglottizmust hangsúlyozza. ${ }^{480}$ Amint a fentiekből is kikövetkeztethető, a 19. század utolsó évtizedeiben még nagyon szorosra füződik a tudományszemlélet és a felekezeti hovatartozás közötti viszony. A (nemzet)állami berendezkedés intézményesülése és a szekularizáció miatt az egyházak szerepének háttérbe szorulása még nem jelenti a felekezeti

\footnotetext{
${ }^{478}$ John Bowring erdélyi kapcsolatairól, az angol-magyar unitárius érintkezésekről, azok kulturális, polgári fejlődést befolyásoló liberális „ideo(teo)lógiai” vonatkozásairól is érdemben tájékoztat: Kovács 2011, különösen: 37-41.

${ }^{479} \mathrm{E}$ kérdésben lásd BRANDT 2003.

${ }^{480}$ Itt kapcsolnék vissza Julianne Brandt idézett tanulmányára, amely a felekzeti és nemzeti identitáskonstrukciók egymásból való építkezésére is felhívja a figyelmet, ami azért fontos, mert látszik, hogy mind az egyházak szekularizációja, mind a nacionalizmus ideológiája mennyire nem egyoldalú folyamat, hanem modellek alapján építkezik.
} 
kötődések erősségének megtörését, ezért sem elhanyagolandó aspektusa ez az identitáskomponens a 19. század végének társadalom- és értelmiségtörténeti kutatásainak.

Brassai Sámuel és Meltzl Hugó egyedülálló jelentőségű közös vállalkozásuk révén fontosak a kultúraközi közvetítés 19. századi koncepciója felől. Az egymás mellé rendelő és a kultúrák önazonosságát látszólag tiszteletben tartó többnyelvű lap az összehasonlítás módszere által kívánja értékesként megmutatni a különböző népek, nemzetek kulturális termékeit, irodalmát. Az összehasonlítás módszertanát David Damrosch Brassai nyelvészeti munkásságában véli felfedezni, ami a goethei világirodalomfogalom kulturális-politikai kontextusaként tekinthető történeti filológiával hozható kapcsolatba. ${ }^{481}$

Itt csatolnék vissza ismét a korábbi alfejzethez. Brassai, amint a vele készített öregkori beszélgetés is tükrözi, elsősorban a nyelv mint világképző rendszer, a nyelvészet és a hozzá köthető tudományos módszertan iránt érdeklődik. Bár Meltzl Hugó kevésbé érdekelt a nyelvfilozófiában, más generációs közösség tagja, mint a század utolsó évtizedeiben már ahistorikusnak tűnő tudós Brassai, mégis találkozik szemléletük. Meltzl nemzetiségi identitását csak a román nyelvű narratív elbeszélésekből kirajzolódó, románokhoz való viszonyában példáztam. A tapasztalt szimpátia, mint látjuk, Meltzlnek az idegen kultúrák és irodalmak iránti érdeklődéséből fakadhat. Mindemellett, az osztrák császárság és magyar királyság területén, a dualizmus korában élő szász evangélikus Meltz1 ${ }^{482}$, a görög katolikus és görögkeleti románok Magyarországon a magyarokhoz képest eltérő politikai helyzetben élnek. A magyarországi etnikai csoportok akkori politikai helyzethez való viszonyát különbözőnek látom, bár e viszony föltárása nyilván alapos kutatást követel, hiszen nemcsak 19. századi struktúrákkal, hanem azok előzményeivel is kellene foglalkozni, például a szász és román nemzetiségek saját történeti narratíváival, elkülönülő politikai álláspontjaikkal - ez viszont túlhaladja e kötet kérdésfelvetését. ${ }^{483}$

Damrosch a történeti filológiát említi olyan diszciplínaként, amely a nacionalizmus és kozmopolitanizmus közötti feszültséget magában rejti, és ennek kapcsán G. G. Gervinus és J. Grimm munkásságát a nacionalizmus példáiként sorolja. Nem nehéz innen belátni azt a nemzetiségi

\footnotetext{
${ }^{481}$ Vö. Damrosch 2007, 161-163.

${ }^{482}$ Hozzátenném, hogy Brassai családneve erdetére utal. Boros György, Brassai életrajzírója kutatásai arról árulkodnak, hogy apai ágon a tudós brassói, lutheránus vallású német családból származik, és a társadalmi mobilitás (megélhetés, munka) volt az oka a torockói beházasodásnak. Brassai anyai ágon pedig szintén a társadalmi mobilitás - lelkészi pálya révén Torockóra-Torockószentgyörgyre került székely nemesi, a kissolymosi Koncz családhoz kötődik. Lásd erről bővebben: Boros 1927, BERKi 2007a.

${ }^{483}$ Brassai azért érdekes ebből a szempontból, mert gyakorlatilag túlélte a 19. századot, Magyarország, Erdély történeti-politikai változásainak szemtanúja volt.
} 
törekvést, amely az erdélyi román értelmiségiek körében már a 18. század végén elkezdődött éppen a szótárírói, összehasonlító nyelvészeti-történeti kutatásaiknak köszönhetően. Az „Erdélyi Iskola”-ként számon tartott értelmiségi kör és az általuk képviselt eszmei mozgalom jelentette a dákoromán kontinuitáselmélet, a román nyelv latin eredetének és a nemzetegység koncepciózus kibontakozásának táptalaját. ${ }^{484}$ A nyelvészeti érdeklődésű Grigore Silaşi ${ }^{485}$ filológiai történeti kutatásainak köszönhetően lesz a román nemzetiségi mozgalmak szereplője a kolozsvári egyetemen, a Iulia-egyletben és az ASTRA-ban. A Iulia-kapcsán kirobbant botrányban került elötérbe. A tevékenységét részletesebben elemző alfejezetben már utaltam erre a kérdésre. Azt hangsúlyoznám ezen a ponton, hogy identitásának meghatározó komponenseit képezik nyelvészeti, nyelvtörténeti kutatásai, amelyek benne állnak a saját nemzetiségével kapcsolatos történeti-politikai diskurzusban, azok önleírásait bővítik. Tehát nem véletlen, hogy Silaşi a passzív politikusok álláspontját képviseli, velük áll kapcsolatban, nemzetiként elképzelt román identitását gyakorlatilag is felvállalja, hiszen szakmai identitásánál fogva olyan elméleti koncepcióval azonosul, amely történetileg is találkozik a politikai-nemzeti törekvésekkel. Látszik az is, hogy Silaşi más érdekek miatt válik szélsőségesebbé, és képvisel eltérő álláspontot, a nemzetit az egyetemesség felől belátó Meltzlhez vagy Brassaihoz képest. A magyarok éppen ezért tekintik és bírálják őt, a románok viszont emiatt ismerik el ${ }^{486}$, és látják hazafias tettként munkásságát. ${ }^{487}$ Fordítva múködik a dolog a kolozsvári egyetem második román tanára esetében. A Budapesten kedvelt, de Bukarestben renegátnak tekintett Grigore Moldován sajátos identitása talán a Silaşitól eltérő szakmai életút felől is értelmezhetô.

${ }^{484}$ Lásd erről bővebben, a magyar-román kapcsolatok felől is: DeÉR-GÁLDI 1943, Borsi 1993, 17-63., I. Tótн 1998, BÁRdi 1998, Miskolczy 2005. A román (nyelvű) szakirodalomból ehhez a kérdéshez lásd például: Mitu 1997, Boia 1999.

${ }^{485}$ Például a macedóniai román nyelv bemutatása kapcsán a megértés és a román nyelv egységes voltát éppen a régi Dáciára való hivatkozás keretei között képzeli el Silași. Vö. Dr. Szilasi Gergely, A maczedoniai román nyelvjárás = Erdélyi Múzeum 1875/9, 142-147., 1875/10, 157-161., 1876/2, 20-24. Ezt a tanulmányt előzőleg román nyelven közölte folytatásokban a Transilvania c. lap 1874-es évfolyama több számában.

${ }^{486}$ A román nyelvü Silași-irodalomban éppen Jacob Grimmtől idéznek (Limba noastră este istoria noastră), amikor Silași nyelvészeti munkásságát vizsgálják. Lásd például: Gabriel Vasiliu, Lingvistul = Studii și Cercetări Etnoculturale, Bistrița, 93-96.

${ }^{487}$ Eddig nem jeleztem, de az életpályája felől sem tünik véletlennek Silași nemzetkoncepciója, hiszen olyan intézményekben jár az erdélyi iskola képviselői nyomdokán, mint a kolozsvári piaristák iskolája vagy a bécsi Pazmaneum, ahol a román származású diákok elkülönülő csoportokként szerveződnek és identitásuk megerősítésére törekednek. Silași lelkészi család sarja, ő maga is lelkészi képesítést szerez, szemináriumigazgató, ilyenként szorosabban kapcsolódik a (nemzeti) közösségi érdekképviselethez. 


\subsection{Grigore Moldovántól Moldován Gergelyig}

\subsubsection{A Moldován-irodalom dilemmái}

Grigore Moldován több ponton felbukkant már eddig a kötetben: a román színház ügye, Mihai Eminescu, a román népköltészet recepciója kapcsán, sőt egyetemi tanári minőségében is. Grigore Silaşitól eltérően nem külföldi (teológiai) egyetemi tanulmányok elvégzése és intézményigazgatói munkásság után érkezik a kolozsvári egyetemre ${ }^{488}$, hanem Kolozsváron a piaristáknál, majd a Jogakadémián folyatott tanulmányai után rövid ügyvédi, majd tanfelügyelői foglalatosságait cseréli egyetemi tanárságra. 1878-ban oktatásszervezői érdemei elismeréséül kap királyi tanácsosi címet. Mind Moldován, mind Silaşi tagja a kolozsvári EME-nek. Emellett Silaşi a románok ASTRA egyesületének szervezésében is szerepet vállal, míg Moldován csak magyar szervezetek iránt érdeklődik: az Erdélyi Irodalmi Társaság és a Kemény Zsigmond Társaság tagja lesz. Silaşit a Román Tudományos Akadémia, Moldovánt a Kisfaludy Társaság választja tagjai sorába. Az EME-tagság, az új egyetem tanári karához való tartozás szellemi, anyagi és infrastrukturális lehetőségeket kínál mindkettejük számára, mégis az előbb jelzett eltérő tájékozódás beszédes románságuk perspektívájából. Moldovánnak a román színház ügyével foglalkozó tárcája és más írásai értelmezésekor már idéztem egyéni véleményét és nemzeti identitásának problematikusságát, amit egyetemi tanárrá választásakor a román sajtó a "renegát” jelzővel illet.

Ha Domokos Sámuel bibliográfiájában keressük, nem találjuk sem nevét, sem munkáit a magyarra fordított román szerzők között. Ebből naivan arra következtethetünk, hogy Moldovánnak nincsenek irodalminak minősíthető, kapcsolattörténeti jelentőséggel bíró szövegei. Amennyiben Nicolae Bălcescu, Timotei Cipariu, Gheorghe Şincai, Andrei Şaguna - akiknek munkássága csupán egy tágabb értelemben vett irodalomfogalom mentén illeszthető e kötetbe - mégis jelen van a bibliográfiában, annyiban az még

\footnotetext{
${ }^{488}$ A két egyetemi tanár kapcsán, őket „fehér hollónak” nevezve ironizált Stelian Mândruț román történész a 2010. április 23-án tartott A kolozsvári magyar tudományegyetem c. konferencián: mindkettő Gergely, mindkettő görög katolikus, viszont más oldalon állottak. Amíg Silașit a magyar közösség bírálta nemzetiségi törekvéseiért, a Iulia-egyletért, addig Moldovánt a román. Kettejük összehasonlítása nem új jelenség. Eleve adódik az összevetés lehetősége, hiszen Moldován Silași örökébe lép az egyetemen. Az összevetésre egy román nyelvű tanulmány törekszik (Gabriel Vasiliu, O paralelă între activitatea lui Grigore Silași și cea a lui Grigore Moldován, profesori de limba română la Universitatea din Cluj $(1872-1919)=$ Studii și cercetări etnoculturale 1997/III, 115-119.), a szövegnek mégsem sikerül pártatlannak lennie, és már a második oldalon Silași fontosságát hangsúlyozza. Kettejük munkásságáról írva, Vasiliu Moldován kritikusaira is kitér, munkáit mennyiségileg kevésnek és kevésbé eredetinek tartja a Silașiéhoz képest.
} 
beszédesebbé teszi Moldován hiányát. A bibliográfia bevezetőjében és annak román változatában megemlíti őt Domokos: Moldován Gergelyként. ${ }^{489}$ Következetesen magyar változatban használja a nevét. Származását tekintve, Grigore Moldován szamosújvári görög katolikus román. Már korábban kitértem a 19. században gyakorolt névhasználatra, a magyarosított változatokra, amelyek főként a hivatalos, a magyar nyelv hatalmi pozíciójának következményei. Ezt problematizálja például egy, a kolozsvári Brassai-hagyatékban található, Meltzl Hugóhoz írott levelében Szentkatolnai Bálint Gábor: „Nagyon óhajtanám, hogy az angol és egyéb idegen tudósok neveit úgy hagyták volna, amint én írtam, mert az angolok már többször fölszólaltak nevüknek magyaros elferdítése ellen pl. minő iszonyú ostobaság volna Hyde Clarke-ot Clarke Hyde-ra csavarni, pedig már tettek ily félét a bölcs magyar Akadémiában. Ezért én határozottan „Max Müller” és nem Müller Miksa stb. féle csavarás mellett vagyok. Ami idegen, hagyjuk azt idegennek s ne csavarjuk magyar alakba, mert az nevetséges". ${ }^{490}$

Olyan egyszerü kérdés, mint a névhasználat is bonyolulttá válik, ha nemzeti értelemben differenciáljuk. Amennyiben Moldovánt megpróbáljuk beilleszteni ebbe a kategóriába, akkor elfedjük az életműnek azon aspektusait, amelyek a befogadását egyoldalúvá teszik, és amelyek elválaszthatatlanok Moldován identifikációs próbálkozásaitól. Akár a többi román származású értelmiségi esetében, itt is a román névváltozat mellett maradok, annak ellenére, hogy belátom, ez a választás nem jelenti a kérdés megoldását. Viszont kompromisszumok nélkül nem lenne lehetséges az olyan többes kötődésü értelmiségiek vizsgálata, akik identifikációikban ellenállnak mind az egykorú, mind a későbbi fogalmi apparátusnak, és megerősítenek abban a felismerésünkben, miszerint homogén jelentésekkel bírnak fogalmaink, és ezek a jelentések nem pusztán időben, hanem egyéni használataikban is különbözőek. Moldován egyik reprezentatív példája ezeknek a figuráknak.

Domokos Sámuel például eltekint a kérdés problematikusságától, és a magyar változat mellett dönt, hiszen Moldován bibliográfiában szereplő szövegei (népköltészetii ${ }^{491}$ és néhány szépirodalmi fordítása, tanulmányai) magyar nyelvhasználatuk miatt mind a recepció oldalán helyezhetők el, a

\footnotetext{
${ }^{489}$ Dомокоs 1966, 19., valamint 44.

${ }^{490}$ Bálint Gábor levele, Athén 1888. április 8. [A kézirat lelőhelye: Erdélyi Unitárius Egyház Gyűitőlevéltára] Egy kevéssel korábbi korszak ilyen szempontú vizsgálatához lásd például: DЕÁK 2000.

${ }^{491}$ Moldován 1867-től szerepel román népköltészeti (népdalok, balladák, kolindák és újabb müfajok: közmondások, mesék, találós kérdések) alkotások magyar tolmácsolójaként magyarországi lapokban. A szépirodalmi (Fỡvárosi Lapok, kolozsvári Hölgyfutár), családi (Képes Világ), ismeretterjesztő (Hazánk s a Külföld, Ország-Világ), balközép (Magyar Polgár) és liberális (Kolozsvár) politikai lapok hasábjain, de saját folyóirata, az Ungaria mellékletében (Magyar-Román Szemle) is közöl fordításaiból. Ács Károly után Moldován neve a Kisfaludy Társaság által
} 
magyar nyelvű irodalom részei, és nem a primér, román nyelvű szövegek sorában, külön tételként. Ismételten a modern értelemben vett, nyelvalapú nemzeti irodalomfogalom inhomogenitásával találkozunk. Moldován sajátos önazonosság-tudata és ahhoz kapcsolható munkássága tartja távol a modern értelemben vett nemzeti kultúrák hozzá való közeledését és megértését.

Életrajzi adatait közlik ugyan a különböző lexikonok (Szinnyei, Pallas, néprajzi, etnográfiai, magyar életrajzi) ${ }^{492}$, alig találunk életművét tárgyaló írásra. Magiszteri dolgozatomban, majd kutatásaim során magam is életműve értelmezéséhez kerestem szempontokat ${ }^{493}$, és úgy gondolom, hogy a Moldován kapcsán felbukkanó jelzők (renegát, kitagadott, ellentmondásos vagy a román irodalom Hajdú Győzője) megbélyegző jellegűek, eleve távol tartják az értelmezést. Viszont éppen ennek az értelmiségi szerepnek a rekonstrukciója vezethet el részint a 19. század vége Magyarországának és Osztrák-Magyar Monarchiájának nemzeti és nemzetiségi problémáihoz, azoknak árnyaltabbá tételéhez, illetve a kivételek, jelesül a hatalmi diskurzustól eltérő értelmiségi identitások értelmezéséhez.

Bármennyire is nehezíti a kérdés politikai jellege, illetve a megbélyegző értelmezési hagyomány rétegeinek megbontása ennek tárgyalását, nem gondolom azt, hogy elvetendő ez a kutatási irány vagy továbbra is elítélendő Moldován munkássága. A kutatás mellett érvként felhozható az a tény is, hogy egy későbbi perspektívából kevésbé legitim a bíráskodás gesztusa. A Moldován problematikus identitása mögött rejlő tartalmak és azok építkezésének, érvrendszerré alakulásának vizsgálata, rekonstruálási kísérlete megláttathatja Moldován gondolkodásának és cselekvési stratégiáinak logikáját.

Nyilván igaza lehet Avram P. Todornak abban, hogy Moldován irodalmi megnyilatkozásai minden esetben politikai töltetűek, és mivel állandóan harcol az erdélyi román közvéleménnyel, amely politikai állásfoglalása miatt bírálja, kezdeményezései kudarcba fulladnak, óriási munkássága negatív eredményekhez vezet. ${ }^{494}$ Viszont ez a negatív előjel is nézőpont kérdése. A kitagadottság is perspektívafüggő, és egy nyelvi közösségen belül is megosztja a véleményeket (amíg a román történetírás vagy egye-

is értékelt népköltészeti fordítások szerzői - Iosif Vulcan, Iulian Grozescu és Ember György - mellé kívánkozik.

${ }^{492}$ Megtaláljuk az Österreichisches Biographisches Lexikonban Moldován Gergely (Grigore) címszó alatt, amelyet Benda Kálmán jegyez. [http://www.biographien.ac.at/oebl/oebl_M/ Moldován_Gergely_1845_1930.xml - utolsó látogatás: 2010. július 10.]

${ }^{493}$ 2003. november 22-én A Magyar Tudomány Napja Erdélyben című kolozsvári konferencia Bölcsészet-, Nyelv- és Történettudományi Szakosztálya I. szekciójában Az Eminescu-tolmácsolások mint kulturális stratégiák. Hagyományos és rendhagyó kutatási technikák az összehasonlító irodalomban című előadásomban már Grigore Moldovánt is vizsgáltam.

${ }^{494}$ ToDor 1983, 54. 
temtörténet elhallgatja, esetleg renegátnak nevezi Moldovánt ${ }^{495}$, a román etnológia szakmai érvek felől értékesnek látja munkásságát, vagy például Köpeczi Béla idézőjelezi a kitagadott jelzőt, ezzel kérdőre vonva/elbizonytalanítva érvényességét $\left.{ }^{496}\right)$.

Az elkövetkezendőkben ${ }^{497}$ azzal próbálkozik az alfejezet, hogy Moldován néhány kötetben vagy különlenyomatként megjelent munkájában, esetenként azok paratextuális elemeiben és elsődleges kontextusaikban felismerhető szerzői intenciókat, identifikációs gesztusokat az életmű és a köré épülő kulturális kapcsolatok felől értelmezze.

\subsubsection{Fordítás - népisme. Moldován, az etnográfus}

Amint arra Köpeczi Béla is rámutatott ${ }^{498}$, nem csupán politikai koncepciója jellemezheti Moldovánt, hanem tanári és etnográfusi tevékenysége is. Emellett szól az a tény, hogy például a legújabb, reprezentatív igényú román nyelvű etnográfus biobibliográfia negatív értékítéletek nélkül szemlézi a folklorista Moldován munkásságát. A vonatkozó szócikk román származású magyar folkloristaként tekinti Moldovánt, aki a román-magyar közeledést a néprajzban valósította meg, hiszen fordításait ennek szolgálatába állította. Moldován esetében a román etnológusokat bemutató lexikon nem tud román nyelvű sajtóbeli publikációt sorolni, és ezt a hiányt éppen Moldován identitására vonatkozó kijelentése oldja fel. ${ }^{49}$ Ehhez képest például a Magyar néprajzi lexikon etnográfusnak és irodalomtörténésznek nevezi azt a Moldovánt, aki „politikailag a magyar királyság integritását támogatta, ezért - román származása ellenére - az erdélyi román irredenta mozgalom élesen támadta". ${ }^{500}$

Moldován életművébe szervesen illeszkedik néprajzi érdeklődése, mégis valamennyire szétszálazható munkássága. Ebben az alfejezetben életműve azon szakaszával foglalkozom, amely megelőzi egyetemi tanári munkásságát, hiszen ebben a szakaszban másnak látom politikai érdeklődését, mint a későbbiekben, amikor nyilvánosan felvállalja álláspontját, aminek karrierjét is érintő következményei vannak.

\footnotetext{
${ }^{495}$ Grigore Moldován munkássága újragondolásának kérdését Sorin Mitu vetette fel 1998-ban a BBTE történelem szakos diákjainak tartott egyetemi tanévnyitó beszédében. Lásd Mitu 1998.

${ }^{496}$ 2003-ban 18 perces dokumentumfilmet rendezett Sas Péter a következő címmel: Egy megtagadott hazafi: Moldován Gergely.

${ }^{497}$ Nem foglalkozom Moldován politikai írásainak bemutatásával és értelmezésével, mert mind a magiszteri dolgozatom, mind a hivatkozott tanulmányok megteszik azt. Lásd: BERKI 2004, BERKI 2005B.

${ }^{498}$ KÖPECZI 2000, KÖPECZI 2001.

${ }^{499}$ DATCU 2006.

${ }^{500}$ Ortutay 1977.
} 
1884-ben Koszorú a román népköltészet virágaiból metaforizáló című fordításkötetet jelentet meg, K. Papp Miklós kiadásában, a Magyar Polgár nyomdájában. ${ }^{501}$ Előszóval látja el kötetét, és itt jegyzi meg, hogy a román népdal által tolmácsolt, a kertészeti tökélytől távol álló vadvirágok egyesítő erővel bírnak: a bennük létező érzések a nép lányát a kisasszonnyal, az embert az úrral egyesítik, eltörölve a rangbeli különbségeket.

A maroshévízi Urmánczy Ilona a népszeretet példájaként lesz az, akinek Moldován e kötetét ajánlja. A fenti elképzelés és az Urmánczyra való hivatkozás azért fontos, mert innen látszik, hogy Moldován nem csupán a magyar és román nyelvű kultúrák közötti közvetítésként értelmezi fordítói tevékenységét, hanem a lefordítandó román alkotások értékét abban látja, hogy képesek eltörölni a társadalmi különbségeket. A népköltészet és fordítása kettős homogenizációt jelent tehát: társadalmit és nemzetit. ${ }^{502} \mathrm{~A}$ fordítást ez esetben tudatosan felvállalt érdekek működtetik.

A továbbiakban egy olyan művel foglalkozom, amely éppen műfajisága és a vele kapcsolatos prekoncepciók alapján apolitikusnak látszik, és elkerülte a Moldován-szakirodalom figyelmét. ${ }^{503}$

Egy évvel korábban, 1883-ban Moldován egy borszéki fürdőidény élményeit osztja meg olvasóival, itt ismerkedett meg Urmánczy Ilonával. ${ }^{504}$ A Domokos Sámuel-féle bibliográfiából hiányzik ez a mü, látszólag nem része a kapcsolattörténetnek. Az Albert Jánosnak ${ }^{505}$ ajánlott kiadvány elöszava utal arra, hogy nem tudományos munka, hanem a privát érzelmeké, és a hely népszerüsítése szándékával íródott. Alaposabb vizsgálata talán visszacsatolja a tematikájában és módszertanában az irodalom külpolitikája felé tekintő kutatást az irodalom szűkebb értelmezéséhez, hiszen az elbeszélés narratív technikái, az énmegjelenítések, a műfaj és a vele járó lehetőségek mind szempontjai e szövegelemzésnek.

\footnotetext{
${ }^{501}$ Moldován 1884.

${ }^{502}$ A társadalom e kettős tagoltsága Moldován politikaiként tekintett írásában is megtalálható. Amikor egy évtizeddel később Magyarok, románok címmel adja ki a nemzetiségi ügy kritikájaként kínált kötetét, abban amellett, hogy hangsúlyozza, hogy a románság a magyarokkal szemben kialakított közösségtudatát a történeti-jogi értelemben vett társadalomszerkezet befolyásolta, bemutatja, hogy miként oszlik a románság intelligenciára és köznépre. A Gyáni-Kövér-féle társadalomtörténeti munka felől ez a kategorizálás a rang és presztízs alapján történik.

${ }^{503} \mathrm{Az}$ a tény is beszédes, hogy a rendelkezésünkre álló gyér szakirodalom főként Moldován teoretikus (politikai) szövegeire, lapvállalkozásaira koncentrál.

${ }^{504}$ Moldován 1883.

${ }^{505}$ Albert János barátomnak Tordán, 1883. március 6-án, Moldován Gergely - olvasható az ajánlás. Albert János (1821-1908) tordai unitárius lelkész és gimnáziumigazgató. Brassai Sámuel rokona.
} 
E Moldován-kötet, az életmű többi darabjához hasonlóan, a megismertetés jegyében fogant. Eltekintve attól, hogy a városhoz társított hőség és bezártság ellentéteként jelenik meg itt az utazás, a vidéki fürdő és sajátos ideje; az utazás-elbeszélések műfajába íródik a többrétegű szöveg: „még egy nő se olyan kíváncsi, mint az utazó. Szeretné minden halomnak megismerni a históriáját, minden érdekli, lesz geológus, asztronómus, füvész, bogarász, nemzetgazda, illetőleg lenne szívesen, ha tudna; amint lépésről lépésre figyel - és lát, amit magának aztán nem tud megmagyarázni". ${ }^{506}$

A megfigyelés és látás módszertanát magáénak valló utazó éppen a hétköznapi életből kilépve szembesül annak korlátaival, például a szakmai hivatásosodás egyik negatív következményével: a világot nem képes teljességében megragadni, nincsenek eszközei a megfigyelt természet totális megértéséhez. ${ }^{507} \mathrm{~A}$ felsorolt tudományágak módszertanilag a jelzett kompetenciabeli különbségek ellenére nagyon közel állnak éppen a megfigyelés és leírás által a Moldován elsődleges érdeklődését képező etnográfiához. Állíthatjuk, hogy a tudományosság igényének elvetése csak részlegesen történik meg, hiszen a szerző etnográfusi szemmel látja és értelmezi élményeit. A terepmunka egyik lehetőségét képező szóbeliségről árulkodik az elbeszélői perspektíva, vagyis az olvasó egyes szám második személyben való megszólítása. A kíváncsiság, megismerés meg figyelem mind a racionalitáshoz köthető gondolkodási folyamatok, amelyek fontosságát kiemelve, Moldován az előszóban megfogalmazottakat roncsolja. Ezt teszi akkor is, amikor többrétegű szöveget hoz létre: élménybeszámolóit lokális jelentőségű regékkel, saját gyűjtéseivel tarkítja. ${ }^{508}$ Helytörténeti jelentőségü adatokat közöl, forrásait megnevezve, vagy a fürdő vendégkönyvében olvasható bejegyzéseket osztályozza és kommentálja ${ }^{509}$, vagy azok alapján statisztikai felmérést végez. ${ }^{510}$

\footnotetext{
${ }^{506}$ I.m. 10.

${ }^{507}$ Moldován fenti megállapítása ahhoz a váltáshoz kapcsolható, ami a polihisztorok 19. század végi megítélésére jellemző. A specializáció okozta tudásbeli töredezettség és szakbarbárság ellenében ismét értékesként mutatkozik meg a számos tudományágban jártas szaktudósok tájékozottsága. Lásd a Brassai Sámuel vagy Herman Ottó iránti már-már kultikus tiszteletet vagy annak gesztusát, hogy az „utolsó polihisztor” szószerkezet pozitívra vált a 20. században és versengésszerűen jelennek meg az ilyen profilú tudóséletrajzok. Például vö. A múlt magyar tudósai, Akadémiai Kiadó, Bp., 1991.

${ }^{508}$ Lásd az Egy rege a forrásról, Egy másik rege, Az erdő leánya, A tündérkert c. fejezeteket.

${ }^{509}$ Például: simpla, manupropria nélküli nevek; szerelmesek, melancholikusok, bölcsek, véleményezők, feltűnősködők, reklámcsinálók, „revisorok”, a gyáva névtelenek.

${ }^{510}$ A lakhely szerint Marosvásárhely, Gyergyó és Kolozsvár sorrendet állít fel, külföldiek esetében Iași-Bukarest a sorrend. Állás és foglalkozás szerint kereskedők (91), földbirtokosok (54), tanügyiek (47), magánzók (20) közül látogatják legtöbben a fürdőt. Nemi szempontból: „Borszéken mindig nagyobb a női, mint a férfi közönség.", és külön csoportot képeznek azok az asszonyok és lányok, akiket „,az emancipációt még el nem ismerő korban, állásukra nézve külön osztályozni nem lehetett". Moldován 1883, 124.
} 
A román-magyar kapcsolat az idézett kötet több pontján is előkerül. ${ }^{511}$ Augusztus elsején elbeszélőnk Moldovába kirándul, a tizenhárom tagú társaságból Blaha Lujzát és férjét, Splényi Ödönt is megnevezi. A kirándulás kapcsán kerülnek előtérbe érzelmei: „,szívem összeszorult e hídon [Tölgyesnél, a határon, „passus kellett” -kiegészítés általam B.T.]. Nem tudom, hogy másnál milyen érzést idézett elő a határ átlépése, de engem alterált. Mintha valami súgta volna: »ne menj el, maradj itt! « Pedig az egész kirándulás egy tréfa volt $s$ tudtam, hogy néhány perc múlva visszatérünk, de valami lekötött a földgöröngyhöz, hogy megcsókoljam azt, mielőtt átlépek rajta". .12

A határátlépés, a haza elhagyása az idegenség és otthontalanság képzetét keltheti. Azért nem problematizálom a Moldován és múve elbeszélője közötti viszonyt, mert szövege valós helyszínei és szereplői, az élmények megosztásának szándéka, az énelbeszélés elsősorban a referenciális, de esetenként a reflexív olvasás lehetőségét (is) kínálja. Az érzékletesen vázolt gesztus: az anyaföld megcsókolása, a kirándulás rövidségének hangsúlyozása a szülőföldhöz ragaszkodás mellett többletjelentéssel gazdagodik. Ezzel a gesztussal Magyarországhoz való tartozását és lojalitását fejezi ki az elbeszélő, eléggé túlzóan. Blaha Lujza miatt fordulnak vissza, aki rosszul érezte magát, azt viszont Moldován nem árulja el, hogy miért. Az elbeszélő explicitté tett zavara és Blaha rosszulléte találkozik Moldovában, azé a Blaha Lujzáé, akit azelőtti este a borszéki mulatóklub ${ }^{513}$ elnökeként éppen az elbeszélő vezet be a társaságba, aki a magyar nemzet reprezentatív figurája. Az az elbeszélői fogás, amellyel Moldován impliciten kapcsolatba hozza elbeszélője és Blaha rosszullétét, arra játszik rá, hogy a nemzetet jelképező színésznővel közös a hazán kívüli térhez, az idegen földhöz való viszonyulás. Ezt az idegenséget az elbeszélő annak hangsúlyozásával fokozza, hogy a határnál dolgozó román katonaság csak románul beszél. Ha a korabeli olvasónak nem lennének Moldován származására vonatkozó információi, akkor a Moldován Gergely szerzői név alapján problémamentesen gondolhatná azt magyarnak és természetesnek láthatná a gesztust. Bár ebben az esetben is beszédes a név, hiszen származásra utal: moldovai, vagyis a román fejedelemség területéről származó.

\footnotetext{
${ }^{511}$ A kötet szempontjából kevésbé specifikusan itt: Egy román úr fürdik az egyik medencében, egy magyar úr nézi, nézi. Egyszer, hogy igen sokáig fürdött a román úr, azt mondja neki oláh nyelven: „Domnule! Pre multu siedi!”- (Uram! igen sokat ülsz!) A román úr pedig azt feleli vissza magyarul: „Nem tudom magyarul!” Íme! Tehát elfelejti az ember saját anyanyelvét s idegen nyelveken kezd conversálni, mint jó hajdanában az apostolok. Ez a Lobogó hatalma. Moldovín 1883, 52.

${ }^{512}$ I.m. 68.

${ }^{513}$ A magyar-román közeledést szolgálja, július 29-én egy felhívására válaszolva, többen aláírnak az összetartás és egyetértés jegyében, köztük Moldován Gergely, elbeszélőnk. Lásd A bot és a "mulató-clubb" c. fejezetet. MoLdován 1883, 140.
} 
Amennyiben Moldovánnal azonosítjuk az elbeszélőt, és ezt a lehetőséget maga írja bele szövegébe, akkor előfeltevéseink szerint román származásával ellentétes a román földhöz való viszonya, hazájához való ragaszkodásában a magyarok/nem románok viselkedését mintázza. A sors iróniája éppen Moldován (szerzői) nevében munkál, hiszen mint származásjelöló, éppen ahhoz a területhez köti megtagadhatatlanul, amelybe kirándul: Moldvához.

A románokkal a szöveg más fejezeteiben is foglalkozik. Egyfelől a borszéki Kossuth-kút körül láttatja őket, ott, ahol nyelvi sokszínúség jellemzi a fürdőzőket, akik között a románok összetartó társaságként különülnek el, és román nyelven politizálnak. Összetartozásuk viszonylagos, hiszen az elbeszélő a iaşi-i és bukaresti románok eltérő gondolkodásmódját bizonyítja. Másfelől Marie Cantacuzine [!] és Huszár Ilona kapcsolatával illusztrálja a két nép közötti kapcsolatot. A román lány bemutatása jó alkalom arra, hogy a románokról írjon. Arról, amit fentebb is említettem: hogy nem képeznek homogén nemzeti közösséget, erőteljesen különböznek a moldvaiak a havasalföldiektől, a iaşi-iak a bukaresti románoktól, akiket ráadásul az „erdélyrészi veniturák” a magyarországi románok gyülöletére biztatnak. ${ }^{514}$ Huszár Ilona viszont "meghódított egy lelket s így hazafias kötelességének eleget tett" ${ }^{\prime \prime 15}$, hiszen Marie magyar nyelvet tanul tőle, hatására magyar népdalt zongorázik.

Ez a példa egyszerre szemlélteti azt, hogy a nevelés teszi receptívvé az embereket, és azt, amint a nevelés hódításként, hierarchikus viszonyként, jelentőségében pedig hazafias tettként értelmeződik. Így a nyelvtanulás, a másik kultúra iránti érdeklődés egyáltalán nem semleges, hanem akár egyoldalú és ideologikus is lehet. Két nő kapcsolata válik illusztratív példává annak ellenére, hogy az elbeszélés egy pontján a nőket okolja a különbözőségekért. Hosszabban idézek ebből a részből: [...] a természettudósok korántsem tudják megállapítani azt az időt, amely a németet, oláht, magyart meg a zsidót nemzette és e világra hozta volna; sem azt, amelyben kiváló anyagból külön lepény módjára sütötte volna ki a bárót, grófot, herceget, firtlit meg a plebset, azt a zsíros polgárt, meg azt a harisnyás parasztot durva kézzel, hanem csak azt tudják megállapítani, amelyben az ember keletkezett vad állapotban, bottal a kezében, meztelenül, árván és elhagyatottan. [...] még a fürdőn is igen nagyok a válaszfalak ember és ember, család és család, faj és faj között. [...] A nő csinálja a társadalomban a különbséget, az állás, születés és rang szerint minden osztály önmagának bogarakat nevel és azok szerint él" ${ }^{516}$ Sajátosan vázolja az emberiség (vagy

\footnotetext{
${ }^{514}$ I.m. 153.

${ }^{515}$ I.m. 154.

${ }^{516}$ I.m. 138-139.
} 
csak az erdélyi nemzetiségek?) eredettörténetét, amely szerint a születésben egyenlők az emberek, a nevelés, szocializálódás, a társadalmi lét teszi őket különbözővé. A történeti-jogi értelemben vett társadalomszerkezetet kezdi ki az elbeszélés idézett része, de hasonló, bírálható szerkezetben (rang és presztízs szerinti struktúra) fedezi fel kora társadalmát, hiszen a fürdőzők nemzetiségi és foglalkozási csoportokra különíthetőek. ${ }^{517}$ A nők az élet biztosítékai, de a családban, amíg a férfi része és aktív szereplője a közösségi alkalmaknak, addig a nő távol marad, nem közeledik. Blaha Lujza éppen e közeledés szimbóluma lesz ${ }^{518}$, hiszen fellépései a szórakozás olyan alkalmaira vonnák az oly különböző fürdőközönséget mint a Mulató-klub által szervezett bál, bankett, fáklyászene. A fürdőzés mint egészségmegőrzéssel kapcsolatos időtöltés ${ }^{519}$ az utazás, kirándulás mellett a társasági életnek is kedvez. Például a szövegben többször felbukkanó szerelem, párválasztás vagy egy majdani házasság lehetősége kellemes álommá, azaz a valóságon túlivá változtathatja a Borszéken töltött heteket. Ugyanakkor olyan szabadidős tevékenységeken is részt vehetnek a fürdőzők, amelyek szórakoztató funkcióikban ideologikusak lehetnek: a Mulató-klub említett rendezvényei a népek közötti közeledést szolgálják.

A románok kapcsán a szép lányokat, a tábortűznél való bámészkodásukat, a Blaha Lujza által negyedórás időzése alatt megcsodált oláh táncot és a vásárolt moldvai ordát, sajtot, a drága pénzért kapható román „dulcsászát" említi még az elbeszélés. A románok mellett más nemzetiségek is előkerülnek a müben, korántsem akkora súllyal és főként sztereotipikusan: a cigányokat zenészként, a zsidókat pedig vidámnak láttatja, ellentétben a moldvai zsidókkal.

A magyarokat azért nem soroltam az imént, mert nyilvánvaló, hogy Moldován az ő perspektívájukat tartja sajátjáénak, emellett magyar nyelven számol be fürdőélményeiről, vagy magyar forrásmunkákat idéz Borszék kapcsán. Az a Moldován Gergely, aki szerzőként és elbeszélőként jelen van a szövegben, a magyarok társaságában láttatja magát, miközben

\footnotetext{
${ }^{517}$ Vö. GYáNI-KöVÉR 1998.

${ }^{518}$ Blaha Lujza Alapítványt hoz létre a Vallás- és Közoktatási Minisztérium ezen alkalmak jövedelméből, melynek kamatja „két szegény, de jó tanuló gyermek fölsegélésére fordíttassék vallás- és nemzetiségi különbség nélkül." A szövegből kiolvasható a Blaha Lujzához való kultikus viszonyulásmód másik fontos része az elbeszélő következő vallomása: „Én pedig felírtam a művésznő legyezőjére: Bírna Borszék százszor annyit, / Mit amit bír összevéve,/ Mert bálványa vagy egy népnek,/ Te vagy ma legdrágább gyöngye." [kiemelések tőlem - B.T.] Lásd: Moldován 1883, 64., 65.

${ }^{519}$ A mi kuránk címü fejezetben az orvosi recept során részletezi az elbeszélő az idő lassú, ráérős eltöltésével együtt járó feladatokat (hosszú akkomodációs időt hagyni, nem gondolkodni, a látottakra koncentrálni, társaságra találni), amelyek során hat hét alatt a fürdőzők hatványozott erőre lelnek. A szabadidő, általánosabban pedig az időfogalom differenciálódásához lásd: LÁzÁr 1991, különösen: 15-48., 60-117., 175-213.
} 
gondosan figyel a magyar és román kapcsolatokra, a különbözőségekre, azokat elbeszélésében részletesen illusztrálja. Elbeszéléséből az olvasható ki, hogy az egészségjavító kúrán kívül több dolog foglalkoztatta Moldován Gergelyt: népköltészeti gyűjitések adatközlőktől, a magyar-román közeledés és nem utolsósorban, az „idény szépei”, ismerősök és ismeretlenek. Érdemes látni a szép lányok sorát. A két nép közötti kapcsolatok kitűnő példájaként bemutatott Marie Cantacuzino és Huszár Ilona nyitja a listát, majd a többiek, akiket szintén itt ismert meg Moldován: az arisztokrata származású Ugron és Splényi bárónők, az a toplicai/maroshévízi Urmánczy Ilona, akinek népköltészeti fordításkötetét ajánlja Moldován egy évvel később, Csontú kisasszony Moldvából ${ }^{520}$, Gál Juliska Budapestről, Bartalis Tinka Szárhegyről és a „Gyertyánffy leány” Brassóból. Nem véletlenszerü e lista alakulása sem, mint ahogy a szöveg terében az elbeszélő megfigyelései, leírásai, illusztratív példái vagy népköltészeti közlései sem azok. Tiszteletben tartva éppen a szöveg egy részében kárhoztatott származást mint rangot biztosító tényezőt, az arisztokrata lányokat sorolja előbb, illetve azokat, akik természetességükön és szépségükön kívül koncepciójában fontos szerepet játszanak. Bár az elbeszélő relatívként veti föl a szép és rút kategóriáit, egy „oláh mondással” érvel saját preferenciái mellett: nem az a szép, ami szép, hanem az, ami nekem tetszik. ${ }^{521}$ Ismét nem lehet véletlenszerü a román „mondás" használata, és ez annak a jele, hogy mennyire sajátosan gondolkodik Moldován. A szépséget olyan kategóriaként láttatja, amely nagyon szubjektív, és nem önelvű, jelentései az egyéni érdekeknek rendelődnek alá.

Az elbeszélésben mindvégig olyan elbeszélőként van jelen tehát Moldován Gergely, aki a magyarokkal vállal közösséget, az ő társaságukat keresi. Blaha Lujzával, férjével, Splényi Ödönnel barátkozik, teljesen beilleszkedik gondolkodásmódjukba. A magyarokhoz való kötődése részint megengedi, hogy kívülállóként szemlélje és akár sztereotipikusan gondolja el a más nemzetiségeket - bár a cigányokra, zsidókra vonatkozó sztereotipikus gondolkodás nemcsak a magyarokra, hanem más népcsoportokra is jellemző -, másrészt azért lehet problematikus, mert gondolkodásmódjában, szófordulataiban leleplezi a román kultúrában való jártassága. Tudjuk, hogy később sem jelent gondot Moldovánnak sajátos identifikációs elképzelése, mert nyíltan vállalja, hogy ő magyarországi román, aki ilyenként jó magyar állampolgár. Bizonyára munkája müfajiságához alkalmazkodott, amikor nem foglalkozott koncepciózusan saját identitásával, ellentétben későbbi politikainak számító írásaival. Mégis, amennyiben e szövege a pri-

\footnotetext{
${ }^{520}$ Moldován magyar helyesírással írta a nevét, mint ahogy a szárhegyi lányét is. Nem a lányok nemzetisége a döntő szempont e felsorolásban, de valószínúsíthető, hogy Csontú kisasszony román származású.

${ }^{521}$ Moldován 1883, 183.
} 
vát érzelmek tere, akkor látható, hogy a férfi Moldován Gergely számára nem csak a női szépség ad okot azok kifejezésére, hanem e szubjektivitás, a magánéleti érzelmek keretébe vonja saját és mások társasági életét, ennek kapcsán pedig a nyelv, kultúra és nemzetiség viszonyának kérdését. A fürdőzés, a pihenés és szabadidőtöltés az idő- és térbeli távolságból tudatosan megszerkesztett elbeszéléssel találkoztunk.

E szövegében egyfelől nyomon követhetjük Moldován csoportkötődéseit, problémaérzékenységét, másfelől etnográfusi érdeklődését. Megfigyelései, leírásai arról árulkodnak, mennyire nem egyértelműsíthető egyéni nézőpontja: a románokról úgy ír, hogy jobbára elfedi saját kötődését; ritkábban, érvelésében mégis kamatoztatja azt. Egyszerre képes kívülállóként és „,bennszülöttként” erősen differenciáltnak látni ezt a népcsoportot, és hozzá képest homogénnek a magyarságot.

Bár ekkor a néprajztudomány gyermekcipőben jár, Moldován életmüvét végigkísérik gyűjtései, közlései, fordításai és vonatkozó tanulmányai. A nyomtatásban megjelent Moldován-művek jelentőségét mind a román, mind a magyar etnográfusok felismerik. Annak ellenére, hogy Moldován fő célja az ismertetés, a közvetítés, az általa publikált anyag mennyisége és minősége (például a műfaji változatosság mint érdem) a gyűjtő tájékozottságáról, jártasságáról, problémalátásáról árulkodik. Ennek valószínúleg Moldován is tudatában volt, hiszen Rudolf főherceg vállalkozása, Az Osztrák-Magyar Monarchia írásban és képben címü többkötetes népismertető munka elindításakor levélben fordul Jókai Mórhoz. Levelében Torda-Aranyos megyére vonatkozó javító szándékú észrevételei mellett nem mulasztja el felajánlani segítségét a régióval kapcsolatos fejezetek megírásához. ${ }^{522}$ Moldován királyi tanfelügyelőként szignálja keltezetlen levelét. Oktatásszervezői munkája vitte a régió közelébe a szamosújvári fiatalembert. Foglalkozása legnagyobb hozadéka számára a királyi tanácsosi cím volt. Torda-Aranyos megyei tanfelügyelőként ${ }^{523}$, bejárva a vidéket, részben a régió népességére, román és magyar lakosokra, életmódjukra, szokásaikra láthatott rá, részben néprajzi tárgyú gyüjtéseket végezhetett „terepen”,

${ }^{522}$ Olyan földrajzi tévedésekre hívja fel a figyelmet, illetve olyan részleteivel egészíti ki Torda-Aranyos megye leírását, amelyek történetileg akár napjainkig is a vidék jellegzetességeiként tekinthetőek: a scărișoarai jégbarlang, Torockó melletti csepegőbarlang, búvópatakok, torockói Székelykő, a Jára völgye és nevezetességei, a Szent László-kultusz jelei, Aranyos mente és az aranymosás, Torda mint fejedelmi város „,sóbányáival, fényes múltjával, országygyűléseivel, római várával, vízvezetékével". Vö. Moldován Gergely Jókai Mórhoz [A kézirat lelőhelye: OSZK Kt. Fond V/392.]

${ }^{523}$ Megjegyzendő, hogy az 1882-ben induló Kolozsvári Közlöny, az erdélyi szabadelvű párt lapja tan- és művelődésügyi rovatát szerkeszti. Ebben a szerkesztői munkában kollegái: Koós Ferenc (Brassó megyei), Horváth László (tanfelügyelő, Horváth Mihály erdélyi főispán öcscse vö. PÁL 2009. Váradi Károly (Kolozs megyei) is közremüködnek Éltes Károly kanonok mellett. 
amelyek „leírásai” és értelmezései publikációkként írói munkásságát is megalapozták. A tanfelügyelői minőség nem zárta ki a „népisme”, e leíró jellegű új tudományág művelését és ennek kapcsán Moldován íróvá válását. Néprajzi érdeklődése nem szűnik meg egyetemi tanárrá válásával sem. Ez utóbbi tisztségének köszönhetően lesz az EME tagja, 1887-tól pedig az Erdélyi Múzeumban közli a témában írott tanulmányait, különlenyomatként is megjelenteti a Lázár Istvánnal közösen kiadott könyv általa írt fejezetét, az Alsó-Fehér vármegye román népét bemutató munkáját. ${ }^{524} \mathrm{Va}$ lóban munkatársa lesz a rudolfi vállalkozásnak ${ }^{525}$, amely elképzelésében tökéletesen találkozik a Moldován által számos alkalommal megfogalmazott eszmével. ${ }^{526}$ A kölcsönös megismerés igénye, az ebből származó felismerés, miszerint hasonlón ${ }^{227}$ a történelmi múlt, egyazon közös érdeket szolgál: az összetartozás eszméjét, a birodalmi létét, a közös hazáét. ${ }^{528}$ Egyébként a

${ }^{524}$ Moldován 1899. [Megjegyzem, hogy az előszót 1897 áprilisában keltezi Moldován, és 1896-ban, tehát egy évvel korábban jelennek meg Az Osztrák-Magyar Monarchia írásban és képben c. munkába írt szövegei.]

${ }^{525}$ A néprajzi fejezetek megírásához Moldovánon kívül Ioan/Iosif Goldiș görögkeleti püspökhelyettest, aradi főgimnáziumi tanárt, Carmen Sylva fordítót és a népköltészeti fordításaiért Kisfaludy társasági tagságot nyert Iosif Vulcant is felszólítják. Mindketten tagjai a Román Tudományos Akadémiának. Külön vizsgálat tárgya lehetne, hogy e két munkatárs Moldovánhoz képest hogyan látta a vállalkozást és annak eszmeiségét. Iosif Vulcan is a megismertetés, népek közötti barátság eszméjét fogalmazta meg saját fordításai kapcsán, viszont lapja, a Familia a román nyelvü kultúra terjesztését szolgálta, szimpátiával fordult a román nemzetiségi törekvések fele. Végül csupán Moldován szerepel szerzőként a munkában.

${ }^{526}$ A Rudolf főherceg által írt bevezetőből idézek: „Mennél behatóbban vizsgáljuk az egyes népcsoportok jó tulajdonságait és sajátságait, úgy szintén azoknak egymástól szellemi és anyagi tekintetben való kölcsönös függését, annál nagyobb mértékben fog erősbülni azon összetartozandóság érzete, melynek hazánk népeit egymással össze kell kapcsolni. Azon népcsoportok, melyeket nyelvük, szokásaik és részben eltérő történelmi kifejlődésük a népesség többi alkotó részeitől elkülönítettek azáltal, hogy nemzeti egyéniségük a monarchia tudományos leíróinál az őket megillető elismerésre talál, bizonyára kellemesen lesznek érintve, s ezáltal egyszersmind felhíva arra, hogy szellemi súlypontjukat az osztrák-magyar monarchiában keressék. [...] Azután [a népélet és népi sajátosságok leírása után, amiben Moldován is érdekelt] következnek a jó és balsors között lefolyt hosszú idők változatos küzdelmei; s eközben szemlélhetni fogjuk, hogy csatlakozik egyik nép a másik mellé, hogy sorakozik egyik ország a másikhoz; egyre szilárdabban tömörül a sok különféle néptörzs, az érdekköz hatalma egyesíti őket benső összeköttetésük természeti törvénnyé válik, s így tárul föl szemeink előtt a jelenkor képe, a nagy és hatalmas osztrák-magyar monarchia, mindnyájunk hazája." Az Osztrák-Magyar Monarchia írásban és képben. Rudolf trónörökös főherceg őcsászári és királyi fensége kezdeményezéséből és közremüködésével, Magyar Királyi Állami Nyomda kiadása, Budapest, 1887, 12-13., 16.

${ }^{527}$ Vajda Mihály szerint Az Osztrák-Magyar Monarchia írásban és képben kísérlete lenne a monarchiabeli irodalmak összehasonlító irodalomtörténetének. VAJDA 1991. Itt jegyzem meg, hogy Fried István szerkesztésében több, a Monarchia irodalmait tárgyaló kötet jelent meg.

${ }^{528}$ A közös haza alatt Moldován elsősorban Erdélyt értheti, hiszen ott él, ott várakozik majd az első világháború idején, utána pedig a Romániában maradás mellett dönt. Erdély területileg és jogilag is meghatározott zártsága 1867 után szünik meg végleg, amikor elveszíti autonómiáját. Ennek következményeként olyan hazafogalmak társulnak hozzá, mint a patria pro- 
vállalkozás Délkelet-Magyarországgal, azaz Erdéllyel foglalkozó részében jegyzi A románokról szóló alfejezetet, bár a Jókaihoz írott levelében az Aranyos vidékének (etnográfiai) leírásához ${ }^{529}$ ajánlotta segítségét. Moldován írása tehát a rengeteg munkatársat, köztük számos ismerősét felvonultató monarchiairodalom részévé válik. A rudolfi kezdeményezés módszertanilag hasonlít a Meltzl-Brassai-féle vállalkozáshoz oly módon, hogy bár birodalmi keretek között helyezi egymás mellé és mutatja összetartozónak a nagyon is sokszínü monarchiabeli népességet, nyelveket és kultúrákat, mégis az összehasonlítás lehetőségét kínálja. Nyilván el is tér a kolozsvári koncepciótól annyiban, hogy nem többnyelvűek a kötetek, bár német és magyar, de részeiben például tót nyelvü változata is napvilágot lát.

Jogosan kérdezhetjük tehát, hogy ki volt az, akit Grigore Moldovánként emleget a disszertáció. Ismerjük származását és felekezetiségét, viszont ezek mennyiben befolyásoló tényezői identitásának? Mennyiben tulajdoníthatunk jelentőséget ennek? Miként román Moldován? Bár kijelenti, hogy nem tagadta meg románságát, melyek identitása e komponensének ismérvei? Ha meg magyarnak vallja magát, akkor hogyan kötődik ehhez az etnikumhoz.

\subsubsection{Karrier és életmü. A szövegek mögötti én}

Moldován munkássága felől folyamatszerüen és sajátos időrendben követhető nyomon Moldován koncepciójának alakulása.

Amíg fiatalon még román nyelvü cikkek írására vállalkozik ${ }^{530}$, a hatvanas évektől magyarországi magyar lapokban közölt fordításai kötik mindkét kultúrához, amikor a román népköltészet műfaji változatosságát ültetik át magyar nyelvre és teszik e kultúra részévé. A hetvenes években kezdi el a román irodalmat népszerüsítő cikkeinek sorát ${ }^{531}$ a kolozsvári Magyar Polgár címú politikai lap tárcarovatában. A kolozsvári újságban a román lapok szemléjét is ő jegyzi. 1873-ban a Figyelóben közöl irodalom-

pria és patria communis. A patria propria „édes hazaként” történetileg változatos és sokszínű társadalmi identifikációt jelentett. Lásd erről bővebben: Bárdi 2000, 123-137. A patriotizmus szakirodalmához lásd például: Cole-UNOwsky 2009.

${ }^{529}$ Az Alsó-Fehér vármegyéhez tartozó vidéket végül Lukács Béla, Hunyad megyét Téglás Gábor, a cigányokat Rudolf főherceg mutatja be.

${ }^{530}$ Grigoriu Moldovánu, Ceva despre corone, Teatrulu rusescu = Familia 1866, 103-104., 270-271. Doine poporale din Transilvania = Familia 1867, 461.

${ }^{531}$ A román népköltészeti közlések és azokkal kapcsolatos értekezéseivel párhuzamosan közli irodalomtörténeti jellegü tanulmányait: $A$ román nyelv és irodalom = Magyar Polgár 1871/286-288., A román színügy = Magyar Polgár 1872/36-39 és 42-43., A román irodalom a múlt század második felében 1872/194, Bolintinean Demeter = Magyar Polgár 1872/213 [A szeptember 18-i számban közölt írás nekrológként is értelmezhető, hiszen Bolintineanu szeptember 1-jén hunyt el.] 
történeti jellegú írást. ${ }^{532}$ Nem sokkal e tanulmánya előtt egy másik szerző, Rádl Ödön olaszországi utazásai és az ottani pangó irodalmi élet apropóján értekezik a román költészetről. ${ }^{533}$ Bár Rádl nem nevezi meg forrásait, sokkal tájékozottabb szerzőnek tűnik, mint Moldován. Ezek az írások egyformán irodalomtörténeti szempontúak, azonos témakört vizsgálnak, és egyszerre jelzik, hogy az Andrei Mureşanu - Dimitrie Bolintineanu - Vasile Alecsandri triász egyértelmúen uralja a hetvenes évek román (nemzeti) irodalmi gondolkodását.

Moldován irodalomtörténetet tárgyaló írásait ${ }^{534}$ azért említem, mert nem gondolom a véletlen múvének, hogy a népköltészeti alkotások fordítása és elméleti megközelítése mellett a műköltészet ismertetésére is kiterjed figyelme. Az elsősorban néprajzi érdekeltségű tanfelügyelő, hírlapíró a következőket állítja egyik írásában: a magyar irodalom, mondhatni, kimerítően ismeri a román népköltészetet, míg a müköltészetről kevés tudomása van. ${ }^{535} \mathrm{~A}$ kultúrák egymáshoz hasonlóan értékesként való láttatása és a megismertetés eszmeisége íratja ezeket a sorokat.

Ugyanarra a logikára járnak tehát népköltészeti fordításközléseinek, néprajzi és irodalmi írásainak intenciói: a megismertetés és a két nép közötti közeledés szándékával íródnak - magyar nyelven. Román nyelvű publikációi elmaradnak. Bizonyára több érdek áll döntései mögött. Ezeket teljességükben éppen az életmü problematikussága és a szakirodalom egyoldalú hallgatása miatt lehetetlenség feltárni, mégis tehetünk néhány észrevételt.

Grigore Moldován esetében nem sikerült kideríteni, hol őrzik hagyatékát, kéziratait, levelezését, pedig azok számos tekintetben előmozdíthatták volna e fejezetet. Leveleit azok címzettjei felől sikerült megtalálni, például egy Balázsfalvához kapcsolódó levelezésgyüjteményben ${ }^{536}$, Koós Ferenc emlékiratait tartalmazó kötetben. ${ }^{537}$

1909-ben, majd 1913-14-ben Moldován levelet vált Ioan Rațiuval. Ekkor ő már egyetemi, Rațiu pedig középiskolai tanár és ez utóbbi magántanári ügye képezi a levelezés tárgyát. Eszerint már 1909 körül felmerült a kolozsvári egyetem román tanszékén egy magántanári állás meghirdetése. Tudjuk, hogy Nicolae Drăganu jóval később, az 1917/18-as tanévtől lesz a tanszék magántanára. De miről szól a Moldován-Rațiu-levelezés? Mol-

\footnotetext{
${ }^{532}$ Moldován 1873.

${ }^{533}$ RÁDL 1871.

${ }^{534}$ 1871-től 1874-ig (évi egy-egy cikkben) értekezik a román irodalomról, irodalomtörténetről a fővárosi Figyelő, Fỗvárosi Lapok, Atheneaum c. lapokban.

${ }^{535}$ Moldován 1873, 329.

${ }^{536}$ Kelt Balázsfalván...A román-magyar levelezés múltjából 1746-1916., Kriterion, Bukarest, 1985. [közreadja Ioan Chindriș és Kovács Ferenc.]

${ }^{537}$ BeKE (szerk.) 1971.
} 
dován felszólító hangnemben indítja levelét: magántanári ügyét immár el kell intéznünk. ${ }^{538}$ Ő közvetít, illetve belülről látja a kérdést: többen szóvá teszik, Moldován is egyetért azzal a ténnyel, hogy Rațiu nem írt magyar nyelven („magam is abban a véleményben vagyok, hogy aki egy magyar egyetemen magántanári habilitátusért folyamodik, köteles magyar nyelven is tudományos munkásságot felmutatni"539). Emiatt levelében Moldován arra kéri Rațiut, hogy vonja vissza kérvényét és akkor nyújtsa be újra, ha ezt a feltételt teljesítette. Négy évvel később, 1913-ban is ennek kapcsán váltanak levelet, hogy majd 1914. december 22-én Moldován arról tudósítsa Rațiut, hogy „„ügye [...] balul ütött ki, ajánlatunk a karban kisebbségben maradt". ${ }^{540}$

Az egyetemi oktatói állások betöltésének egyik lehetőségét világítják meg Moldován levelei: idejében elkezdett tudatos készülés a pályára; nem akármilyen, hanem magyar nyelvü tudományos munkásság (a szakmaiság kérdése nem kerül elő a levelekben, mint ahogy az sem, hogy kik az esetleges pályázók, akikhez képest Rațiu alulmarad); lobbizás, amelyhez megfelelő személyi kapcsolathálóra van szükség. Ez a lehetőség pedig a magántanári státus elnyerését olyan folyamatként láttatja, amely korántsem objektív és szakmai döntések, hanem személyes játszmák, a mecenatúrára emlékeztető protekciók eredménye.

Ezek a levelek némiképp a saját életpályát értelmezik. A magyar nyelv (és általa impliciten kultúra és nemzet) mellett kötelezi el magát. Nem mellékes, hogy a magyar nyelvet beszélő közösség másféle (politikai) hatalommal rendelkezik, mint a román nyelvü. Karriertörténete sikeresnek mutatja ezt a döntést és elköteleződést: a magyar állami oktatási rendszerben kezdetben tanfelügyelőként, majd egyetemi tanárként dolgozik. Hozzá kell tennünk, hogy nem a nyelviség az egyetlen meghatározó tényezője ennek a történetnek, bár nyilvánvalónak tưnik, hogy magyar nyelvű irodalomtörténeti értekezései, tárcái legitimálhatták tudományos tevékenységét, a magyar intézményekben megtalált helye és kialakult kapcsolatai segíthették, hiszen a bölcsészkari egyetemi tanári szerepkörhöz nem rendelkezett kellő képzettséggel (jogot végzett, nem peregrinált stb.).

\footnotetext{
${ }^{538}$ Moldován Gergely Ioan Rațiuhoz, Kolozsvár, 1909. november 20. = Kelt Balázsfalván $\ldots$ A román-magyar levelezés múltjából 1746-1916., Kriterion, Bukarest, 1985, 312. [közreadja Ioan Chindriș és Kovács Ferenc.] Megjegyzendő, hogy a vizsgált levelek csak úgy kerülhettek ebbe a válogatásba, ha a két fél valamelyikét nem a román kultúrához társítjuk, például Rațiut románként és Moldovánt magyarként azonosítjuk!

${ }^{539}$ Uo.

${ }^{540}$ Moldován Gergely Ioan Rațiuhoz, Kolozsvár, 1914. dec. 22. = Kelt Balázsfalván... A románmagyar levelezés múltjából 1746-1916., Kriterion, Bukarest, 1985, 312. [közreadja Ioan Chindriș és Kovács Ferenc.]
} 
Néhány olyan levelét vizsgálom az alábbiakban, amelyek a Kolozsvárt működő Moldován kapcsolathálójára világítanak rá. Egyoldalú a vizsgálat, mert részint egyelőre kevés forrás áll a rendelkezésemre, részint nem látható például Moldován kolozsvári románokhoz való viszonya. Belátva azt, hogy a magyarokhoz való viszony vizsgálatával talán akaratlanul is Moldován magyarsága mellett érvelek, az érdekel az egész történetben, hogy miként juthat el oda a róla szóló szakirodalom, hogy magyarként vagy románként, lojálisként vagy renegátként aposztrofálja. Az érdekel, hogy Moldován hogyan gondolkodik minderről, és életművében milyen fogódzókat szolgáltat ilyenfajta megítéléséhez.

Az MTA Kézirattára őrzi Moldován Herman Ottóhoz és Márki Sándorhoz írott leveleit. Az ornitológus tudóssal váltott levelei közül egyet írt 1872-ben. E levele a Magyar Polgárról tudósít, amelynek mindketten munkatársai voltak, illetve az alábbiakról: „én a »Hon«-nak rendes munkatársa lettem, cikkenként 5 forint tiszteletdíjban részesülök, ezt teszem azért, hogy Papp Miklós lássa, hogy nem egyedül ő reá támaszkodok. Semmi új hírt nem írhatok, minden a régi lábon áll, holnap után van az egyetem megnyitása. Bélával az »Album« ügyét nem adtuk fel. Steinnal megkötöttük a szerződést a kinyomatás iránt, K. P. M. 200 forinttal kért többet $\mathrm{s}$ nekünk volt annyi eszünk őt a faképnél hagyni" ${ }^{541}$

Látjuk e levélből, hogy Moldován elképzelésében mi számít Hermant érdeklő információnak: a valamikori közös munkahelyi hírek mellett Moldován elsősorban magáról tudósít. Hivatalos állása mellett kormánypárti politikai lapoknál dolgozik. Arra a K. Papp Miklósra utal, akivel Herman politikai nézetei miatt konfliktusba kerül éppen ebben az évben, és emiatt hagyja el a szerkesztőséget. Moldován pedig egy évtized múlva mégis K. Papp Miklóssal adatja ki köteteit. Hory Bélával Részvét-albumot ${ }^{52}$ szerkesztenek, Stein Jánosnál jelentetik meg, ehhez kéri Herman közreműködését. Kolozsvár életében minden bizonnyal óriási jelentőséggel bír a tudományegyetem beindítása és megnyitása, lehet, hogy nem pusztán személyes érdeklődésből ered a levél erre vonatkozó mondata.

Szinnyei József életrajzgyűjteménye K. Papp Miklóst olyan szerkesztőként láttatja, akinek házában az erdélyi főurak és Kolozsvár értelmiségi rétege egyaránt megfordultak. ${ }^{543}$ Moldován számára a hírlapírás, a szerkesztőségi jelenlét ${ }^{544}$ e közösségbe való belépés feltételeit teremtették meg.

${ }^{541}$ Moldován Gergely Herman Ottóhoz, Kolozsvárt 1872.9/11. [A kézirat lelőhelye: MTAK Kt Ms 269/57.]

${ }^{542}$ Moldován Gergely-Hory Béla (szerk.), Részvét-album a kolozsvári és marosvásárhelyi árvaházak javára, Kolozsvárt, Stein János m. kir. egyetemi nyomdásznál, 1872.

${ }^{543}$ SZINNYEi 1891-1914.

${ }^{544}$ Lásd például a következő szerkesztőségi üzenetet: Moldován Gergely urat kérjük, szíveskedjék szerkesztőségünket meglátogatni. = Magyar Polgár 1871/235, 319. 
Egy későbbi levél különös figyelmet érdemel. 1889-ben ezt írja Moldován Hermannak: ,[...] ha szükséged volna nagyobb anyagra, például a madarak énekének, hangjának utánzataira, több madárról közmondásra, babonára stb. a legnagyobb készséggel szolgálok". ${ }^{545}$ Szakmailag is találnak kapcsolódási pontokat ${ }^{546}$, hiszen Moldován etnográfiai tájékozódása segítségére lehet a módszertanilag hasonlóan működő, megfigyelésre alapozó, leíró tudományágnak, a madártannak.

Márki Sándorral folytatott levelei kezdetben szakmai vonatkozásúak: Moldován recenziót ír A Bihari román irókról. Ezt közli Márkival, és még két dolgot: „röviden, de melegen” írt, és „ügyesen van összeállítva, úgy a román, mint a magyar irodalomnak szolgálatot tesz vele" ${ }^{547}$ A recenzió müfaji követelménye tarthatja távol a bírálatot vagy értékelést, ezért írhat melegen Moldován, és erre hívhatja fel a szerző figyelmét a neki küldött levelében. Amitől talán még szimpatikusabbnak tünhetett Moldovánnak a Márki-mü, az éppen a román irodalom egy - regionálisan összetartónak láttatott - szeletének ismertetése magyar nyelvű munkában. Ekkorra már ő is rendelkezik pár azonos célzatú kiadvánnyal, ami presztízskérdésként értelmezhető, mert megtörténhet, hogy ezért küldi el neki Márki kötete egy példányát. A közös koncepción kívül a nyolcvanas évek végétől a kolozsvári egyetemen egymás kollegái és barátok lesznek. Ezt a barátságot példázza egy levélrészlet:

„Kedves leveled éppen aznap érkezett, amikor közös Zsuzsi nénétek a ravatalon feküdt. Meghalt 16-án hajnalban, és 17-én délután (szombaton) eltemettük. Kedves nőd őnagyságának üzeneteit sem adhattuk át, miután az Öreg sok szenvedés után csendesen elhunyt, ami reá nézve áldás vala. Ilka Őnagyságának gratulációját igen nagy köszönettel vette, a szíves megemlékezés nagyon jól esett neki. Finályék nem is várhatták, s nem is várták tốletek, utazóktól a megemlékezést. Szívesen veszik ők utólagosan is ezt. Szádeczky a múlt csütörtökön (15-én) utazott keresztül Marosvásárhelyre kedves feleségéhez. Engem táviratilag értesített az átutazásról s kinn voltam. Jó barna arcot váltott, - ritka szakáll, amit ha levett ügyesebb lesz, mint volt. Néhány percig voltunk együtt. Kevés minden a régi. Bálint Gábor is azzal a vonattal érkezett egy nagy daganattal a nyakán, stupírt alak. Újság nincs. Itt vannak a tüzoltók $\mathrm{s}$ pár cirka áru is. Meg várjuk a királyt. -Tégedet érdekelni fog, ha már nem tudod, vagy talán meg se kellene írni, hogy a III. képezdei osztályba senkit fel

${ }^{545}$ Moldován Gergely Herman Ottóhoz, Kolozsvárt 1889. III/31. [A kézirat lelőhelye: MTAK Kt. Ms 269/58]

${ }^{546}$ Máskor fényképeket küld Moldován Hermannak ezzel a szöveggel: „,Barátom Ottó! Küldöm a képeket. Te elég jól ismered a román fajt. Válassz az alakok közül intencióid szerint. Mindig kész híved, Dr. Moldován Gergely." Kolozsvárt 1906. április 24-én. Költség számlák szerint 5 k 40 f. [A kézirat lelőhelye: MTAK Kt. Ms 269/62]

${ }^{547}$ Moldován Gergely Márki Sándornak, Várfalva, 1881.VII/29. [A kézirat lelőhelye: MTAK Kt. MS 5163/1119] 
nem vesznek. Hanem ez nem tussírozhat. Magánúton is tanulhatja a III., IV. osztályt s a vizsgákra előállhat Mariska. Jó időtöltést kívánunk. Nőm csókolja a hölgyeket - kis kezeiket csókolva téged ölelve maradok híved, Moldován Gergely." 548

A baráti viszonynál is szorosabb kapcsolatról árulkodik ez a levél Moldován, Márki és a kolozsvári egyetem bölcsészkara tanárai között. Közös rokon elhalálozásáról ad hírt Moldován. A levél alapján arra a következtetésre juthatunk, hogy Moldován révén kerülhet rokonságba Márki Sándorékkal ${ }^{549}$, illetve Finály Henrikékkel. Márki lányának iskoláztatása kapcsán új hírekkel szolgál. Bár nincsenek adataink, de ha kiderülne, hogy Grigore Moldován felesége ${ }^{550}$ magyar családból származik, akkor a házasság a mikroszociális beilleszkedésen kívül tágabb társadalmi közösségben kamatoztatható fordulatot jelentene életében. Egyetlen apró adatot sikerült találni Moldován feleségére vonatkozóan, hogy tagja a Vöröskereszt fiókegyletének. ${ }^{551}$

A távolban levő Márkit a családi eseményen kívül egyetemi kollégái elfoglaltságai is érdekelhetik, ezért kerül elő a történész Szádeczky-Kardoss Lajos vagy az orientalista-nyelvész Bálint Gábor, illetve Moldován hozzájuk való viszonyulása. ${ }^{552}$ A Hermanhoz küldött levélhez hasonlóan egyetlen mondatban utal egy Kolozsvár (de talán személye) számára jelentős eseményre: a király látogatására.

Valamennyien tagjai az Erdélyi Irodalmi Társaságnak, amely az EMKE megalakulása hatására szerveződött. ${ }^{553}$ Mind a kötetben korábban vizsgált Sándor József, mind Moldován, Finály, Szádeczky vagy Hory Béla tagja az

\footnotetext{
${ }^{548}$ Moldován Gergely Márki Sándornak, 1895.VIII/19. [A kézirat lelőhelye: MTAK Kt. MS 5163/1121]

${ }^{549}$ A Márki család kolozsvári életét illetően lásd: Gyarmati 2005, 192-231.

${ }^{550}$ Más, Márkinak írott levélben is tolmácsolja felesége üdvözletét, például: „Ellával együtt sok boldog Sándor napot kívánunk. A méltóságos asszonynak üdvözletünket küldjük. Maradtam Cluj (Kolozsvár) 1922 márczius 14-én hived, Dr. Moldován Gergely.” Moldován Gergely Márki Sándornak [A kézirat lelőhelye: MTAK Kt. MS 5163/1131] A hetvenes évek elött kötöttek házasságot, hiszen fiuk, Moldován István 1871. augusztus 15-én született Kolozsvárt. Vö. SZINNYEi 1897-1914.

${ }^{551}$ A Kolozsvári Közlöny 1882. március 17-i lapszáma külön rovatban követi a városban megforduló idegenek névsorát. A Hungária Nemzeti Szálloda vendégei sorában március 16-án, csütörtökön ott található: Moldován Gergely tanfelügyelö és neje, Torda. Itt jegyzi meg a lap, hogy a feleség melyik szervezet tagja. A következő, 18-iki lapszámban már nem szerepel a Moldován család a névsorban. Legközelebb március 25-én közli ismét a lap Moldován nevét, abból az alkalomból, hogy Tordán népszerü felolvasást tartott az iparosokonak.

${ }^{552}$ Egyetemi tanársága utolsó évtizedében Moldován ugyanabban a házban bérel lakást, ahol Bálint Gábor vagy Farkas Gyula, Kelemen Lajos lakik, de ahol az EME és az EMKE titkári hivatala is működik: Magyar utca 37. Vö. GAAL 1995.

${ }^{553}$ Ennek kapcsán lásd: Gyalui 1939.
} 
irodalmi tekintélyekként megnevezett tiszteletbeli tagok (Brassai, Dózsa Dániel, Gyulai Pál, Salamon Ferenc, Szabó Károly, Szász Károly, Szilágyi Sándor) mellett. Az erdélyi irodalom nemzeti irányú művelését célként megfogalmazó irodalmi társaság felolvasó ülésein több alkalommal is szerepel Moldován ${ }^{554}$, de a fordító Révai Károly, vagy Dora D’Istria, De Gerando Antonina, a 20. században például a műfordítóként is elismert Áprily Lajos, Berde Mária, Dsida Jenő.

Grigore Moldován tanárkollégáival nem csupán az irodalmi társaságban talál közösségre, hanem például Az Osztrák-Magyar Monarchia írásban és képben című vállalkozásban ${ }^{555}$ és az Erdélyrészi Kárpát-Egyesületben (EKE). Ez az egyesület szintén az EMKE, azaz éppen Sándor József (majdani EKE-alelnök) kezdeményezésére jött létre a 19. század utolsó évtizedében, és ernyőszervezetéhez hasonlóan ideologikus. ${ }^{556}$ Az etnográfiát, fürdőügyet és természetjárást támogató egyletbeli tagság Moldován számára nem csupán szakmai közösséget jelent, hanem ennél többet; a közös - Erdély etnikumközi kapcsolatai iránti - érdeklődést és közvetetten: társadalmi beilleszkedést. Egy példát hoznék erre csupán. A fent idézett levél évében, 1895-ben alakult meg az EKE székelyudvarhelyi osztálya, amely alkalomból hangversennyel egybekötött estélyt rendeznek. Ide érkezik Moldován Szádeczky Lajos társaságában. Szádeczky tart beszédet, de vacsorakor már mindketten pohárköszöntőt mondanak. ${ }^{557}$ Az EKE Kolozs vármegyét ismertető kötettervében szintén szerepet vállal, a görög katolikus és görögkeleti egyházak történetére és a román nép etnográfiájára vonatkozó részek megírása lesz a feladata. Ilyen értelemben valóban nem tagadja meg románságát, amennyiben magyar nyelvű publikációit állandóan a román kultúrkörből meríti.

Az etnográfia mint népismertetés kiválóan találkozik tehát Moldovánnak a nemzetek közötti kapcsolatról kialakított koncepciójával. ${ }^{558}$ A kolozsvári egyetemi tanár több magyar kulturális intézmény tagjaként kerülhetett be a város magyar értelmiségi közösségébe.

\footnotetext{
${ }^{554}$ A Társaság történetének 1920 és 1938 közötti időszakában Grigore Moldován Emlékeimből címen két ízben is felolvasást tart. Erre utal Gralui 1939, 23.

${ }^{555}$ Például Szádeczky a régi Erdély alkotmányos szervezetéről, Márki az aradi síkságról, Erdély szomszédos hegyvidékeiről értekezik.

${ }^{556}$ A tájak nemzetiesítését Magyarország példáján vizsgálja: Popova-Nowak 2006, T. Szabó 2008, 100-197.

${ }^{557}$ Egyesületi élet = Erdélyi Gyopár 1895/3-4.[az EKE lapja; http://www.erdelyigyopar.ro/18953-4/1180-egyesuleti-elet.html - utolsó látogatás: 2012. július 25.]

${ }^{558}$ Grigore Moldován identitását vizsgáló tanulmányában Weber Péter is felhívja a figyelmet a kérdés összetettségéből kínálkozó több szempontú megközelítésére, de arra is, hogy mennyiben befolyásolta Moldovánt etnográfiai érdeklődése politikai állásfoglalásaiban, érvelésében. Vö. Weber 1999.
} 
Az Erdélyi Irodalmi Társaság, az EKE, EMKE tagságát összevetve például az egyetemi tanárokkal, vagy az EME-tagokkal, netalán az Unió szabadkőműves páholy tagságával, azt látni, hogy a 19. század végének humán érdeklődésű értelmiségi rétege Kolozsvárt egyszerre tagja az egymáshoz eszmeiségükben nagyon közel álló intézményeknek. Ilyen tekintetben homogénnek látszik ez az elit, amelynek Moldován kapcsolathálója révén tagja lesz. Sőt Moldován az EKE-t képviseli akkor, amikor annak központi tagjaként részt vesz az udvarhelyi ünnepségen. ${ }^{59}$

A kolozsvári kapcsolatháló kialakítása fontos lehetett Moldován számára, és a magyar közösséghez való tartozását legitimálta. Mellesleg, 1919 után mind Moldován, mind Márki Kolozsvárt várakozik. Később a történész a Szegeden beindított egyetemre távozik, ahogyan Szádeczky-Kardoss is. Moldován Kolozsvárt marad. Az akkor 74 éves tanár nyugdijazását is kérheti, már nem éri meg számára elhagyni a várost. A szakmailag legitimálható döntést természetesen számos egyéb tényező befolyásolhatta, amelyek azért roppant érdekesek a kutatás további folyamatában, mert Erdély, így Kolozsvár is a román állam része lesz, felügyelete alá tartozik, és Moldován identitása szempontjából igaz, hogy csupán tíz évig (1930-ban hal meg), de meghatározó lehet. Nem gondolom, hogy dilemmát vagy pálfordulást jelentene kiforrott gondolkodása szempontjából, mégsem hagyható figyelmen kívül ennek tanulmányozása.

Tudjuk, hogy Moldován kevés ideig tanul Szamosújváron. Kolozsvárra kerülvén, a piaristáknál érettségizik, majd jogi tanulmányai végeztével először a városban talál megélhetésre. A többéves itt-tartózkodás indítja el azt a folyamatot, amely során megerősíti a magyarokkal kialakított kapcsolatait, amelyeknek elsődleges potenciális közege az intézményesített oktatás, az iskolai szocializáció.

A kegyesrendiek gimnáziumi oktatása az erdélyi románság szempontjából óriási jelentőséggel bír: a szegény diákok továbbtanulását szorgalmazó és a jótékonykodók által anyagi támogatást biztosító intézetként vonzza az erdélyi görögkeleti és görög katolikus diákokat. A 18. századtól kezdődően román diákgenerációk sora kerül ki az intézményből, akik saját kultúrájuk alakításában fontos szerepet töltenek be ${ }^{560}$ Természetesen a felekezeti kötődést sem szabad kihagynunk, hiszen a görög katolikus diákok számára ez is befolyásoló tényező lehetett.

${ }^{559}$ Talán nem fölösleges megjegyezni, hogy a budapesti Magyar Természetbarát Szövetség lapja 2000-ben megemlékezik Moldován Gergely születésének 155. évfordulójáról. Lásd: Viszszatekintés = Természetbarát Híradó 2000/96. [www.fsz.bme.hu/mtsz/hirado/th0003.htm - utolsó látogatás: 2012. július 25.]

${ }^{560}$ Ehhez a kérdéshez lásd: Biró 1926. Az intézmény diákságához lásd: VARGA 2000. 
1926-ban a főgimnázium 150 éves oktatási intézményi létét ünneplő véndiákok kötettel ${ }^{511}$ tisztelegnek. A kötetben a rend-, gimnáziumtörténet mellett jeles tanárokról és egykori diákokról szóló írásokat, valamint véndiákok emlékezéseit találjuk. Apor Péter, báró Jósika Miklós, dr. Erődi-Harrach Péter, Torma Miklós és dr. Jancsó Benedek, Kuncz Aladár és mások szövegei közé illeszkedik dr. Moldován Gergely, azaz Grigore Moldován írása: A piaristák melegében címmel..$^{562} \mathrm{~A}$ visszatekintés gesztusa, a múlthoz való nosztalgikus viszonyulás meghatározó komponense e szövegeknek, amelyekből a Hála-virágok címü fejezet épül. A fejezetcím és az emlékezés technikái mint szövegszervező elvek tartják távol az emlékezés tárgyának objektív megközelítését, és az egykori diáktapasztalatokat a tisztelet, hála kultikus perspektívájába helyezik.

Amikor a nyolcvanas éveibe lépő Moldován 1926-os visszaemlékezését vizsgálom, már egy világháború utáni Romániában elő értelmiségi soraival foglalkozom. Teszem azt azért, mert éppen az emlékezés technikája miatt válik érdekessé a számvetésként, értékelésként értelmezhető szöveg, amely történetileg engedi láttatni Moldován önértelmezését. Erre ő maga játszik rá, amikor már az elején így fogalmaz: „,szinte magamnak teszem fel azt a kérdést, miként volt lehetséges az, hogy a szamosújvári hét és a kolozsvári kilenc, összesen a magyar kultúra tizenhat esztendei hatása ellenére mint román író ${ }^{563}$ kezdettem meg pályafutásomat? Hol szereztem magamnak erre a képességet, mi tartotta fenn bennem a nemzeti érzést, a román »én«-t, hogy a magyartól elsajátított tudományt fajom javára értékesítsem? Szeretnék feleletet adni erre a kérdésre most, hogy a piaristák jubileumára én is hálás érzéssel figyelek". 564

A balázsfalvi iskola mellett a kolozsvári intézmény felbecsülhetetlen értékkel bír a görög katolikus és görögkeleti (román) fiatalok intézményes oktatásában a 19. században is. Ezért a leghálásabb Moldován. A kötelességtudó diákok a tanárok rokonszenvét érezték, emellett pedig a szegény sorsúak anyagi támogatásban részesültek - felekezeti és nemzetiségi megkülönböztetés nélkül. ${ }^{565} \mathrm{~A}$ jótékonykodás pedig elsősorban társadalmi és nem nemzetiségi kérdéssel kapcsolatos érzékenységet, odafigyelést jelentett, hiszen a 19. század második feléig az utóbbi szempont fel sem merült. Tehát az a jótékony viszonyulásmód, amit Moldován 1926-ben nemzetisé-

\footnotetext{
${ }^{561}$ GYöRGY (szerk.) 1926. [A továbbiakban, amikor Moldován Gergely szövegére hivatkozom: Moldován 1926]

${ }^{562}$ Moldován 1926, 88-92.

${ }^{563}$ Már érettségi előtt (1867) publikált a Familia, Umoristul, Gura satului és Aurora lapokban.

${ }^{564}$ Moldován 1926.

${ }^{565}$ Példának okért, 1851-ben az I. Ferenc József által adományozott egyéves ösztöndíjat a következőképpen osztották szét: egy római katolikus, négy görög katolikus, három görögkeleti és egy protestáns vallású tanulónak ítélték oda. BIRó 1926, 38.
} 
giként értelmez, az előző század hatvanas éveiben még nem az etnicitás alapján működött, hanem felekezeti és társadalmi szempontok határozták meg, illetve az intézményt fenntartó piarista rend ideológiájának része volt.

A nemzetiségi diákok iránti toleráns viselkedést Jancsó Benedek és Balogh Artúr is megemlíti. Ez utóbbi kapcsán talán szándékosan emeli ki Moldován azt, hogy a román diákoknak milyen kötelezettségeik voltak, hiszen viszonozhatatlannak tünik számára az intézmény jótékonysága. A hálaadást erőteljesebbé teszi az aránytalannak felmutatott kapcsolat további érvekkel való alátámasztása. Ilyen érvként kerül elő egyfelől az, hogy Moldován csak alkalomadtán lehetett részese annak, hogy tanárai közvetlen közelébe férkőzhessen, például az étkezdében helyettesítve az egyik támogatott diáktársát. Ezen alkalom felelevenítésével azt is felfedi, hogy ő nem tartozott a támogatott román diákok közé. Apja kántor és építészmester is volt, valószínü, hogy fedezni tudta fia taníttatását haláláig, amikortól az ifjú Moldován egyházi támogatásban részesül. ${ }^{566}$ Másfelől, tanárai tudása iránti hálájának ad hangot: gyermekként csodálattal szemlélte őket, majd később a mintakövetés hajtóerejét képezte az általuk birtokolt tudás - impliciten pedig annak többletjelentései, jelesül a tudás közvetítése, továbbadása, a tanítás és megismertetés vagy az ezzel járó társadalmi pozíció. ${ }^{567}$

Kétszer is előfordul a szövegben, hogy a „piaristák csináltak embert” belőle. A magyarázattal sem marad adósunk: a türhetőtől a kitűnő osztályzatig bejárt utat köszönheti nekik. Ebből a perspektívából teszi jelentésessé és értékesebbé saját életpályáját: az egykori diák egyetemi tanárként, sőt rector magnificusként mond pohárköszöntőt tanárai asztalánál a jubileumi ünnepségen, ami egyszerre jele a tiszteletnek, hálának, valamint annak is, hogy karrierje meghaladta tanáraiét. Moldován (élet)története egyértelműen pozitív fejlődési ívként rendeződik a szöveg mellékszálaként, hiszen írása szerint a lényeg a román identitás tiszteletén van, azon, hogy az erdélyi (magyar) egyházi oktatás nem szorította vissza az élénkülö felekezeti-etnikai törekvéseket, mi több, toleránsan viszonyult hozzájuk.

\footnotetext{
${ }^{566}$ „Atyja 1866-ban elhalálozott; ekkor Vancsa János szamosújvári püspök pénzsegélyben részesítette; a balázsfalvi káptalan, a Bobb-, később a Ramonczay-féle alapítványokat adományozta neki." = SzINNYEI 1897-1914.

567 „Boldog voltam, hogy tanáraim között lehetek: hogy beléletükbe belepillanthatok. Menynyire érdekelt beszédük! Nemegyszer gondoltam arra, hogy boldogság volna ilyen környezetben, ilyen tudósok között élni, akik annyi szépet tudnak és beszélnek! Gyermeki vágyaim teljesültek. A piarista atyákhoz nagy szeretettel vonzódtam. Mint egyetemi tanár köztük éltem, s asztaluk áldásait nagyon sokszor élveztem."= MoLDován 1926, 90.
} 
A visszaemlékezés szerint a román diákok az intézmény szervezeteiben jelen voltak, de ezzel párhuzamosan saját önképzőköri tevékenységet folytattak, a román templom szertartásain énekeltek. Ennek apropóján Alexandru Radu és Ioan S. Bădescu társaságában magát román íróként láttatja, dacára a magyar iskolázottságnak. Felvillantja társai iskola utáni életútját: Radu tanár, a Dacia c. lap szerkesztője Romániában; Bădescu is ide távozott, költő, lapszerkesztő, tanfelügyelő volt, a visszaemlékezés idején már egyikük sem él.

Úgy gondolom az sem véletlenszerü, hogy diáktársaihoz viszonyítja önmagát Moldován, aki hozzájuk képest ellentétesen cselekedett: nem vándorolt ki Romániába, hanem Magyarországon maradt. Bădescuhoz hasonlít pályája annyiban, hogy tanfelügyelő, de a magyarországi iskolaügyet szolgálja; irodalmár, amennyiben a román irodalom történeti alakulását, kanonikus figuráit magyar nyelven ismerteti; lapszerkesztő. Az Ungaria címü román nyelvü magyarországi lapot szerkeszti. Egy kitérő erejéig foglalkozom e lappal. ${ }^{568}$

\subsubsection{Ungaria}

Bármennyire is visszásnak tünhet e kitérő címe, Grigore Moldován az 1890-es években komolyan gondolta, hogy visszatér a román nyelvű publikáláshoz, és egy olyan lapot szerkeszt, amely társadalmi, tudományos és irodalmi kiadvány, és amely a magyar-román kölcsönös megismerést szolgálja.

Lapja címe korántsem jelentéktelen: egy ország nevére utal, Magyarországéra, amely ekkor a millenniumi emlékünnepélyre készül. A nemzetiségi konfliktusok vagy a dualista politikai berendezkedés, a monarchiabeli lét ellenére egységes nemzetállamként jeleníti meg magát az ország, és ezredéves múltját (re)konstruálja.$^{569} \mathrm{~A}$ lap bevezető írásában e koncepció mellett kötelezi el magát a szerkesztő, aki egyszerre tartja magát a törvény és nemzetiség szerint románnak és magyar állampolgárnak. ${ }^{570}$ Mellesleg Moldován életpályája alakulása mutatja, hogy esetenként a nemzetisé-

\footnotetext{
${ }^{568} \mathrm{Az}$ Ungariát és mellékletét a Magyar-Román Szemlét tartalmilag részletesen feltárta: KöPECZI 2001.

${ }^{569}$ Ezzel foglalkoztam Az 1896-os millenniumi megemlékezések: kiállitás és irodalomtörténet című államvizsga-dolgozatomban. A megkonstruáltság és vizualitás kérdéskörét a következő írásomban tárgyaltam: BERKI 2005a.

570 ",[... [ viețuim în Ungaria, în statul creat de națiunea maghiară, într-un stat, care este în biruința ungurilor de o mie de ani." Dătorințele noastre = Ungaria. Revistă socială-științificăliterară, ed. Grigoriu Moldovánu, Kolozsvár (Cluj), Tipografia Magyar Polgár, 1892/1,1. [Köpeczi Béla tévesen idézi a cikk címét, továbbá tanulmánya több helyen tartalmaz félreértelmezéseket, egy példa: Florea Bozgant ügyvédnőként említi, holott nem női, hanem férfi keresztnévről van szó.]
} 
gi identitás és egyéb identifikációs lehetőségek (nemzeti, szupra- vagy transznacionális stb.), illetve a hibrid vagy köztes identitások, valamint a kettős kötődés mennyire bonyolult formáira találhatunk a magyarországi, ezen belül az erdélyi (multikulturális, multikonfesszionális, multietnikus) közösségben.

A már oly ismerős megfogalmazással találkozunk ismét: nyitni kell a magyar kultúra felé, békésen együttélni, a közös boldogságért, bizalomért munkálkodni; ezzel a felhívással pedig Moldován eltávolítja lapját és magát a Bukarest felé tájékozódó magyarországi román értelmiségtôl. Ebben a kontextusban már nem tünik furcsának az az állandó vitahelyzet, amelybe a lap kerül: a magyar szép- és tudományos irodalom román nyelvű tolmácsolása mellett a Memorandum-pört és a köré szerveződő állásfoglalásokat napirenden tartja a lap, valamint teret ad a Moldovánt támadó irodalmi és politikai szövegeknek is. Idővel elmarad népköltészeti gyưjtéseinek közlése és a szerkesztőségi üzenetekben, majd külön cikkekben (Chestii personale, La anul nou, Atac la atac stb.) válaszol a munkásságát sérelmező levelekre, illetve perlekedik a Tribuna, a Telegraful român és a Gazeta de Transilvania cikkeivel, személyes konfliktusokba kerülve Slavicicsal, Miron Román mitropolitával. Slavici kapcsán érdemes megjegyezni, hogy a politikai különbségek és a polémia ellenére ${ }^{571}$ Moldován lapjában jelennek meg novellái 19. századi magyar fordításai, leszámítva a Familiában publikált $A$ rab gólya címüt. ${ }^{572}$ Felmerül ismét e fordítások minőségének kérdése, de amennyiben ismerjük a szerkesztő koncepcióját, az másodlagossá válik, hiszen a magyar kultúrához való közelítés az elsődleges cél. Egyébként ide kapcsolható az a kérdés is, hogy a román értelmiségiek közül kik azok, akik munkatársai a lapnak. ${ }^{573}$

Bár a lap címoldala nem tartalmazza a politikai jelzőt, mégsem tekinthetjük független lapnak, mert ha egyéb nem is, de Moldován politikai álláspontja egyértelmúen kiolvasható belőle. Többen fel is róják neki, hogy miért is gondolhatta komolyan, azt, hogy román nyelven szerkeszt egy, a magyar állam eszméjét, és abban az etnikumok testvériségének lehetőségét hirdető lapot. Moldován lapkoncepciója a birodalmi identitással kap-

\footnotetext{
${ }^{571}$ Nem Moldován személyes polémiája ez, hanem más szinten például a Kolozsvári Közlöny is elítélendőnek tartja a Tribuna c. lap magyarokkal kapcsolatos írásait. Például a Tribuna szerint „Petőfi szerb, Arany horvát! - No, hát ha az ily ignoráncia hírlapírás-számban megy, akkor trucból mi is lefoglaljuk Slavici szerkesztőt - cserepár magyarnak. Semmi tiltakozás!" = Kolozsvári Közlöny 1885. december 6 .

${ }^{572}$ Dávid 1976, 93.

${ }^{573}$ Például az a Ioan Rațiu, akivel a magántanárság ügyében levelezik Moldován vagy Florea Bozgan, karánsebesi ügyvéd; Vasile Rebrean, népi alkotások gyüjtője, a román regényíró, Liviu Rebreanu apja; Mihai Bodiu, aki Moldován fiával együtt tiltakozik a memorandisták ellen.
} 
csolatos és nem egyedülálló. ${ }^{574}$ Tudjuk, hogy az állam támogatja Moldován lapának a megjelenését. ${ }^{575}$ Sőt, mi több, amíg korábban a nemzetiségi kérdéseket tárgyaló munkáját a képviselőházban részletezi és elismerően értékeli gróf Bethlen István ${ }^{576}$, addig egy évvel később Iuliu Maniu a román lapszerkesztők ellen indított sajtóperek kapcsán a magyar „reakcionárius” politikát kifogásolva hozza szóba Moldován lapjának függetlenségét. Idézek ebből a szövegből: „Miután csak a Lumina, amely a függetlenségi párt politikáját folytatja, továbbá Burdia ${ }^{577}$ úr lapja, amely az alkotmánypárt politikáját támogatja és a Hungária, amely a mindenkori kormány politikáját folytatja... (Zaj és felkiáltások jobbfelől: Tehát már három van!) miután kizárólag ezek a lapok azok, amelyek ügyészi üldözésben nem részesülnek, ez igenis azt bizonyítja, hogy önök csak azokat a román lapokat nem üldözik, amelyek az önök politikáját nem támadják, hanem azt támogatják" ${ }^{578}$

A lap románok által kifogásolt eszmeisége így találkozik egy számukra szintén taszító tényezővel: az anyagi támogatottsággal. A lapban tételesen megfogalmazott kultúra-közvetítési program annyiban tér el Moldován korábbi munkásságától, hogy a lapszerkesztő anyanyelvén publikál, román nyelven ismerteti a magyar irodalmat, fordítva is kipróbálja azt, amit már több évtizede a román kultúra felől érkezve megkísérelt. Az anyagi támogatottság szempontjából azt láthatni, hogy a magyar állam a magyar kultúrát teszi hozzáférhetővé a románok számára, és egy olyan koncepciót támogat, amely a nemzetiségi különbségeken felülemelkedve azokat egyenrangúaknak, egymással párbeszédbe állíthatóaknak, egymásba átfordíthatóaknak tartja, és mindezt a magyar államiság elismerésével teszi. A lap kapcsán kibontakozó országgyưlési vita arról győz meg, hogy Grigore Moldován erős politikai elkötelezettsége mekkora előnyökkel jár számára: értékelik magatartását, a nemzetiségi ügy kapcsán írt érteke-

${ }^{574}$ Vö. a birodalmi identitás kapcsán S. VARGA 2005. Kemény G. Gábor többkötetes munkájában számos olyan példát találunk, amelyek a nemzetiségek sajtóorgánumainak állami támogatásával kapcsolatosak, és ebben az esetben ez nemcsak egyszerú támogatás, hanem a hatalmon levő pl. liberális párt kisebbségek előtti megmutatkozási lehetősége is egyben. Vö. KeMÉNY 1956.

${ }^{575}$ A szerkesztő egy lábjegyzetben utal erre, illetve a kötetbe felveszi Sándor János KisKüküllő megyei főispán levelét báró Bánffy Dezső miniszterelnökhöz egy kormánytámogatással megjelenő román néplap ügyében. E levél kiemeli egy államilag szubvencionált lap fontosságát a nemzetiségi mozgalmak ellensúlyozásában, erre példa Moldován lapja. Ezzel kapcsolatban lásd: KemÉnY 1956, 26. és 333-334.

${ }^{576}$ Moldován Gergely, Magyarok, románok. A nemzetiségi ügy kritikája, Gombos és Sztupjár könyvnyomdája, Kolozsvár, 1894 című munkájáról lásd: 136. országos ülés 1907. április 10. = Képviselőházi Napló 1906/VIII., 151. [http://mpgy.ogyk.hu, illetve www.arcanum.hu/onap utolsó látogatás: 2012 júliusa]

${ }^{577}$ Burdia Szilárd alkotmánypárti képviselő 1906-1911 között, Karánsebes polgármestere. Vö. Sturm 1906, 304.

578 320. országos gyűlés 1908. május 11. = Képviselőházi napló 1906/XVIII, 151. 
zését, támogatják lapját anyagilag, és eszmeileg is, abban az értelemben, hogy kiesik a politikai szempontból bírálható, perbe fogható lapszerkesztők sorából. Maniu a magyarosítási politika részének tekinti ezt a lapot, illetve mindazt, ami Moldovánnal történik, és ezért kárhoztatja az egészet. Mindemellett látni kell azokat a különbségeket is, amelyek a perbe fogott román sajtótermékek, lapszerkesztők koncepciói és a Moldovánéi között megfogalmazhatók.

Az állam által támogatott lapot Veress Endre az Erdélyi Múzeumban ismerteti mint olyan kiadványt, amely kultúrmissziót végez. ${ }^{579}$ Nincsenek adataink a lap olvasóiról, a munkatársakat, az EME lapjának olvasóit, Moldován kapcsolathálóját és esetleg a hozzá hasonlóan gondolkodó diákokat leszámítva, nem tudhatjuk kik olvashatták, mekkora hatással lehetett, mennyiben volt ismert vagy népszerü ez az elképzelés a szélesebb magyar, román vagy más ajkú magyarországi olvasóközönség körében. Hasznos lenne megvizsgálni komparatív szempontok alapján, hogy más magyarországi nemzetiségek esetében találunk-e hasonló kapcsolattörténeti jelentőségü kezdeményezéseket, amelyek politikailag meghatározottak.

Az is beszédes az Ungaria szempontjából, hogy a szerkesztő maga foglalja össze 1917-ben lapja magyar irodalmi „,anyagát”, mindazt, ami román nyelven ott megjelent. ${ }^{580}$ Cikke forrásértéke mellett létjogosultságát igazoló és a koncepciót hangsúlyozó téttel bír. A román nyelvű lapból hozza vissza Moldován eredeti közegébe a magyar irodalmat, hiszen a MTA hivatalos kiadványában sorolja fel lapja magyar vonatkozású szövegeit. Sikeresnek láttatja a lapot, mert megtörtént a közvetítés a publikáció szintjén, mindamellett, hogy olyan tartalmak is átkerültek szerinte a román olvasókhoz, amelyek ellentétesek voltak azok koncepcióival. Megjegyzem, hogy a lap történelmi szövegei például a szent koronával, Szent Istvánnal, honfoglalással, jog-, eredettörténettel, azaz éppen a kilencvenes években előtérbe került, kutatott magyar őstörténettel foglalkoznak, de mellettük magyar irodalmi anyagként szerepelnek a következő témák: római műveltség és Erdély kapcsolata, az oláh kenézség vagy a székelyek eredete. Moldován elégedett lapja fogadtatásával, de éppen az általa jelzett ellentétes álláspontok, a személyét ért bírálatok, a párhuzamosan zajló nemzetépítkezés, és például Erdély kisajátítása az ott lakó etnikumok történetírásában megkérdőjelezik azt. Mint ahogyan az a szándéka is, hogy saját lapját annak megszűnte után éppen a magyar anyag felől forrásértékűnek láttassa ${ }^{581}$,

${ }^{579}$ VERESS 1894.

${ }^{580}$ Moldován 1917.

581 ,illőnek és szükségesnek tartom, hogy az Ungaria ezen magyar anyaga végképpen eltemetve ne legyen. Legyen egy magyar közlönyben ez az anyag összefoglalva, hogy ha valaha valaki a tárgy iránt érdeklődnék, azt ott megkaphassa és céljaira felhasználhassa." I.m. 541-542. 
vagy egyszerüen maradandóvá tegye. Nem semleges az sem, hogy melyik „magyar közlönyben” jelenteti ezt meg: az Akadémiai Értesítő a magyar tudományosság reprezentatív fóruma, itt jelenik meg Moldován cikke, implicit módon legitimálva a lapot, a szerkesztőt, a koncepciót.

Egy fontos dologra reflektál Moldován cikke felvezetőjében, jelesül: a magyar nyelv terjedése mellett a magyar érzés és szellem térfoglalását kell szorgalmazni. Ez az állítása egyben arra is utal, hogy az eredeti alkotás nyelvét elfedik ugyan a fordítások, de az olyan entitás, amely eleve többletjelentéssel, nemzetreprezentatív funkcióval bír. A nemzeti érzés és szellem e cikk szerint tehát olyan érték, amely a nyelvtől független és minden müben ott munkál, még a fordítások során nem torzul, hanem átvihető jelentéskomponens; ezért a fordítás gyakorlata a kulturális javak közvetítésének eszközévé válhat, és ezért bír oly nagy jelentőséggel Moldován életművében. Ha visszacsatolunk a Brassai-Meltzl-féle vállalkozáshoz, láthatjuk, hogy ahhoz képest miként gondolkodik Moldován: bár mindannyian lefordíthatónak tartják a különböző nyelvü nemzeti irodalmakat, Moldován számára mégsem merül fel az a fordítással szembeni bizalmatlanság vagy a nemzeti nyelvek értékesként való felmutatásának az a koncepciója, ami kollegáit többbnyelvű lap szerkesztésére indítja.

Tudnivaló, hogy a 19. század második felében még nem beszélhetünk nemzeti közösségről olyan értelemben, hogy arra az egynyelvűség lenne jellemző. Ebből a perspektívából Moldován lapja a románság számára akár fölöslegesnek tűnhet, hiszen a többnyelvű Magyarországon, a kötelező (magyar nyelvű) oktatási rendszerben szocializálódott románság hamarabb ismerhette a tág értelemben vett magyar irodalmat és kultúrát, mint esetleg a magyar ajkúak a románt. Ellenben számolni kell azzal a tényezővel, hogy a század végére erősödő politikai identitástudatok egyre inkább differenciálódnak és konfrontálódnak az ezeréves államiságát ünneplő magyar nemzettől. Innen nézve nyer értelmet Moldován lapja a magyarság szempontjából: ha a románság nem közeledik, akkor a magyar nyelvü irodalmat közelíti felé. Ez Moldován érvelésében a következőképpen fordul elő: „a román vérmesebb közönség így türelmesebb lett a magyar irodalmi alkotásokkal szemben, amikről előbb még hallani sem akart". ${ }^{582}$ Egyébként a közeledésnek, közvetítésnek, kapcsolatnak legkevesebb két aspektusa van, így a magyar közösség román irodalom iránti érdeklődése és a román irodalom magyarítása is ehhez a játszmához tartozik. Továbbá, az irodalmi kapcsolattörténet szempontjából teljesen fordítottnak látszik az érdeklődés iránya - a 20. századig legfőképpen a románok azok, akik magyar nyelven ismertetik, tolmácsolják saját kultúrájukat, szűkebben vett irodalmukat.

\footnotetext{
${ }^{582}$ Moldován 1917, 550.
} 
Az Ungaria magyar tartalma kapcsán jó példa tehát arra, hogy az állameszmét szolgáló Moldován miként jeleníti meg a magyar irodalmat és kultúrát, lapja milyen magyar irodalom-fogalmat, és visszacsatolva a korábbi gondolathoz, milyen nemzeti érzést és szellemet továbbít. Ez a szerkesztői koncepció (a mögötte álló kormánytámogatással), a fordítás funkcionalista fogalmának e példája hatalmi diskurzusként értelmezhető és ilyenként a gyarmatosítás elméleti előfeltevéseivel hozható összefüggésbe, ezért nem véletlen Veress Endre recenziójában a kultúrmisszió fogalma.

Harminckét évi egyetemi tanári tapasztalatáról is számot ad e cikkében: „,[...] igen sok jeles diák fordult meg a kezemen. A tőlük elfoglalt állásokban megfeleltek hivatásuknak. De gondolt-e nálunk valaki az évenként ily módon kikerülő ifjúsággal, hogy az okszerüen felhasználtassék? Senki. Egy okos kormányzat a tanévek végén szemlét tartott volna az életbe kikerülő ifjak felett. A jó gazda a termés javát a magtáraiba helyezi el. Nálunk megfordítva történt a dolog. A legjavát lefoglalta magának Románia, a többit a felekezetek, az államnak egynehány kivétellel csak az jutott, aki már ott elhelyezhető nem volt. Így hiába terjesszük a magyar nyelvet, ha a magyar múveltséggel bíró egyéneink más hatóságok és befolyások alá kerülnek, és engedjük, hogy szétvert nyájként elbolyongjanak". ${ }^{583}$

Az idézet tehát a cikk egészét olyan szöveggé kerekíti, amely egyszerre szól a lap magyar tartalmáról, koncepciójáról és magáról a szerkesztőről. A Moldován-életmüben járatos olvasónak nem hangzik idegenül a fenti idézet, hiszen Moldován Válasziratában ${ }^{584}$ ugyanazt a kérdést veti fel: a magyar intézményekből kikerülő román diákok a magyarok ellen fordulnak, kivándorolnak, és a román nemzeteszme legelkötelezettebb szolgálóivá válnak.

A kolozsvári egyetem román hallgatóiról végzett vizsgálatom felől igazat adhatunk Moldovánnak: valóban számos diák az oktatási rendszer feltételezett outputjától eltérő módon viselkedik. Kérdésfelvetésében a legérdekesebb az a hierarchia, amely a végzős diákok termésként/termékként való felhasználása kapcsán vázol. Románia után a felekezetek által kínált állások rendelkeznek a legnagyobb vonzerővel, majd a magyar állam Moldován szerint érdektelensége, nem megfelelő gazdálkodása folytán - zárja a sort, a nagyon érzékletes „szétvert nyáj”-hasonlattal. Moldován egyetemi tanári munkájának csekély eredménye, esetleges hiábavalósága legitimálja az állammal szembeni számonkérő hangnemet. Az államnak szerinte jobban oda kellene figyelnie az oktatási rendszer müködtetésének felügyeletére, olyannyira, hogy saját érdekei felől sajátítsa vagy használja ki az oktatási intézményeiből kikerülőket, nemzetiségi és felekezeti

\footnotetext{
${ }^{583}$ Moldován 1917, 552.

${ }^{584}$ Vö. MoLdován 1891.
} 
különbségek nélkül. (Mellesleg ez a hazafiasságot előtérbe helyező állameszme áll Moldován egyéni identitása mögött is.) Az, hogy 1917-ben még probléma számára a magyar állam hatásköre, arra vezethető vissza, hogy a 20. század elejére sem sikerült annak nemzetivé válnia; hogy a felekezetek és intézményeik még mindig erőteljes (szakmai, nemzeti) identitásképző funkcióval rendelkeznek például a románság esetében. Moldován cikke impliciten ugyan, de utal arra, hogy az egyetemről kikerült diákok csak a magyar állam keretei között lesznek nemzeti szempontból közösség. Ha Moldován életművére fordítjuk saját mondatait, akkor ő nem a „szétvert nyáj" része, hanem az állam szempontjából a termés legjava, ilyenképpen a legjobb hazafi. Idáig úgy jutott el, hogy nemzetiségi identitását egy olyan, magát nemzetállamnak nevező politikai hatalomhoz köti, amely illuzórikusnak tünik akár számára is.

Erre vonatkozó kételyeit fogalmazza meg egy ismeretlenhez írt levelében cikke megjelenésének évében: „A kérdéses tanulmányom következtetései egy hosszú élet megfigyeléseinek eredményein alapulnak. Nem tehetek róla, erőszakot, meggyőződésemen el nem követhetek. Ha a jövőt rózsaszínben láthatnám, magam volnék a magyar nemzeti államnak a legboldogabb polgára, csakhogy én ma még ezt az államot is veszélyeztetve látom. A mai állapotokban én nem látok nemzeti megújhodást, hanem látok egy fenekestől való felfordulást, hamis irányt, hamis jelszavakat, amelyeknek első áldozata a magyar lesz, s amelyek Magyarországból megteremtenek egy második Macedóniát. Abban aztán a magyar ne várjon sem kegyelmet, sem kíméletet. Vajha csalódnám! Annyi tény, hogy próféciámat megérni nem szeretném. Lehet, hogy nagyon sötéten látok, hogy talán a szemeim immár rosszak, de lelkemből meg vagyok győződve, hogy rend Magyarországon csak egy magyar erős nemzeti kormány alatt lehet, minden másféle kísérletezés állambontó kész veszedelem. ${ }^{585}$

Bizonyára a nemzetiségi ügyről írt tanulmánya képezi a levélváltás tárgyát. Az élettapasztalatai által alakított és kiforrott koncepcióhoz ragaszkodó Moldován az ún. balkáni háborúk vesztesére utal, amikor a magyar állam veszélyeztetett helyzetét taglalja. E levelében nevezi magát „régi vágányokon járónak". Önminősítése egyben politikai gondolkodására is érvényes, és megteremti annak a lehetőségét, hogy identitását a hungarustudathoz társítsuk. A modern értelemben vett nemzettudathoz képest zárványként müködik Moldován esetében ez a nemzetkoncepció, amely a honosság alapján, nyelvi, felekezeti és kulturális különbségtétel nélkül foglalja magában Magyarország polgárait.

${ }^{585}$ Moldován Gergely ismeretlenhez [A kézirat lelőhelye: OSZK Kt. Levelestár] 
Moldován számára az állam, amelynek polgára, a haza, amely honosságát jelenti, kitüntetett fontossággal bír, ezért kötelezi el magát amellett a nyelv és kultúra mellett, amelyhez ilyen módon hozzátartozik. Ezért sem véletlen lapja címadása, vagy például egyik álneve, amelyet Domokos Sámuel hozzá társít: Erdély ${ }^{586}$. Ugyanakkor önazonosságának hangsúlyozása ezért is nagyon érdekes: módszertanilag kiváló terepet biztosít a történeti keresztezés elméletének hasznosítására. Egyetlen életmű vizsgálatakor egyidejüségükben láthatjuk két kultúra interakcióját ugyanazon személy értelmezésében, hiszen a kultúraközi kapcsolatok kétoldalúsága, egymásra való hatásának összjátéka jellemzi Moldován megszólalásait akkor, amikor magyar állampolgársága mellett románsága megtartásával együtt érvel. E hibriditás nem csupán ezt az életművet magyarázza, hanem e személy csoportkötődéseit is, sőt továbbmenve, arra az erdélyi értelmiségi közegre is érvényes, amely többnyelvűsége révén különböző életvilágok részese lehetett a 19. században.

\subsubsection{2. Életpálya a hazában}

A nemzetállam fogalmának magyarországi példáját érzékletesen szemlélteti Moldován életpályája, karriertörténete, sőt munkái eszmeisége, koncepciója által. Annak ellenére, hogy Moldován egy nemzetiségi származásúnak tekintendő értelmiségi, számára a nemzethez való tartozás az állampolgársággal azonos jelentéstartalmú identifikációs lehetőség, amely ebben az esetben a saját nemzetiségi kötődések fölött áll, és egyáltalán nincs konfliktusos viszonyban azzal. Ezért nem nevezhetjük Moldovánt egyértelmủen a magyar vagy a román nemzet tagjának, mert a 19. század végére, 20. század elejére sem egyértelműsíthető a magyarországi nemzetfogalom. A fogalom magyar vonatkozásban is többértelmü ${ }^{587}$, és számolnunk kell a magyarországi vagy a monarchiabeli etnikumok párhuzamos nemzetépítkezési törekvéseivel, gyakorlataival, amelyek egymás ellenében, a kisajátító versengések közepette jönnek létre és múködnek. ${ }^{588}$

Visszatérve Moldován piaristákat méltató visszaemlékezésére, nem hagyhatjuk figyelmen kívül annak zárógondolatait: „,[a] libapásztortól, a kis borjúhajcsártól a felszállás a rektori székig mindenesetre szép emelkedés volt. Az utat, az irányt nekem a piarista atyák mutatták meg. 1908-ban a Lyceum Önképzőköre számára István fiam emlékére ötszáz korona alapítványt tettem valamelyik jobb irodalmi dolgozat megjutalmazására. Ezzel is csak hálámat akartam kifejezni azok iránt, akik velem szemben oly

\footnotetext{
${ }^{586}$ Vö. Фомокоs 1966, 162.

${ }^{587}$ Ehhez a kérdéshez legutóbb lásd: S. VARGA 2005.

${ }^{588}$ Erre például Moldován is utal, a bukaresti román ifjakhoz írt Válasziratában Románia és Dobrudzsa viszonya kapcsán, illetve a kérdést részletesen elemzi: IoRDACHI 2001, 121-152.
} 
atyailag tudtak viselkedni. Kalapot emelek a Piarista-rend, a Kegyes Atyák előtt, $\mathrm{s}$ véghetetlen boldognak érzem magamat, hogy jubiláris ünnepükön alkalom nyílt igaz hálámnak ismét kifejezést adni". ${ }^{589}$

A hálaadás különböző lehetőségeit kihasználó Moldován nem csupán anyagilag kívánja jelképesen viszonozni az irányában tapasztalt kegyességet, hanem ezzel a gesztusával mintha azok szerepében láttatná magát, akik valamikor őt is segítették: alapítványtételével a diákság irodalmi próbálkozásait támogatná. Ugyan fia emlékére teszi mindezt, viszont azzal, hogy itt felemlegeti, más jelentést nyer. Azt sem hagyhatjuk kommentár nélkül, ahogyan utolsó bekezdését indítja. Saját karrierje szempontjából a piarista intézmény a felemelkedés lehetőségét jelentette, onnan kikerülve nem a román önképzőköri közösséghez kötődik, hanem magyar nyelvü szerzőként, magyarországi állami intézményekben tevékenykedik. Az állampolgári jogokat és lehetőségeket maximálisan kihasználva teszi - saját maga számára óriási jelentőséggel bíró - sikertörténetté életpályáját. Legalábbis visszaemlékezése erről győz meg bennünket.

Érdemes megvizsgálnunk az egyetemi tanárságban tetőző karriert társadalomtörténeti szempontból. Kovács Gábor és Kende Gábor az egyetemi tanárok rekrutációját vizsgáló tanulmányukban ${ }^{590}$ a középosztály és iskoláztatás nagy témájához illeszkedve, a kérdés számos aspektusára hívják fel a figyelmet. A tanulmány szerint a kinevezés körülményei (éve, a születési év, hely), az 1920 utáni állapotokhoz való viszony vagy a vallási megoszlás szempontjai mellett egyaránt fontos mind az apák, esetleg a nagyapák foglalkozásának, státusának, kapcsolathálójának, intézményrendszeri beágyazottságának kutatása. Egyébként, az ilyen indíttatású kutatások olyan viszonyhálót rendezhetnek az egyetemi tanári karrier köré, amely felől jobban belátható annak alakulástörténete.

Szinnyei József biobibliográfiájába Moldován maga küldi be saját ${ }^{591}$ és fia adatait. Eszerint a tiszteletbeli bölcseleti doktor, királyi tanácsos és egyetemi tanár apja Gergely építész és oláh kántor Szamosújváron ${ }^{592}$. Az oláh kántorság egyértelmúen a felekezetiség és etnikai identitás együttállását mutatja. Az egyház intézményéhez (is) kapcsolódó apa foglalkozásához képest fia pályamobilitása nagyon erős. (Mellesleg, éppen e mobilitás veti föl az identifikációs problémákat azon közösségek felől, amelyekhez Moldován kötődik, hiszen a szakmai teljesítmények egyéb érdekekkel társul-

\footnotetext{
${ }^{589}$ Moldován 1926, 92.

${ }^{590}$ Kovács-Kende 2006.

${ }^{591}$ Moldován Márki Sándorhoz írott levelei között találtam rá egy kéziratos életrajzára, amely megegyezik a Szinnyei kötetében publikálttal. Az életrajz zárómondata: Idealja a magyar-román őszinte testvériség, minden téren ez ideálnak szolgált stb. stb. kerekítsd ki, amint neked tetszik. [A kézirat lelőhelye: MTAK Kt. MS 5163/1134]

${ }^{592}$ SZINNYEi 1893-1914.
} 
nak. Mindemellett az is látszik, hogy az egyéni preferenciák nem annyira az egyén, mint inkább a közösségek számára okoznak fejtörést: a magyar és román nyelvű másodlagos irodalom tematizálja egyfelől a túlzott lojalitás áldozatává váló és másfelől a renegát, nemzetáruló értelmiségit.)

A korábban vizsgált visszaemlékezése szerint Moldován 1858-ban került a kolozsvári piarista gimnáziumba, ahol 1867-ben, éppen a kiegyezés évében ${ }^{593}$ érettségizett huszonkét évesen. Ez politikai szemléletét is meghatározhatta, hiszen fiatalkori élettapasztalatait a Habsburg Monarchiában szerezte, és érettségi után már az Osztrák-Magyar Monarchiának lesz polgára. Számára a románság politikai passzivitása, sérelmei és jogkövetelései kevésbé lehetnek érzékeny problémák, hiszen az 1848/49-es szabadságharc idején alig hároméves, a románok nemzeti megerősödését és politikai játszmáit legitimáló, a hatvanas években megszervezett ország- és nagygyưlések idején pedig még diák, aki ekkor még semlegesnek bizonyul a kérdés iránt.

Mind apja halála után, mind a kolozsvári jogászképzés ideje alatt egyházi (vagy annak tulajdonában levő) alapítványok teszik lehetővé taníttatását, ami felekezetileg erősebb kötődést feltételez. Mivel Grigore Moldován életpályájának vizsgálatával egy alfejezetben foglalkozom, lehetetlen olyan, a kérdés szempontjából alapvető fontosságúnak tekinthető források feltárása és értelmezése, amelyek például Moldován felekezeti kötődéséről szolgáltatnának adatokat. Ez egy későbbi vizsgálat tárgya lehet, már csak azért is, mert, amint apja példáján látjuk, a felekezetiség és etnikum esetében, illetve Moldován életrajzában egybeeső identifikációs kategóriák. Hogy a fiatalabb Grigore Moldován hogyan látja saját identitását, az innen, az idős Moldován leírásából is érdekes lehet. Megtörténhet, hogy annyiban román Moldován, amennyiben felekezetéhez hủ marad.

Meg kell említenünk, hogy 1885-ben a budapesti Vasárnapi Újság594 közli - az akkor tanfelügyelőként dolgozó - Moldován anyjának halálhírét: özvegy Moldován Gergelyné 63 évesen hunyt el Szamosújváron. Ebből az adatból több mindenre következtethetünk, bár éppen a nők 19. századi társadalmi helyzete és szereplehetőségei miatt férfitársadalomként körvonalazódik a kortárs szakirodalomban is Magyarország. Viszont a család férfiágú kutatása mellett ugyanolyan jelentőséggel bírhat a női is. Például e hír alapján meghatározhatjuk Moldován anyjának születési évét (1822), korát fia születésekor (23 év), illetve azt, hogy majdnem húsz esztendeig volt özvegy, vagy azt, hogy Moldován negyvenévesen maradt szülei nélkül. Másfelől, az elhalálozás helye azt jelzi, hogy csupán Moldován vált

\footnotetext{
${ }^{593}$ A kiegyezés politikai eseményének megítélése nem volt egyértelmű sem a magyar, sem a magyarországi nemzetiségi közösségek számára. A románok kiegyezéssel kapcsolatos attitűdjéről, politikai elképzeléseiről részletes elemzést készített: Bínó 2002, PÁL 2010.

${ }^{594}$ Vasárnapi Újság 1885/49.
} 
lakhelyet, nem anyjával, hanem saját családjával él egy városban. Továbbá, a budapesti lap a szomorú eseményt a gyászoló társadalmi státusa és presztízse alapján találhatja hírértékűnek.

Moldován családjánál maradva, egyetlen fia, István ${ }^{595} 1871$. augusztus 15-én született Kolozsvárt. ${ }^{596}$ Szinnyeinél még a továbbiakat tudjuk meg róla: jogi tanulmányait Grazban, Genfben és Kolozsvárt végezte, 1894-ben doktori, 1896-ban Budapesten ügyvédi diplomát nyert és 1897-ben ugyanott ügyvédi irodát nyitott, Bánffy György (1845?-1929) gróf főajtónálló uradalmainak jószágigazgatója és a család jogtanácsosa. Azzal a Ioan Rațiuval közli a Tiltakozás az egyetemi román ifjúság nevében kiadott replika ellen $\mathrm{c}$. írását 1892-ben, akivel apja a magántanári állás ügyében levelet vált.

A legfiatalabb Moldován életpályája az apjáéhoz hasonlóan, de mégis más körülmények között alakul. Lehetősége nyílik külföldi egyetemi tanulmányokra, amelyek apja iskolázottságának nagy hiányát jelentik. Doktori címe már nem csupán tiszteletbeli, hanem szakirányú képzésben elnyert minősítés. A jogi képzettségét és az ügyvédi pályán való elhelyezkedését mintakövetésnek tekinthetjük. Apjához képest rá a pályastabilitás jellemző inkább, hiszen kitart választott szakmája mellett. A 20. század elején is annak a Bánffynak a szolgálatában találjuk, akinek fia a majdani jeles író, grafikus és politikus Bánffy Miklós alig két évvel fiatalabb nála. Érdemes megemlíteni azt is, hogy Bánffy György a Kolozsvárt, Hory Bélánál őrzött családi levéltárát az EME-nek ajándékozza, minek következtében az egyesület igazgató tagjai sorába választja Bánffyt, aki dr. Moldován István ügyvédnek köszönetet mond. ${ }^{597} \mathrm{Az}$ derül ki ebből az adatból, hogy összefutnak a szálak: István apjának, az idősebb Moldovánnak barátja Hory Béla árvaszéki ülnök, akinél munkaadója, Bánffy György elhelyezi a családi levéltárat. Mind az apa, mind a fiú majdani kapcsolathálója tehát egyformán fontos mindkettejük számára, és a magyar társadalomba való beágyazottságukat erősíti.

1907 karácsonyán apja nála tölti az ünnepet Bánffyhunyadon. ${ }^{598}$ A fiatal Moldován itt működteti ügyvédi irodáját. 1908-ban halt meg, erre utal apja korábban említett alapítványa. A fia halála jótékonykodásra sarkallja a pedagógustársadalom csúcsára felemelkedett apát. ${ }^{599}$ Ennek egy másik bi-

\footnotetext{
${ }^{595}$ Nemzeti identitása vizsgálata nem szempontja e kötetnek, bár azért érdemel figyelmet, mivel apja esetében láttuk, mennyire nem alkalmazható ez a kategória. Megjegyzem, Szinynyeinél egyetlen utalás sincsen, ami a fiatal Moldovánt például románként láttatná.

${ }^{596}$ Grigore Moldován ekkor még joghallgató, hiszen 1872-ben fejezi be tanulmányait, és lesz ügyvéd Kolozsvárott. Vö. SzinnYei 1893-1914.

${ }^{597}$ Lásd erről bővebben: Különfélék. Adományok az Erdélyi-Muzeum-Egyletnek = Erdélyi Múzeum 1903/5, 282-284.

${ }^{598}$ Vö. Moldován Gergely levele Hermann Ottóhoz [A kézirat lelőhelye: MTAK Kt. Ms 269/64.]

${ }^{599}$ A foglalkozás presztízsértékéről, illetve a 19. század vége egyetemi tanárainak keresetéről lásd: MAzsu 1995.
} 
zonyítéka, hogy 1909-ben a kolozsvári Egyetemi Diákasztal számára 3000 korona alapítványt tesz „derék, szorgalmas, szegény román anyanyelvű fiú részére" ${ }^{\prime 600} \mathrm{Ez}$ az összeg a kisebb alapítványok sorába tartozik a jogi kar évi 200, az orvosi kar tanárainak egyszeri 1200, illetve Szacsvay Sándorné Wesselényi Jozefa 10000 koronás ösztöndíja, alapítványa mellett.

Moldován István románsággal való viszonyát egyetlen publikációja dokumentálja, amit tiltakozásképp írnak kollegájával a bukaresti román ifjak replikája ellen. Ezzel a szöveggel, annak ellenére, hogy az irredentizmus ellen foglalnak állást, a román nemzetiségi törekvésekhez, a Memorandum-mozgalomhoz köthetők. ${ }^{601}$ Nem áll szándékomban e politikai indíttatású polémia vizsgálata, mégis azért utalok erre a szövegre, mert ugyanabba a gondolkodásmódba helyezhető, amelyet az apa Moldován képvisel, ezért történhet meg, hogy néhol az ő nevéhez társítják a több nyelven (magyarul, románul, franciául) megjelentetett tiltakozást.

Említettem korábban, hogy a fiatal Moldován a monarchiabeli grazi egyetemen tanul. Az ELTE Egyetemi Levéltára elektronikus adatbázisaiban az egyetem diákságára kereshetünk rá. Itt egyértelműen azonosítható: Moldován Stephan (Moldován), nemzetisége: ung., életkor: 18 éves, származási hely: Klausenburg, vallása: römisch-katolisch, apa foglalkozása: univ. prof., belépés 1889 W, kilépés 1890 S, fakultás: Jurist. Szempontunkból több érdekes vonatkozása is van ennek az adatsornak. A névhasználat zárójeles helyesbítése, a nemzetiségi identifikáció a diák magyarságát hivatott legitimálni. Az a tény, hogy a beiratkozási íven nem a görög katolikus, hanem a római katolikus vallás szerepel (a hiba/elírás lehetőségét most félretéve) apja szempontjából nyerhet igazán értelmet: a valamikori tanfelügyelő nem saját, etnikai hovatartozását (is) jelző vallásúvá kereszteli fiát, hanem római katolikusnak, amely Magyarországon felülreprezentált felekezet. Valószínúsíthető, hogy amennyiben Moldován magyar nőt vesz feleségül - egyik Márkinak írott levelében Ellával együtt köszönti Márkit névnapján ${ }^{602}-$, annak felekezetét követheti fiuk, és ez magyarázhatja apjáétól eltérő vallását. Ez az adat ugyanakkor azt is jelezheti, hogy Moldován nem ragaszkodott saját vallása átörökítéséhez. A román elithez való viszonyának konfliktusossá válása talán felekezeti kötődéseit is fellazíthatta, ennek következtében alig találunk saját kijelentésein kívül olyan fogódzókat, amelyek románságát legitimálnák.

A kolozsvári egyetem román bölcsészhallgatóira vonatkozó vizsgálataim szerint két diák tanul Grazban. Mind a többször hivatkozott Ioan Rațiu, mind Eneas Zeflean román nemzetiségüként iratkozik be. Mihelyt Moldo-

\footnotetext{
${ }^{600}$ PusKás-Puskás 2005.

${ }^{601}$ Lásd erről bővebben: Köpeczi (főszerk.) 1986.

${ }^{602}$ Moldován Gergely Márki Sándorhoz [A kézirat lelőhelye: MTAK Kt. Ms 5163/1131.]
} 
ván István magyar nemzetiségűnek tartja magát, apja, Grigore Moldován románsága válik kérdésessé. Hozzá hasonló módon fogalmazhatunk: az oláh kántortól, a román-magyar egyetemi tanártól a magyar ügyvédjelöltig tart az a mára bonyolultnak tünő folyamat, amely az etnikai és nemzeti identitás 19. század végi összeegyeztetésének szükségessége miatt válik problematikussá e család tagjai, legfőképpen a köztes helyzetbe szoruló Grigore Moldován-Moldován Gergely számára.

Annak ellenére, hogy kevés adatot találtam Grigore Moldován fia, Moldován István életpályájáról, a fentebb vizsgáltak alapján érdemes úgy látni a Grigore Moldovánét, hogy családtörténetének rekonstruálása eredményes lehet, hiszen az iskoláztatást megelőzően e mikroközösség kínál mintákat és motivációkat, amelyek az identifikációs dilemmákat magyarázhatják. Igaz, hogy ebből a perspektívából a fiatal Moldován közelíthető meg leginkább, mivel több generáción keresztül mutatkoznak meg azok a struktúrák, minták, kapcsolatok, amelyek iskolázottságát, karrierjét, társadalmi státusát, identitását meghatározták.

$\mathrm{Az}$ alfejezet végéhez érve, Grigore Moldován helyett meggyőzőbb Moldován Gergelyt használni, azzal a kiegészítéssel, hogy nem pusztán a magyaros névhasználat szokása munkál ebben, hanem az a felismerés is, miszerint olyan magyar állampolgárok éltek a 19. század végén, 20. század elején Magyarországon, akiknek etnikai identitása különbözik a nemzetitől, és e különbség elméletileg összeegyeztethető, kibékíthető. Az alfejezetben a magyar mint nemzetjelölő fogalom homonimikusságáról győződtünk meg. A több nemzetiséget felölelő, azok fölött szervezendő nemzetállam olyan különbségeket eltörlő apparátus lesz Moldován Gergely elképzelésében, amely hatalmánál fogva homogenizációs erőként tud működni. Az államalkotó nemzet (kultúr)fölényét hangsúlyozó Moldován a románságot hozzá képest alárendelt és függő viszonyban látja, és népismereti kutatásai felől azzal erősíti meg elképzelését, hogy például az Alsó-Fehér vármegyei románok szókincse azt tükrözi, hogy a románság a magyaroktól olyan szavakat vesz át, amelyek a politikai, gazdasági, társadalmi konszolidáltságra vonatkoznak, mindez pedig nem kölcsönös. ${ }^{603}$ A nyelvből rekonstruálható életvilág, a kognitív nyelvészettel kapcsolatba hozható gondolkodás jellemző Moldován okfejtésére, amely szervesen illeszkedik elképzelésébe: az állami bölcs kormányzás áldozatokra késztetheti a románságot, vagy nem ismerve, igényeit figyelmen kívül hagyva, általuk veszélyeztetheti önmagát.

Nem nevezhetjük asszimilációnak azt, ami Moldovánnal történik, mivel a végsőkig kitart románsága hangoztatásában, illetve ezzel egy időben bizonytalannak kell tartanunk a „románsága” kifejezést. Fia önazonossága

${ }^{603}$ Moldován 1899, 102. 
az egyetemi beiratkozáskor viszont a beolvadás folyamatát villantja föl. Egy korábbi fejezetben idéztem már Nagy Péter Tibort, megismétlem állítását: az iskolázott nemzetiségi tisztviselők egy része a felső társadalmi osztályba kerülve feltehetően »nemzetiséget váltott«. Vagyis, erre irányuló presszió nélkül is magyarnak mondta magát. ${ }^{604}$ Korábban a mikrostrukturális kutatások melletti érvként hoztam ezt az idézetet. Most az elbizonytalanított „,nemzetiségi váltásra” hívnám föl a figyelmet. Nagy Péter Tibor tanulmánya több pontján az iskoláztatás ellenében az iskolázott közeget tekinti a legfontosabbnak az abban tevékenykedő szabadfoglalkozású nemzetiségiek asszimilációja kapcsán. Szintén ő állítja, hogy a felekezetiség regionálisan, ezen belül pedig a románok esetében - bizonyos támpontot jelent, hiszen a vallás megváltoztatásának (lévén, hogy ez egy nehézkes adminisztratív aktus) kisebb a valószínűsége, mint a nemzetiség megváltoztatásának, minthogy az utóbbi népszámlálási deklaráció kérdése. ${ }^{605}$

Moldován Gergely esete, bár érintőlegesen kapcsolatba hozható ezzel a vizsgálattal, éppen azért válik fokozottan érdekessé, mert nehezen tekinthető nemzetiségváltásnak. A fentiek azt mutatják, hogy a nemzetiségi és nemzeti különállásáról van szó, és ez a differenciálás nem ragadható meg egykönnyen mai fogalmaink felől. A dolog folyamatszerüségében igazat adhatunk Nagy Péter Tibornak, mert a Moldován család története alapján azt láttuk, hogy a görög katolikus román nagyapának görög katolikus román-magyar fia, annak pedig római katolikus magyar fia lesz. Férfiágon történnek a váltások, amelyek bizonyára nem közömbösek a család nőtagjai identitása szempontjából. A nemzetiségváltás vagy asszimilácó Moldován István esetében következik be, és amennyiben az adattárban előforduló felekezetisége valós adat, akkor rétegzettebb folyamat körvonalazódik.

A magyarországi etnikumok nemzeti identitásának 19. századi megerősödése kerül szembe a magát nemzetállamként definiáló Magyarországgal, ennélfogva pedig a magyar nemzettel. Moldován Gergely e konfliktusos viszony kibékíthetősége mellett foglal állást mind identifikációjában, mind egész életművében. Életművét metadiskurzusnak tekinthetjük, amennyiben az arról is szól, ahogyan Moldován folyamatszerűen alakítja ki saját álláspontját és annak különössége miatt állandó megerősítésére kényszerül. Mellesleg a különösség vagy differenciálódás azon közösség szempontjából lesz elítélendő, amely etnikai identitása nemzetiesítésén dolgozik, és amely számára a század végén megalakuló Románia nemzetállami keretet biztosít. A (nemzet)állam mint intézmény 19. századi fogalma és századvégi valósága egyaránt hatással van az európai etnikumokra és azok po-

\footnotetext{
${ }^{604}$ NAGY 2006, 20

${ }^{605}$ Uo. [kiemelés az eredetiben]
} 
litikai, társadalmi, gazdasági, kulturális létformáira, szervezeteire. Ezért történhet meg az, hogy a magyarországi etnikumok az országgal határos szomszédos politikai berendezkedések által is befolyásolva, nemzeti közösségekként kezdenek el önmagukról gondolkodni, ehhez kapnak külső megerősítést. ${ }^{606}$

A magyarországi egyetemekről kikerülő román értelmiségiek esetében láttuk, hogy egyrészt az országban maradás nem feltétlenül jelenti a magyar közösséggel való azonosulást, hanem inkább a saját, a román közösséghez való tartozást és ennek keretei között megvalósuló (erdélyi) román nemzetépítést, amely a magyarokéval párhuzamos folyamat. Másfelől, a román királyság potenciális nemzeti közösségként kínál identifikációs lehetőséget az erősebb nemzettudattal rendelkező, a magyarországi tapasztalatokkal konfliktusos viszonyt kialakító román értelmiségieknek (például a nagyszebeni Tribuna munkatársainak). Moldován Gergelyt föként a szélsőséges politikai nézeteket vallók ítélik el (Onisifor Ghibu, Ioan Slavici). Nem ő az egyetlen olyan román származású magyar állampolgár a 19. század második felében, aki magyar nyelvtudását, kapcsolathálóját saját érdekein kívül, magyar állami intézményekben alakítja, majd kamatoztatja. Elég arra az Emanuil Gojdura/Gozsdu Manóra gondolni, aki identitása szempontjából szintén problematikus, és akit Moldovánhoz hasonlóan kárhoztattak kortársai. Viszont Moldovántól eltérően, azért válhatott mégis a románság pozitív figurájává, mert vagyonával, alapítványával több száz román diák taníttatását tette lehetővé.

Moldován életműve a román publikációktól a román népköltészet magyar fordításán, a román irodalom és népi kultúra magyar nyelvű ismertetésén keresztül jut el a kizárólag magyar nyelvű irodalmi munkássághoz, amely tematikájában mindvégig kötődik a román kultúrához. Politikai írásai pedig elméleti elképzeléseinek, munkássága koncepciójának legitimáló szövegei. Magyar nyelven írt szépirodalminak tekinthető népszínműveit is meg kell említenünk munkássága összefoglalásakor. ${ }^{607} \mathrm{Az}$ idézett kritika

${ }^{606} \mathrm{E}$ kérdést érintőlegesen tárgyalja, illetve a tágabb probléma lényegi vizsgálatát nyúitja: KARÁdY 1997a, 151-196.

${ }^{607}$ Ady Endre a Nagyváradi Naplóban referál a Flórika szereleme c. Moldován-mű bemutatójáról: „röviden jellemezve az úgynevezett átlag színművekhez tartozik. Adva van egy új köntös, amelyben régi ismerős adatokat fedezünk fel, akik éppen úgy járnak, kelnek, beszélnek, dalolásznak, mint igen sok más népszínműben, azzal a különbséggel, hogy itt a magyar paraszt ruháját az oláh gúnya váltja fel. [...] Nálunk a bemutatót kevés számú közönség nézte végig, de azért lelkesen tapsolt a híres oláh nótának: a Styi-tu-nak és a szintén sikerült oláh táncoknak." Ady szerint a román táncok és a sajátos népviselet válnak a darab olyan értékeivé, amelyek felől a közönség érdeklődésébe ajánlja az előadást. Lásd: Ady Endre, Flórika szerelme. Bemutató a Szigligeti Színházban = Nagyváradi Napló 1902. február 16. [Ady Endre összes müvei, http://mek.oszk.hu/00500/00583/html/ady25.htm - utolsó látogatás: 2012. július 12.] 
egy színmű előadásában nem annak témájában vagy specifikus eszköztárában, dramaturgiai megszerkesztettségében látja annak érdemét, hanem az irodalmon, drámán túli jelentésekben, amelyek a látványhoz („,román köntös") és zenéhez (a betanított román néptáncok), tehát az etnikum kulturális sajátosságaihoz, a másság felismeréséhez köthetők és túlmutatnak a szükebb értelemben vett irodalomfogalmon.

A magyar íróvá váló Moldován munkássága azért is érdekes, mert a század végén fordítva próbálja ki azt, amit korábban tett: a magyar irodalmat román nyelvre átültetve közelíti a román nyelvű olvasókhoz. Eltekintve az Ungaria mögötti érdekektöl, olyan értelemben utalok vissza e lapra, hogy visszacsatolok a kötet egy korábbi részéhez, a fordítók kilétéhez. Az látszik az Ungaria hasábjain, hogy a magyar irodalom román nyelvű ismertetését is többségben románok vagy többnyelvű régióban szocializálódott értelmiségiek végzik, mert a magyarok közül kevesen ismerik a nyelvet olyan szinten, hogy fordításra vállalkozzanak. A kölcsönösség tehát Moldován e vállalkozásával teljesedik ki: a másik, a számára befogadó kultúrát viszi közelebb a különállóságát felismerő és egyre inkább hangsúlyozó román kultúrához.

A modern értelemben vett nemzetkoncepciót félretéve közelíthetünk csak munkásságához, hiszen Moldován identifikációs elképzelései felülírják azt. Munkássága vizsgálata leplezheti le azokat az érdekeket, amelyek csoportkötődései kialakításában, személyes karriertörténete felépítésében motiválják, vagy abban, hogyan gondolkodik államról, nemzetről, etnikumokról. Népismereti érdeklődése teszi ideologikussá munkásságát: a fordítást olyan megismertetési gyakorlatként látja, amely a nyelvi különbségek eltörlése által mutathatja meg a román kultúra értékességét, de sajátosságait is, valamint a megértés lehetőségét megteremtve, a közeledést, (bizonyos ponton az általa is illuzórikusnak tűnő) elfogadást, a megbékélést szolgálja. Annyiban tér el Moldován az alkalmi fordítóktól, hogy munkássága éppen ideologikuma révén találkozik azokkal a hatalmi játszmákkal, amelyek a 19. és 20. század fordulóján az állam és a benne élő etnikumok (bonyolult és megoldhatatlan konfliktusoktól nehezített) viszonyrendszerét meghatározta. Úgy gondolom, hogy nem járható az az út, amely félreteszi vagy elítéli a Moldován és a hozzá hasonló értelmiségiek életmúvét. Irodalmi munkássága értelmezése, a belőlük felismerhető elképzelések, az életpályáját müködtető motivációk és érdekek sokkal fontosabbak. A Moldovan/Moldován kérdés eldöntetlensége, a magyar állampolgárságú román származású értelmiségi identifikációs gesztusainak megértése képezte vizsgálataim tárgyát, és továbbra is érdeklődésem homlokterében marad. 


\section{3. Összegzés}

Meltzl Hugó és Moldován Gergely német és román származású értelmiségiként válik Brassai Sámuel társaságában a kolozsvári egyetem tanári karának tagjává. Munkásságuk bizonyos aspektusainak felvillantása, levelezéseik vizsgálata arról győzött meg, hogy vállalkozásaik érdekek mentén bontakoznak ki, szoros összefüggésben állanak saját azonosságtudatukkal, tágabb értelemben pedig azokkal az identifikációs lehetőségekkel, amelyek a magyarországi társadalomban vagy a megerősödő nemzetállamban rendelkezésükre állnak, vagy külföldi mintákból táplálkoznak. Amíg Meltzl és Brassai az összehasonlító történeti nyelvészet felől érkezve az egyes nemzeti nyelvü irodalmak egyetemessége mellett érvel oly módon, hogy távol tartja magát a nacionalizmustól, addig Grigore Silaşi, a kolozsvári egyetem első román tanára éppen a nacionalizmus számára szolgáltat érveket tudományos munkásságával, és válik a magyar elképzelés felől szélsőséges nézetek képviselőjévé. Moldován Gergely másféle szakmai tapasztalatok felől gondolkodik a román közösségről, és a magyar nemzetállam elismerését szorgalmazza. Mindannyian a magyar állam polgárai és ezzel egyidőben különböző módon gondolkodnak. Meltzl és Brassai a kozmopolitizmus, Silaşi a román, Moldován a magyar nacionalizmus fele közeledik.

Mindannyian Erdély többnyelvü társadalmának tagjai, következésképp, szocializációjuk sem egypólusú, hanem ez együttélő nemzetiségekhez, a környezetben beszélt nyelvekhez, fellelhető kultúrákhoz képest alakul. Valamennyien két- vagy többnyelvúek, az oktatási rendszer miatt pedig a magyar kultúrában is jártasságot nyernek. Etnikai identitásuk olyan identitáskomponensekkel gazdagodik, amelyek társadalmi beilleszkedésüket, csoportkötődéseiket is meghatározzák.

Brassai és Meltzl esetében arról győződhettünk meg, miképp kamatoztatják nyelvtudásaikat, többes kulturáltságukat lapvállalkozásukban, miként ismerik fel előnyként mindezt, és impliciten miként gondolkodnak egy nemzetek fölötti identifikációs lehetőségről, amely a világpolgársággal mutat rokonságot. Ilyen módon a multikulturalitás, a poliglottizmus a multietnicitást fölülíró kategóriaként működik. Moldován Gergely többnyelvűsége a magyar társadalomban és politikában bekövetkező változások révén egyazon logikára, az egynyelvűség, mi több, a magyar nemzetállam logikájára alakul át oly módon, hogy megőrizni kívánja etnikai identitását. Az asszimilácó ellenében instrumentalizált multietnicitás a modern értelemben vett nemzetkoncepciót kezdi ki mind a magyar, mind a román nemzet kapcsán: a nemzeti állampolgársághoz képest alárendelt 
funkcióban kívánja megőrizni Moldován etnikai identitását, amely ezáltal nemzet alattiként definiálható.

Silaşit azért hoztam szóba ebben a fejezetben, mert esete Moldován ellenpéldája. Számos közös jellemző mellett éppen a politikai értelemben vett elköteleződés differenciálja kettejüket. Silaşi nem a magyar, hanem a román nemzet tagja kíván lenni. A nem államalkotó román etnikum a 19. század második felében nemzetiként elképzelt intézményrendszert kialakítva próbál építkezni főként Erdélyben, és ilyenként kerül kapcsolatba a hasonló politikai stratégiákkal dolgozó Magyarországon kívüli, román királysági, azaz regáti nemzetelképzeléssel: „Nagy-Románia” eszméjével, a dáko-román kontinuitás elvével. Ilyenként válhat magyar szempontból irredentává, román szempontból pedig a nacionalizmus, a nemzetépítés hősévé a magyarországi Silaşi, aki tehát etnikai identitását román nemzetiként erősíti meg.

A nemzetiségi lét különböző lehetőségeit példázzák a fejezetben vázolt értelmiségi életpályák és a hozzájuk társítható koncepciók. A birodalmi keretek között legitimitásáért küzdő magyar nemzetállamban a nemzetiségiek számos identifikációs lehetőséggel bírnak. A fejezetben bemutatott egyéni példák azokat a döntéseket is láttatják, amelyek alapján a magyarországi nemzetiségiek gondolkodnak önmagukról. A párhuzamos nemzetépítkezés Silaşi-féle elképzelése mellett ott találjuk az átjárásokat teremtő fordító vagy idővel a magyar nemzetállam mellett elkötelezett, magát magyarként megmutató Moldovánt. 


\section{KONKLÚZIÓK}

A rendkívül tág kapcsolattörténeti kérdésfelvetéssel dolgozó kötet nem véletlenül tűnik szerteágazónak. A különböző fejezetek alfejezetei számos esetben roppant fontos kérdéseket mutatnak meg, amelyek e munka lezárultával is tovább munkálnak, majdani alaposabb feltárást követelve. Az esettanulmányok láncolataként tekinthető kötet azért nem kíván monografikusan szerveződni, mert azt a vizsgált kérdés, vagyis a kapcsolattörténet maga lehetetleníti el. A 19. század végén, 20. század elején megélénkülő irodalmi közvetítések az intézményesülés előzményeinek tekinthetőek csupán, hiszen láttuk, hogy az első kötetbe szervezett, román költészetet tolmácsoló fordításgyűjteményekre a 20. század első évtizedéig kell várni.

A fordítástörténeti kiindulópont eleve két kultúra metszéspontján helyezi el a dolgozatot, ezáltal sokkal rétegzettebbé teszi azt, például az egyetlen irodalmat vizsgáló kutatásokhoz képest. Következésképp, jóval nehezebb dolga van a kapcsolattörténet kutatójának, hiszen figyelmét megosztva, egyszerre kell összpontosítania a vizsgálandó kultúrákra, ebből következően pedig arra is kell vigyáznia, hogy lehetőségei szerint megőrizze pártatlanságát. A kötet magyar nyelve eleve kontextualizálja és kijelöli a megközelítés irányát, ilyenformán, a magyar kultúra mozgásteréből, tehát egyenlőtlenül hozza szóba a magyar és román kulturális kapcsolatokat. A magyar kultúrát anyanyelviként ismerő, a románt a szocializációban, oktatásban elsajátító és vizsgáló kutatóként kulturálisan meghatározott tudásom prekoncepcióit akaratlanul müködtetem, annak ellenére, hogy törekedtem a reflektált értelmezésre. Mindemellett éppen a kapcsolattörténeti kiindulópont követelte meg azt a módszertani keretet, amely a kapcsolatot oda-vissza müködő történeti viszonyhálóként kezeli, és a szinkronitás és diakronitás elvére figyelve, annak keresztmetszeteire kíváncsi. 
A magyar-román irodalmi kapcsolatok így a szűkebb értelemben vett irodalom fogalmát átlépve, a kapcsolattörténeti jelentőségük mellett a multidiszciplináris megközelítésnek köszönhetően újabb forrásokkal, értelmezési szempontokkal bővültek. Láttuk, hogy a folyóirat-kultúra felbecsülhetetlen értékkel bír a fordítások megjelentetési közegeként. A korábban kevésbé fontos szerkesztôi üzenetek lettek forrásai akár az Eminescu, akár a magyar nyelvű fordításai körüli irodalmi recepciónak. Az irodalomtörténet segédtudományaként tekintendő kapcsolattörténet számára további kiaknázatlan csemegéket tartogatnak mind az elérhetô vagy lappangó, esetleg feldolgozatlan, ilyenképpen pedig a kutatás számára hozzáférhetetlen személyes hagyatékok, mind a kéziratban maradt levelezések, írásművek, mind az elektronikusan immár hozzáférhető prozopográfiai adattárak, vagy a politikai szakirodalomhoz tartozó, de az irodalom intézményrendszerét érintő országgyülési jegyzőkönyvek.

A magyarországi románok kultúrája iránt a 19. század második felében felélénkülő érdeklődés problematikusabb annál, mint amilyennek első pillanatra tűnik. A 19. század második felének, a 20. század elejének politikai, társadalmi és kulturális közegére való figyelés nélkül lehetetlen lett volna értelmezni azt a jelenséget, amely a népek, nyelvek és kultúrák közötti közeledés ideologikumába íródik. Ezzel együtt pedig ismét hangsúlyozandó a kapcsolatok vizsgálatának történeti kérdésfelvetése, hiszen láttuk, hogy korántsem öncélúak és egyértelmúek a fordítói gyakorlatok és a kultúrák közötti közvetítések. Esetünkben egyfelől a nemzetiségi kérdés 1867 után véget nem érő országgyülési vitákat eredményez, másfelől, amint arra a bibliográfiai adattárak vizsgálata rámutat, nem nevezhetjük érdeklődésnek azt, ami kiváltja a folyamatot. A 19. század második felében még többnyelvű Erdélyben, de Magyarországon is a nemzetállami építkezéssel egy időben zajlik a magyar és nemzetiséginek nevezhető nemzeti kultúra, irodalom fogalmi kidolgozása, intézményrendszeri megszilárdulása. Ezt a folyamatot a központosítás és az államhatalmi felügyelet ellenére is a párhuzamos elképzelések müködtetik. A kultúrák közvetítő erejébe vetett hit ilyenként válik ideálissá, és egyben illuzórikussá, sőt a másodlagos diskurzus számára hatalmivá. Jelen kötet is leleplezi azokat a hatalmi politikákat, amelyek például a románok és szerbek nemzeti színházügyét, vagy a fordítói gyakorlatok elméleteit, tágabban pedig a magyarországi nemzeti és nemzetiségi értelmiségiek koncepcióját meghatározzák. Következésképp a kapcsolattörténet tágabb keretét az értelmiségtörténeti kontextus képezte, amely a fordítók nyelvismerete vizsgálatától jutott el azok identifikációs dilemmáihoz. 
Az egyes fejezetek arra világítanak rá, hogy milyen érdekek motiválják a fordítókat, milyen elképzeléseik vannak a két kultúráról, az azok között feltételezhető kapcsolatokról, de arra is, hogy a kérdést vizsgáló másodlagos irodalom néhol problematikusnak tünik éppen a nemzeti irodalomfogalom kizárólagos múködtetése miatt.

A mai román nemzeti irodalomtörténet kulcsfigurájának, Mihai Eminescu költészetének első magyar nyelvű fordításai megkövetelték az életmű magyarországi vonatkozásainak értelmezését, amelynek kapcsán a nemzetállam és nemzetiségek viszonyát is sikerült egy konkrét eset, a román nemzeti színházügy elemzésével szemléltetni. Kiderült, hogy az országgyưlésben zajló belügyi vita költségvetésről szóló része nem kerülhette meg a nemzetiségi követeléseket, amelyeknek a képviselők bármely adódó alkalommal hangot adnak. Az országgyưlési vita elemzése vezetett el ahhoz a felismeréshez, miszerint a különböző etnikumok országgyứlési képviselői kohéziós erőként, egymásra utaltságukból erőt és érveket kovácsolva működtek - a hatalmon levő magyar képviselők, a hivatalos politikai elképzelés ellenében. Megjegyzendő, hogy annak ellenére, hogy nemzetiségi képviselőkként említi őket a kötet, az országgyülésbe - az ország adminisztratív szervezettségéből fakadóan - a különböző megyei kerületek juttatták őket. Elsősorban tehát lokális érdekeket kellett képviselniük, amelyek bizonyos esetekben a régió etnikai összetétele miatt akár nemzetiségi színezetet is nyertek. A lokális kérdések tehát találkozhattak az erősödő nemzetiségi törekvésekkel, amelyek azt illusztrálják, hogy az egyenjogúság törvényként megvalósult ugyan, de érvényesítése, gyakorlati megvalósítása nem történhetett meg a magát politikai értelemben nemzetállamként konstruáló Magyarországon.

A magyar nyelvű korai Eminescu-recepció néhány olyan irodalmi párhuzamot tárt föl, amelyek mentén a magyar olvasóközönség számára ismerőssé tették a román költőt. A vizsgált szövegek kontextuális elemei pedig azt bizonyítják, hogy a nyelvválasztás akár külsőleg befolyásolt opció is lehetett. Ezért történhetett meg, hogy magukat románnak valló értelmiségiek akaratlanul is a magyar recepciótörténet jelentős figuráivá váltak.

Sándor József első Eminescu-fordítóként lett érdekes a kapcsolattörténet számára. A retrospektív megközelítést lehetővé tevő kései, 1964-es felfedezés a fordítás gyakorlatát figyelmen kívül hagyva emelte ki a fordítás elsőségét értékként, és ezzel egy időben a többi Eminescu-fordító felől minősítette azt kevésbé értékesként. Az első fordítókat a nyelvek, kultúrák ekvivalenciáját feltételező, a hűséget követelményként megfogalmazó fordítói elméletek felől látták dilettánsoknak a kapcsolattörténészek. Ezt 
az értékelést félretéve, a Sándor Józseffel, majd a Laurențiu Brannal és Révai Károllyal - Eminescu verseit elsőkként magyarra átültető fordítókkal - foglalkozó alfejezet a fordítók nyelvi kompetenciáját, motivációját társadalomtörténeti szempontból, szocializáltságuk felől közelítette meg, láttatva azt is, hogy fordításaik korántsem öncélúak, a kultúrák közötti közvetítést pedig érdekek motiválják: más népek irodalmának megismertetése, a megismerhetőség által a megértés és elfogadás eszméje. Ez a fordítói elképzelés eltért attól a fordításelméleti gondolkodástól, amely a 19. század második felében a magyar irodalomban működött. A presztízzsel rendelkező külföldi nyelvek és kultúrák iránt érdeklődő magyar irodalmi élet mintákat keresett és talált, kölcsönzött. Emellett pedig alulmaradt a hazai, azaz az országhatáron belül eső etnikumok iránti érdeklődés. Újragondolva a kérdést ez azzal is magyarázható, hogy a 19. század közepe után politikailag átrendeződő magyarországi társadalom a 20. század elejéig olyan értelemben vált modernné, hogy a (nemzet)állam kiterjesztette felügyeletét a gazdaság, a társadalom és a kultúra egészére. A magyar irodalom nemzetiként való intézményesülése éppen ekkor kezdődött el. A nyelvalapú irodalomfogalom térhódítása és kanonizálódása mindenképp összefüggött a politikai értelemben is nemzetiesedő Magyarországgal, mindez impliciten ahhoz járult hozzá, hogy a nemzet alattiként elképzelt etnikai közösségek és a nemzet közötti távolság elmélyült. A nyelvalapú magyar irodalomfogalomtól, az általa meghatározott egynyelvüségtől/ egyneműségtől elkülönülni látszanak azok a nemzetiségi irodalmak, amelyek évtizedekkel korábban ahhoz tartoztak. A kérdést érdemes folyamatszerüségében látni, hiszen a hungarus-tudaton alapuló magyar irodalomfogalom a századforduló olyan jelentős vállalkozásában is koncepciózusan került elő, mint a Szinnyei-féle Magyar irók élete és munkái. Az elkülönülésre kényszerített nemzetiségi irodalmak a fordítás útján mutathatták meg önmagukat, közeledtek ismét a magyar irodalomhoz ekként legitimálva létüket és értékességüket. A nyelvtudás mellett ez a tény is magyarázhatta a románok fordítói érdeklődését. Természetesen akkor lenne jogosabb ez a kijelentés, ha a többi magyarországi nemzetiségi irodalomfordítás mögötti érdekeket is látnánk, és ha azokat egyazon koncepcióba rendezhetnénk.

Sándor József életpályájának rekonstruálása olyan értelemben válik a kötet egyik kulcsfejezetévé, hogy az alkalmi irodalmi fordító román irodalom, kultúra és politika iránti érdeklődéséhez kerestem és rendeltem kontextusokat. Érveket találtam abban a tekintetben, hogy mi motiválta irodalmi foglalatosságait, miként kamatoztatta többes kulturáltságát, majd miként határolódott el élete bizonyos szakaszában politikusi szakmai karrierjét kialakítva, mindentől, ami nem a magyar nemzet(állam)hoz és Erdély ügyéhez tartozó, így a nemzetiségi kérdéstől és a román kultúrától is. 
A román kultúra magyar nyelvű megmutatkozása még nem teljesítette azt az illuzórikus szándékot, amely a közvetítést megalapozta. A megismerés és annak következményeként elképzelt elfogadás és megbékélés „kultúrmissziója” a 20. század elejéig kevésbé vált eredményessé. A kötet két esetben ellenpontozza ezt a történeti tényt. Mihai Eminescu recepciója kapcsán a De ce nu-mi vii c. verse népszerüségét említi, illetve Moldován Gergely Flórika szerelme c. népszínműve bemutatója kapcsán Ady Endre írásának vonatkozó részeit idézi. Mindkét esetben irodalmon kívüli tényezők (megzenésített változat, azaz dallam, illetve sajátos népviselet és néptánc) pozitív hatása biztosítja az el/befogadást. Az írásbeliség ellen/mellett munkáló befogadási lehetőségek, a hallásra és látásra alapozott előadásmódok, tehát az írás- és olvasástudást megelőző észlelési, érzékelési módozatok legitimálják a valódi recepciót. E két példa felől megkockáztatható az a megállapítás, miszerint a 19. és 20. század fordulóján a széles befogadó közönség számára még mindig óriási jelentőséggel bír a szóbeli kultúra.

A fordítói gyakorlatok mögött felismerhető egyéni motivációk mozdították el a kutatást a szocializáció, az iskolázottság és a szakmai identitás vizsgálata felé, hiszen a későbbi művészi fordítások elemzői éppen ebben a tekintetben marasztalták el az inkompetensnek tekinthetö, nem költőfordítók tevékenységét. A magyar irodalom rendszerében önálló alrendszerként működő fordításgyakorlatok idővel intézményesültek, a Kisfaludy, Petőfi, és az Erdélyi Irodalmi Társaság is elismerte, majd szorgalmazta a fordítók kultúra-közvetítő tevékenységét. A népköltészeti tolmácsolások után az irodalmi alkotások rendre a magyar nyelvű irodalom részeivé váltak, hiszen a fordítások az eredetire utaló paratextuális elemektől eltekintve, elfedték a müvek identitását.

A magyar-román kapcsolattörténet értelmiségtörténeti esettanulmányai képezik a kötet legfontosabb nóvumát és hozadékát, hiszen az ötödik fejezet olyan források segítségével próbált a magyar és román irodalom, kultúra, társadalom és politika századfordulós kérdéseire választ adni, amelyekkel eddig nem foglalkozott a vonatkozó szakirodalom.

A román egyetemi hallgatók prozopográfiai adataiból kiinduló mikrostrukturális kutatások eredményeit feldolgozó fejezet csak elvileg foglalja össze azt a jelentékeny adategyüttest, amelyet a mellékletben helyeztem el, és amely további, részletesebb értelmezésre ad lehetőséget. A kapcsolat másik oldalának, a román kultúrának értelmiségtörténeti megközelítése több szempontból volt fontos. Egyfelől a másik, azaz a román oldalt is megvilágítja. Ellensúlyozza a kapcsolattörténet egyoldalúságát mindamellett, hogy nem feltétlenül a magyar irodalmat románul fordítókra öszszpontosít. Másfelől megmutatja, hogy a magyar intézményi keretek mi- 
lyen hatással voltak a nemzetiségi fiatalokra, milyen pozitív vagy negatív identifikációs lehetőségeket kínáltak, illetve azt is, hogy sem a személy-, sem a kultúraközi kapcsolatok nem voltak politikamentesek. A magyar és román kapcsolatok a nacionalizmus kontextusában váltak konfliktusossá, és ettől a ténytől nem tekinthetünk el, bármennyire is irodalmi szempontú a kutatás. Az aktuális politikai kontextus azért sem volt elhanyagolandó, mivel esetenként a fordítók politikai szerepeket vállaltak - Sándor József országgyúlési képviselő - vagy politikai koncepciójukat exponálva, munkásságukat is ahhoz igazították, és ha az életmüvet, a fordítók szövegterméseit saját fordításaik kontextusaként tekintjük, számolnunk kell azok minden aspektusával.

A kolozsvári egyetem román diákjainak vizsgálata a beiratkozási anyakönyvek, a vég- és távozási bizonyítványok adatai segítségével a kötet kérdésfelvetésének fordított megközelítését nyújtotta, és a másik oldalról szolgáltatott magyarázatot arra a kérdésre, hogy a 19. század utolsó harmada magyar irodalmi életének kanonikus figurái, vagy a müfordítás elméleti és gyakorlati szakemberei az európai irodalmakra való figyeléshez képest miért viszonyultak másképp, miért nem voltak jelen a román kultúrával kiépítendő kapcsolatokban. A román nyelv és irodalom például az angol, francia, német vagy más európai nyelvekhez és irodalmakhoz képest egyrészt az országon belüli, nagyon közeli kultúrához tartozott, másrészt presztízs tekintetében a magyar irodalom szempontjából alulmaradt. Harmadsorban pedig az országban fellelhető nemzetiségi irodalmak iránti érdeklődés hiánya abból is fakadhatott, hogy a modern értelemben nemzetivé váló magyar kultúrának idővel számolnia kellett azokkal a kultúrákkal, amelyek éppen a nemzeti ilyen képzete működtetése révén peremre szorultak, vagy kiestek azon fogalom jelentésköréből, amely korábban még magában foglalta azokat. A nyelvalapú irodalomfogalom kánonivá válásának egyik következménye tehát a magyarországi irodalom differenciálódása, illetve a magyar irodalom mellett körvonalazódó nemzetiségi irodalmak kérdése.

A román diákok önszerveződése a jótékonyság és a szabadidős tevékenységek mellett (kultúr)politikai célokat szolgált, irredentának tekintett eszméket képviselt éppen az erdélyi román elittel fenntartott kapcsolatai révén. A felsőfokú oktatási intézmény számos tényezője befolyása ellenére sem múködött asszimilációs közegként, hiszen amint Grigore Silaşi vagy akár a románságában megkérdőjelezett Moldován Gergely munkássága és diákokra tett hatása jelzi, az egyetem végzettjei továbbra is etnikai és főként felekezeti kötődéseik alapján választottak (munka)helyet maguknak a magyarországi vagy a regáti (az akkori romániai) társadalomban. Viszonylag rövid az a majdnem öt évtized, amellyel a Ferenc József Tudo- 
mányegyetem hatása és jelentősége mérhető, amellett pedig a 20. századi nagy politikai átrendeződés teljesen megfordította az erőviszonyokat, ezért a magyar intézményben szocializálódott román származású elit vizsgálata olyan értelemben nem lehet teljes, hogy a 20. század dereka körül lezárandó életpályák rekonstruálhatóak ugyan, de 1918 után tovább folytatódtak, az a korszak pedig teljesen más kérdések felől teszi érdekessé a témát.

Ebből a részkutatásból adódott annak a kérdéskörnek a vizsgálata, amellyel a hatodik fejezet foglalkozik. Ez a fejezet olyan identifikációs lehetőségeket modellál konkrét példák alapján, amelyek különböző felekezetű és nemzetiségü egyetemi tanárok sajátjai. Az általuk létrehozott vállalkozások, életmúveknek (ön)reprezentatív funkciót tulajdonítva vizsgáltam azok jelentőségét egy-egy életpályán belül, de kapcsolattörténeti vonatkozásaikban is. Az egyéni önleírásokként, metadiskurzusokként is szolgáló életművek a század utolsó harmadában, a nemzeti nyelvekről és kultúrákról való gondolkodást illusztrálhatják. Amíg Brassai Sámuel és Meltzl Hugó a goethei világirodalom-fogalmat értelmezte újra, az irodalomtörténeti összehasonlítást jelölve ki módszerként egy olyan lapban, amely egyszerre több, és zömében új diszciplínát (etnológia, antropológia) több mint tíz nyelven jelenített meg, és egyébként a poliglottizmus elvét a fordítás ellenében működtette, addig Moldován Gergely korai, román nyelvű publikációival szembefordulva, magyar nyelvű íróként kötelezte el magát a magyar nemzetállam eszméje mellett, és etnográfusként a népi költészet magyar nyelvű tolmácsolását a megismerés episztemológiai funkciójával ruházta fel. Brassai és Meltzl a kozmopolitizmus és egyetemesség képzeteihez közelített vállalkozásában, amely ennélfogva egy nemzetek fölött álló birodalmi vagy azon túlmutató világpolgári identitás melletti érvként látható. Moldován Gergely - családja generációs vizsgálata a rendelkezésre álló adataink alapján - az asszimiláció útját járta: román származású magyar állampolgárként építette fel karrierjét, és került konfliktusba nemzetiségi közösségével. Esetében a nemzetiségi (származására utaló) identitását írja fölül a politikai értelemben vett nemzeti és a számunkra eldöntetlennek vagy kevert identitásúnak látszó Moldován mind a magyar, mind a román, azaz az egyértelműen leírható nemzeti kategória felől válik problematikussá. Nem áll rendelkezésünkre éppen a nemzetiesedés dacára olyan fogalmi eszköztár, amely a 19. század második felétől kérdésesnek tűnő identifikációs szereplehetőségeket meggyőző módon leírhatná és értelmezné. Ezért szükséges az egyes életpályák, egyéni élettörténetek alapos vizsgálata, amely láthatóvá teszi a nemzetállami berendezkedés és modern értelemben vett nemzeti identitás ellenére tovább élő, lappangó vagy zárványként működő identifikációs paradigmákat, ugyanakkor rá- 
kényszerít annak felismerésére, hogy történetileg kibontakozó folyamatok valamennyire letisztult kategóriái miként vizsgálandók fölül éppen a szélsőséges példák és modellek felől. Felismerhetjük azt, hogy első kolozsvári egyetemi tanárainak egybeeső szakmai identitásaik mennyire eltérő jelentéskomponensekkel rendelkeztek: egyéni önazonosságukat szakmai életpályájuk, karrierjük mellett elsősorban felekezetiségük befolyásolta, amely, amint a fejezet példái megmutatták, elválaszthatatlan etnikai identitásuktól, és nagymértékben meghatározta életszemléletüket, tudománykoncepciójukat. A vallásos türelem liberalizmusát képviselő unitárius vallás egyetemességét hirdető, evangélikus Meltzl Hugó másként minősül nemzetiséginek vagy németnek/szásznak Magyarországon vagy a Monarchiában, mint a görög katolikus magyar állampolgár, Moldován Gergely románnak. Ez a megállapítás pedig a kapcsolatok minőségét oly módon érinti, hogy azokat egyenlőtleneknek, alá-fölérendeltségi viszonyaikban láttatja, és így a kapcsolattörténetet a hatalom, az ideologikusság kérdéséhez köti.

A korszak szórványos fordításai, a különböző fordítói elképzelések azt az igényt jelzik, hogy a (magyarországi) román kultúra miként keresi helyét a magyar nyelvú irodalomban. A kötet egészére visszatekintve, talán legfontosabb hozadéka abban áll, hogy láttatni engedi azt, hogy az, amit román-magyar irodalmi kapcsolatokként címében megfogalmaz, a kutatások és esettanulmányok nyomán mennyire másként értelmezendő: a 19. század utolsó harmadában még nem lehet a nemzetit egyértelmű differenciáló kategóriaként kezelni, bármennyire is ez alapján építkezik a kapcsolattörténet tudománya. 


\section{SZAKIRODALOM}

A kolozsvári m. k. Ferenc József Tudományegyetem Bölcsészeti Karának hallgatói. [A kézirat lelőhelye: Román Állami Levéltár, Kolozsvár, Fond 315., reg. 141. és 152.]

A kolozsvári magyar királyi Ferenc József Tudományegyetem Tanácsai és doktorai névkönyve I. kötet 1872-1910. [A kézirat lelőhelye: Román Állami Levéltár, Kolozsvár, Fond 315., reg. 111.]

A magyar ev. ref. collegium magaviseleti tabellái az 1866/67 tanévról. [A kézirat lelőhelye: Erdélyi Református Egyházkerület Gyüjtőlevéltára, Kolozsvár]

A nagyenyedi ev. ref. Collegium tanuló ifjúsága magaviseleti tabellái az 1870/71. ik tanévről. [A kézirat lelőhelye: Erdélyi Református Egyházkerület Gyüjtőlevéltára, Kolozsvár]

A nagyenyedi ev. ref. teljes gymnasiumban az 1873/4. tanév végével tartott érettségi vizsgálatról Kimutatás. [A kézirat lelőhelye: Erdélyi Református Egyházkerület Gyüjtőlevéltára, Kolozsvár]

A Vallás és Közoktatásügyi M. K. Minisztérium által a Kolozsvári Ferenc József Tudományegyetem tanácsához intézett elvi jelentôségü rendeleteinek gyüjteménye az 1872/3-1898/9. tanévekról, Kolozsvárt, 1900.

Ábrahám - Gereben - SteKovics 2003

Ábrahám Barna-Gereben Ferenc-Stekovics Rita (szerk.), Nemzeti és regionális identitás Közép-Európában, PPKE, Piliscsaba.

ÁвRAнÁm 2004

Ábrahám Barna, Az erdélyi románság polgárosodása a 19. század második felében, Csíkszereda, Pro-Print Kiadó. 


\section{Ács 1857}

Ács Károly, Levél Jókai Mórhoz = Magyar Sajtó 1857/185, 745-746.

Acta Comparationis Litterarum Universarum. Összehasonlító Irodalomtörténelmi[!] Lapok, editores et ordinatores dr. Samuel Brassai et dr. Hugo Meltzl, J. Stein, Claudiopoli. [1877-1887]

Acta Reg(iae) Scient(iarum) Universitatis Claudipolitanae Francisco-Josephinae. Beszédek [utóbb: Beszámoló] 1872-1944.

Alexandru Roman Márki Sándorhoz [A kézirat lelőhelye: MTAK Kt. Ms 5165/651]

Alexandru Roman Szinnyeihez [A kézirat lelőhelye: MTAK Kt. Ms 790/62]

H. F. Amiel Meltzl Hugónak [A kézirat lelőhelye: MTA Kt. Ms 4744/55-80.]

Arany 1966

Arany János, [A Shakespeare magyar kiadása ügyében előterjesztett jelentés] = Keresztúri Dezső (szerk.), AJÖM. Hivatali iratok I. (1831-1865), Akadémiai, Budapest.

AsAd 2004

Talal Asad, $A$ kulturális fordítás fogalma a brit társadalomantropológiában = N. KOVÁCS 2004, 97-133.

BĂLAȘ-Bódis 2004

Lucia Bălaş-Bódis Ottilia, Oameni de seamă ai Sălajului. Dicționar biobibliografic, Zalău. [vol. I.]

Bálint Gábor levele, Athén 1888. április 8. [A kézirat lelőhelye: Erdélyi Unitárius Egyház Gyűjtőlevéltára]

BÁRDI 1998

Bárdi Nándor (összeáll.), Erdély a históriában, Pro-Print, Csíkszereda, 1998.

BÁRDI 2000

Bárdi Nándor (szerk.), Konfliktusok és kezelésük Közép-Európában, Teleki László Alapítvány, Budapest.

BÂRSEANU 1902

Andrei Bârseanu, Istoria şcoalelor centrale româneşti greco-orientale din Braşov, Tipografia Curcu \& Comp., Braşov. 
BART-KLAUdy 1980

Bart István-Klaudy Kinga (szerk.), Fordításelméleti szöveggyüjtemény, Tankönyvkiadó, Budapest.

BARTH 1996a

Fredrik Barth, Ethnic Groups and Boundaries = Werner Sollors (et alli ed.), Theories of Ethnicity. A Classical Reader, New York University Press, 294-325. [1969]

BARTH 1996b

Frederik Barth, Régi és új problémák az etnicitás elemzésében = Regio 1996/1, 3-25. [Barthnak az 1993-as amszterdami konferencián elhangzott elöadása, fordította: Sajó Tamás]

BЕКE 1971

Beke György (szerk.), Koós Ferenc, Életeim és emlékeim, Kriterion, Bukarest.

BÉKÉs 1997

Békés Vera, A hiányzó paradigma, Latin Betűk, Debrecen.

BÉKÉs 2004

Békés Vera, Magyar tudósok és intézmények a modernitás kihívásában = Békés Vera, A kreativitás mintázatai. Recepció és kreativitás, Áron, Budapest.

BENő 2003

Benő Attila, Fordítási elvek a XIX. században = Egyed Emese (szerk.), "Szabadon fordította...". Fordítások a magyar színjátszás céljaira a XVIIIXIX. században, Scientia, Kolozsvár, 2003, 7-35.

BERÉNYi 2005

Berényi Zsuzsanna Ágnes, Budapest és a szabadkőmüvesség. [A szerző kiadása]

BERKI é.n.

Berki Tímea, Călătorie sau peregrinare. Cazul "ultimului polihistor" din Transilvania: Brassai Sámuel (1800-1897). [kézirat, megjelenés előtt]

BERKI 2004

Berki Tímea, Az Eminescu-tolmácsolások mint kulturális stratégiák, Kolozsvár. [magiszteri dolgozat, kézirat] 
BERKI 2005a

Berki Tímea, „....a jelen és jövő hasznára visszatükröztetve”. Millenniumi kiállitás és a látvány retorikája = DEBRECZENI Attila - GÖNCZY Mónika (szerk.), "Et in Arcadia ego", Kossuth Egyetemi Kiadó, Debrecen, 2005, 501-513.

BERKI 2005b

Berki Tímea, Kulturális stratégiák. Moldován Gergely esete a magyarokkal és a románokkal = Filo-Logikák. RODOSZ-Tanulmányok 2004-2005/1., 237-247.

BERKI 2007a

Berki Tímea, A polihisztor viselkedéshagyomány erdélyi magyar tudósok körében = Egyed Emese - Biró Annamária, Demeter Zsuzsa, Kovács Eszter (szerk.), Felvilágosodás, Erdély, Erdélyi Múzeum, 39-51.

BERKI 2007b

Berki Tímea, Brassai Sámuel kritika-értelmezései az 1850-es években. Egy példa: Criticai Lapok 1855 = Keresztény Magvetó, 288-294.

BERKI 2008a

Berki Tímea, Életrajz-írás és nemzeti panteon. Iosif Vulcan vállalkozásai = Korondi Ágnes - T. Szabó Levente (szerk.), Értékek és ideológiák a magyar irodalomban, Kolozsvári Magyar Irodalomtudományi Tanszék-Láthatatlan Kollégium, 2008, 175-197.

BERKI 2008b

Berki Tímea, $A z$ „Elméleti bumm” és saját hitek. Takáts József köteteiről = Korunk 2008/5., 121-125.

BНABHA 1999

Homi K. Bhabha, DisszemiNáció. A modern nemzet ideje, története és határai = N. Kovács Tímea (szerk.), A kultúra narratívái, Kijárat, Budapest, 85-121.

Bíró 2002

Bíró Sándor, Kisebbségben és többségben. Magyarok és románok, 1867-1940, Pro-Print, Csíkszereda.[1989]

Bínó 1926

Bíró Vencel, $A$ kolozsvári római katolikus fögimnázium története = GYöRGY (szerk.) 1926, 18-39. 
BoIA 1999

Lucian Boia, Történelem és mítosz a román köztudatban, Kriterion, Bukarest-Kolozsvár.

Boia 2009

Lucian Boia, "Germanofilii”. Elita intelectuală românească în anii Primului Război Mondial, Humanitas, Bucureşti.

BoIA 2008

Stelean Boia, Ioan Slavici - Tribuna şi tribunismul în context european = Studii de ştiință şi cultură 2008/15, 75-83.

Borsi 1993

Borsi-Kálmán Béla, Nemzetfogalom és nemzetstratégiák, Akadémiai Kiadó, Budapest.

Borsi 1995

Borsi-Kálmán Béla, Illúziókergetés vagy viselkedéskényszer? Román-magyar nemzetpolitikai meggondolások és megegyezési kísérletek a XIX. században, Kriterion-Balassi, Kolozsvár-Budapest.

Вот (coord.) 2001

Ioana Bot (coord.), "Mihai Eminescu, poet național român"-Istoria şi anatomia unui mit cultural, ed. Dacia, Cluj-Napoca. [Discobolul]

BRAN-RÉvai 1910

Bran Laurențiu-Révai Károly, Román költókből, Nagybánya.

BRANDT 2003

Julianne Brandt, Felekezeti és nemzeti identitás a 19. századi Magyarországon: a protestáns egyházak = Századvég 2003/29, 3-39.

Brassai Sámuel Nagy Péterhez [A kézirat lelőhelye: MTAK Kt, Ms 4745/107-108.]

Brassai Sámuel Toldy Ferenchez [A kézirat lelőhelye: MTAK Kt. Irod. Lev. 4r. 105.]

BRASSAI 1861

Brassai Sámuel, Még is valami a forditásról = Szépirodalmi Figyelő 1861/19., 20., 27., 28., 30-33., 48-50., 289-291., 305-307., 417-419., 433-436., 465-468., 481-485., 497-501., 513-516., 753-757., 769-771., 785-788. 


\section{BRETTER-DeÁK 1995}

Bretter Zoltán-Deák Ágnes (szerk.), Eszmék a politikában: a nacionalizmus, Tanulmány Kiadó, Pécs.

Breznay et alii 1896

Breznay et alii, A felsőoktatásügy Magyarországon. Az 1896-iki ezredéves országos kiállitás alkalmára a Vallás- és Közoktatásügyi magyar királyi minisztérium megbízásából, Budapest, Hornyánszky könyvnyomdája.

BRUBAKER 1996

Rogers Brubaker, Nationalism Reframed. Nationhood and the National Question in the New Europe. Cambridge University Press.

BRUBAKER 2001

Rogers Brubaker, Csoportok nélküli identitás = Beszélő 2001/7-8., 60-68.

BRUbaker 2006

Rogers Brubaker, Nemzeti kisebbségek, nemzetiesitó államok és anyaországok az új Európában = Regio, 2006/3, 3-30.

BugNARIU 1964

Teofil Bugnariu, A legelső magyar Eminescu-fordítás = Korunk 1964/10, 1456-1458.

BuZAși 1994

Ioan Buzași, Eminescu şi Blajul, ed. Iriana, Bucureşti.

CĂLINESCU 1989

Călinescu George, Mihai Eminescu élete, Dacia Könyvkiadó, Cluj-Napoca.

CÂmpeanu 2000

Remus Câmpeanu, Elitele româneşti din Transilvania veacului al 18-lea, Presa Univeristară Clujeană.

Cole-Unowsky 2009

Laurence Cole-Daniel L. Unowsky (ed.), The Limits of Loyalty: Imperial Symbolism, Popular Allegiances, and State Patriotism in the Late Habsburg Monarchy, Austrian and Habsburg Studies, vol. 9.

CRĂCIUN-CRĂCIUN (ed.) 1989

Cristina Crăciun-Victor Crăciun (ed.), Ei l-au văzut pe Eminescu, Dacia. 
Creția 1998.

Creția Petru, Testamentul unui eminescolog, ed. Humanitas, Bucureşti.

Cristea 1895

Cristea Illés, Eminescu élete és müvei. Tanulmány az újabb román irodalom köréből, Szamosújvártt, Todorán Endre Aurora könyvnyomdája.

CRIŞAN 1973

Al. Crişan, Familia (1865-1906). Contribuții monografice, ed. Facla, Timişoara.

DAMrosch 2007

David Damrosch, A Weltliteratur kultúrpolitikája. Goethe, Meltzl és az öszszehasonlító irodalom kezdetei = Irodalomtörténet 2007/2., 161-179. [ford. Kupán Zsuzsánna]

Datcu 2006

Iordan Datcu, Dicționarul etnologilor români, Saeculum, f.l.

DÁvid 1976

Dávid Gyula, Találkozások. Tanulmányok a román-magyar irodalmi kapcsolatok múltjából, Dacia, Kolozsvár.

DÁVIDHÁzi 1987

Dávidházi Péter, Egy irodalmi kultusz müködése = Valóság 1987/12, 57-70.

DÁvidHÁzi 2004

Dávidházi Péter, Egy nemzeti tudomány születése: Toldy Ferenc és a magyar irodalomtörténet, Universitas, Budapest.

DEÁK 2000

Deák Ágnes, „Nemzeti egyenjogúsítás”. 1849-1960, Osiris, Budapest.

DemÉNy 2000

Demény Lajos, A bukaresti magyarok adakozása az MTA-székház épitésére 1860-ban = Magyar Tudomány 2000/12, 1529-1531.

DeÉr-GÁldi 1943

Deér József-Gáldi László (szerk.), Magyarok és románok. I-II., Athenaeum, Budapest. [Magyar Történettudományi Intézet Évkönyve]

DÉTIENNE 2000

Marcel Detienne, Comparer l'incomparable, Seuil, Paris. 
Dinurseni 1897

Dinurseni Ilie, Alesandru Roman. 1826-1897. Tipografia Arhidiecesană, Sibiu.

Dомокоs 1966

Domokos Sámuel, A román irodalom magyar bibliográfiája, 1831-1960, Irodalmi Könyvkiadó, Bukarest.

Dомокоs 1985

Domokos Sámuel, Új adatok Eminescu első magyar fordítóiról és méltatóiról = D.S., Magyar-román irodalmi kapcsolatok, Gondolat, Bp., 1985, 44-54. [Filológiai Közlöny, 1962/1-2., 147-151.]

Drimba 1974.

Lucian Drimba, Iosif Vulcan, ed. Minerva, Bucureşti.

DRIMBA 1994

Lucian Drimba, Eminescu la „Familia”, ed. Cogito, Oradea.

Dulfu 1881

Dulf Péter, Alexandri Vazul múködése, Kolozsvárt, Stein János egyetemi nyomdásznál.

EMLÉKKÖNYV 1997

Emlékkönyv a m. kir. Ferenc József Tudományegyetem (1872-1944) létesítésének 125. évfordulója alkalmából, Bolyai Egyetem Barátainak Egyesülete, Bolyai Egyetemért Alapítvány, Budapest.

ENGEL 1964

Engel Károly, Eminescu első erdélyi magyar nyelvú méltatói = Korunk $1964 / 5$.

ENGEL 1972

Engel Károly, Contribuții ale comparatiştilor maghiari din Transilvania până la primul război mondial = Istoria şi teoria comparatismului în România, ed. Alexandru Dima şi Ovidiu Papadima, Academia R.S.R., Bucureşti, 1972, 139-151.

ENGEL 1984

Köllő [Engel] Károly, Két irodalom mezsgyéjén. Tanulmányok a román-magyar irodalmi kapcsolatok történetéből, Kriterion, Bukarest. 
Familia. Fóia enciclopedica si beletristica cu ilustratiuni, proprietariu, redactoru si editoru: Iosif Vulcanu, Tipografia lui Érközy, Galgóczy si Kocsi, Pest'a. [1865-1904]

FARKAS 2000

Farkas Jenő, Peremsors avagy a küldetéstudat kényszere = Nagyvilág 2000/11. [http://www.inaplo.hu/nv/200011/19_FARKAS_JENO.html utolsó látogatás 2012. július 19.]

FARKAS 2008

Farkas Jenő, A román irodalom magyar recepciója = Korunk 2008/8. [http:// korunk.org/?q=node/8\&ev=2008\&honap=8 - utolsó látogatás: 2012. július 19.]

FARKAS 2010

Farkas Jenő, A vígjátéktól az avantgárdig. Tanulmányok, Palamart, Budapest.

FASSEL (hrsg.) 2002

Acta Comparationis Litterarum Universarum, hrsg. Horst Fassel, Klausenburg, Presa Universitară Clujeană.

Feischmidt 1997

Feischmidt Margit (szerk.), Multikulturalizmus: kultúra, identitás és politika, Osiris, Budapest.

Feischmidt 2002

Feischmidt Margit, Szimbolikus konfliktusok és párhuzamos nemzetépités = Gergely András (szerk.), A nemzet antropológiája, Új Mandátum Kiadó, Budapest.

FInTA 1939

Finta Gerő, Eminescu költeményeiből, Minerva, Kolozsvár.

FRIED 1996

Fried István (szerk.), A „szükséges népszövetség” a müvelödés történetében. (irodalmi, kulturális érintkezések a Monarchiában), Szeged.

FrIEd 2001

Fried István (szerk.), Osztrák-Magyar Modernség a Boldog (?) békeidőben (Osztrák-magyar-kelet-közép-európai összefüggések), Szeged, 2001. 
FRIED 2002a

Fried István, A közép-európai szöveguniverzum, Budapest, Kisebbségkutatás Könyvek.

FRIED 2002b

Fried István (szerk.), "Lelkek a pányván”. Osztrák-magyar-közép-európai müvelödési kapcsolatok, Szeged.

Fried 2002c

Fried István, Kétnyelvüség, kettôs kulturáltság Kelet-Közép Európában = Uö, Írók, müvek, irányok, Szeged, 151-168.

FRIED 2007

Fried István, Az Acta Comparationis Litterarum nyomában = Tiszatáj 2007/3, 95-107.

GAAL (szerk.) 1975

Összehasonlító Irodalomtörténeti Lapok, vál., s.a.r. Gaal György, Kriterion, Bukarest.

GAAL 1995

Gaal György, Magyarok utcája. A kolozsvári egykori Bel-és Külmagyar utcák telkei, házai, lakói, EME, Kolozsvár. [Erdélyi Tudományos Füzetek 221., sorozatszerkesztő: Dávid Gyula]

GAAL 2001

Gaal György, Egyetem a Farkas utcában, Erdélyi Magyar Müszaki Tudományos Társaság, Kolozsvár.

GÁLDI 1935

Gáldi László, A magyar Eminescu = Vasárnap 1935/2, 33-35.

GÁLdi 1939

Gáldi László, Finta Gerő, Eminescu költeményeiből = Láthatár 1939/5, 235-236.

GÁLDi 1940

Gáldi László, Kölcsey és Eminescu = Vasárnap 1940/8., 268-270.

GÁLDi 1941

Gáldi László, A kolozsvári egyetem hatása a román tudományra = Erdély magyar egyeteme, Kolozsvár, 285-299. 
GÁLDI 1942

Gáldi László, Eminescu és az erdélyi románság = Láthatár 1942/6.

\section{GÁLDI 1943}

Gáldi László, Újabb magyar-román irodalmi kapcsolatok = Deér JózsefGáldi László (szerk.), Magyarok és románok, I-II. kötet, Magyar Történettudomány Intézet Évkönyve, Athenaeum, Budapest, 423-457.

GÁLdi 1987

Gáldi László, A kolozsvári egyetem hatása a román tudományra = Bálint István János (szerk.), Kincses Kolozsvár, Magvető, Budapest. [http://mek. niif.hu/07500/07523/html/02.htm\#119 - utolsó látogatás: 2012 júliusa]

GazDA é.n.

Gazda István (szerk.), Brassai Sámuel (1800-1897) akadémikus, unitárius tudós, a kolozsvári egyetem professzora, nyelvész, matematikus, botanikus, irodalmár, zenetudós, fordító munkásságának és az életében róla megjelent irásoknak a kronológiája - Tájékoztató jellegü bibliográfiai adatokkal. [http:// mek.oszk.hu/05100/05142 - utolsó látogatás: 2012 júliusa]

\section{GAZDA 1997}

125 éve nyílt meg a Kolozsvári Tudományegyetem, Magyar Tudománytörténeti Intézet, Piliscsaba. [összeállította Gazda István, I-II. kötet]

Gazeta de Transilvania 1884.

GYARMATI 2005

Gyarmati Zsolt, Polgári otthon a Márki-napló tükrében (1892-1902) = Gy.Sz., Nyilvánosság és magánélet a békeidők Kolozsvárán, Komp-Press, Korunk, Kolozsvár.

Gyalui 1939

Gyalui Farkas, Az Erdélyi Magyar Irodalmi Társaság ötven éve. 1888-1938, Erdélyi Magyar Tudományos Intézet, Kolozsvár.

GYÁNI-KövÉr 1998

Gyáni Gábor-Kövér György, Magyarország társadalomtörténete a reformkortól a második világháborúig, Osiris, Budapest.

GYÁNi 2001

Gyáni Gábor, Érvek a kettős struktúra elmélete ellen = Korall 2001/3-4., 221-232. 
Cs. GYímesi 1992

Cs. Gyímesi Éva, Gyöngy és homok, Kriterion, Bukarest.

Glodariu 1998

Eugenia Glodariu, Asociațiile culturale ale tineretului studios român din Monarhia Habsburgică 1860-1918. Biblioteca Musei Napocensis XVII, Cluj.

GYörgy (szerk.) 1926

Dr. György Lajos (szerk.), Öreg diák visszanéz, kiadják a kolozsvári Római Katolikus Főgimnázium öreg diákjai, Minerva Rt., Cluj-Kolozsvár.

GYÖRGY 2006

György Béla, A romániai Országos Magyar Párt a román parlamentben = Bárdi Nándor-Simon Attila (szerk.), Integrációs stratégiák a magyar kisebbségek történetében, Somorja, 2005. június 9-10. [rendezte Fórum Kisebbségkutató Intézet, Teleki László Alapítvány]

GYÖRFI-DEÁK 2001

Györfi-Deák György, Eminescu în presa sălăjană = Transilvania jurnal 8. ian. 2001, 4. [http://www.gyuri.go.ro/eminsj.htm - utolsó látogatás: 2012 júliusa]

Grulai 1905

Gyulai Pál, Nőíróink = GY. P., Kritikai dolgozatok. 1854-1861, MTA, Budapest, 1905, 272-307.

Gulyás 1941

Gulyás Pál, Magyar írók élete és munkái, Budapest, 1941.

HANÁK 1999

Hanák Péter, A kert és a műhely, Balassi Kiadó, Budapest.

HEINRICH 1905

Heinrich Gusztáv, Egyetemes irodalomtörténet, Franklin Társulat, Budapest. [II. kötet]

ILLYÉs 2008

Illyés Zsuzsa, A kozmopolitizmus képzetei és az összehasonlitás módszertana az Acta Comparationis Litterarum Universarum c. folyóiratban, Kolozsvár. [Államvizsga-dolgozat, irányító T. Szabó Levente] 
IMRE 1944

Imre Sándor, A Ferenc József Tudományegyetem a századforduló táján, A Rothermere-alap jövedelméből kiadja a M. Kir. Ferenc József Tudományegyetem, Kolozsvár.

INGOLD 2004

Tim Ingold, A forditás müvészete egy folytonos világban = N. Kovács 2004, 47-73.

IORDACHI 2001

Constantin Iordachi, "A románok Kaliforniája": a román határ kiterjesztése Észak-Dobrudzsában 1878-1913 = Replika 2001/41-42., 239-261.

Jauss 1999

H. R. Jauss, A recepció elmélete $=$ Recepcióelmélet-esztétikai tapasztalat-irodalmi hermeneutika, Osiris, Bp., 1999, 9-36.

KAKASSY 1962

Kakassy Endre, Eminescu élete és költészete, Irodalmi Könyvkiadó, Bukarest.

Kalla (szerk.) 1997

Kalla Zsuzsa (szerk.), Kegyelet és irodalom, PIM könyvei, Budapest.

KARÁDy (bölcsészkarok)

Karády Viktor, A bölcsészkarok oktatói és az egyetemi piac szerkezete a dualista korban (1872-1918) [http://www.karadyviktor.uni.hu - utolsó látogatás: 2012 júliusa]

KARÁdy é.n.

Karády Viktor, Remarques sur le recrutement ethnique et confessionnel des étudiants en Hongrie à l'époque de la Monarchie Bicéphale multi-culturelle (1867-1918), [http://karadyviktor.uni.hu/keret.cgi?/recrutement.htm utolsó látogatás: 2012 júliusa]

KARÁdy 1997a

Karády Viktor, Egyenlötlen elmagyarosodás, avagy hogyan vált Magyarország magyar nyelvü országgá? = Uö, Zsidóság, polgárosodás, asszimiláció. Tanulmányok, Cserépfalvi kiadása.

KARÁDy 1997b

Karády Viktor, Iskolarendszer és felekezeti egyenlötlenségek Magyarországon (1867-1945), Replika Kör, Budapest. [Replika könyvek] 
KARÁDY - NASTASĂ 2004

Karády Viktor - Lucian Nastasă (szerk.), The University of Kolozsvár/ Cluj/Cluj and the Students of the Medical Faculty (1872-1918), CEU/Ethnocultural Diversity Resource Center, Budapest/Cluj.

KARÁDy 2008

Karády Viktor, Multikulturális szakértelmiség a dualista korban? Felekezet és etnikum a Kolozsvári Egyetem medikusainak rekrutációs jellemzői között (1872-1918) = Új pedagógiai szemle, 2008, 74-96.

Keller 2007

Keller Márkus, Tanárok, egyesületek, államok. A középiskolai tanárok professzionalizációja a 19. század második felében = Korall 2007/28-29., 59-87.

KEMÉNY 1956

Kemény G. Gábor, Iratok a nemzetiségi kérdés történetéhez Magyarországon a dualizmus korában. 1892-1900, Tankönyvkiadó, Budapest.

Képviselőházi napló 1865, 1869, [http://mpgy.ogyk.hu, illetve www.arcanum. hu/onap - utolsó látogatás: 2012 júliusa]

KesE 1999

Kese Katalin, Kultúra és filológia a román tanszék történetének tükrében, ELTE Levéltára, Budapest.

KIBÉDi 1934

Kibédi Sándor, Eminescu összes költeményei, Fraternitas nyomda, ClujKolozsvár.

KIss 1924

Kiss Ernő, Révai Károly = Cultura 1924/1., 59-63.

KLAUDy 1991

Klaudy Kinga, Magyar forditástudomány a 19. században. Brassai Sámuel nézetei a fordításról = Szüts L.-Kiss L. (szerk.), Tanulmányok a magyar nyelvtudomány témaköréból, Akadémiai Kiadó, Budapest, 387-394.

KLAudy 1995

Klaudy Kinga, A nyelvészeti forditáselmélet keletkezése = Uő, Bevezetés a fordítás elméletébe, Scholastica, 15-31.

Kolozsvári Közlöny. Az erdélyrészi szabadelvü párt lapja, szerk. Békésy Károly, Kolozsvár [1872, 1882, 1884, 1885.] 


\section{Komáromi 2005}

Komáromi Sándor, Meltzl Hugó és a korai komparatisztika - Kolozsvári változatok az egyetemességre = Országos Idegennyelvü Könyvtár Évkönyve 2004, Budapest, 2005, 173-210.

KöPECzI (főszerk.) 1986

Köpeczi Béla (főszerk.), Erdély története, Akadémiai Kiadó, Budapest. [III. kötet]

KöPECZI 2000

Köpeczi Béla, Egy kitagadott: Moldován Gergely (1845-1930) = Kisebbségkutatás, 2000/2. [http://www.hhrf.org/kisebbsegkutatas/kk_2000_02/ cikk.php?id=248 - utolsó látogatás: 2012. július 27.]

\section{KöPECZi 2001}

Köpeczi Béla, Moldován Gergely, a lapszerkesztő= Kisebbségkutatás, 2001/1. [http://www.hhrf.org/kisebbsegkutatas/kk_2001_01/cikk.php?id=404 utolsó látogatás: 2012. július 27.]

Koselleck 1997

Reinhart Koselleck, Az aszimmetrikus ellenfogalmak történeti-politikai szemantikája, Jószöveg Mühely Kiadó, 1997. [ford. Szabó Márton]

Koselleck 1998

Reinhart Koselleck, Ellenségfogalmak = Szabó Márton (szerk.), Az ellenség neve, Jószöveg Könyvek, Budapest, 12-24.

Kovács-Kende 2006

Kovács I. Gábor-Kende Gábor, Egyetemi tanárok rekrutációja a két világháború közötti Magyarországon = Kövér György (szerk.), Zsámbékok. Középosztály és iskoláztatás Magyarországon, Századvég, Budapest, 417-509.

KovÁcH 1996

Magyar élet a régi Bukarestben. Levelestár a 19. század második feléből, bev. tanulmány, jegyzetek Kovách Géza, ELTE BTK, Budapest.

KovÁcs 2011

Kovács Sándor, Angolszász-magyar unitárius érintkezések a 19. században, Kolozsvár, Erdélyi Múzeum-Egyesület. [Erdélyi Tudományos Füzetek 269.] 
KövÉr 2006

Kövér György (szerk.), Zsámbékok. Középosztály és iskoláztatás Magyarországon, Századvég Kiadó, Budapest.

Kozma 1969

Kozma Dezső, Petőfiana = Korunk 1969/7, 1102-1104.

Kozma 1972

Kozma Dezső, A valóság igézete: irók kolozsvári szerkesztôségekben a századfordulón, Dacia, Kolozsvár.

Kozma 2000

Kozma Dezső, Eleven örökség. Tanulmányok, Tinivár, Kolozsvár.

Kozma 2009

Kozma Dezső, Meltzl Hugó és a magyar irodalom = Korunk 2009/10.

KRISTóf 1942

Kristóf György, Tudományos intézetek Erdélyben 1919-ig, EME, Kolozsvár.

LADÁNYI 1969

Ladányi Andor, A magyarországi felsőoktatásügy a dualizmus kora második felében, Felsőoktatási Pedagógiai Kutatóközpont, Budapest.

LAJTAI 2006

Lajtai L. László, A komparatisztikától a történeti keresztezésig. A francia társadalomtörténet útkeresései Marc Blochtól az histoire criosée-ig = Sic Itur Ad Astra 2006/1-2., 73-83.

LAKNER 1993

Lakner Judit, Halál a századfordulón, MTA Történettudományi Intézet, Budapest.

LÁzÁR 1991

Gellériné Lázár Márta (vál.), Időben élni. Történeti-szociológiai tanulmányok, Akadémiai, Budapest.

LAZĂR 2002

Marius Lazăr, Paradoxuri ale modernizării. Elemente pentru o sociologie a elitelor culturale româneşti, Cluj Napoca, ed. Limes, 2002, 25. 


\section{Le Goff-Köpeczi 1985}

Jacques le Goff-Béla Köpeczi (dir.), Intellectuels francais, intellectuels hongrois. 18e-20e siècles, Akadémiai Kiadó-CNRS, Budapest-Paris.

LUPU-ŞTEFĂNESCU 1980

Ioan Lupu - Cornelia Ştefănescu (coord.), Bibliografia relațiilor literaturii române cu literaturile străine în periodice 1859-1918, ed. Academia R.S.R.

Maiorescu 1883

Titu Maiorescu (ed.), Poezii de Mihai Eminescu, ed. Librăriei Socec\&Comp., Bucureşti.

\section{MAKKAI 1997}

Makkai László, Erdély magyar egyeteme = Emlékkönyv a Magyar Királyi Ferenc József Tudományegyetem (1872-1944) létesítésének 125. évfordulója alkalmából, Bolyai Egyetem Barátainak Egyesülete, Bolyai Egyetemért Alapítvány, Budapest. [első megjelenés ideje: 1941.]

\section{MÁRKi 1881}

Márki Sándor, Bihari román írók, kiadja Hollósy Jenő, Nagyvárad, 1881.

\section{Márki 1922}

Márki Sándor, A kolozsvári m. k. Ferenc József Tudományegyetem története 1872-1922, Szeged.

\section{MÁtrai 1871}

Mátrai Ernő, A kolozsvári egyetem mint culturai szükséglet, Aigner LajosStein János, Pest-Kolozsvár.

\section{Mazsu 1991}

Mazsu János, Iskoláztatás és alfabetizáció = Mazsu János (szerk.), Iparosodás és modernizáció, KLTE, Debrecen, 101-124.

Mazsu 1995

Mazsu János, A szellemi foglalkozásúak jövedelmi viszonyainak alakulása a dualizmus időszakában = Kövér György (szerk.): Magyarország társadalomtörténete: szöveggyüjtemény. A reformkortól az első világháborúig, 2. kötet, Nemzeti Tankönyvkiadó, 36-49. [első megjelenés: 1980.]

Meltzl Hugó egyetemi tanári működésére vonatkozó iratok. [A kézirat lelőhelye: OSZK Kt. Analekta lit. 4083] 
Meltzl Hugó indítványa francia szakcsoport felállitásáról. [A kézirat lelőhelye: OSZK Kt. Analekta 4085]

Meltzl 1878

Meltzl Hugó, Az unitárius egyház polyglottismusa mint irodalmi eszköz, tekintve Brassai Sámuel külföldi kitüntetése alkalmából = Keresztény Magvető 1878/13, 192-196.

Micu (red.) 1880

Micu Andrei (red.), Reporutulu generale despre starea si activitatea societatii junimei universitare din Cluj, Julia pe anii academici 1877/8 si 1878/9., Gherla.

Miskolczy 2005

Miskolczy Ambrus, Románok a történeti Magyarországon, Lucidus, Budapest.

Mitu 1997

Sorin Mitu, Geneza identității naționale la românii ardeleni, Bucuresti, Humanitas, 1997.

Mitu 1998

Sorin Mitu, Egyetem, értelmiségiek és nacionalizmus = Korunk 1998/10. [http://epa.oszk.hu/00400/00458/00010/10k22.htm - utolsó látogatás: 2012 júliusa]

Módos 2005

Módos Péter (szerk.), Közép-Európai olvasókönyv, Osiris, Budapest.

Moldován Gergely levelei Hermann Ottóhoz. [A kézirat lelőhelye: MTAK Kt. Ms 269/64.]

Moldován Gergely ismeretlenhez. [A kézirat lelőhelye: OSZK Kt. Levelestár]

Moldován Gergely Jókai Mórhoz. [A kézirat lelőhelye: OSZK Kt. Fond $\mathrm{V} / 392$.]

Moldován Gergely levele a MTA-hoz. [A kézirat lelőhelye: MTAK Kt. RAL 1007/ 1887]

Moldován Gergely levelei Márki Sándornak. [A kézirat lelőhelye: MTAK Kt. MS 5163/1119-1136]

Moldován Gergely Szilágyi Sándornak. [A kézirat lelőhelye: OSZK Kt. Fond IX/431] 
Moldován Gergely Thallóczy Lajoshoz. [A kézirat lelőhelye: OSZK Kt. Fond $\mathrm{XI} / 694]$

\section{Moldován 1873}

Moldován Gergely, Három román költő = Figyelő 1873/ 28, 329-331.

Moldován 1883

Moldován Gergely, Egy fürdőidény Borszéken, Magyar Polgár könyvnyomdája, Kolozsvár.

\section{Moldován 1884}

Moldován Gergely, Koszorú a román népköltészet virágaiból, Magyar Polgár könyvnyomdája, Kolozsvár.

Moldován 1888

Moldován Gergely, A román nyelvtan kézikönyve, Horatsik János könyvkereskedése, Kolozsvár.

Moldován 1899

Moldován Gergely, Alsófehér vármegye román népe. Néprajzi tanulmány, Nagyenyedi Könyvnyomda és Papírárugyár Rt., Nagyenyed. [különlenyomat Alsófehér vármegye monográfiájából]

Moldován 1917

Moldován Gergely, Egy román szemle magyar irodalmi anyaga = Akadémiai Értesítő 1917, 540-552.

Moldován 1924

Moldován Gergely, Eminescu Mihály kálváriája = Erdélyi Irodalmi Szemle 1924/2, 130-136.

\section{Moldován 1926}

Grigore Moldován, A piaristák melegében = György Lajos (szerk.), Öreg diák visszanéz, Minerva Rt., Cluj-Kolozsvár.

NAgy 2001

Nagy Levente, Emóció, ráció, frusztráció. Mihai Eminescu politikai publicisztikája = Pro Minoritate 2001 ősz [http://www.prominoritate.hu/download/Nagy_Levente_2001_osz.pdf - utolsó látogatás: 2012 júliusa]

Nagy 2005

Nagy Péter Tibor, Az állami befolyás növekedése a magyarországi oktatásban 1867-1945 = Iskolakultúra 2005/6-7. 
NAGy 2006

Nagy Péter Tibor, A kolozsvári bölcsészkar és természettudományi kar hallgatóságának felekezeti rekrutációja (1872-1918) = Magyar Pedagógia 2006/1, 5-28.

NAstasĂ 2004

Lucian Nastasă, Intelectualii şi promovarea socială. Pentru o morfologie a câmpului universitar, Limes, Cluj.

NAstAs 2006

Lucian Nastasă, Itinerarii spre lumea savantă. Tineri din spațiul românesc la studii în străinătate, Limes, Cluj.

NAstASĂ 2007

Lucian Nastasă, "Suveranii" universităților româneşti. Mecanisme de selecție şi promovare a elitei intelectuale, Limes, Cluj.

NastasĂ 2010

Lucian Nastasă, Intimitatea amfiteatrelor. Ipostaze din viaţa privată a universitarilor "literari” (1864-1948), Limes, Cluj.

NeAmȚu 1979

Neamtu, G., Activitatea lui Alexandru Roman ca membru al Academiei Române = Crisia 1979/IX., 271-293.

NiRANJANA 2004

Tejaswini Niranjana, A szövegek és a kultúrák reprezentálása: Forditáselméletek és etnográfia = N. Kovács (szerk.) 2004, 133-175.

N. Kovács 2004

N. Kovács Tímea, Kultúrák, szövegek és határok: a fordítás = Uő (szerk.), A forditás mint kulturális praxis, Jelenkor, Pécs. [Sensus füzetek]

N. Kovács (szerk.) 2004

N. Kovács Tímea, A fordítás mint kulturális praxis, Jelenkor, Pécs. [Sensus füzetek]

Ortutay 1977

Ortutay Gyula (főszerk.), Magyar Néprajzi Lexikon, Akadémiai, Budapest.

PAjkossy 1993

Pajkossy Gábor, Egyletek a reformkori Magyarországon = História 1993/2, 6-9. 
PÁL 2009

Pál Judit, Erdélyi föispánok a Tisza-éra végén 1890-91. = Korunk 2009/4

PÁL 2010

Pál Judit, Unió vagy "unificáltatás"? Erdély uniója és a királyi biztos müködése. 1867-1872, Erdélyi Múzeum, Kolozsvár. [Erdélyi Tudományos Füzetek 267.]

Pallas 1893-1897

A Pallas Nagy Lexikona, Pallas Irodalmi és Nyomdai Rt., Budapest, 1893-1897.

Pavelea 1996

Traian Pavelea, Grigore Silaşi = Studii şi Cercetări Etnoculturale, Muzeul Județean Bistrița-Năsăud 1996/2, 147-156.

Petrașcu 1892.

Nicolae Petraşcu, Mihai Eminescu, Bucureşti.

Petri 1901-1904

Petri Mór, Szilágy vármegye monographiája, Budapest, Szilágy vármegye közönsége.

Petrușan f.a.

Gheorghe PETRUŞAN, Iosif Vulcan şi revista Familia, publicație a Uniunii Românilor din Ungaria, Officina.

PLĂMĂDEALĂ 1987

Plămădeală Antonie, Contribuții istorice privind perioada 1918-1939. Elie Miron Cristea - documente şi corespondență, Sibiu.

Pop 1875

Vasile Gh[erman] Pop, Conspect asupra literaturii româneşti şi literaților ei de la început şi până astăzi, Bucureşti, Tipografia Alecsandru A., 201-203.

Pop 2007

Vlad Pop, Septimiu Albini la Tribuna (1886-1894) = Anuarul Institutului de Istorie G. Barițiu, Cluj.

POPA 1998

Mircea Popa, Aspecte literare şi culturale româno-maghiare, ed. Dacia, Cluj-Napoca. 
PoPOVA-NOWAK 2006

Irina V. Popova-Nowak, A nemzet felfedezésének Odüsszeiája = Korall 2006/26, 128-153. [ford. Kármán Gábor]

Puskás-PusKás 2005

Puskás Lajos-Puskás Attila, A kolozsvári Egyetemi Diákasztal, A Mensa Academica alapításának története = Erdélyi Múzeum 2005/1-2, 133-148.

RADó 1883

Radó Antal, A magyar müfordítás története 1772-1831., Budapest, Révai testvérek kiadása.

RÁDL 1871

Rádl Ödön, A román költészetről = Nagyvárad 1871/250-254.

RAȚiU 1911

Dr. Ioan Rațiu, Blajul. Scurte notițe informative, Tipografia Curcu \& Comp., Braşov.

RÉGENI 1958

Régeni András, Az Eminescu- és Petőfi-emlékeket ôrző Balázsfalván = Müvelődés 1958/8, 18-19.

RÉTHY-VÁCZY1983

Réthy Andor-Váczy Leona, Magyar irodalom románul. 1830-1970, Kriterion, Bukarest.

Rıтоóк 1975

Ritoók János, Goethe és a világirodalom. Válogatás, előszó és jegyzet, Kriterion, Kolozsvár. [Téka-sorozat]

RüEgG (ed.) 2004

Walter Rüegg (ed.), A History of theUniversity in Europe, Cambridge University Press. [Universities in the Nineteenth and Early Twentieth Centuries. 1800-1945, vol. III.]

SÁNDOR 1910

Sándor József, Az EMKE megalapitása és negyedszázados müködése 1885-1910, Kolozsvár.

SÁNDOR 1912

Sándor József, EMKE negyedszázados örömünnepének s a kapcsolatos kolozsvári országos közmüvelődési kongresszusnak leírása, EMKE, Kolozsvár. 


\section{Simuț 2010}

Ion Simut, Prima pledoarie pentru o istorie critică a literaturii române = România literară 2010/3. [http://www.romaniaculturala.ro/images/articole/comsimut3012010.pdf - utolsó látogatás: 2012. július 11.]

Sipos 1915

dr. L. Sipos Kamilló, A nemzetiségi kérdés könyvészetéhez c. müvéből, Kolozsvár, Gombos Ferenc lyc. Könyvnyomda.

ŞOTROPA-DRĂGANU 1913

Vrigil Şotropa-Nicolae Drăganu, Istoria şcoalelor năsăudene scrisă cu prilejul jubileului de 50 de ani de existență (1863-1913) a Gimnaziului superior fundațional din Năsăud, Năsăud, 1913.

STURM 1897

Sturm Albert (szerk.), Országgyúlési almanach 1897-1901. Rövid életrajzi adatok a főrendiház és a képviselőház tagjairól, Budapest, 1897.

Sturm 1901

Sturm Albert, szerk., Országgyúlési almanach 1901-1906. Rövid életrajzi adatok a förendiház és a képviselőház tagjairól, Budapest.

S. VARGA 2005

S. Varga Pál, A nemzeti költészet csarnokai. A nemzeti irodalom fogalmi rendszerei, Balassi, Budapest.

Szabó 1998

Szabó Márton (szerk.), Az ellenség neve, Jószöveg Könyvek, Budapest.

SzAвó 1989

Szabó Péter, A végtisztesség. A fóúri gyászszertartás mint látvány, Magvető, Budapest.

SzABó - SzÖGI 1998

Szabó Miklós-Szögi László, Erdélyi peregrinusok, Mentor, Marosvásárhely, 1998.

\section{SZÁDECZKY 1905}

Szádeczky Lajos, Különfélék. A história nem mese s a mese nem história = Erdélyi Múzeum, 1905/168-173.

SzajbÉly 2005

Szajbély Mihály, A nemzeti narratíva szerepe a magyar irodalmi kánon kialakulásában, Universitas, Budapest. 
SzÁsz 1859

Szász Károly, A müfordításról = Magyar Sajtó 1859/219, 890, 1859/220, 894-895, 1859/221, 898-899, 1859/222, 902-903, 1859/223, 906-907.

SzÁsz 1993

Szász Zoltán, Románok egyesületei a magyar államban. 1867-1918= História 1993/2, 19-20.

Szegedy-Maszák (főszerk.) 2007

Szegedy-Maszák Mihály (főszerk.), A magyar irodalom történetei I-III., Budapest, Gondolat.

SENi-SENi 2006

Ioanela Alis Seni-Ioan Seni, 140 de ani de la înființarea Academiei Române. Academicienii năsăudeni şi spiritul cărturăresc năsăudean = Transilvania 2006/3, 34-53.

SZENTPÉTERY 1935

Szentpétery Imre, A bölcsészettudományi kar története 1635-1935, Magyar Egyetemi nyomda, Budapest. [A Királyi Magyar Tudományegyetem története, IV. Kötet]

SigMiREAN 2000

Sigmirean Cornel, Istoria formării intelectualității româneşti din Transilvania şi Banat în epoca modernă, Presa Universitară Clujeană.

Sigmirean-Pavel 2002

Cornel Sigmirean-Aurel Pavel, Fundația "Gojdu”. 1871-2001, Editura Universității Petru Maior, Tg-Mureş.

SZILÁGYi 2001

Szilágyi Márton, Lisznyai Kálmán. Egy 19. századi írói életpálya társadalomtörténeti tanulságai, Budapest, Argumentum.

SZILÁGYi 2003

Szilágyi Márton, Irodalomtörténet és társadalomtörténet = Bódy Zsombor-Ö. Kovács József (szerk.), Bevezetés a társadalomtörténetbe, Hagyományok, irányzatok, módszerek, Osiris Kiadó, Budapest, 559-572.

SZILÁGYi 2009

Szilágyi Márton, Az irodalomtörténeti biográfiák hasznáról és használatáról. Egy készülő Csokonai-biográfia mikrotörténeti alapjai= Sic Itur ad Astra 2009/59, 19-47. 
SZILÁGYI N. 1978

Szilágyi N. Sándor, Világunk a nyelv, Kriterion, Bukarest.

SZILÁGyi N. 2003

Szilágyi N. Sándor, Nyelvében él a nemzet = Uö, Mi egy más. Közéleti írások, Kalota, Kolozsvár, 753-793.

Szilágy-Somlyó. Társadalmi hetilap, a Szilágy-Somlyó gazdasági egylet közlönye. Felelős szerkesztő és kiadó Nagy László, társszerkesztők Csák Alajos, Hulimka Sándor. Szerkesztőség, kiadóhivatal: ev. ref. papi háznál. [1888-1891]

\section{SZINNYEI 1891-1914}

Szinnyei József, Magyar írók élete és munkái, Hornyánszky Viktor könyvnyomdája, Budapest. [http://mek.oszk.hu/03600/03630/html/index.htm - utolsó látogatás: 2012. július 17.]

SCURTu 1940

Vasile Scurtu, În amintirea lui Nicolae Drăganu = Arhiva Someşeană 1940/28, 102-105.[Drăganu életmüvének szentelt lapszámról van szó, melynek általános címe: Nicolae Drăgan. Fragmente de amintiri]

Sző́cs 1895

Szőcs Géza, Eminescu, Krafft W. Könyvnyomdája, Nagy-Szeben.

SzÖGI-KIss (szerk.) 2003

Szögi László-Kiss József Mihály (szerk.), Magyarországi diákok bécsi egyetemeken és föiskolákon. 1849-1867, közreadja az ELTE Levéltára, Budapest.

SĂLĂGEAN-EPPEL 2007

Tudor Sălăgean-Marius Eppel, Masoneria în Transilvania, International Book Acces, 2007.

STAN 1969

Elena Stan, Poezia lui Eminescu în Transilvania, Editura pentru Literatură, Bucureşti.

Stefanelli 1983.

Teodor V. Stefanelli, Amintiri despre Eminescu, Junimea, Iaşi.

Stein János levele Brassaihoz [A kézirat lelőhelye: Erdélyi Unitárius Egyház Gyüjtőlevéltára] 
STRAJE 1973

Mihail Straje, Dicționar de pseudonime, ed. Minerva, Bucureşti.

TAKÁTs 2001

Takáts József, Nyolc érv az elsődleges kontextus mellett = ItK 2001/ 3-4., 316-324.

TAKÁTs 2006

Takáts József, Módszertani berek. Írások az irodalomtörténet-irásról, Jyväskylä. [Doktori dolgozat, kézirat]

TAKÁTs 2007

Takáts József, Ismerős idegen terep. Irodalomtörténeti tanulmányok és bírálatok, Kijárat Kiadó, Budapest.

TANCO 1998

Teodor Tanco, Dicționar literar 1639-1997 al județului Bistrița-Năsăud, ed. Virtus Romana Rediviva, Cluj-Napoca.

THIMÁr 2001

Thimár Attila, A „Társaság állapotja”. Egy irodalomtörténeti adatbázis megtervezésének tanulságai = ItK 2001/1, 90-107.

Todor 1939

Avram P. Todor, Eminescu în literatura maghiară. De la 1890 la $1939=$ Convorbiri literare 1939/6-9, 1153-1233. [Comemorarea lui Eminescu]

ToDor 1983

Avram P. Todor, Traduceri din literatura română în ungureşte = Uő, Confluențe literare româno-maghiare, Kriterion, Bucureşti.

TöRÖк 2002

Török Zsuzsa, Mirôl és hogyan beszél Petelei Kolozsvárja = Gábor CsillaSelyem Zsuzsa (szerk.), Kegyesség, kultusz, távolitás, Scientia, Kolozsvár, 125-173.

TöRöк 2005

Török Zsuzsa, Ralph Waldo Emerson Arany János Szépirodalmi Figyelőjében (Adalék az esszé 19. századi honosításának történetéhez) = Normakövetés és normaszegés 19. századi elméletekben és müfajokban, Debrecen, 2005, 27-41. [Studia Litteraria, XLIII.]

Törzskönyv. 1902-1919. [A kézirat lelőhelye: Román Állami Levéltár, Kolozsvár. Fond 315, reg. 152.] 
То́тн 2005

Tóth Árpád, Önszervező polgárok. A pesti egyesületek társadalomtörténete a reformkorban. L'Harmattan, Budapest.

I. То́тн 1998

I. Tóth Zoltán, Az erdélyi román nacionalizmus első százada, Pro-Print, Csíkszereda.

T. SzAвó 2001

T. Szabó Levente, "Neveknek nemes tónusú kidolgozás által új fény adassék”. Az életrajz XIX. századközépi poétikája = Selyem Zsuzsa (szerk.) Rodosztanulmányok. Nyelvészet és irodalomtudomány. A Romániai Magyar Doktorandusok és Fiatal Kutatók Szövetsége rendezte I. tudományos konferencia anyaga, Kriterion, Bukarest-Kolozsvár, 2001, 43-68.

T. SzAвó 2006

T. Szabó Levente, A magyartanárság születése, Gyulai Pál egyetemi tanársága és a magyar irodalomtörténeti képzés hivatásosodása = ItK 2006/6, 677-701.

T. SzAвó 2007

T. Szabó Levente, Mikszáth, a kételkedő modern, L'Harmattan, Budapest.

T. SzAвó 2008

T. Szabó Levente, A tér képei: tér, irodalom, társadalom, Komp-Press, Korunk, Kolozsvár.

Ungaria. Revistă social-ştiințifică, red. Grigoriu Moldován, Kolozsvár (Cluj), Tipografia Magyar Polgár. [1891/1892, 1893/februarie, martie, decembrie, 1894/februarie-iunie]

URECHE 1996

Lazăr Ureche, Virgil Şotropa (1867-1954) = Studii şi Cercetări Etnoculturale, Muzeul jud. Bistrița-Năsăud 1996/2, 157-164.

VAJDA 1964

Vajda György Mihály, Összehasonlító Irodalomtörténelmi Lapok = Helikon 1964/1, 115.

VAJDA 1991

Vajda György Mihály, = Fried István (szerk.), A Monarchia a századfordulón (Monarchia-irodalmak és irodalmak a Monarchiáról), JATE BTK, Szeged, 11-22. 
VAJDA 2000

Vajda György Mihály, Egy irodalmi Közép-Európáért, Fekete Sas Kiadó, Budapest.

VARGA 2010

Varga Attila, Elite masonice maghiare. Loja Unio din Cluj 1886-1926. In documente inedite, Argonaut, Cluj.

VARGA 2000

Varga Júlia, A Kolozsvári Királyi Líceum hallgatósága 1784-1848, ELTE Egyetemi Levéltár, Budapest.

VAss 2010

Vass Laura, A kozmopolitizmus-vita a 19. század végének magyar irodalmában, Kolozsvár. [Szakdolgozat-kézirat]

Végbizonyítványok. 1893/4-1898/9, 1899/1900-1903/4, 1907/8-1910/11, 1911/12-1914/15 [A kézirat lelőhelye: Román Állami Levéltár, Kolozsvár. Fond 315, reg. 46., 59., 80., 90.]

Veress 1894

Veress Endre, Dr. Moldován Gergely „Ungaria”-ja = Erdélyi Múzeum 1894/3, 177-179.

[VERITAS] 1908

Veritas, A nagymagyarországi románok egyházi, iskolai, közmüvelődési, gazdasági intézményeinek és mozgalmainak ismertetése, Uránia könyvnyomda, Budapest.

Iosif Vulcan Márki Sándorhoz [A kézirat lelőhelye: MTAK Kt. Ms 5167/178]

VuLCAN 1869

Iosif Vulcan, Panteonulu romanu. Portretele si biografiele celebritatiloru romane, Pesta, tipariu lui Al. Kocsi.

WEBER 1999

Peter Weber, O identitate distinctă printre românii ardeleni. Profesorul Grigore Moldován (1845-1930) = Ionuț Costea-Valentin Orga (coord.), Familie şi societate. Studii de istorie a Transilvaniei, Clusium, Cluj, 133-139.

WERnER-ZimMERMANN 2006

Michael Werner-Bénédicte Zimmermann, Beyond Comparison: Histoire Croisée and the Challenge of Reflexivity = History and Theory 2006/45, 30-50. 
WERNER-ZIMMERMANN 2007

Michael Werner-Bénédicte Zimmermann, Túl az összehasonlításon: histoire croisée és a reflexivitás kihívása = Korall 2007/28-29., 5-30. [ford. Kiss Zsuzsanna] 



\section{MELLÉKLET}

\subsection{Kulturális egyezmény}

[Forrás: Országgyűlési irományok, 1947/I., 59. számú irat, 279-280]

\section{Indokolás}

„a kulturális együttműködés tárgyában, Bukarestben 1947. évi november hó 25. napján aláírt magyar-román egyezmény becikkelyezéséről" szóló törvényjavaslathoz.

Van szerencsém becikkelyezés céljából benyújtani a múlt év november hó 25-én aláirt magyar-román kulturális egyezmény szövegét. Aláirására Bukarestben, a minisztertanács előzetes felhatalmazása alapján került sor. A kormányküldöttséget a miniszterelnök úr vezette; az egyezményt román részről Octav Livezeanu tájékoztatásügyi miniszter, magyar részről pedig Ortutay Gyula vallás- és közoktatásügyi miniszter írták alá.

Ez az első kulturális egyezmény, amelyet a két nép egymással köt. Örömmel nyújtom be becikkelyezésre, mert az egyezmény megkötésére irányuló feltétlen készség azt bizonyítja, hogy mind a magyar mind a román nép elhatározó módon felismerte annak szükségességét, hogy egymásrautaltságukban kialakult kapcsolataikat intézményes formában biztosítsák és fejlesszék. A kulturális egyezmény megkötése tehát szerves fejlődés eredménye, melyhez az út az egymásrautaltság felismerésén keresztül vezetett. Ennek az útnak a járása nem volt könnyü, mert a két népet - történelmük során - lelketlen külső erők oly sokszor állították egymással szembe, hogy a velük született jóérzés és emberség a másik fél irányában már-már kialvóban volt. Végre azonban megtört az átok s a sokat szenvedett két nép felismerte helyét egymás mellett. Másképp nem is 
történhetett. Olyan két nemzet, amelyiknek annyi elnyomásban volt része, és amelyiknek lelkéből oly céltudatosan irtották mindenkor az emberség érzését csak azért, hogy szolgáljon és, hogy a másik ellen felhasználható legyen, a lélektan és a sors igazságszolgáltatásának törvénye szerint meg kellett, hogy találja egymás kezét. Ez megtörtént. Ennek a kézfogásnak törvénybe való rögzítését kérem.

A kulturális egyezmény aláírását szerencsés társadalmi és egyéni kezdeményezések előzték meg. Bukaresti meghívásra magyar írók és művészek jártak még 1946 koratavaszán a román fővárosban, az akkori vallásés közoktatásügyi miniszter vezetésével. A múlt év májusában az egész magyar közvéleményt lekötő ünnepségek keretében fogadhattuk fővárosunkban Groza Péter román miniszterelnök urat néhány minisztere, a román parlament több tagja, valamint a román irodalmi, tudományos és művészeti élet vezetőszemélyiségeinek kíséretében. Ezen kívül is nálunk a Magyar-Román Társaság, Romániában pedig a Román-Magyar Társaság komoly munkával és elvitathatatlan eredménnyel népszerúsítették a két nép baráti összefogásának gondolatát. Számos művész kereste fel a másik ország közönségét és mindenkor őszinte fogadtatásra találtak. A két ország vezetôsége hivatalos intézmények létesítésével is bizonyította a másik néphez való közeledési vágyát, valamint azt, hogy az egymás területén élő, és a másik nép etnikumához tartozó tömegeket a többségi nép fiaival egyenlő jogú állampolgároknak tekinti. A demokratikus Románia oly széles iskolaügyi hálózatot engedélyezett a romániai magyarság részére az alsófokú oktatástól az egyetemig, amilyenre a román történelemben még nem volt példa. Mi is mindent elkövettünk, hogy az országunk területén élő román nemzetiséget múveltségében minél magasabbra emeljük. A két nép közeledésének gyakorlati megvalósítására pedig a Mocsáry Lajos Magyar-Román Kollégium létesítésével maradandó példát szolgáltattunk.

A becikkelyezésre benyúitott kulturális egyezmény, az újabban kötött többi kulturális egyezményhez hasonlóan, - többek között - egy vegyesbizottság felállításáról rendelkezik, amelyik - kulturális kapcsolatok kérdésében - tanácsadó, kezdeményező és felülvizsgáló tevékenységet folytat és ezáltal a kulturális egyezmény tárgyát képező egész területet mindenkor áttekinteni köteles. Már magának ennek a szervnek az életrehívása biztosítékot fog nyújtani arra, hogy a most becikkelyezésre kerülő kulturális egyezmény pontjaiban foglaltak nem fognak holt betűk maradni. Az egyezményben egyébképpen kölcsönösen biztosítjuk a kulturális cserét tudományos és múvészeti téren egyaránt és kölcsönösen széles körben lehetőséget nyitunk arra, hogy a másik szerződő fél népét és életét közönségünk minél hathatósabban megismerhesse. 
Amikor a kulturális egyezmény becikkelyezését kérem, azt abban a tudatban teszem, hogy ezzel a ténnyel a Magyar Törvényhozás szükséges és egyben üdvös cselekedetet gyakorol.

Budapest, 1948. évi január hó 9. napján.

dr. Ortutay Gyula s. k., vallás- és közoktatásügyi miniszter

\subsection{A Kolozsvári Magyar Királyi Ferenc József Tudomány- egyetem Bölcsészkara román diákjai}

[1. szülőhely, 2. születési dátum, 3. szülő/gyám, 4. szülő foglalkozása, 5 . érettségi helye, 6. ösztöndíj, 7. egyetemi évek, 8. abszolutórium, 9. szak, 10. külföldi tanulmány, 11. rendes/rendkívüli hallgató, 12. doktori cím, 13. foglalkozás]

\section{Görögkeletiek}

1. Pipos János, 1.1856, 2. Csíkszentmárton, 3. János, 4. főispán, 5. Gyulafehérvári Római Katolikus Főgimnázium, 7. 1875/76.

2. Nikora Vince, 1.1857, 2. Margonda, 3. János, 4. földművelő, 5. Nagyszebeni Állami Főgimnázium, 6. Pedagógiai képzésre, 7. 1876-1880.

3. Pipos Péter, 1. 1858, 2. Gyulafehérvár, 3. Viktor, 4. bányaigazgató, 5. Gyulafehérvári Római Katolikus Főgimnázium, 7. 1876-1880, 12. 1882. 13. tanár (†1913)

4. Pipos Pompilius, 1.1857, 2. Hondol, 3. Vazul, 4. lelkész, 5. Gyulafehérvári Római Katolikus Főgimnázium, 1876/77., 13. hírlapíró

5. Moldován Szilveszter, 1. 1856, 2. Aranyosegerbegy, 3. Simon, 4. lelkész, 5. Brassói Ortodox Főgimnázium, 6. állami, 7.1880-1885, 10. 3-4. félév Bécs, 13. publicista

6. Kapusán Illés, 1. 1859, 2. Kolozsvár, 3. Illés, 4. földműves, 5. Kolozsvári Római Katolikus Főgimnázium, 7. 1886-1888.

7. Bogdan Nicolaus (Miklós) 1. kb.1865, 2. Hídvég, 3. György, 4. földmúves, 5. Brassói Ortodox Főgimnázium, 6. Gozsdu, 7. 1887-1891., 13. tanár, tankönyvíró

8. Costa János, 1. 1864, 2. Kavásd, 3. Péter, 4. tanító, 6. „Elena Birta Ghiba", 7. 1886/7, 10. 1887-1890 Budapesti MKT BTK

9. Dan Pompilius, 1. 1871, 2. Zernest, 3. Nikodim, 4. tanító, 6. Gozsdu, 7. 1888-1892., 13. tanár, tanügy föfelügyelő 
10. Vătăşan György, 1. 1872.04.11., 2. Zoltán, 3. György, 4. lelkész, 5. Brassói Ortodox Főgimnázium 1891, 6. Gozsdu, 7.1891-1894, 1896/7, 8. 1897.06.07., 13. tanár, tankönyvíró

11. Wilt György, 1. 1871, 2. Hátszeg, 3. Péter, 4. kisbirtokos, 5. Dévai Főreáliskola 1892, 6. Gozsdu, 7. 1891-1897, 8. 1898.05.28., 10. 1893-1897 MKFJT TTK, 12. 1898., 13. tanfelügyelő

12. Vaszy György, 1. 1871, 2. Szászáhuz, 3. Miklós, 4. földműves, 5. Nagyszebeni Állami Főgminázium, 6. Gozsdu, 7. 1894/5

13. Bottyán József, 1. Dédács, 2. 1875. 02.07., 3. Bíró Gábor, 4. iparos/kovács, 5. Dévai m.k. Allami Főreáliskola 1895 (Sigmireannál: Szászvárosi Református Gimnázium, de a végbizonyítványon mindkettő szerepel.), 6. Gozsdu 200 frt.1899-től 300 frt., 7. 1895-1900 (8 félév) 8.1900. 06.12., 9. magyar-német, 10. 1899/00 Budapesti MKT BTK, 13. tanár

14. Popovici Aurel, 1. Dank (Levéltári végbizonyítvány : Szász-Lóna), Kolozs, 2. 1876.09.21., 3. Mureşan Gábor 4. lelkész, 5. Kolozsvári Római Katolikus Főgimnázium 1895, 6. 200 frt (Gozsdu), 7. 1895-1900., 8. 1900.06.08.

15. Scurtu János, 1. 1877.03.17., 2.Brassó, 3. gyám: dr. Saftu Vazul, 4. lelkész, 5. Brassói Ortodox Főgimnázium 1895, 6. nincs (levéltári forrás)/ Soc. Transilvania, Gozsdu (SIG ${ }^{609}$ ), 7. 1895-1899 (de ebből csak 1898/9-es tanév MKFJT BTK), 8. 1899.06.16., 10. 1895-1898. Budapesti MKT BTK, 1900/1 Leipzig, 13. irodalomtörténész

16. Sztója Miklós, 1. Rakovita TM, 2. 1875.03.28., 3. Péter, 4. földművelő, 5. Lugosi Főgimnázium 1895, 6. 200frt. (Gozsdu), 7. 1895/96-1899/1900, 8. 1900.06.09., 13. tanár, tankönyvíró

17. Suciu Traian, 1.1880.02.08., 2. Olt-Bogát, 3. János, 4. lelkész, 5. Brassói ortodox Főgimnázium 1900, 6. Gozsdu 500 korona, 7. 1900-1905., 8. 1908.11.04., 9. latin-görög, 13. tanár

18. Roşiescu Cornelius, 1. 1864.10.16., 2. Kolozsvár, 3. gör. kel. özvegy román esperesné,7. 1902/03., 9. román nyelv.

19. Popescu Kornél, 1. 1877, 2. Nagyszeben, 6. állami (ortodox SIG) 8. 1906.05.19., 10. 1901-1905 Budapesti MKT BTK

20. Boca Romulusz, 1. 1880.08.31.. 2. Szászváros, 7. 1903/4., 13. Aurel Vlaicu támogatója, polgármester

21. Sedean Ábrahám, 1. 1882.08.11., 2. Rehó, 3. János, 4. földműves, 5. Naszódi Alapítványi Főgimnázium, 6. Gozsdu, 7. 1903-1908., 8. 1908.06.03., 10. 1907-1908 Budapesti MKT BTK, 12. 1911.10.21., 13. tanár

${ }^{609}$ Cornel Sigmireannál talált adat. Vö. SIGMIREAN 2000. 
22. Bezsán Szilviusz, 1. 1885.02.02., 2. Nagytótfalu, 3. János, 4. lelkész, 5. Békési Református Főgimnázium, 6. "Elena Ghiba Birta" és Gozsdu, 7. 1905-1909. 8. 1909.06.19.

23. Leményi Bran Eleonora, 1. 1885.08.15., 2. Szelistye, 3. Liviu, 4. ügyvéd, 5. Nagyszebeni Állami Főgimnázium, 7. 1905-1908., 8. 1908.06.02., 10. 1904/5 1. félév Genf, 11. 1904-1905. rendkívüli hallgató, 12. 1908.12.12., 13. leányiskolai tanár

24. Stanca Sebastian, 1. 1878.10.17., 2. Petrozsény, 6. állami (ortodox SIG) 8. 1910.05.21., 10. 1901-1905 Budapesti MKT BTK, 13. lelkész (Vulcan, Szászsebes, Kolozsvár), hírlapíró, író, orvos

25. Hango János, 1. 1888.02.07., 2. Hollómező, 3. János, 4. földmüves, 5. Szamosújvári Állami Főgimnázium, 6. „Nicolau Vlad”, 7. 1908-1912, 8. 1912.07.05.

26. Görög Elvira Rozália, 1. 1884.03.20., 2. Gyulafehérvár, 3. Konstantin, 4. halott, 5. Gyulafehérvári Római Katolikus Főgimnázium, 7.1909-1913, 10. MKFJT TTK 1908-1910 r.k. hallgató, 1910-1913.

27. Ludu András, 1. 1877.08.06., 2. Betlen BV, 3. János, 4. segédjegyző, 5. Balázsfalvi Görög Katolikus Főgimnázium, 7. 1910-1912.

28. Pelle Sándor Szevér, 1. 1892.06.01., 2. Belényes, 3. Sándor, 4. lelkész, 5. Belényesi Görög Katolikus Főgimnázium, 6. Gozsdu, 7. 1910-1914, 8. 1914.06.03., 10. 5-6. félév Leipzig.

29. Rimbaş Aurel, 1. 1886.05.04., 2. Brad, 3. Péter, 4. lelkész, 5. Balázsfalvi Görög Katolikus Főgimnázium, 7. 1910-1914, 8. 1915.10.02.

30. Kotrus János, 1. 1889.04.09., 2. Kiskerék, 3. Aron, 4. lelkész, 5. Brassói Ortodox Főgimnázium, 6. Gozsdu, 7. 1911-1914, 11. 1914/15 rendkívüli hallgató.

31. Demian Cendeu Aron, 1. 1891.02.17., 2. Balsa, 3. János, 4. földbirtokos, 5. Balázsfalvi Görög Katolikus Főgimnázium, 6. „Trandafil”, Gozsdu, 7. 1911-1915, 1917/18.

32. Damian György, 1. 1888.06.01., 2. Brád, 3. Vazul, 4. esperes, 5. Brassói Ortodox Főgimnázium, 6. „Trandafil”, 7. 1912-1915, 13. történetíró

33. Debu Vazul, 1. 1882.12.31., 2. Sarkaica, 3. Péter, 4. lelkész, 5. Balázsfalvi Görög Katolikus Főgimnázium, 7. 1912-1914, 13. tanár

34. Mocan Tivadar, 1. 1895.01.26., 2. Aranyosfö, 3. Tivadar, 4. kisbirtokos, 5. Tordai Állami Főgimnázium, 6. Gozsdu, 7. 1913-1915, 13. +1916.

35. Pica János, 1. 1887.01.31., 2. Reusor, 3. János, 4. földműves, 7. 1913/4

36. Bodea Szilárd, 1. Csicsógyörgyfalva, 2. 1891. 04. 23., 3. Szilárd, 4. lelkész, 5. Brassói Ortodox Gimnázium, 6. állami, 7. 1914-1918 . 
37. Keller Irén, 1. 1896.10.06., 2.Vajdahunyad, 3. Nándor, 5. Budapesti Leánygimnázium, 6. állami, 7. 1914-1918., 10. 5. félév Budapest.

38. Fodorean György Tulliusz, 1. 1895.04.07., 2. Aranyosbánya, 3. Miklós, 4. tanító, 6. „Trandafil”, 7. 1914-1916.

39. Nemes Leontina, 1. 1897.11.10., 2. Székelyföldvár, 3. József, 4. kisbirtokos, 5. Kolozsvári Református Főgimnázium, 6. Pedagógiai képzésre, 7. 1915-1919.

40. Cărpinişan Silviu, 1. Rehó, 2.1897.08.30., 3. Gerasim, 4. banki hivatalnok, 6. „Trandafil”, 7. 1918/1919 2. félév, 10.1918/19 1. félév Budapesti MKT BTK, 13. tanár

41. Daicoviciu Szilárd, 1. 1898.03.01., 2. Kavarán, 3. Damaskin, 4. tanító, 6. Gozsdu, 7. 1918/19, 13. történész, egyetemi tanár, RTA tagja

42. Popa Aurel, 1. 1888.03.14., 2. Felsőárpás, 3. János, 4. lelkész, 7. 1918/19 2. félév 10. 1918/19 Budapesti MKT BTK, 13. tanár

\section{Görög katolikusok}

1. Kriszte Demeter/ Cristea Demetrius, 1.1850, 2. Szálva, 3. Anitia, 5. Naszódi Alapítványi Főgimnázium, 6. Naszódi Vagyonközösségi, 7. 1873-1876 11. 1872/73-rendkívüli hallgató, 13. †1913

2. Scridon Gabriel, 1. 1851, 2. Földra, 3. Larion, 4. földmüves, 5. Naszódi Alapítványi Főgimnázium, 6. Naszódi vagyonközösségi, 7. 1872-1875, 13. tanár

3. Ionaşcu Basilius, 1. 1851, 2. Telcs, 3. János, 4. tanító, 5. Naszódi Alapítványi Főgimnázium, 6. Naszódi Vagyonközösségi, 7.1873-1875, 13. +1913.

4. Lupoe János, 1. 1853, 2.Oláhszentgyörgy, 3. Constantin, 4. földmüves, 5. Naszódi Alapítványi Főgimnázium, 6. Naszódi vagyonközösségi, 7. 1873-1878, 13. tanár

5. Tanco János, 1. 1851, 2. Monor, 3. Péter, 4. lelkész, 5. Naszódi Alapítványi Főgimnázium, 6. Naszódi vagyonközösségi, 7. 1873-1876, 13. tanár

6. Russu Viktor, 1. 1843, 2. Menyő, 5. Szatmári Római Katolikus Főgimnázium, 7. 1874-1877, 13. (hely)történész, lelkész, író

7. Újlakán Péter, 1. 1849, 2. Úzdiszentpéter, 3. György, 4. lelkész, 7. 1874-1878, 10. 1874/I. Bécs, 13. esperes

8. Rocneanu László, 1. 1852., 2. Bethlen, 3. Elek, 4. földműves, 5. Naszódi Alapítványi Főgimnázium, 6. "Simion Romantai", 7. 1875/76., 13. tanár 
9. Dulfu Péter, 1. 1856, 2. Tóhát, 3. Tivadar, 4. földműves, 5. Kolozsvári Római Katolikus Főgimnázium, 7. 1876-1880, 12. 1881.06.10., 13. író

10. Onisoru Gábor, 1. 2. Zágra, 3. Onisor, 5. Naszódi Alapítványi Főgimnázium, 6. Naszódi vagyonközösségi, 7. 1876-1881, 8. 1882.06.09, 12. 1882, 13. tanár

11. Prézsa/Presia János, 1.1856, 2. Felsőgáld, 3. István/ Müler Anna, 4. földművelő/ földbirtokos, 5. Gyulafehérvári Római Katolikus Főgimnázium, 7. 1876/77, 1879/80. 10. 1877-1879 Budapesti Teológiai Intézet, 1885-1887 Budapesti MKT JK

12. Ungur Ágoston, 1.1854, 2. Nyíres, 3. gyám: Suru Miklós, 7. 1876-1879.

13. Vajda Emil, 1. 1858, 2. Nagyszeben, 3. gyám: Lázár Sándor, 4. tanácsos, 5. Kolozsvári Unitárius Főgimnázium, 6. "Vaida Gavril”, 7. 1876-1880, 12. 1881, 13. tanár

14. Papp/Popu Benjámin, 1. 1858.02.06., 2. Barót, 3. György, 4. hivatalnok, 5. Brassói Római Katolikus Főgimnázium, 6. állami, 7. 1877-1883, 10. 1883-1885 Budapesti MKT BTK

15. Bárdosi Győző, 1. 1858, 2. Szilágysomlyó, 3. Gyula, 4. iskolai tanfelügyelő, 5. Nagykőrösi Tanítóképző Intézet, 7. 1878/79

16. Verzariu Emil, 2. Lekence, 3. Miklós, 7. 1878/79, 13. hivatalnok

17. Tógya Pál, 1. 1854, 2. Komjátszeg, 3. János, 4. földmüves, 5. Kolozsvári Római Katolikus Főgimnázium, 7. 1879-1881.

18. Boneu Vazul, 1. 1854, 2. Borgóbeszterce, 3. Zaharie, 4. földmüves, 5. Naszódi Alapítványi Főgimnázium, 6. Naszódi vagyonközösségi, 7. 1880-1883, 13. tanár

19. Catul József, 1. 1861.01.01., 2. Naszód, 3. György, 4. szücsmester, 5. Naszódi Alapítványi Főgimnázium, 7. 1880-1884, 13. †1913.

20. Dumbrava Vazul, 1. 1859, 2. Szászrégen, 3. László, 4. tanár, 5. Belényesi Görög Katolikus Főgimnázium, 7. 1881 1. félév, 10. 1881-1884 MKFJT TTK.

21. Pop Constantin, 1.1862, 2. Óradna, 3. Zaharie, 4. földmüves, 5. Naszódi Alapítványi Főgimnázium, 6. Naszódi Vagyonközösségi, 7.1881/1., 8. 1892.04.06., 10. 1881-1885 MKFJT TTK, 12. 1892.

22. Cosmulei Demeter, 1. 1860, 2. Telcs, 3. Tenase, 4. földmüves, 5. Balázsfalvi Görög Katolikus Főgimnázium, 6. Naszódi vagyonközösségi, 7. 1881-1886, 13. folklórkutató

23. Albu János, 1.1856, 2. Bethlen, 4. halott, 7. 1882-1884.

24. Halitia Sándor, 1.1862, 2. Oláhszentgyörgy, 3. Miksa, 4. postamester, 5. Naszódi Alapítványi Főgimnázium, 6. Naszódi vagyonközösségi, 7. 1882-1891, 13. tanár, lelkész 
25. Szvintz Pál, 1. Földra, 2. 1864, 3. Konstantin, 4. földműves, 5. Naszódi Alapítványi Gimnázium, 6. "Simeon Tanco"- naszódi vagyonközösségi, 7. 1883-1888.

26. Tatár János, 1. 1859, 2. Lózsárd, 3. János, 4. halott, 5. Kolozsvári Római Katolikus Főgimnázium, 7. 1883/4.

27. Coşbuc György, 1. 1866, 2. Hordó, 3. Sebestyén, 4. lelkész, 5. Naszódi Alapítványi Főgimnázium, 6. Naszódi vagyonközösségi, 7. 1884-1886, 13. költő, RTA tagja

28. Gheție János, 1. 1862, 2. Varalyú, 3. József, 4. földmüves, 7. 1884-1888, 12. 1897.

29. Sotropa Virgil, 1. 1888.12.06., 2. Telek, 1867.12.05., 2. Gyergyószentmiklós, 3. Sándor, 4. (nyugdíjas) fiskális hivatalnok, 5. Naszódi Alapítványi Főgimnázium, 6. Naszódi vagyonközösségi, 7. 1885-1888, 1892-1894. 10. 1889/1890 Budapesti MKT BTK, 13. tanár

30. Bodiu Mihály, 1. 1864?, 2. Kisrebra, 3. György, 4. földműves, 5. Naszódi Alapítványi Főgimnázium, 6. Naszódi vagyonközösségi, 7. 1887-1891, 13. tanár

31. Fodor János, 1. 1867.06.24., 2. Mohály, 3. János, 4. földműves, 6. “Al. St. Sulutiu", 7. 1887-1894.

32. Chețianu Ambrus, 1. 1863.04.07., 2. Nagyercse, 3. Simon, 4. lelkész, 6. Balázsfalvi alapítványi, 7. 1888/1., 10. 1887/1. Budapesti MKT, 1888-1891 MKFJT TTK, 12. 1892, 13. tanár

33. Marginean Sándor, 1. 1865.07.20., 2. Balázsfalva, 4. halott, 5. Balázsfalvi Görög Katolikus Főgimnázium, 6. "Simion Romantai", 7. 1888-1892.

34. Nikóra János, 1. 1864, 2. Felek, 3. Vazul, 4. tanító, 5. Kolozsvári Római Katolikus Főgimnázium, 7. 1888-1892., 8. 1892.05.13., 12. 1892., 13. tanár

35. Ordace Miklós, 1. 1859, 2. Parva, 3. Login, 4. földműves, 5. Balázsfalvi Görög Katolikus Főgimnázium, 6. Naszódi vagyonközösségi, 7.1888/89 első félév, 10. 1888/89 2. félév Budapesti MKT BTK

36. Bologa P.Atanaz, 1. 1865.10.21., 2. Ludas, 5. Balázsfalvi Görög Katolikus Főgimnázium, 6. "Alexandru St. Sulutiu", 7. 1889/90.

37. Pecurariu János, 1. 1869, 2. Rágla, 3. László, 4. tanító, 5. Naszódi Alapítványi Főgimnázium, 6. Naszódi vagyonközösségi, 7. 1889-1894, 13. tanár

38. Precup Gábor, 1. 1865.11.08., 2. Kőfarka, 3. Iszay, 4. jegyző, 6. “Alexandru St. Sulutiu, 7. 1889-1892, 13. tanár

39. Brândza János, 1. 1866, 2. Butyin, 3. Todor, 4. nagybirtokos, 6. Gozsdu, 7. 1890-1895. 
40. Kéri János, 1. 1868.10.28., 2. Nagyvárad, 3. Bereczki Zsuzsánna, 5. Belényesi Görög Katolikus Főgimnázium, 7. 1891-1894.

41. Rácz János, 1. 1869.05.10., 2. Doboka, 3. Mihály, 4. földmúves, 5. Kolozsvári Római Katolikus Főgimnázium, 7. 1891-1895, 8. 1899.05.26., 10. 3-4. félév Graz, 12. 1900, 13. tanár

42. Cherebețiu Viktor, 1.1869, 2. Kolozsvár, 3. Elek, 4. birtokos, 5. Balázsfalvi Görög Katolikus Főgimnázium, 7. 1892-1894.

43. Muresian Gábor, 1.1858.07.05, 2. Nagyvárad, 3. Péter, 4. földmüves, $7.1892 / 3$.

44. Harsia Iustinian, 1. Kisnyulas, 2.1869.12.27., 3.Elias, 4. földművelő, 5. Balázsfalvi Görög Katolikus Főgimnázium, 6. 400 frt. ("Al. St. Sulutiu"/ balázsfalvi görög katolikus papneveldétől), 7.1893-1896.

45. Zánk Gergely, 1.1870.12.05., 2. Néma, 3. Samu, 4. földművelő, 5. Kolozsvári Római Katolikus Gimnázium, 6. 400 frt (tanár-?), 7. 1893-1896.

46. Mayer János, 1. 1878.02.08., 2. Beszterce, 3. János, 4. m.k. pénzügyőri felvigyázó, 5. Székelyudvarhelyi Római Katolikus Főgimnázium, 6. van (Naszódi vagyonközösség ösztöndíja), 7. 1897-1901.

47. Scridon István, 1. 1877.11.17., 2. Földra, 3. József, 4. földműves, 5. Naszódi Alapítványi Főgimnázium, 6. naszódi vagyonközösségi ösztöndíj, 7. 1897-1900.

48. Szabó Emil, 1. 1876.07.24., 2. Ajton, 3. Gergely, 4. görög katolikus lelkész, 5. Balázsfalvi Görög Katolikus Főgimnázium, 6. "Simion Romantai", 7. 1897-1900, 8. 1904.06.18.

49. Selagian Kamil, 1. 1873.04.08., 2. Kismajtény, 3. Néhai Selagian János esperes, Vezend/Pap Rachel (SIG), 5. "végzett teológus" (levéltári forrás), 6. "az egyházmegyéből"/Szamosújvári esperesi ösztöndíj, 7. 1897-1901.

50. Tomuta János, 1. 1874.01.20., 2.Naszód, 3. Demeter, 4. földműves, 5. Szamosújvári Teológiai Intézet, 7. 1897/1898, 13. lelkész, hivatalnok

51. Bichigean Vazul, 1. 1880.01.10., 2. Naszód, 3. gyám: özv. Bichigean Jakabné, 5. Naszódi Alapítványi Főgimnázium, 6. Naszódi vagyonközösségi ösztöndíj, 7.1898-1092, 8. 1902.06.03., 9. görög-latin. 10. 1900-1901, 5-6. félév Budapest BTK, 13. tanár, fordító

52. Caliani Ágoston, 1. 1879.09.20., 2. Lompérd, 3. Bazil, 4. görög katolikus lelkész, 5. Nagyszebeni Állami Főgimnázium 1898, 6. nincs (levéltári forrás), Simion Romantai (SIG), 7. 1898-1902. 8. 1902.06.10., 13. tanár 
53. Pop János, 1.1868.02.28., 2. Naszód, 4. halott, 5. Naszódi Alapítványi Főgimnázium, 7.1898-1900, 10. 1887-1889 Budapesti MKT BTK

54. Hosszú János, 1.1880.01.20., 2. Balázsfalva, 3. József, 4. gimnáziumigazgató, 5.1899, 7. 1899/1900, 9. történelem-földrajz, 13. tanár

55. Pteancu Sándor, 1.1878.05.01., 2. Barlafalu, 3. György, 4. görög katolikus tanító, 7. 1899-1902, 8. 1903.02.28., 9. latin-görög 10. Budapesti MKT HTK absolutóriuma, 13. tanár, tankönyvíró

56. Gajia Aurel, 1. 1880.01.21., 2. Sinfalva, 3. Sándor, 4. lelkész, 5. Naszódi Alapítványi Főgimnázium 1900, 7. 1901-1906., 8. 1905.12.21., 9. történelem-földrajz, 10. 1904/05 Budapesti MKT BTK.

57. Giurgiu János, 1. 1877.03.24., 2. Kajántó, 3. Miklós, 4. lelkész, 5. Balázsfalvi Görög Katolikus Főgimnázium, 6. “Transilvania”(SIG), 7. 1901-1903. MEGJ. jogi kar által kiállított végbizonyítvány alapján is beiratkozik, 9. román és latin nyelv.

58. Hetco Péter, 1. 1881.09.06., 2. Monospéter, 3. Péter, 4. lelkész, 5. Nagyváradi Római Katolikus Főgimnázium, 6. S. "Transilvania", 7. 1901-1906, 8. 1907.06.07.

59. Papp Kornél, 1. 1883.01.20., 2. Laczfalu, 3. Jakab, 4. lelkész, Batarcs, 5. Belényesi Görög Katolikus Főgimnázium 1901, 7. 1901-1906., 8. 1909.04.01., 9. történelem-földrajz

60. Pascu János, 1. 1878. 2. Nagykomlós, 3. Tódor, 4. földbirtokos, 5. 1895, 7. 1901-, 9. román nyelv-filozófia, MEGJ. Jogi absolutórium alapján is beiratkozik

61. Pável Konstantin, 1.1876.11.11., 2. Beél, 3. Miklós, 4. földműves, 7. 1902-1904, 8. 1904.06.04.

62. Méra Jenő, 1. 1885.03.06., 2. Mezőméhes, 3. Ágoston, 5. Marosvásárhelyi Római Katolikus Főgimnázium, 7. 1904-1908., 8. 1909.04.22., 13. tanár

63. Sanjoan Kornél 1. 1885.09.23., 2. Major, 3. Dániel, 4. jegyző, 5. Naszódi Alapítványi Főgimnázium, 6. Naszódi vagyonközösségi és Gozsdu, 7. 1904-1908., 8. 1908.06.02., 13. tanár, fordító

64. Botha László, 1. 1883.03.12., 2.Csernefalva, 3. János, 4. földmúves, 7. 1905-1908.

65. Kapusán Lőrincz, 1.1882.10.05., 2. Magyarnagyzsombor, 3. Jakab, 4. jegyző, 5. Belényesi Görög Katolikus Főgimnázium, 7. 1905/06 10. Budapesti Müegyetem 1901/I., MKFJT TTK 1902-1904.

66. David Zakariás, 1. 1882.03.28., 2. Nagykeresztes, 3. István, 4. tanító, 5. Balázsfalvi Görög Katolikus Főgimnázium, 7. 1905-1906. 
67. Motogna Viktor, 1.1885.11.03., 2. Emberfő, 3. Simon, 4. földműves, 5. Naszódi Alapítványi Főgimnázium, 7. 1905-1909, 8. 1909.06.03., 13. (egyetemi) tanár

68. Rusz Ciprian, 1. 1883.06.29., 2. Hosszúmező, 3. Tivadar, 4. tanító, 5. Szamosújvári Állami Főgimnázium, 7. 1905-1910, 8. 1910.06.03.

69. Széles Jenő, 1.1882.12.21., 2. Nagylozna, 3. István, 4. tanító, 7.1905-1908.

70. Stetiu Silvia, 1. 1885.05.12., 2. Szamosújvár, 3. Gerő, 4. halott, 5. Kolozsvári Római Katolikus Főgimnázium, 7. 1905/06, 11. 1904/05 rendkívüli hallgató

71. Suciu Péter, 1.1883.09.09., 2. Mezőkecsed, 6. S. Ramontzai 7.1905/06, 8. 1910.10.22., 10. 1906-1910 Budapesti MKT BTK, 1911/1912 Berlin, 13. tanár

72. Zeflean Eneas Dionis, 1. 1885. 06.08., 2. Abrudbánya, 3. Dénes, 4. kovács, 5. Balázsfalvi Görög Katolikus Főgimnázium, 7. 1905-1909, 8. 1909. 06.01., 10. 5-6. félév Graz

73. Georgescu János, 1. 1889.03.16., 2. Szkorej, 3. János, 4. iskolaigazgató, 5. Balázsfalvi Görög Katolikus Főgimnázium, 7. 1907/1908, 8. 1918.02.25. 10. 1913-1916 Budapesti MKT BTK, 13. tanár

74. Hetco György, 1. 1884.07.20., 2. Vedresábrány, 3. Péter, 4. lelkész, 5. Nagybányai Állami Főgimnázium, 7. 1907-1909, 8. 1912.05.25.

75. Ossian János, 1. 1885.03.27., 2. Középhomoród, 3. Pamfil, 4. lelkész, 5. Belényesi Görög Katolikus Főgimnázium, 6. "Pavel", 7. 1907-1910, 8. 1910.06.18.

76. Pecurariu Pop Jenő, 1. 1880.04.24., 2. Fenes, 3. János, 4. lelkész, 5. Balázsfalvi Görög Katolikus Főgimnázium, 7. 1907-1910.

77. Precup Emil, 1. 1881.02.22., Kisrebra, 3. Anton, 4. lelkész, 5. Naszódi Alapítványi Főgimnázium, 6. Naszódi vagyonközösségi, 7. 1907-1911, 8. 1911.10.24., tanári oklevél: 1912.03.03., 13. tanár

78. Timbus Endre, 1 1883.08.24., 2. Rózsapataka, 3. Miksa, 4. földmüves, 5. Balázsfalvi Görög Katolikus Főgimnázium, 6. S. "Transilvania", 7. 1907-1910, 1911-1913, 9. magyar-latin, 10. MKFJT TTK 1906/07 MEGJ. Nagyváradi Hittudományi Intézet kitűnő bizonyítványa

79. Todorán József, 1. 1889.05.14., 2. Szamosújvár, 3. Endre, 4. kereskedő, 5. Szamosújvári Állami Főgimnázium, 6. Szamosújvári püspöki, 7. 1907-1912, 8. 1912.04.24.

80. Deac Szilvius Horatius, 1. 1889.01.27., 2. Kisszék, 3. Dávid, 4. lelkész, 5. Szamosújvári Állami Főgimnázium, 6. Szamosújvári püspöki, 7. 1908-1910., 8. 1913. 09.24. 10. 1910-1912 Budapesti MKT BTK 
81. Hațieganu Aurel, 1. 1883.03.26., 2. Ördöngösfüzes, 3. János, 4. esperes, 5. Balázsfalvi Görög Katolikus Főgimnázium, 7. 1908/9.

82. Muresianu Szabin Pompejus, 1. 1891.08.20., 2. Oboz, 3. Auxentius, 4. lelkész, 5. Szamosújvári Görög Katolikus Főgimnázium, 6. Szamosújvári püspöki, 7. 1908-1912, 8. 1913.05.13.

83. Pap/Popu Demjén, 1.1888.07.25., 2. Ispánmező, 3. Ezekil, 4. községi jegyző, 5. Dési Állami Főgimnázium, 7. 1908-1912, 8. 1913.05.06.

84. Gitta Aurel, 1. 1891.02.16., 2.Venter, 3. Kornél, 4. lelkész, 5. Belényesi Görög Katolikus Főgimnázium, 7. 1909-1913, 11. 1913/14 rendkívüli hallgató

85. Kende János Szevér, 1. 1881.09.26., 2. Gyulafehérvár, 3. György, 4. birtokos, 5. Gyulafehérvári Római Katolikus Főgimnázium, 7. $1909 / 11$

86. Al. George Florian, 1. 1888.11.13., 2. Oláhszentgyörgy, 3. Leon, 4. földműves, 5. Naszódi Alapítványi Főgimnázium, 6. Naszódi vagyonközösségi, 7. 1909/1910., 8. 1914.06.21., 10. 1912-1914 Budapesti MKT BTK, 12. 1914.06.27.

87. Kontros Endre, 1. 1893.03.30., 2. Szatmár, 3. Ferenc, 4. hivatalnok, 5. Ungvári Királyi Katolikus Főgimnázium, 7. 1911-1914.,8. 1922. 10. Szegedi TE BTK

88. Lupean Sándor, 1. 1887.07.16., 2. Magyarforró, 3. János, 4. kovácsmester, 6. "Al. St. Sulutiu", 7. 1911-1913., 10. 1911/12 1. félév, 1912/13 2. félév, 1913/14 Budapesti MKT BTK

89. Dancu Vazul, 1.1890.06.13., 2. Csicsóholdvilág, 4. lelkész, 5. Szatmári Római Katolikus Főgimnázium, 6. "Petran Ioan”, 7. 1912-1915.

90. Morariu János, 1. 1892.11.01., 2. Lónapoklostelke, 3. Vazul, 5. Balázsfalvi Görög Katolikus Főgimnázium, 7. 1912-1914.

91. Macrea Tivadar, 1. 1891.08.20., 2. Felsőbudák, 3. Nesztor, 4. földműves, 5. Naszódi Alapítványi Főgimnázium, 6. Naszódi vagyonközösségi, 7. 1914-1917.

92. Kornya György, 1. 1897.05.25., 2. Kolozsvár, 3. György, 4. pénzügyi ellenőr, 5. Dési Állami Főgimnázium, 7. 1915/16.

93. Lipán Mihály, 1. 1893.11.19., 2. Óradna, 3. Simon, 4. földműves, 5. Naszódi Alapítványi Főgimnázium, 6. Naszódi vagyonközösségi, 7. 1915-1919, 10. 3-4. félév Budapesti MKT.

94. Serban János, 1. 1896.06.01., 2. Naszód, 3. János, 4. főszolgabíró, 7.1915-1919, 10. 1915/16 Budapesti MKT BTK

95. Polivka Margit, 1. 1897.01.24., 2. Szkeus, 5. Kolozsvári Marianum Leánygimnázium, 6. Baron Rudits József, 7. 1916-1919.

96. Szucs Koriolánusz, 1. 1895.12.19., 2. Alfüged, 3. Tamás, 4. tanító, 5. "Al. Ladai", 7. 1917-1919, 13. (román akadémiai) kutató 
97. Câmpian Sándor, 1893.07.17., 2. Palatka, 3. Todor, 4. földműves (halott), 5. Balázsfalvi Görög Katolikus Főgimnázium, 7. 1918/19.

98. Malai Antal, 1. 1895.05.13., 2. Nagyilva, 3. Danil, 4. lelkész, 5. Szamosújvári Állami Főgimnázium, 7. 1918/19.

99. Martian Lazar, 2. Víziszilvás, 7. 1918/19.

100.Ratiu Gergely, 1. 1895.08.19., 2. Torda, 7.1918/9 2. félév

101.Rebreanu Kornélia, 1. 1897.01.13., 2.Abrudbánya, 3. Demeter, 5. Besztercei Evangélikus Főgimnázium, 7. 1918/19. 



\section{NÉVMUTATÓ}

Ábrahám Barna 12, 25, 30, 74

Abt Antal 140, 142

Abui, Valer 114

Ács Károly 53, 70, 71, 95, 176

Adamescu, Gheorghe 57

Ady Endre 54, 59, 60, 211, 219,

Albert János 179

Albini, Septimiu 93, 243

Alecsandri, Vasile

Alexandru, Vlahuță 42, 44, 59, 91, 150,

Alexi, Gheorghe/Alexics György 37, $38,39,57,60,99,116$

Amiel, Henri Frédéric 169, 170, 224

Apor Péter 195

Apponyi Albert 130

Áprily Lajos 102, 193

Arany János 43, 67, 69, 96, 100, 104, $169,198,224,248$

Asachi, Gheorghe 134

Asad, Talal 77, 224

Asbóth Oszkár 116

B. Molnár Lehel 9

Babeş, Vicențiu 24, 27

Bădescu (Bágyai), Ioan 46, 57, 150, 197
Bajor Andor 102

Bălaş, Lucia 93, 224

Bălcescu, Nicolae 54, 175

Balogh Artúr 196

Bánffy Dezső 199

Bánffy György 207,

Bánffy Miklós 207

Bárdi Nándor 143, 174, 187, 224, 234

Barițiu, George 113, 138, 243,

Bârseanu, Andrei 224

Bart István 225,

Barth, Fredrik 225

Bartha Miklós 82, 85

Bartók György 80

Batsányi János 64

Beke György 79, 188, 225

Békés Vera 165, 166, 225

Békésy Károly 145, 236

Benda Kálmán 177

Beniuc, Mihai 102

Benő Attila 66, 225

Beöthy Zsolt 122

Berde Áron 109, 133, 163,

Berde Mária 61, 74, 102, 193

Berényi Zsuzsanna Ágnes 84, 225

Bethlen Bálint 85

Bhabha, Homi K. 226 
Bichigean, Vasile 129, 261

Bíró Sándor 129, 206, 226

Bíró Vencel 194, 195, 226

Blaha Lujza 181, 183, 184

Bobory Károly 21

Bódis Ottilia 93, 224

Bodiu, Mihai 198, 260

Bodiu, Nicolae 116

Bodnár Zsigmond 122

Bogdanu, Nicolae 119

Boia, Lucian 16, 78, 127, 174, 227

Boia, Stelian 99, 227

Boileau, Nicolas 159

Bolinitineanu, Dimitrie 12, 27, 37, 38, $54,57,93,139,187,188$

Bónis Sámuel 141

Borlea, Sigismund 20, 25, 27

Boros György 171, 173

Borsi-Kálmán Béla 174, 227

Bot, Ioana 35, 227

Bowring, John 171, 172

Bozgan, Florea 197, 198

Bölöni Sándor 89, 92

Bran, Emil 90, 92, 93, 97

Bran, Laurențiu 5, 8, 51, 58-62, 76, 77, 88-101, 150, 218, 227, 276, 278

Brandt, Julianne 172

Branisce, Valer 58

Brassai Sámuel 6, 67-70, 100, 101, 103, 104, 109, 110, 113, 133, 153, 154, 155, 160, 162-174, 176, 179, 180, $187,193,201,213,221,224,225$, 226, 227, 233, 236, 240, 247, 276, 278 ,

Bretter Zoltán 20, 228

Brubaker, Rogers 26, 83, 228

Bud, Tit 97

Budenz József 157, 158, 165

Bugnariu, Teofil 76, 77, 86, 89, 228

Burdia Szilárd 199

Buzaşi, Ioan 14, 228
Butariu, Nicolae 19

Cacoveanu, Ştefan 14

Călinescu, George 44, 228

Câmpeanu, Remus 228

Canini, A. M., 77

Cantacuzino, Marie 184

Caragiale, Ion Luca 28

Cărtărescu, Mircea 33, 34

Ceauşescu, Nicolae 103

Chester, Frank D. 171

Cicero, Marcus Tullius 80, 103

Ciocan, Ioan 116, 129

Cipariu, Timotei 12, 54, 138, 175

Cole, Laurence 187, 228

Coroian, Iuliu 138

Coșbuc, George 17, 37, 54, 55, 57, 60, $93,97,127,135,136,149,260$

Crăciun, Cristina 32, 228

Crăciun, Victor 32, 228

Crăciunescu, George 19

Creția, Petru 32, 76, 229

Crişan, Alexandru 12, 229

Cristea, Miron Ilie 38, 41-45, 47-50, 130, 135, 229, 243, 275, 276

Cugler, Carol von 91

Cugler-Poni Matilda 58, 60, 91, 97, 98, 150

Cunțan, Maria 132

Cuza, Alexandru Ioan 75, 79

Cs. Gyímesi Éva 96, 234

Csák Alajos 89, 90, 247

Csernátony Lajos 24

D'Istria, Dora 193

Damrosch, David 154, 155, 173, 229

Dante, Alighieri 159

Datcu, Iordan 93, 178, 229

Dávid Gyula 62, 73, 154, 198, 229, 232

Dávidházi Péter 54, 229

De Gerando Antonina 193 
Deák Ágnes 20, 176, 228

Deák Ferenc 22, 25, 54, 82, 87

Decker, Carol 105

Deér József 174, 229, 233

Demény Lajos 79, 229

Dengi János 57

Densusianu, Aron 13

Depărățeanu, Alexandru 58

Descartes, René 80, 82

Desseanu, Simion 57, 116, 150

Dessewffy, Emil 79

Détienne, Marcel 26, 229

Dinurseni, Ilie 18, 41, 230

Domokos Sámuel 11, 52, 53, 54, 56, $57,59,60,62,65,73,88,89,94$, $100,102,108,135,175,176,179$, 204, 230

Dózsa Dániel 193

Drăgan, Iuliu 150

Drăganu, Nicolae 115, 127, 129, 188, 245,247

Drimba, Lucian 12, 15, 16, 105, 230

Dsida Jenő 102, 193

Dubenschi, Gabriela 132

Dulf, Petru 41, 57, 98, 127, 134-136, $139,150,230,259$

Dumbrava, Vasile 119, 259

Dux Armin 57, 58, 100

É. Kiss Katalin 166

Eckermann, Johann Peter 154

Egyed Emese 9, 225, 226

Éltes Károly 185

Ember György 57, 58, 94, 96, 177

Emilian, Cornelia 44

Eminescu, Mihai 5, 7, 8, 11-19, 21, $23,25,27,28,29,31-52,54,58$, 60-63, 65, 73-78, 86, 88-94, 96-98, 100-105, 107, 130, 135, 137, 144, 150, 175, 177, 216-219, 225 , 227-236, 241, 243, 244, 247, 248

Engel Károly 75, 76, 154, 230
Eppel, Marius 84, 247

dr. Erődi-Harrach Péter 195

Euripidész 103, 127

Farkas Gyula 192, 231

Farkas Jenő 7, 9, 17, 18, 34, 37, 52, 97, 105 ,

Fassel, Horst 154, 155, 231

Feischmidt Margit 143, 231

Ferenc József (I.) 109, 195

Ferenczi Zoltán 87

Fialla Lajos 79

Finály Henrik 109-111, 113, 156, 191, 192

Finta Gerő 61, 102, 231, 232

Flaubert, Gustave 159

Florian, Al.George 129, 264

Franyó Zoltán 11, 62, 75

Fried István 69, 154, 186, 231, 232, 249

Gaal György 113, 154, 162, 192, 232

Gáldi László 14, 15, 48, 49, 96, 102, $136,174,229,232,233$

Gálfi Lőrinc 84

Gane, Nicolae 93

Gazda István 168, 233

Gellériné Lázár Márta 183, 238

Gereben Ferenc 74, 233

Gerevich Emil 134

Gervinus, Georg Gottfried 158, 173

Gheorghiu-Dej, Gheorghe 103

Gherea Dobrogeanu, Constantin 44

Ghibu, Onisifor 211

Glodariu, Eugenia 130, 131, 234

Goethe, Johann Wolfgang 84, 132, $154,170,173,221,229$

Goga, Octavian 17, 37, 54, 58, 60, 71, $96,97,150$

Goldiş, Ioan 186

Gozsdu/Gojdu, Emanoil 128, 130, 211, 246, 255-258, 260, 262 
Görög Elvira Rozália 131, 257

Grandea, Grigore Haralambie 12

Grimm, Jacob 173, 174

Grozescu, Iulian 177

Gulyás Pál 89, 234

Gyalui Farkas 192, 193, 233

Gyáni Gábor 24, 25, 121, 124, 125, 151, $179,183,233$

Gyarmati Zsolt 192, 233

Györffy Miklós 155

Györfi-Deák György 92, 234

György Béla 83, 234

György Lajos 126, 195, 226, 234, 241

Gyulai Pál 47, 67, 69, 104, 156, 193, 234, 249

Hajdú Győző 177

Hanák Péter 234

Haşdeu, Bogdan Petriceicu 58, 60, 139

Heine, Heinrich 55

Heinrich Gusztáv 38, 157, 234

Henszlmann Imre 24

Herman Ottó 180, 190-192, 207, 240

Hodoş, Iosif 20, 27, 29

Holló Lajos 82

Holtzmann, Adolf 156, 159

Hóman Ottó 110

Homérosz 103

Horváth Albert 57-59, 96, 100

Horváth Andor 100

Horváth Ignác 97

Horváth László 185

Horváth Mihály 185

Hory Béla 190, 192, 207

Hugo, Victor 34, 55

Hulimka Sándor 89, 247

Humboldt, Alexander von 166

Huszár Ilona 182, 184

I. Tóth Zoltán 174, 249

Ilea, Filimon 14
Illyés Zsuzsa 154, 169

Imre Sándor 109, 136, 140, 235

Ingold, Tim 138, 235

Ionescu, Alexandru 27, 33

Ionescu, Lazăr 19,

Iordachi, Constantin 204, 235

Iosif, Ştefan Octavian 56

Irányi Dániel 24,

Irányi Ödön 89

Isac, Aurel 138

Isac, Emil 57, 58, 60

Ivánka Imre 24

dr. Jancsó Benedek 195, 196

Jauss, Hans Robert 72, 235

Jékely Zoltán 102

Jókai Mór 53, 55, 70, 89, 185, 187, 224, 240

Jósika Miklós 195

Justus 146

Károly (I.) 139

K. Papp Miklós 179, 190

Kabos Ede 89

Kacziány Géza 57

Kakassy Endre 101, 235

Kalla Zsuzsa 36, 235

Kant, Immanuel 38, 39

Karády Viktor 80, 108, 114, 117, 118, $120,121,133,148,211,235,236$

Kelemen Lajos 192

Keller Irén 131, 132, 258

Keller Márkus 126, 236

Kemény G. Gábor 148, 149, 199, 236

Kende Gábor 205, 237

Keresztes Erzsébet 79

Kese Katalin 116, 236

Kibédi Sándor 61, 62, 102, 236

Kirman,? 171

Kiss Ernő 95, 99, 236

Kiss József Mihály 247 
Klaudy Kinga 68, 225, 236

Klein Félix 113

Koch, Max 155

Komáromi Sándor 155, 161, 162, 169, 237

Koós Ferenc 74, 79, 185, 188, 225

Koselleck, Reinhart 29, 147, 237

Kovách Géza 79, 237

Kovachich Márton György 53

Kovács Ferenc 188, 189

Kovács Gábor 205, 237

Kovács János 171

Kovács Sándor 9, 171, 172, 237

Kozma Dezső 9, 154, 238

Kozma Ferenc 171

Kölcsey Ferenc 48, 232

Köpeczi Béla 141, 178, 197, 208, 237, 239

Körner, Theodor 43, 155

Kövér György 24, 25, 124, 125, 151, $179,183,233,237-239$

Kremnitz, Mite 77

Kristóf György 48, 85, 238

Kriza János 28

Kuk Jenő 21

Kuncz Aladár 195

Kuun Géza 84, 85

L. Sipos Kamilló 81, 85, 245

Ladányi Andor 116, 238

Lajtai L. László 238

Lakner Judit 36, 238

Lapedatu, Ion 19

Lázár István, 186

Lazăr, Marius 55, 56, 238

le Goff, Jacques 239

Leményi Bran, Eleonora 131-133, 257

Lenau, Nikolaus 36, 43, 275, 277

Lessing, Gotthold Ephraim 156

Longfellow, Henry Wadsworth 75

Longinus, Dionysius 68
Lövei Klára 75

Lupu, Ioan 55, 99, 239

Macedonski, Alexandru 38

Madách Imre 48, 86, 87, 96

Maiorescu, Titu 14, 15, 32, 37, 44, 48, $49,73,75,92,139,239$

Makkai László 140, 239

Mândruț, Stelian 175

Márki Sándor 57, 59, 65, 74, 94, 96, 113, 140, 150, 190, 191-194, 205, 208, 224, 233, 239, 240, 250

Martinescu, Pericle 76

Mátrai Ernő 110, 113, 239

Mátyás Flórián 129, 165

Maupassant, Guy de 99

Mazsu János 207, 239

Meltzl Hugó 109, 110, 112, 123, 153-164, 169-174, 176, 187, 201, 213, 221, 222, 224, 229, 237, 238, $239,240,276,278$

Micle, Veronica 16

Micu Klein, Samuil 53

Micu, Andrei 127, 138, 140, 143, 240

Mihutz György 119

Mikszáth Kálmán 89, 249

Miskolczy Ambrus 9, 174, 240

Mitu, Sorin 174, 178, 240

Mocioni, Alexandru 24, 27

Módos Péter 240

Moldován Gergely 29, 30, 39, 40, 54, 57-60, 83, 95, 96, 101, 109, 115, $116,122,128,130,142,150,153$, 174-214, 219-222, 226, 237, 240, $241,249,250,276,278$

Moldován István 192, 204, 207-210

Moldovan, Silvestru 130

Mureşanu, Andrei 37, 38, 46, 58, 135, 188

Mureşanu, Iacob 138, 146

Musset, Alfred de 55 
N. Kovács Tímea 8, 69, 72, 78, 85, 97, 224, 226, 235, 242

Nagy Károly 57

Nagy László 89, 92, 247

Nagy Levente 18, 241

Nagy Péter 81, 165, 166, 227

Nagy Péter Tibor 80, 123, 124, 134, 210, 241, 242

Nastasă-Kovács, Lucian 9, 80, 91, 108, 114, 236, 242

Naum, Anton 91, 97

Neamțu, G. 112, 116, 242

Negruzzi, Costache 27, 38, 93

Nemes, Leontina 131, 132, 258

Nicoară, Vicentiu 116

Nicoleanu, Nicolae 38

Niranjana, Tejaswini 77, 242

Nistor, Silvestru 116

Nyáry Pál 22

Nyéki Takács Nándor 141

Onişor, Gavril 134, 135, 139, 259

Onişor, Victor 129

Orosz György 119

Ortutay Gyula 178, 242, 253, 255

Osváth József 57

P. Szathmáry Károly 25, 26, 79

Pajkossy Gábor 138, 242

Pál Judit 19, 185, 206, 243,

Papp László 114

Páska Zoltán 141

Pataj Sándor 57

Pavel, Aurel 48, 128, 246

Pavel, Constantin 58, 262

Pavelea, Traian 160, 161, 243

Perpessicius 32, 76

Petelei István 75, 168, 248

Petőfi Sándor 43, 48-51, 54, 55, 71, 96, 156, 169, 172, 198, 244, 275, 277

Petraşcu, Nicolae 37, 243
Petri Mór 90, 92, 243

Petruşan, Gheorghe 12, 243

Plămădeală, Antonie 243

Platon 68

Pletosu, Grigore 129

Polivka Margit 131, 132, 264

Pompiliu, Miron 17

Pompilius, Dan 130, 255

Pop, Dumitru 97

Pop, Gavril 138

Pop, Sigismund 18

Pop, Vasile Gh[erman] 31, 32, 144, 243,

Pop, Vlad 93, 243

Popa, Mircea 243

Popescu, Emilian 57

Popfiu, Iustin 17, 46

Popova-Nowak, Irina V. 193, 244

Popovici, Iosif 27, 116,

Popu, Constantin 134, 259

Pražák, Richard 54

Presia, János 119, 259

Pulszky Ferenc 164

Pumnul, Aron 12-15, 42

Puskás Attila 208, 244

Puskás Lajos 208, 244

Putnoky Miklós 58

Rácz Miklós 119

Rádl Ödön 57, 58, 188, 244

Radó Antal 64, 65, 104, 244

Radu, Alexandru 197

Radu, Ioan 134

Rădulescu, Răzvan 33, 34

Rajner Pál 21

Rájnis József 64

Rákóczi Ferenc 79, 145, 146

Rațiu, Ioan 188, 189, 198, 207, 208, 244, 261

Rebrean, Vasile 198

Rebreanu, Cornelia 131, 265 
Régeni András 14, 244

Répay Dániel 119

Réthy Andor 244

Révai Károly 38, 57-59, 61, 62, 94-100, 193, 218, 227, 236

Reviczky Gyula 48

Riedl Szende 157

Ritoók Zsigmond 155

Roman, Alexandru 17, 18, 27, 41, 111, $112,116,122,123,130,224,242$,

Roman, Miron 138, 198

Rosetti, Dimitrie 59, 60

Rudits József 132, 264

Rudolf föherceg 185-187

Rüegg, Walter 122, 166, 244

S. Varga Pál 69, 199, 204, 245,

Şaguna, Andrei 54, 175

Sălăgean, Tudor 84, 247

Salamon Ferenc 193

Salamon János 79

Sándor János 199

Sándor József 5, 8, 11, 51, 58, 61, 62, 73-87, 89, 92-94, 96, 100, 104, 144, $150,192,193,217,218,220,244$, 276

Sardou, Victorien 28

Sas Péter 178

Savigny, Friedrich Carl von 69

Schiller, Friedrich 27, 43, 132, 154, 155

Schopenhauer, Arthur 156, 275, 277

Schöpflin Aladár 58, 60

Scribe, Eugène 28

Scurtu, Ioan 130, 135, 256

Scurtu, Vasile 115, 247

Sebesi Jób 141

Seni, Ioan 114, 246

Seni, Ioanela Alis 114, 246

Seni, Valer 129

Șerban, Ioan 129, 264
Shakespeare, William 28, 66, 67, 99, 224,

Schleiermacher, Friedrich 166

Siegescu József 116

Sigmirean, Cornel 41, 48, 109, 119, $120,128,129,131,132,246,256$

Silaşi, Grigore 109, 110, 112-117, 122, $127,128,133,137,139,140-144$, $146,147,160,161,174,175,213$, $214,220,243$

Sylva, Carmen 87, 91, 186

Simon Aurél 95, 97, 99

Simuț, Ion 17, 245

Sincai, Gheorghe 53, 54, 175

Sion, George 38, 46

Slavici, Ioan 12, 14, 93, 198, 211, 227

Sólyom Fekete Ferenc 84, 85

Sólyom Fekete Margit 84

Şotropa, Virgil 127, 129, 160, 161, 245, 249,260

Splényi Ödön 181, 184

Stan, Elena 39, 247

Stănescu, Imre 24

Stefanelli, Teodor V. 37, 247

Ştefănescu, Cornelia 55, 99, 239

Stein János 140, 155, 171, 190, 224, 230, 239, 247

Stekovics Rita 74, 223

Sterca Șuluțiu, Alexandru 59, 60, 98, 260, 261, 264

Stețiu, Silvia 131, 263

Sztója, Miklós 154, 256

Stoica Dénes 59

Strajanu, Mihail 14, 19, 29

Straje, Mihail 41, 248

Sturm Albert 82, 83, 87, 199, 245

Suciu, Dumitru 114

Szabó Emil 51, 57, 135, 261

Szabó Károly 193

Szabó Márton 29, 237, 245

Szabó Péter 36, 245 
Szádeczky-Kardoss Lajos 61, 191-194, 245

Szajbély Mihály 54, 245

Szamosi János 48,113

Szánthó Vitus 57

Szász Béla 75

Szász Domokos 81

Szász Gerő 81

Szász Károly 66-70, 100, 101, 193, 246

Szász Károly, ifj. 141

Szász Zoltán 139, 245

Szegedy-Maszák Mihály 246

Székely János 102

Széles Jenő 57, 263

Széll Kálmán 19

Szemlér Ferenc 102

Szendrey Júlia 67

Szent István 200

Szentkatolnai Bálint Gábor 176, 191, 192, 224

Szentpétery Imre 121, 246

Szilágyi Márton 9, 30, 105, 246

Szilágyi N. Sándor 45, 72, 247

Szilágyi Sándor 193, 240

Szinnyei József 13, 36, 45, 61, 66, 75, 80, 81, 87, 112, 122, 141, 157, 177, 190, 192, 196, 205, 207, 218, 224, 247

Szopori Nagy Miklós 58

Szőcs Géza 38, 45-51, 58, 62, 100, 247

Szögi László 132, 165, 245, 247

Sztripszky Hiador 119

T. Szabó Levente 9, 16, 29, 40, 41, 54, $74,193,226,234,237,249$

Takáts József 8, 9, 18, 62, 63, 69, 93, $105,226,248$

Tanco Miklós 122

Tanco, Teodor 248

Tapodi Zsuzsa 9

Tăutu, George 12
Téglás Gábor 187

Thimár Attila 112, 248

Țichindeal, Dimitrie 127, 139

Tiganetea, Dumitru 129

T,iple/Cziple, Alexandru 97

Tisza Kálmán 22-24

Todor, Avram P. 62, 73, 101, 177, 248

Toldy Ferenc 164, 165, 169, 227, 229

Torma Miklós 195

Torouțiu, I.E. 33

Tóth Árpád 138, 249

Tóth Tamás 166

Török Zsuzsa 65, 144, 248

Trefort Ágoston 114, 141

Tukididesz 103

Unowsky, Daniel L. 187, 228

Ureche, Grigore 27

Ureche, Lazăr 161, 249

Urmánczy Ilona 179, 184

Váczy Leona 244

Vajda Emil 134, 259

Vajda György Mihály 154, 163, 164, 186, 249, 250,

Vajda János 48

Vajna Farkas 150

Vancea, Ioan 138, 196

Várady Aurél 82

Váradi Károly 185

Varga Attila 85, 250

Varga Júlia 126, 194, 250

Vasiliu, Gabriel 174, 175

Vass Laura 169, 250

Vătăşan, Nicolae 122

Veress Endre 200, 202, 250

Veritas 126, 250

Versényi György 57

Viciu, Alexiu 116

Virág Benedek 53

Vitkovics Mihály 65 
Vlahuță, Alexandru 42, 44, 59, 91, 150

Voltaire 159

Vörösmarty Mihály 48, 96, 172

Vrchlick, Jaroslav 54

Vulcan, Iosif 12-17, 19, 27-29, 36, 46, $53,54,57,59,60,71,91,112,116$, $127,150,177,186,226,230,231$, 243,250

Wachter Frigyes 24

Weber Péter 193, 250

Wekerle, Sándor 130

Wenckheim Béla 22

Werner, Michael 8, 107, 250, 251

Wesselényi Jozefa 208

Xenopol, Alexandru Dimitrie 46

Zeflean, Eneas 208, 263

Zeyk Domokos 85

Zilahi Béla 75

Zimmermann, Bénédicte 8, 107, 250, 251

Zöld Gábor 141

Zsedényi Ede 19

Zsiga Nicolae 12 

REZUMAT

\section{ELITE ŞI CONTACTE CULTURALE MAGHIARO-ROMẨNE ÎN A DOUA JUMĂTATE A SECOLULUI AL 19-LEA}

Lucrarea se ocupă cu contactele literare româno-maghiare de la sfârşitul secolului al 19-lea şi începutul secolului al 20-lea, din ultimele decenii ale Monarhiei Austro-ungare. Bibliografia amplă, care legitimează conceptul de „literatura Monarhiei” legat de termenul de ",europenism central şi estic”, marginalizează sau nu include cultura românilor din Ungaria, aceasta fiind doar parțială. Acest aspect $\mathrm{m}$-a influenţat în definirea temei şi problematicii tezei. Istoria sensului şi conceptului de literatură națională devine problema centrală a volumului, deoarece perioada studiată ne oferă numeroase exemple care depăşesc limitele caracterului național ale literaturilor.

Cartea nu este o monografie comparatistică, nici o lucrare de istorie a recepției, ci se vrea a fi un experiment contactologic care îmbogățeşte atât tematic, cât şi prin resurse şi documente noi istoria traducerilor culturale româno-maghiare de la sfârşitul secolului al 19-lea.

Recepția literaturii scrise în limba română este reprezentată de traducerile sporadice ale unor intelectuali, publicate în diferite periodice. Consider, că interpretările mai târzii ale acestora operează pe o dublă scară, de aceea această carte încearcă a contextualiza gesturile primelor traducători pentru a le înțelege mai bine dintr-o perspectivă sincronă lor, nu dintr-una ulterioară, cum ar fi concepția estetică a literaturii.

Analiza recepției porneşte de la debutul lui Mihai Eminescu, de la primele sale scrieri polemice din literatura română din Monarhia Austro-Ungară. Există două studii despre viața şi opera poetului, apărute în limba maghiară, scrise ca disertații de doctorat în 1895. Sunt monografii pozitiviste, dar ne oferă paralelisme interesante în contextul literaturii maghiare sau străine din acea vreme (Lenau, Schopenhauer, Petőfi). Aceste disertații, integrându-se în literatura de specialitate maghiară legată de Eminescu, sunt foarte interesante din punctul de vedere al limbii, şi anume, disertația doctorandului român (viitorul patriarh Miron Cristea, doctorand al Universității din Pesta) care tratează literatura română în limba maghiară, devine parte a literaturii maghiare. Acest fapt ține de anomaliile recepției, neproblematizate până acum, iar studiul disertației şi al contextului ei va aduce argumente legate de folosirea limbii maghiare nu ca o decizie individuală, ci ca obligativitate impusă de puterea limbii oficiale la universitatea din Pesta. 
Studiind contextul traducerilor, atragem atenția asupra periodicelor maghiare din epocă, unde apar traducerile poeziei româneşti (ziare şi gazete locale), care până azi figurau ca simple date în lucrările de istorie a presei, fără a se recunoaşte valoarea lor în contactele literare. Poeziile traduse din Eminescu sunt publicate pentru prima oară în numărul special (de Crăciun, 1885) al ziarului Kolozsvári Közlöny, sau în rubrica de foileton a gazetei Szilágy-Somlyó (1889-1891), reprezentând pretenția sau exigența pe de o parte a editorilor de presă, pe altă parte a cititorilor - multiculturali, cunoscători a mai multor limbi - din Transilvania, şi nu în ultimul rând şi practica de traducător a unor intelectuali cu socializare multiplă, cu experiență în folosirea celor două limbi. Sándor József traduce în limba sa maternă, pe când românul Laurențiu Bran din limba sa maternă, fapt ce conduce la problematica cunoştinței limbilor, dar implicit şi la cea a omogenității şi omonimității literaturilor, culturilor naționale diferențiate prin atributele „maghiar” şi „român”. Această perioadă este caracterizată de modernizarea societății, de concepția de stat a Ungariei în contra realității dualismului austro-ungar. Canonizarea conceptului de literatură maghiară națională se leagă de acest proces politic, adâncind distanțarea națiunii maghiare de comunitățile etnice.

După aceste capitole, cartea tratează acel aspect metodologic, care vede experiența în diferite culturi ca rezultat al proceselor de socializare, legitimate fertil de realitatea multiculturală şi poliglotă a Monarhiei. Identificarea studenților Facultății de Litere de la Universitatea Maghiară Regală, mai târziu Universitatea Franz Iosif, relevă şi problematica identificării naționale ale acestora, respectiv defineşte cu concizie faptul, că disciplinele catedrei române ale universității atrag doar studenții de etnie română. Realitatea aceasta explică lipsa profesioniştilor din rândul traducătorilor maghiari ai literaturii române, deoarece străinătatea limbii persistă până în primele decenii ale secolului 20, în contra traducerilor existente.

Abordarea temei din perspectiva cercetării elitelor devine o noutate a domeniului de cercetare, prin care se reprezintă diferența concepției de cultură, de naționalitate, respectiv implicit se dezvăluie şi diferitele politici ale transmisiunilor culturale. Cartea prezintă câteva studii de caz. Brassai Sámuel şi Hugo von Meltzl redactau o revistă poliglotă, comparativă şi interdisciplinară, apropiindu-se de cosmopolitism, universalitate, aducând argumente pentru o identitate supranațională, imperialistă. Grigore Moldovan trecea peste publicațiile sale în limba română pentru a deveni scriitor maghiar, fidel statului național maghiar, păşind pe drumul asimilației: ca cetățean maghiar de naționalitate română, însă a fost considerat trădător din perspectiva comunității sale etnice. Figura lui devenea problematică atât pentru comunitatea română, cât şi pentru cea maghiară, iar identitatea lui etnică din acest punct de vedere părea inaccesibilă, fiind o identitate hibridă.

Traducerile sporadice din această epocă, diferitele concepții ale traducătorilor arată cum îşi caută locul literatura română în cea maghiară în ultimele decenii ale Monarhiei Austro-Ungare. Cel mai important aspect al tezei ne arată, că relațiile literare româno-maghiare, după studiile de caz ale lucrării, nu pot fi diferențiate pe baza caracterului național, deoarece la sfârşitul secolului al 19-lea conceptul de națiune, de stat național, de literatură şi cultură națională era încă în curs de formare. 
ABSTRACT

\section{INTELLIGENTSIA AND ROMANIAN- HUNGARIAN CULTURAL CONTACTS IN THE SECOND HALF OF THE 19TH CENTURY}

The paper deals with the Romanian-Hungarian literary contacts in the late 19th century and early 20th century, the last decades of the Austro-Hungarian Monarchy. The extensive bibliography, which legitimized the concept of "Monarchy-literature" about the term Central and Eastern Europeanism, marginalizes or does not include the cultures of Romanians in Hungary, considering partially this literature. This influenced me in defining the topic and thesis of the problems. History of meaning and concept of national literature becomes the central issue of the thesis, as the period studied gives us many examples that go beyond national character of the literatures.

The book is not a comparative monograph, not a history of reception, but wants to be an experiment in study of the contacts that enriches both thematically and through new documents the history of Romanian-Hungarian translations from the late 19th century.

The reception of the Romanian literature is represented by sporadic translations made by intellectuals, published in various periodicals. I think that their interpretations operates on a double scale, but this book tries to contextualize gestures of the translators to better understand their synchronic perspective, not from a later point of view of the aesthetical concept of literature.

The analysis of the reception is starting from the debut of Romanian poet Mihai Eminescu, from his first polemical texts appeared in the Romanian literature of the Austro-Hungarian Monarchy. There are two studies in Hungarian, written as doctoral dissertations in 1895 . There are positivist monographies, but also gives us interesting parallels in the context of Hungarian and foreign literature (Lenau, Schopenhauer, Petofi).

This dissertations are very interesting in terms of language, namely, is a work of a Romanian author (the future Patriarch, Miron Cristea, Ph.D., University of Pest) presenting the Romanian literature, but from the perspective of the language used in the dissertation, is a Hungarian work, and becomes part of the Hungarian literature. This fact holds reception anomalies, unquestioned so far, and the study of this dissertation and its context will make arguments about the use of Hungarian language not as an individual decision, but as an obligation imposed by the power of language in the University of Pest. 
Exploring the context of translation can reinterpret our knowledge about the Hungarian periodicals of the time, because the translations of Romanian poetry appear in local newspapers, which until now were only listed in the press history, without recognizing their value in Hungarian and Romanian literatures contact. The poems of Eminescu translated into Hungarian are published for the first time in the special issue (Christmas 1885) of Kolozsvári Közlöny, and in the feuiletton of the Szilágy-Somlyó newspaper (1889-1891), representing a claim or requirement on the part of press-publishers, on another part of the - multicultural, knowing many languages - readers from Transylvania, and not least the translation and practice of intellectuals discernible in the use of two languages (the politician, the organizer of institutions, József Sándor; the theologian Laurențiu Bran). Their translations are the results of the literary preoccupation from the special literary circles of the religious boarding schools, attended by translators. With everything that Sándor and Bran deal with translating Eminescu's poetry, their work gives us interesting examples of studies of the contacts and cannot be classified by the same criteria. This period is characterized by modern society, the concept of the Hungarian state in contrast with the reality of the Austro-Hungarian Dualist Monarchy. The canonization of the concept of the literature is laid to the Hungarian national political process, deepening the distance between the Hungarian nation and the ethnic communities.

The second half of the book link to see that methodological issue which sees experience in different cultures as a result of the process of socialization, legitimated by the multicultural and multilingual reality of the Monarchy. Identifying students of the Faculty of Letters at the Royal Hungarian University, later named Franz Joseph, deals with the Romanian side in this study of intercultural contacts and reveals the issue of the national identification of the students and also defines that the Romanian department of the university attract only Romanian students. This reality also explains the lack of professionals between Hungarian translators of Romanian literature, the foreign character of the Romanian language persist until the first decades of the 20th century, against the existing translations.

The book contains a chapter that reinterprets the literary contacts from the perspective of intellectual careers, representing the different concepts of the cultures, of their characteristics defined by language, by nationality; that implicitly reveals the different policies of cultural transmissions.

Brassai Sámuel and Hugo von Meltzl are editors of a comparative and interdisciplinary multilingual magazine, approaching to cosmopolitanism, universalism, bringing arguments to a supranational identity. Moldovan Grigore passed abandoned publicizing in Romanian, becoming a Hungarian writer true to the Hungarian national state: as a Hungarian citizen with Romanian nationality, he was loyal to the Hungarian state, and was considered a traitor from the perspective of his ethnical community. Became a problematic figure of the Romanian nation and for the Hungarian also, and his hybrid identity of this view seemed inaccessible.

Sporadic translations of this period, the different conceptions of translators of the Romanian poetry, show the way pieces of Romanian literature are looking for their place in the Hungarian literature. The most important issue of the thesis is that the Romanian-Hungarian literary contacts, the case studies of dissertation 
cannot be differentiated on the basis of national character, because since the late 19 th century the concept of the nation, state, national literature and national culture were still just developing. 



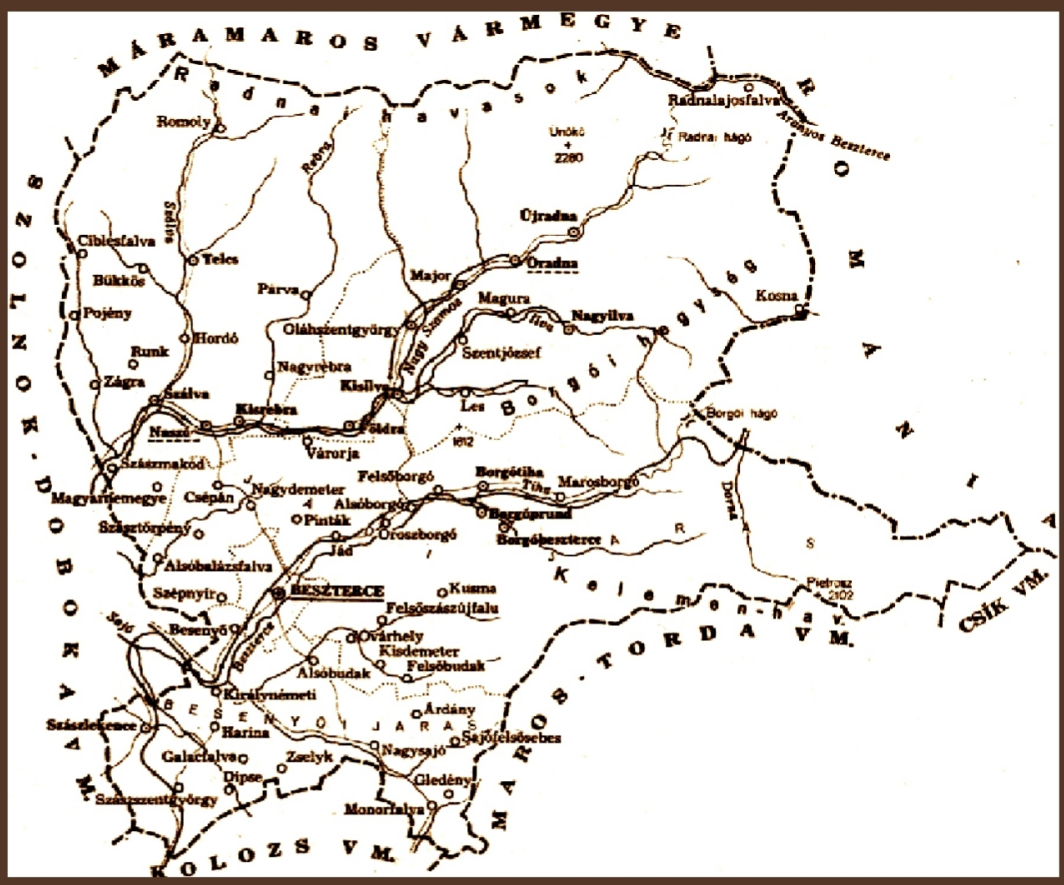

A kötet az Osztrák-Magyar Monarchia utolsó évtizedeinek román-magyar kulturális kapcsolatait értelmiségtörténeti keretbe helyezi. A multikulturalitás és multietnicitás bonyolult kérdésköre elválaszthatatlan a 19. század vége Magyarországának kapcsolattörténeti vizsgálatától. A többnyelvü, többkultúrájú és ezért mára kevésbé egyértelmünek tünő egyéni és közösségi identitások történelmi (társadalmi, felekezeti, szakmai) életvilágába vezet el a kötet. Ugyanakkor az értelmiségtörténeti kapcsolathálók részleges felgöngyölítését nyújtja, amely a kolozsvári Ferenc József $M$. K. Tudományegyetem román származású diáksága tanulmányainak és egyetem utáni életpályájának alakulását követi, és amely az egykorú kulturális életet sajátosan meghatározó egyetemi tanárok nyelv- és kultúrafogalmát, identifikációs gesztusait, karriertörténetét vázolja.

ISBN 978-606-8178-60-8

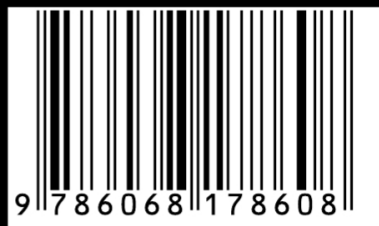

